\title{
Beta and Gamma Dose Calculations for PWR and BWR Containments
}

Prepared by D. B. King

Sandia National Laboratories

Prepared for

U.S. Nuclear Regulatory

Commission

\section{When printing a copy of any digitized SAND Report, you are required to update the markings to current standards.}




\section{AVAILABILITY NOTICE}

Availability of Reference Materials Cited in NRC Publications

Most documents clted in NAC publications will be avallable from one of the following sources:

1. The NRC Publlc Document Room, 2120 L Street, NW. Lower Level, Washington, DC 20555

2. The Superintendent of Documents, U.S. Government Printing Offlce, P.O. Box 37082, Washington, DC 20013-7082

3. The National Technical Information Service, Springfield, VA 22161

Although the listing that follows represents the majority of documents cited in NRC publications, It is not Intended to be exhaustive.

Referenced documents avallable for inspection and copying for a fee from the NRC Public Document Room Include NRC correspondence and Internal NRC memoranda; NRC Office of Inspectlon and Enforcement bulletins, circulars, Information notices, Inspection and investigation notices; Licensee Event Reports; vendor reports and correspondence; Commission papers; and applicant and licensee documents and correspondence.

The following documents In the NUREG serles are avallable for purchase from the GPO Sales Program: formal NRC staff and contractor reports, NRC-sponsored conference proceedings, and NRC booklets and brochures. Also avallable are Regulatory Guides. NRC regulations in the Code of Federal Regulations, and Nuclear Regulatory Commission Issuances.

Documents avallable from the National Technical Information Service Include NUREG series reports and technical reports prepared by other federal agencies and reports prepared by the Atomic Energy Commission, forerunner agency to the Nuclear Regulatory Commission.

Documents avaliable from public and special technlcal libraries Include all open literature items, such as books, Journal and perlodical articles, and transactions. Federal Register notices, federal and state legislation, and congressional reports can usually be obtained from these libraries.

Documents such as theses, dissertations, foreign reports and translations, and non-NRC conference proceedings are avallable for purchase from the organization sponsoring the publication clted.

Single coples of NRC draft reports are available free, to the extent of supply, upon written request to the Office of Information Resources Management, Distribution Section, U.S. Nuclear Regulatory Commission, Washington, DC 20555.

Coples of Industry codes and standards used in a substantive manner in the NRC regulatory process are maintained at the NRC Llbrary, 7920 Norfolk Avenue, Bethesda, Maryland, and are avallable there for reference use by the publlo. Codes and standards are usually copyrighted and may be purchased from the originating organization or, If they are American National Standards, from the American National Standards Instltute, 1430 Broadway, New York, NY 10018.

\section{DISCLAIMER NOTICE}

This report was prepared as an account of work sponsored by an agency of the United States Government. Neither the United States Government nor any agency thereof, or any of their employees, makes any warranty, expresed or implied, or assumes any legal liability of responsibility for any third party's use, or the results of such use, of any information, apparatus, product or process disclosed in this report, or represents that its use by such third party would not infringe privately owned rights. 
NUREG/CR-5175

SAND88-1605

R3, RV

\section{Beta and Gamma Dose \\ Calculations for \\ PWR and BWR Containments}

Manuscript Completed: June 1989

Date Published: July 1989

Prepared by

D. B. King

Sandia National Laboratories

Albuquerque, NM 87185

Prepared for

Division of Engineering

Office of Nuclear Regulatory Research

U.S. Nuclear Regulatory Commission

Washington, DC 20555

NRC FIN A1051 
Other Report in the Series

NUREG/CR-4949, "Source Term Calculations for Assessing Radiation Dose to Equipment", R.S. Denning, R. Freeman-Kelly, P. Cybulskis, L.A.Curtis, Battelle Columbus Laboratory, July 1989. 


\section{ABSTRACT}

Analyses of gamma and beta dose in selected regions in PWR and BWR containment buildings have been performed for a range of fission product releases from selected severe accidents. The objective of this study was to determine the radiation dose that safety-related equipment could experience during the selected severe accident sequences. The resulting dose calculations demonstrate the extent to which design basis accident qualified equipment would also be qualified for the severe accident environments. Surry was chosen as the representative PWR plant while Peach Bottom was selected to represent BWRs. Battelle Columbus Laboratory performed the source term release analyses. The $A B$ epsilon scenario (an intermediate to large LOCA with failure to recover onsite or offsite electrical power) was selected as the base case surry accident, and the $\mathrm{AE}$ scenario (a large break LOCA with one initiating event and a combination of failures in two emergency cooling systems) was selected as the base case Peach Bottom accident. Radionuclide release was bounded for both scenarios by including spray operation and arrested sequences as variations of the base scenarios. Sandia National Laboratories used the source terms to calculate dose to selected containment regions. Scenarios with sprays operational resulted in a total dose comparable to that $\left(2.20 \times 10^{8}\right.$ rads) used in current equipment qualification testing (for design basis accidents or Regulatory Guide 1.89). The base case scenarios resulted in some calculated doses roughly an order of magnitude above the current $2.20 \times 10^{8} \mathrm{rad}$ equipment qualification test region. 
CONTENTS

Page

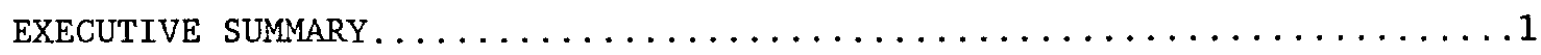

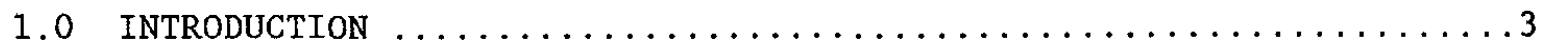

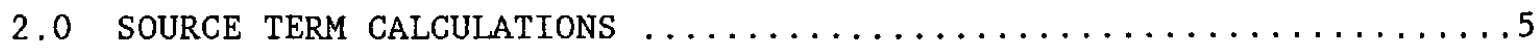

2.1 Surry Source Term Calculations $\ldots \ldots \ldots \ldots \ldots \ldots \ldots \ldots \ldots \ldots$

2.2 Peach Bottom Source Term Calculations ..............6

3.0 RADIATION DOSE CALCULATIONAL TOOLS $\ldots \ldots \ldots \ldots \ldots \ldots \ldots \ldots \ldots$

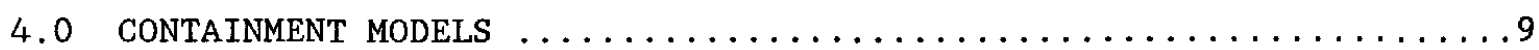

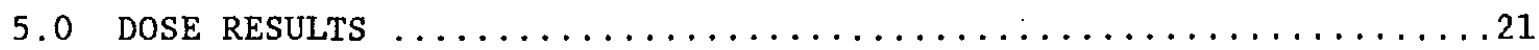

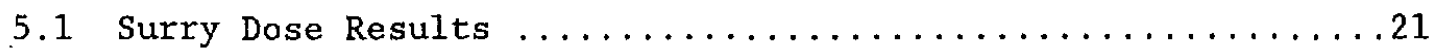

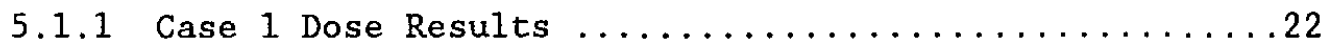

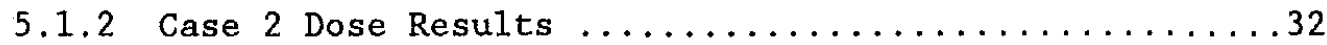

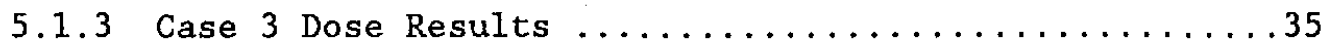

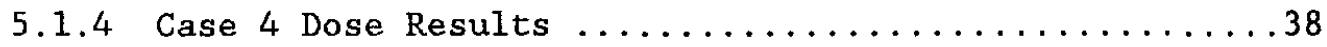

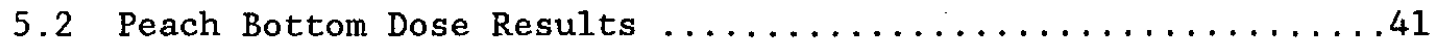

5.2 .1 Case 1 Dose Results ...................... 41

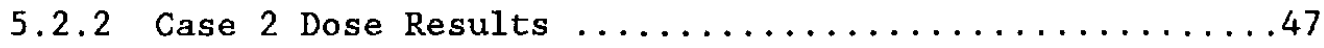

5.2.3 Case 3 and Case 4 Dose Results ...............49

5.3 Comments on Surry and Peach Bottom Case 1

and Case 2 Dose Results ....................... 51

5.4 Comments on PATH and ITS Isotope Inventory $\ldots \ldots \ldots \ldots \ldots \ldots \ldots 2$

5.5 Other Dose Rate and Dose Work ..................... 59

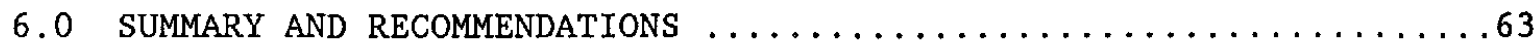

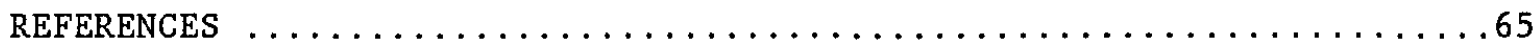

APPENDIX A ITS CONTAINMENT BUILDING ZONES $\ldots \ldots \ldots \ldots \ldots \ldots \ldots \ldots \ldots$

APPENDIX B ADDITIONAL DOSE RATE AND DOSE FIGURES............. B-1

APPENDIX C AIRBORNE, WALL, FLOOR, AND SUMP CONTRIBUTIONS

TO DOSE RATES FOR SELECTED CONTAINMENT LOCATIONS .........

APPENDIX D MAJOR ISOTOPE CONTRIBUTORS TO TOTAL DOSE........... 
4.1 Surry Containment Section A ......................

4.2

4.3

4.4

4.5

4.6

4.7

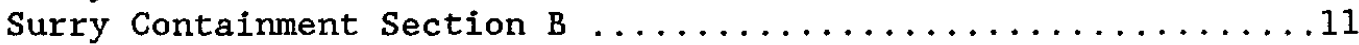

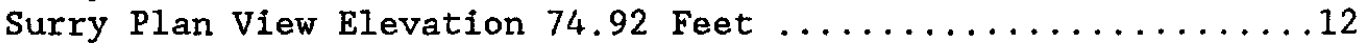

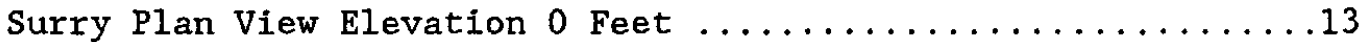

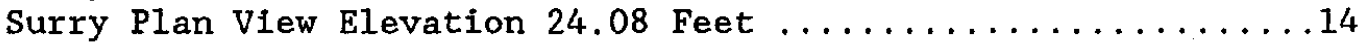

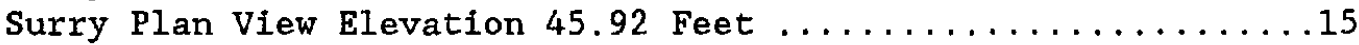

5.1 .1 Surry Gase 1 Basement Total Gamma Dose $\ldots \ldots \ldots \ldots \ldots \ldots \ldots \ldots 23$

5.1 .2 Surry Case 1 Basement Total Beta Dose ..................24

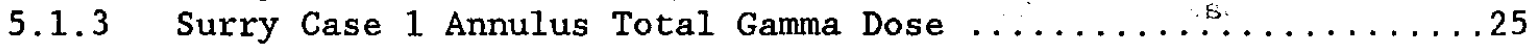

5.1 .4 Surry Case 1 Annulus Total Beta Dose ...................25

5.1.5 Surry Case 1 Operating Floor and Dome Total Gamma Dose ......26

5.1 .6 Surry Case 1 Operating Floor and Dome Total Beta Dose .......26

5.1.7 Surry Case 1 Steam Generator A Cubicle Gamma Total Dose . . . ..28

5.1.8 Surry Case 1 Steam Generator A Cubicle Beta Total Dose ......28

5.1 .9 Surry Case 1 RHR Cubicle Total Gamma Dose ................29

5.1.10 Surry Case 1 RHR Cubicle Total Beta Dose ................29

5.2.1 Peach Bottom Case 1 Drywe11 Total Gamma Dose ...........42

5.2.2 Peach Bottom Case 1 Drywe11 Total Beta Dose ..............43

5.2.3 Peach Bottom Case 1 Wetwe11 Total Gamma Dose ............44

5.4 .1 Reg Guide 1.89 Noble Gas Gamma and Beta Dose ............60

5.4.2 Surry Case 4 Annulus Total Gamma and Beta Dose ..........61

5.4.3 Surry Case 4 Dome Total Gamma and Beta Dose .............62

A.1 Surry Containment Zones for Surface Sources .............

A.2 Surry Containment Zones for Floor Sources ...............

A. 3 Surry Steam Generator A Cubicle Zones .................4

A.4 Peach Bottom Drywel1 Zones for Surface Sources ............. 5

A.5 Peach Bottom Drywell Zones for Floor Sources .............6

B.1 Surry Case 1 Basement Gamma Dose Rate .................

B.2 Surry Case 1 Basement Beta Dose Rate ...................

B.3 Surry Case 1 Annulus Gamma Dose Rate .................

B.4 Surry Case 1 Annulus Beta Dose Rate ..................

B.5 Surry Case 1 Operating Floor and Dome Gamma Dose Rates ...... B-4

B.6 Surry Case 1 Operating Floor and Dome Beta Dose Rates ........ B-4

B.7 Surry Case 1 Steam Generator A Gubicle Gamma Dose Rates ...... B-5

B.8 Surry Case 1 Steam Generator A Cubicle Beta Dose Rates ....... B-5

B.9 Surry Case 1 RHR Cubicle Gamma Dose Rates ............... 6

B.10 Surry Case 1 RHR Cubicle Beta Dose Rates ................

B.11 Surry Case 1 Steam Generator B Gamma Dose Rate ...............7

B.12 Surry Case 1 Steam Generator B Beta Dose Rate ...............7

B.13 Surry Case 1 Steam Generator B Total Gamma Dose ............8 
B.14 Surry Case 1 Steam Generator B Total Beta Dose ............8-8

B.15 Surry Case 1 In-Core Instrumentation Room Gamma Dose Rate .............................

B.16 Surry Case 1 In-Core Instrumentation Room Beta Dose Rate ................................ 9

B.17 Surry Case 1 In-Core Instrumentation Room Tota1

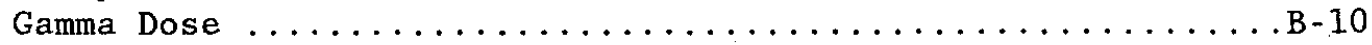

B.18 Surry Case 1 In-Core Instrumentation Room Total

Beta Dose ................................ 10

B.19 Surry Case 2 Basement Gamma Dose Rate ................. B-11

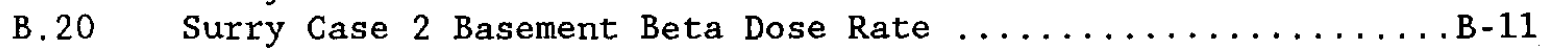

B.21 Surry Cáse 2 Basement Total Gamma Dose ...................

B.22 Surry Case 2 Basement Total Beta Dose .................. 12

B.23 Surry Case 2 Annulus Gamma Dose Rate .................13

B.24 Surry Case 2 Annulus Beta Dose Rate ...................

B.25 Surry Case 2 Annulus Total Gamma Dose .................. 14

B.26 Surry Case 2 Annulus Total Beta Dose ................. 14

B.27 Surry Case 2 Operating Floor and Dome Gamma

Dose Rate ............................... 15

B.28 Surry Case 2 Operating Floor and Dome Beta Dose Rate ....... B-15

B.29 Surry Case 2 Operating Floor and Dome Tota1 Gamma Dose ...... B-16

B.30 Surry Case 2 Operating Floor and Dome Total Beta Dose ...... B-16

B.31 Surry Case 2 Steam Generator A Gamma Dose Rate ............. B-17

B.32 Surry Case 2 Steam Generator A Beta Dose Rate .............. 17

B.33 Surry Case 2 Steam Generator A Total Gamma Dose ............ B-18

B.34 Surry Case 2 Steam Generator A Total Beta Dose ............ B-18

B.35 Surry Case 2 RHR Cubicle Gamma Dose Rate ................ 19

B.36 Surry Case 2 RHR Cubicle Beta Dose Rate ................ B-19

B.37 Surry Case 2 RHR Cubicle Total Gamma Dose ............... 20

B.38 Surry Case 2 RHR Cubicle Total Beta Dose ................ 20

B.39 Surry Case 2 Steam Generator B Gamma Dose Rates ............ B-21

B.40 Surry Case 2 Steam Generator B Beta Dose Rates ............. 21

B.41 Surry Case 2 Steam Generator B Total Gamma Dose ............ B-22

B.42 Surry Case 2 Steam Generator B Total Beta Dose ............ B-22

B.43 Surry Case 2 In-Core Instrumentation Room Gamma

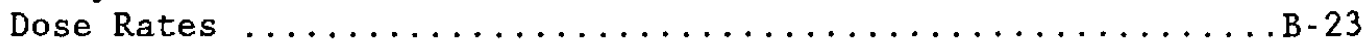

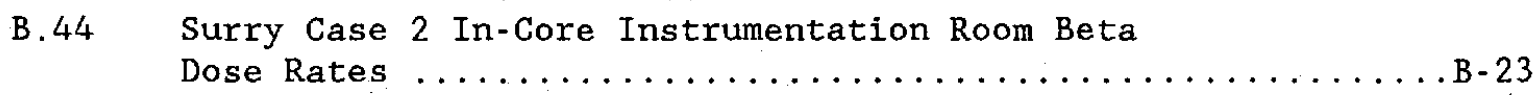

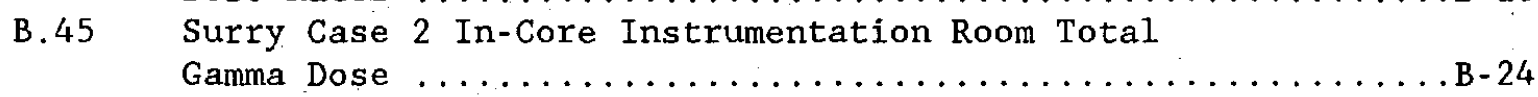

B.46 Surry Case 2 In-Core Instrumentation Room Total

Beta Dose ............................... 24

B.47 Surry Case 3 Basement Gamma Dose Rate ................ 25

B.48 Surry Case 3 Basement Beta Dose Rate ................. . 25

B.49 Surry Case 3 Basement Total Gamma Dose ............... B-26

B.50 Surry Case 3 Basement Total Beta Dose ................ 
B.51 Surry Case 3 Annulus Gamma Dose Rate ................

B. 52

B. 53

B. 54

B. 55

B. 56

B. 57

B. 58

B. 59

B. 60

B. 61

B. 62

B. 63

B. 64

B. 65

B. 66

B. 67

B. 68

B. 69

B. 70

B. 71

B. 72

B. 73

B. 74

B. 75

B. 76

B. 77

B. 78

B. 79

B. 80

B. 81

B. 82

B. 83

B. 84

B. 85

B. 86

B. 87

B. 88

Surry Case 3 Annulus Beta Dose Rate ................... 27

Surry Case 3 Annulus Total Gamma Dose ................ B-28

Surry Case 3 Annulus Total Beta Dose ................. 28 Surry Case 3 Operating Floor and Dome Gamma

Dose Rate .................................. 29

Surry Case 3 Operating Floor and Dome Beta

Dose Rate ................................. 29

Surry Case 3 Operating Floor and Dome Total

Gamma Dose ............................... 30

Surry Case 3 Operating Floor and Dome Total

Beta Dose ................................. 30

Surry Case 3 Steam Generator A Gamma Dose Rate ............. B-31

Surry Case 3 Steam Generator A Beta Dose Rate .............. 31

Surry Case 3 Steam Generator A Total Gamma Dose ............. 32

Surry Case 3 Steam Generator A Total Beta Dose .............. 32

Surry Case 3 Steam Generator B Gamma Dose Rate .............. 33

Surry Case 3 Steam Generator B Beta Dose Rate ................. 33

Surry Case 3 Steam Generator B Total Gamma Dose ............. B-34

Surry Case 3 Steam Generator B Total Beta Dose ...............34

Surry Case 3 RHR Cubicle Gamma Dose Rate .................. 35

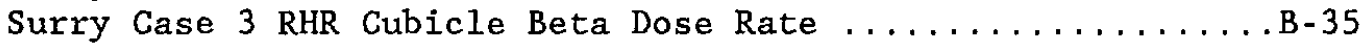

Surry Case 3 RHR Cubicle Total Gamma Dose ................

Surry Case 3 RHR Cubicle Total Beta Dose .................. 36

Surry Case 3 Incore Instrumentation Room Gamma

Dose Rate ................................ B-37

Surry Case 3 Incore Instrumentation Room Beta

Dose Rate ............................... B-37

Surry Case 3 Incore Instrumentation Room Total

Gamma Dose .............................. 38

Surry Case 3 Incore Instrumentation Room Total

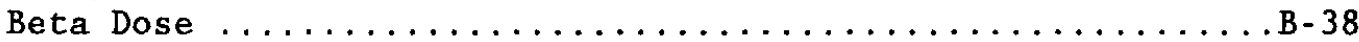

Surry Case 4 Basement Gamma Dose Rate ................... 39

Surry Case 4 Basement Beta Dose Rate ..................... 39

Surry Case 4 Annulus Gamma Dose Rate .................. . 40

Surry Case 4 Annulus Beta Dose Rate ................... . . . . .

Surry Case 4 Basement Gamma Total Dose ................. B-41

Surry Case 4 Annulus Total Gamma Dose .................... 41

Surry Case 4 Operating and Dome Gamma Dose Rate ............ 42

Surry Case 4 Operating Floor and Dome Beta Dose Rate ........ B-42

Surry Case 4 Operating Floor and Dome Gamma Total Dose ......B-43

Surry Case 4 Operating Floor and Dome Beta Total Dose .......B-43

Surry Case 4 Steam Generator A Gamma Dose Rate ............. B-44

Surry Case 4 Steam Generator A Beta Dose Rate .............. 44

Surry Case 4 Steam Generator A Gamma Total Dose ............. B-45

Surry Case 4 Steam Generator A Beta Total Dose ............ 45 
B.89 Surry Case 4 Steam Generator B Gamma Dose Rate ........... B-46

B.90 Surry Case 4 Steam Generator B Beta Dose Rate ............. 46

B.91 Surry Case 4 Steam Generator B Total Gamma Dose ........... B-47

B.92 Surry Case 4 Steam Generator B Total Beta Dose ............ B-47

B.93 Surry Case 4 RHR Cubicle Gamma Dose Rate ............... 48

B.94 Surry Case 4 RHR Cubicle Beta Dose Rate .................. B-48

B.95 Surry Case 4 RHR Cubicle Total Gamma Dose ................ . 49

B.96 Surry Case 4 RHR Cubicle Total Beta Dose ................ 49

B. 97 Surry Case 4 Incore Instrumentation Room Gamma

Dose Rate ............................. 50

B.98 Surry Case 4 Incore Instrumentation Room Beta

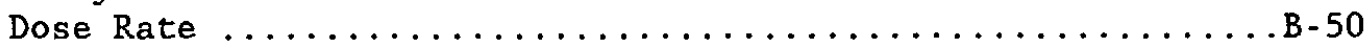

B.99 Surry Case 4 Incore Instrumentation Room Total

Gamma Dose .............................. 51

B. 100 Surry Case 4 Incore Instrumentation Room Total

Beta Dose .............................. 51

B.101 Peach Bottom Case 1 Drywe11 Gamma Dose Rates .............

B.102 Peach Bottom Case 1 Drywe11 Total Gamma Dose .............. 53

B.103 Peach Bottom Case 1 Drywe11 Beta Dose Rates ............... 54

B.104 Peach Bottom Case 1 Drywel1 Total Beta Dose .............. . 55

B.105 Peach Bottom Case 1 Wetwel1 Gamma Dose Rate ................56

B.106 Peach Bottom Case 1 Wetwe11 Total Gamma Dose ............. B-57

B.107 Peach Bottom Case 2 Drywell Gamma Dose Rate ................58

B.108 Peach Bottom Case 2 Drywell Total Gamma Dose ...............59

B.109 Peach Bottom Case 2 Drywell Beta Dose Rate ................60

B.110 Peach Bottom Case 2 Drywel1 Total Beta Dose ...............61

B.111 Peach Bottom Case 2 Wetwe11 Gamma Dose Rates .............. B-62

B.112 Peach Bottom Case 2 Wetwel1 Total Gamma Doses .............63

B.113 Peach Bottom Case 3 Drywel1 Gamma Dose Rates ..............64

B.114 Peach Bottom Case 3 Drywe11 Total Gamma Dose .............. B-65

B.115 Peach Bottom Case 3 Drywe11 Beta Dose Rates ..............66

B.116 Peach Bottom Case 3 Drywell Total Beta Dose ..............67

B.117 Peach Bottom Case 3 Wetwell Gamma Dose Rate .............. B-68

B.118 Peach Bottom Case 3 Wetwell Total Gamma Dose ..............6-69

B.119 Peach Bottom Case 4 Drywel1 Gamma Dose Rate ............... . 70

B.120 Peach Bottom Case 4 Drywel1 Beta Dose Rate .................70

B.121 Peach Bottom Case 4 Drywell Total Gamma Dose ..............71

B.122 Peach Bottom Case 4 Drywel1 Total Beta Dose ................71

B.123 Peach Bottom Case 4 Wetwell Gamma Dose Rate ...............72

B.124 Peach Bottom Case 4 Wetwell Total Gamma Dose ...............72 
4.1

4.2

4.3

5.1

5.2

5.3

5.4

5.5

\section{6}

5.7

5.8

5.9

C. 1

C. 2

C. 3

C. 4

C. 5

C. 6

C. 7

C. 8

C. 9

C. 10

C. 11

C. 12

C. 13

C. 14

C. 15

C. 16

C. 17

C. 18

C. 19

C. 20

C. 21

C. 22

C. 23

C. 24

C. 25

C. 26

C. 27

C. 28

C. 29

C. 30

Surry Compartment Identification $\ldots \ldots \ldots \ldots \ldots \ldots \ldots \ldots \ldots$

Surry Dose Point Locations ....................... 17

Peach Bottom Dose Point Locations .................. 20

Case I Dose Rate and Total Dose.................... 30

Case 2 Dose Rate and Total Dose.................... 33

Case 3 Dose Rate and Total Dose.................... 36

Case 4 Dose Rate and Total Dose........................ 39

Peach Bottom Case 1 Dose Rate and Dose................ 46

Peach Bottom Case 2 Dose Rate and Total Dose........... 48

Peach Bottom Case 3 Dose Rate and Total Dose............ 50

Radionuclide Inventory Calculated by BCL .............. 54

Gamma Total Energies Used by PATH $\ldots \ldots \ldots \ldots \ldots \ldots \ldots \ldots \ldots$

Surry Case 1 Basement Gamma Dose Rates ...............

Surry Case 1 Basement Beta Dose Rates ................

Surry Case 1 Annulus Gamma Dose Rates ..................

Surry Case 1 Annulus Beta Dose Rates ................. 4

Surry Case 1 Dome Gamma Dose Rates .................. 5

Surry Case 1 Dome Beta Dose Rates ................... 6

Surry Case 1 Steam Generator A Cubicle Gamma Dose

Rates ................................. -7

Surry Case 1 Steam Generator A Cubicle Beta Dose

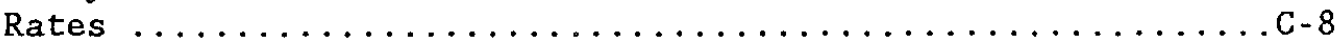

Surry Case 1 RHR Cubicle Gamma Dose Rates ................ 9

Surry Case 1 RHR Cubicle Beta Dose Rates ................ -10

Surry Case 2 Basement Gamma Dose Rates ................. -11

Surry Case 2 Basement Beta Dose Rates ................. -12

Surry Case 2 Annulus Gamma Dose Rates .................. C-13

Surry Case 2 Annulus Beta Dose Rates .................. 14

Surry Case 2 Dome Gamma Dose Rates ................... 15

Surry Case 2 Dome Beta Dose Rates ................... -16

Surry Case 2 Steam Generator A Cubicle Gamma Dose

Rates .................................. 17

Surry Case 2 Steam Generator A Cubicle Beta Dose

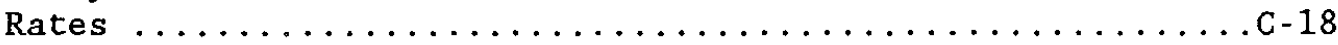

Surry Case 3 Basement Gamma Dose Rate ................. 19

Surry Case 3 Annulus Gamma Dose Rate .................. 20

Surry Case 4 Basement Gamma Dose Rate .................. 21

Surry Case 4 Annulus Gamma Dose Rate ................... 22

Peach Bottom Case 1 Drywell Gamma Dose Rates .............. 23

Peach Bottom Case 1 Drywe11 Beta Dose Rates ............... 26

Peach Bottom Case 1 Wetwe11 Gamma Dose Rates ............. -28

Peach Bottom Case 2 Drywe11 Gamma Dose Rates ............... 29

Peach Bottom Case 2 Drywell Beta Dose Rates ............... 33

Peach Bottom Case 2 Wetwel1 Gamma Dose Rates .............. 35

Peach Bottom Case 3 Wetwell Gamma Dose Rates .............. 36

Peach Bottom Case 4 Wetwell Gamma Dose Rates .............. 37 
D.1 Surry Major Radionuclide Contributors to Gamma Dose ........ D-1

D.2 Surry Major Radionuclide Contributors to Beta Dose ........D-5

D.3 Peach Bottom Drywe11 Major Radionuclide

D.4 Peach Bottom Drywell Radionuclide Contributors

D.5 Peach Bottom Wetwell Major Radionuclide Contributors

D.6 Peach Bottom Wetweli Major Radionuclide Contributors

to Beta Dose ............................ 21 


\section{Acknowledgment}

This study could not have been completed without the assistance of Sarah Higgins and Mike Luker of Sandia National Laboratories. I thank them for their patience, enthusiasm, and inexhaustible supply of energy. 


\section{EXECUTIVE SUMMARY}

Analytical investigations of potential beta and gamma radiation dose to selected regions in PWR and BWR containment buildings have been conducted for a range of fission product releases from selected severe accidents. Total dose was calculated for the selected severe accident sequences using NUREG-0956 methods. Battelle Columbus Laboratory (BCL) has calculated time-dependent distributions of radionuclides within containment following severe accident scenarios using the NRC source term code package. The selected LWR severe accident conditions did not satisfy the design basis accident (DBA) criteria but were realistic estimates of severe accidents that have many characteristics of the prescribed DBA as used in the equipment qualification rule 10CFR50.49 and Regulatory Guide 1.89. Sandia National Laboratories (SNL) used the resulting radionuclide distributions to calculate radiation dose in containment. The dose calculation results provide a basis to evaluate the extent to which DBA qualified equipment is also qualified for the selected severe accident environments.

Surry was chosen to be the representative PWR plant because it is one of the NUREG-1150 reference plants for which many source term code package analyses have been performed. Peach Bottom was selected as a representative BWR plant due to available source term code package work that supported the preparation of NUREG-0956. Both plants have been extensively analyzed and are representative of a large number of plants.

The accident scenario selected by BCL for the PWR analysis was the AB epsilon scenario. The $A B$ epsilon scenario is an intermediate to large LOCA with failure to recover onsite or offsite electrical power. BCL noted that this scenario would produce the most severe radionuclide release into containment. Three additional variations of the $A B$ epsilon scenario were developed to envelope the radionuclide release for less severe accidents. The first variation investigated the effect of reestablishing core cooling and arresting the sequence before vessel failure by removing all radionuclide contribution from the core-concrete attack period. Variation two simulated spray operation with full core meltdown. All airborne activity (except noble gas activity) and surface activity were washed to the sump. The third variation was an arrested sequence with spray operation. No leakage from containment to the environment was assumed in any of the cases.

The BWR accident scenario selected to determine radionuclide release to containment was the $\mathrm{AE}$ sequence. The $\mathrm{AE}$ sequence is a large break LOCA with one initiating event and a combination of failures in two emergency cooling systems. The $\mathrm{AE}$ sequence is analogous to the $\mathrm{PWR} A \mathrm{AB}$ sequence. Three additional variations of the $\mathrm{AE}$ scenario were also developed to bound the radionuclide release. These variations were identical in nature to the PWR variations for no core-concrete attack and containment spray operation.

Calculated radionuclide releases for the source terms were time dependent locational distributions within containment following the accident. Locational distribution refers to airborne radionuclide release, radionuclide plateout on walls, radionuclide deposition to floors, or radionuclide release washed into the sump. The BCL Surry PWR source term 
calculations treated the containment as a single volume and the Peach Bottom BWR source term calculations treated the containment as two volumes (the drywell and wetwell).

Gamma dose rate was calculated by Sandia using the PATH point kernel code. PATH calculations are based upon exponential attenuation from source point to dose point with appropriate adjustment by buildup factors. PATH was developed at General Atomic. Beta dose rates were calculated using the ITS code. ITS calculations use Monte Carlo solution of linear time-integrated electron radiation transport.

Combinational geometry subroutines in PATH and ITS allowed true modeling of each room or containment region in both Surry and Peach Bottom. Major structures such as walls, ceilings, and floors were modeled for each containment. Rooms and containment regions were generally further divided into subzones for beta dose calculations.

The results of this study represent a scoping effort and provide approximate estimate of dose. The radionuclide release for the airborne, plateout, and waterborne sources was assumed to be uniformly distributed throughout containment at each calculational time period. Containment models were kept relatively simple due to the scoping nature of this study. The calculations do allow the effects of engineering safety features (ESF) operation from case to case to be compared. The effect of compartment size and structure on dose will also be evident from the results.

The accident scenario calculations with sprays operational for the Surry PWR resulted in a maximum total dose of $2.60 \times 10^{8}$ rads in interior compartments, $1.80 \times 10^{8}$ rads in the basement, $2.3 \times 10^{8}$ rads in the annulus, and $7.3 \times 10^{7}$ rads in the dome region. Maximum Peach Bottom total dose during spray operation was calculated to be $1.10 \times 10^{8}$ rads in the drywell. For comparison, Reg Guide 1.89, Appendix D, suggests an equipment qualification dose of $2.20 \times 10^{8}$ rads. Safety-related equipment is currently tested through $-2.2 \times 10^{B}$ rads. Radionuclide release to containment during spray operation appears to pose no significant challenge to equipment tested to $2.20 \times 10^{8}$ rads.

The base Surry AB epsilon severe accident scenario calculations resulted in maximum total doses of $2.3 \times 10^{9}$ rads in interior compartments, $3 \times$ $10^{9}$ rads in the basement, $1.2 \times 10^{9}$ rads in the annulus, and $1.7 \times 10^{9}$ rads in the dome region. Peach Bottom severe accident calculations resulted in a maximum total dose of $1.8 \times 10^{9}$ rads in the drywe11. The calculated total dose is roughly an order of magnitude above current equipment qualification testing limits.

The results from this study suggest two follow-on tasks. Studies designed to calculate the physical transport of radionuclides from the release point in containment to other parts of containment should be performed. Assuming instantaneous radionuclide dispersement in containment results in low dose rate calculations in the release zone and conservative dose rate calculations far from the release point. The base case Surry and Peach Bottom beta surface dose rate calculations should be re-examined with more finely divided zoned regions; this exercise should result in improved (and possibly lower) dose calculations. 


\subsection{INTRODUCTION}

During a loss-of-coolant accident (LOCA), reactor core fuel damage may occur resulting in release of fission product inventory from the core to the containment. Brookhaven National Laboratory published an early analysis (WASH-740) ${ }^{1}$ of a nuclear power plant accident and fission product release in 1957 . This publication specified the radiation source term to be an instantaneous release of 50 percent of the noble gases, 50 percent of the halogens, and 50 percent of the solid fission products from the reactor fuel. The WASH-740 source term was believed to represent an upper bound; the release values were assumed high due to lack of technical data at the time. Fission product transport from the core to the rest of containment was not analyzed. Current accident source terms were reestimated in TID 14844.2 The TID source term is similar to the WASH-740 source term and assumes 100 percent release of noble gases, 50 percent release of iodine, and 1 percent release of solid fission products. The fission product release pathway or physical phenomena were not modeled or analyzed in either study. Current NRC Regulatory Guides use the TID source terms as representative values for an upper bound credible accident source term. These source term values form the basis for the current radiation environment under which safetyrelated equipment must be qualified to operate.

The Accident Source Term Program was initiated by the NRC after the Three Mile Island Unit 2 accident. The scope of the program included assessing the technical basis for predicting severe accident source terms, to develop improved methods of analysis, and to determine whether the existing treatment of source terms in the regulatory process was conservative. The results of the NRC staff reassessment of analytical procedures for estimating accident source terms were published in NUREG-0956, "Reassessment of the Technical Bases for Estimating Source Terms,": in June $1986 . .^{3}$ The report recommended that the Source Term Code Package (STCP) be used as a basis for source term analyses; the STCP represents an improved approach to predicting severe accident source terms.

The objective of this SNL study was to determine the radiation dose that safety related equipment could experience during the severe accident sequences using updated source terms based on NUREG-0956 methods. Battelle Columbús Laboratory (BCL) developed time-dependent distributions of radionuclides within containment following a severe accident using the STCP. The radionuclide release for the LWR accident conditions were realistic estimates of severe accidents that have many of the characteristics of the prescribed DBA as used in the equipment qualification rule 10CFR50.49 and Regulatory Guide 1.89.4 Sandia National Laboratories used the radionuclide distribution supplied by $B C L$ to calculate radiation dose in containment. The source term and dose calculation results will demonstrate the extent to which DBA qualified equipment would also be qualified for severe accident environments. 


\subsection{SOURCE TERM CALCULATIONS}

Source term calculations were performed for a PWR containment (Surry) and a BWR containment (Peach Bottom). Surry was chosen as a representative PWR containment because it is one of the NUREG-1150 reference plants for which a number of STCP analyses have been performed. Peach Bottom was also chosen due to STCP work performed to support the preparation of NUREG-0956. Both plants have been extensively analyzed and are representative of a large number of plants.

\subsection{Surry Source Term Calculations}

Three accident scenarios were considered for the Surry source term calculations: $\quad A B$ epsilon, $S_{2} D$ epsilon, and TMLB epsilon. BCL concluded that the $A B$ epsilon scenario would provide the best basis for analyzing equipment radiation dose and dose rates. BCL noted that the $A B$ epsilon scenario involved the fastest core meltdown due to early core uncovery, there was little radionuclide retention in the reactor coolant system, there was no overlying pool of water in the reactor cavity which could scrub out the released radionuclides, and there was no operation of containment sprays which could lead to rapid removal of airborne radionuclides. The conditions listed above would produce a radionuclide release into containment simulating a severe accident.

Four variations of the $A B$ epsilon scenario were developed to provide an envelope of radionuclide release. Case 1 STCP was the base case with full core meltdown; the results were taken directly from the STCP analyses. No leakage to the environment from containment was assumed; therefore, the results were renormalized to account for any predicted leakage to the environment by the STCP analyses. The Case 1 calculation ended at 24 hours at which time airborne radionuclides other than the noble gases were assumed to be deposited to surfaces. Case 2 investigated the effect of reestablishing core cooling and arresting the sequence without RPV failure. The radionuclide contribution from the core-concrete attack period was thus removed. Case 3 simulated containment spray operation by removing all airborne radioactivity (except noble gas activity) instantaneously to the sump. No activity was assumed to remain on the containment surfaces. Case 3 also involved full core meltdown. Case 4 was an arrested sequence with spray operation and simulated a design basis accident. Airborne activity in Case 4 was transferred directly to the sump and no activity was assumed on the containment surfaces.

For all cases, ORIGEN2 calculations were performed to determine the time dependent inventory of radionuclides during the first year following the accident. The ORIGEN2 calculations were needed because the codes used to calculate dose rate to equipment require the activity of all released radionuclides as a function of time. 


\subsection{Peach Bottom Source Term Calculations}

$\mathrm{BCL}$ selected the $\mathrm{AE}$ sequence to use for calculating radionuclide release to containment for a severe accident. The $A E$ sequence is analogous to the $P W R A B$ sequence. The characteristics of the $A E$ sequence which made it appropriate to use as a base case are early core uncovery and fission product release, little retention in the reactor coolant system, direct release of radionuclides to the drywell during the in-vessel melting period, large ex-vessel release of fission products, and no operation of the drywell spray.

Four variations of the $\mathrm{AE}$ sequence were also developed to bound the radionuclide release to containment. Case 1 was the base case with full core meltdown. Any leakage which was predicted to occur after containment failure by the STCP was reassigned to the airborne species in the drywe11. Case 2 was an arrested sequence; the contribution due to the core-concrete attack was removed from the results. Case 3 simulated drywell spray operation by removing all airborne radionuclides to the suppression pool. No activity was assumed to remain on the drywell surfaces. Full core meltdown was assumed. Case 4 simulated an arrested sequence with drywell sprays operating and approximates a design basis accident.

An ORIGEN2 calculation was also performed for the Peach Bottom Source term calculations.

Sections 1.0 and 2.0 of the text have summarized the text from NUREG/CR 4949, "Source Term Calculations for Assessing Radiation Dose to Equipment." This work was performed by Battelle Columbus Laboratory. The reader is referred to NUREG/CR-4949 for greater detail regarding the source term calculations.

Source term is defined in this report to be the release of radioactive material from the core to the containment. Release of radioactive material from the containment to the environment was not considered in this report.

Radionuclide releases for the source terms were time-dependent locational distributions within containment following the severe accident. The locational distributions refer to airborne radionuclide release, radionuclide diffusion to walls, radionuclide deposition to floors, and radionuclide release to the sump. The Surry PWR source term calculations treated the containment as a single volume and the Peach Bottom BWR source term calculations treated the containment as two volumes (the drywell and the wetwel1). 


\subsection{RADIATION DOSE CALCULATIONAL TOOLS}

Two computer codes were used to calculate radiation dose rate in containment for the radioactive beta and gamma fission product source terms calculated by BCL. One code (PATH) was used to calculate gamma dose rate, and the second code (ITS) was used to calculate beta dose rate.

The PATH ${ }^{5}$ code is a shielding code which uses the common point-kernel integration technique to treat gamma radiation from reactors, radioactive components, and complex piping systems. The code is based upon exponential attenuation from source point to dose point with appropriate adjustment by buildup factors. PATH's major features include complex geometry capability, various source options, and an extensive data library for radionuclides. The PATH code was developed by the General Atomic Company .

Beta or electron dose rates were calculated using ITS" "The Integrated Series of Coupled Electron/Photon Monte Carlo Transport Codes." This series of codes allow the state-of-the-art Monte Carlo solution of linear time-integrated coupled electron/photon radiation transport problems. Physical rigor of the codes has been maintained by using the best available cross sections and sampling distributions as well as the most complete physical model for describing the production and transport of electron/photon cascade from $1.0 \mathrm{GeV}$ to $1.0 \mathrm{keV}$. The particular code version chosen out of the integrated TIGER series (ITS) was ACCEPT. The ACCEPT code provides the ability to calculate electron transport through three-dimensional multimaterial geometries. The ITS was developed at Sandia National Laboratories. 


\subsection{CONTAINMENT MODELS}

The volume of the Surry containment building is approximately $1,750,000$ cubic feet $\left(5.0 \times 10^{10} \mathrm{~cm}^{3}\right)$. The geometry of the structure is considerably different from a large dry containment in that it is highly compartmentalized with the only large open volumes being the dome and operating floor. The containment model used in Surry was similar to that used in the ANS Source Term Study. ${ }^{7}$ Two longitudinal sections of the building are shown in Figures 4.1 and 4.2. Plan views of the reactor building are shown in Figures 4.3 through 4.6. The compartments are identified in Table 4.1.

Each room in the Surry containment building (Table 4.1) was modeled for the gamma dose rate calculations with the PATH code through use of available combinatorial geometry subroutines. The Surry containment building rooms were generally further subdivided for the beta dose rate calculations using combinatorial geometry subroutines available in ITS. Appendix A shows the containment building zones used for the beta dose rate calculations.

Beta and gamma dose rates were calculated for representative points in the dome, operating floor, upper annulus, lower annulus, basement, the incore instrumentation room, the residual heat removal (RHR) cubicle, steam generator A cubicle, and steam generator B cubicle. The dose point locations (A-J) for the dome, operating floor, upper annulus, and lower annulus are shown in Figures 4.1 and 4.3. The dose point locations (A-I) for the basement are shown in Figure 4.4. Figure 4.5 illustrates the dose point locations (A-E) for the RHR cubicle and steam generator A cubicle. Figure 4.6 shows the incore instrumentation room and steam generator $B$ cubicle dose point locations (A-E). Table 4.2 lists the containment building coordinates for all of the dose point locations. Dose point locations are given in terms of $x, y$, and $z$ coordinates in feet. The $x$ and $y$ axes are labeled in Figures 4.3 through 4.6.

The Peach Bottom containment is divided into two zones. The drywell has a light bulb shape with the stem of the bulb pointing upward. The drywell is connected to a toroidal wetwell at the base of the inverted bulb. The drywell and wetwell are made of steel. The drywell volume is approximately 159,000 cubic feet $\left(4.5 \times 10^{9} \mathrm{~cm}^{3}\right)$, and the wetwell volume is approximately 119,000 cubic feet $\left(3.37 \times 10^{9} \mathrm{~cm}^{3}\right.$ ). A longitudinal section of the Peach Bottom nuclear power plant is shown in Figure 4.7.

The Peach Bottom drywell was modeled as one volume for the gamma dose rate calculations. The reactor vessel and its pedestal were also modeled in place as illustrated in Figure 4.7. The wetwe11 was modeled in two zones; that of the torus itself and the torus room which surrounds the torus. The drywell was further subdivided for the beta dose rate calculations. The drywell zones used for the beta dose rate calculations are illustrated in Appendix A. 


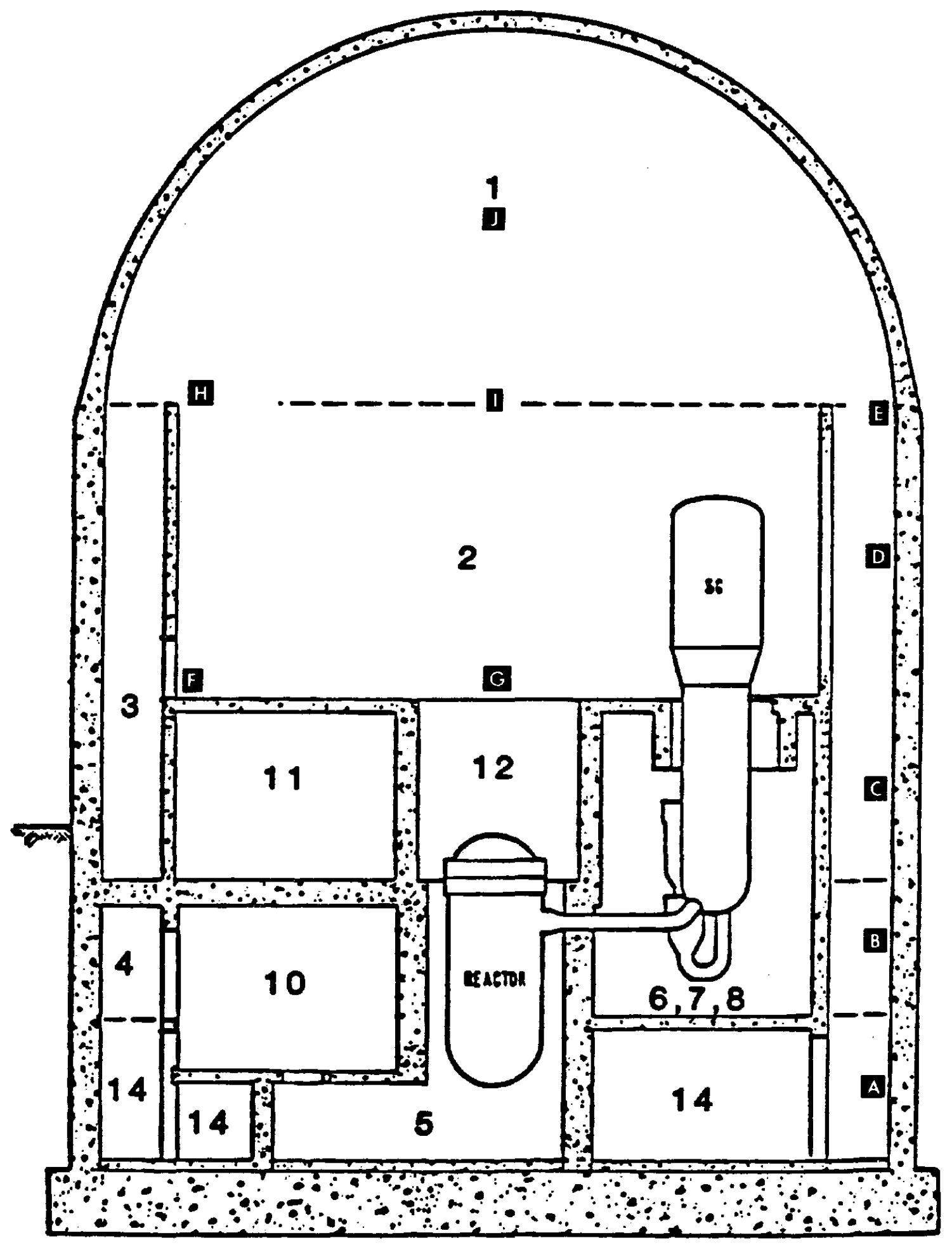

Figure 4.1. Surry Containment Section A 


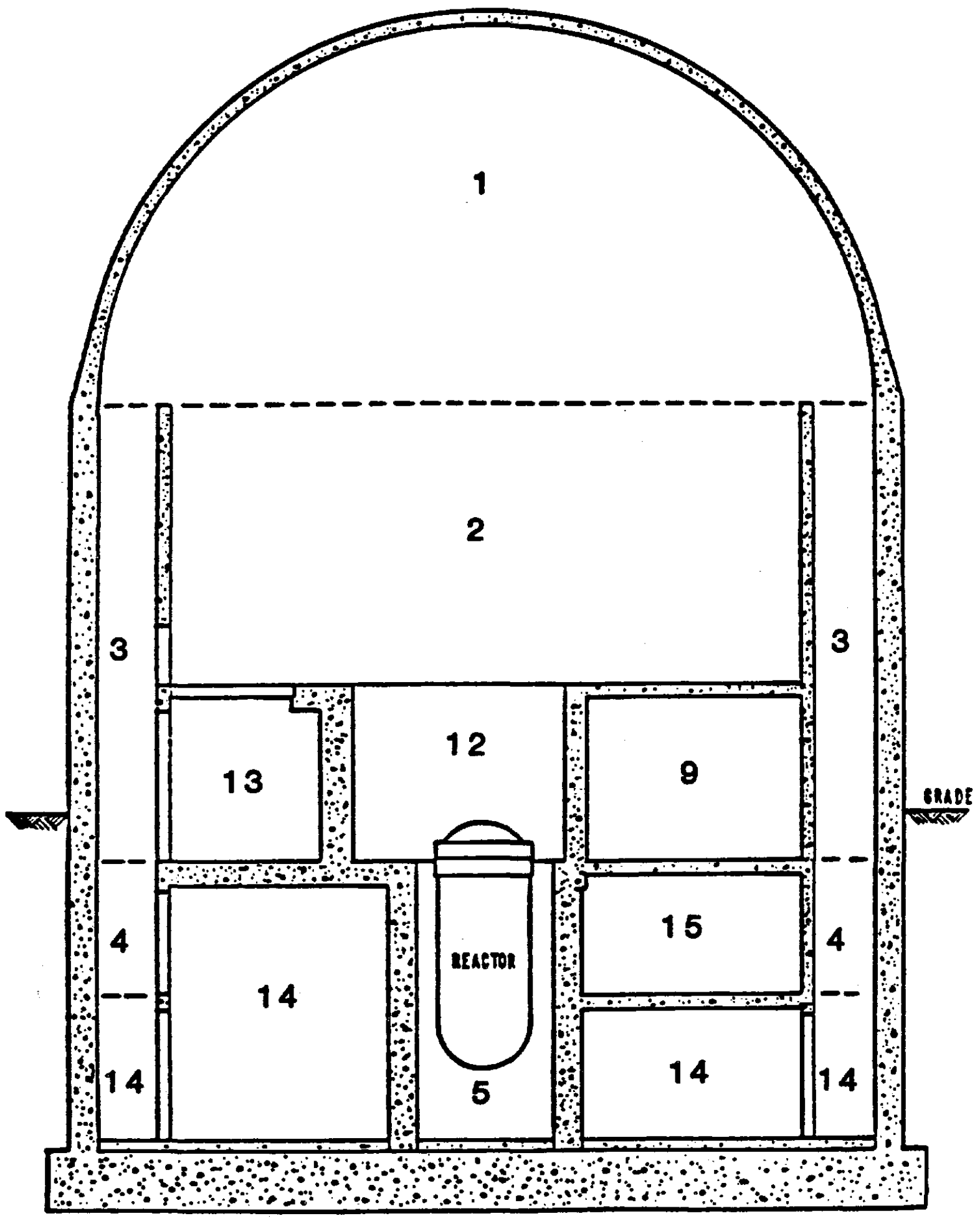

Figure 4.2. Surry Containment Section B 


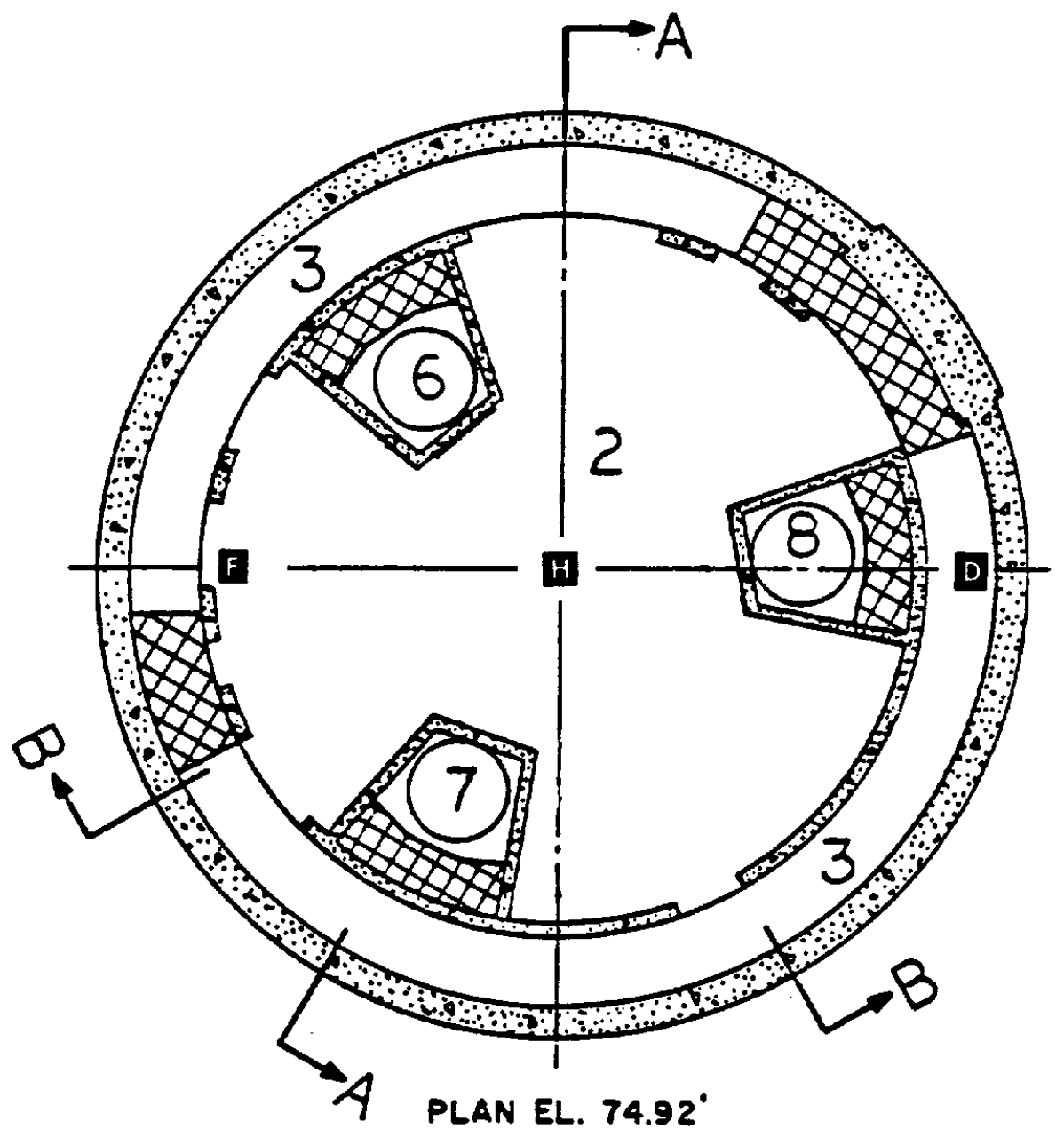

Figure 4.3. Surry Plan View Elevation 74.92 Feet 


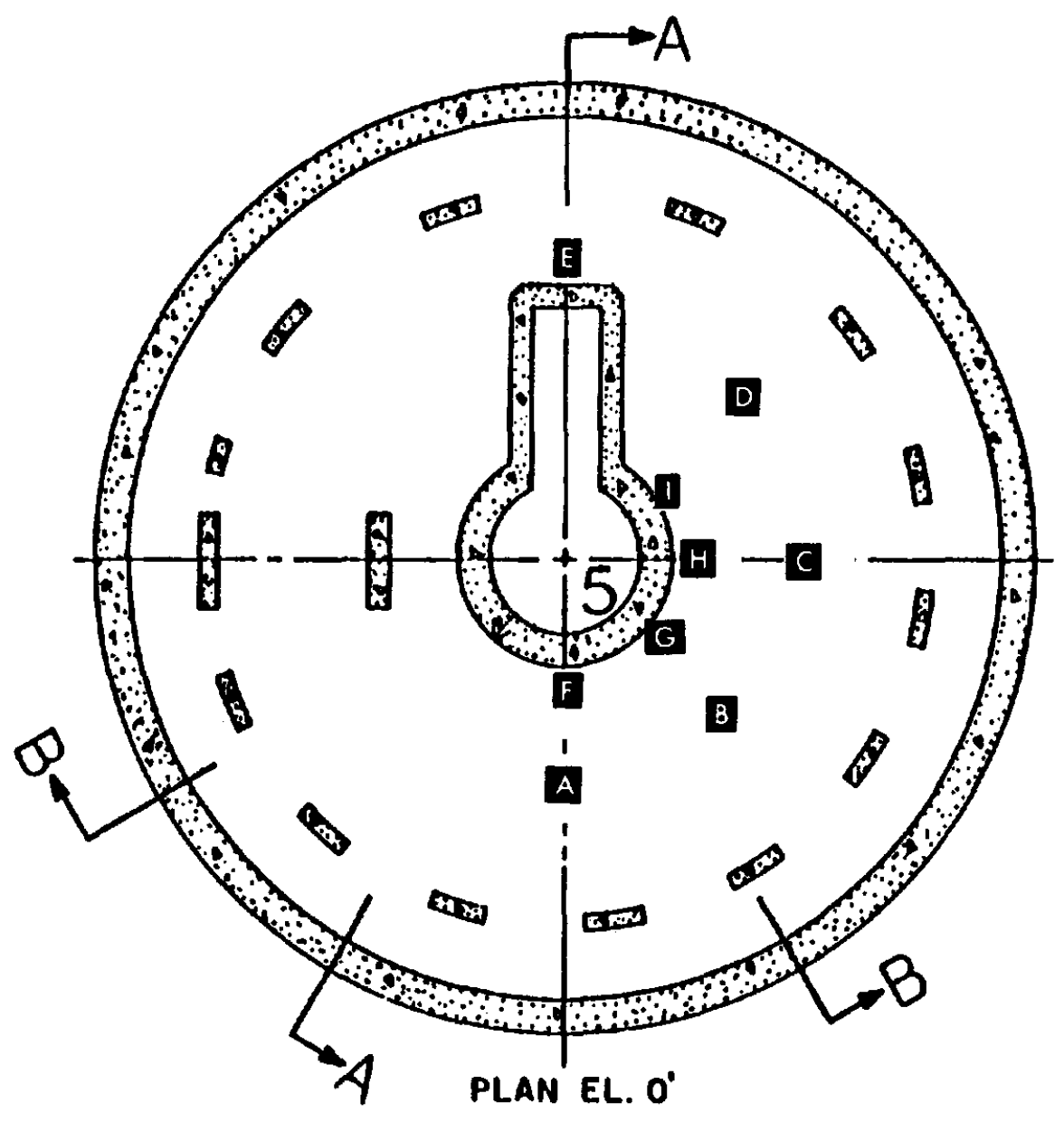

Figure 4.4. Surry Plan View Elevation 0 Feet 


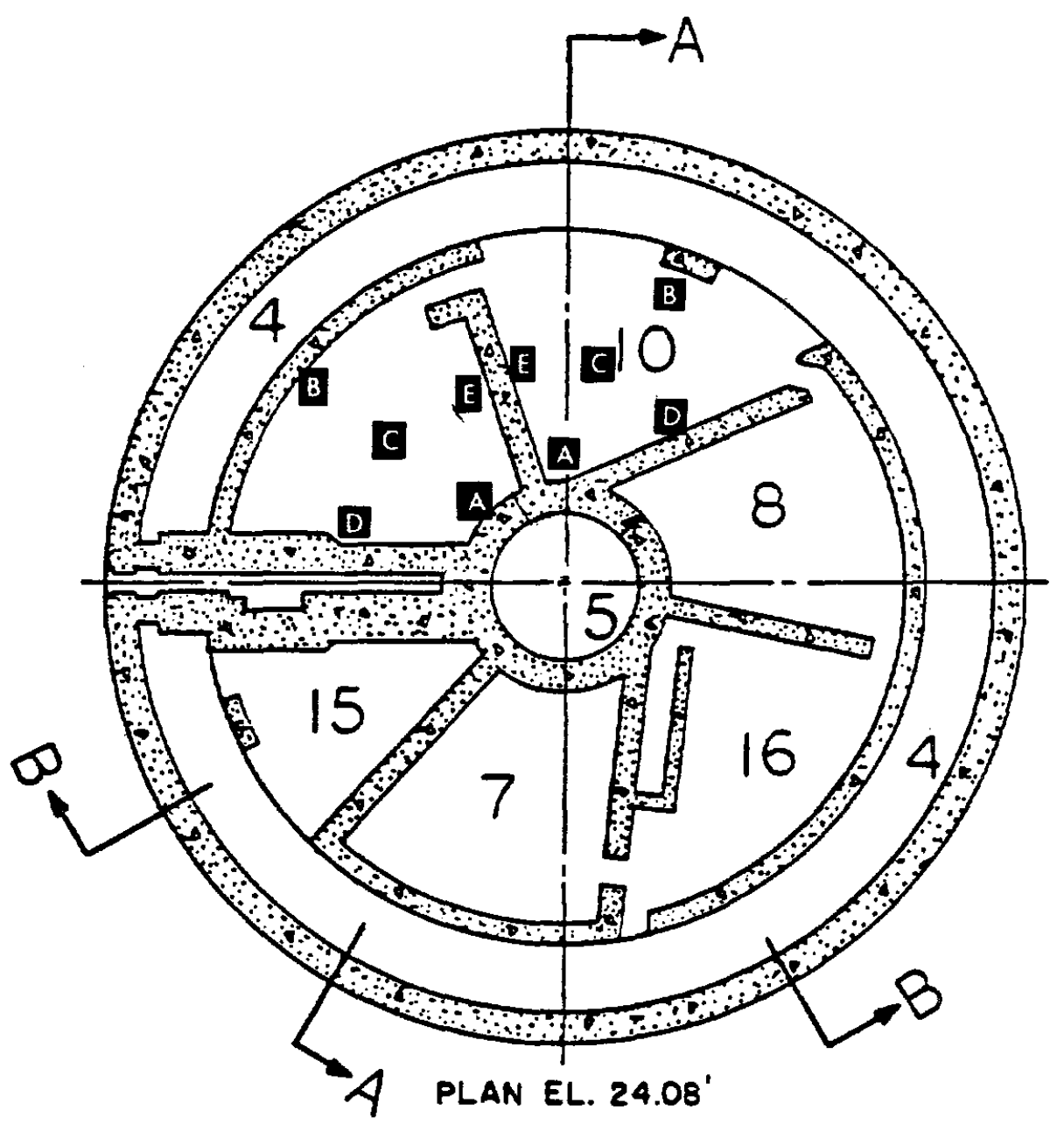

Figure 4.5. Surry Plan View Elevation 24.08 Feet 


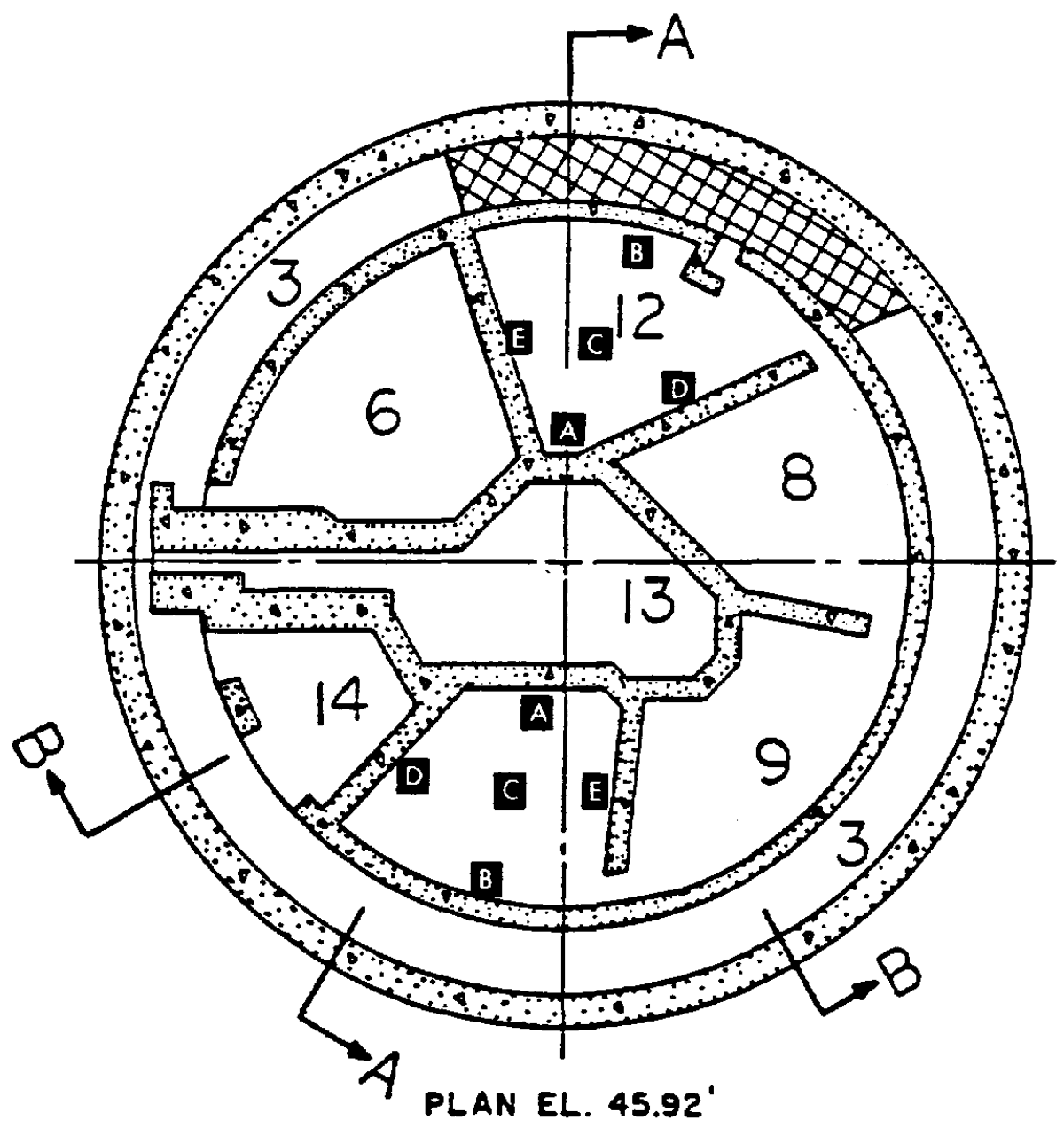

Figure 4.6. Surry Plan View Elevation 45.92 Feet 
Table 4.1

Surry Compartment Identification

Compartment No.

1

2

3

4

5

6

7

8

9

10

11

12

13

14

15
Compartment

Dome

Operating Floor

Upper Annulus

Lower Annulus

Reactor Cavity

Steam Generator A Cubicle

Steam Generator B Cubicle

Steam Generator C Cubicle

Pressurizer Cubicle

RHR Cubicle

Incore Instrumentation Room

Refueling Cavity

Upper Hoist Space

Basement

Pressurizer Relief Tank Cubicle
Volume

$\left(f t^{3}\right)$

519,633

347,065

263,512

75,915

11,678

46,834

40,529

42,363

24,613

30,315

31,114

33,032

13,847

253,757

18,793 
Table 4.2

Surry Dose Point Locations

\section{Dose Point}

Dome, Operating Floor, and Annulus
A
B
C
D
E
F
G
$\mathrm{H}$
$\mathrm{I}$

Basement

$\begin{array}{rrr}0.0 & -39.3 & 12.0 \\ -27.8 & -27.8 & 12.0 \\ 39.3 & 0.0 & 12.0 \\ 27.8 & 27.8 & 12.0 \\ 0.0 & 39.3 & 12.0 \\ 0.0 & -16.0 & 12.0 \\ -11.3 & -11.3 & 12.0 \\ 16.0 & 0.0 & 12.0 \\ 11.3 & 11.3 & 12.0\end{array}$

RHR Cubicle
A
B
C
D
E

Steam Generator A Cubicle

Location ( $f t)$

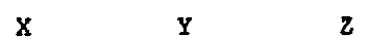

$\begin{array}{rrr}63.0 & 0.0 & 12.0 \\ 63.0 & 0.0 & 34.0 \\ 63.0 & 0.0 & 59.5 \\ 63.0 & 0.0 & 97.5 \\ 63.0 & 0.0 & 120.0 \\ 0.0 & -51.0 & 75.0 \\ 0.0 & -51.0 & 120.0 \\ 0.0 & 0.0 & 75.0 \\ 0.0 & 0.0 & 120.0 \\ 0.0 & 0.0 & 150.0\end{array}$

$\begin{array}{lll}63.0 & 0.0 & 12.0 \\ 63.0 & 0.0 & 34.0\end{array}$

$\begin{array}{lll}63.0 & 0.0 & 59.5\end{array}$

$\begin{array}{lll}63.0 & 0.0 & 97.5\end{array}$

$\begin{array}{lll}63.0 & 0.0 & 120.0\end{array}$

$\begin{array}{lll}0.0 & -51.0 & 75.0\end{array}$

$\begin{array}{lll}0.0 & -51.0 & 120.0\end{array}$

$\begin{array}{lll}0.0 & 0.0 & 120.0\end{array}$

$\begin{array}{lll}0.0 & 0.0 & 150.0\end{array}$
A
B
C
D

$\begin{array}{lll}-3.0 & 14.7 & 28.0\end{array}$

$\begin{array}{lll}14.0 & 46.6 & 28.0\end{array}$

$\begin{array}{lll}5.5 & 30.8 & 28.0\end{array}$

$\begin{array}{lll}17.1 & 23.0 & 28.0\end{array}$

$\begin{array}{lll}-7.7 & 30.9 & 28.0\end{array}$

$\begin{array}{lll}-11.5 & 10.6 \quad 48.5\end{array}$

$\begin{array}{lll}-36.8 & 31.3 & 48.5\end{array}$

$\begin{array}{lll}-24.2 & 21.0 & 48.5\end{array}$

$\begin{array}{lll}-32.5 & 7.0 & 48.5\end{array}$

$\begin{array}{lll}-11.9 & 30.5 & 48.5\end{array}$ 
Table 4.2

Surry Dose Point Locations (Concluded)

\section{Dose Point}

Steam Generator B Cubicle

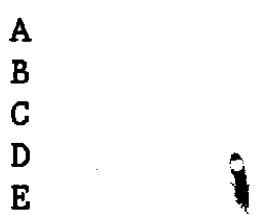

Incore Instrumentation Room

\begin{tabular}{rcc}
\multicolumn{3}{c}{ Location (ft) } \\
\hline $\mathrm{X}$ & $\mathrm{Y}$ & $\mathrm{z}$ \\
& & \\
5.8 & -21.4 & 48.5 \\
-12.2 & -48.2 & 48.5 \\
-3.2 & -34.8 & 48.5 \\
-23.5 & -28.1 & 48.5 \\
7.0 & -35.5 & 48.5
\end{tabular}

$\begin{array}{lll}-0.7 & 15.7 & 59.5\end{array}$

$\begin{array}{lll}18.9 & 45.8 \quad 59.5\end{array}$

$9.1 \quad 30.8 \quad 59.5$

$\begin{array}{lll}19.5 & 23.8 & 59.5\end{array}$

$\begin{array}{lll}-8.2 & 31.8 & 59.5\end{array}$ 


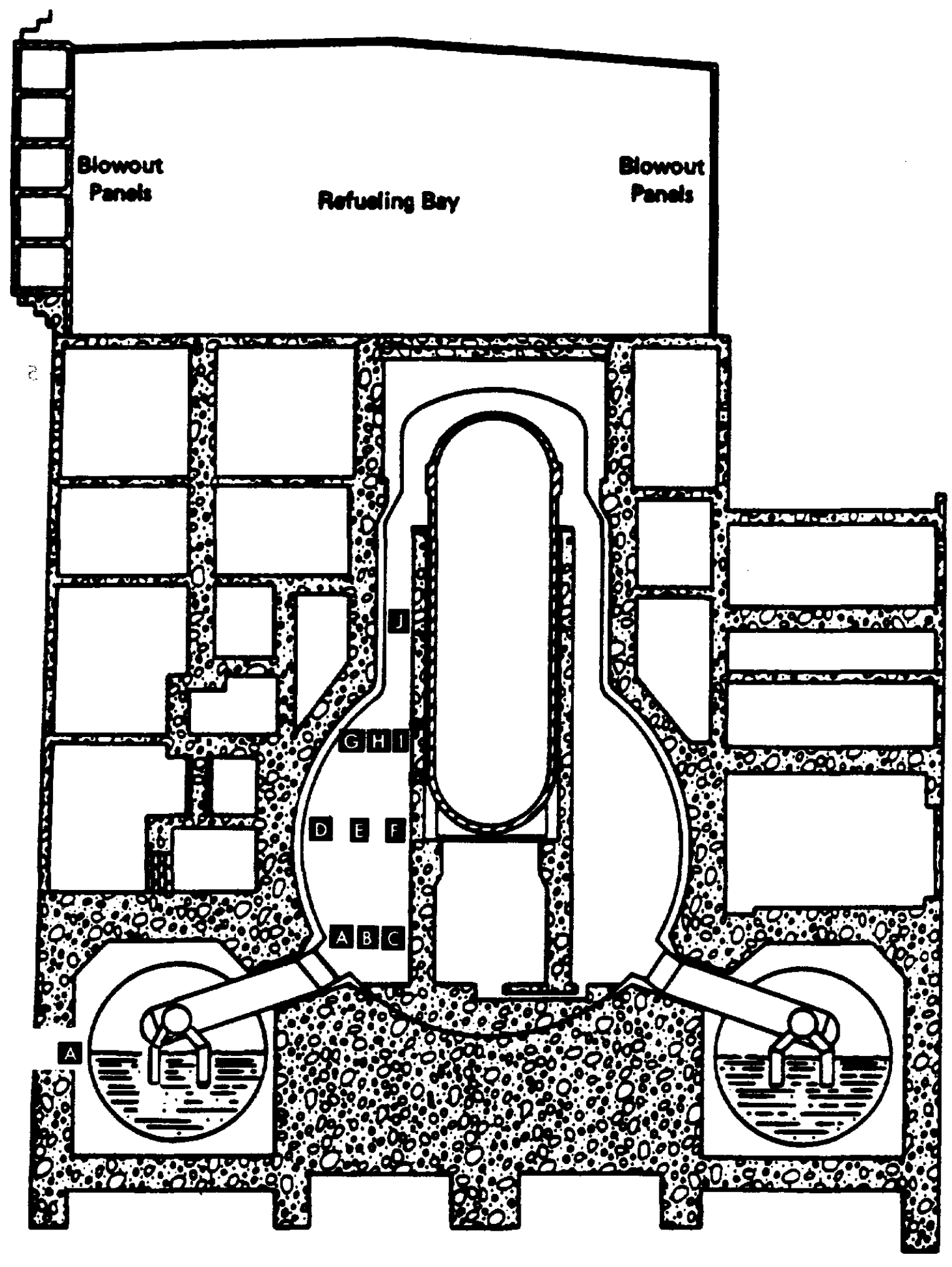

Figure 4.7. Peach Bottom Containment Section 
Beta and gamma doses were calculated for representative points in the drywell and wetwell torus room. Dose point locations for the drywell and torus room are shown in Figure 4.7. Location $J$ in the drywell represents three dose points at the same drywell elevation. Location $A$ in the wetwell represents two dose points at the midpoint elevation of the torus. The first wetwell point is in the torus room and the second wetwell point is in one of the quad rooms. Table 4.3 lists the dose point coordinates for the drywell and torus room.

Table 4.3

Peach Bottom Dose Point Locations

Dose Point

Drywe11

A

B

C

D

E

F

G

$\mathrm{H}$

I

J

K

L

Wetwel1

\begin{tabular}{ccc}
\multicolumn{3}{c}{ Location $(f t)$} \\
\hline$x$ & $y$ & $z$ \\
& & \\
26.8 & 0.0 & 126.7 \\
20.1 & 0.0 & 126.7 \\
13.9 & 0.0 & 126.7 \\
32.0 & 0.0 & 145.0 \\
23.3 & 0.0 & 145.0 \\
13.9 & 0.0 & 145.0 \\
26.7 & 0.0 & 163.6 \\
20.3 & 0.0 & 163.6 \\
13.9 & 0.0 & 163.6 \\
18.8 & 0.0 & 187.2 \\
16.4 & 0.0 & 187.2 \\
13.9 & 0.0 & 187.2
\end{tabular}

$-52.5-51.0$

112.6

$\begin{array}{lll}-56.0 & -54.0 & 112.6\end{array}$




\subsection{DOSE RESULTS}

The dose rate and dose results presented in this report represent a scoping effort to obtain an estimate of dose rate and dose. Containment models were kept relatively simple due to the scoping nature of this study. Experience gained in using PATH, ITS, and the containment models will provide better insight into using these tools for future accident dose calculations.

Dose rate is very specific to containment building structure and timedependent spatial distribution of radionuclides as well as knowledge of radionuclide energy release and accident scenarios. The radionuclide release for the airborne, plate-out, and waterborne sources was assumed to be uniformly distributed throughout containment; multicompartment radionuclide transport throughout containment after the accident scenarios was beyond the scope of this work. Treating the source as uniformly spatially distributed is expected to result in high estimates of dose in the surry containment building during early time periods in the accident. Other studies have assumed uniform distribution in PWR containments that are relatively open and have modeled the containments as large open cylinders. Treating source terms as being uniformly distributed in Peach Bottom should produce reasonable results because the drywell is relatively open, and uniform mixing could also be expected to occur for radionuclide release into the wetwell.

These calculations also allow the relative magnitudes of dose and dose rate for each case to be compared. The effects of ESF operation can also be compared from case to case.

The effect of compartment size and structure on dose rate and total dose will also be evident from the results. Modeling of major equipment was beyond the scope of this work. All compartments and regions in containment are modeled as open rooms. Major structural features such as floors, walls, and ceilings have been taken into account.

\subsection{Surry Dose Results}

Four variations of the $A B$ epsilon scenario were calculated. This scenario involves an intermediate to large LOCA with failure to recover onsite or offsite electrical power. Containment vessel meltthrough occurs. Case 1 is the base case or the $A B$ epsilon scenario itself. Case 2 investigates the effect of arresting the base scenario; all coreconcrete attack radionuclide release is removed. Case 3 is the base case with sprays operational; all airborne activity (except noble gas) has been removed to the sump. Containment surfaces are assumed to have no activity. Full core meltdown occurs. Case 4 is similar to Case 3 but is an arrested sequence.

The results are presented in terms of dose rate and total dose to selected containment regions. Figures are used to illustrate combined airborne, wall, floor, or sump total doses. Abbreviated tables are used to present combined airborne, wall, floor, or sump dose rates at one hour and one year; the integrated total dose at one year for these source 
terms is also presented in the abbreviated table. Detailed tables are presented in Appendix $C$, which break out the individual airborne, wall, floor, or sump contribution to dose rates for selected containment locations.

\subsubsection{Case 1 Dose Results}

Figures 5.1.1 and 5.1.2 illustrate total dose for the Case 1 accident at the basement dose point locations A through $I$. Basement integrated gamma dose at one year ranged from 1.7 to $2.7 \times 10^{8}$ rads. Basement integrated beta dose at one year ranged from 0.97 to $2.8 \times 10^{9}$ rads. Appendix $C$ lists the relative dose rate contributions of the airborne, wa11, and floor sources for representative locations in containment. Tables C.1 and C.2 indicate that the floor source was the leading contributor to gamma and beta dose at location $A$ in the basement. The wall source contribution to total gamma dose at location $F$ showed a substantial increase when compared to location A but did not surpass the contribution due to the floor source. For total beta dose at location F, the wall source and floor source contributions to total dose were approximately equivalent.

Total dose for the Surry annulus is shown in Figures 5.1.3 and 5.1.4. Gamma dose was largest for the location point at the top of the annulus which views the rest of the dome region and at the bottom of the annulus which views the rest of the basement region. Beta dose was highest at the bottom of the annulus. Annulus integrated gamma and beta dose ranged from 0.6 to $1.0 \times 10^{8}$ rads and 0.25 to $1.1 \times 10^{9}$ rads, respectively. The wall source was the major contributor to gamma total dose for annulus locations $\mathrm{C}$ and $\mathrm{E}$; both the floor and wall source were major contributors to gamma total dose at location A (Table C.3). The airborne and wall sources were the major contributors to beta total dose at locations $C$ and $\mathrm{E}$; the floor source made no contribution to total beta dose at $\mathrm{C}$ and $\mathrm{E}$. Both source contributions were roughly equivalent. The floor, wall, and airborne sources were approximately equal contributors to beta total dose at location A (Table C.4).

Operating floor and dome total dose are illustrated in Figures 5.1 .5 and 5.1.6. Gamma dose was highest at the top of the operating floor while beta dose was highest near the walls and floors of the operating floor. Gamma total dose at one year ranged from 0.57 to $1.90 \times 10^{8}$ rads. Beta total dose ranged from $1.1 \times 10^{8}$ rads in the dome center to $1.8 \times 10^{9}$ rads along the walls and floors of the operating floor. The floor and wall sources were major contributors to gamma total dose at locations $\mathrm{H}$, $I$, and $\mathrm{J}$. The airborne source term was also a significant contributor to total dose through 8 hours but rapidly decayed thereafter (Table C.5). Major contributors to the total beta dose at location $J$ were the airborne and wall sources; the operating floor source made no contribution. The airborne source was the only significant contributor to total beta dose at location I; wall and floor source contributions were minor. Total beta dose at location $H$ was due to the airborne and wall sources (Table C.6). 

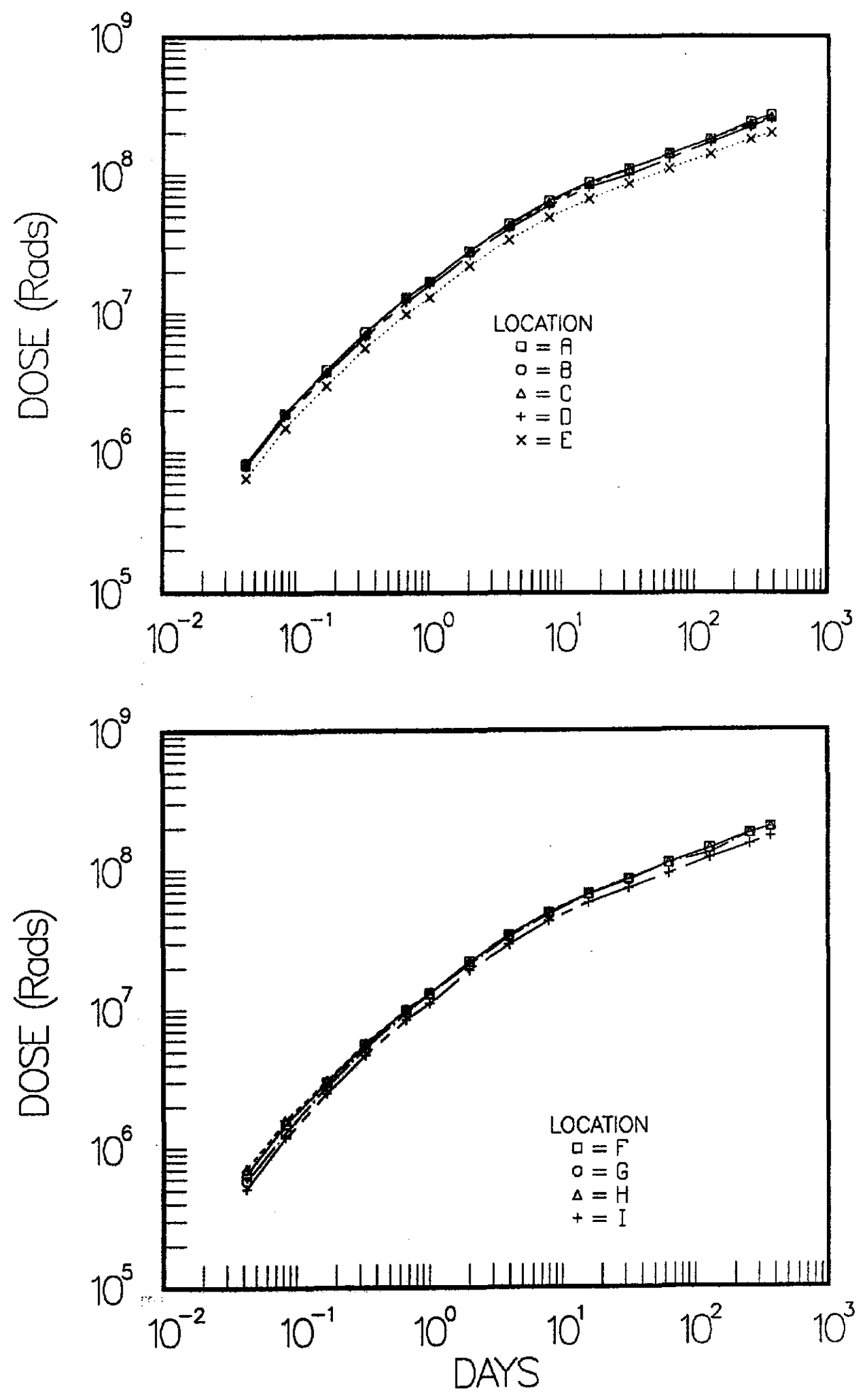

Figure 5.1.1. Surry Case 1 Basement Total Gamma Dose 

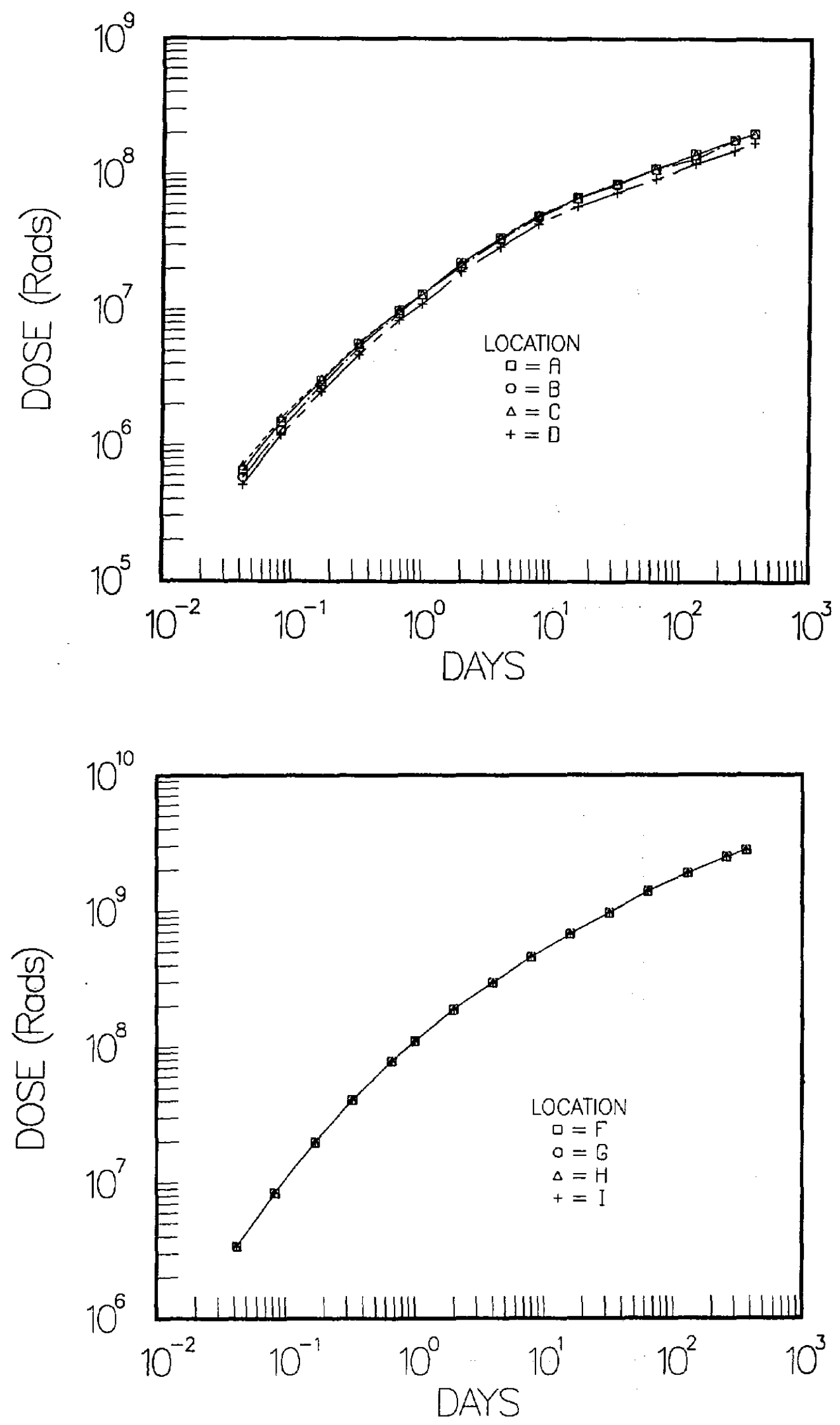

Figure 5.1.2. Surry Case 1 Basement Total Beta Dose 


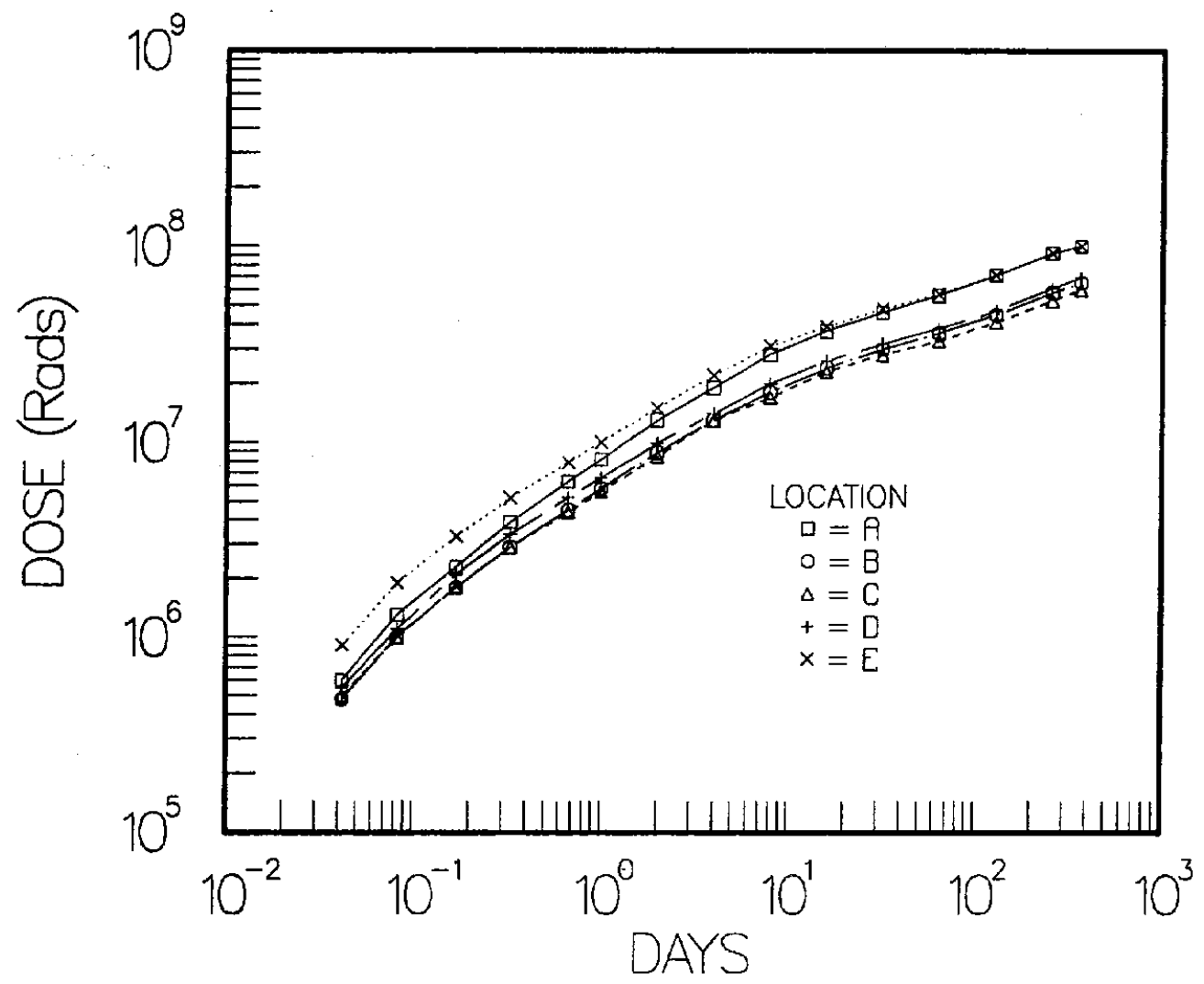

Figure 5.1.3. Surry Case 1 Annulus Total Gamma Dose

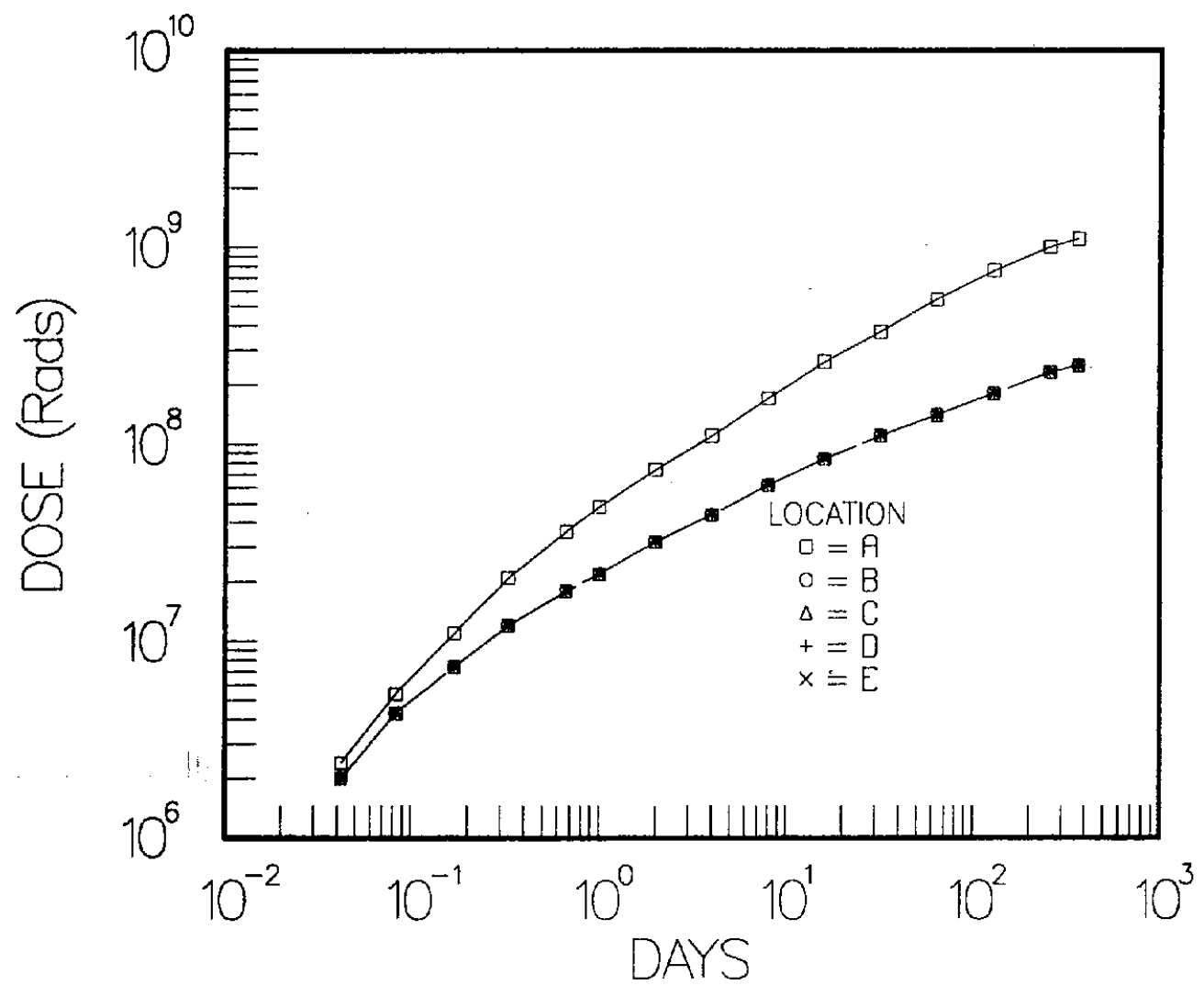

Figure 5.1.4. Surry Case 1 Annulus Total Beta Dose 


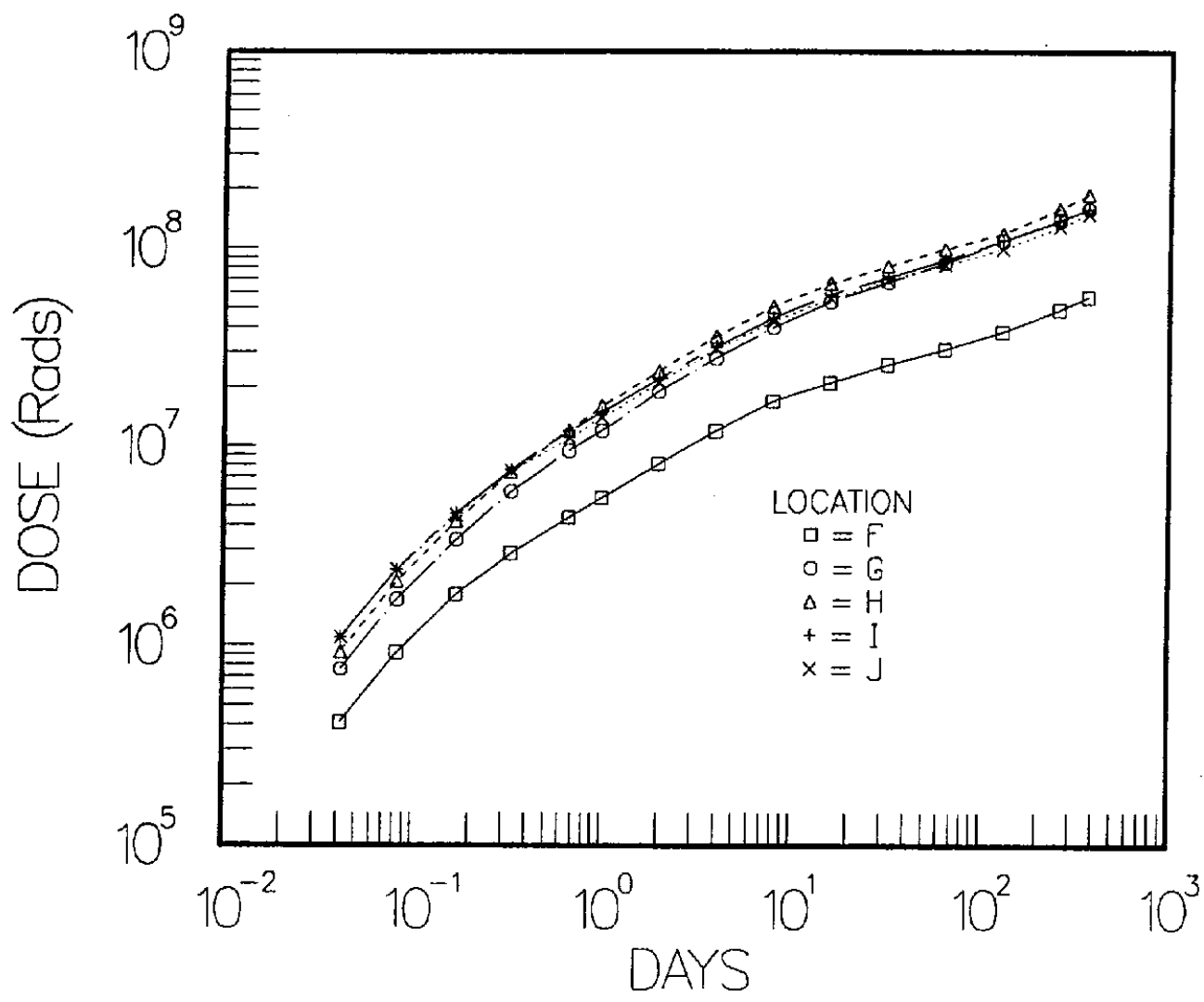

Figure 5.1.5. Surry Case 1 Operating Floor and Dome Total Gamma Dose

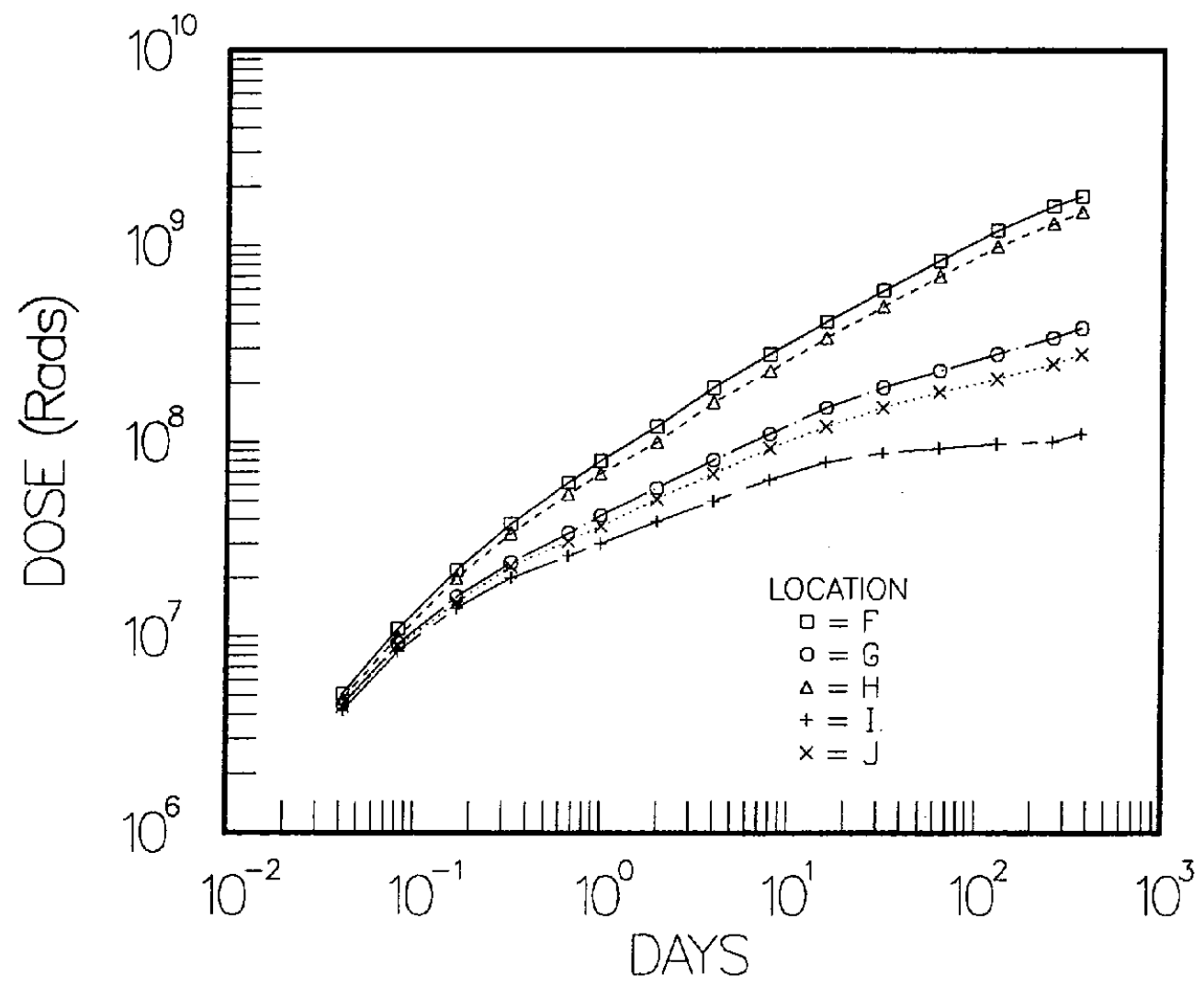

Fígure 5.1.6. Surry Case 1 Operating Floor and Dome Total Beta Dose 
Figures 5.1.7 and 5.1.8 show total dose for the steam generator A cubicle. Gamma dose showed minor fluctuation with respect to cubicle position. Beta dose rate at the walls also showed minor variations with respect to wall location. Beta dose rate at the compartment center was significantly decreased compared to beta dose rate at the walls (wall and floor sources had less effect at the compartment center). Total gamma dose for the cubicle ranged from $6.8 \times 10^{7}$ rads to $8.9 \times 10^{7}$ rads. Total beta dose along the walls at one year ranged from $1.3 \times 10^{9}$ to $2.2 \times 10^{9}$ rads, and total centerline beta dose at one year was approximately $1.7 \mathrm{x}$ $10^{8}$ rads. The wall sources were the major contributors to locations $D$ and $\mathrm{E}$ for total gamma dose. Contribution to total dose at location $\mathrm{C}$ was equally distributed between the wall and floor sources (Table C.7). The floor, wall, and airborne sources were approximately equivalent contributors to the total beta dose at locations $D$ and $E$; the airborne source was the major contributor to dose at location C (Table C.8).

The gamma and beta dose rate figures corresponding to Figures 5.1.1 through 5.1.8 are shown in Appendix B. Steam generator B cubicle dose rate and dose figures were similar to those of steam generator $A$ cubicle and are shown in Appendix $B$.

The RHR cubicle total dose is pictured in Figures 5.1.9 and 5.1.10. The RHR cubicle has a volume of $30315 \mathrm{ft}^{3}$ compared to the steam generator A cubicle volume of $46834 \mathrm{ft}^{3}$. Gamma dose was lower than that in the steam generator $A$ cubicle and showed almost no variation with respect to cubicle position. As in the steam generator A cubicle, beta dose at the walls was higher than the centerline beta dose rate. However, the difference between the centerline and wall dose rate in the RHR cubicle was not as great as the difference in the steam generator A cubicle because the RHR cubicle is 25 percent smaller than the steam generator A cubicle.

The in-core instrumentation room calculated dose rate and total dose values were similar to those of the RHR cubicle and are shown in Appendix B.

Table 5.1 partially summarizes the dose rate and total dose values by presenting the gamma and beta dose rates at 1 hour and 1 year for each location. Gamma and beta total dose is listed at one year.

The gamma and beta dose rate and dose are tabularized in Appendix $\mathrm{C}$. for each calculated time period and according to airborne, wall, floor, or sump source. 


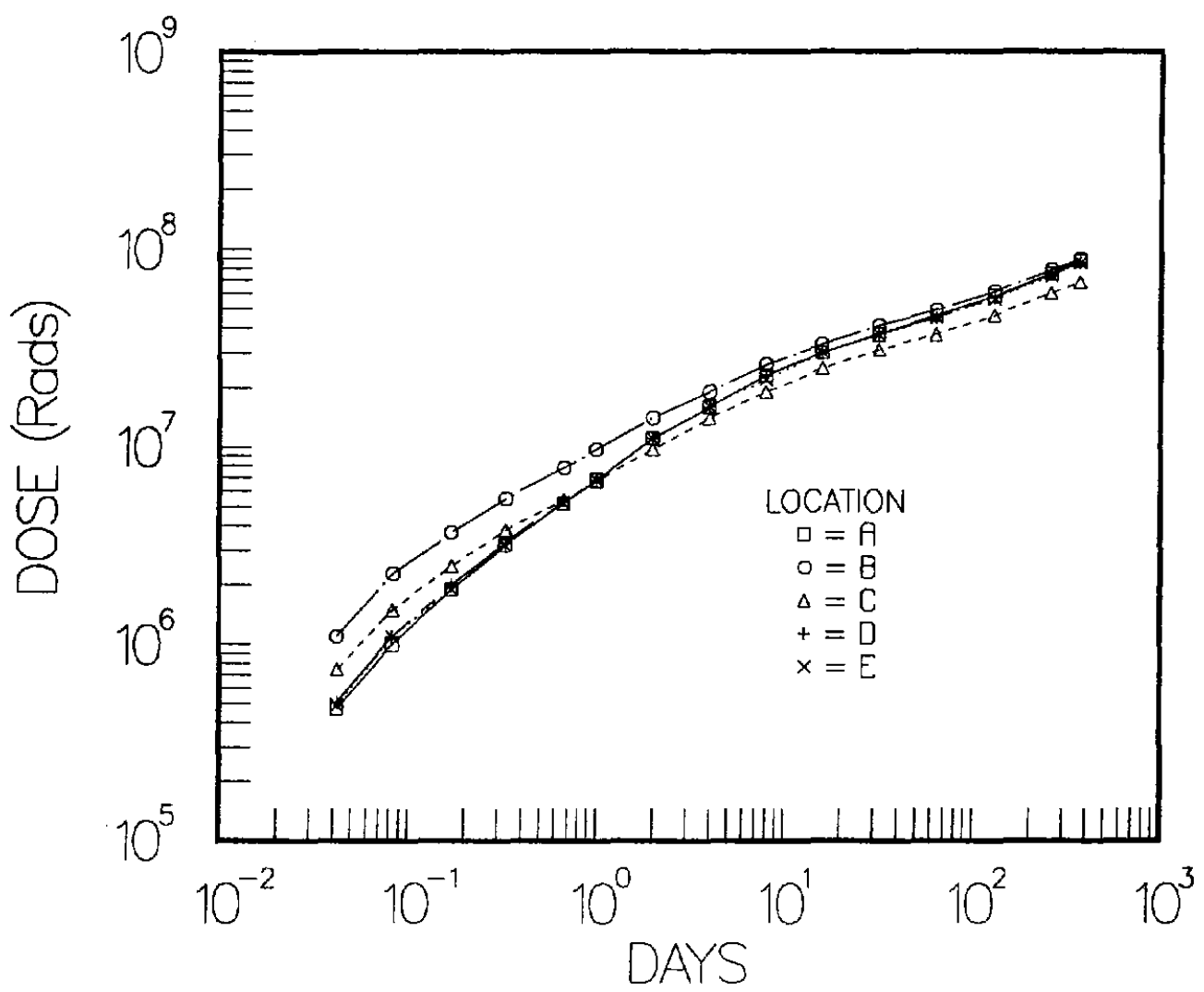

Figure 5.1.7. Surry Case 1 Steam Generator A Cubicle Gamma Total Dose

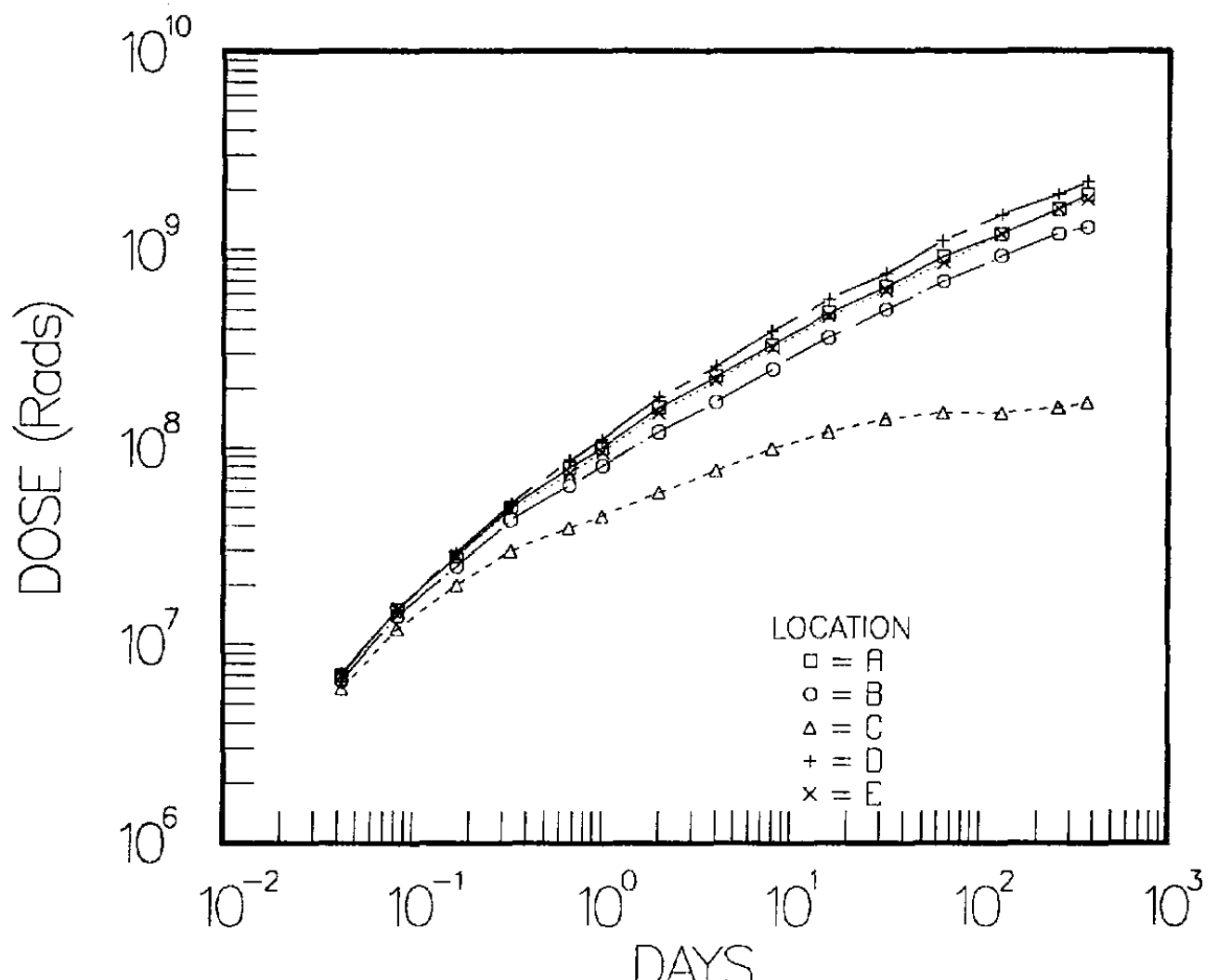

Figure 5.1.8. Surry Case 1 Steam Generator A Cubicle Beta Total Dose 


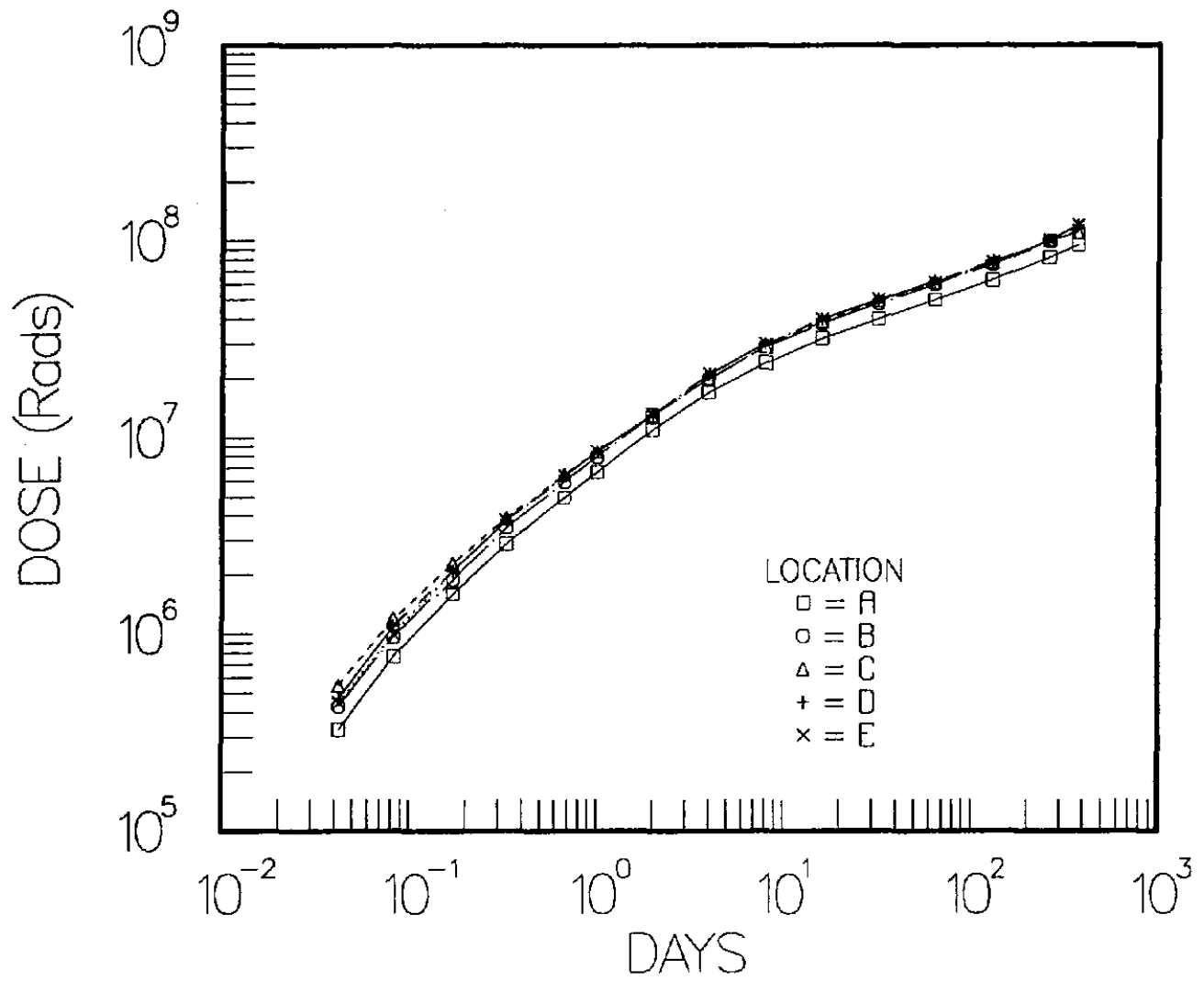

Figure 5.1.9. Surry Case 1 RHR Cubicle Total Gamma Dose

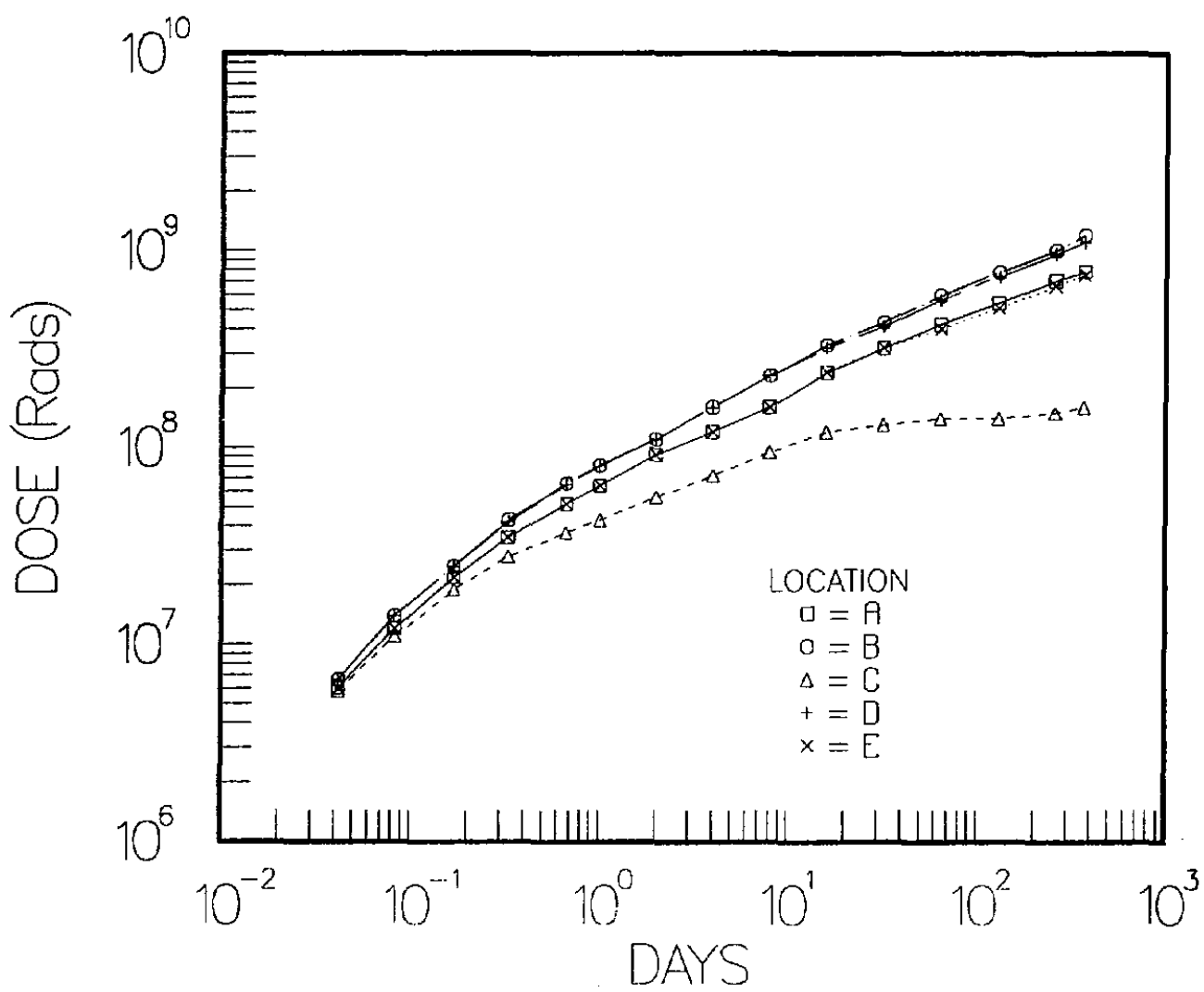

Figure 5.1.10. Surry Case 1 RHR Cubicle Total Beta Dose 
Table 5.1

Case 1 Dose Rate and Total Dose

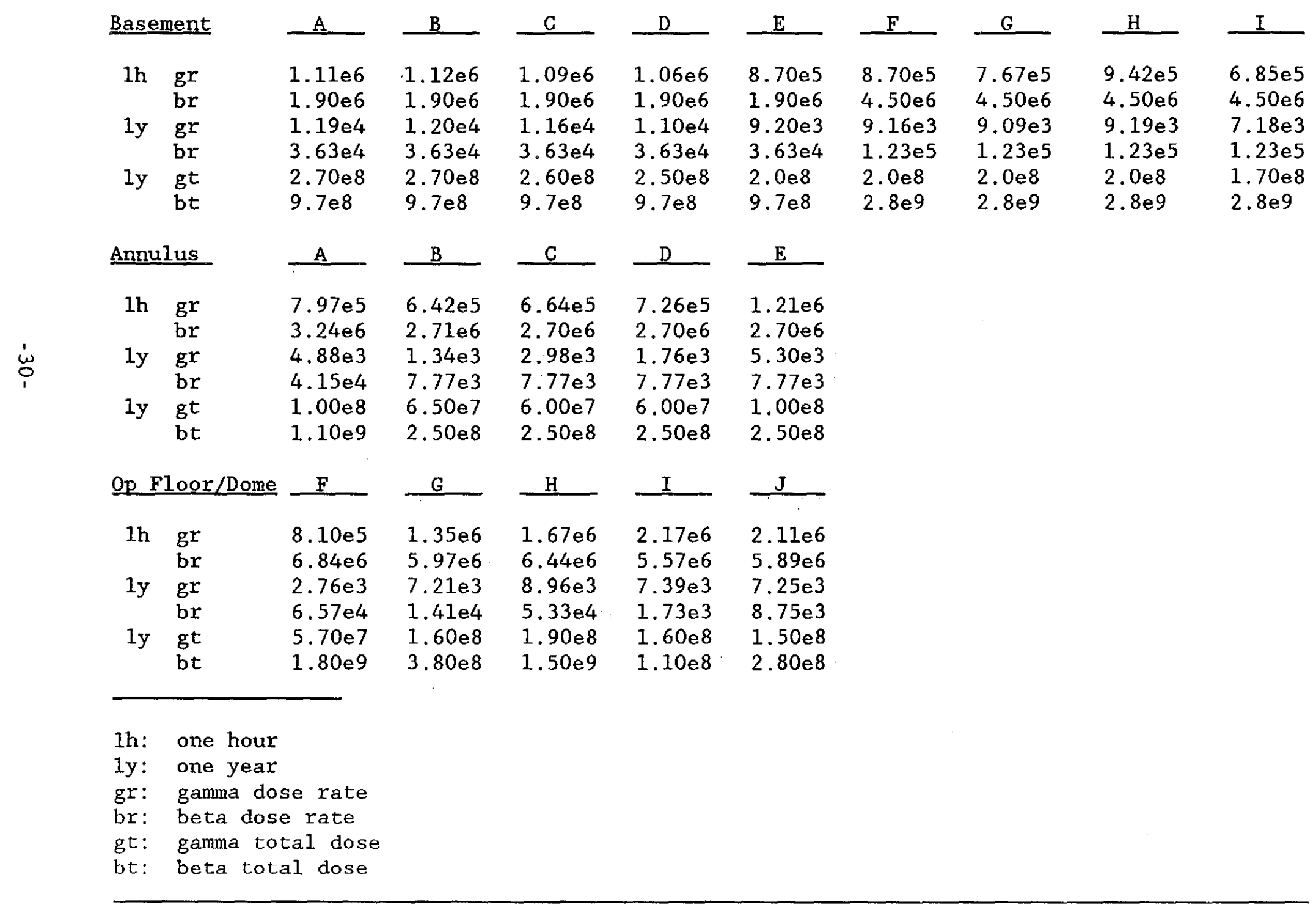


Table 5.1

Case 1 Dose Rate and Total Dose (Continued)

\begin{tabular}{|c|c|c|c|c|c|c|}
\hline \multicolumn{2}{|c|}{ RHR Cubicle } & A & B & $\mathrm{C}$ & $\mathrm{D}$ & $\mathrm{E}$ \\
\hline \multirow[t]{2}{*}{ Ih } & $g r$ & $4.40 \mathrm{e} 5$ & $5.70 \mathrm{e} 5$ & $7.30 \mathrm{e} 5$ & $6.30 \mathrm{e} 5$ & $6.03 \mathrm{e} 5$ \\
\hline & br & $8.03 e 6$ & $8.83 e^{6}$ & $7.66 \mathrm{e} 6$ & $8.81 \mathrm{e} 6$ & $8.03 e 6$ \\
\hline \multirow[t]{2}{*}{$1 \mathrm{y}$} & gr & $4.46 \mathrm{e} 3$ & $5.31 \mathrm{e} 3$ & $5.14 \mathrm{e} 3$ & $5.44 \mathrm{e} 3$ & $5.40 \mathrm{e} 3$ \\
\hline & br & $2.70 \mathrm{e} 4$ & $6.10 \mathrm{e} 4$ & $2.83 \mathrm{e} 3$ & $4.76 \mathrm{e} 4$ & $2.70 \mathrm{e} 4$ \\
\hline \multirow[t]{2}{*}{$1 \mathrm{y}$} & gt & $9.5 \mathrm{e} 7$ & $1.10 \mathrm{e} 8$ & $1.10 \mathrm{e} 8$ & $1.20 \mathrm{e} 8$ & $1.20 \mathrm{e} 8$ \\
\hline & bt & $7.8 \mathrm{e} 8$ & $1.20 \mathrm{e} 9$ & $1.60 \mathrm{e} 8$ & $1.10 \mathrm{e} 9$ & $7.50 \mathrm{e}$ \\
\hline \multicolumn{2}{|c|}{ Steam Gen A } & A & B & $\mathrm{C}$ & D & $\mathrm{E}$ \\
\hline \multirow[t]{2}{*}{$1 \mathrm{~h}$} & $\mathrm{gr}$ & $6.30 \mathrm{e} 5$ & $1.52 \mathrm{e} 6$ & $9.95 \mathrm{e} 5$ & $6.74 \mathrm{e} 5$ & $6.56 \mathrm{e} 5$ \\
\hline & br & $9.36 e 6$ & $8.83 \mathrm{e} 6$ & $8.03 e 6$ & $9.50 \mathrm{e} 6$ & $9.32 \mathrm{e} 6$ \\
\hline \multirow[t]{2}{*}{$1 y$} & $\mathrm{gr}$ & $4.12 \mathrm{e} 3$ & $4.01 \mathrm{e} 3$ & $3.02 \mathrm{e} 3$ & $4.01 \mathrm{e} 3$ & $4.00 \mathrm{e} 3$ \\
\hline & br & $6.83 \mathrm{e} 4$ & $4.23 \mathrm{e} 4$ & $2.78 \mathrm{e} 3$ & $8.67 \mathrm{e} 4$ & $7.05 \mathrm{e} 4$ \\
\hline \multirow[t]{2}{*}{$1 y$} & gt & $8.70 \mathrm{e} 7$ & $8.90 \mathrm{e} 7$ & $6.80 \mathrm{e} 7$ & $8.50 \mathrm{e} 7$ & $8.50 \mathrm{e} 7$ \\
\hline & bt & $1.90 \mathrm{e} 9$ & $1.30 \mathrm{e} 9$ & $1.70 \mathrm{e} 8$ & $2.20 \mathrm{e} 9$ & $1.80 \mathrm{e} 9$ \\
\hline
\end{tabular}

\footnotetext{
1h: one hour

1y: one year

gr: gamma dose rate

br: beta dose rate

gt: gamma total dose

bt: beta total dose
} 


\subsubsection{Case 2 Dose Results}

The Case 2 scenario simulated resumption of emergency core cooling and arresting core meltdown by removing the core-concrete radionuclides calculated in Case 1. Removal of radionuclide activity attributed to the core-concrete attack period resulted in lower dose rates at the selected dose point locations. Table 5.2 summarizes the dose rate and total dose values for gamma and beta radiation and may be compared to Table 5.1 to see the effect of arresting core meltdown. For example, Case 1 basement total gamma and beta dose were $1.7 \times 10^{8}$ to $2.7 \times 10^{8}$ rads and $0.97 \times 10^{9}$ to $2.8 \times 10^{9}$ rads, respectively. Corresponding Case 2 basement total gamma and beta dose were calculated to be $1.1 \times 10^{8}$ to $1.5 \times 10^{8}$ rads and $0.18 \times 10^{9}$ to $1.3 \times 10^{9}$ rads, respectively. The reductions in total dose were due mainly to reductions in activity of the floor and wall sources; the airborne source activity also decreased but not as significantly as the floor and wall sources. The trends noted for Case 1 also apply to the results of Case 2 .

Gamma and beta dose rate values for Case 2 are shown in Appendix B. Airborne, wall, and floor contributions for selected containment locations are listed in Appendix $C$. 
Table 5.2

Case 2 Dose Rate and Total Dose

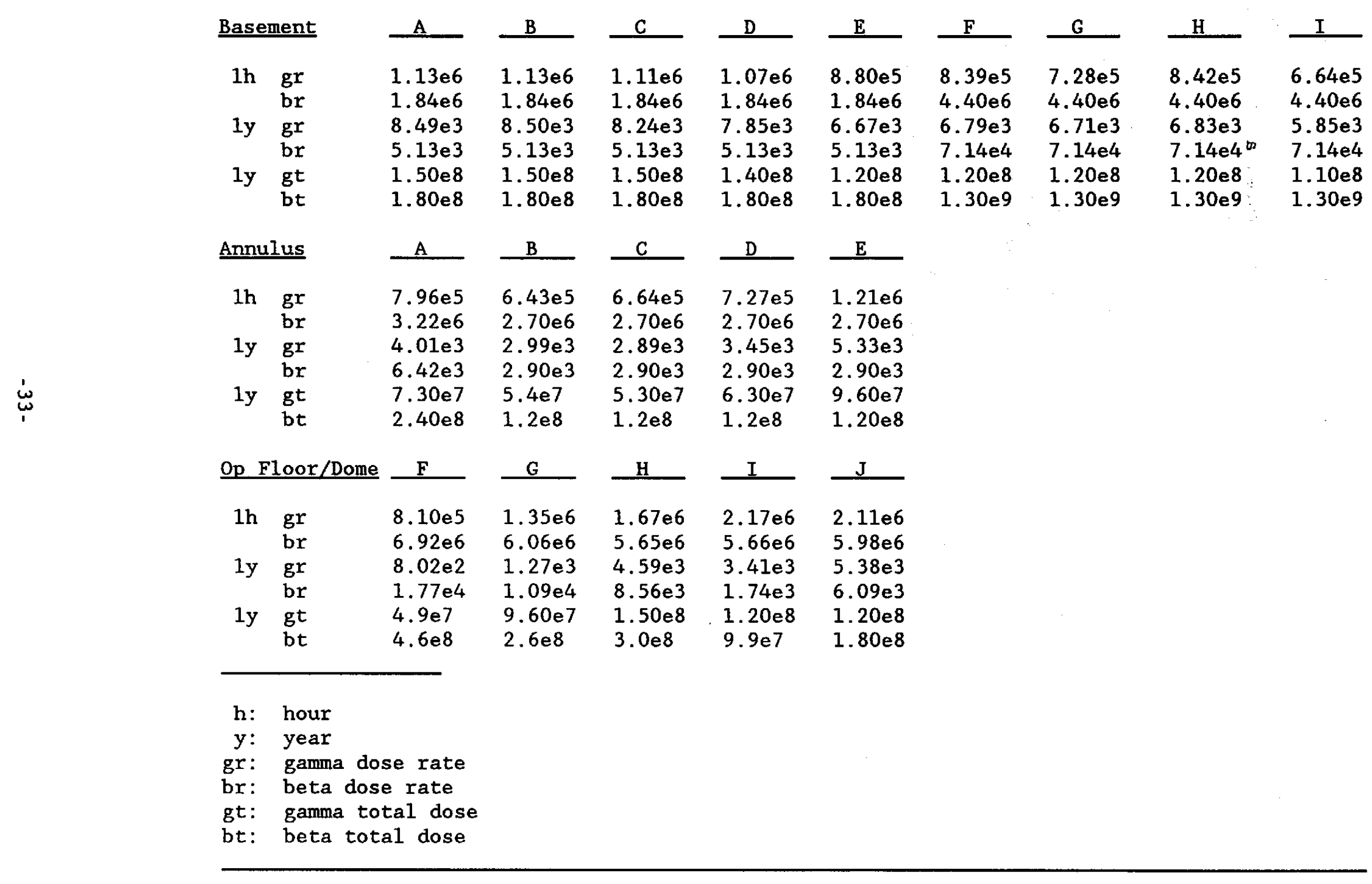


Table 5.2

Case 2 Dose Rate and Total Dose (Continued)

\begin{tabular}{|c|c|c|c|c|c|c|}
\hline RHR C & bicle & A & B & C & D & E \\
\hline $1 \mathrm{~h}$ & $g x$ & $5.08 \mathrm{e} 5$ & $5.78 \mathrm{e} 5$ & $8.00 \mathrm{e} 5$ & $6.88 \mathrm{e} 5$ & $7.33 \mathrm{e} 5$ \\
\hline & br & $7.96 \mathrm{e} 6$ & $8.40 \mathrm{e} 6$ & $7.30 \mathrm{e} 6$ & $8.48 \mathrm{e} 6$ & $7.69 \mathrm{e} 6$ \\
\hline $1 y$ & gr & $3.82 \mathrm{e} 3$ & $4.44 \mathrm{e} 3$ & $3.91 \mathrm{e} 3$ & $4.52 \mathrm{e} 3$ & $4.50 \mathrm{e} 3$ \\
\hline & br & $1.07 \mathrm{e} 4$ & $2.74 \mathrm{e} 4$ & $2.71 \mathrm{e} 3$ & $3.07 \mathrm{e}^{4}$ & $1.07 \mathrm{e} 4$ \\
\hline $1 y$ & gt & $6.80 \mathrm{e} 7$ & $8.0 \mathrm{e} 7$ & $7.20 \mathrm{e} 7$ & $8.10 \mathrm{e} 7$ & $8.10 \mathrm{e} 7$ \\
\hline & bt & $3.20 \mathrm{e} 8$ & $5.8 e 8$ & $1.5 \mathrm{e} 8$ & $6.5 \mathrm{e} 8$ & $3.0 \mathrm{e} 8$ \\
\hline Steam & Gen A & A & B & C & D & E \\
\hline 1h & gr & $6.30 \mathrm{e} 5$ & $1.52 \mathrm{e} 6$ & $9.95 \mathrm{e} 5$ & $6.74 \mathrm{e} 5$ & $6.56 \mathrm{e} 5$ \\
\hline & br & $9.16 \mathrm{e} 6$ & $8.59 \mathrm{e} 6$ & $7.78 \mathrm{e} 6$ & 9.11 e 6 & $9.00 \mathrm{e} 6$ \\
\hline $1 y$ & $\begin{array}{l}\text { gr } \\
\text { br }\end{array}$ & $3.53 \mathrm{e} 4$ & $2.11 \mathrm{e} 4$ & $2.79 \mathrm{e} 3$ & $3.72 \mathrm{e} 4$ & $3.29 \mathrm{e}_{4}$ \\
\hline $1 y$ & gt & $6.70 \mathrm{e} 7$ & $6.80 \mathrm{e} 7$ & $4.70 \mathrm{e} 7$ & $6.50 \mathrm{e} 7$ & $6.70 \mathrm{e} 7$ \\
\hline & bt & $7.10 \mathrm{e} 8$ & $4.90 \mathrm{e} 8$ & $1.70 \mathrm{e} 8$ & $7.40 \mathrm{e} 8$ & $6.90 \mathrm{e} 8$ \\
\hline
\end{tabular}

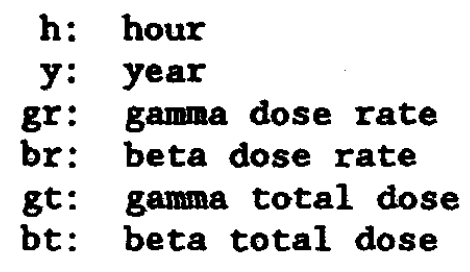




\subsubsection{Case 3 Dose Results}

Table 5.3 shows the basement total dose for the Case 3 accident scenario. Calculations showed slight gamma dose rate dependence on position. The combined air and sump sources caused the gamma dose in the basement to be larger than the beta dose during spray operation. Basement total gamma dose at one year ranged from $1 \times 10^{8}$ to $1.4 \times 10^{8}$ rads, and total beta dose at one year was $3.7 \times 10^{7}$ rads. Total gamma dose was dominated by the sump source contribution; the airborne source contribution was at least one order of magnitude smaller than that of the sump source (Table C.19). The beta total dose was due entirely to the airborne source; the sump source was attenuated completely within the sump water.

Gamma dose decreased with increasing annulus elevation as the sump source activity had less influence at higher containment elevations (Table C.20). Gamma total dose in the annulus ranged from $7 \times 10^{7}$ rads at the lower annulus levels to $2.9 \times 10^{6}$ rads at the top of the annulus. Total beta dose at one year for the annulus was $6.8 \times 10^{7}$ rads.

Gamma and beta total dose in the upper regions of containment were due only to airborne sources. Gamma dose for the Case 3 operating floor and dome region were largest in the dome and at the top of the operating floor region. Total gamma dose ranged from $1.6 \times 10^{6}$ rads to $4.6 \times 10^{6}$ rads while total beta dose was $1.6 \times 10^{8}$ rads.

The steam generator A cubicle airborne source resulted in slight gamma dose variation with respect to the five dose point locations. The steam generator A cubicle was modeled as one volume for the beta calculations, therefore, spatial dose rate calculations were not possible. Total dose gamma values at one year ranged from $9.6 \times 10^{5}$ to $1.7 \times 10^{6}$ rads, and the total dose beta value was calculated to be $2.6 \times 10^{8}$ rads. Dose rates and total dose value figures for Case 3 are presented in Appendix $B$.

The airborne and sump contributions to dose rate for the document and annulus regions are listed in Appendix. C. All dose rates for the remainder of containment are due to airborne activity only. 
Table 5.3

Case 3 Dose Rate and Total Dose

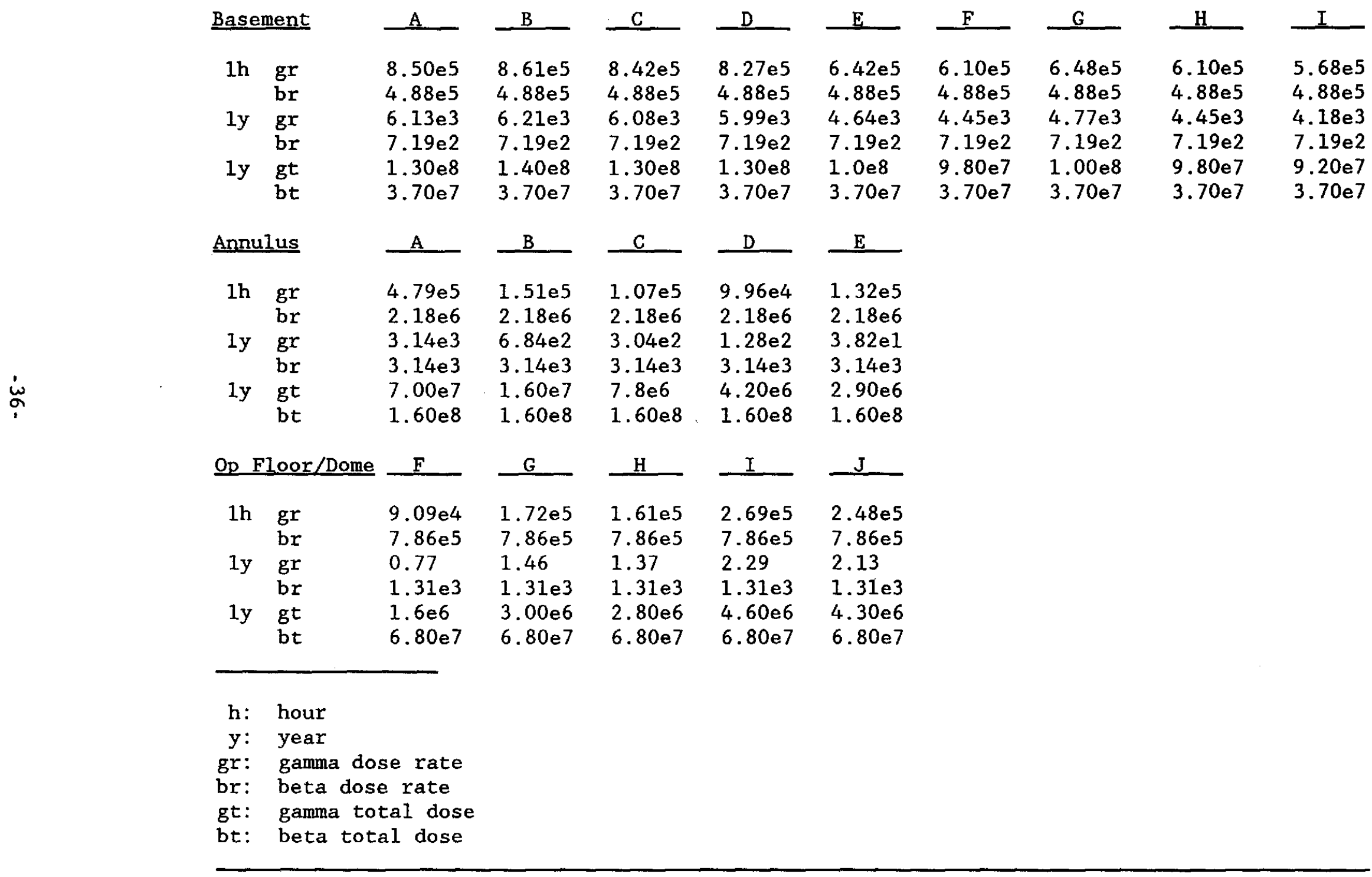


Table 5.3

Case 3 Dose Rate and Total Dose (Continued)

\begin{tabular}{|c|c|c|c|c|c|c|}
\hline \multicolumn{2}{|c|}{ Steam Gen A } & A & B & $\mathrm{C}$ & $\mathrm{D}$ & $\mathbf{E}$ \\
\hline $1 \mathrm{~h}$ & $g x$ & $5.82 \mathrm{e} 4$ & $5.57 \mathrm{e} 4$ & $1.00 \mathrm{e} 5$ & $6.94 \mathrm{e} 4$ & $6.51 \mathrm{e} 4$ \\
\hline & br & $3.08 \mathrm{e} 6$ & $3.08 \mathrm{e} 6$ & $3.08 \mathrm{e} 6$ & $3.08 \mathrm{e} 6$ & $3.08 \mathrm{e} 6$ \\
\hline $1 y$ & $g r$ & 0.50 & 0.40 & 0.80 & 0.60 & 0.50 \\
\hline & br & $4.85 \mathrm{e} 3$ & $4.85 \mathrm{e} 3$ & $4.85 \mathrm{e} 3$ & $4.85 \mathrm{e} 3$ & $4.85 \mathrm{e} 3$ \\
\hline $1 y$ & gt & $1.00 \mathrm{e} 6$ & $9.60 \mathrm{e} 5$ & $1.70 \mathrm{e} 6$ & $1.20 \mathrm{e} 6$ & $1.10 \mathrm{e} 6$ \\
\hline & bt & $2.60 \mathrm{e} 8$ & $2.60 \mathrm{e} 8$ & $2.60 \mathrm{e} 8$ & $2.60 \mathrm{e} 8$ & $2.60 \mathrm{e} 8$ \\
\hline$\underline{\mathrm{RHR} C}$ & abicle & A & B & $\mathrm{C}$ & $\mathrm{D}$ & $E$ \\
\hline $1 \mathrm{~h}$ & gr & $3.15 \mathrm{e} 4$ & 4. $31 e^{4}$ & $8.19 \mathrm{e} 4$ & $5.15 \mathrm{e} 4$ & $4.74 \mathrm{e} 4$ \\
\hline & $\mathrm{br}$ & $2.99 \mathrm{e} 6$ & $2.99 \mathrm{e} 6$ & $2.99 e 6$ & $2.99 e 6$ & $2.99 \mathrm{e} 6$ \\
\hline $1 y$ & gr & 0.27 & 0.37 & 0.71 & 0.44 & 0.41 \\
\hline & br & $4.86 \mathrm{e} 3$ & $4.86 \mathrm{e}^{3}$ & $4.86 \mathrm{e}^{3}$ & $4.86 \mathrm{e} 3$ & $4.86 \mathrm{e} 3$ \\
\hline $1 y$ & gt & $5.40 \mathrm{e} 5$ & $7.40 \mathrm{e} 5$ & $1.40 \mathrm{e} 6$ & $8.80 \mathrm{e} 5$ & $8.20 \mathrm{e} 5$ \\
\hline & bt & $2.60 \mathrm{e} 8$ & $2.60 \mathrm{e} 8$ & $2.60 \mathrm{e} 8$ & $2.60 \mathrm{e} 8$ & $2.60 \mathrm{e} 8$ \\
\hline
\end{tabular}

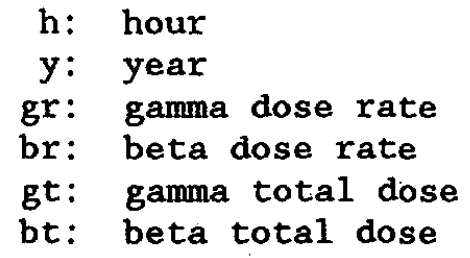




\subsubsection{Case 4 Dose Results}

The Case 3 and Case 4 airborne radionuclide activities were approximately identical. Differences between Case 3 and Case 4 occurred in the sump radionuclide activities. Since Case 4 was an arrested sequence, less radionuclide activity was introduced into the sump when compared to the Case 3 sump activity. Therefore, Case 4 gamma dose rates in the basement region and lower annulus regions can be expected to be less than Case 3 gamma dose rates in the same regions. Beta dose rates for Case 4 were identical to those of Case 3 because the ITS code calculated that no sump electron activity could escape beyond the sump water. All dose points in the basement region were located above the sump in this study.

Table 5.4 lists the gamma total dose for the Surry basement region. Total dose showed a moderate dependence upon location. Total gamma dose for the basement level varied from $5.9 \times 10^{7}$ rads to $8.9 \times 10^{7}$ rads. Recall that Case 3 total gamma dose for the basement region varied from $9.2 \times 10^{7}$ rads to $1.4 \times 10^{8}$ rads.

As in Case 3, dose rate decreased with increasing annulus elevation. Case 4 dose rates were less than the Case 3 dose rates because less activity was in the sump water due to Case 4 being an arrested sequence. Case 4 total gamma dose in the annulus was less than in corresponding Case 3 dose point locations. Interior compartment and dome gamma total doses for Case 4 were identical to those in Case 3.

Dose rate and total dose figures for Case 4 are listed in Appendix B. The airborne and sump contributions to the Case 4 basement and annulus dose rates are listed in Appendix $C$. Dose rates in the remainder of containment are due only to airborne sources. 
Case 4 Dose Rate and Total Dose

\begin{tabular}{|c|c|c|c|c|c|c|}
\hline \multicolumn{2}{|c|}{ Basement } & $\mathrm{A}$ & B & $\mathrm{C}$ & D & E \\
\hline & & $8.50 \mathrm{e} 5$ & $8.61 \mathrm{e} 5$ & $8.42 \mathrm{e} 5$ & $8.27 \mathrm{e} 5$ & $6.42 \mathrm{e} 5$ \\
\hline & & $4.58 \mathrm{e} 5$ & $4.58 \mathrm{e} 5$ & $4.58 \mathrm{e} 5$ & $4.58 \mathrm{e} 5$ & $4.58 \mathrm{e} 5$ \\
\hline & $r$ & $4.86 \mathrm{e} 3$ & $4.92 \mathrm{e} 3$ & $4.82 \mathrm{e} 3$ & $4.74 \mathrm{e} 3$ & $3.67 \mathrm{e} 3$ \\
\hline & $\mathbf{r}$ & $7.14 \mathrm{e} 2$ & $7.14 \mathrm{e} 2$ & $7.14 \mathrm{e} 2$ & $7.14 \mathrm{e} 2$ & $7.14 \mathrm{e} 2$ \\
\hline & $t$ & $8.70 \mathrm{e} 7$ & $8.90 \mathrm{e} 7$ & $8.70 \mathrm{e} 7$ & $8.50 \mathrm{e} 7$ & $6.60 \mathrm{e} 7$ \\
\hline & $t$ & $3.70 \mathrm{e} 7$ & $3.70 \mathrm{e} 7$ & $3.70 \mathrm{e} 7$ & $3.70 \mathrm{e} 7$ & $3.70 \mathrm{e} 7$ \\
\hline \multicolumn{2}{|c|}{ Annulus } & A & B & $\mathrm{C}$ & D & $\mathrm{E}$ \\
\hline \multirow[t]{2}{*}{$1 \mathrm{~h}$} & $r$ & $4.80 \mathrm{e} 5$ & $1.51 \mathrm{e} 5$ & $1.07 \mathrm{e} 5$ & $9.96 \mathrm{e} 4$ & $1.32 \mathrm{e} 5$ \\
\hline & $r$ & $7.97 e 5$ & $7.97 e 5$ & $7.97 e 5$ & $7.97 \mathrm{e} 5$ & $7.97 e 5$ \\
\hline \multirow[t]{2}{*}{$1 \mathrm{y}$} & $r$ & $2.49 \mathrm{e} 3$ & $5.42 \mathrm{e} 2$ & $2.41 \mathrm{e} 2$ & $1.02 \mathrm{e} 2$ & $3.05 \mathrm{e} 1$ \\
\hline & $\mathbf{r}$ & $1.30 \mathrm{e} 3$ & $1.30 \mathrm{e} 3$ & $1.30 \mathrm{e} 3$ & $1.30 \mathrm{e} 3$ & $1.30 \mathrm{e} 3$ \\
\hline \multirow[t]{2}{*}{$1 \mathrm{y}$} & $t$ & $4.60 \mathrm{e} 7$ & $1.10 \mathrm{e} 7$ & $5.30 e 6$ & $3.20 \mathrm{e} 6$ & $2.70 \mathrm{e} 6$ \\
\hline & $t$ & $6.80 \mathrm{e} 7$ & $6.80 \mathrm{e} 7$ & $6.80 \mathrm{e} 7$ & $6.80 \mathrm{e} 7$ & $6.80 \mathrm{e} 7$ \\
\hline \multicolumn{2}{|c|}{ Op Floor/Dome } & 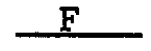 & G & H & I & $\mathrm{J}$ \\
\hline \multirow{2}{*}{$1 \mathrm{~h}$} & gr & $9.10 \mathrm{e} 4$ & $1.72 \mathrm{e} 5$ & $1.61 \mathrm{e} 5$ & $2.70 e 5$ & $2.49 e^{5}$ \\
\hline & br & $2.35 \mathrm{e} 6$ & $2.35 \mathrm{e} 6$ & $2.35 e 6$ & $2.35 \mathrm{e} 6$ & $2.35 \mathrm{e} 6$ \\
\hline \multirow[t]{2}{*}{1} & $\mathrm{gr}$ & 0.58 & 0.58 & 1.10 & 1.10 & 0.33 \\
\hline & br & $3.14 \mathrm{e} 3$ & $3.14 \mathrm{e} 3$ & $3.14 \mathrm{e} 3$ & $3.14 \mathrm{e} 3$ & $3.14 \mathrm{e}^{3}$ \\
\hline \multirow[t]{2}{*}{ 1y } & $g t$ & $1.60 \mathrm{e} 6$ & $3.0 \mathrm{e} 6$ & $2.80 \mathrm{e} 6$ & $4.60 \mathrm{e} 6$ & $4.50 e^{6}$ \\
\hline & bt & $1.60 \mathrm{e} 8$ & $1.60 \mathrm{e} 8$ & $1.60 \mathrm{e} 8$ & $1.60 \mathrm{e} 8$ & $1.60 \mathrm{e} 8$ \\
\hline
\end{tabular}


Table 5.4

Case 4 Dose Rate and Total Dose (Continued)

\begin{tabular}{|c|c|c|c|c|c|c|}
\hline$\underline{\mathrm{RHR}} \mathrm{C}$ & ubicle & A & B & C & D & E \\
\hline $1 \mathrm{~h}$ & $\begin{array}{l}g r \\
b r\end{array}$ & $\begin{array}{l}3.14 \mathrm{e} 4 \\
3.08 \mathrm{e} 6\end{array}$ & $\begin{array}{l}4.31 \mathrm{e} 4 \\
3.08 \mathrm{e} 6\end{array}$ & $\begin{array}{l}8.19 \mathrm{e}^{4} \\
3.08 \mathrm{e} 6\end{array}$ & $\begin{array}{l}5.15 \mathrm{e} 4 \\
3.08 \mathrm{e} 6\end{array}$ & $4.77 \mathrm{e} 4$ \\
\hline $1 y$ & $\mathrm{gr}$ & 0.27 & 0.36 & 0.69 & 0.44 & 0.40 \\
\hline & br & $4.82 \mathrm{e} 3$ & $4.82 \mathrm{e} 3$ & $4.82 \mathrm{e}^{3}$ & $4.82 \mathrm{e} 3$ & $4.82 \mathrm{e} 3$ \\
\hline $1 y$ & gt & $5.30 \mathrm{e} 5$ & $7.30 \mathrm{e} 5$ & $1.40 \mathrm{e} 6$ & $8.80 \mathrm{e} 5$ & $8.10 \mathrm{e} 5$ \\
\hline & bt & $2.60 \mathrm{e} 8$ & $2.60 \mathrm{e} 8$ & $2.60 \mathrm{e} 8$ & $2.60 \mathrm{e} 8$ & $2.60 \mathrm{e} 8$ \\
\hline Steam & Gen A & A & B & C & D & $E$ \\
\hline $1 \mathrm{~h}$ & $\begin{array}{l}g r \\
b r\end{array}$ & $\begin{array}{l}5.82 \mathrm{e} 4 \\
3.01 \mathrm{e} 6\end{array}$ & $\begin{array}{l}5.57 \mathrm{e} 4 \\
3.01 \mathrm{e} 6\end{array}$ & $\begin{array}{l}1.00 \mathrm{e} 5 \\
3.01 \mathrm{e} 6\end{array}$ & $\begin{array}{l}6.94 \mathrm{e} 4 \\
3.01 \mathrm{e} 6\end{array}$ & $\begin{array}{l}6.51 \mathrm{e} 4 \\
3.01 \mathrm{e} 6\end{array}$ \\
\hline $1 y$ & $g x$ & 0.49 & 0.47 & 0.85 & 0.59 & 0.55 \\
\hline & $\mathrm{b} r$ & $4.83 e 3$ & $4.83 \mathrm{e} 3$ & $4.83 \mathrm{e} 3$ & $4.83 \mathrm{e} 3$ & $4.83 e 3$ \\
\hline $1 y$ & gt & $1.0 \mathrm{e} 6$ & $9.5 e 5$ & $1.7 \mathrm{e} 6$ & $1.2 \mathrm{e} 6$ & $1.1 \mathrm{e} 6$ \\
\hline & bt & $2.6 \mathrm{e} 8$ & $2.6 \mathrm{e} 8$ & $2.6 \mathrm{e} 8$ & $2.6 \mathrm{e} 8$ & $2.6 \mathrm{e} 8$ \\
\hline $\begin{array}{l}\text { gr: } \\
\text { br: }\end{array}$ & $\begin{array}{l}\text { gamma } \\
\text { beta do }\end{array}$ & $\begin{array}{l}\text { se rate } \\
\text { e rate }\end{array}$ & & & & \\
\hline $\begin{array}{l}\text { gt: } \\
\text { bt: }\end{array}$ & $\begin{array}{l}\text { gamma } t \\
\text { beta to }\end{array}$ & $\begin{array}{l}\text { tal dose } \\
\text { al dose }\end{array}$ & & & & \\
\hline
\end{tabular}




\subsection{Peach Bottom Dose Results}

Four variations of the $\mathrm{AE}$ sequence were calculated. The $\mathrm{AE}$ sequence is a large break LOCA with one initiating event and a combination of failures in two emergency cooling systems. Case 1 is the base case or the $A E$ sequence itself. Case 2 investigates the effect of arresting the core meltdown in Case 1, with core-concrete attack radionuclide release being removed. Case 3 simulates drywell spray operation by removing all airborne activity except noble gases. No activity remains on the containment surface. Case 4 simulates an arrested sequence (with drywell sprays operational) by removing all radionuclide activity generated during core-concrete attack.

\subsubsection{Case 1 Dose Results}

Figures 5.2.1 and 5.2.2 show total dose in the Peach Bottom drywell. Gamma doses showed moderate positional dependence for dose points in the drywe11 bulb; dose was lower for dose points located in the "upper stem" of the drywell bulb. Gamma doses showed minor positional dependence for dose points at the same elevation. The dose at points in the middle of the drywell bulb were greater than the other locations. The floor and wall sources dominated the gamma total dose values; both were within an order of magnitude of each other throughout the entire scenario. The airborne source activity was equal in magnitude to the floor and wall source activities at early scenario times ( $<16$ hours) but rapidly decayed during later scenario times becoming two to three orders of magnitude less than the floor and wall sources (Table C.23).

Beta dose also showed substantial positional dependence in the drywell. Beta dose was highest in the center of the drywell bulb and lowest at the top of the bulb and stem. Dose points near the walls generally had higher dose values than dose points in the bulb interior at the same elevation. Contributions to total beta dose from the airborne, wall, and floor sources were generally within an order of magnitude of one another for locations in the drywell bulb along the wall. Floor contributions were minimal at dose point locations in the drywe11 stem (Table C.24). Early discontinuities in the beta dose rate plots (Appendix B) reflected drywell gas density changes.

Gamma total dose values ranged from $9.8 \times 10^{7}$ rads to $1.8 \times 10^{8}$ rads in the drywell bulb and from $3.3 \times 10^{7}$ rads to $5.2 \times 10^{7}$ rads in the drywell stem. Beta total dose values ranged from $4.7 \times 10^{8}$ rads to $6.6 \times 10^{8}$ rads at the bottom of the drywe 11 bulb, $1.5 \times 10^{9}$ rads to $1.7 \times 10^{9}$ rads at the middle of the drywe 11 bulb, and $1.8 \times 10^{8}$ to $3.5 \times 10^{8}$ rads at the top of the drywell bulb and in the stem.

Figure 5.2.3 illustrates the gamma total dose due to the radionuclide activity in the toroidal wetwell. The gamma dose was significantly reduced when comparing dose values inside the torus room to dose values inside the corner (quad) room. Total gamma dose at one year in the torus room was calculated to be $1 \times 10^{7}$ rads. Total gamma dose in the quad room was $1.6 \times 10^{2}$ rads. Beta dose was not calculated to occur in the 

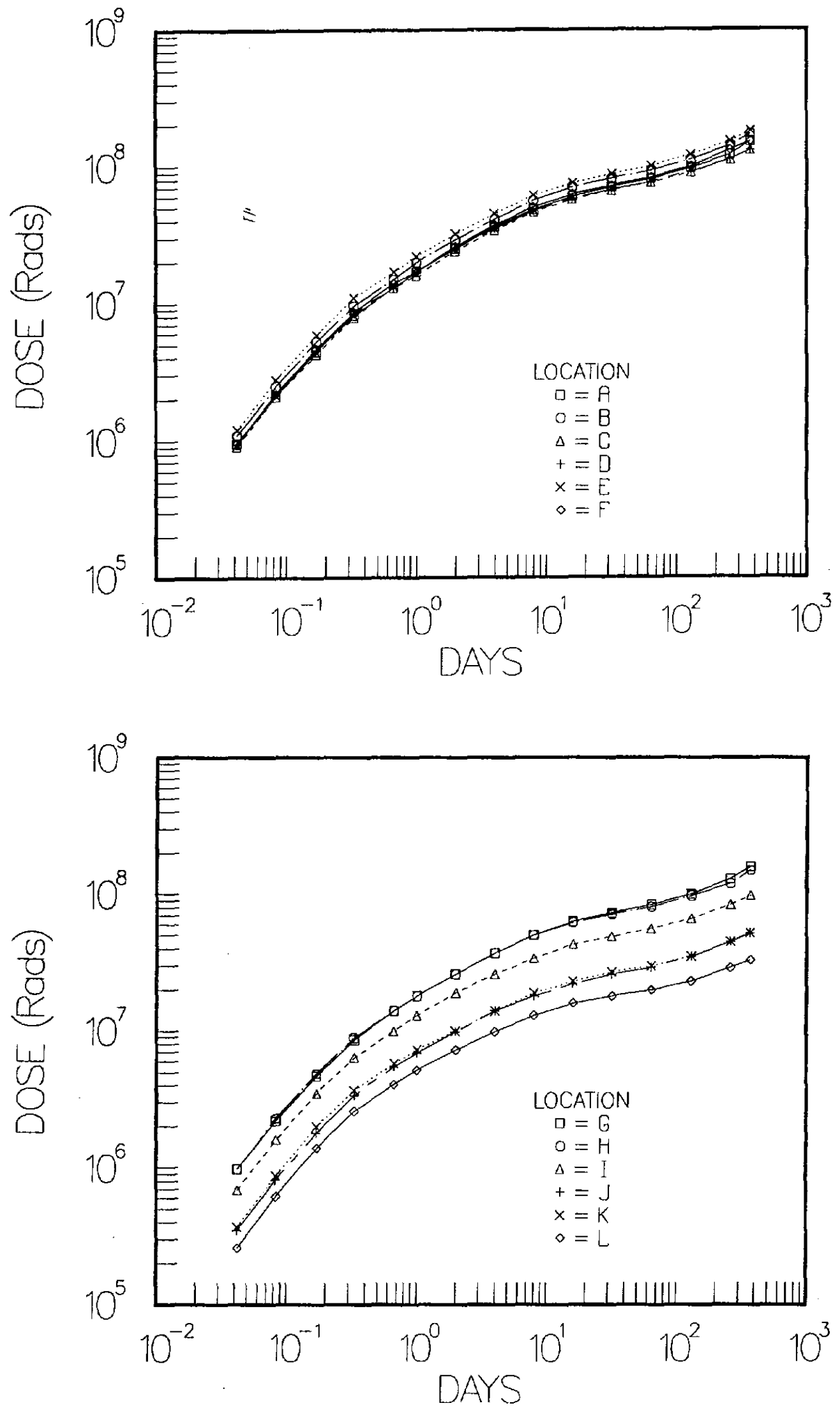

Figure 5.2.1. Peach Bottom Case 1 Drywell Total Gamma Dose 

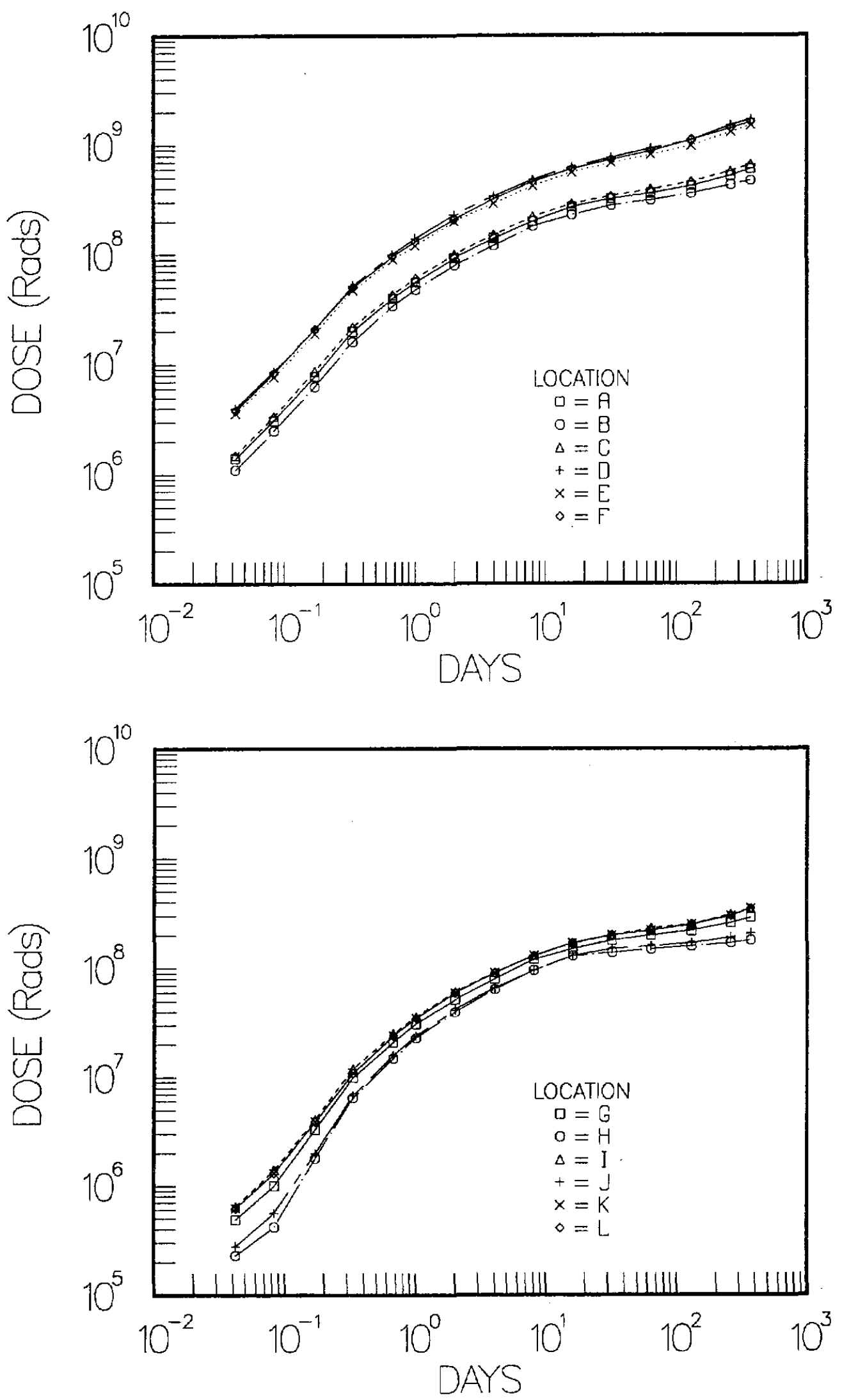

Figure 5.2.2. Peach Bottom Case 1 Drywell Total Beta Dose 


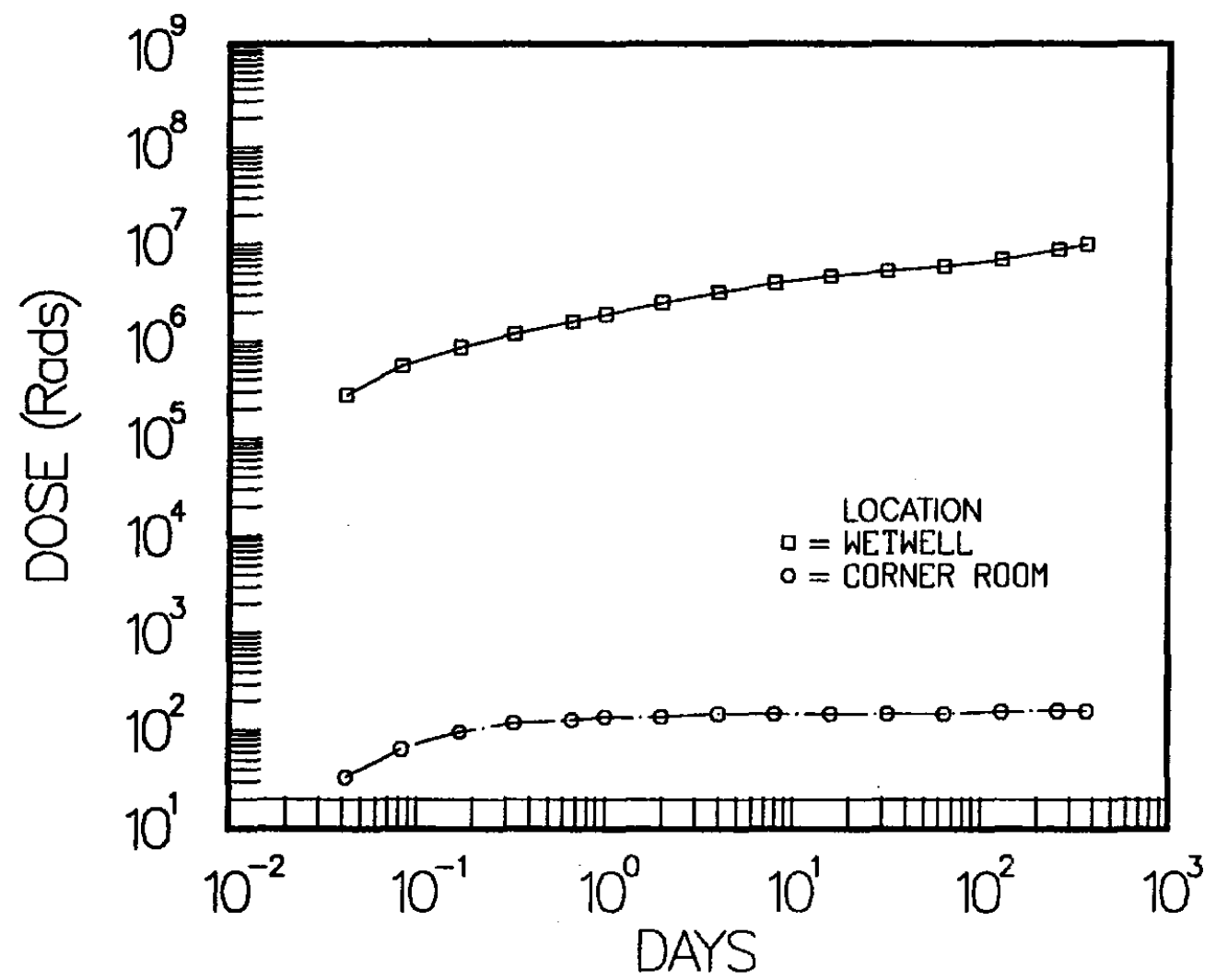

Figure 5.2.3. Peach Bottom Case 1 Wetwell Total Gamma Dose 
torus room due to the shielding of the wetwell torus. Dose at the ceiling of the torus room would be approximately equal to that shown in Figure 5.2.3. Dose in the reactor building just above the torus room (elevation 135) should be similar to the dose calculated to occur in the quad room.

Appendix $B$ contains the dose rate plots corresponding to the doses shown in Figures 5.2.1 through 5.2.3.

Table 5.5 summarizes the dose rate at one hour and one year and total dose at one year.

The airborne, floor, and wall contributions for the Case 1 drywell dose rates are listed in Appendix C. The sump, airborne, and wall contributions for the wetwell dose rates are also listed in Appendix $C$. 
Table 5.5

Peach Bottom Case 1 Dose Rate and Dose

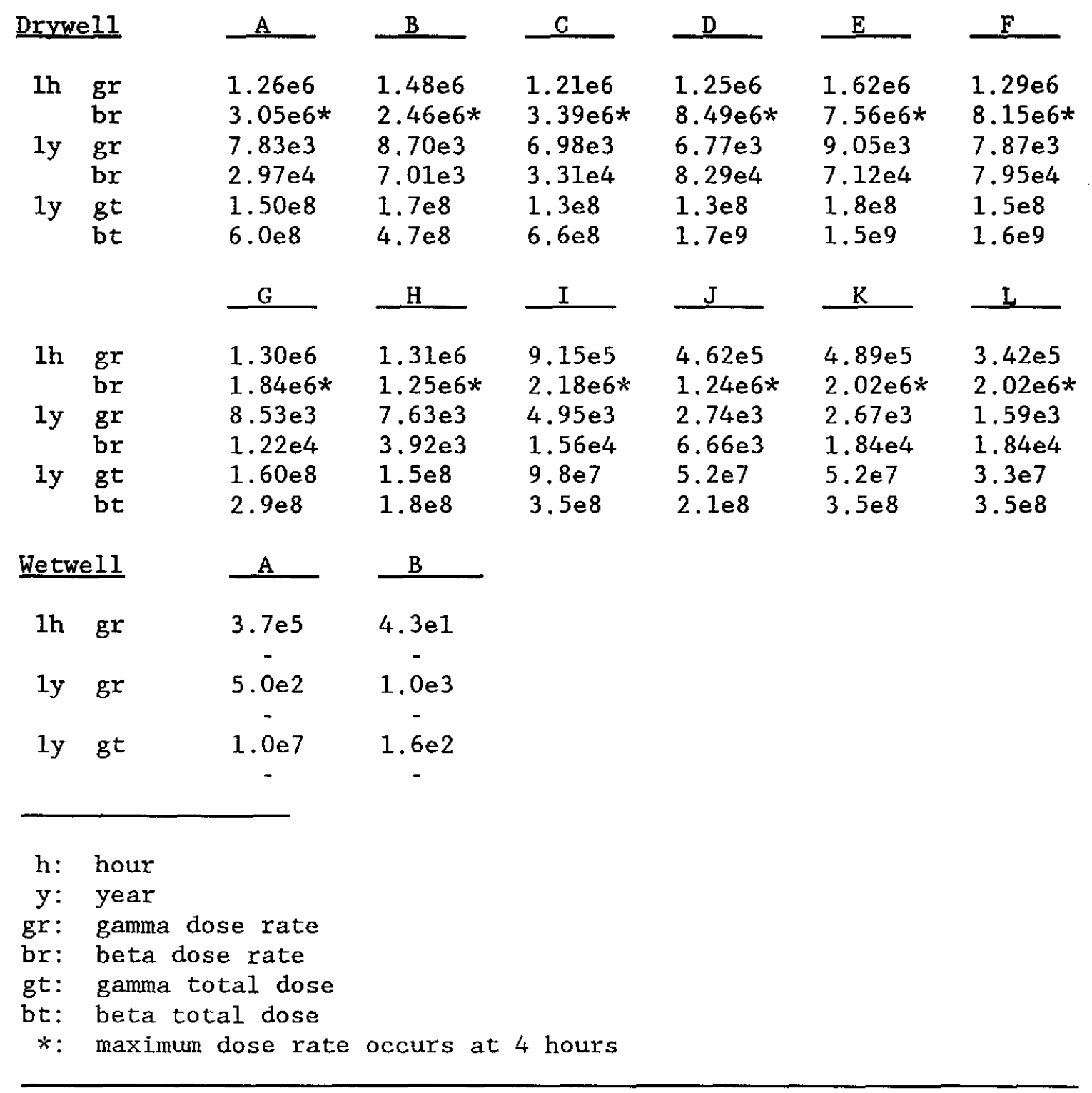




\subsubsection{Case 2 Dose Results}

Table 5.6 summarizes total dose for the Case 2 calculations. Case 2 gamma doses were essentially the same as those calculated for Case 1; PATH calculated no significant differences between the two cases. Drywell beta dose calculated for Case 2 was lower than that calculated for Case 1 , but the fact that these changes can be attributed to scenario radionuclide inventory variations is not clear. The lower beta doses are more likely due to the different thermal-hydraulic conditions (drywell gas temperature, pressure, and density) that were calculated for Case 1 and Case 2. Total maximum beta doses at one year ranged from $2 \times 10^{8}$ rads at the drywell bottom to $6 \times 10^{8}$ rads at the drywell center to 2.1 $x 10^{8}$ rads at the top of the drywell. PATH calculated no difference in wetwe11 gamma dose rates for Case 1 and Case 2.

Case 2 dose rate and total dose figures are given in Appendix $B$. The airborne, floor, and wall contributions for the drywell rates are listed in Appendix C. The wetwell sump, airborne, and wall contributions for the wetwe11 dose rates are also listed in Appendix $C$. 
Table 5.6

Peach Bottom Case 2 Dose Rate and Total Dose

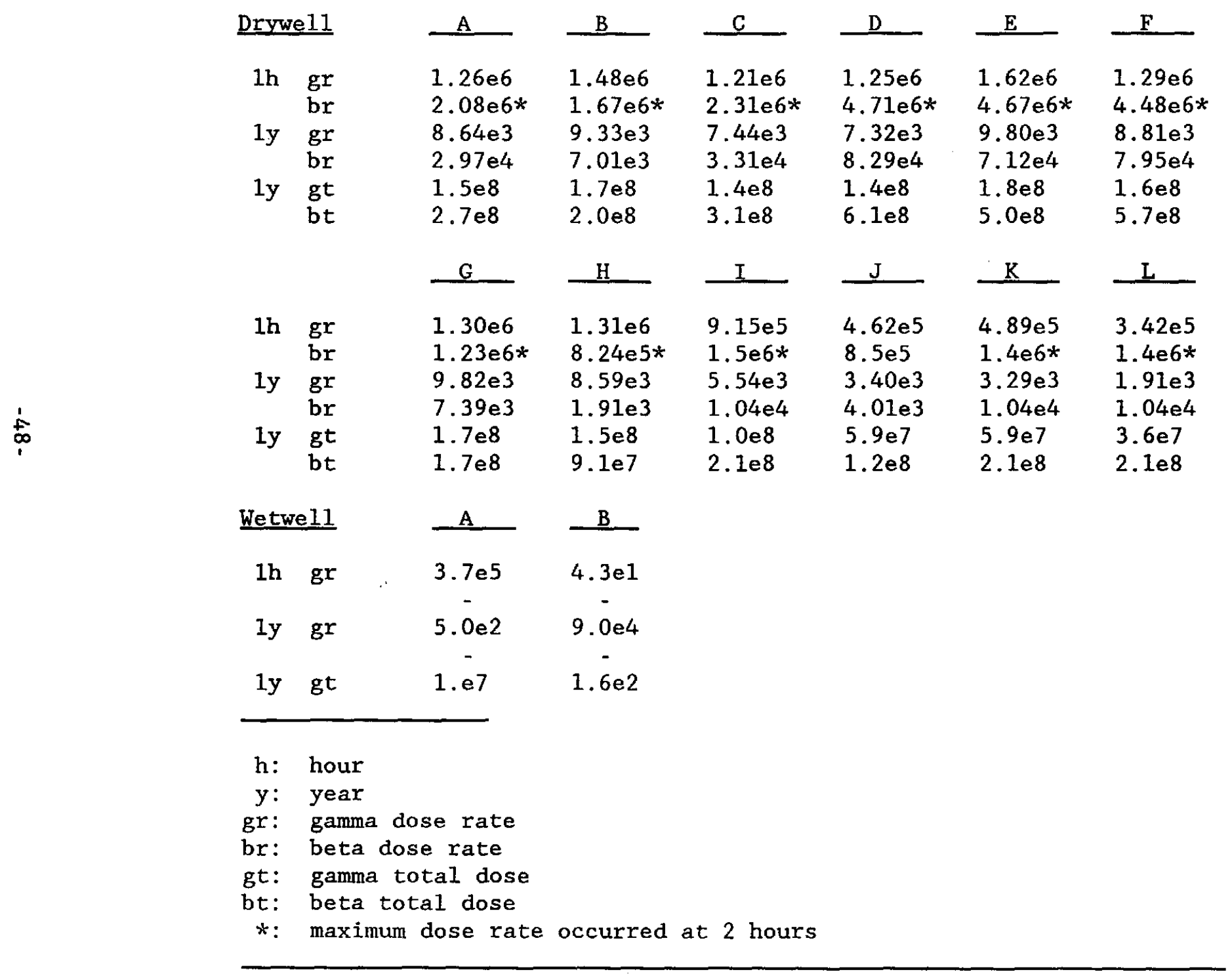




\subsubsection{Case 3 and Case 4 Dose Results}

Spray operation greatly reduced radionuclide activity in the drywell region. Gamma dose showed a moderate dependence on dose point location; this dependence was less than in Case 1 since surface sources were assumed not to exist in Case 3. Total gamma dose at one year ranged from $6.5 \times 10^{6}$ rads in the drywell stem to $1.7 \times 10^{7}$ rads at mid-elevation in the drywell bulb. Case 3 beta dose was also substantially below the Case 1 beta dose. Total beta dose in the drywell was calculated to be $0.93 \times 10^{8} \mathrm{rad}$ at one year. Since only uniform airborne activity was assumed to occur in Case 3, a one volume drywell model was used for Case 3. Therefore, there is no data on beta dose dependence with drywell position.

Total gamma dose in the torus room was $1 \times 10^{7}$ rads. Total gamma dose at one year in the quad room was $1.5 \times 10^{2}$ rads. No beta dose was calculated to occur in the torus room of the wetwell because the steel toroid shielded the torus room from electron activity inside the wetwell torus.

PATH and ITS Case 4 gamma and beta dose rates were almost identical to those calculated for Case 3 . Case 4 dose rate and dose value figures are located in Appendix B.

Table 5.7 summarizes dose rate values at one hour and one year as well as total dose values at one year for Cases 3 and 4 .

Case 3 and Case 4 sump, airborne, and wall contributions to the wetwell dose rates are listed in Appendix $C$. 
Table 5.7

Peach Bottom Case 3 and Case 4 Dose Rate and Total Dose

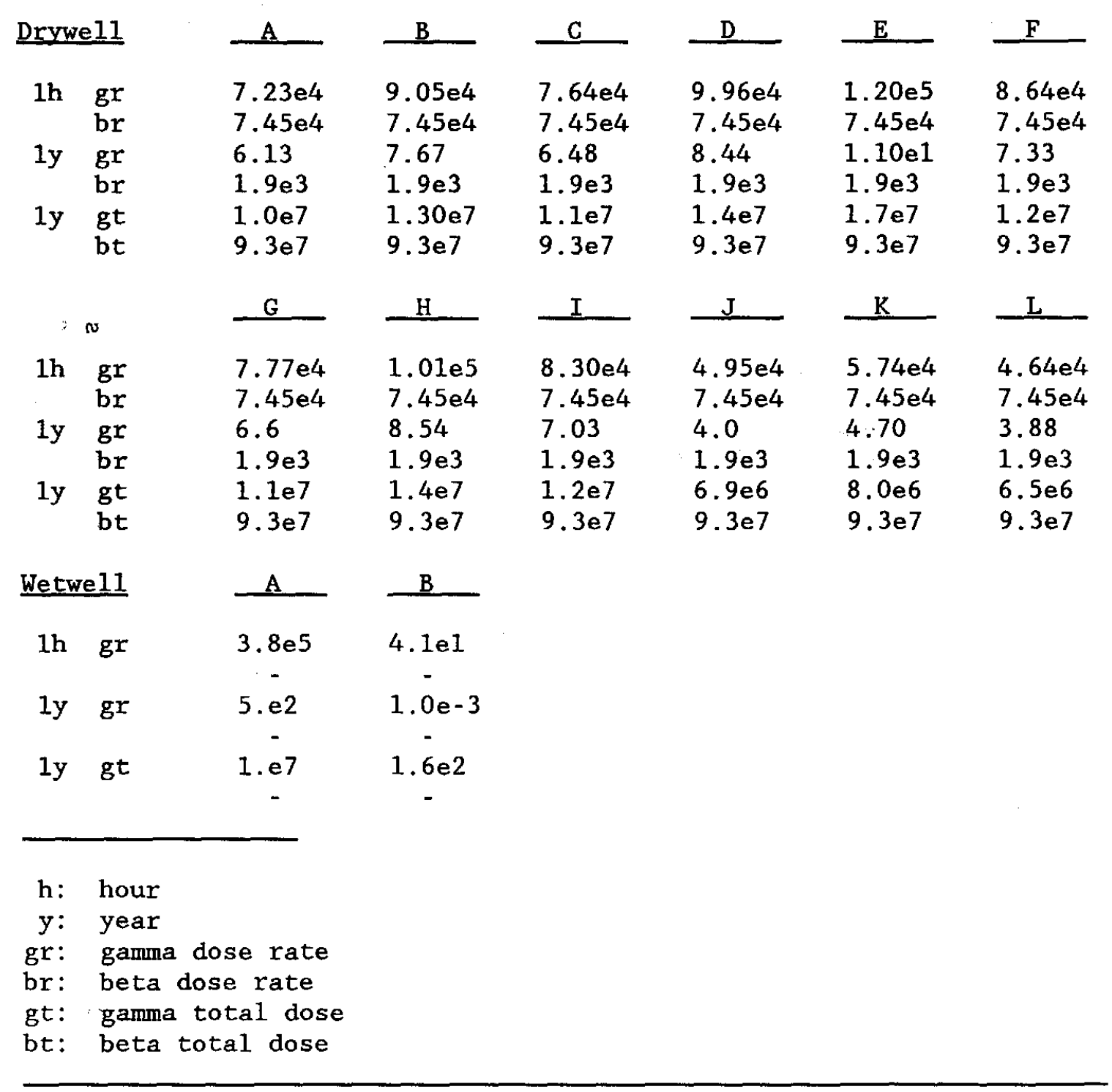




\subsection{Comments on Surry and Peach Bottom Case 1 and Case 2 Dose Results}

The Surry and Peach Bottom Case 1 total dose values are relatively high at certain containment locations when compared to current DBA total dose equipment qualification levels. Locations at which high doses are calculated generally occur where two or more of the airborne, wall, and floor sources have a significant effect on dose rate.

The dose rate tables in Appendix $C$ show that the floor and wall sources are the major contributors to the gamma dose rate values. The gamma floor and wall source dose rates diminish slowly and are significantly higher than the airborne source dose rate after 1 to 4 days into the scenario analysis. At one year, floor and wall gamma dose rate values have been calculated to be in the $10^{3} \mathrm{rads} /$ hour range.

The same general trend between airborne, wall, and floor sources for beta dose was also observed. Beta airborne sources did not diminish as rapidly as the gamma airborne sources, but the beta wall and floor sources resulted in year end dose rates to be roughly an order of magnitude larger than year end dose rates due to the airborne source. At one year, floor and wall beta dose rate values have been calculated to be in the $10^{3}$ to $10^{4} \mathrm{rads} /$ hour range.

The primary reason for the high calculated gamma and beta total dose is due to the radionuclide inventory makeup of the floor and wall sources at latter time periods in the analysis. When compared to the airborne isotopes, the floor and wall sources have isotopes with long lived and relatively high activities combined with large energy decays per particle. The top three isotopes for the floor and wall sources at late time periods included CS 134, BA 137M (a daughter of CS 137), and NB 95. The top three isotopes and their contributions to dose for the Surry and Peach Bottom calculations are listed in Appendix D. The major isotopes are listed for airborne, wall, floor, and sump source terms.

Surry Case 1 total gamma and beta dose was calculated to range from 1.17 $\mathrm{x} 10^{9}$ rads to $3 \times 10^{9}$ rads in the basement, $3.22 \times 10^{8}$ rads to $1.29 \times 10^{9}$ rads in the annulus, $2.7 \times 10^{8}$ rads to $1.86 \times 10^{9} \mathrm{rads}$ in the dome, and $2.38 \times 10^{8}$ rads to $1.99 \times 10^{9}$ rads in the steam generator A cubicle (containment interior). Reg Guide 1.89, Appendix D, suggests an equipment qualification dose of $2.2 \times 10^{8}$ rads. Therefore, Reg Guide 1.89, Appendix D levels are exceeded by 530 to 1360 percent in the basement, 146 to 590 percent in the annulus, 125 to 845 percent in the dome, and 108 to 904 percent in the steam generator A cubicle. The wall and floor sources were the major contributors to the higher doses calculated in this study.

Surry Case 2 total gamma and beta dose was less than the Case 1 total dose. Given the uncertainties in the source calculations, PATH, and ITS codes, the agreement between total calculated dose and the $2.2 \times 10^{8} \mathrm{rad}$ Reg Guide 1.89, Appendix D dose is not bad. Appendix D levels were exceeded by 136 to 645 percent in the basement, 0 to 142 percent in the annulus, 0 to 231 percent in the dome, and 0 to 353 percent in steam generator cubicle A. 
Peach Bottom Case 1 drywell total gamma and beta dose was calculated to range from $2.35 \times 10^{8}$ rads to $1.83 \times 10^{9}$ rads. These calculated doses exceed the Reg Guide 1.89, Appendix D level by 107 to 832 percent. Case 2 drywell total gamma and beta dose ranged from $1.79 \times 10^{8}$ rads to $7.50 \times$ $10^{8}$ rads; Appendix $D$ test levels were exceeded by 0 to 340 percent.

The beta wall and floor dose rate calculations used relatively simple and symmetric zoning of the Surry and Peach Bottom containments. Wall and floor sources were frequently cylindrical, circular, or spherical in nature; therefore zones of concentric cylinders or spheres were often chosen for the containment zones. Nonuniform dose rate variation between adjacent zones has been observed in these calculations and is demonstrated in Table C.2 for a wall source calculation. The beta dose rates for location $F$ under column $W$ were calculated for the zone adjacent to the reactor cavity wall in Figure A.1. Dose rates under column $w^{\prime}$ were calculated for the second zone from the reactor cavity wall. We believe that the simple and symmetric zoning used and the nonuniform dose rates indicate that the current models may provide somewhat conservative wall and floor beta dose rates. Further parametric studies using finer zone nodalizations in regions of containment with calculated high beta dose should be performed.

\subsection{Comments on PATH and ITS Isotope Inventory}

Many gamma shielding codes are limited by the number of radionuclides which they can use for shielding calculations; some problems can occur when the number of radionuclides determined to occur in a simulation exceeds those used by the shielding code.

PATH has a standard gamma energy group structure library to convert an isotopic source into a gamma source energy spectrum. The PATH library can handle 125 isotopes. The source term radionuclide inventory calculated by BCL contains 152 isotopes. Isotopes common to both PATH and the BCL list were limited to 81 of the 152 isotopes. Table 5.8 lists the BCL isotopes; isotopes common to BCL and PATH are noted in Table 5.8.

To quantify the relative contribution of isotopes missing from PATH, beta and gamma decay energies per particle were obtained for all of the BCL isotopes from the ENDF/B- $V^{8}$ data for fission products and actinides. The activity of each isotope for each time period of each case was multiplied by their respective decay energies to get the total energy associated with each isotope as a function of time. The energies of the missing isotopes were then compared with the energies of the isotopes used by PATH. Table 5.9 presents the sum of the isotope energies used by PATH divided by the sum of missing and PATH isotope energies. Table 5.9 only addresses the gamma energies. Table 5.9 shows that the missing gamma isotopes contribute less than 5 percent of the total energies.

Beta energy spectra were available for 131 of the 152 isotopes during the ITS calculations. Table 5.8 also lists the isotopes common to the BCL output and ITS calculations. ENDF/B-V energy calculations similar to 
those discussed above for the gamma energies were also performed for the beta energies. Energies of the missing isotopes contributed less than 2 percent of the total energies. 
Table 5.8

Radionuclide Inventory Calculated by BCL

\begin{tabular}{|c|c|c|c|c|c|c|c|}
\hline U237 & & TC99M & & I133 & $-a, b$ & ND151 & $-a, b$ \\
\hline U239 & & M0101 & $-a, b$ & XE133 & $-a, b$ & PM151 & $-a, b$ \\
\hline NP238 & & TC101 & $-a, b$ & XE133M & $-a, b$ & SM151 & $-b$ \\
\hline NP239 & & Mo102 & $-b$ & TE134 & $-a, b$ & ND152 & $-b$ \\
\hline NP240 & & $\mathrm{TC} 102$ & $-b$ & I134 & $-a, b$ & PM152 & $-a, b$ \\
\hline PU238 & & RU103 & $-a, b$ & $\operatorname{CS} 134$ & $-a, b$ & SM153 & $-b$ \\
\hline PU239 & & RH103M & & $\operatorname{CS} 134 \mathrm{M}$ & & EU154 & $-a, b$ \\
\hline PU240 & & TC104 & $-a, b$ & I135 & $-a, b$ & SM155 & $-b$ \\
\hline PU241 & & TC105 & $-a, b$ & XE135 & $-a, b$ & EU155 & $-b$ \\
\hline PU243 & & RU105 & $-a, b$ & $\mathrm{XE135M}$ & $-a, b$ & SM156 & $-b$ \\
\hline SE79M & & RH105 & $-b$ & $\operatorname{CS} 135 \mathrm{M}$ & & EU156 & $-b$ \\
\hline SE81 & $-b$ & RH105M & $-b$ & $\operatorname{cs} 136$ & $-a, b$ & EU157 & $-b$ \\
\hline SE81M & & RU106 & $-b$ & BA136M & & SM158 & $-b$ \\
\hline BR82 & $-b$ & RH106 & $-a, b$ & $\operatorname{cs} 137$ & $-b$ & EU158 & $-b$ \\
\hline SE83 & $-a, b$ & RH106M & $-b$ & BA137M & $-a, b$ & EU159 & $-b$ \\
\hline BR83 & $-b$ & RH107 & $-a, b$ & $\mathrm{XE138}$ & $-a, b$ & & \\
\hline KR83M & & PD109 & $-b$ & $\operatorname{CS} 138$ & $-a, b$ & & \\
\hline BR84 & $-a, b$ & PD111 & $-b$ & $\operatorname{CS} 139$ & $-a, b$ & & \\
\hline KR85 & $-a, b$ & PD111M & $-b$ & BA139 & $-b$ & & \\
\hline KR85M & $-a, b$ & PD112 & $-b$ & BA140 & $-a, b$ & & \\
\hline RB86 & $-b$ & SB122 & $-b$ & LA140 & $-a, b$ & & \\
\hline KR87 & $-a, b$ & SB124 & $-b$ & BA141 & $-a, b$ & & \\
\hline KR8 8 & $-a, b$ & SB125 & $-a, b$ & LA141 & $-b$ & & \\
\hline RB88 & $-a, b$ & $\mathrm{TE} 125 \mathrm{M}$ & $-b$ & CE141 & $-b$ & & \\
\hline RB89 & $-a, b$ & SB126 & $-b$ & BA142 & $-a, b$ & & \\
\hline SR89 & $-b$ & SB127 & $-a, b$ & LA142 & $-a, b$ & & \\
\hline SR90 & $-b$ & TE127 & $-b$ & PR142 & $-b$ & & \\
\hline Y90 & $-b$ & TE127M & $-b$ & PR142M & & & \\
\hline SR91 & $-a, b$ & SB128 & $-a, b$ & LA143 & $-a, b$ & & \\
\hline Y91 & $-b$ & SB128M & $-a, b$ & CE143 & $-a, b$ & & \\
\hline Y91M & $-a, b$ & $\mathrm{I} 128$ & $-b$ & PR143 & $-b$ & & \\
\hline SR92 & $-a, b$ & SB129 & $-a, b$ & CE144 & $-b$ & & \\
\hline Y92 & $-a, b$ & TE129 & $-a, b$ & PR144 & $-a, b$ & & \\
\hline SR93 & $-a, b$ & TE129M & $-a, b$ & PR144M & & & \\
\hline Y93 & $-a, b$ & SB130 & $-a, b$ & PR145 & $-b$ & & \\
\hline Y94 & $-a, b$ & $\mathrm{I} 130$ & $-b$ & CE146 & $-a, b$ & & \\
\hline Y95 & $-a, b$ & SB131 & $-a, b$ & PR146 & $-a, b$ & & \\
\hline ZR95 & $-a, b$ & TE131 & $-a, b$ & PR147 & $-a, b$ & & \\
\hline NB95 & $-a, b$ & TE131M & $-a, b$ & ND147 & $-a, b$ & & \\
\hline NB95M & $-b$ & I131 & $-a, b$ & PM147 & $-b$ & & \\
\hline
\end{tabular}


Table 5.8

Radionuclide Inventory Calculated by BCL (Continued)

\begin{tabular}{|c|c|c|c|c|c|}
\hline NB96 & $-a, b$ & XE131M & $-b$ & PM148 & $-a, b$ \\
\hline ZR97 & $-a, b$ & TE132 & $-a, b$ & PM148M & $-a, b$ \\
\hline NB97 & $-a, b$ & I132 & $-a, b$ & ND149 & $-a, b$ \\
\hline NB97M & $-a, b$ & TE133 & $-a, b^{\prime}$ & PM149 & $-b$ \\
\hline M099 & $-a$ & TE133M & $-a, b$ & PM150 & $-b$ \\
\hline $\begin{array}{l}\text { a: is } \\
\text { b: is }\end{array}$ & $\begin{array}{l}\text { pes } \\
\text { pes }\end{array}$ & $\begin{array}{l}\mathrm{d} \text { in PAT } \\
\mathrm{d} \text { in ITS }\end{array}$ & & & \\
\hline
\end{tabular}


Table 5.9

Gamma Total Energies Used by PATH

\begin{tabular}{|c|c|c|c|c|c|}
\hline & & & & & \\
\hline & & $\mathrm{C} 1$ & $\mathrm{C} 2$ & $\mathrm{C3}$ & $\mathrm{C} 4$ \\
\hline $1 \mathrm{~h}$ & $\mathbf{a}$ & 0.995 & 0.995 & 0.999 & 0.999 \\
\hline & $\mathbf{w}$ & 0.994 & 0.994 & - & - \\
\hline & $f$ & 0.994 & 0.994 & ' & - \\
\hline & $\mathbf{s}$ & - & - & 0.994 & 0.994 \\
\hline $4 \mathrm{~h}$ & $a$ & 0.945 & 0.992 & 0.999 & 0.999 \\
\hline & $\mathbf{w}$ & 0.985 & 0.991 & - & - \\
\hline & $f$ & 0.975 & 0.991 & - & - \\
\hline & $s$ & - & - & 0.966 & 0.990 \\
\hline $16 \mathrm{~h}$ & $\mathrm{a}$ & 0.992 & 0.999 & 0.999 & 0.999 \\
\hline & $\mathbf{w}$ & 0.973 & 0.990 & - & - \\
\hline & $\mathrm{f}$ & 0.950 & 0.990 & - & - \\
\hline & $\mathbf{s}$ & - & - & 0.956 & 0.990 \\
\hline $2 d$ & $a$ & 0.998 & 0.998 & 0.998 & 0.998 \\
\hline & $w$ & 0.973 & 0.993 & - & - \\
\hline & $\mathrm{f}$ & 0.948 & 0.992 & - & - \\
\hline & $\mathbf{s}$ & - & - & 0.955 & 0.993 \\
\hline $8 d$ & a & 0.995 & 0.995 & 0.995 & 0.995 \\
\hline & $w$ & 0.980 & 0.995 & - & - \\
\hline & $\mathrm{f}$ & 0.964 & 0.994 & - & - \\
\hline & s & - & - & 0.968 & 0.994 \\
\hline $32 d$ & $a$ & 0.956 & 0.956 & 0.956 & 0.956 \\
\hline & $\mathbf{w}$ & 0.977 & 0.988 & - & - \\
\hline & $\mathrm{f}$ & 0.971 & 0.987 & - & - \\
\hline & $\mathbf{s}$ & - & - & 0.972 & 0.987 \\
\hline $128 d$ & $a$ & 0.972 & 0.972 & 0.972 & 0.972 \\
\hline & $w$ & 0.985 & 0.987 & - & - \\
\hline & $\mathrm{f}$ & 0.983 & 0.987 & - & - \\
\hline & $\mathbf{s}$ & - & - & 0.983 & 0.987 \\
\hline $1 y$ & $a$ & 1. & 1. & 1. & 1. \\
\hline & $\mathbf{w}$ & 0.984 & 0.985 & - & - \\
\hline & $f$ & 0.983 & 0.985 & - & - \\
\hline & $\mathbf{s}$ & - & - & 0.983 & 0.985 \\
\hline
\end{tabular}


Table 5.9

Gamma Total Energies Used by PATH (Continued)

\begin{tabular}{|c|c|c|c|c|c|}
\hline & & & tom & & \\
\hline & & C1 & $\mathrm{C} 2$ & $\mathrm{C} 3$ & $\mathrm{C} 4$ \\
\hline $1 \mathrm{~h}$ & $\mathrm{da}$ & 0.996 & 0.996 & 0.999 & 0.999 \\
\hline & $d w$ & 0.995 & 0.995 & - & - \\
\hline & $\mathrm{df}$ & 0.995 & 0.995 & - & - \\
\hline & wa & 0.999 & 0.999 & 0.999 & 0.999 \\
\hline & ww & 0.995 & 0.995 & 0.995 & 0.995 \\
\hline & ws & 0.995 & 0.995 & 0.995 & 0.995 \\
\hline $4 \mathrm{~h}$ & $\mathrm{da}$ & 0.998 & 0.999 & 0.999 & 0.999 \\
\hline & $d w$ & 0.978 & 0.994 & - & - \\
\hline & df & 0.979 & 0.994 & - & - \\
\hline & wa & 0.999 & 0.999 & 0.999 & 0.999 \\
\hline & ww & 0.994 & 0.994 & 0.994 & 0.994 \\
\hline & ws & 0.989 & 0.994 & 0.988 & 0.994 \\
\hline $16 \mathrm{~h}$ & $\mathrm{da}$ & 0.999 & 0.999 & 0.999 & 0.999 \\
\hline & $d w$ & 0.994 & 0.994 & - & - \\
\hline & $\mathrm{df}$ & 0.990 & 0.994 & - & - \\
\hline & wa & 0.999 & 0.998 & 0.999 & 0.998 \\
\hline & Ww & 0.994 & 0.994 & 0.994 & 0.994 \\
\hline & ws & 0.991 & 0.994 & 0.986 & 0.994 \\
\hline $2 d$ & $\mathrm{da}$ & 0.998 & 0.998 & 0.998 & 0.998 \\
\hline & $d w$ & 0.996 & 0.996 & - & - \\
\hline & $\mathrm{df}$ & 0.992 & 0.997 & - & - \\
\hline & wa & 0.998 & 0.997 & 0.998 & 0.997 \\
\hline & $W W$ & 0.997 & 0.997 & 0.997 & 0.997 \\
\hline & ws & 0.993 & 0.997 & 0.987 & 0.996 \\
\hline $8 d$ & $\mathrm{da}$ & 0.995 & 0.995 & 0.995 & 0.995 \\
\hline & $d w$ & 0.997 & 0.997 & - & - \\
\hline & $\mathrm{df}$ & 0.994 & 0.997 & - & - \\
\hline & wa & 0.994 & 0.996 & 0.995 & 0.996 \\
\hline & ww & 0.997 & 0.997 & 0.997 & 0.997 \\
\hline & ws & 0.994 & 0.997 & 0.989 & 0.997 \\
\hline $32 d$ & da & 0.956 & 0.956 & 0.956 & 0.956 \\
\hline & $d w$ & 0.988 & 0.988 & - & - \\
\hline & $\mathrm{df}$ & 0.985 & 0.988 & - & - \\
\hline & wa & 0.956 & 0.965 & 0.956 & 0.965 \\
\hline & wW & 0.989 & 0.989 & 0.989 & 0.989 \\
\hline & ws & 0.985 & 0.988 & 0.981 & 0.987 \\
\hline
\end{tabular}


Table 5.9

Gamma Total Energies Used by PATH (Concluded)

\begin{tabular}{|c|c|c|c|c|c|}
\hline & & & tom & & \\
\hline & & $\mathrm{C} 1$ & $\mathrm{C} 2$ & $\mathrm{C3}$ & $\mathrm{C} 4$ \\
\hline $128 d$ & $\mathrm{da}$ & 0.973 & 0.976 & 0.976 & 0.976 \\
\hline & $d w$ & 0.985 & 0.985 & - & - \\
\hline & df & 0.984 & 0.985 & - & - \\
\hline & wa & 0.974 & 0.979 & 0.974 & 0.974 \\
\hline & ww & 0.985 & 0.985 & 0.985 & 0.985 \\
\hline & ws & 0.985 & 0.985 & 0.984 & 0.984 \\
\hline $1 y$ & $\mathrm{da}$ & 1.0 & 1.0 & 1.0 & 1.0 \\
\hline & $d w$ & 0.982 & 0.982 & - & - \\
\hline & df & 0.982 & 0.982 & - & - \\
\hline & wa & 0.984 & 0.984 & 0.999 & 0.984 \\
\hline & ww & 0.982 & 0.982 & 0.982 & 0.982 \\
\hline & wS & 0.982 & 0.982 & 0.983 & 0.982 \\
\hline
\end{tabular}

$\begin{aligned} \text { a: } & \text { airborne } \\ \text { w: } & \text { wall } \\ \text { f: } & \text { floor } \\ \text { s: } & \text { sump } \\ \text { da: } & \text { drywe11 airborne } \\ \text { dw: } & \text { drywe1l wall } \\ \text { df: } & \text { drywell floor } \\ \text { wa: } & \text { wetwell airborne } \\ \text { ww: } & \text { wetwel1 wall } \\ \text { ws: } & \text { wetwell sump }\end{aligned}$




\subsection{Other Dose Rate and Dose Work}

Appendix D of Regulatory Guide 1.89 presents methodology and sample calculations for equipment qualification radiation dose. This appendix discusses the staff model for calculating dose rates and integrated doses for equipment qualification purposes. Gamma and beta doses were calculated at the midpoint of containment for a PWR plant with a free containment volume of $2.5 \times 10^{6}$ cubic feet and a power rating of 4,100 MWt (Surry has a free containment volume of $1.75 \times 10^{6}$ cubic feet and a power rating of 2,441 MWt). ESF fans and sprays were modeled to be operational. The staff assumed that 50 percent of the iodine core activity inventory and 100 percent of the core noble gas activity inventory were released instantaneously to the containment atmosphere. The reader is referred to Reg Guide 1.89 for further details and assumptions used in the analysis.

The Reg Guide 1.89 airborne noble gas gamma and beta dose are shown in Figure 5.4.1. The Surry Case 4 annulus and dome integrated gamma and beta dose are shown in Figures 5.4 .2 and 5.4.3. No direct comparison is intended since both reactors analyzed are different, but both analyses do show the dose due to noble gas activity. The gamma and beta doses for each analysis have roughly equivalent values; the Surry minimum and maximum dose values bound the staff dose values. 


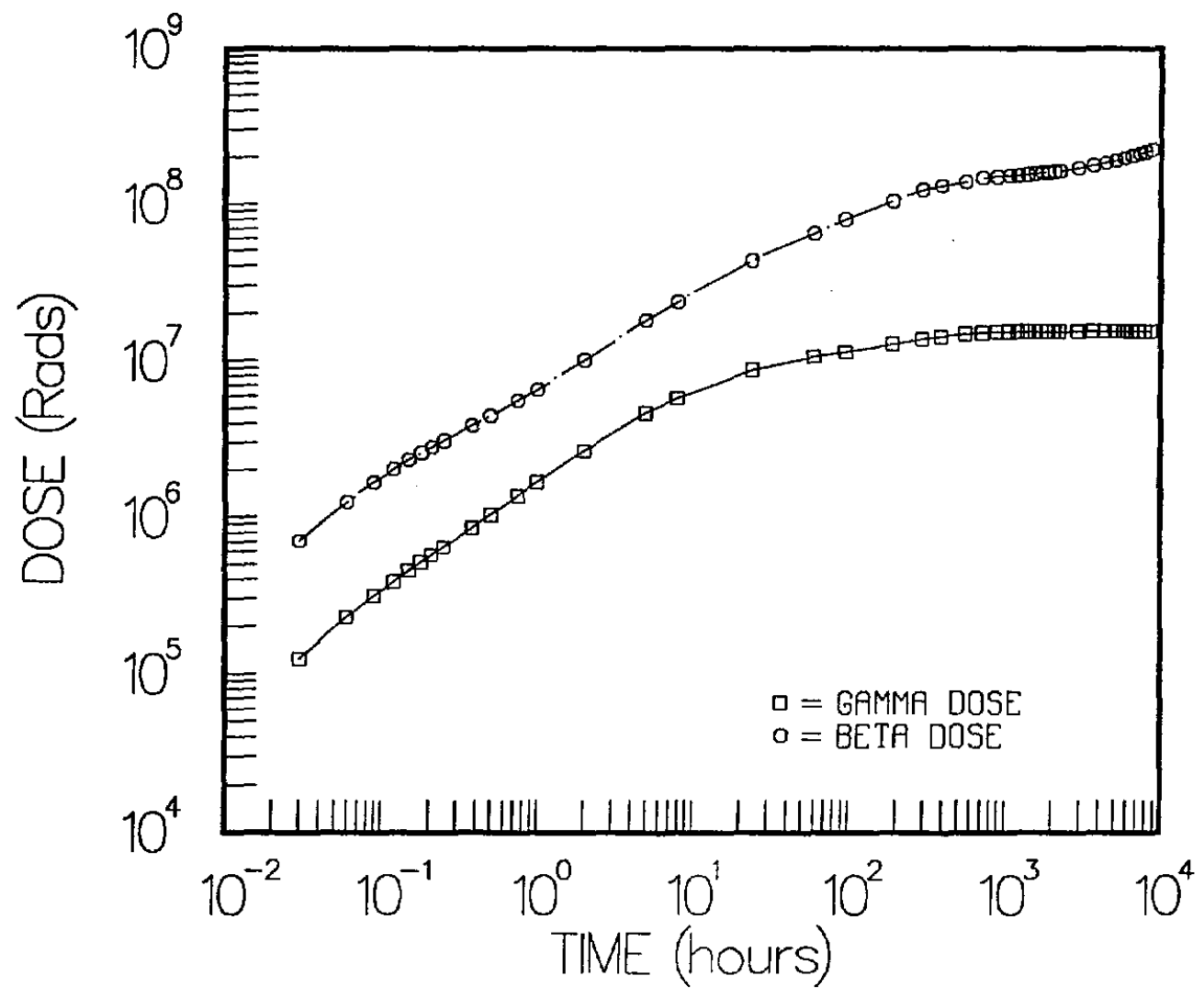

Figure 5.4.1. Reg Guide 1.89 Noble Gas Gamma and Beta Dose 

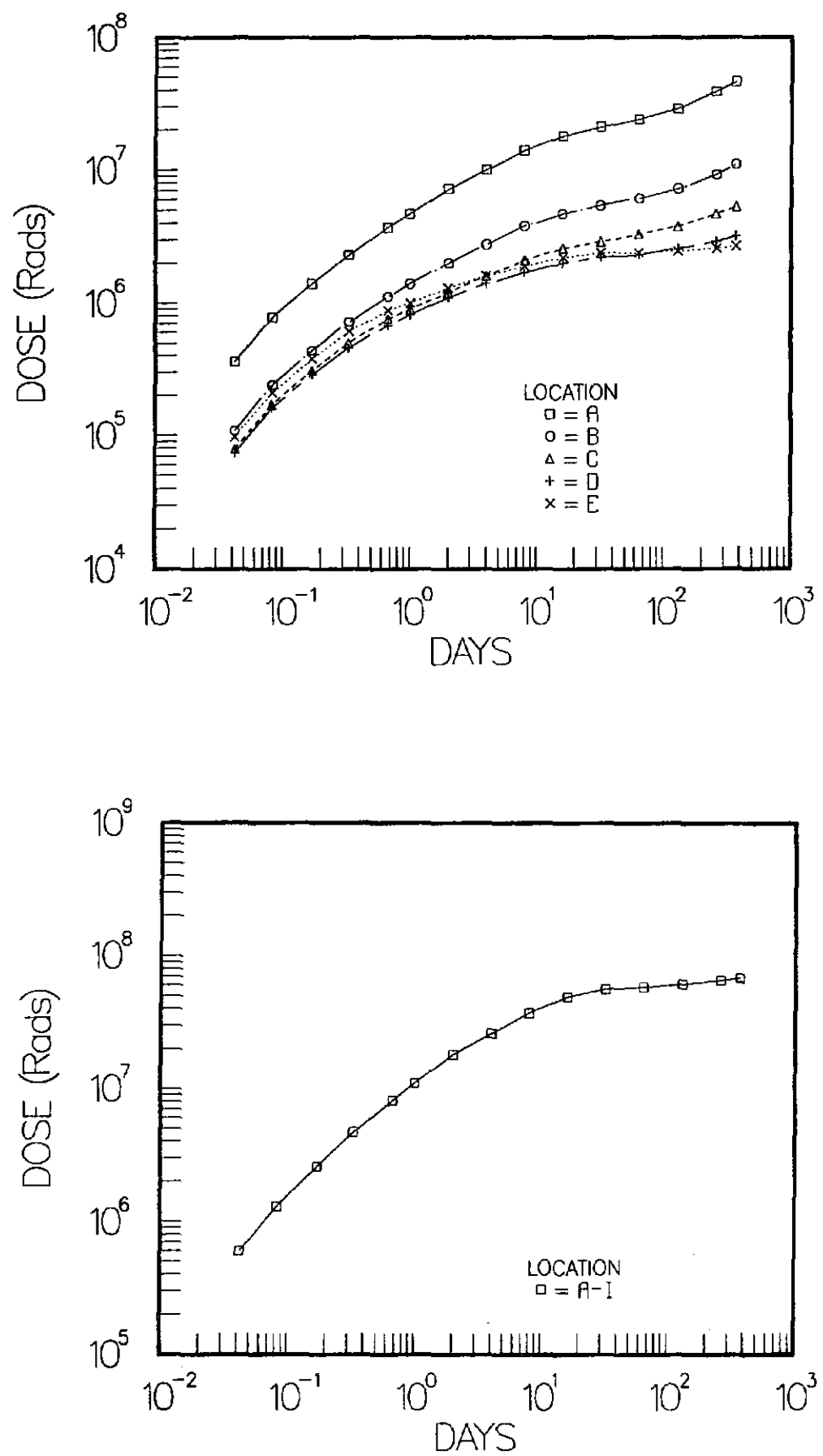

Figure 5.4.2. Surry Case 4 Annulus Total Gamma and Beta Dose 

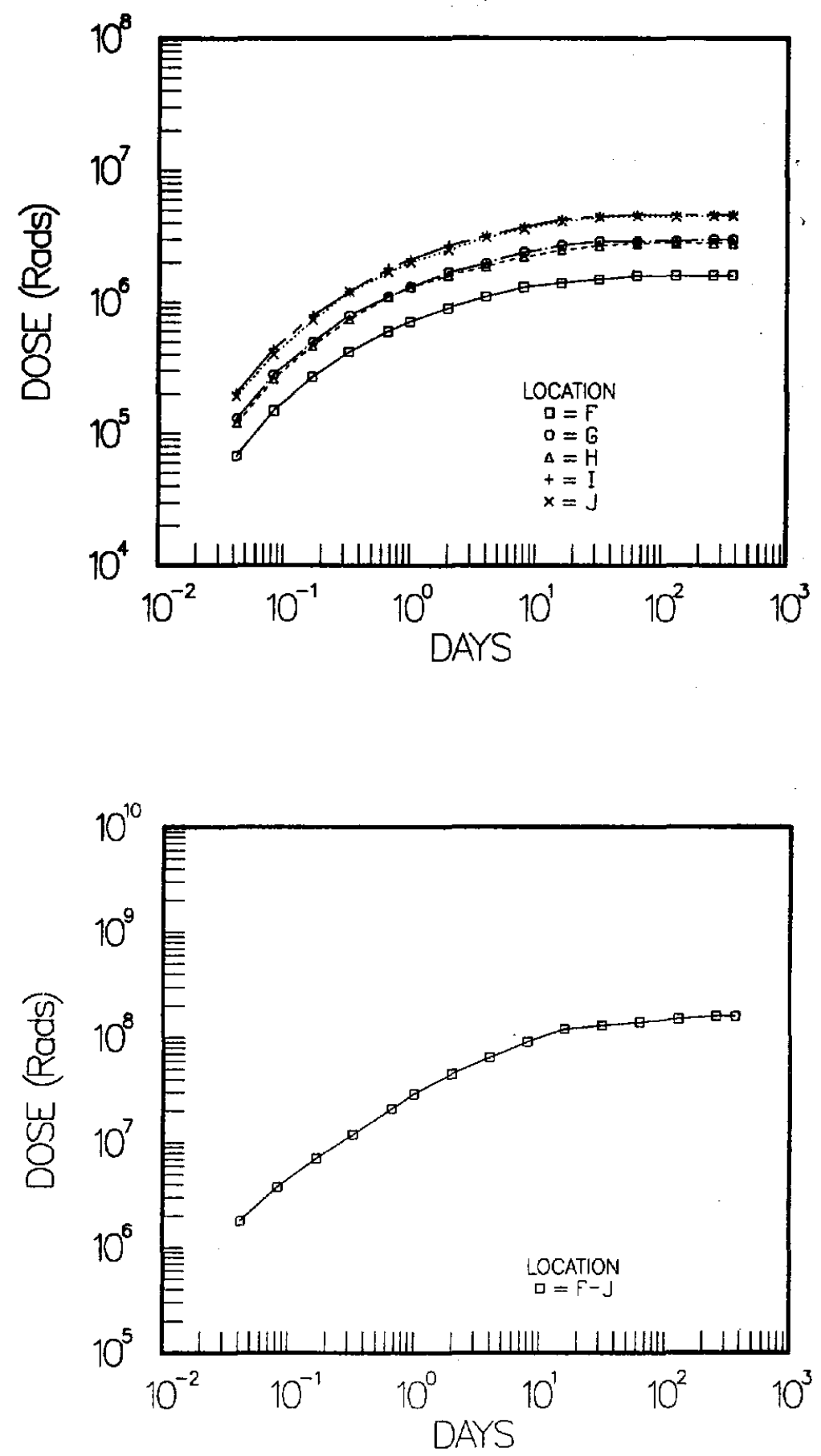

Figure 5.4.3. Surry Case 4 Dome Total Gamma and Beta Dose 


\subsection{SUMMARY AND RECOMMENDATIONS}

Dose rates and total dose have been calculated for the Surry and Peach Bottom containments using radionuclide sources which have been developed as a function of time with the Source Term Code Package. The AB epsilon scenario and three variations were used to calculate dose rate for surry and the AE scenario and three variations were used for Peach Bottom. For each plant, the variations involved (1) an arrested core meltdown, (2) operation of containment sprays and meltdown, and (3) an arrested sequence with operation of containment sprays. The base case for each plant resulted in the highest dose rates and total dose. Surry total gamma and beta dose exceeded the Reg Guide 1.89 Appendix D dose of $2.2 \times 10^{8}$ rads by as much as 1360 percent, and Peach Bottom total gamma and beta dose exceeded the Appendix D dose by as much as 832 percent. Therefore, equipment qualified to Appendix D levels may not be qualified for the base case severe accident levels. The Case 2 arrested sequence dose calculations for both Surry and Peach Bottom resulted in substantial total dose reduction throughout the containments. The majority of dose point locations studied were within a factor of 2 to 3 above the Appendix D levels. Case 3 and 4 scenarios resulted in total gamma and beta doses well below the Appendix D levels; Appendix D qualified equipment exposed to these environments should maintain their functional integrity.

Dose rate calculations in containment are highly dependent on the source term calculations. BCL staff believe that source term analysis uncertainties have been adequately bounded by the case variations selected for this study. Therefore, bounding source terms will give bounding dose rates. BCL staff also believes that the source terms are representative of the increased data base and improved calculational tools.

The BCL Surry source term analysis treated the containment as a single volume, and the Peach Bottom analysis treated the containment as two volumes (the drywell and wetwe11). Deposition of radionuclides to walls, floors, and sumps was also characterized for the two reactor containment models. Galculations of physical transport of radionuclides in a multicompartment containment during and after the accident was beyond the scope of this study. BCL staff believed that the limited containment nodalization was adequate to reasonably predict deposition, but that additional modeling was needed to characterize the effects of compartmentalization.

The Surry dose rate calculations used actual compartment models. Dose rates were calculated for the dome region, operating floor region, basement, annulus, steam generator A cubicle, steam generator B cubicle, RHR cubicle, and incore instrumentation room. Uniform distribution of source terms was assumed for this calculation. This method could result in underestimating dose rate in compartments into which the source is released early in the accident and overestimating dose rate in compartments away from the source release point. Operation of ESFs such as sprays and fans could enhance source mixing in containment. Physical 
transport of radionuclides in a multicompartment containment during the accident should be one area of future work.

Peach Bottom dose rate calculations modeled the drywell as one region and the wetwell as two regions (the wetwell torus and the torus room). Uniform distribution of radionuclides was also assumed during and after the accident; the uniform distribution assumption should be reasonable for the drywell since it is a relatively open volume. . Operation of drywell sprays should also enhance mixing in the drywell. Uniform distribution in the wetwell torus may also be reasonable due to the mixing action of drywell gas/liquid injection into the torus.

Gamma dose rate calculations for Surry and Peach Bottom were true threedimensional calculations. Volume sources and surface sources had to be approximated by a series of point sources. PATH calculations become prohibitively expensive as volume or surface sources are approximated by increasing number of point sources. Although care was taken to characterize the function of dose rate versus source point number, gamma dose rates could vary by as much as \pm 10 percent depending on the source point scheme used. One Peach Bottom and Surry case each should be selected from the eight examined and studied in greater detail assuming that further quantification of radionuclide transport in a multicompartment containment would be available.

ITS beta dose rate calculations for Surry and Peach Bottom were also three-dimensional calculations but were not as versatile as the PATH calculations for containment applications. Three-dimensional containment models are made by combining simple geometric shapes into a number of containment zones. Electron transport can be tracked three-dimensionally from zone to zone. Dose rate calculations are presented in terms of average electron energy deposition in each containment zone from specified electron sources. Finely dividing or nodalizing a containment into small zones would approach true three-dimensional electron dose rate calculations but would also result in prohibitive computing expenses. The Case 1 Surry and Peach Bottom wall and surface source dose rate calculations should be repeated with finer containment nodalization in locations which have high calculated beta doses.

BCL stated the Case 1 scenarios for Peach Bottom and Surry represented worst case radionuclide release. Case 2 scenarios were arrested sequences and radionuclide activity due only to core-concrete attack was removed from the radionuclide output; the removal of only the coreconcrete contribution implies that 100 percent core degradation occurred. Therefore, Case 2 could also represent a worst case scenario for radionuclide release when compared to accident sequences with less core damage. Other lesser core degradation percentages may be more likely to occur during accidents and may result in smaller dose calculations. 
1. Theoretical Possibilities and Consequences of Major Accidents in Large Nuclear Power Plants, WASH-740, U.S. Atomic Energy Commission, June 1957.

2. DiNunno, J. J , et al., Calculation of Distance Factors for Power and Test Reactor Sites, TID-14844, March 1962.

3. Silberberg, M., et al., Reassessment of the Technical Bases for Estimating Source Terms, NUREG-0956, U.S. Nuclear Regulatory Commission, June 1986.

4. Environmental Qualification of Certain Electric Equipment Important to Safety for Nuclear Power Plants, Regulatory Guide 1.89 , U.S. Nuclear Regulatory Commission, June 1984.

5. Su, S. D., et a1., PATH Gamma Shielding Code User's Manual, GAA16772, General Atomic Company, September 1982.

6. Halbleib, J. A. and T. A., Mehlhorn, ITS: The Integrated Tiger Series of Coupled Electron/Photon Monte Carlo Transport Codes, SAND84-0573, Sandia National Laboratories, November 1984.

7. Report of the Special Committee on Source Terms, American Nuclear Society, September 1984.

8. England, T. R., et al., Summary of ENDF/B-V Data for Fission Products and Actinides, EPRI NP-3787, LA-UR83-1285, Electric Power Research Institute, December 1984. 
APPENDIX A

ITS CONTAINMENT BUILDING ZONES 
Beta dose calculations required that the compartments 1isted in Table 4.1 (for gamma dose calculations) be further subdivided because of the shorter range of beta dose when compared to gamma dose. Subdividing the containment too finely would result in exorbitant ITS computing costs. Figure A.1 shows the Surry containment subdivision used when dose rates caused by surface sources were calculated. Figure A.2 shows containment subdivision for floor source calculations. Figure A.3 shows the steam generator A cubicle subdivision; subdivision of the steam generator $B$ cubicle, RHR cubicle, and incore instrumentation room are similar.

Figure A.4 shows the Peach Bottom drywell subdivision for wall surface sources. The Peach Bottom drywell subdivision for floor surface sources is shown in Figure A. 5 . 


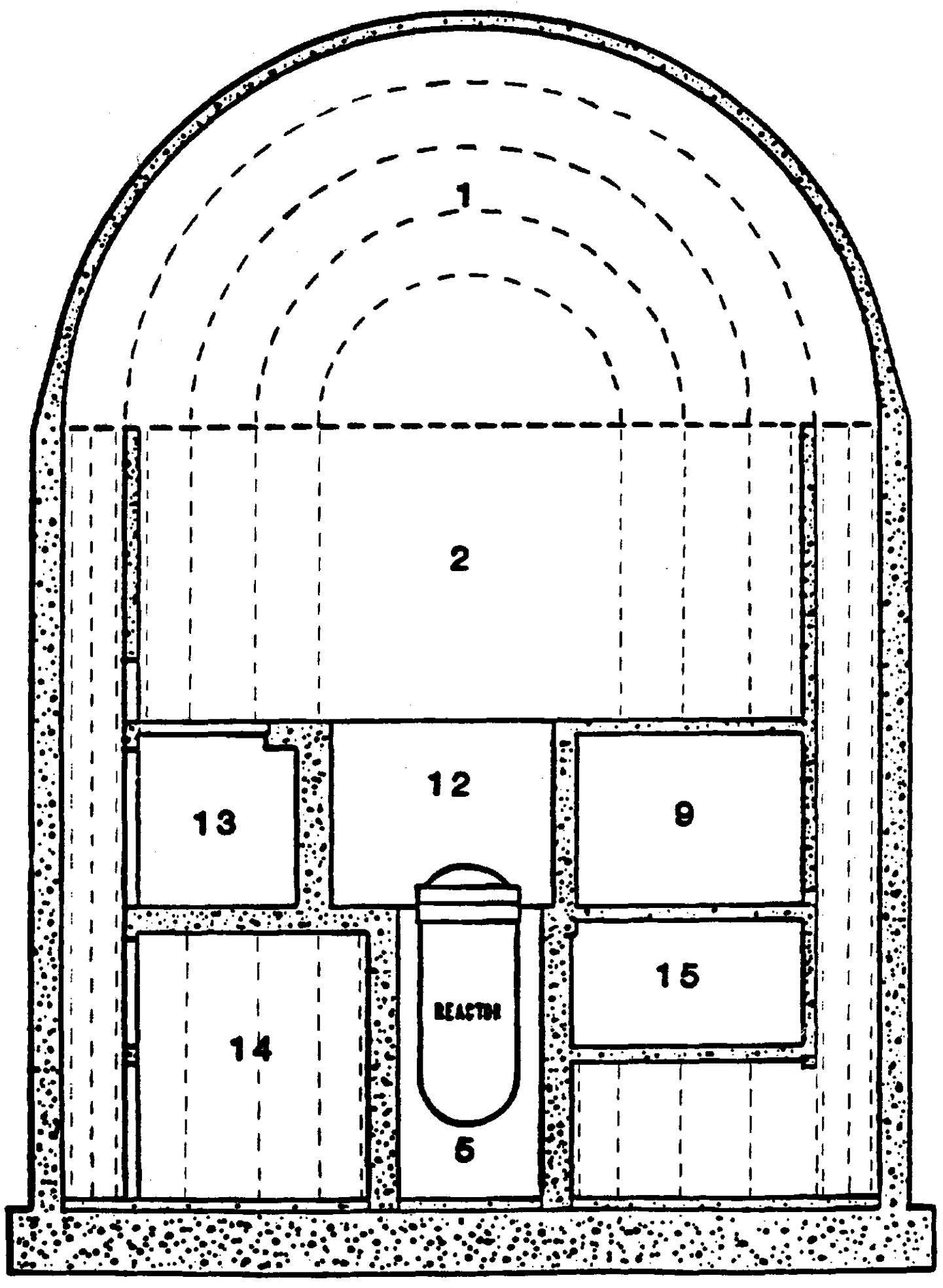

Figure A.1. Surry Containment Zones for Surface Sources 


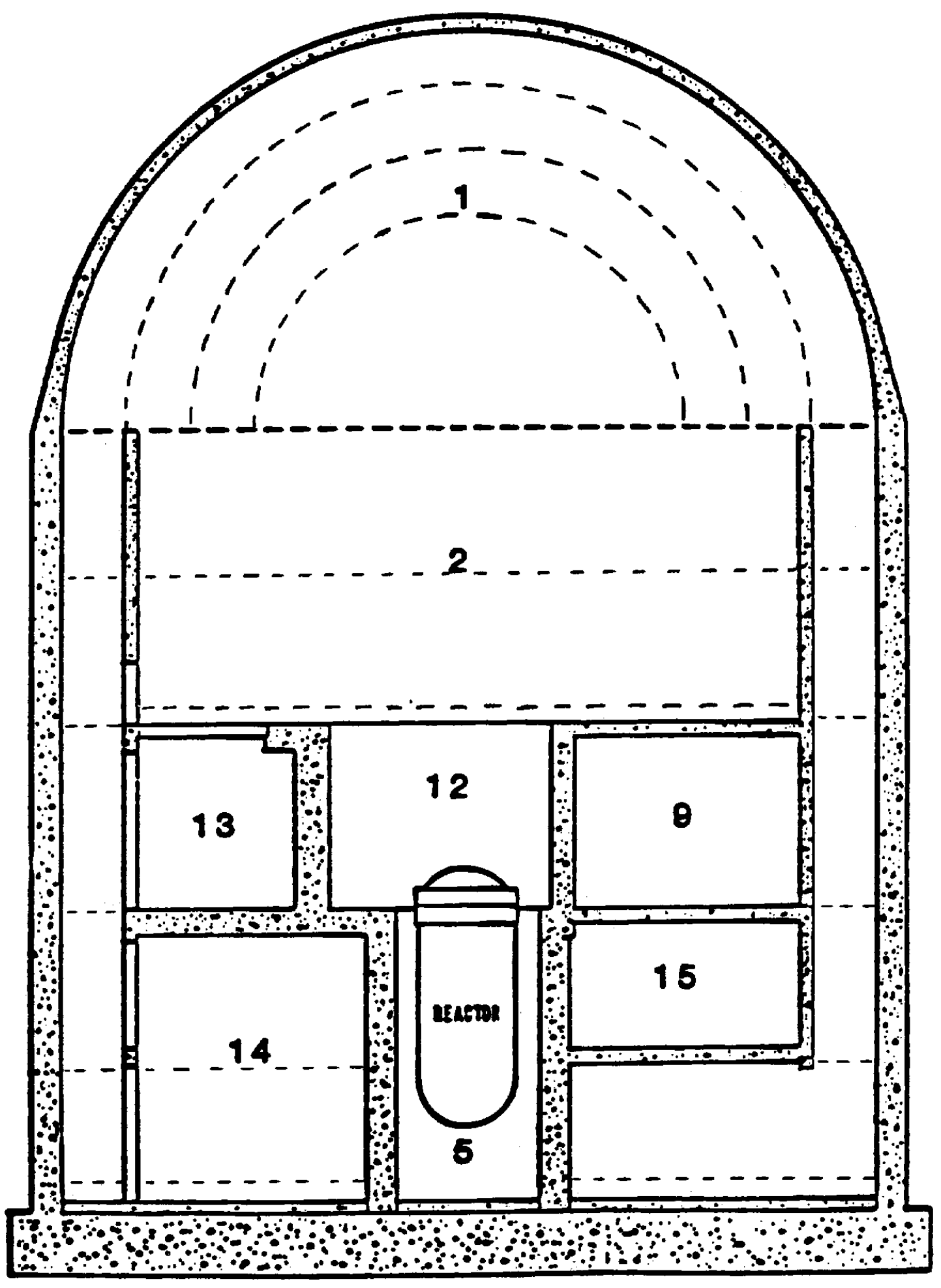

Figure A.2. Surry Containment Zones for Floor Sources 


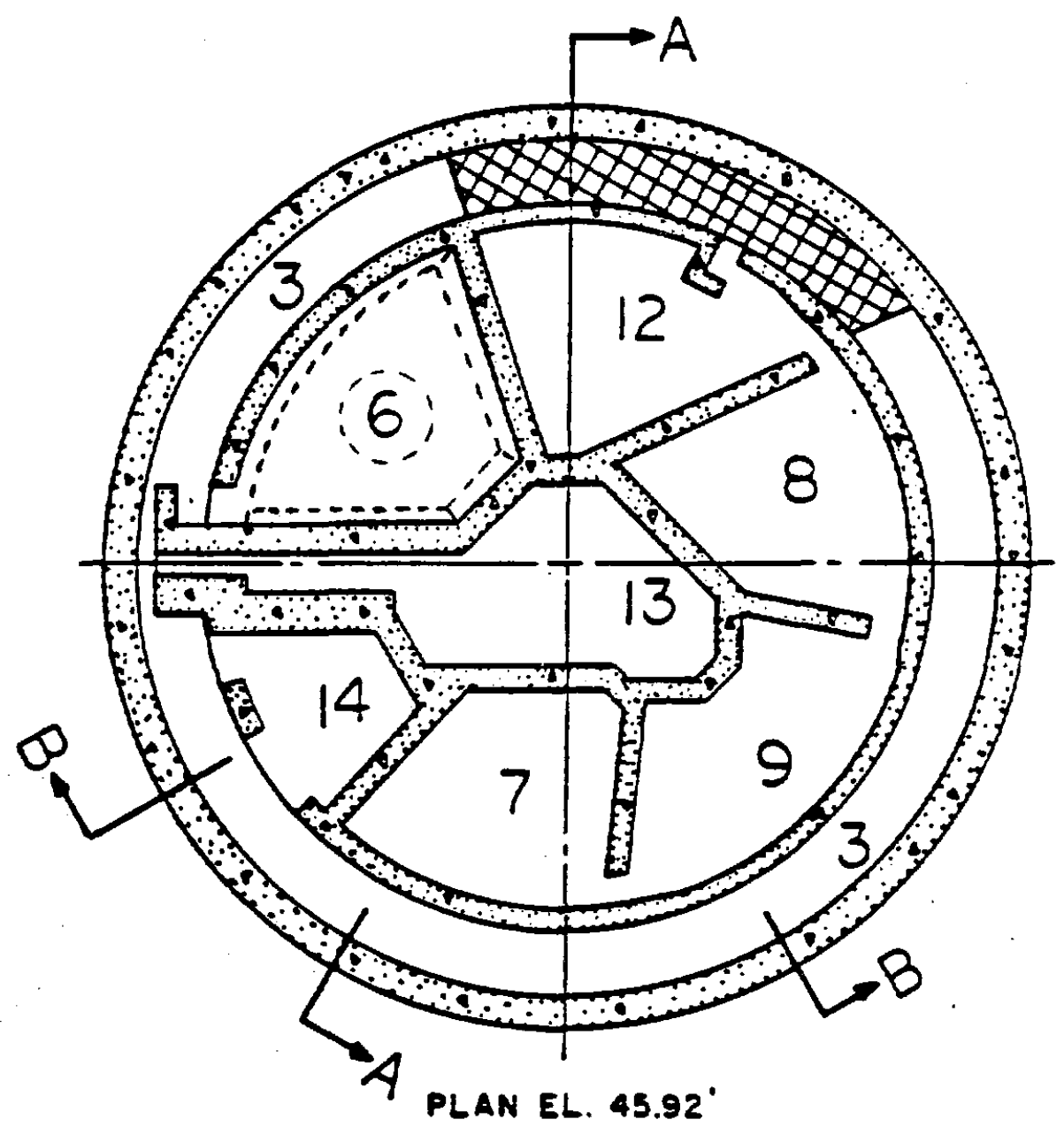

Figure A:3. Surry Steam Generator A Cubicle Zones 


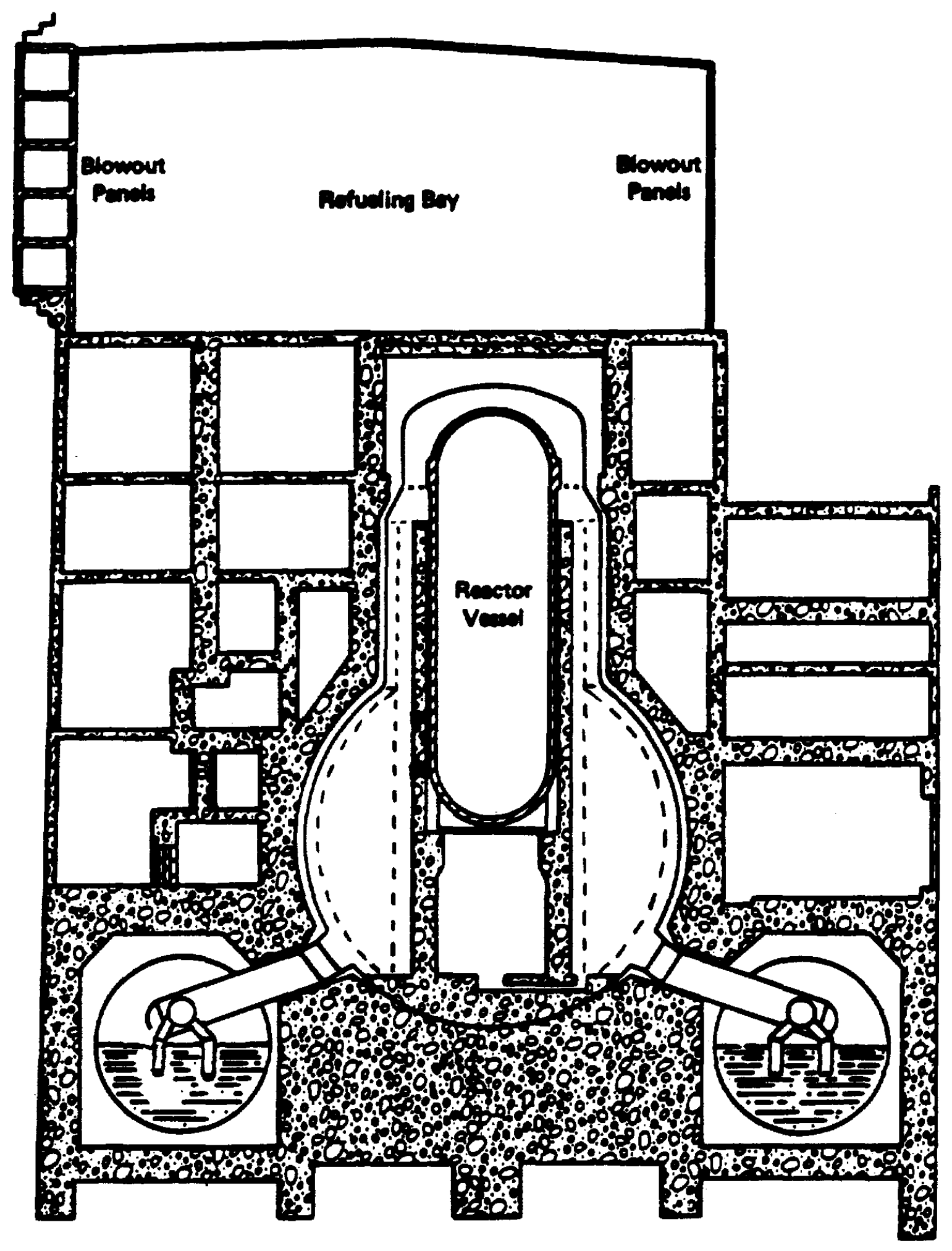

Figure A.4. Peach Bottom Drywell Zones for Surface Sources 


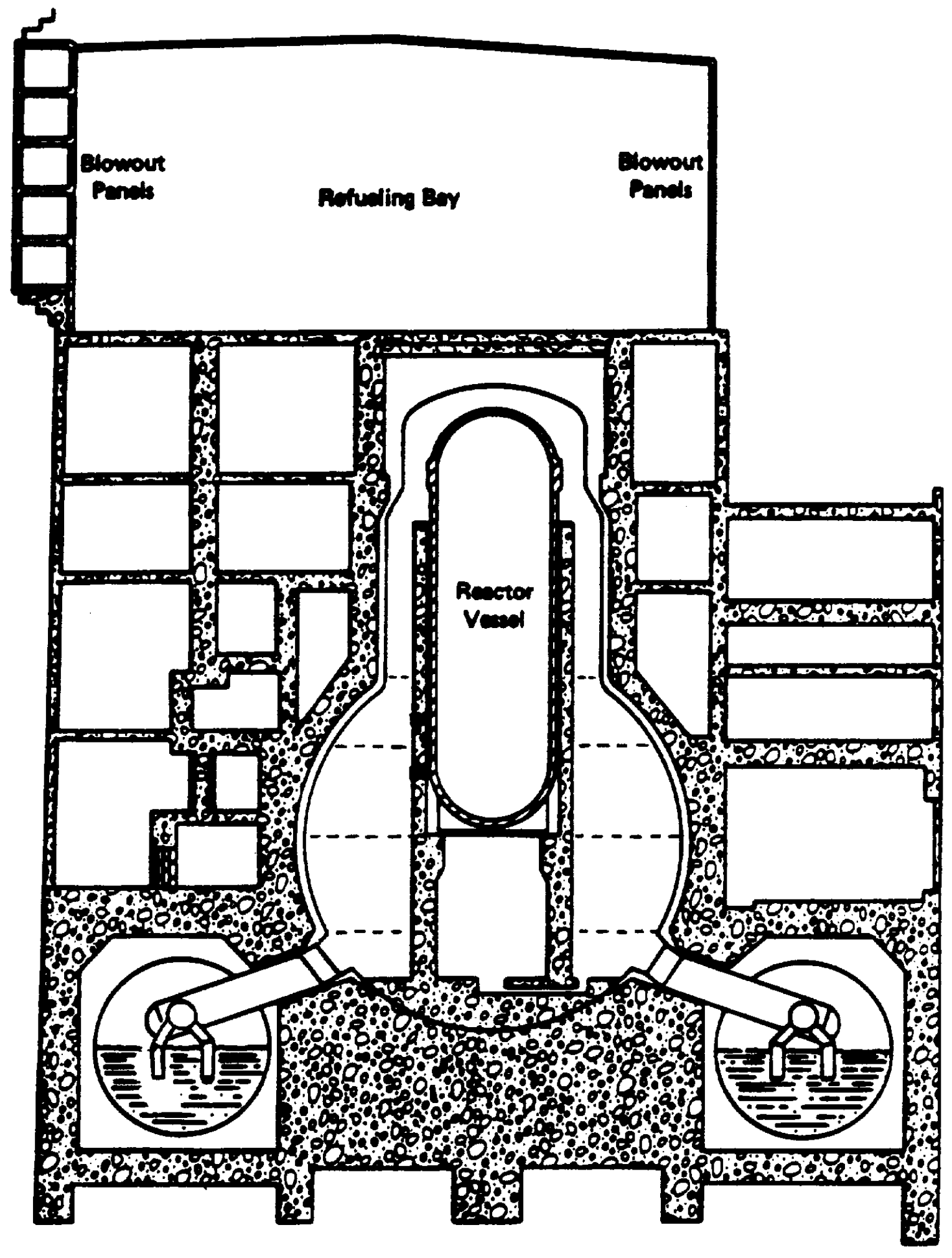

Figure A.5. Peach Bottom Drywel1 Zones for Floor Sources 


\section{APPENDIX B}

ADDITIONAL DOSE RATE AND DOSE FIGURES 

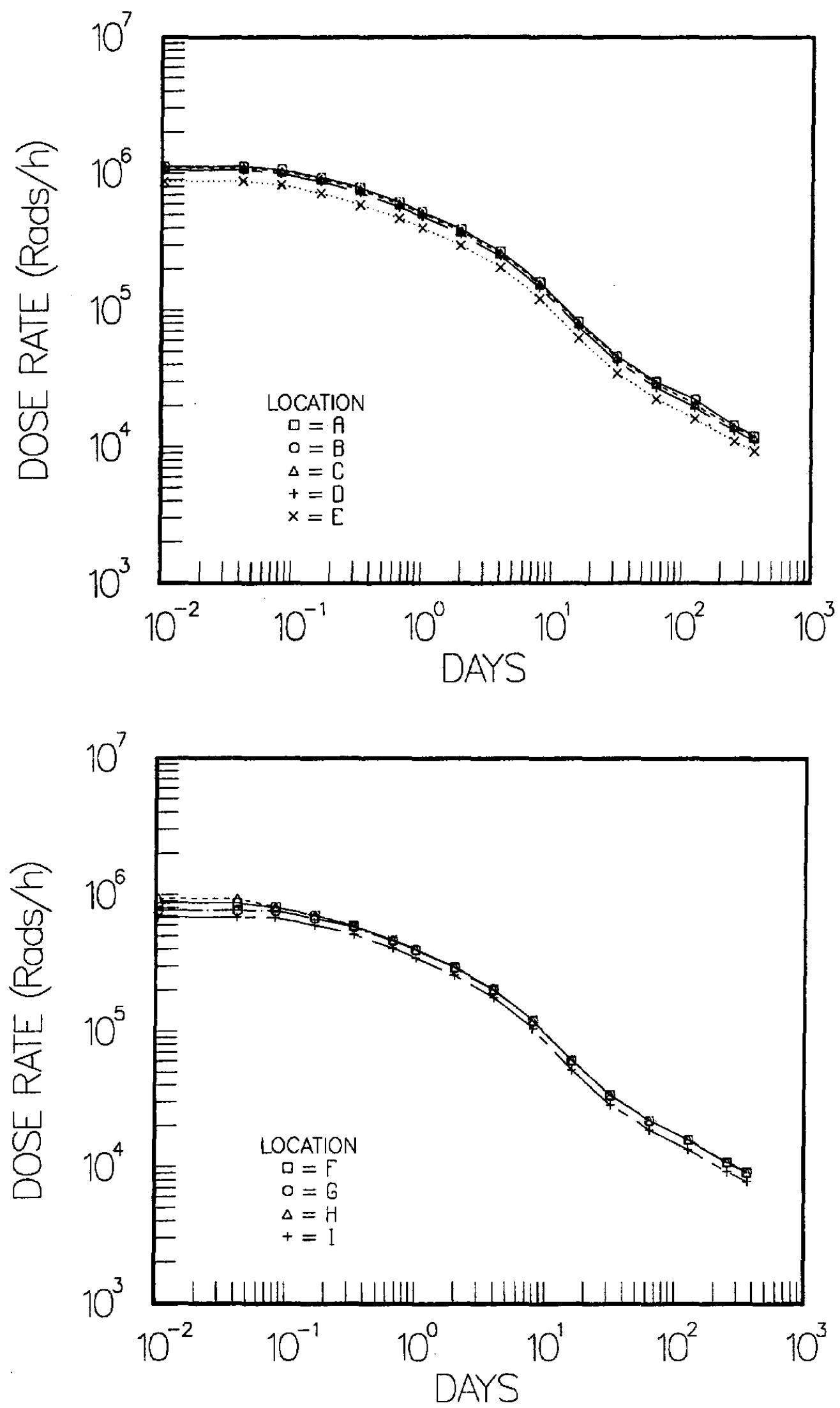

Figure B:1. Surry Case 1 Basement Gamma Dose Rate 

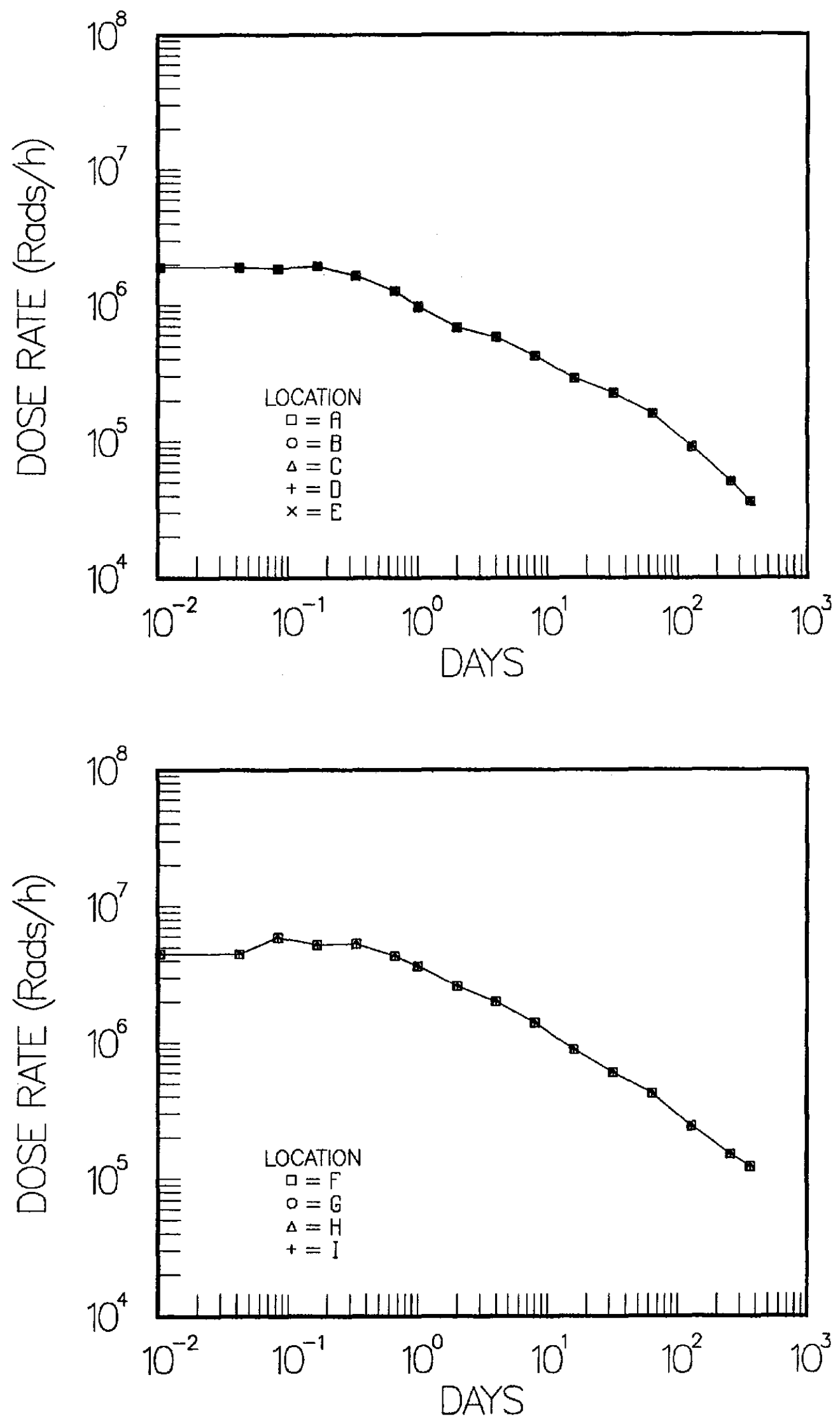

Figure B.2. Surry Case 1 Basement Beta Dose Rate 


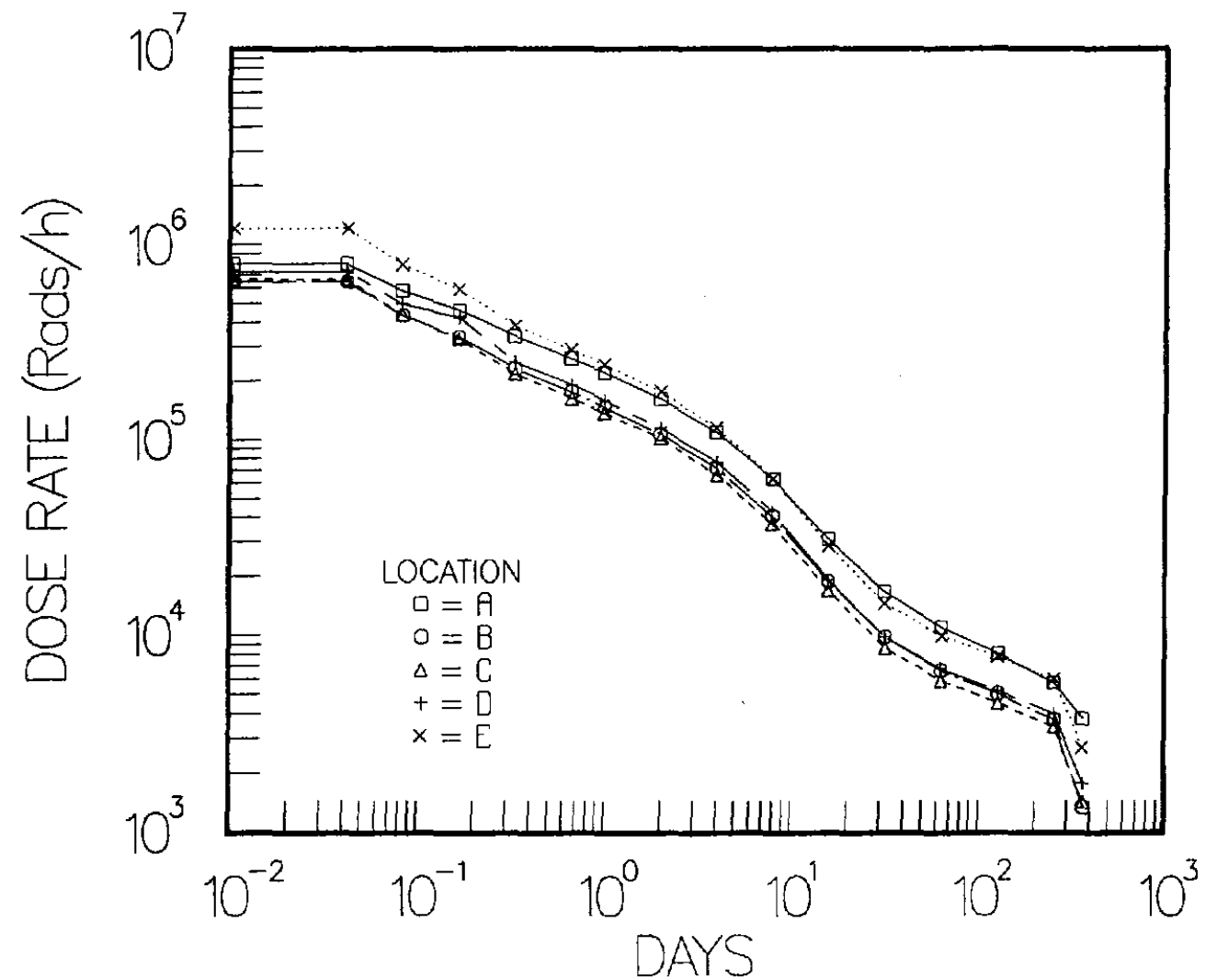

Figure B.3. Surry Case 1 Annulus Gamma Dose Rate

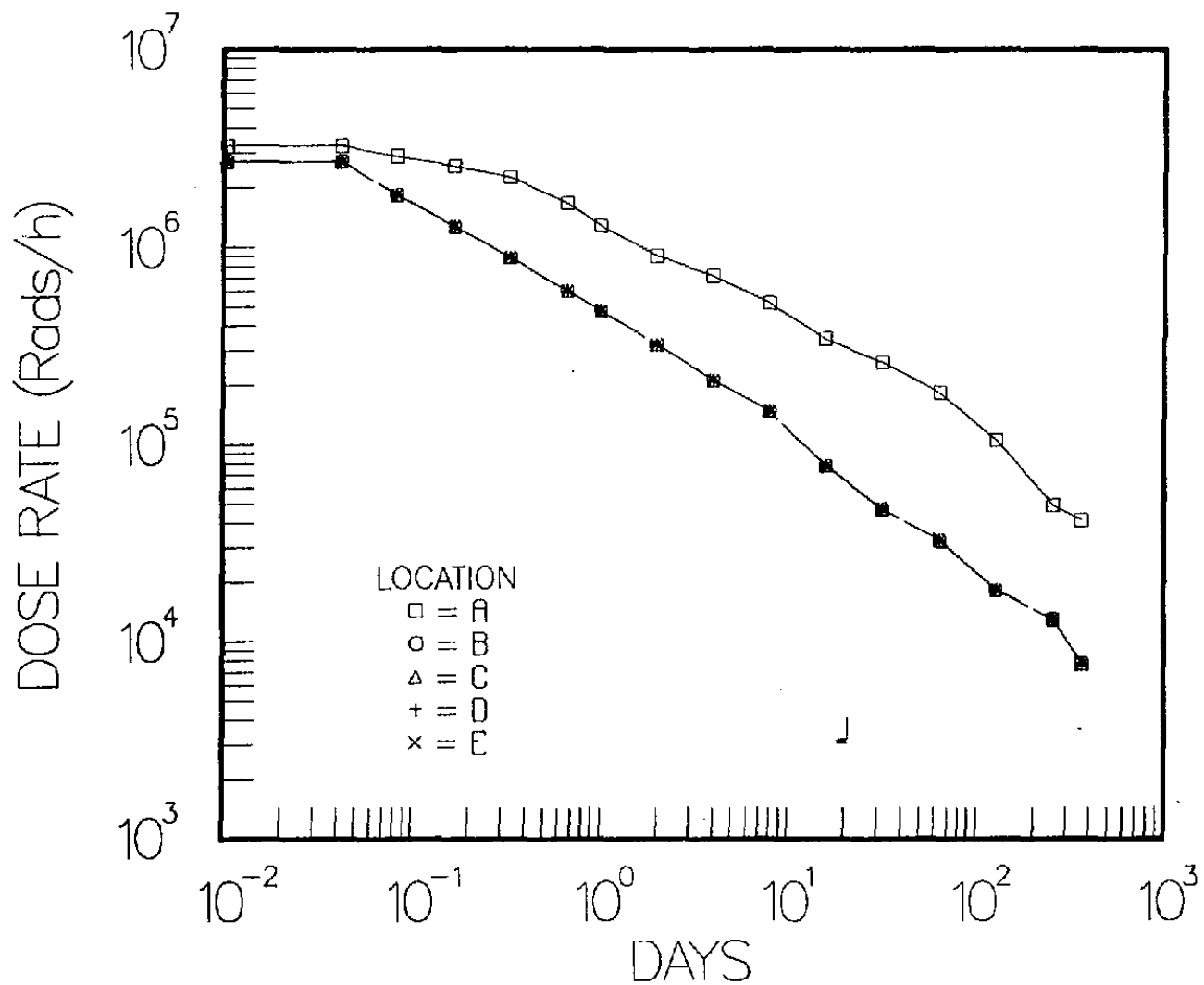

Figure B.4. Surry Case 1 Annulus Beta Dose Rate 


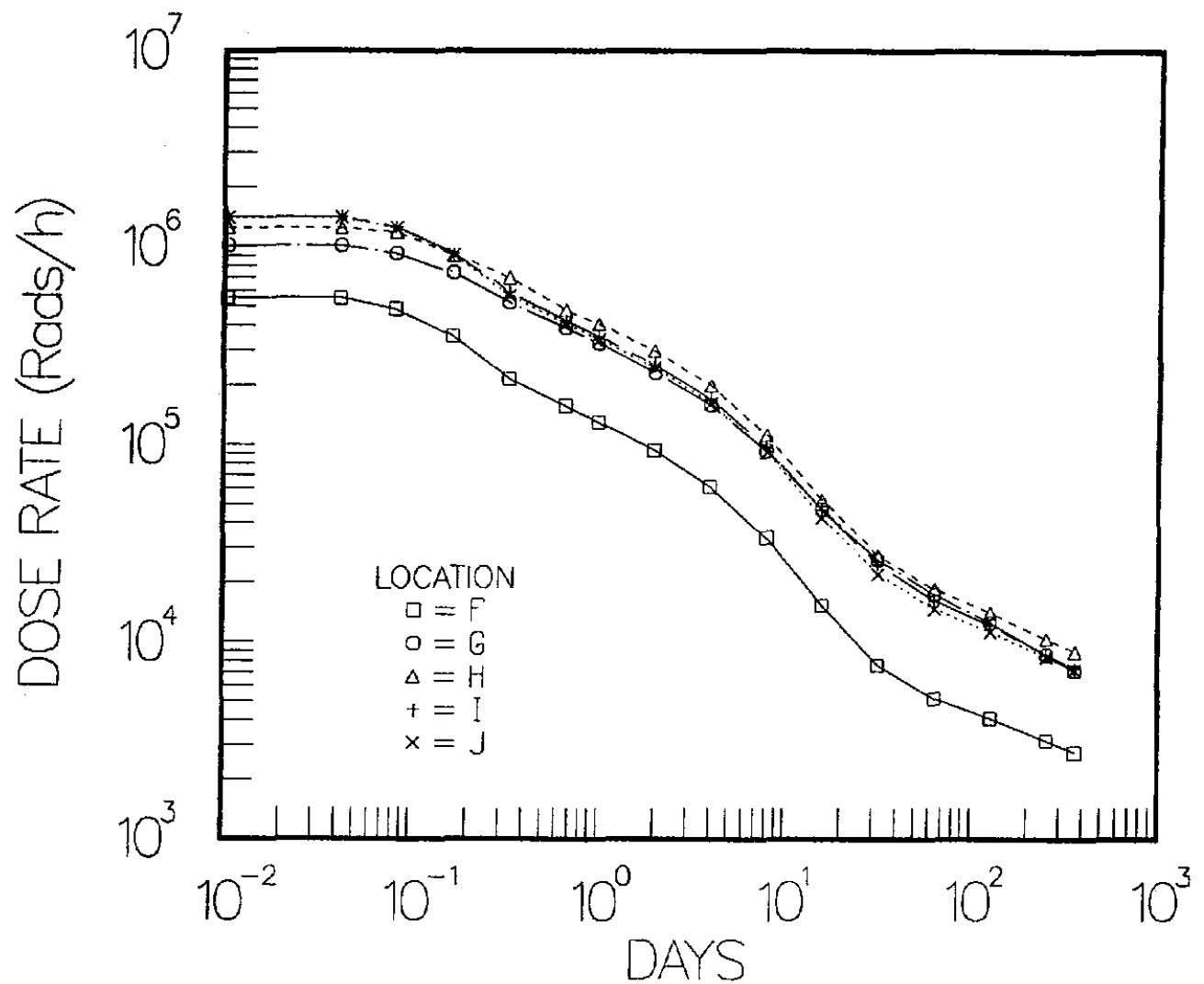

Figure B.5. Surry Case 1 Operating Floor and Dome Gamma Dose Rates

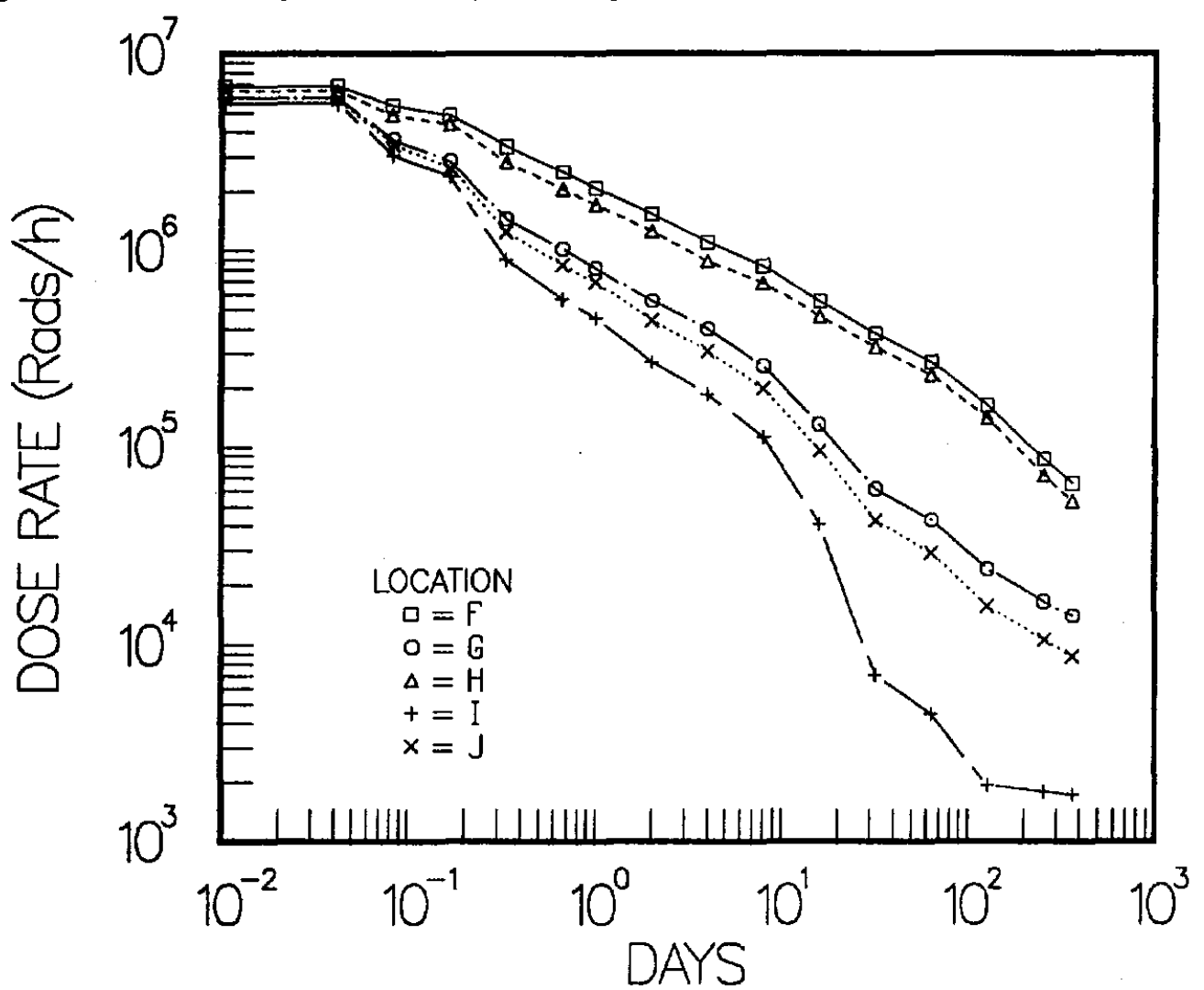

Figure B.6. Surry Case 1 Operating Floor and Dome Beta Dose Rates 


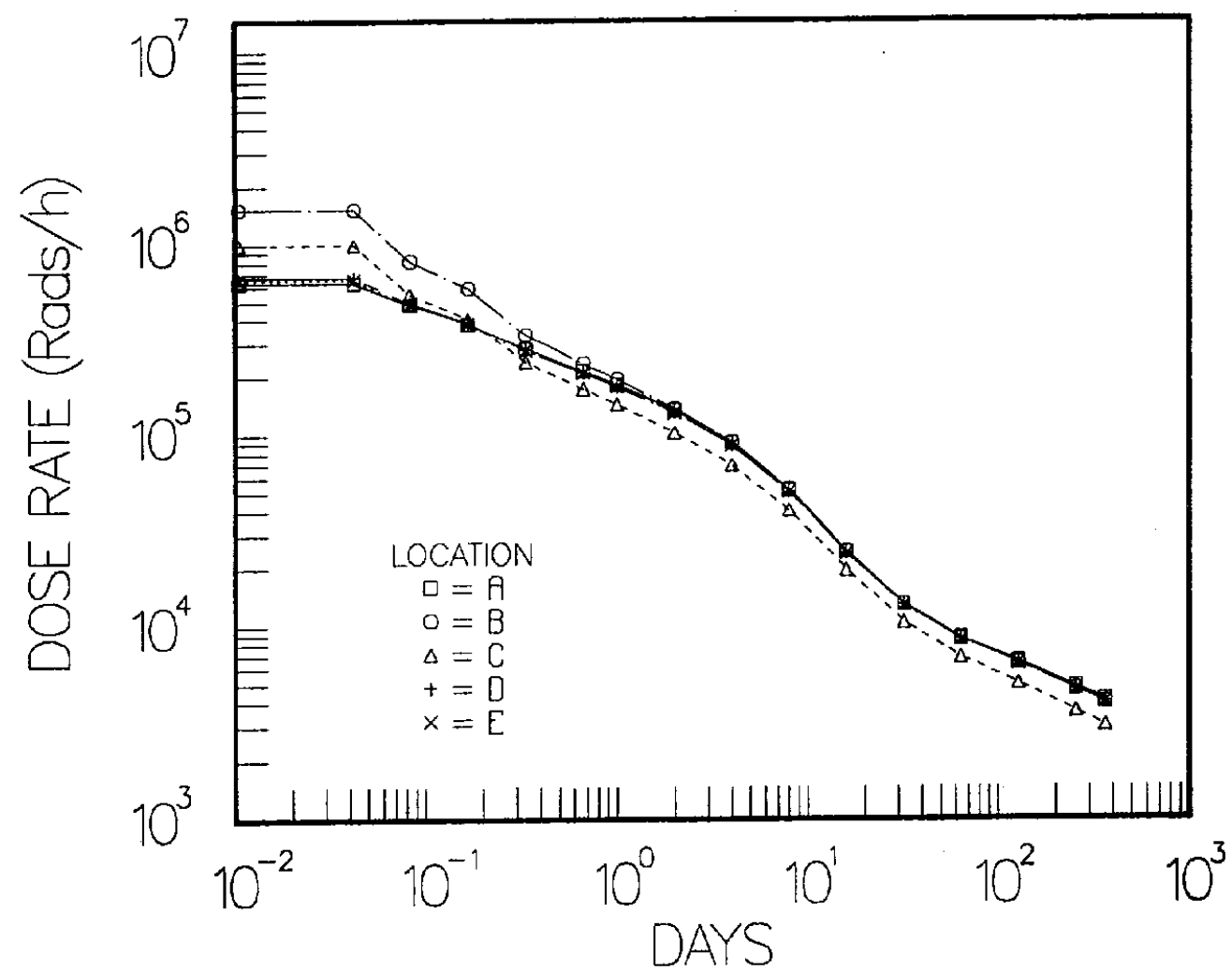

Figure B.7. Surry Case 1 Steam Generator A Cubicle Gamma Dose Rates

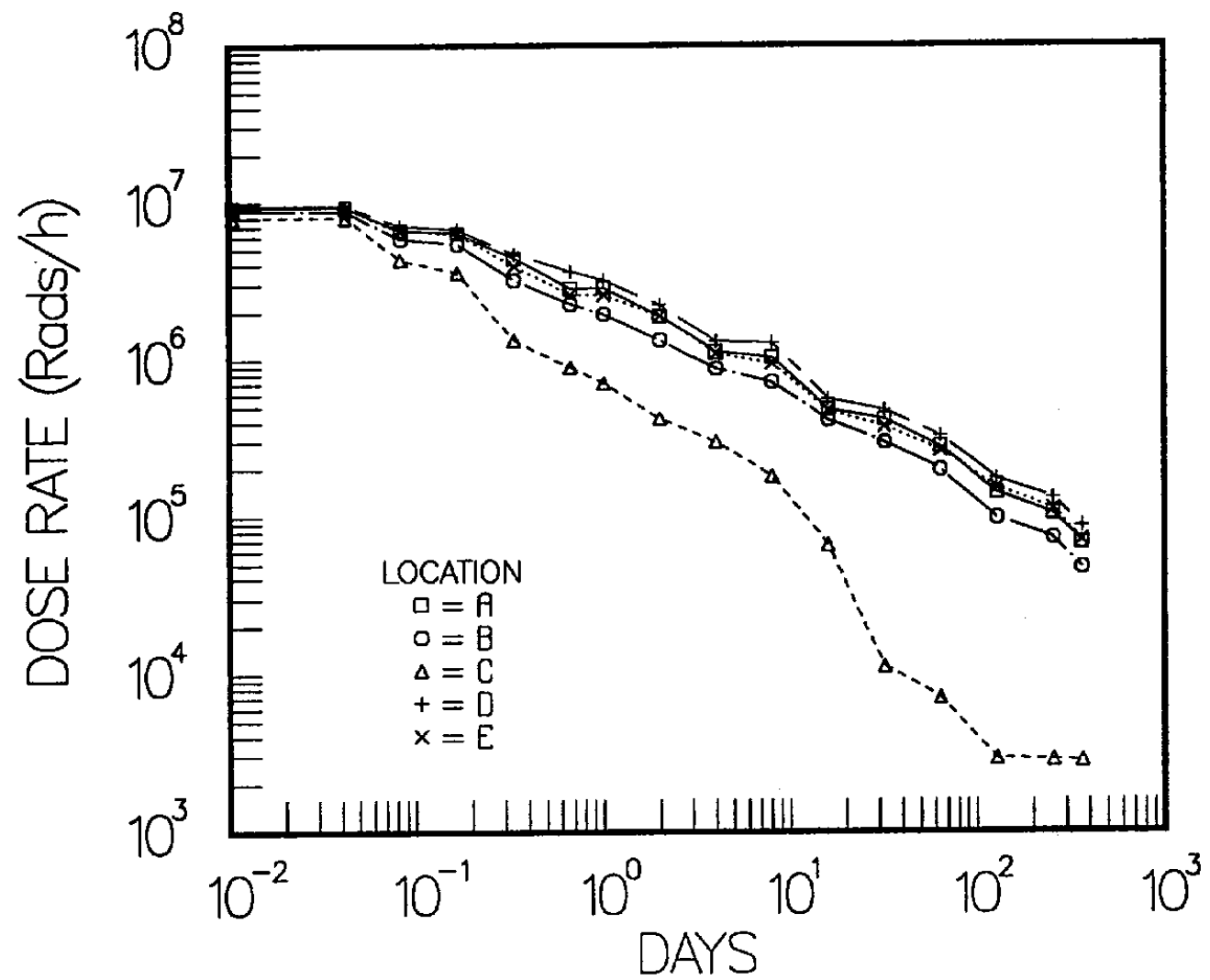

Figure B.8. Surry Case 1 Steam Generator A Cubicle Beta Dose Rates 


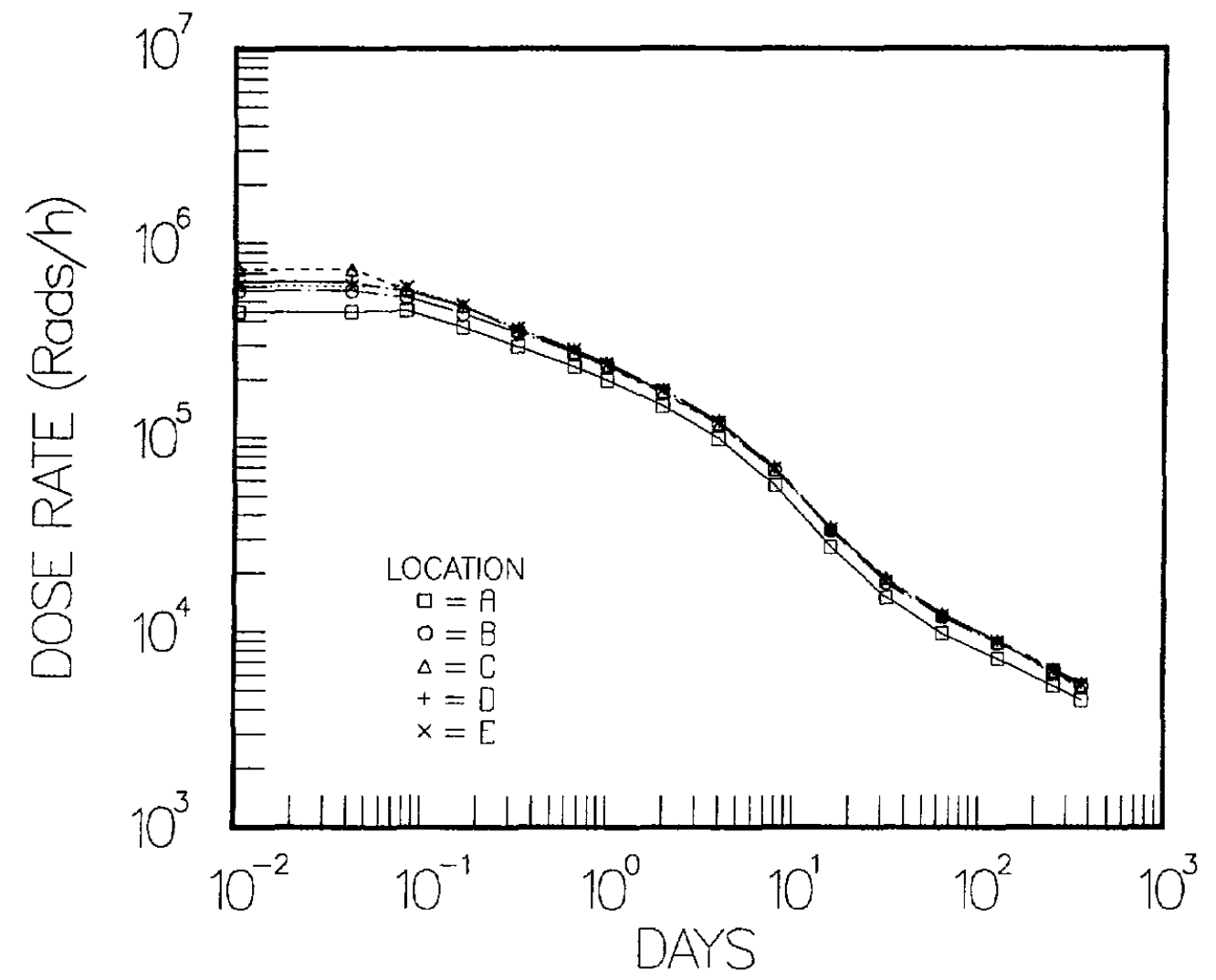

Figure B.9. Surry Case 1 RHR Cubicle Gamma Dose Rates

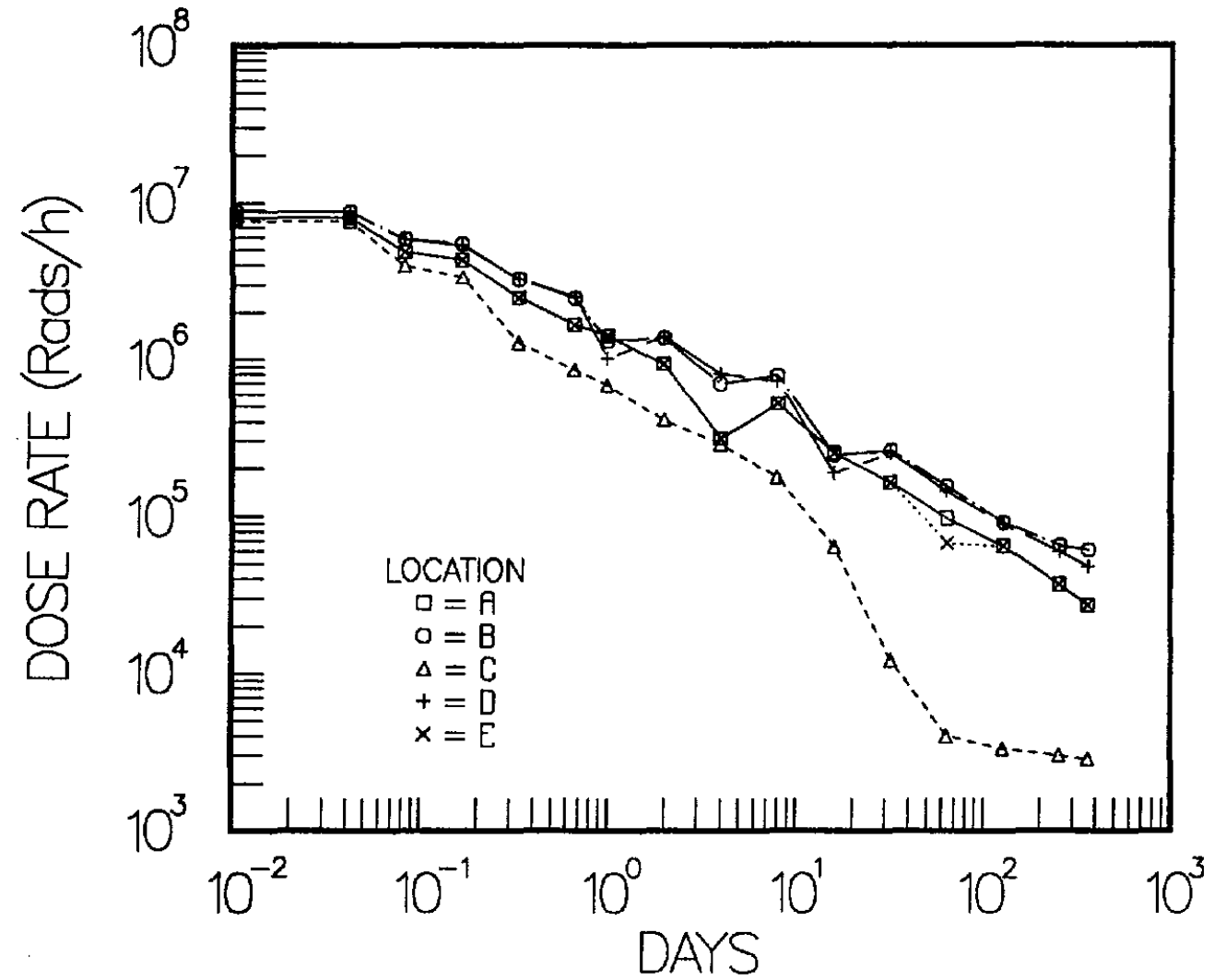

Figure B.10. Surry Case 1 RHR Cubicle Beta Dose Rates 


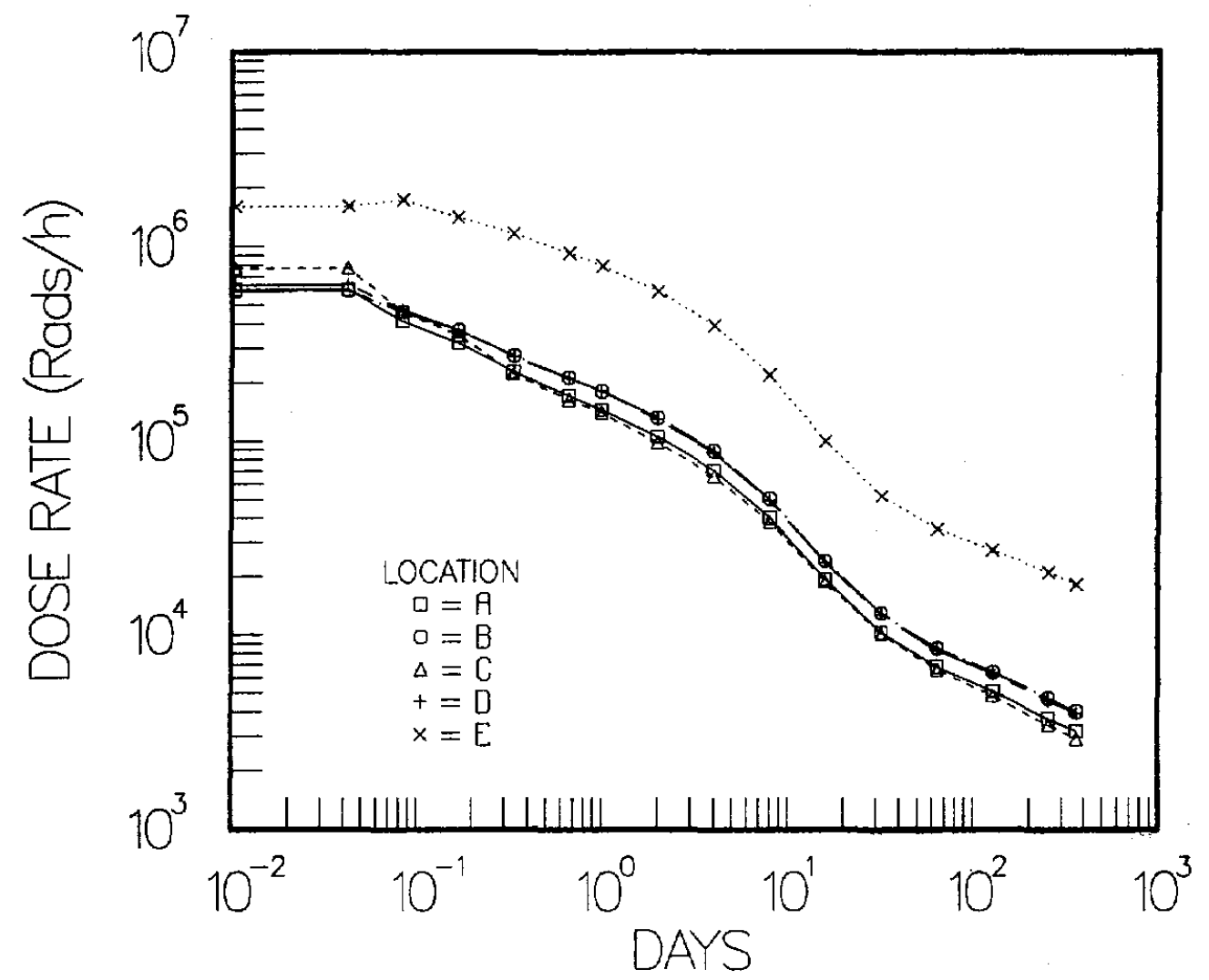

Figure B.11. Surry Case 1 Steam Generator B Gamma Dose Rate

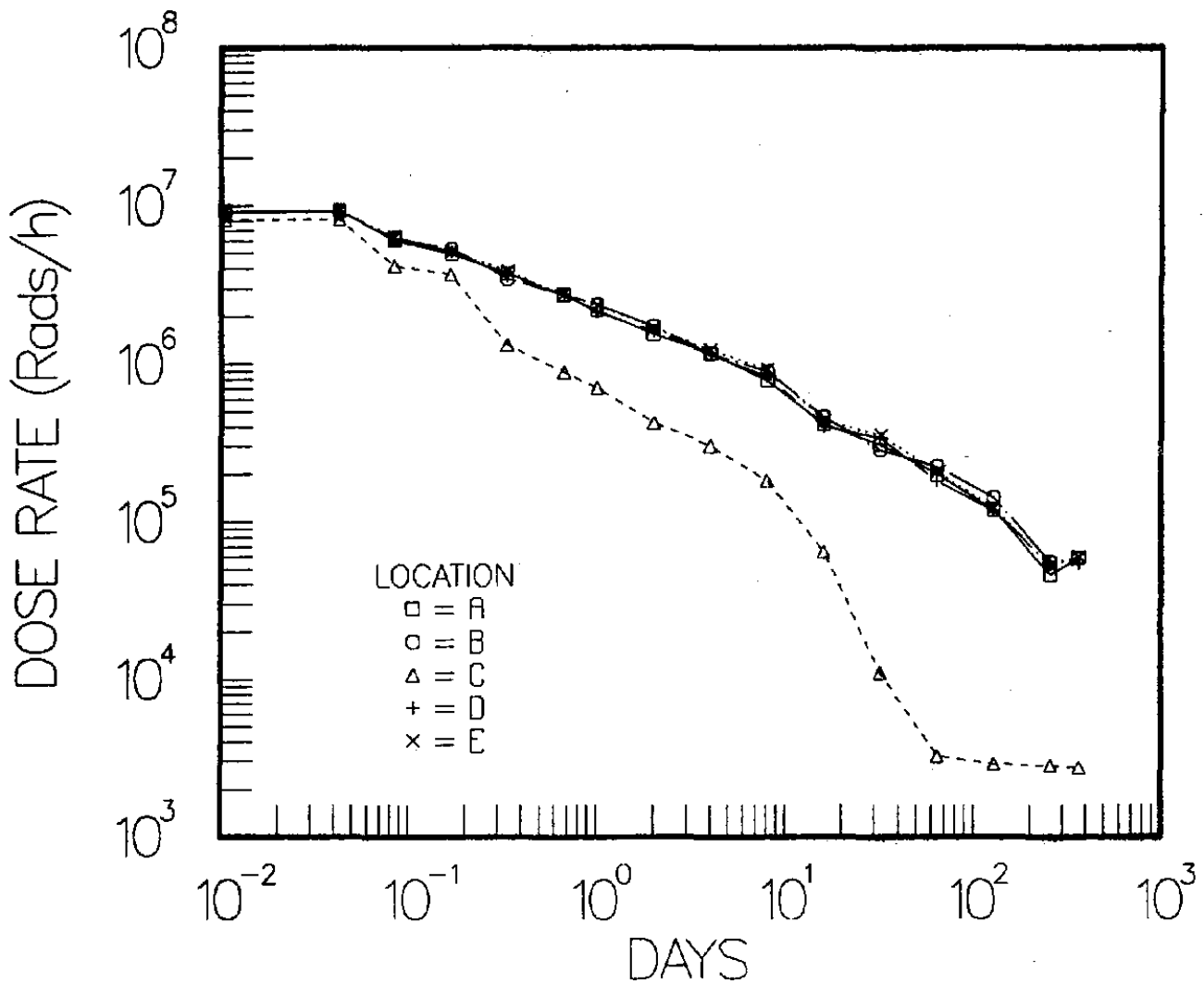

Figure B.12. Surry Case 1 Steam Generator B Beta Dose Rate 


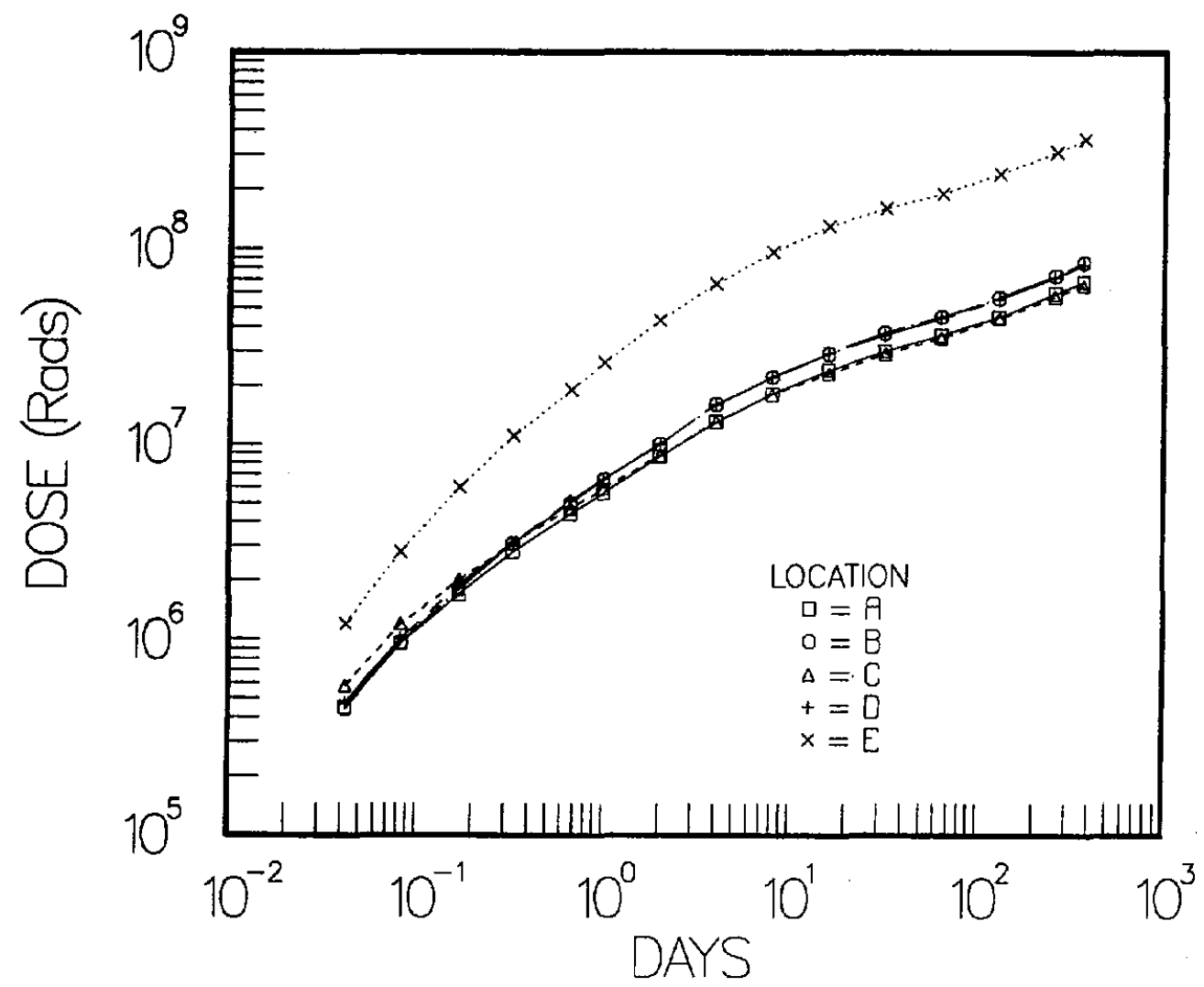

Figure B.13. Surry Case 1 Steam Generator B Total Gamma Dose

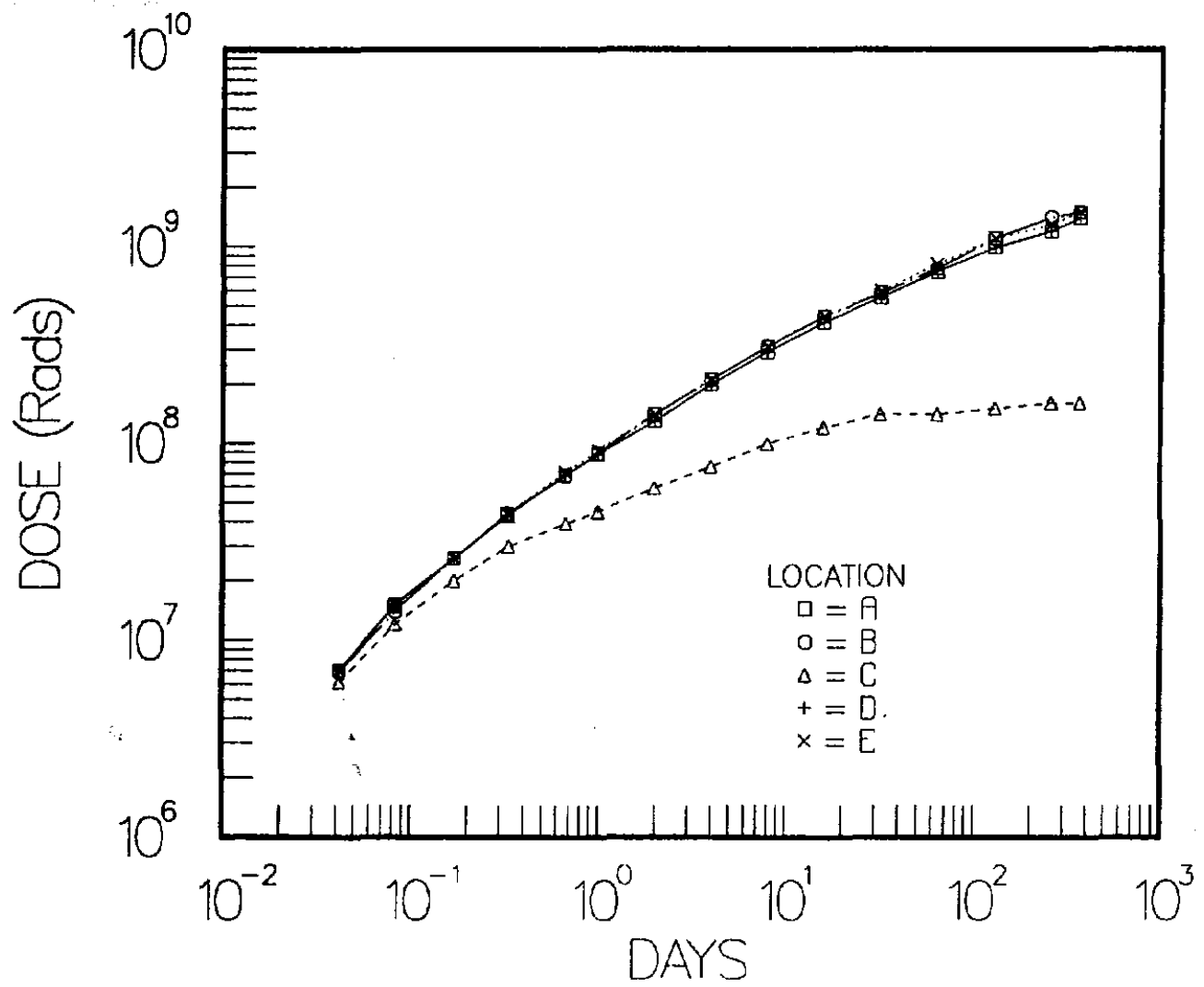

Figure B.14. Surry Case 1 Steam Generator B Total Beta Dose 


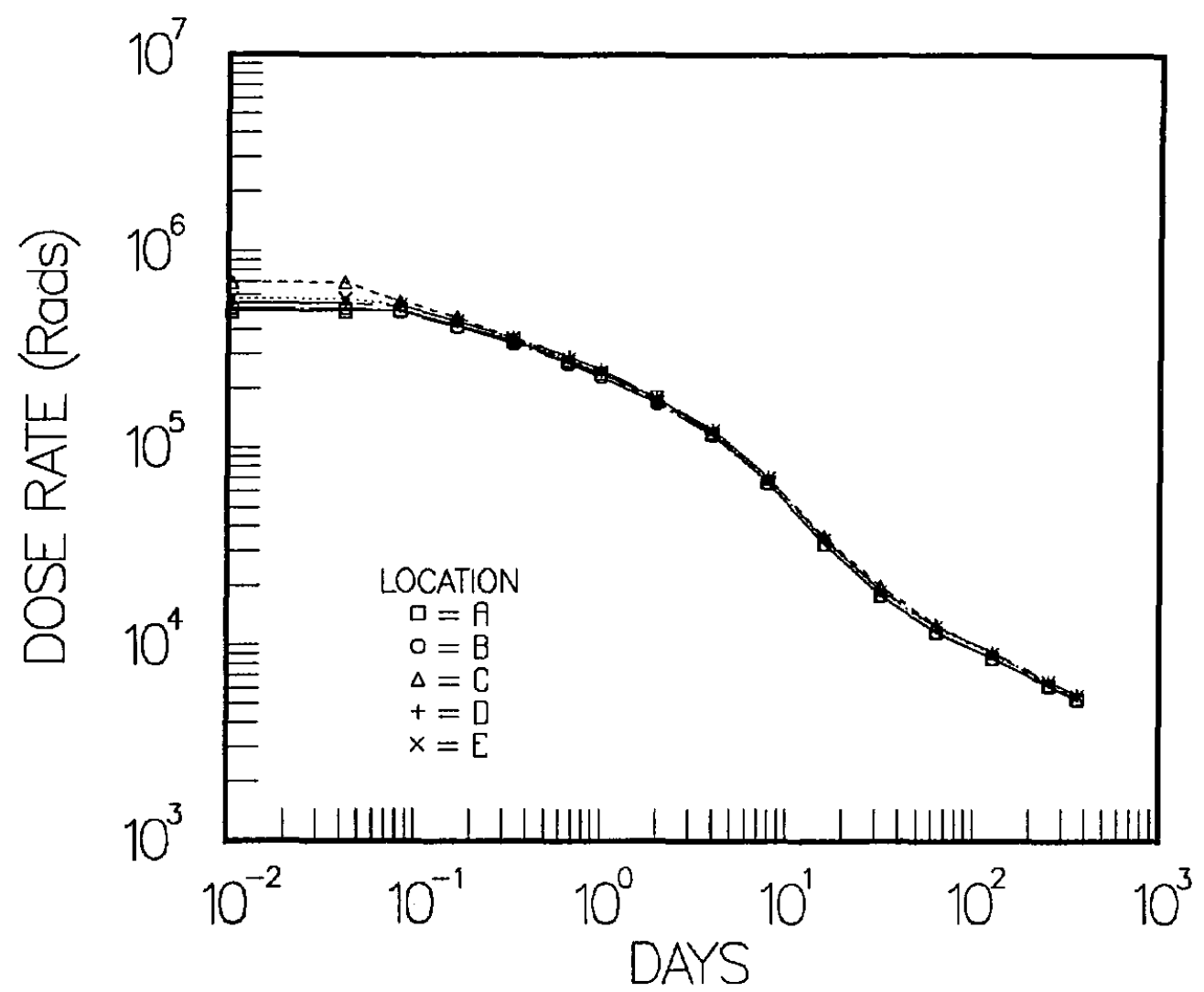

Figure B.15. Surry Case 1 In-Core Instrumentation Room Gamma

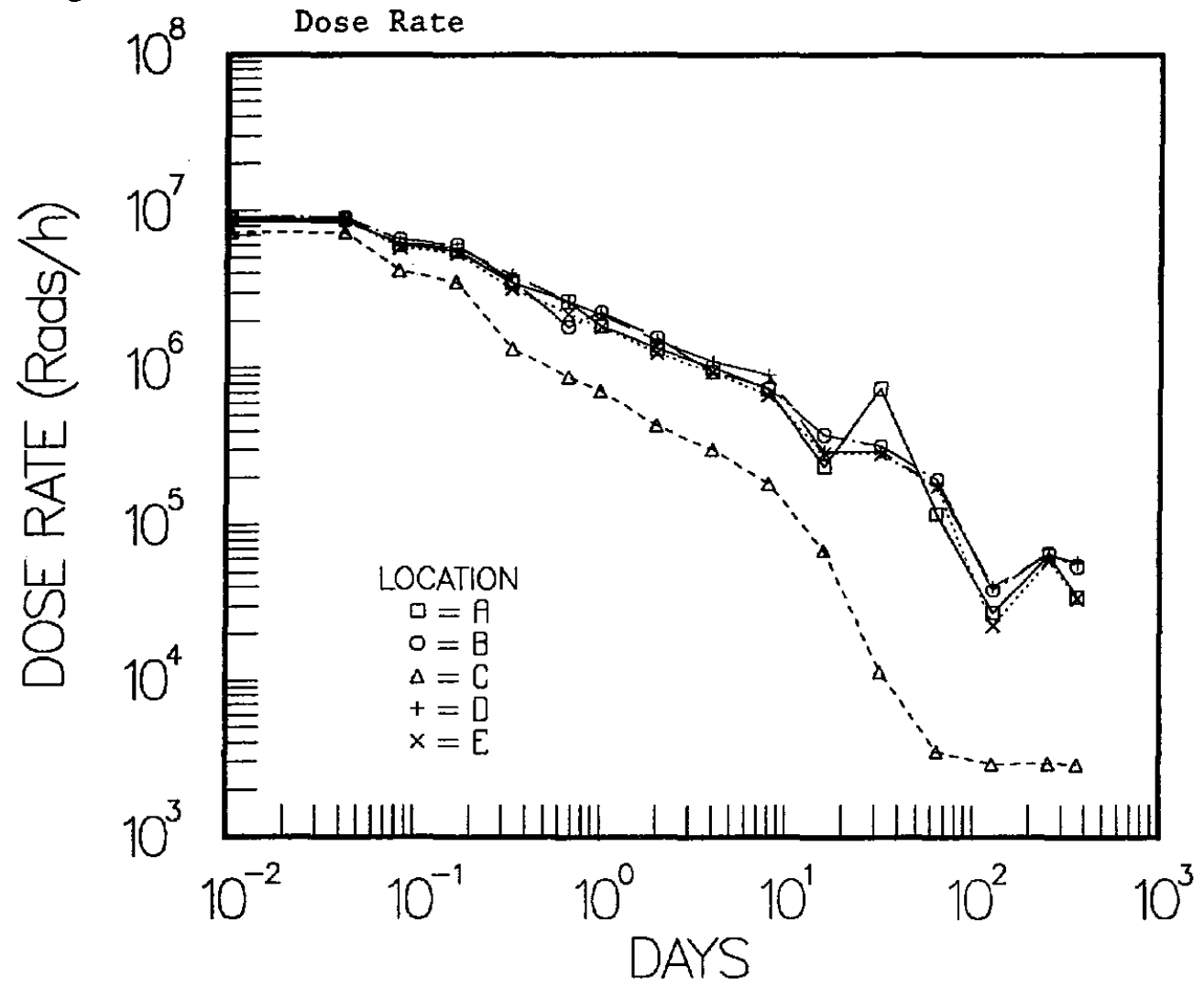

Figure B.16. Surry Case 1 In-Core Instrumentation Room Beta Dose Rate 


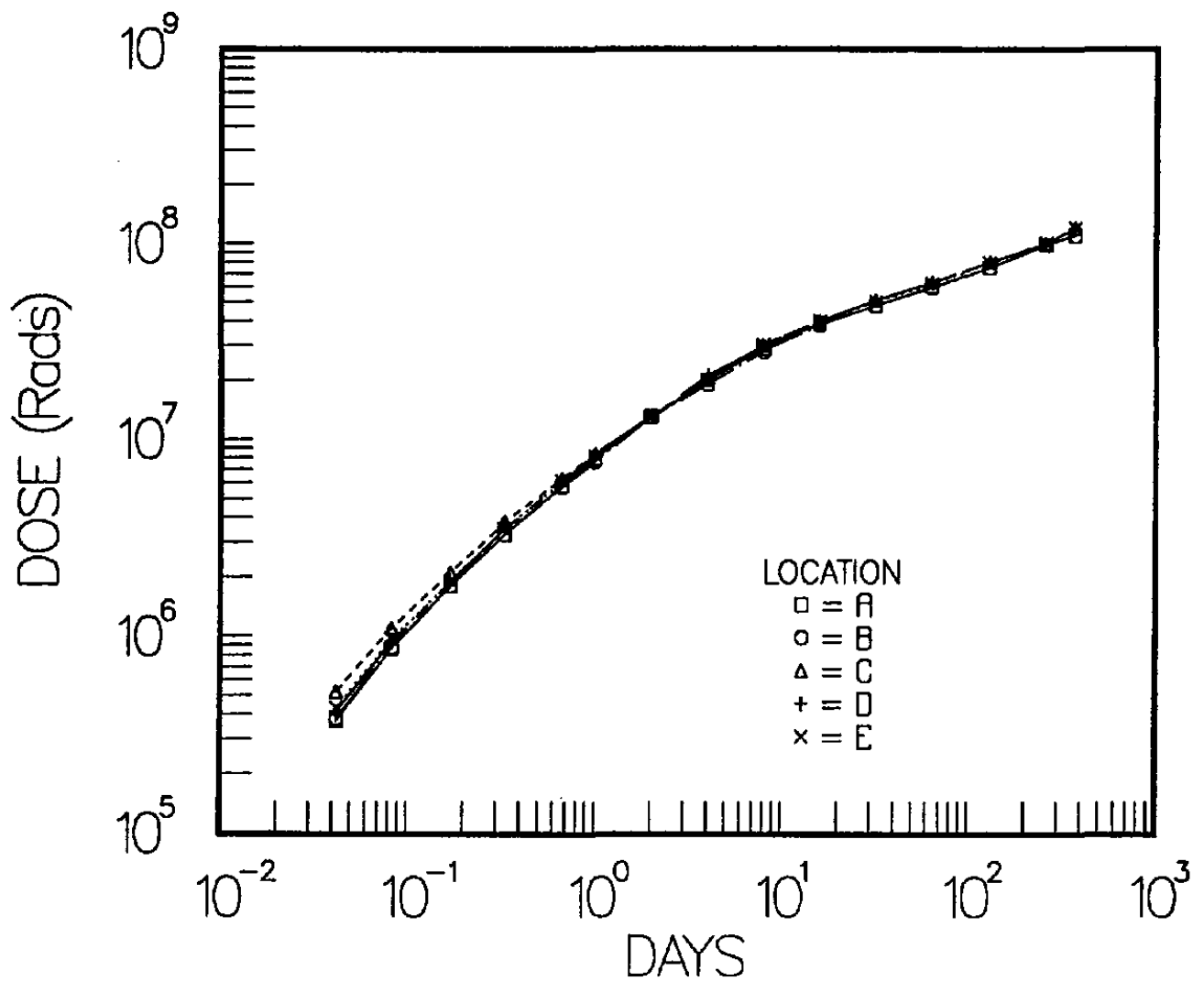

Figure B.17. Surry Case 1 In-Core Instrumentation Room

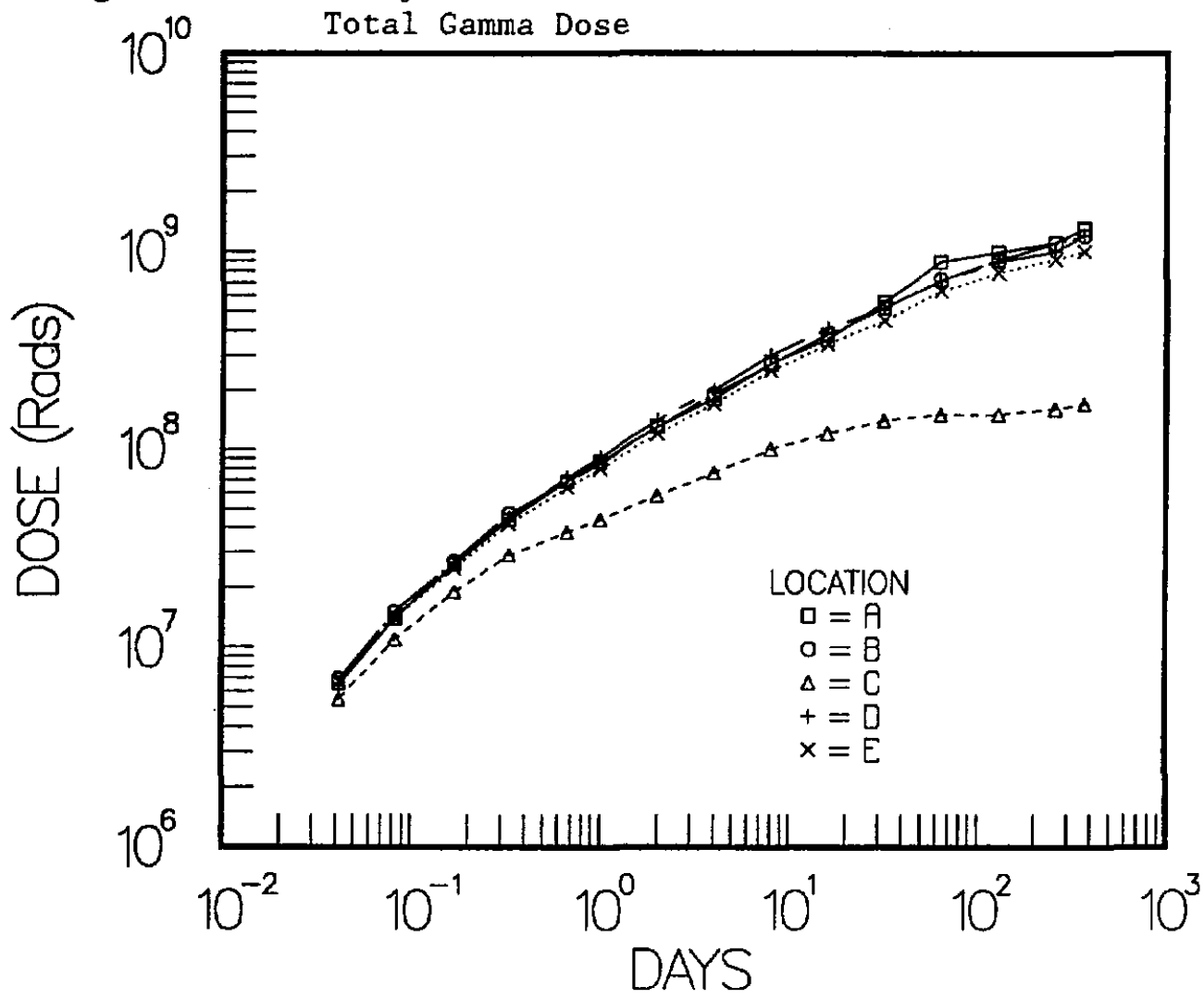

Figure B.18. Surry Case 1 In-Core Instrumentation Room Total Beta Dose 

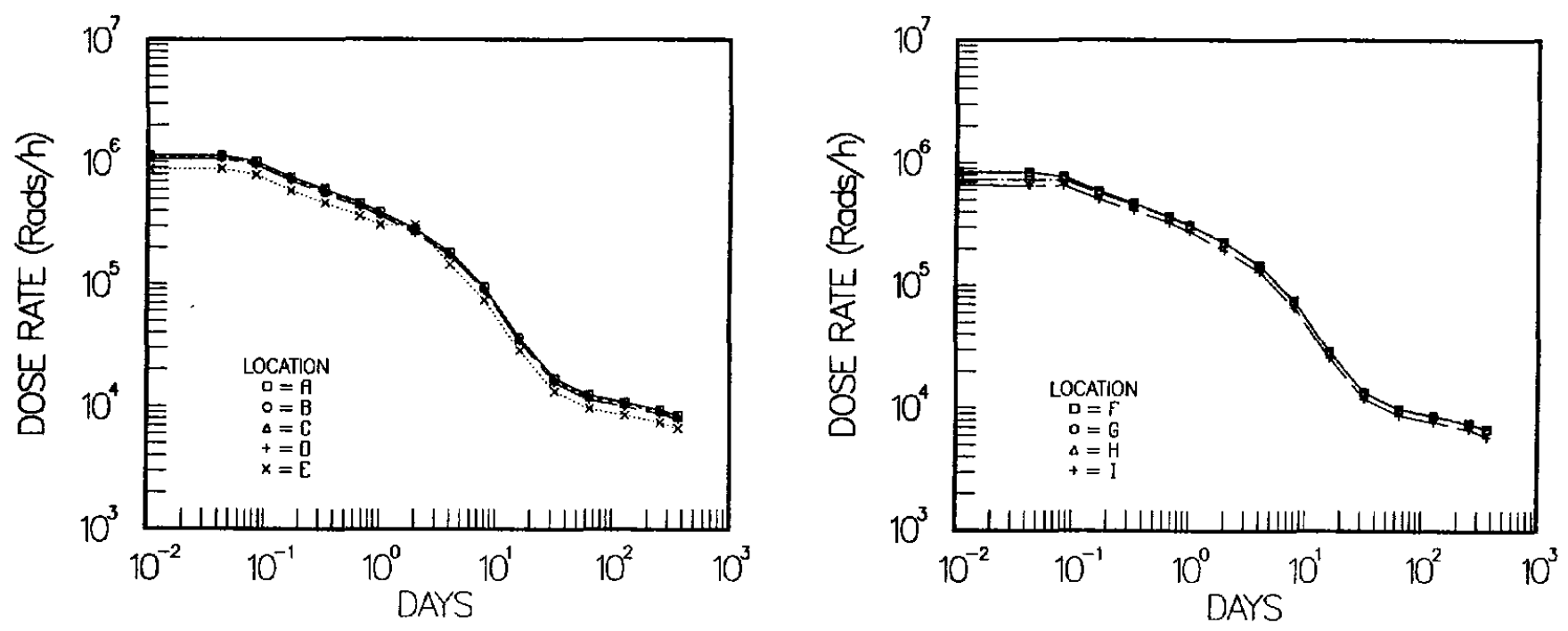

Figure B.19. Surry Case 2 Basement Gamma Dose Rate

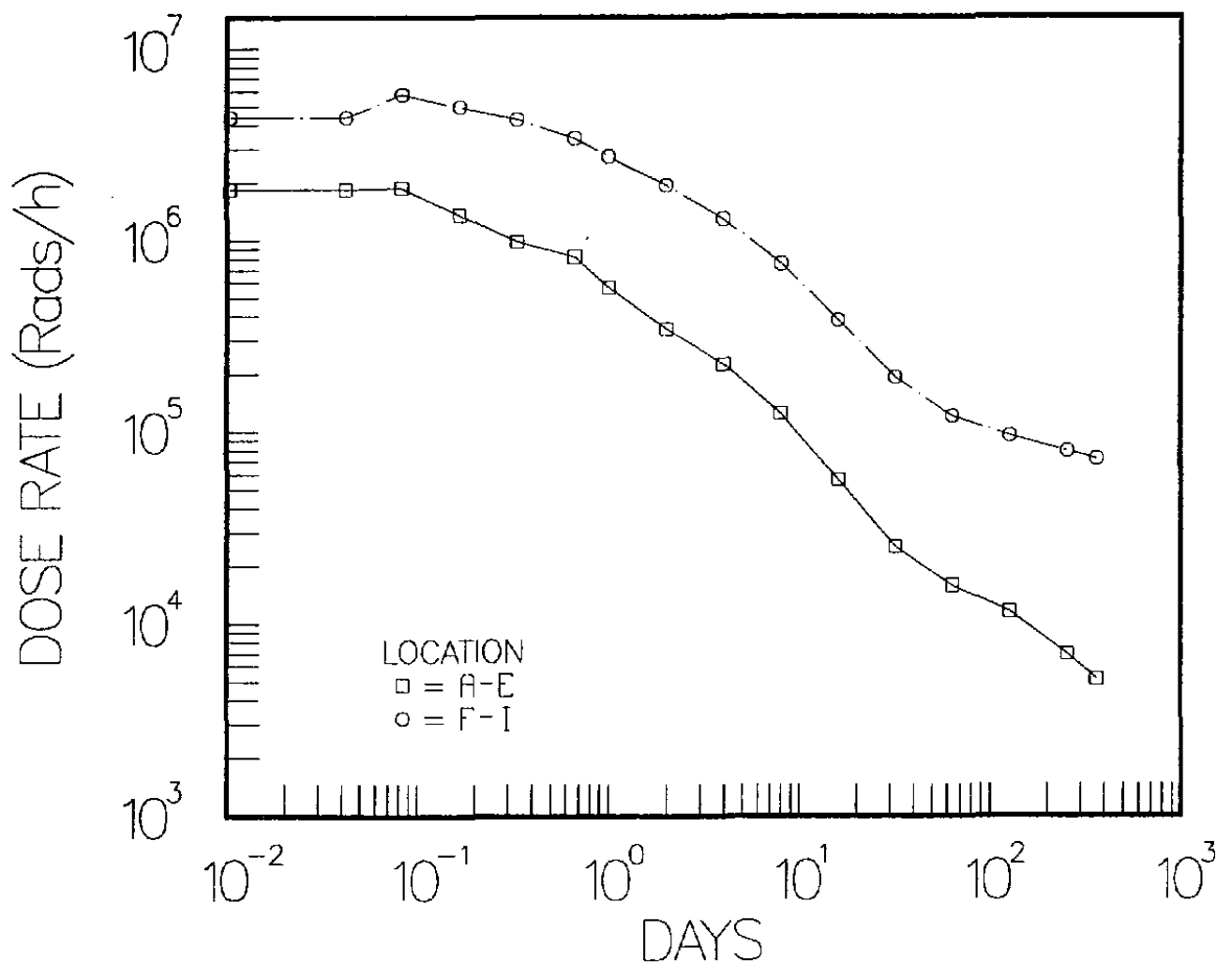

Figure B.20. Surry Case 2 Basement Beta Dose Rate 

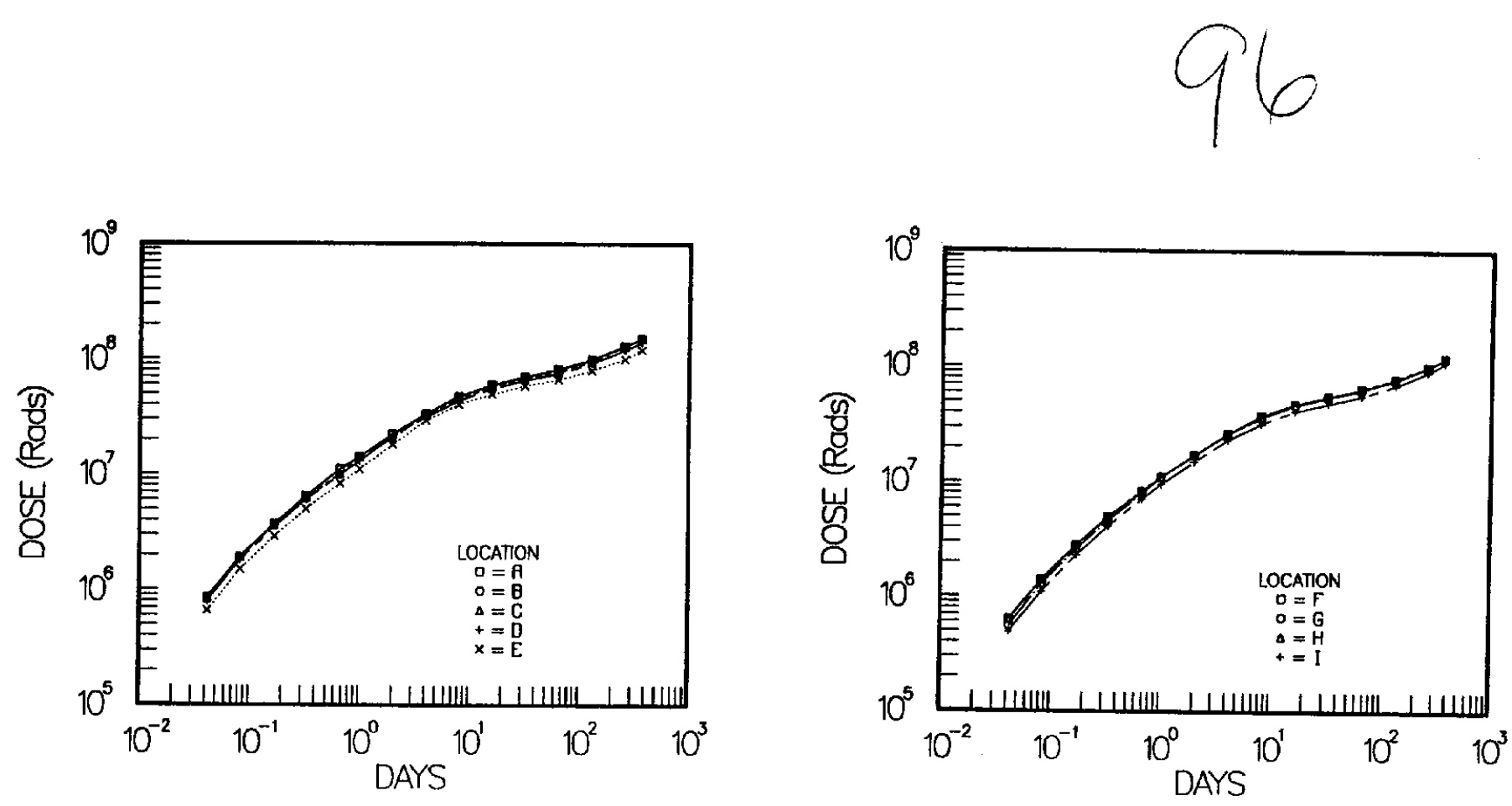

Figure B.21. Surry Case 2 Basement Total Gamma Dose

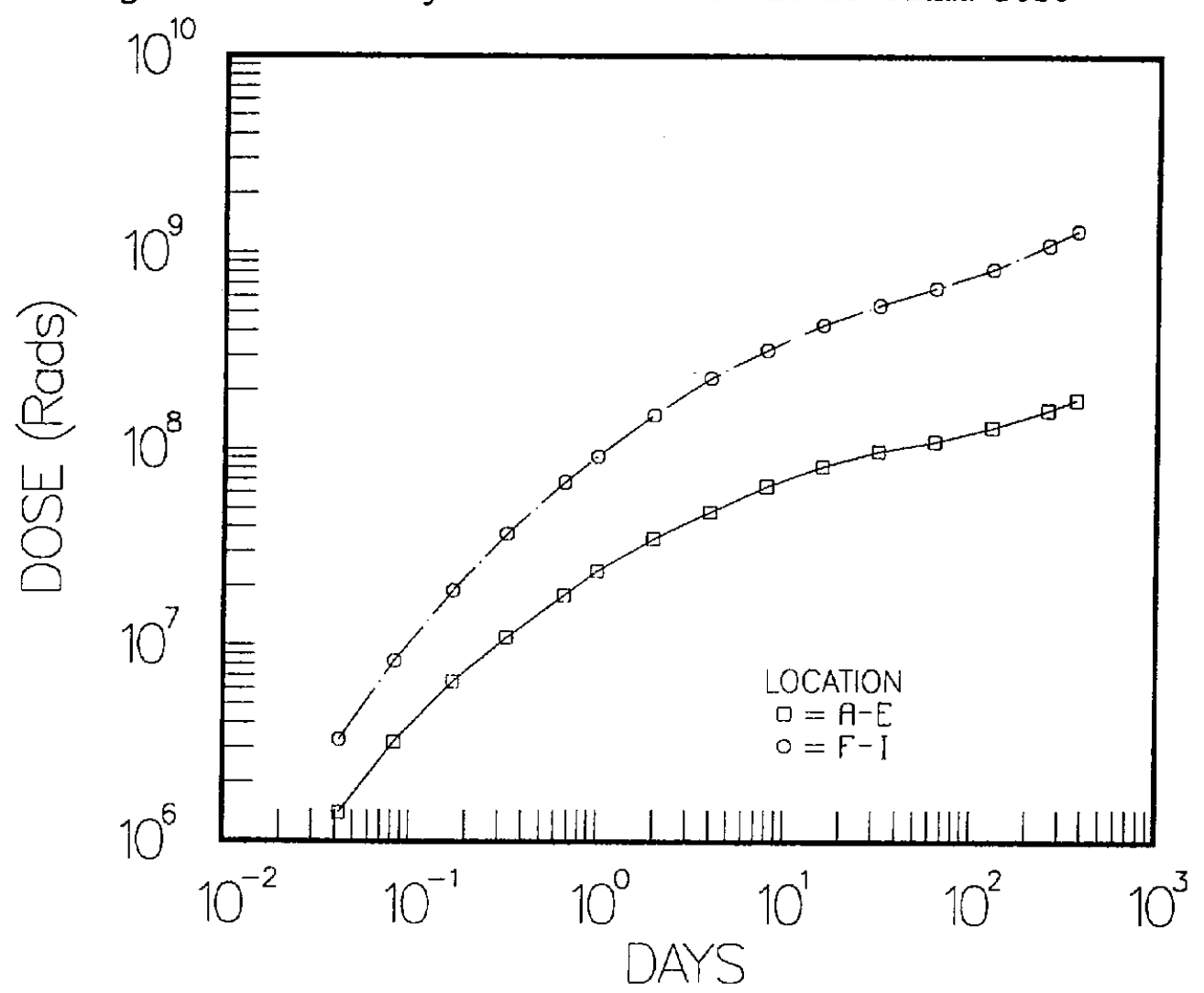

Figure B.22. Surry Case 2 Basement Total Beta Dose 


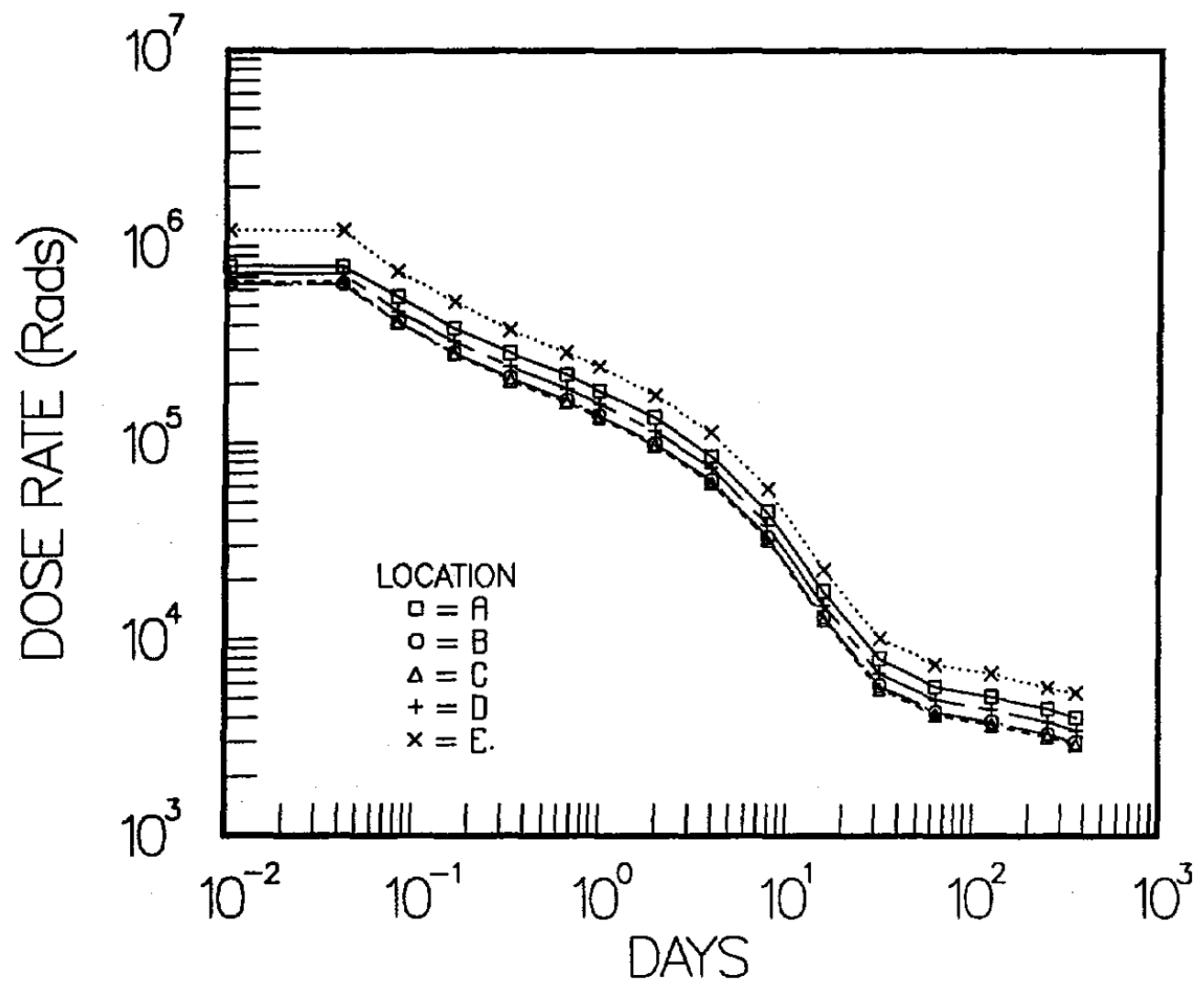

Figure B.23. Surry Case 2 Annulus Gamma Dose Rate

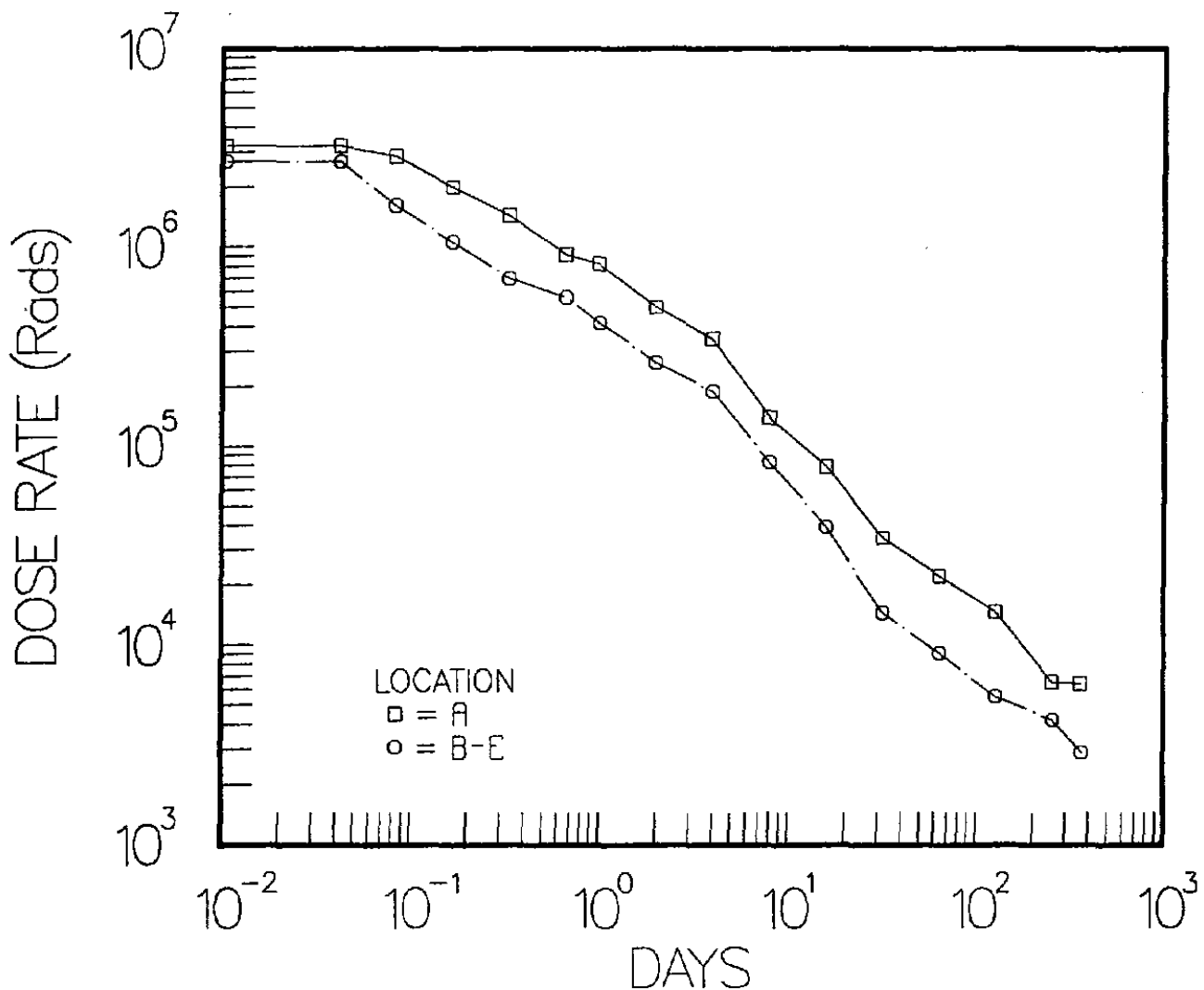

Figure B:24. Surry Case 2 Annulus Beta Dose Rate 


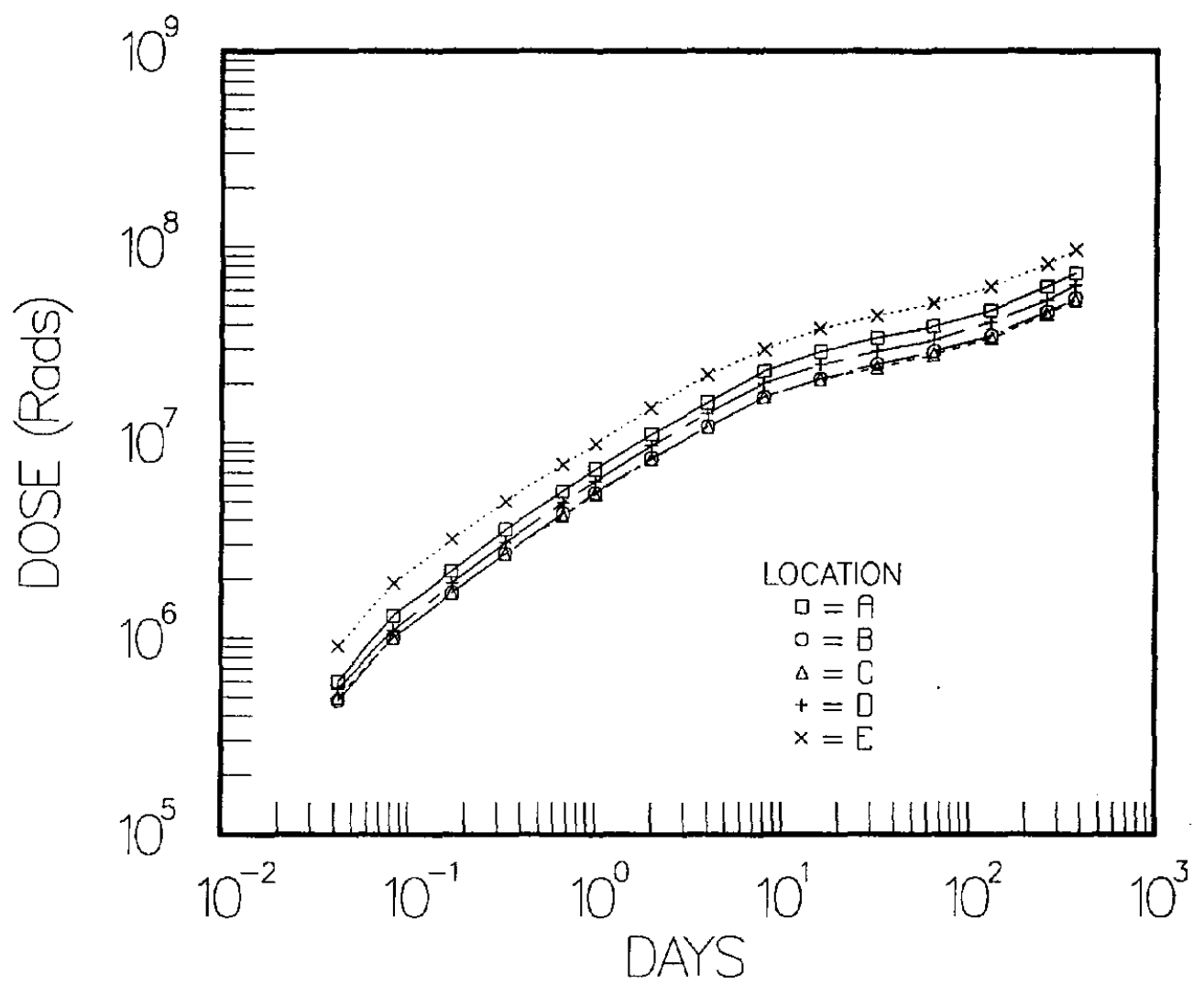

Figure B.25. Surry Case 2 Annulus Total Gamma Dose

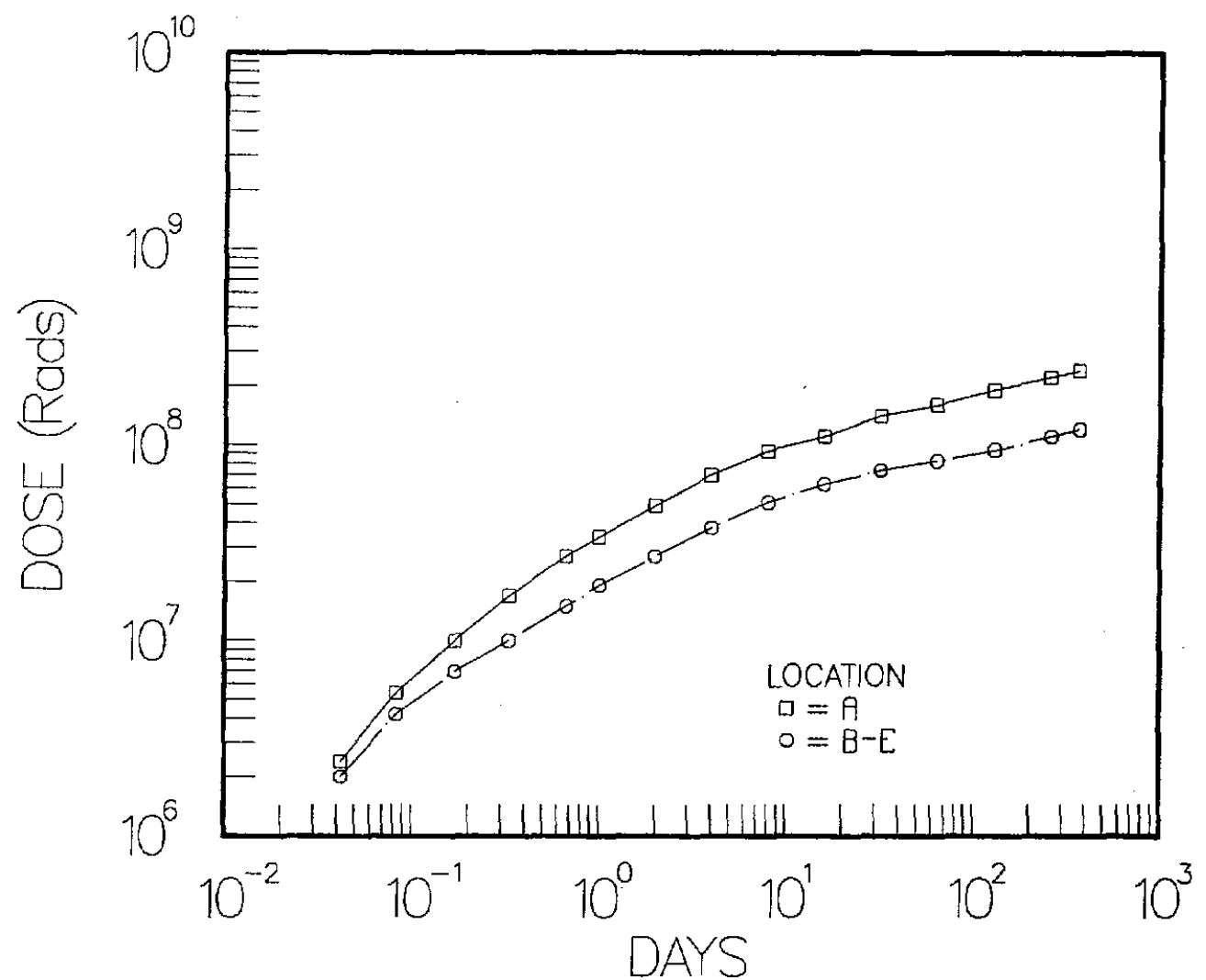

Figure B.26. Surry Case 2 Annulus Total Beta Dose 


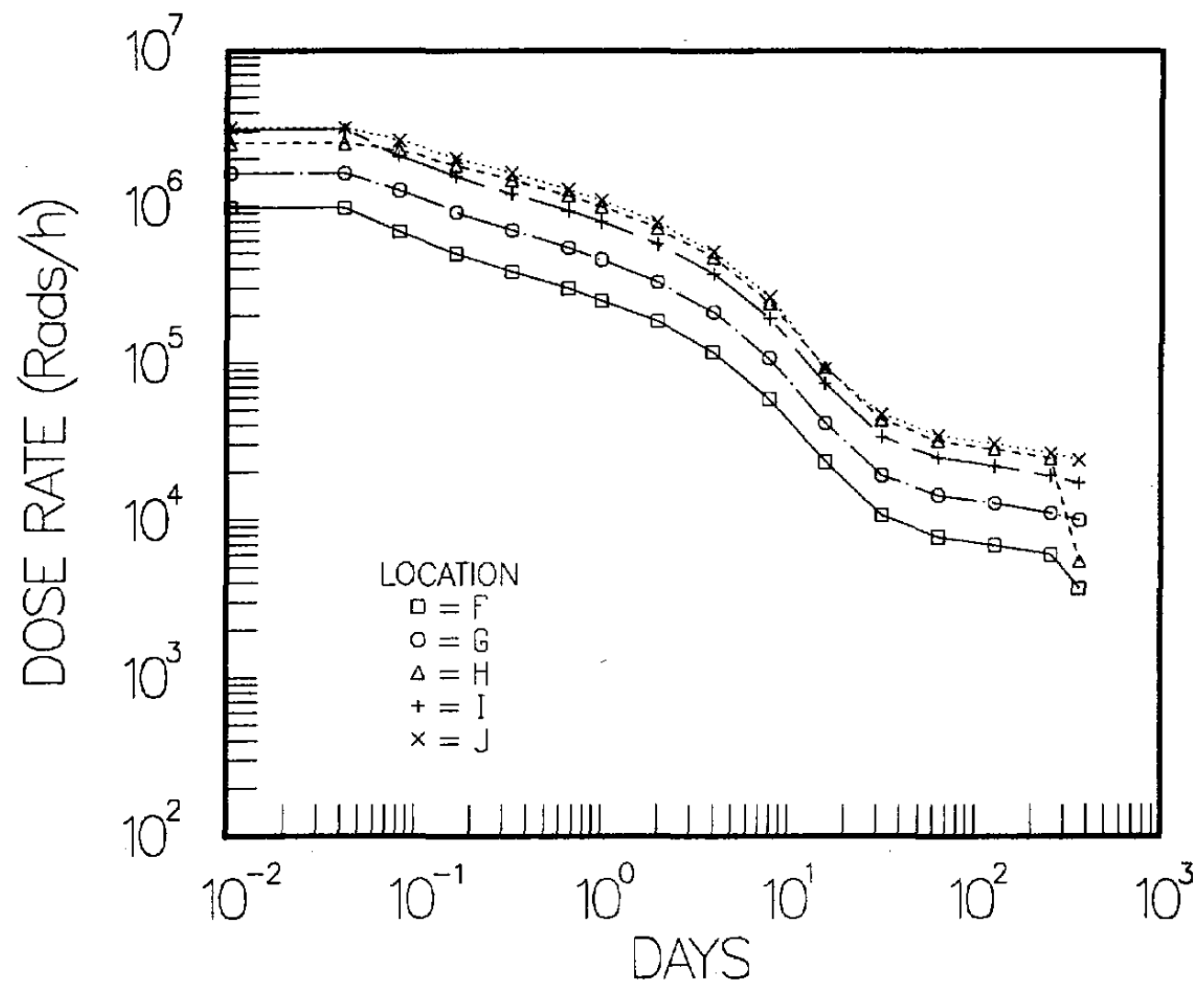

Figure B.27. Surry Case 2 Operating Floor and Dome Gamma Dose Rate

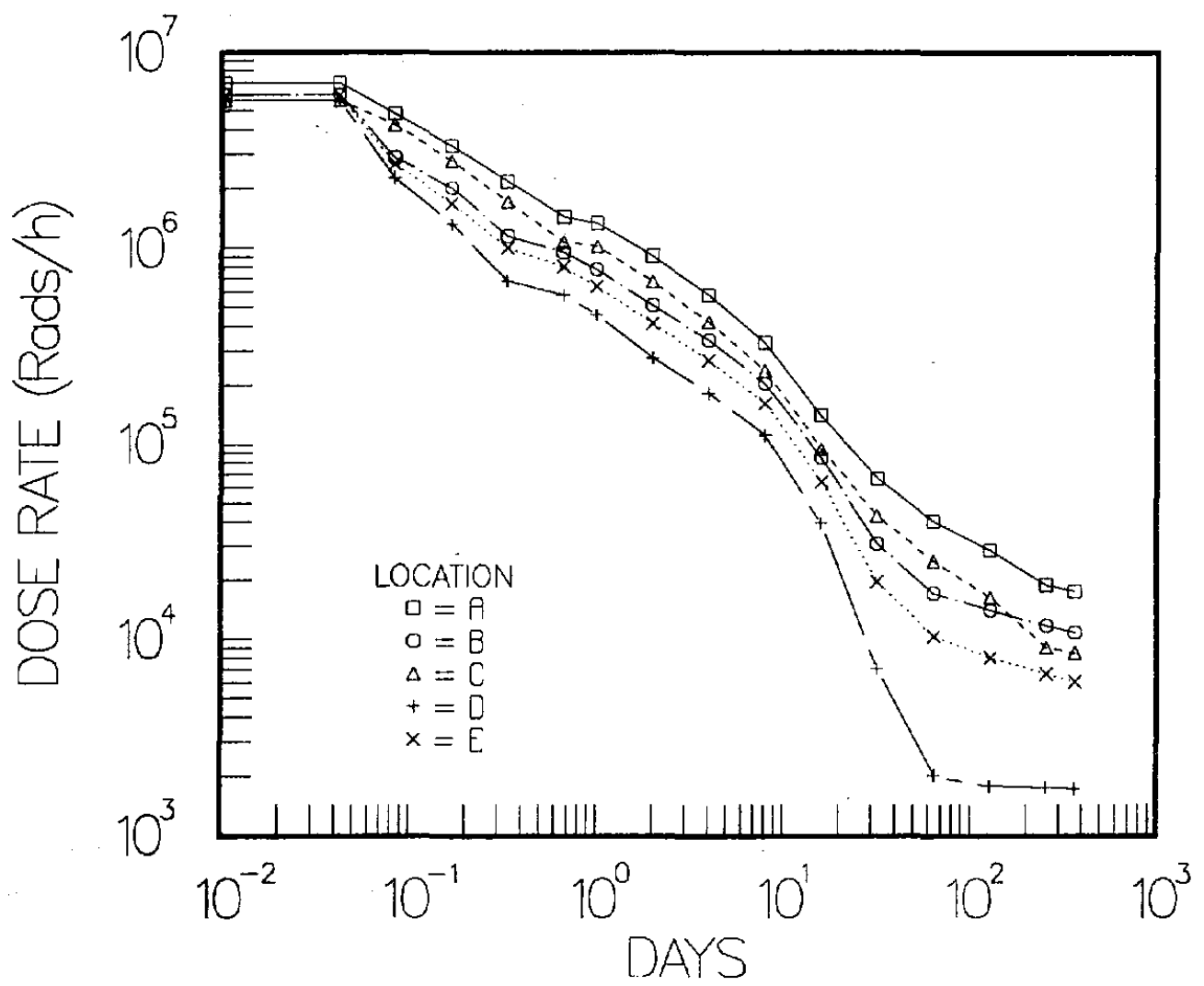

Figure B.28. Surry Case 2 Operating Floor and Dome Beta Dose Rate 


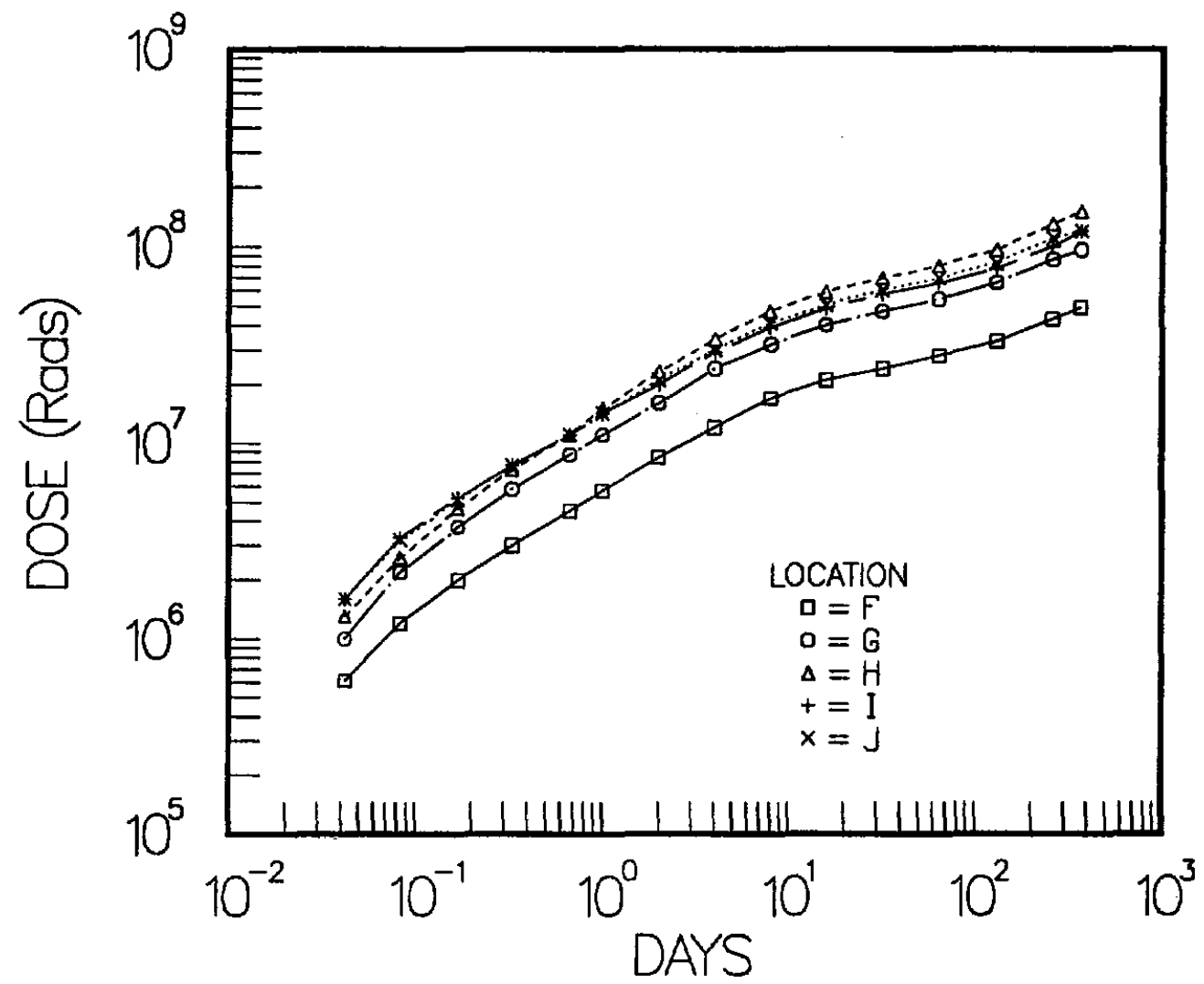

Figure B.29. Surry Case 2 Operating Floor and Dome Total Gamma Dose

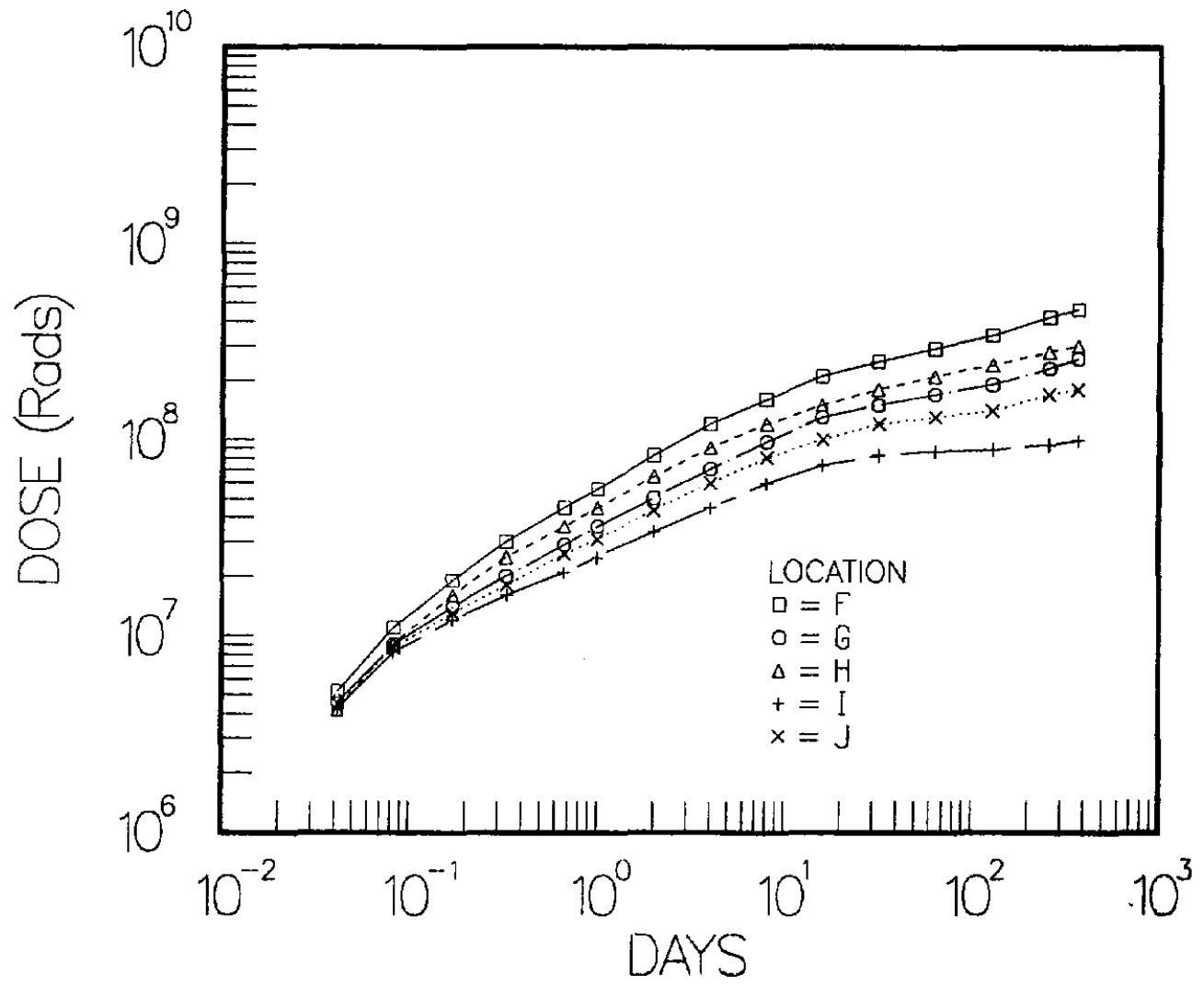

Figure B.30. Surry Case 2 Operating Floor and Dome Total Beta Dose 


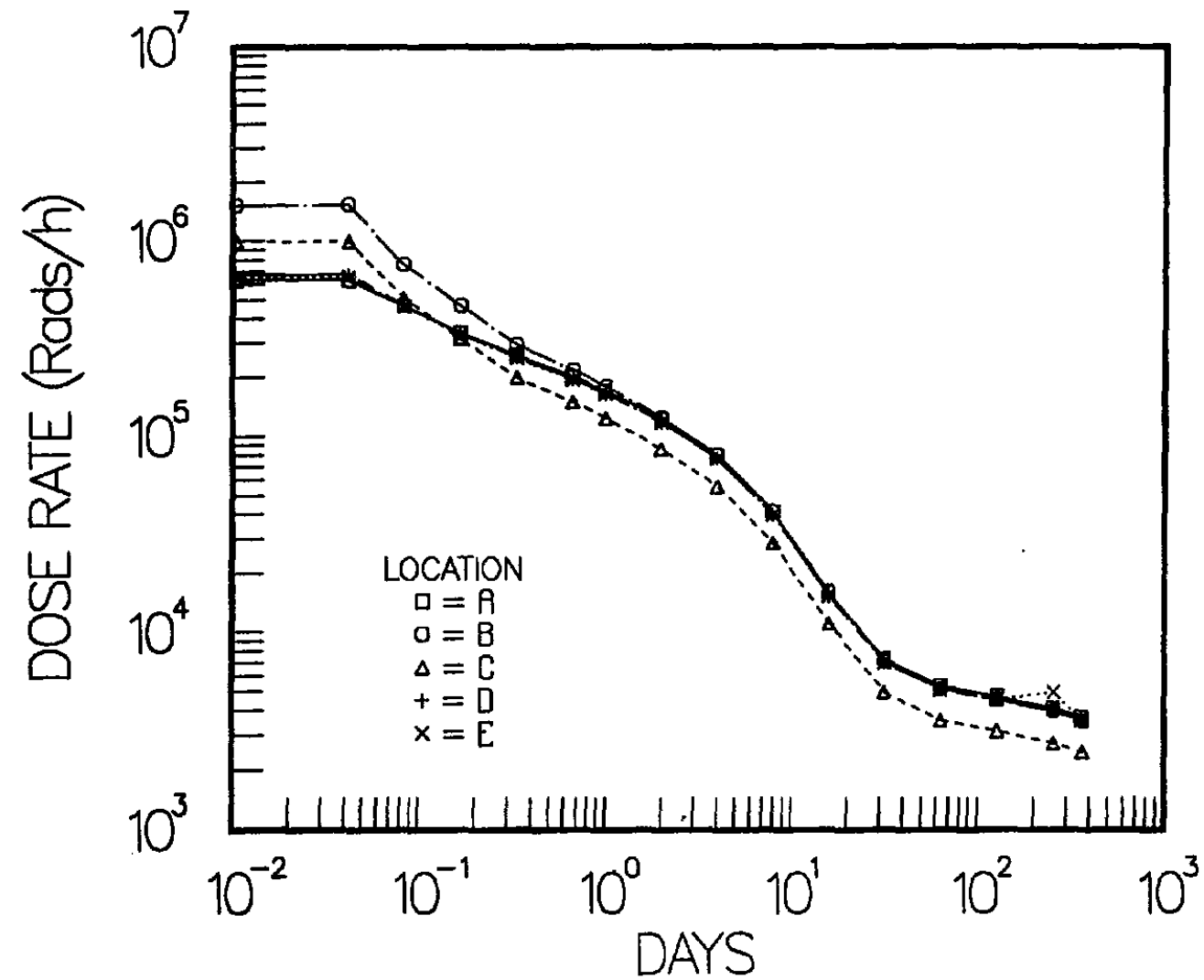

Figure B.31. Surry Case 2 Steam Generator A Gamma Dose Rate

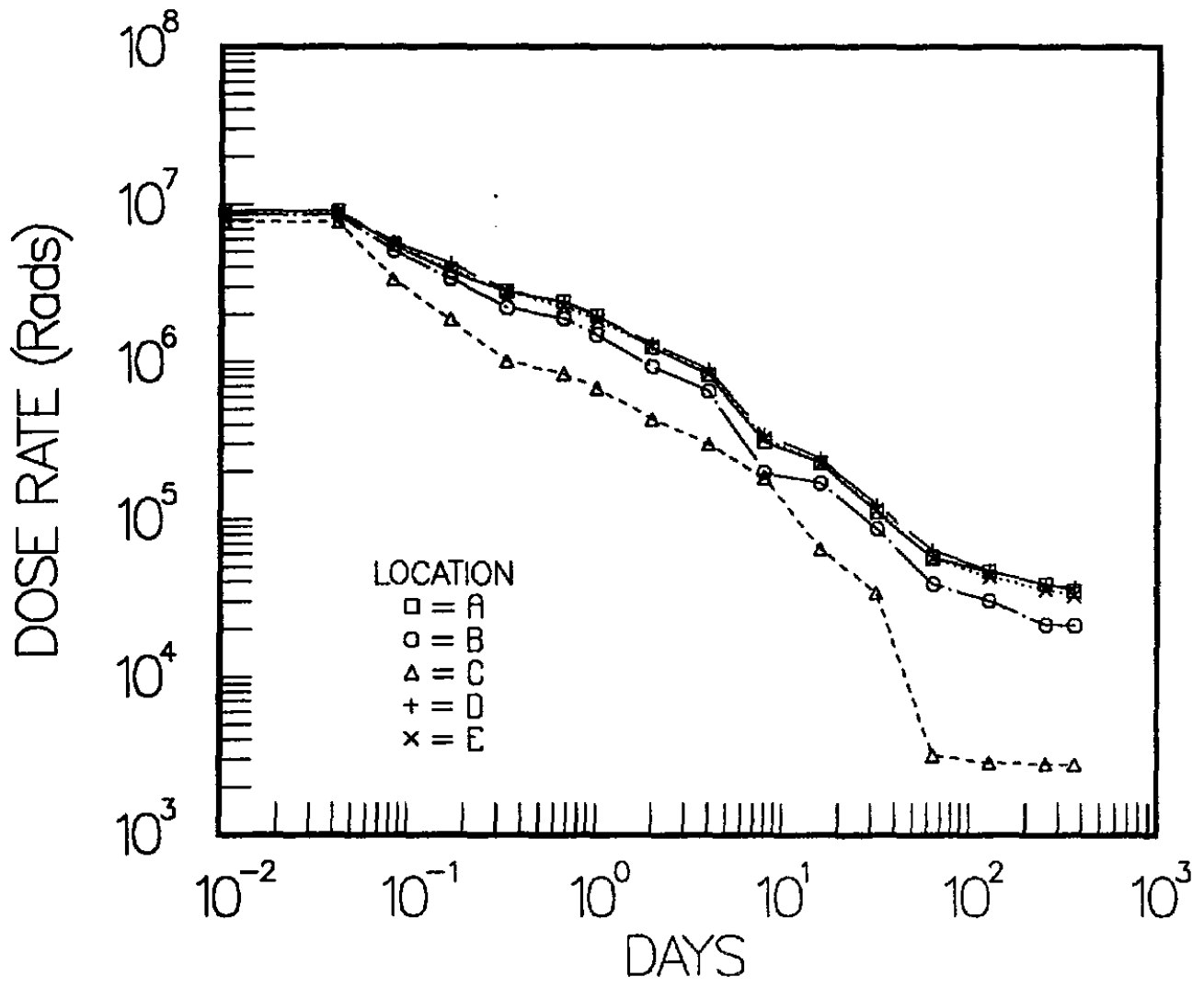

Figure B.32. Surry Case 2 Steam Generator A Beta Dose Rate 


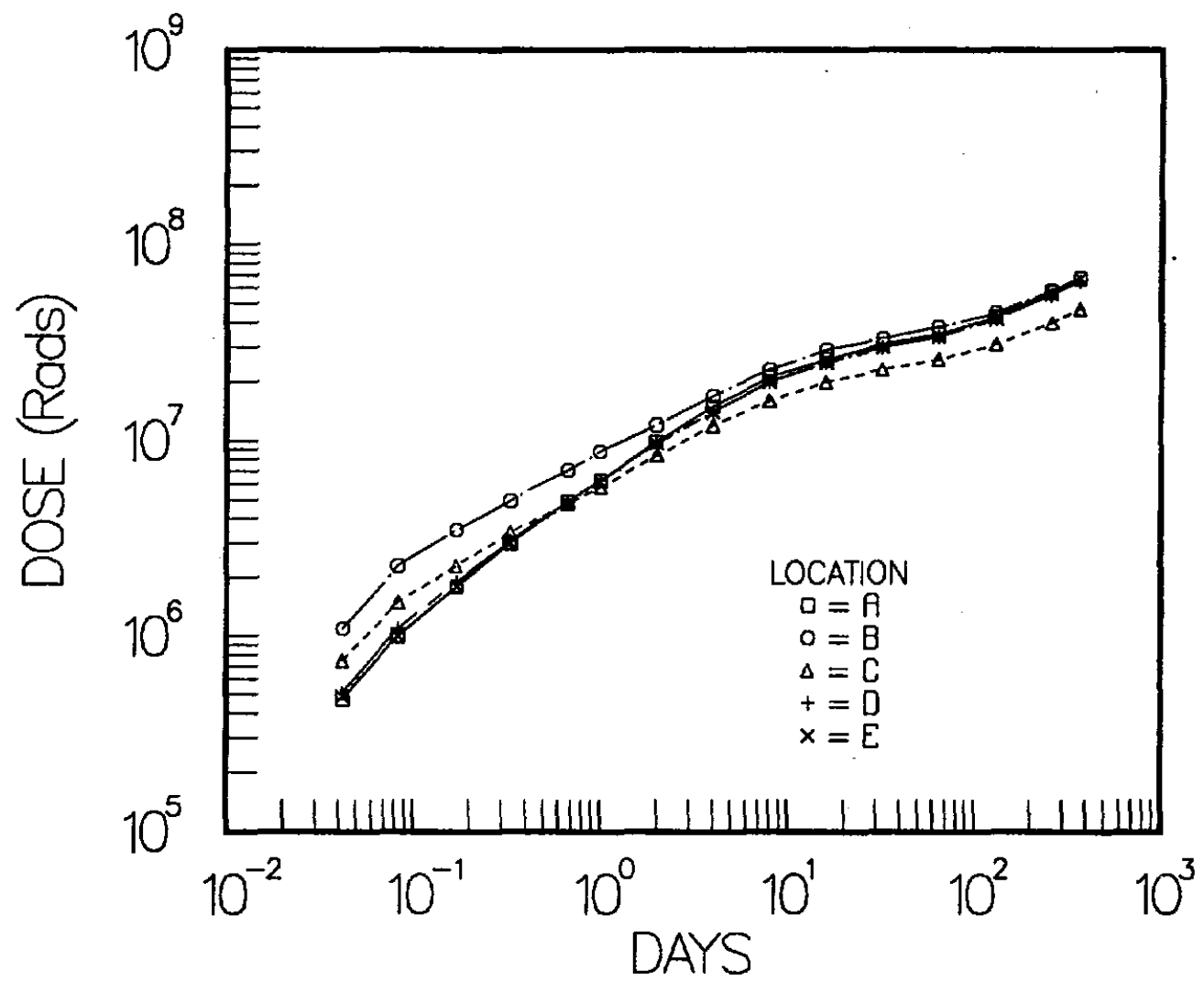

Figure B.33. Surry Case 2 Steam Generator A Total Gamma Dose

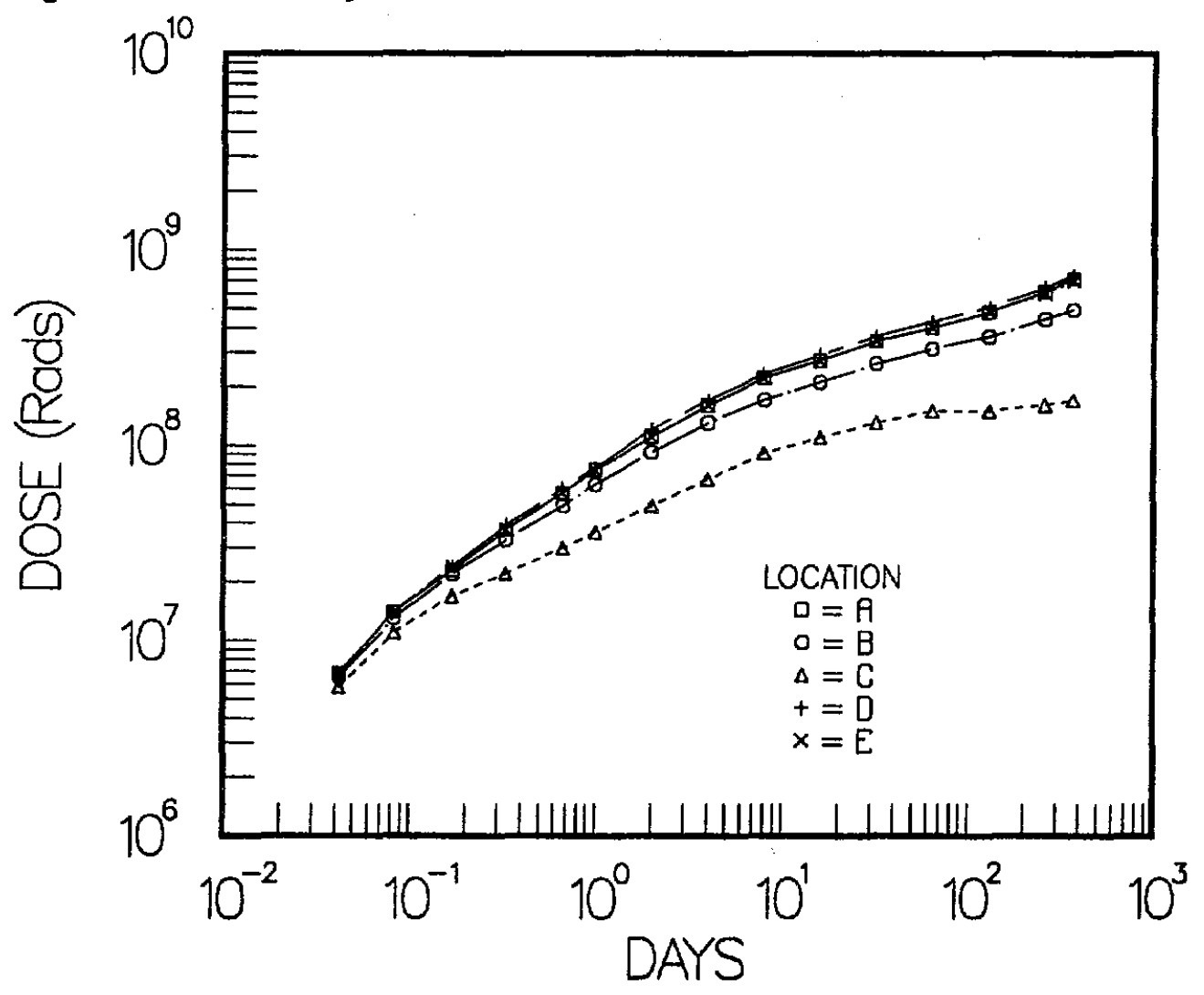

Figure B.34. Surry Case 2 Steam Generator A Total Beta Dose 


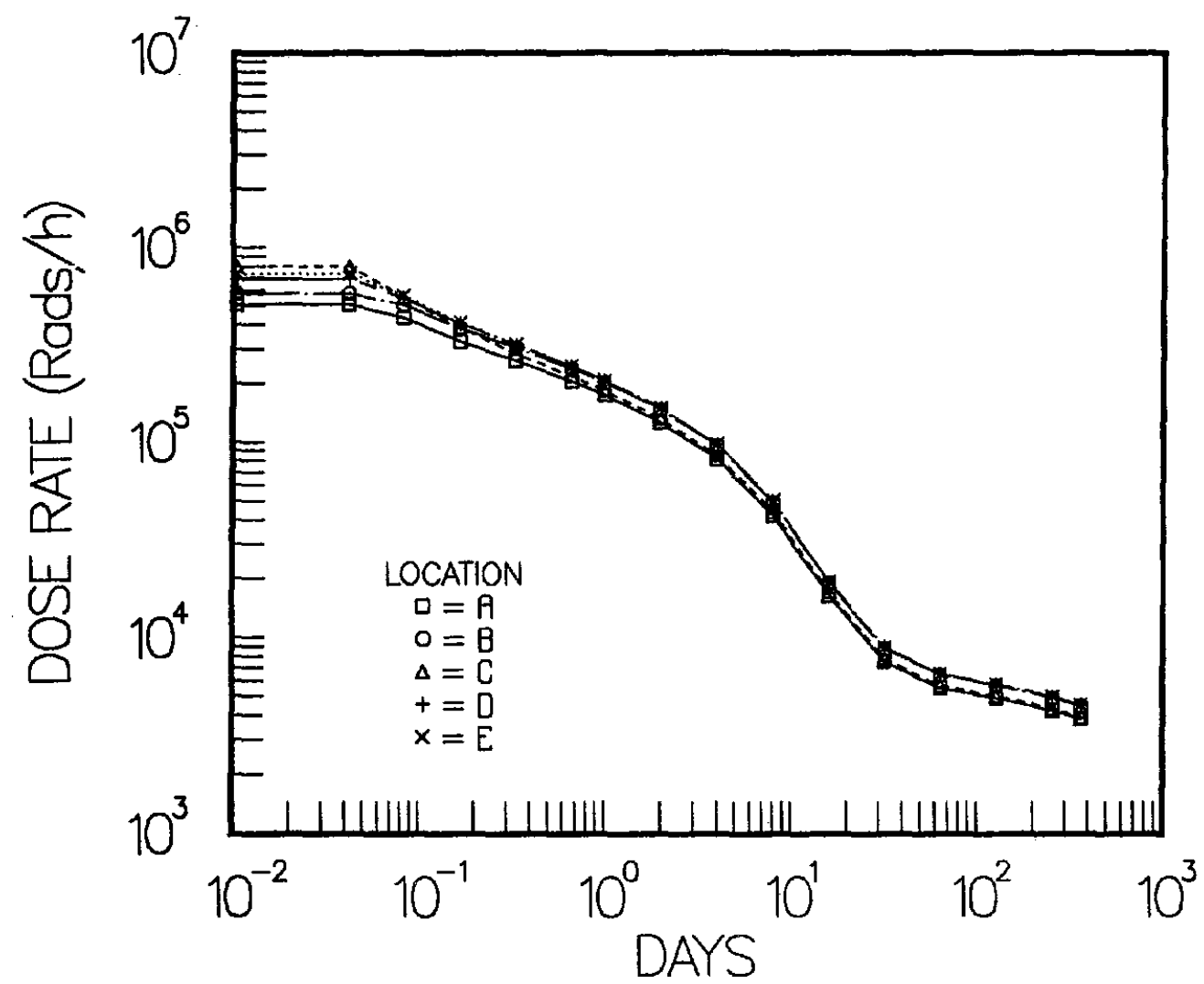

Figure B.35. Surry Case 2 RHR Cubicle Gamma Dose Rate

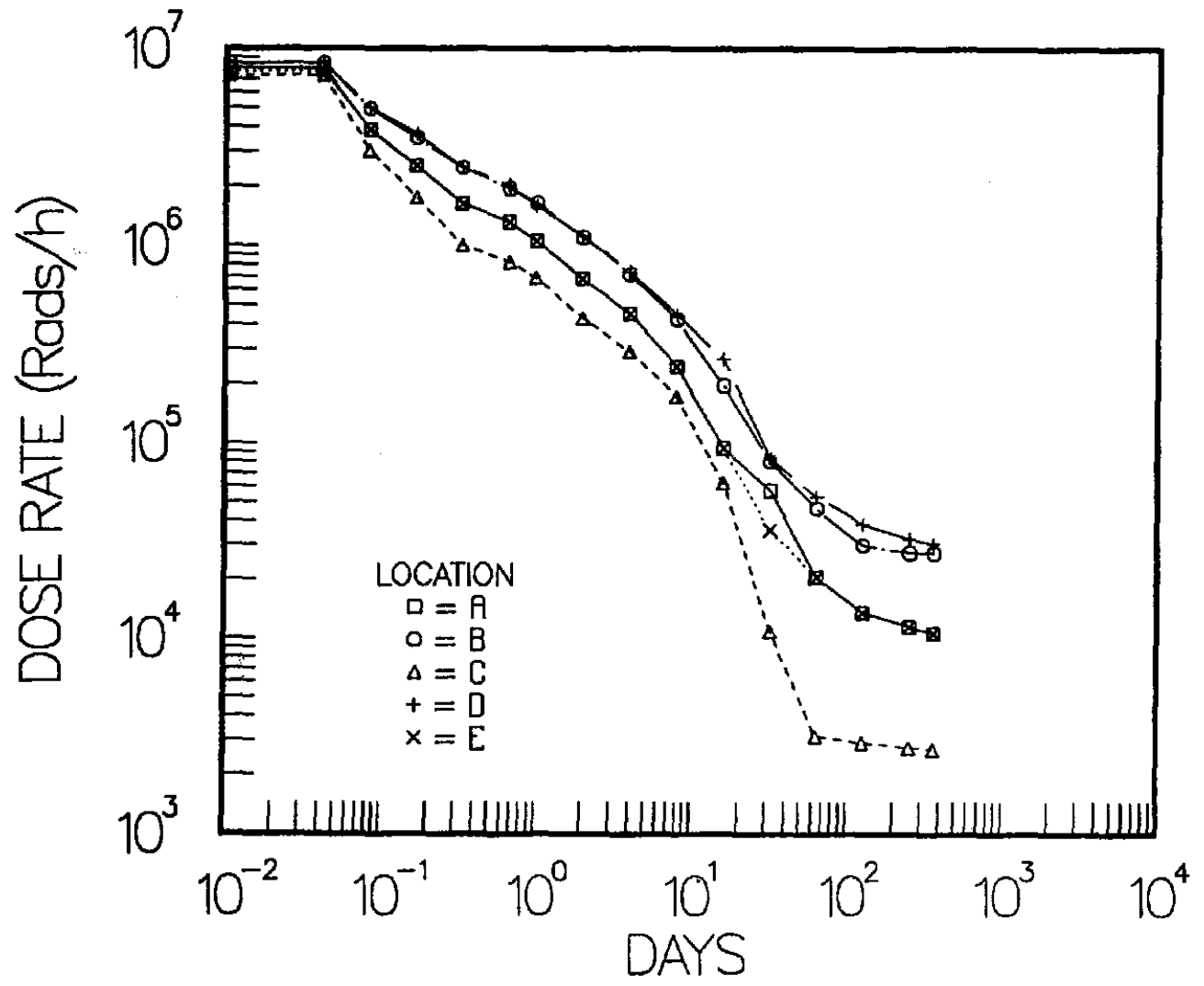

Figure B.36. Surry Case 2 RHR Cubicle Beta Dose Rate 


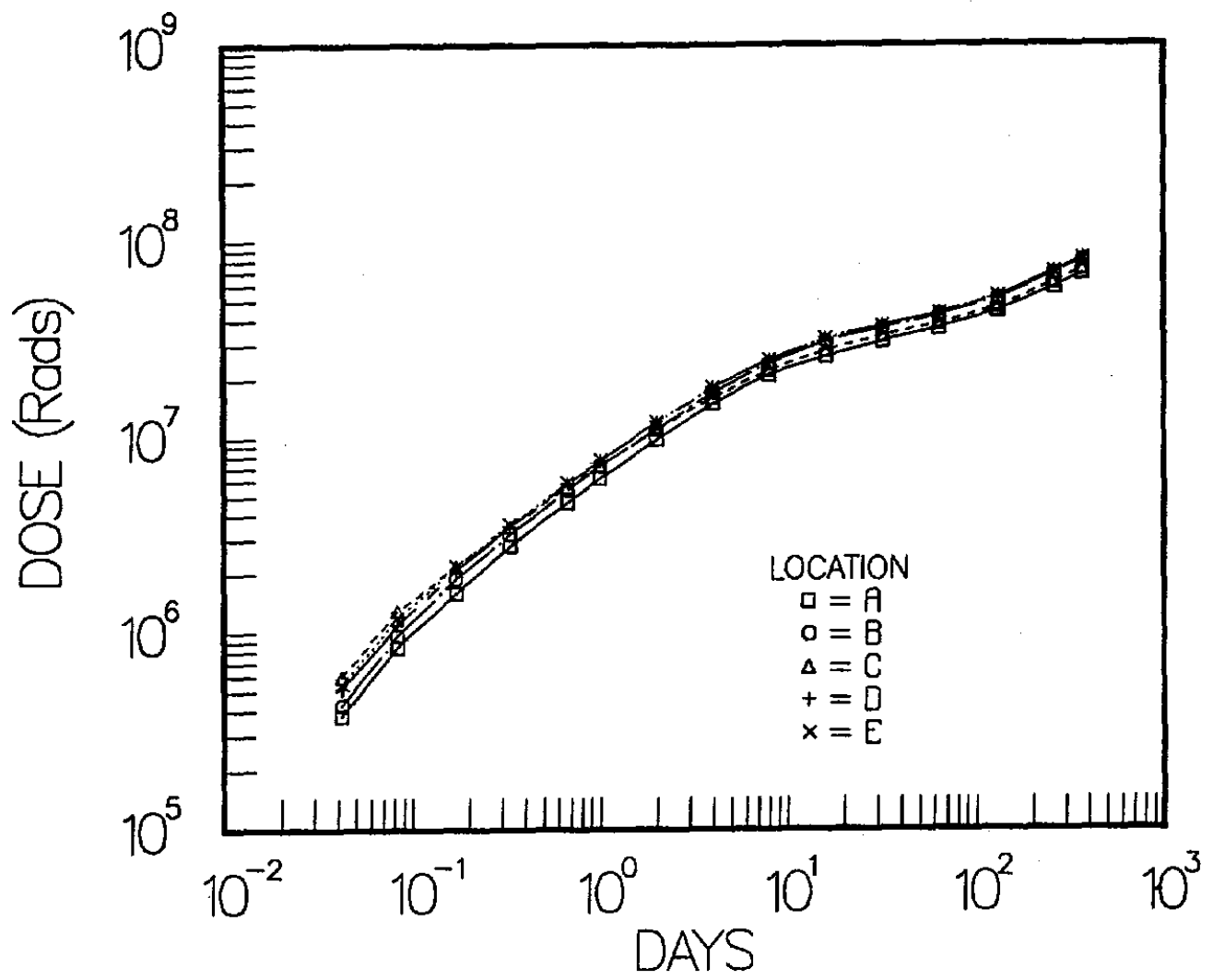

Figure B.37. Surry Case 2 RHR Cubicle Total Gamma Dose

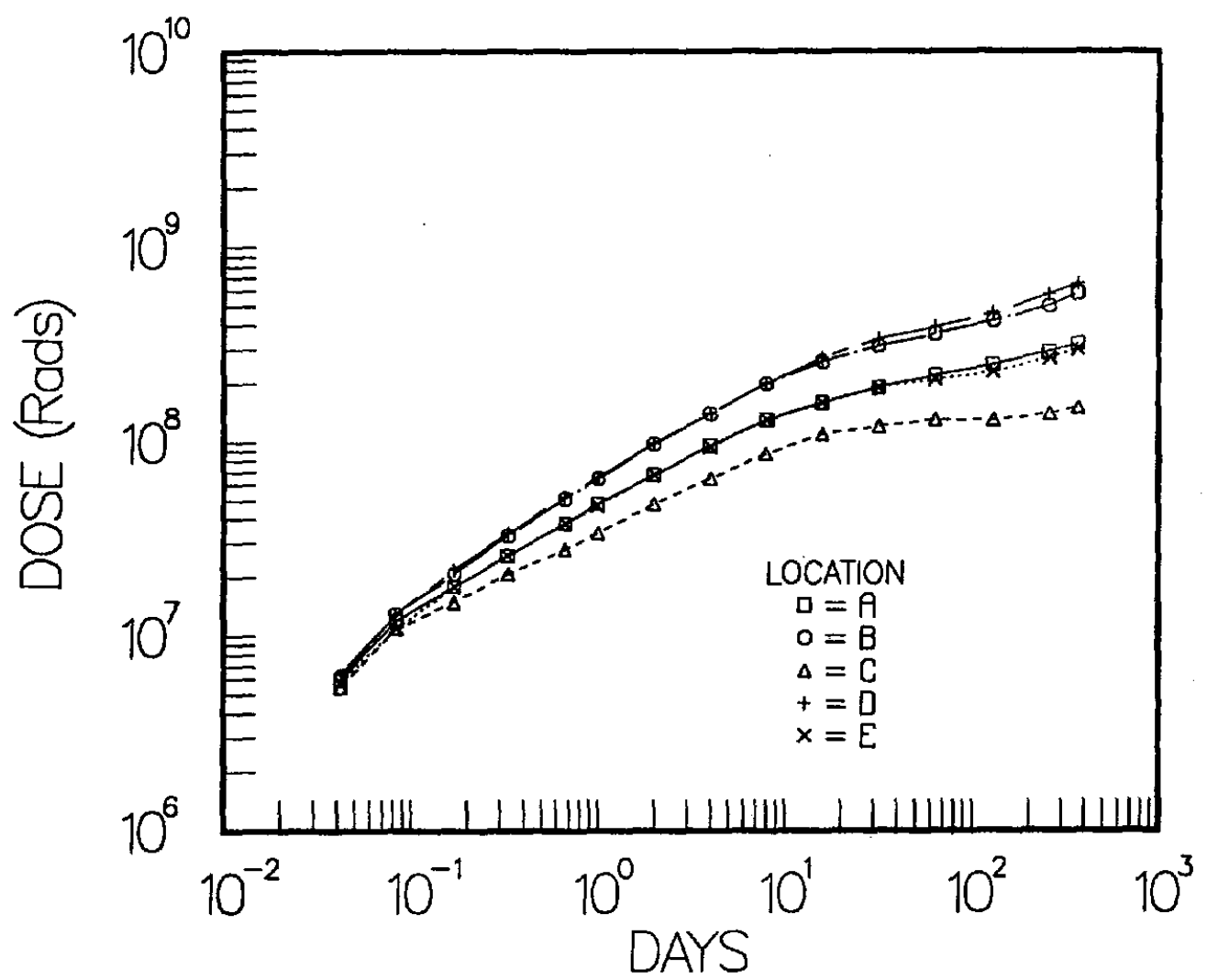

Figure B.38: Surry Case 2 RHR Cubicle Total Beta Dose 


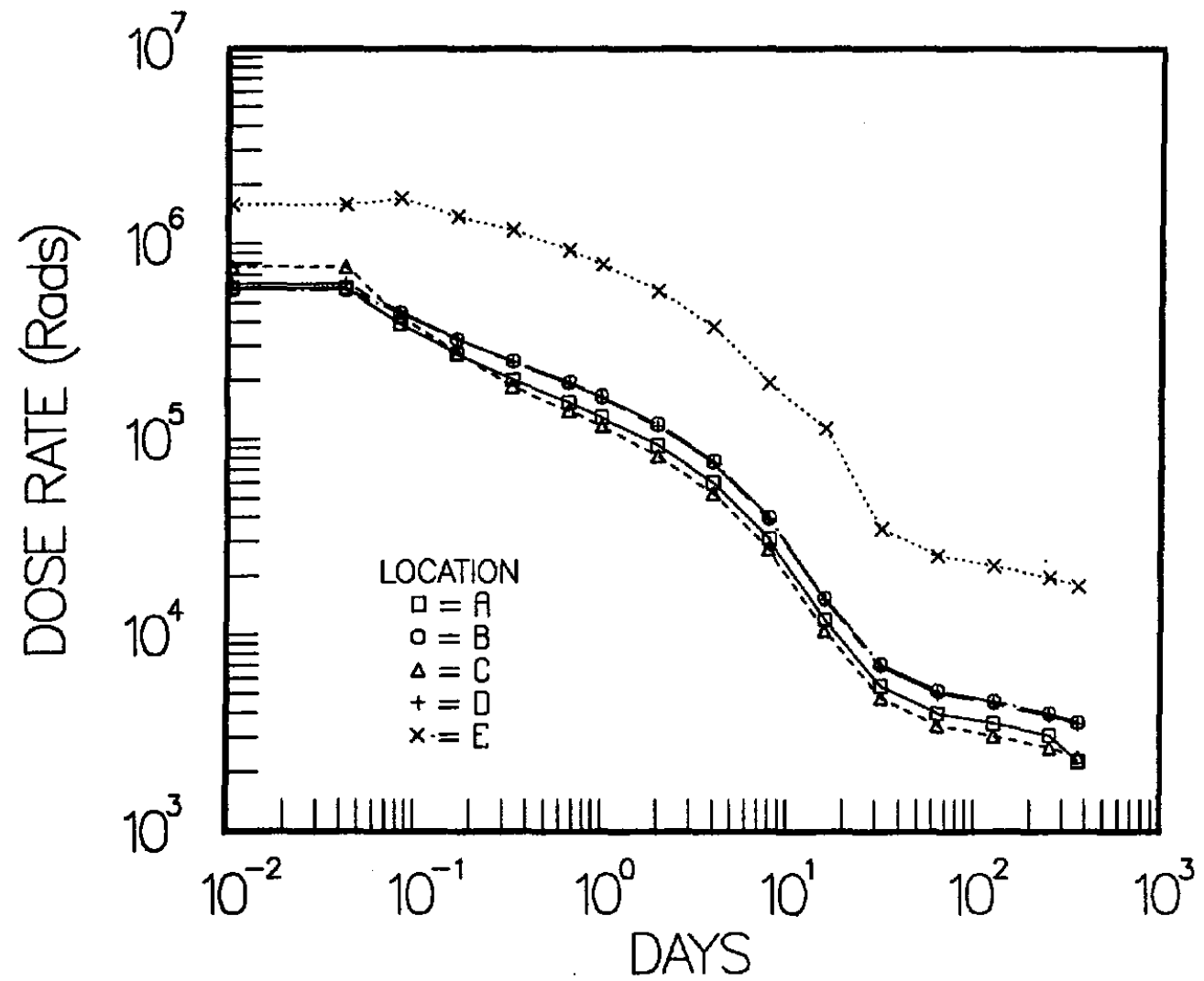

Figure B.39. Surry Case 2 Steam Generator B Gamma Dose Rates

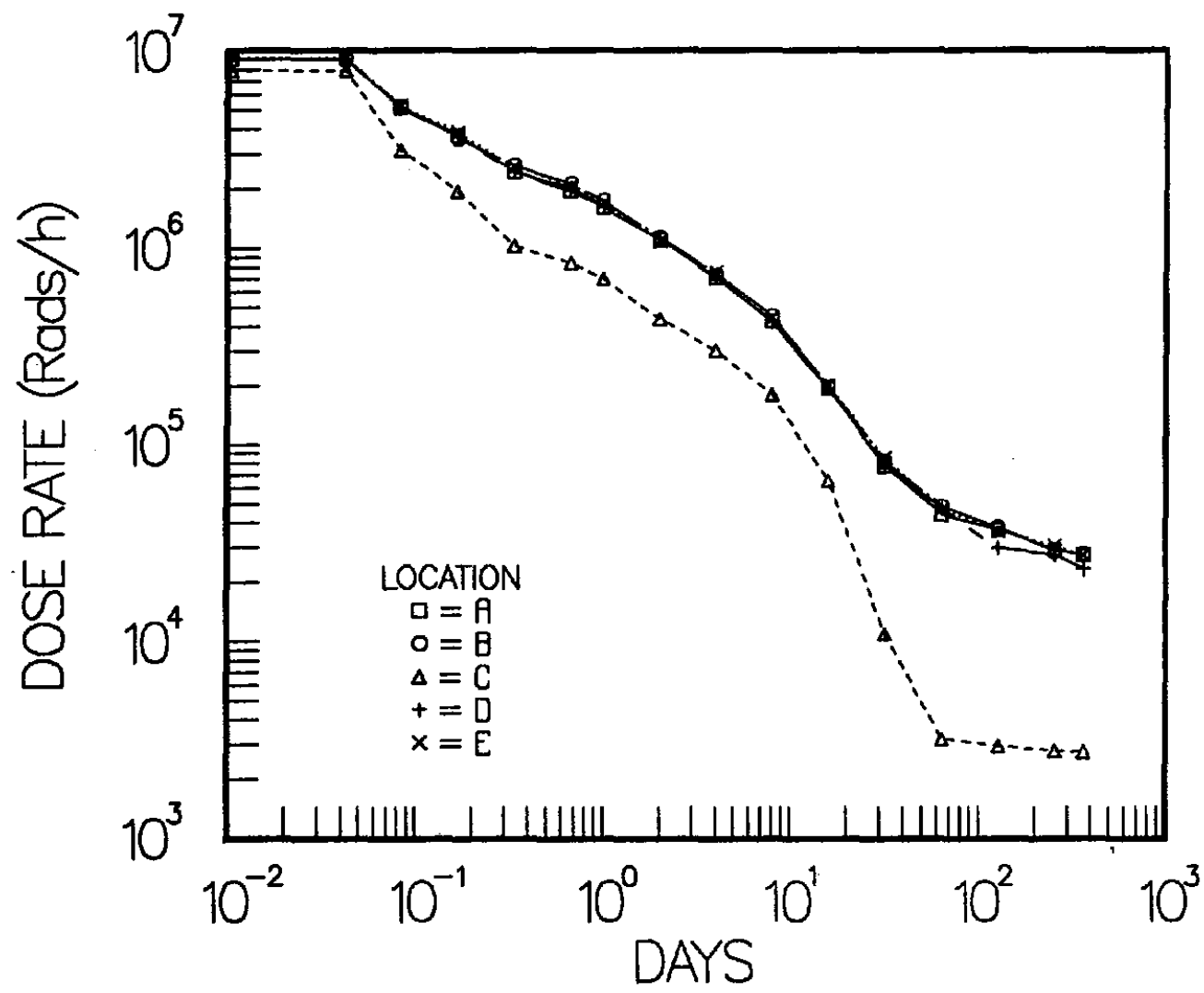

Figure B.40. Surry Case 2 Steam Generator B Beta Dose Rates 


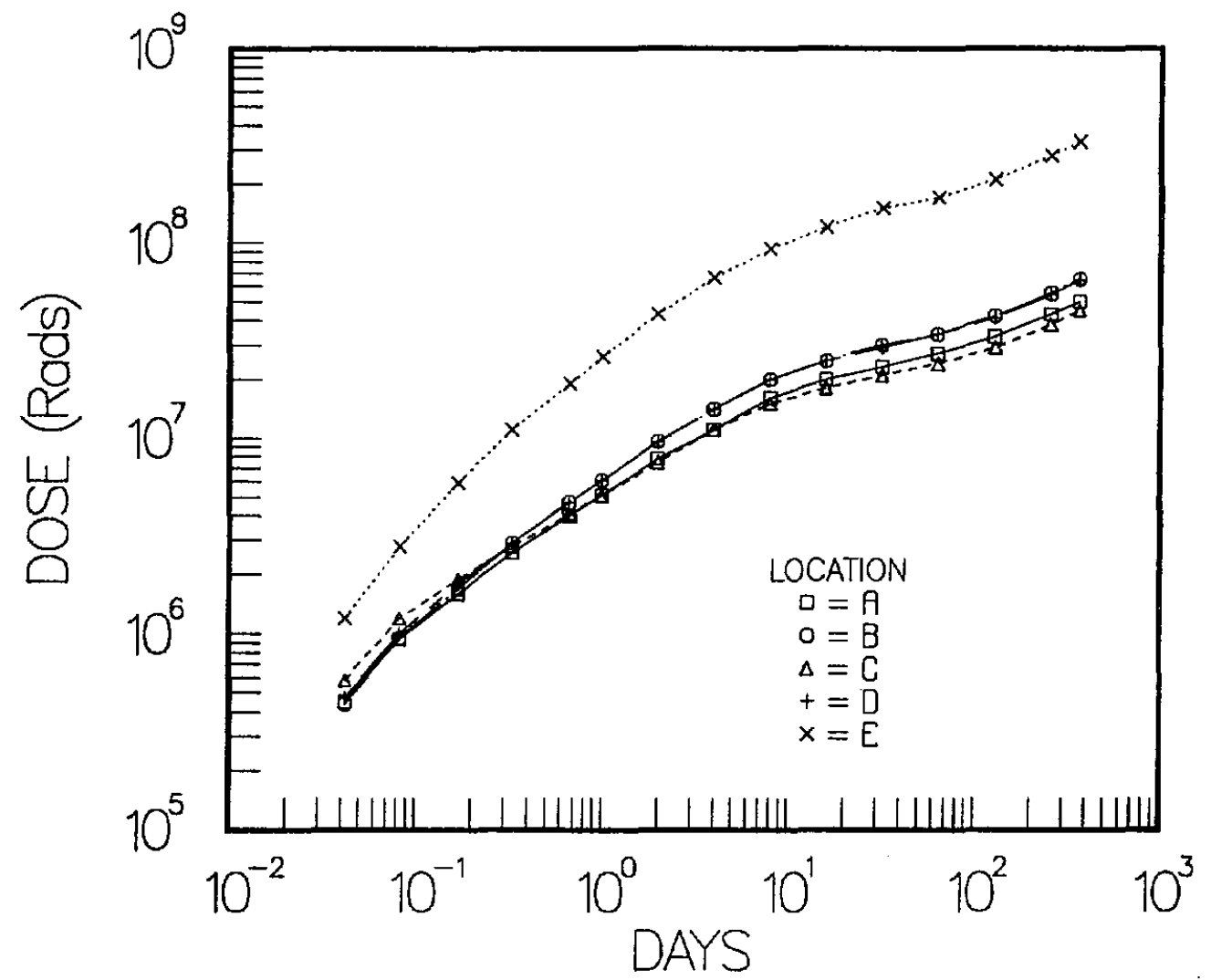

Figure B.41. Surry Case 2 Steam Generator B Total Gamma Dose

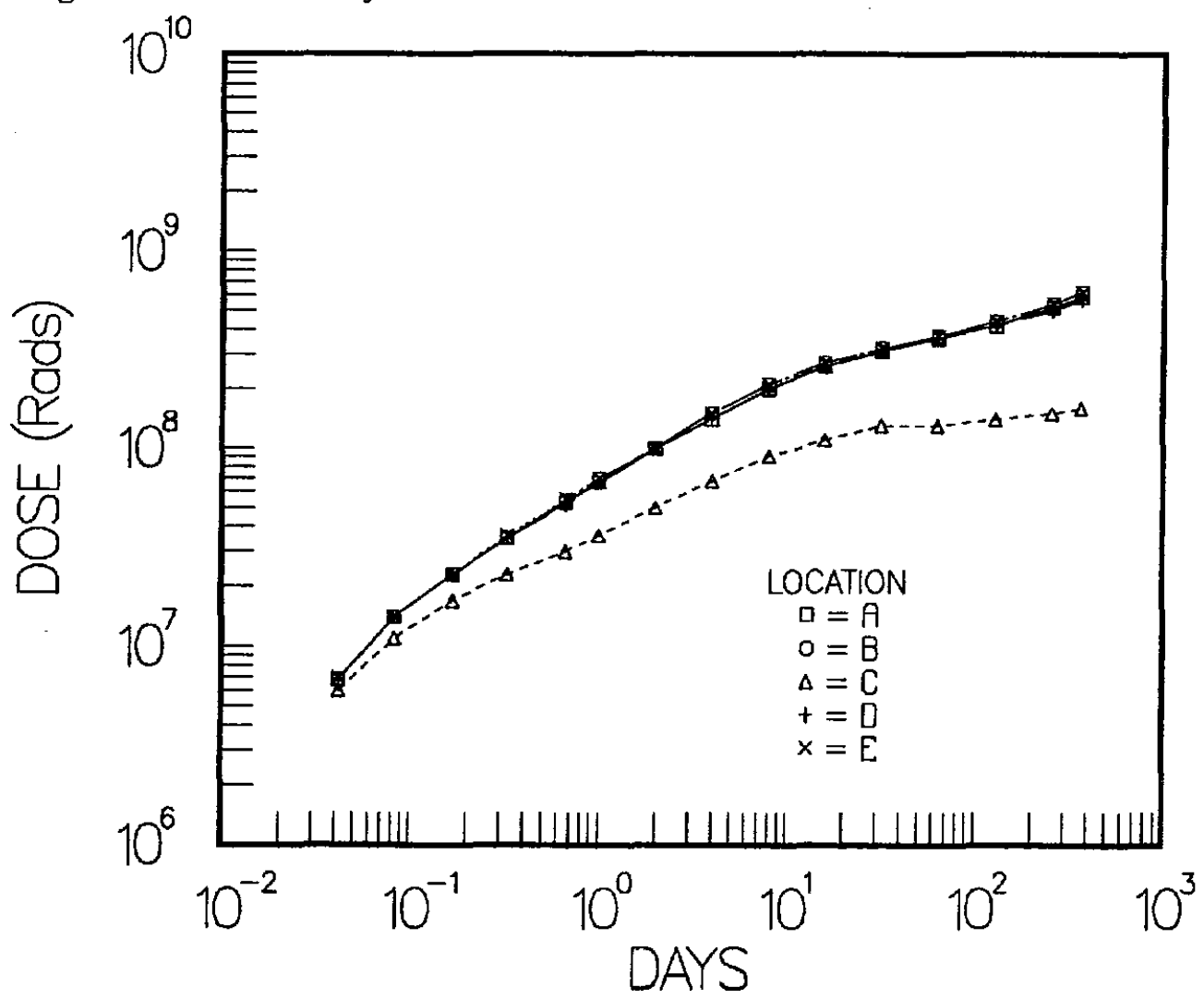

Figure B.42. Surry Case 2 Steam Generator B Total Beta Dose 


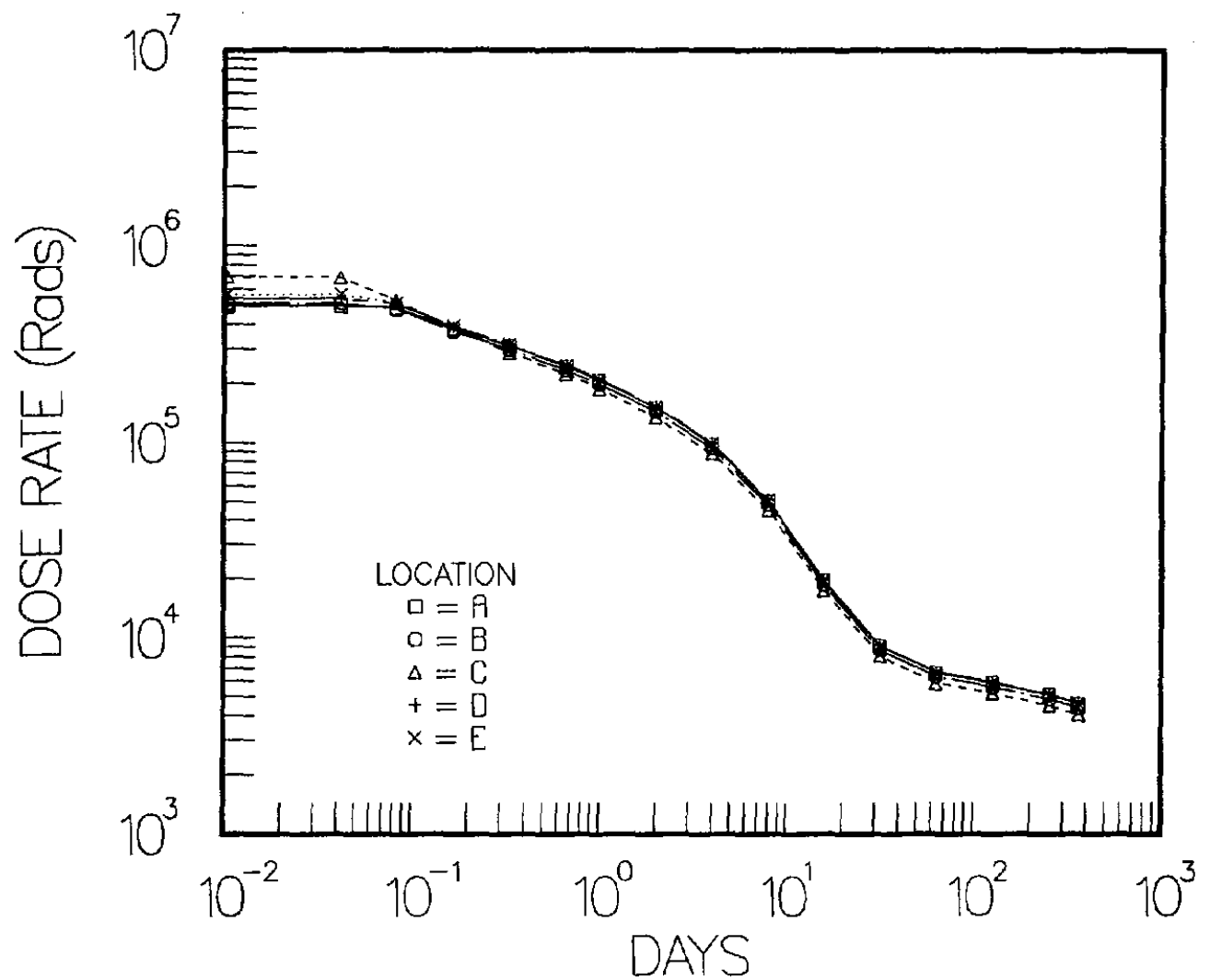

Figure B.43. Surry Case 2 In-Core Instrumentation Room Gamma Dose Rates

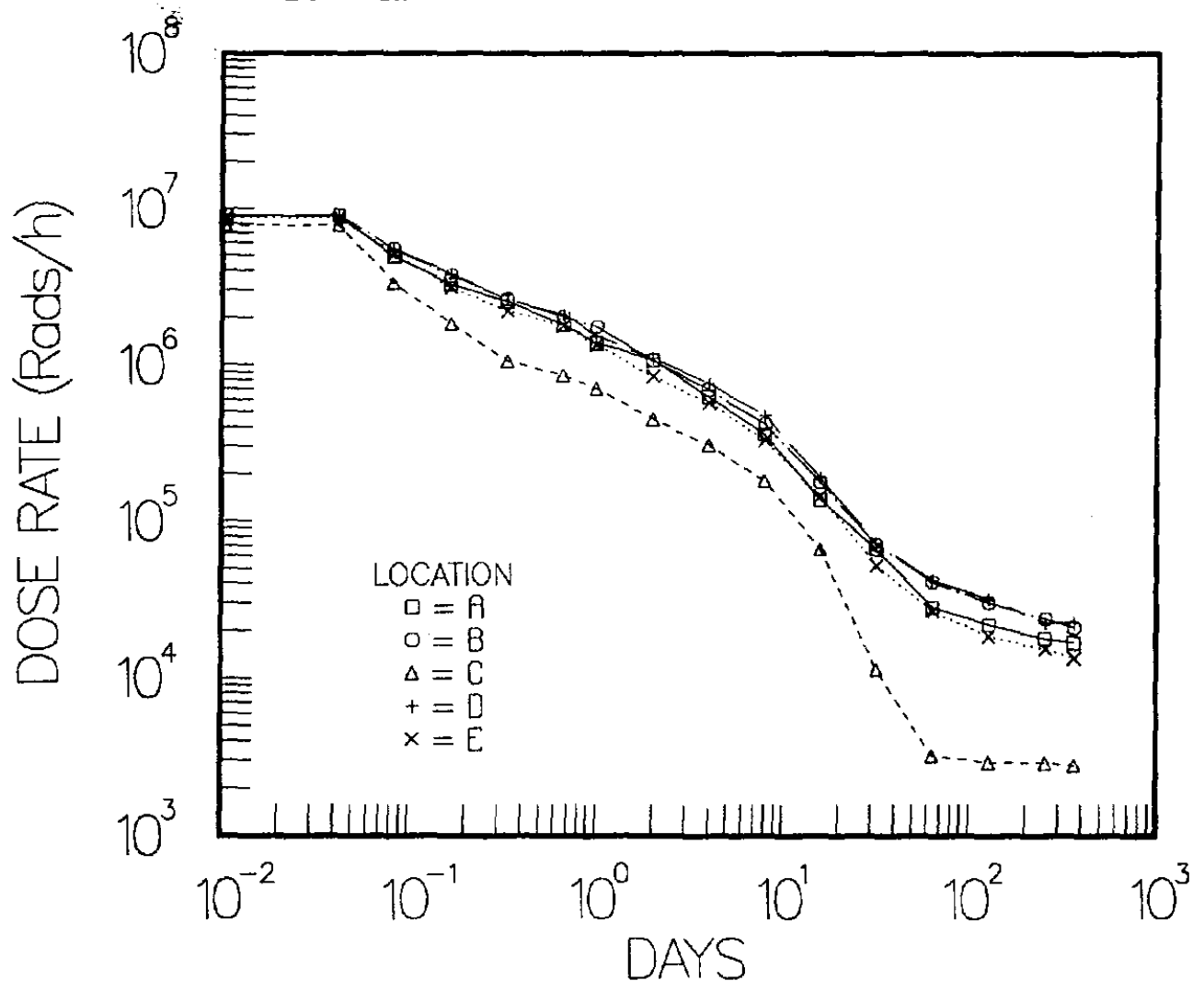

Figure B.44. Surry Case 2 In-Core Instrumentation Room Beta Dose Rates 


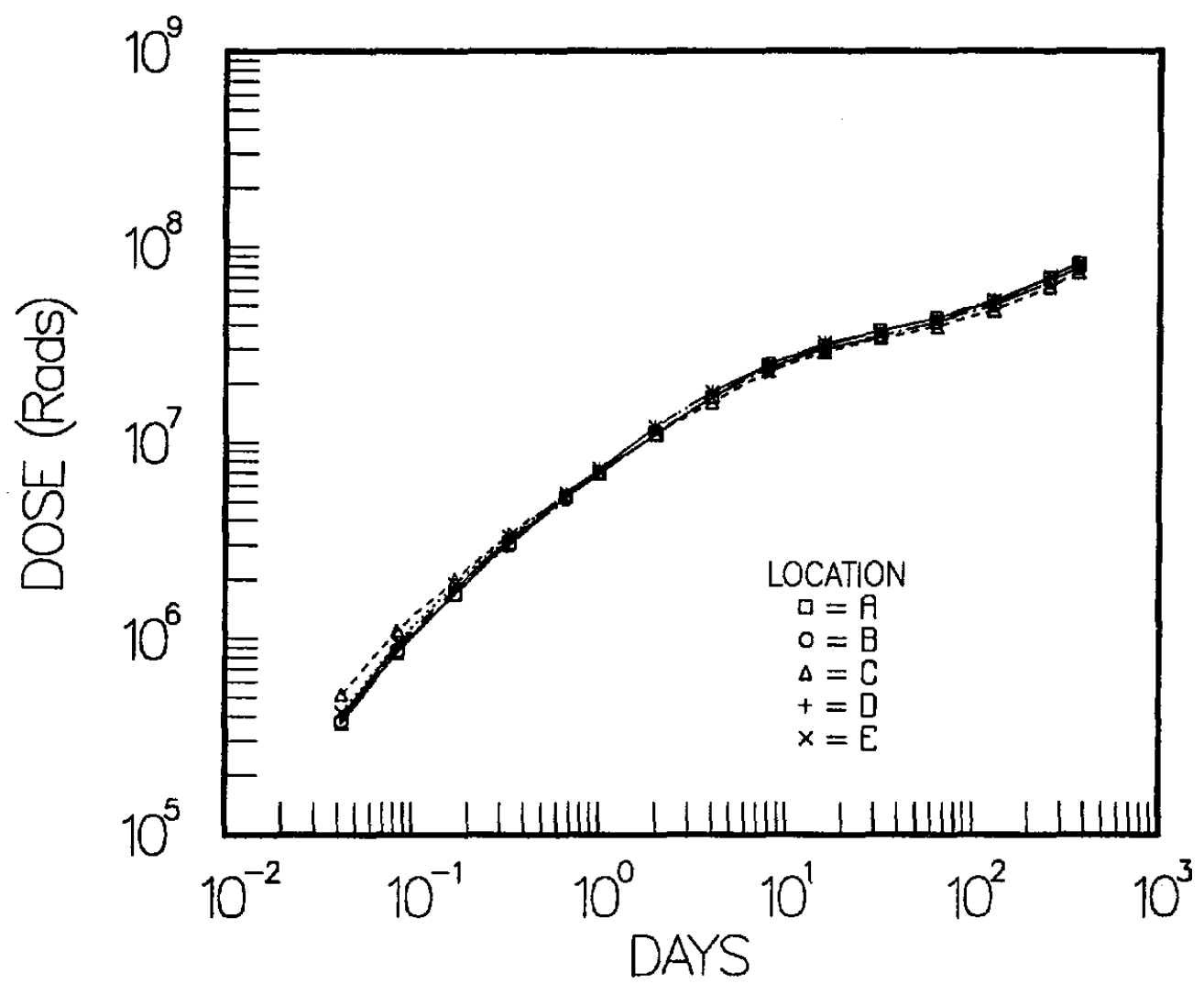

Figure B.45. Surry Case 2 In-Core Instrumentation Room Total Gamma Dose

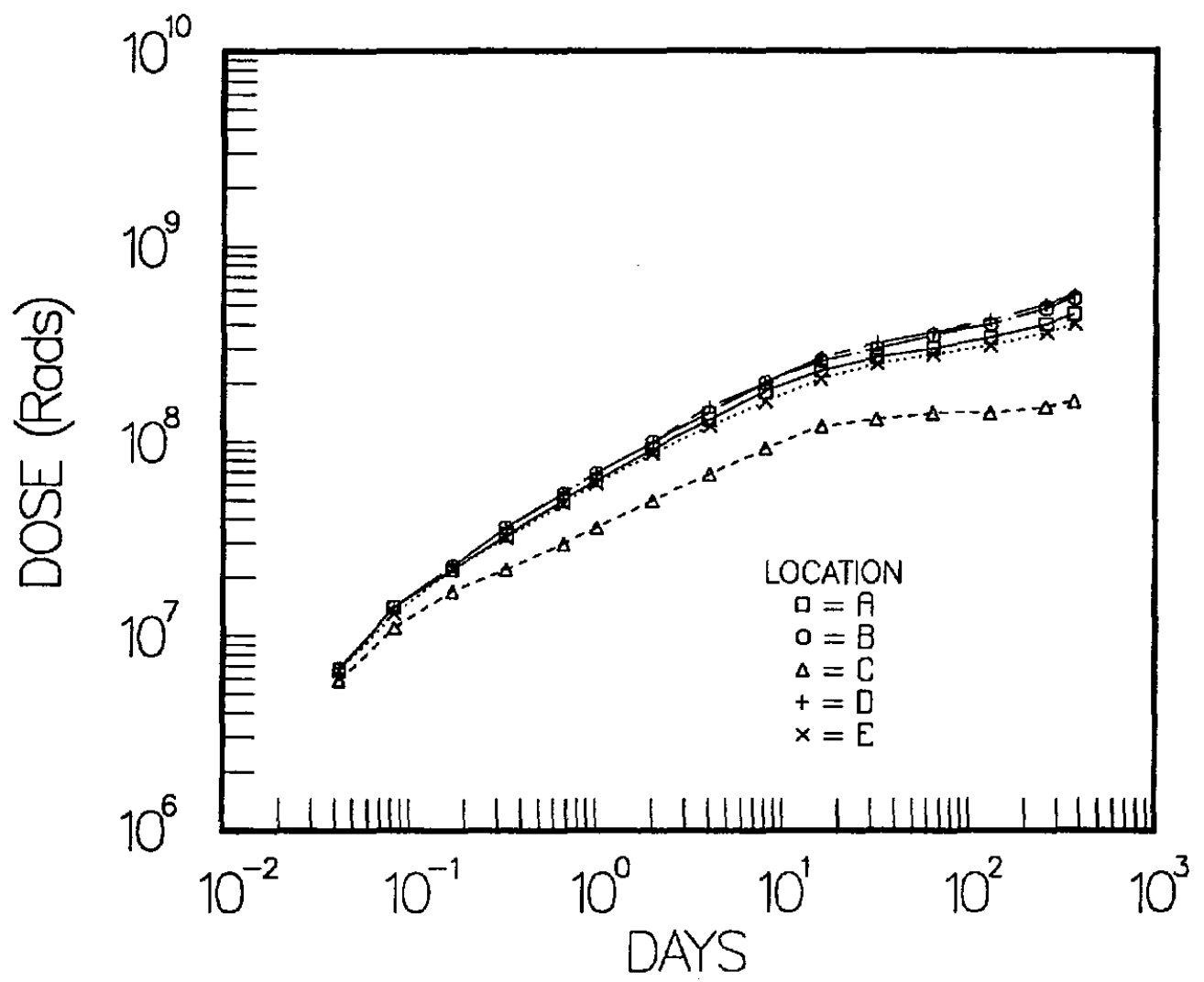

Figure B.46. Surry Case 2 In-Core Instrumentation Room Total Beta Dose 

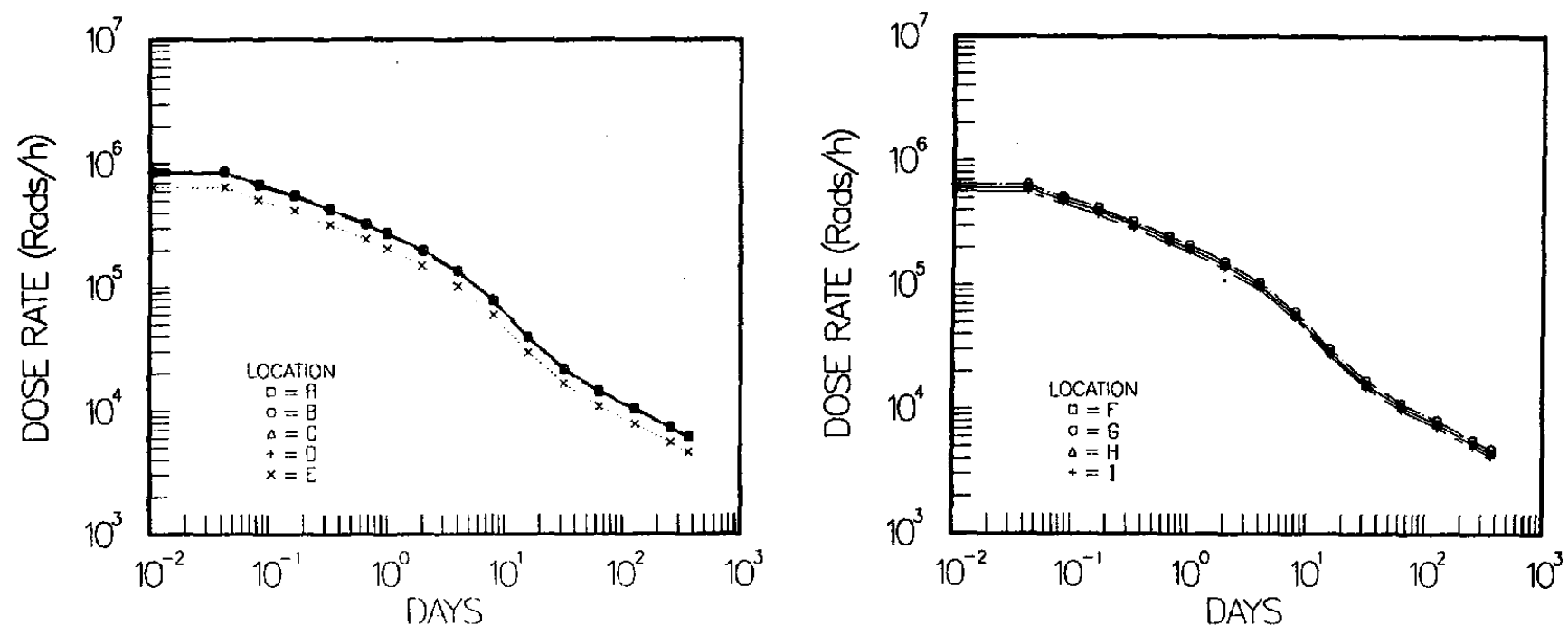

Figure B.47. Surry Case 3 Basement Gamma Dose Rate

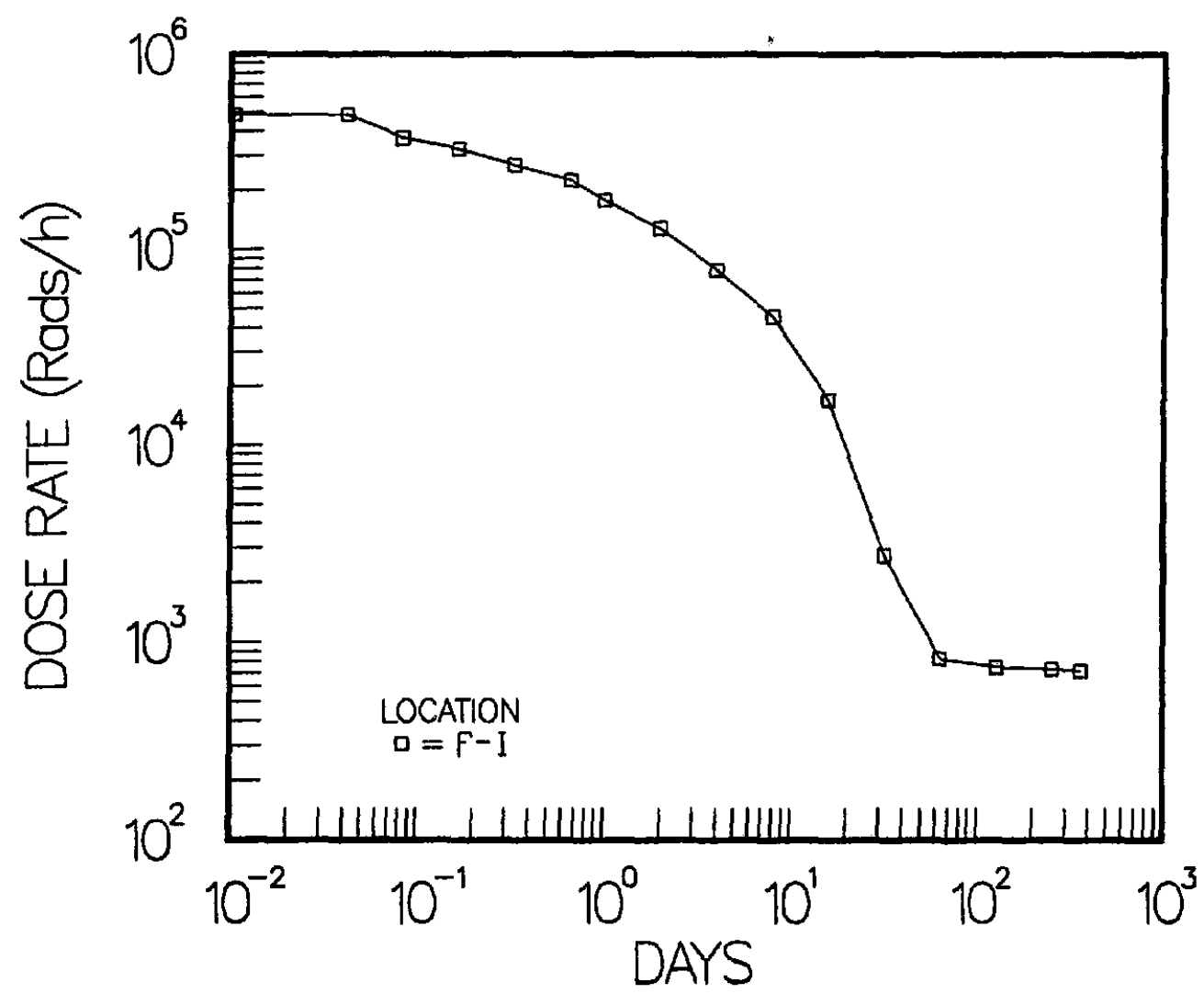

Figure B.48. Surry Case 3 Basement Beta Dose Rate 

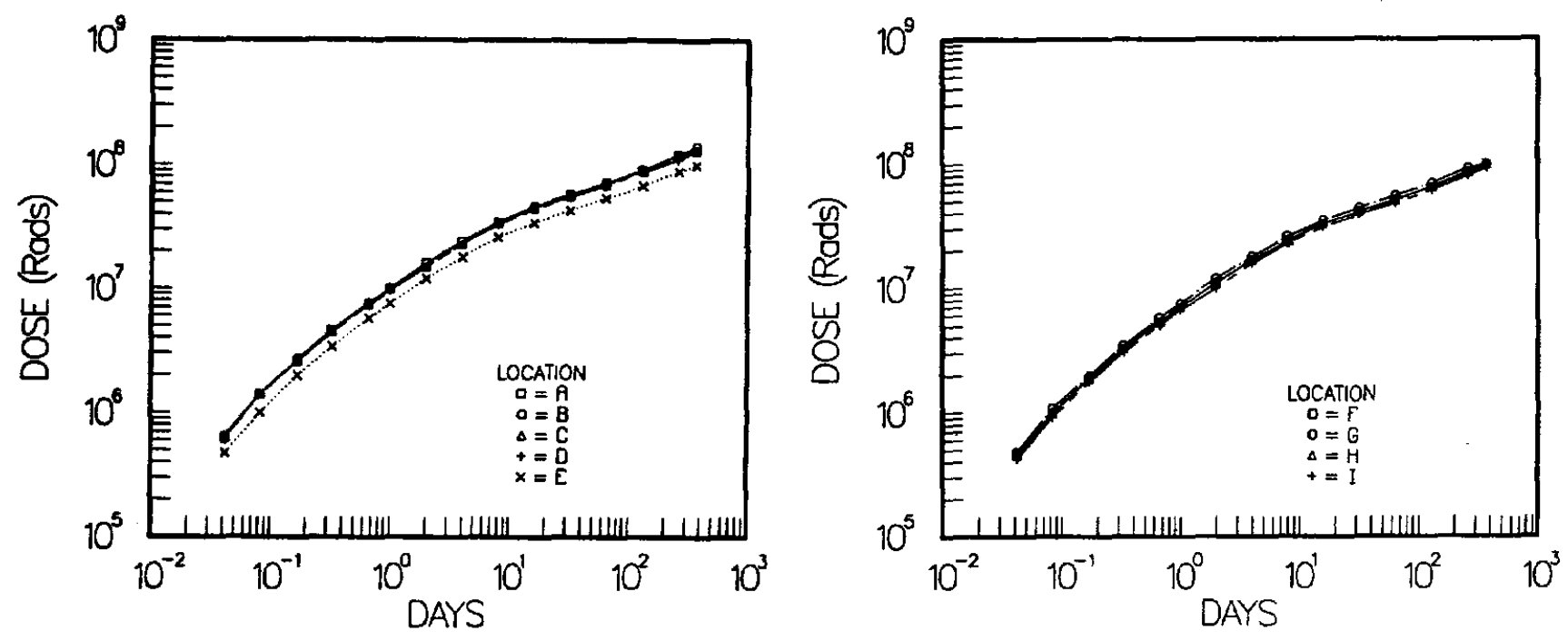

Figure B.49. Surry Case 3 Basement Total Gamma Dose

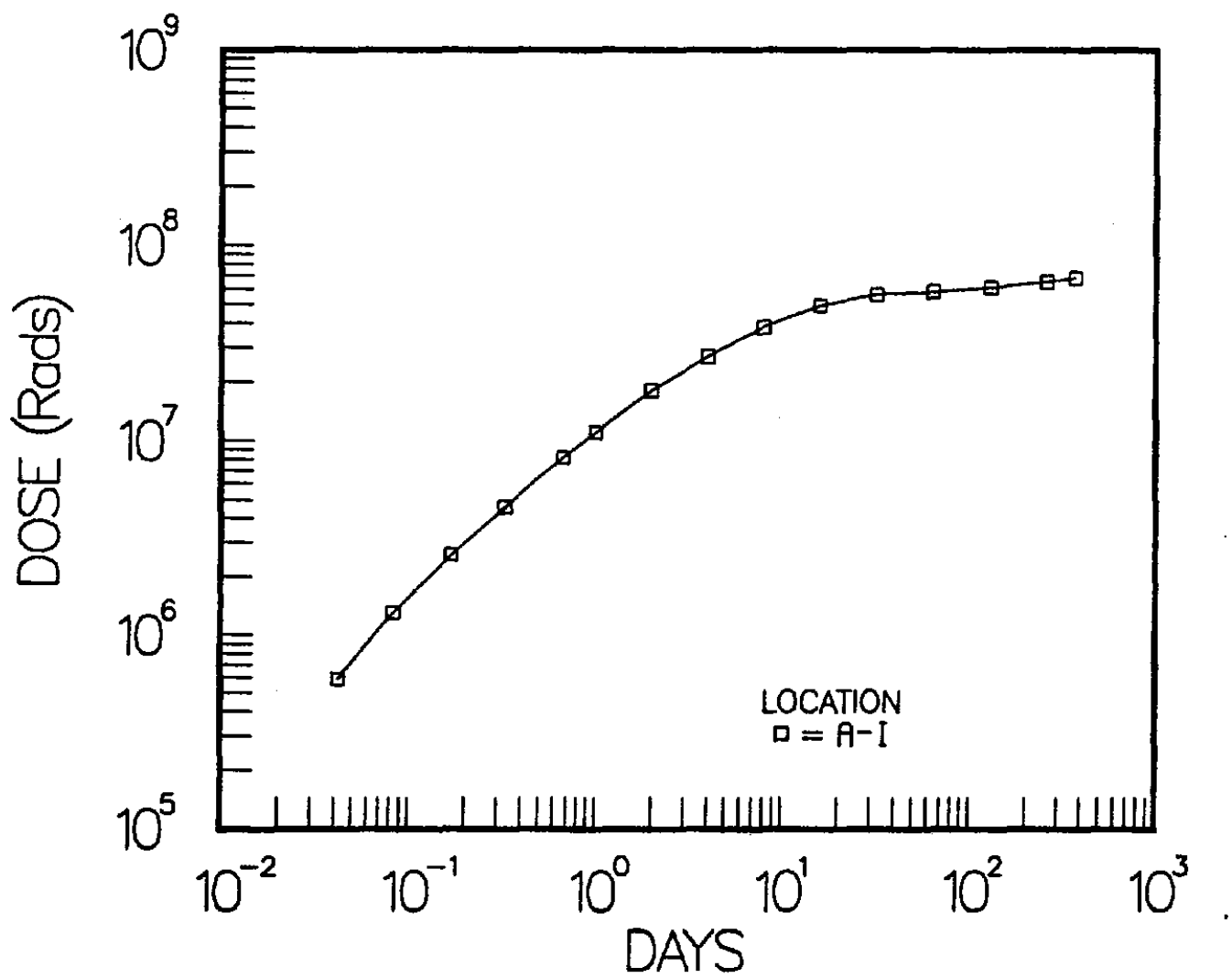

Figure B.50. Surry Case 3 Basement Total Beta Dose 


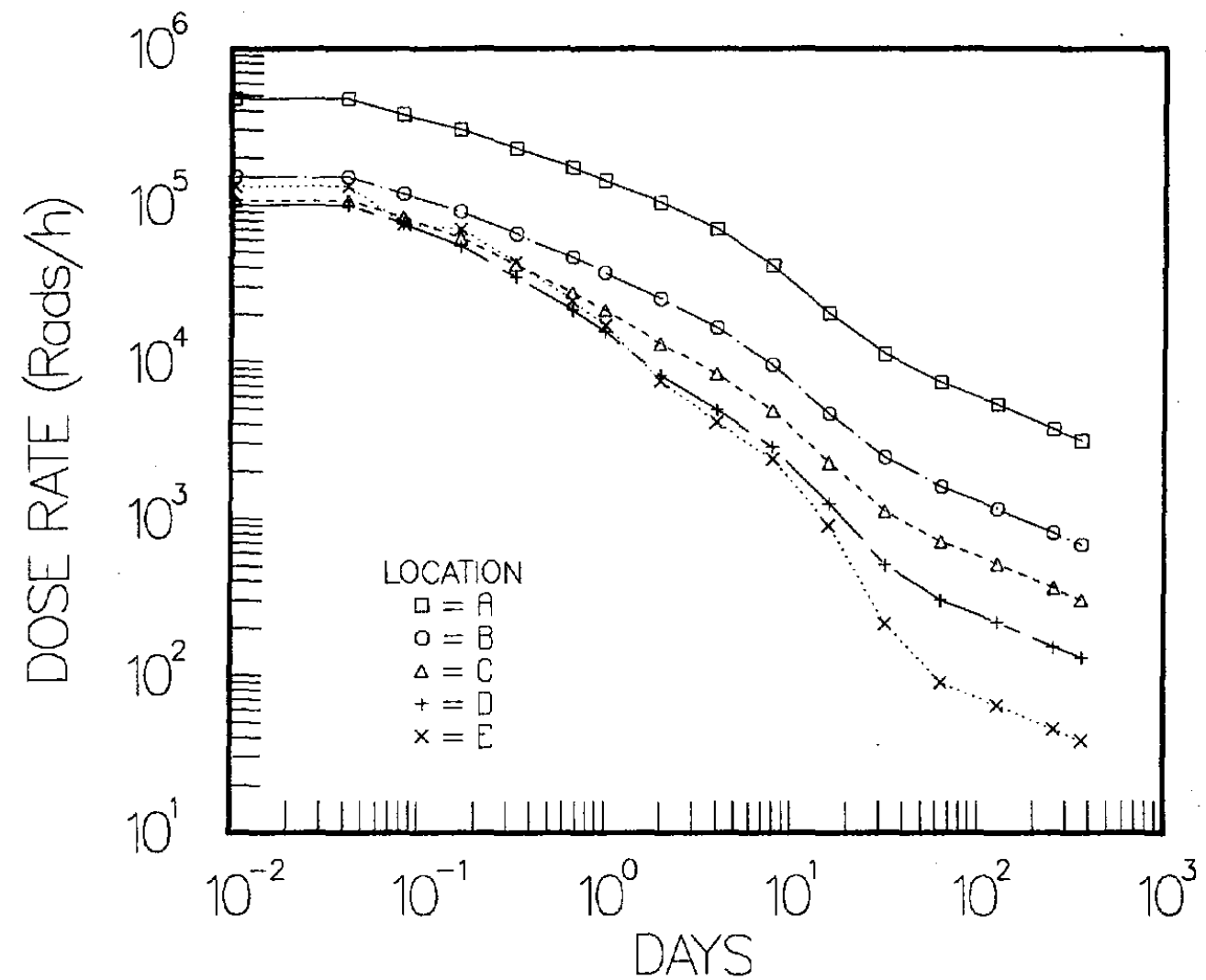

Figure B.51. Surry Case 3 Annulus Gamma Dose Rate

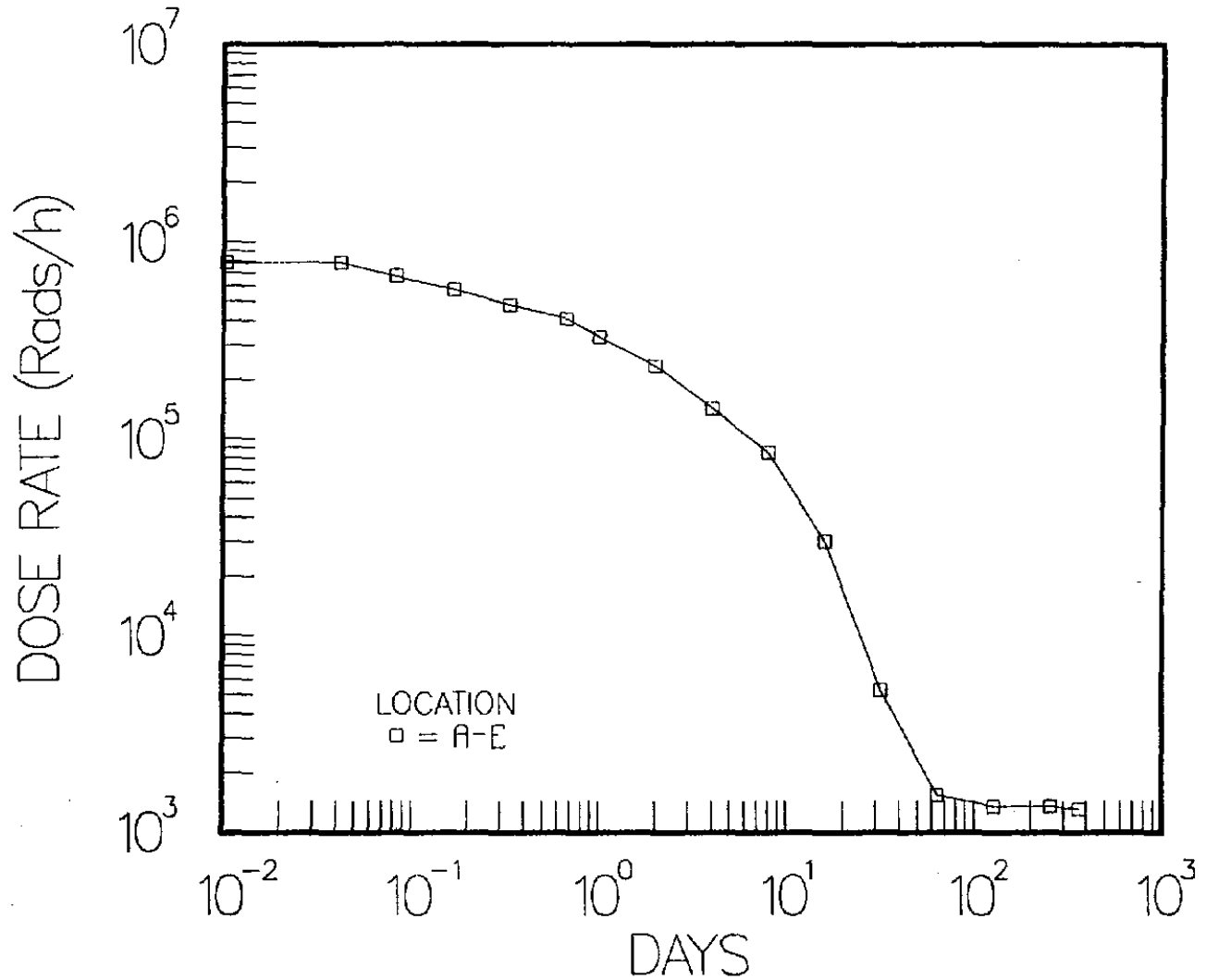

Figure B.52. Surry Case 3 Annulus Beta Dose Rate 


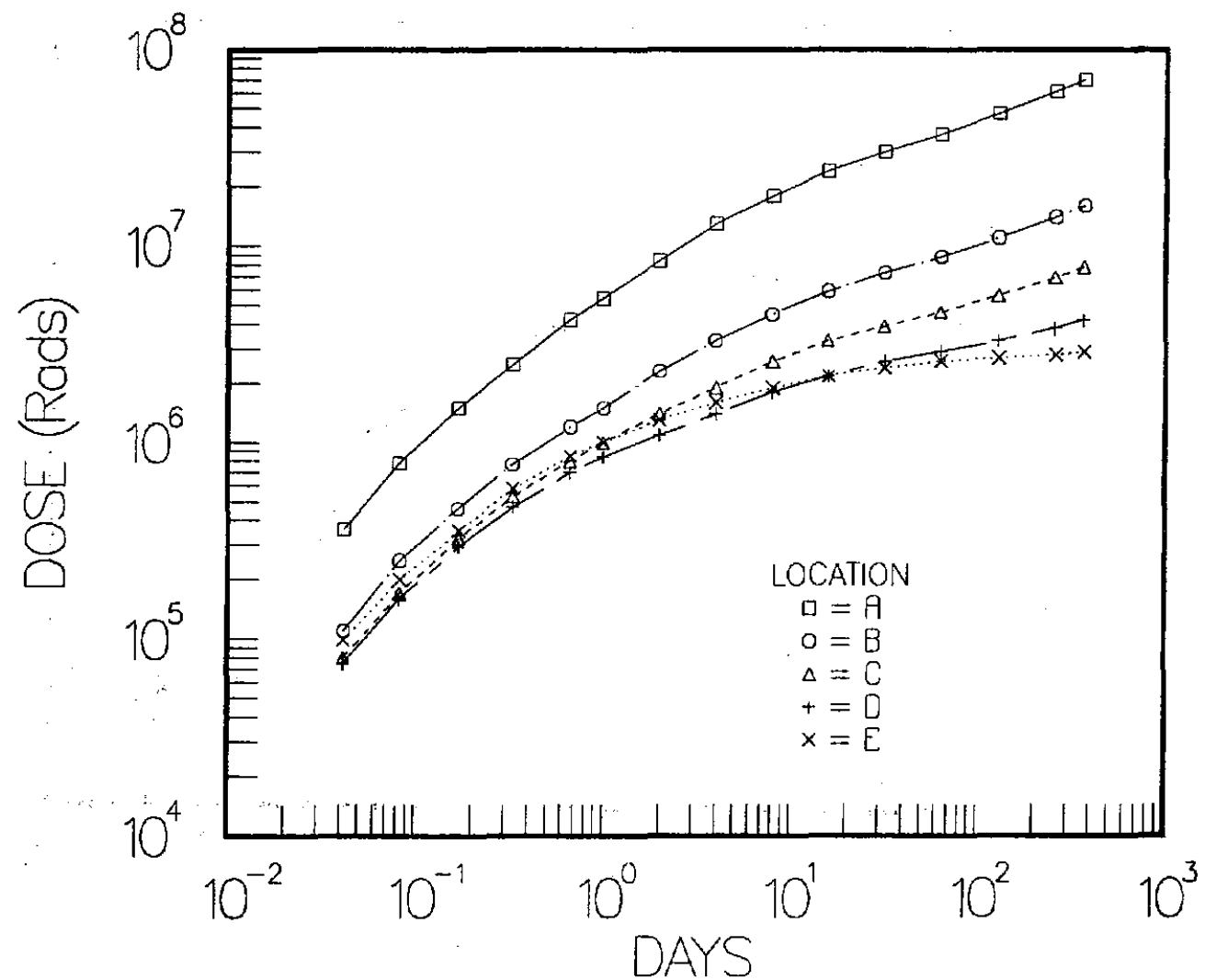

Figure B.53. Surry Case 3 Annulus Total Gamma Dose

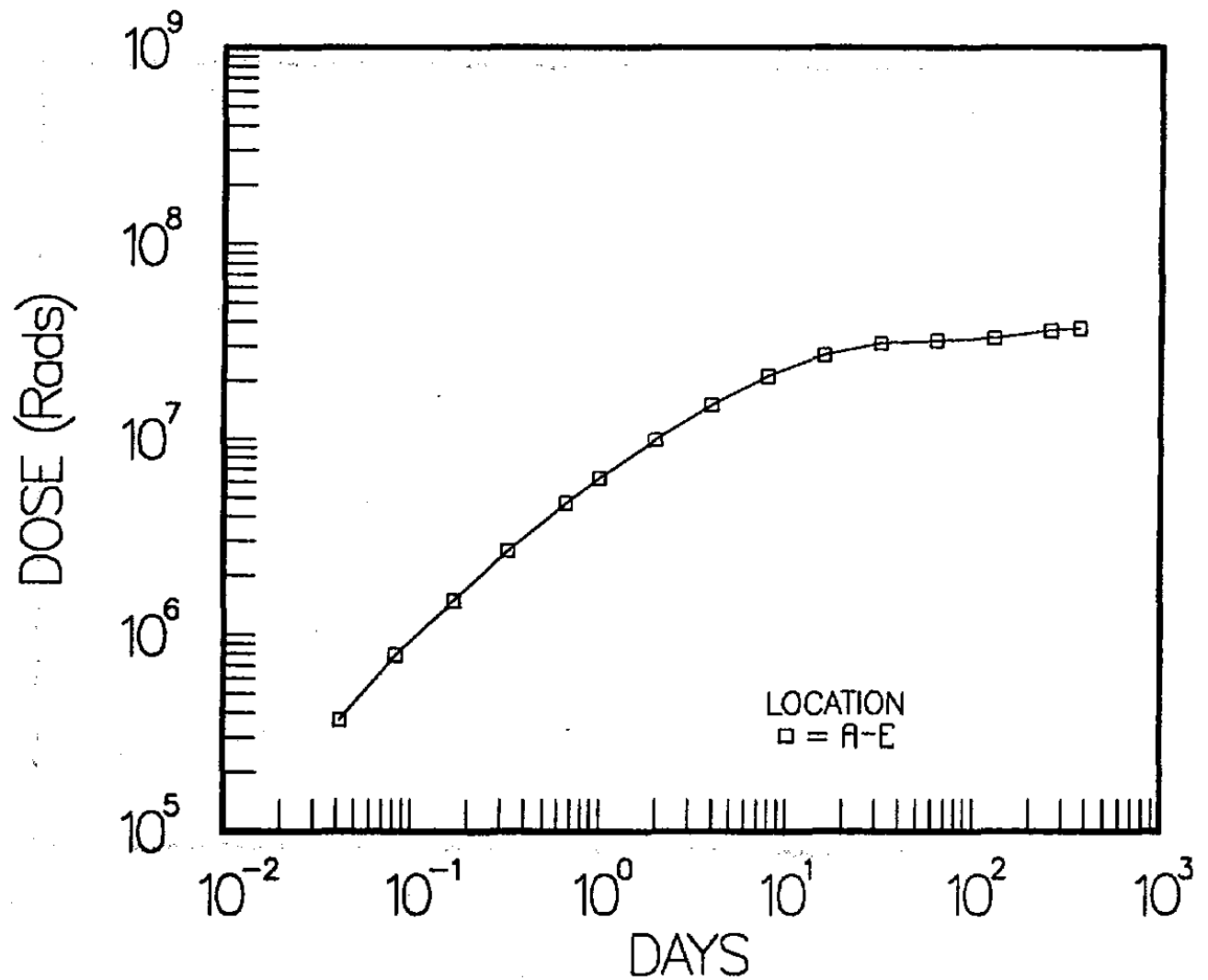

Figure B.54. Surry Case 3 Annulus Total Beta Dose 


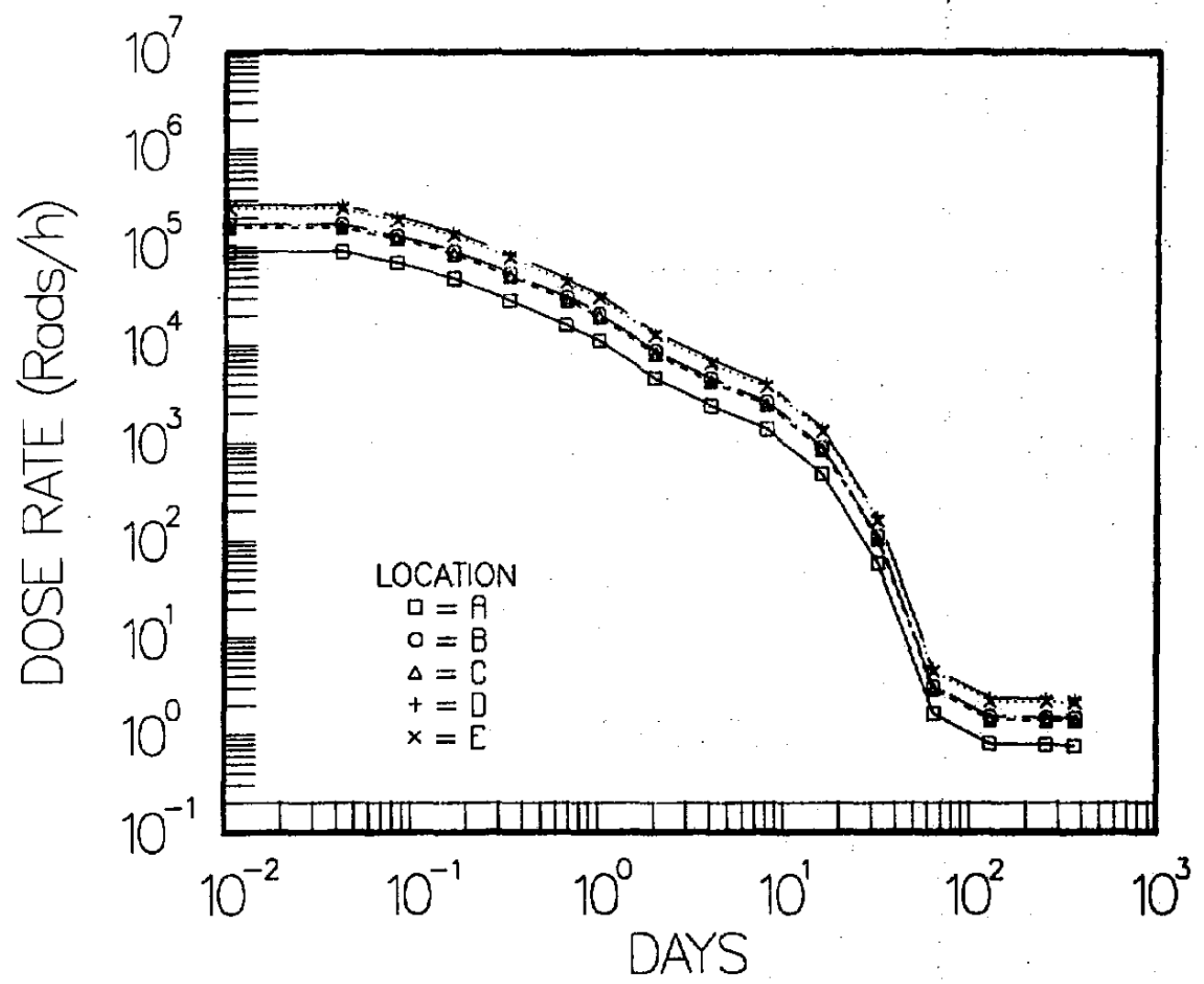

Figure B.55. Surry Case 3 Operating Floor and Dome Gamma Dose Rate

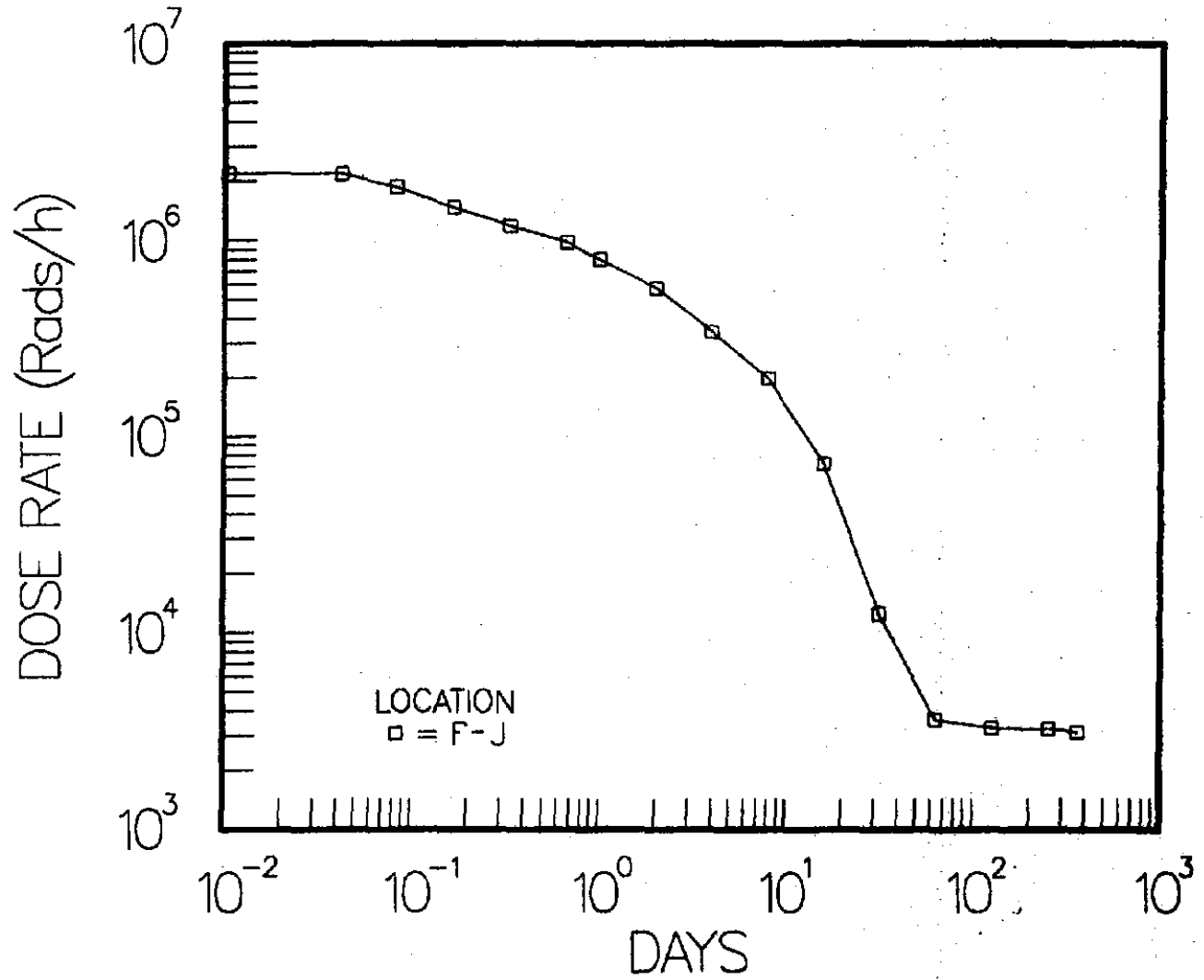

Figure B.56. Surry Case 3 Operating Floor and Dome Beta Dose Rate 


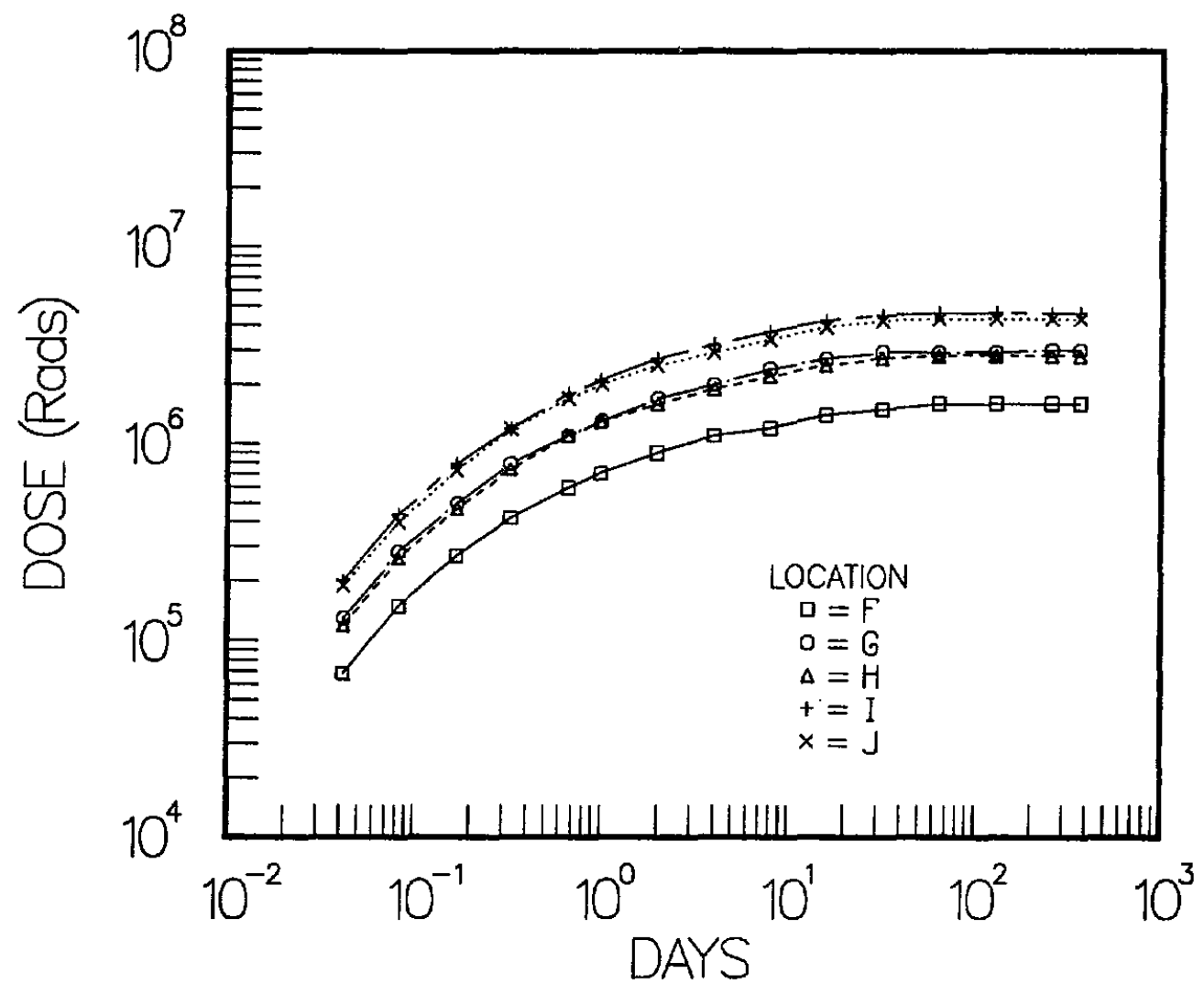

Figure B.57. Surry Case 3 Operating Floor and Dome Total Gamma Dose

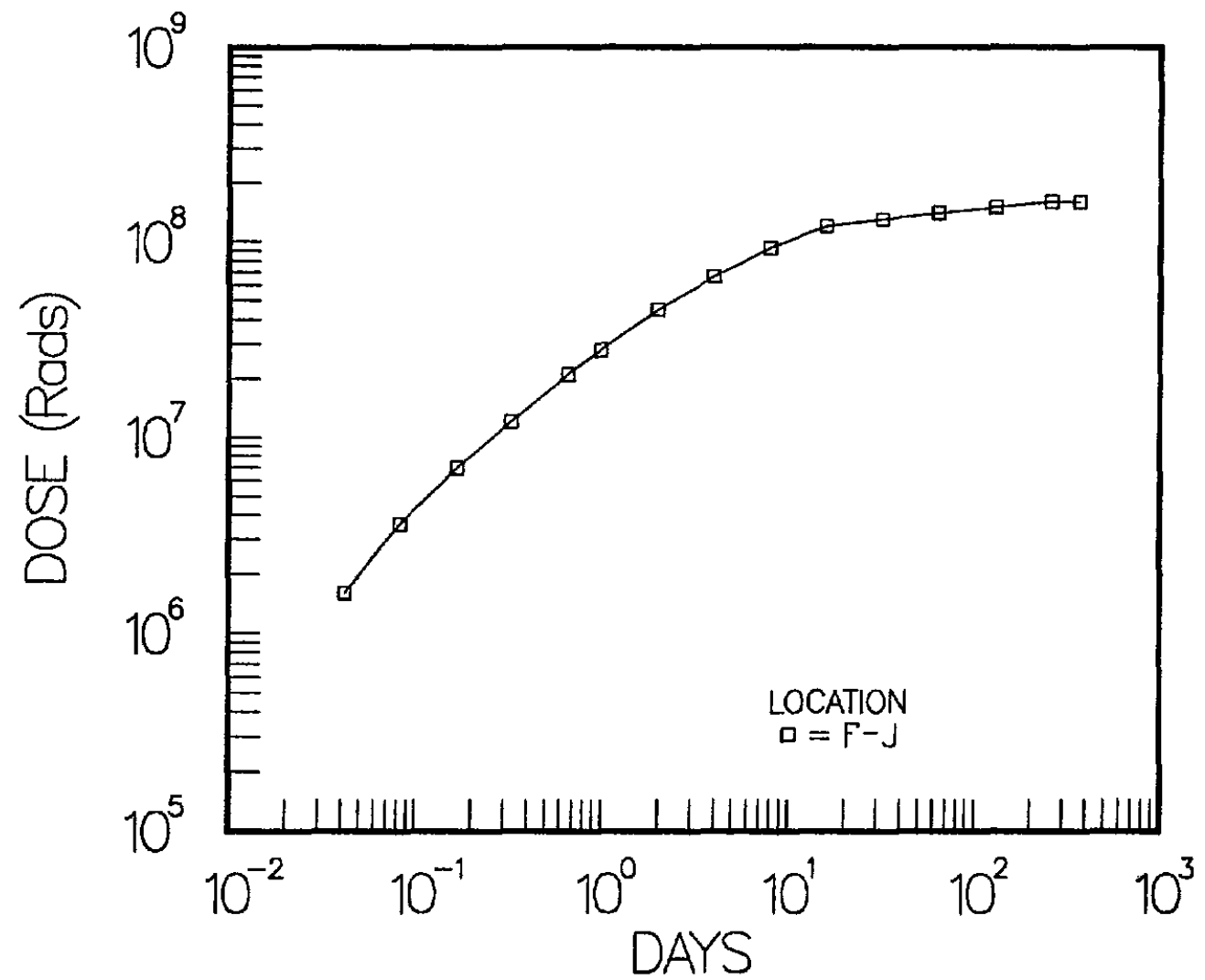

Figure B.58. Surry Case 3 Operating Floor and Dome Total Beta Dose 


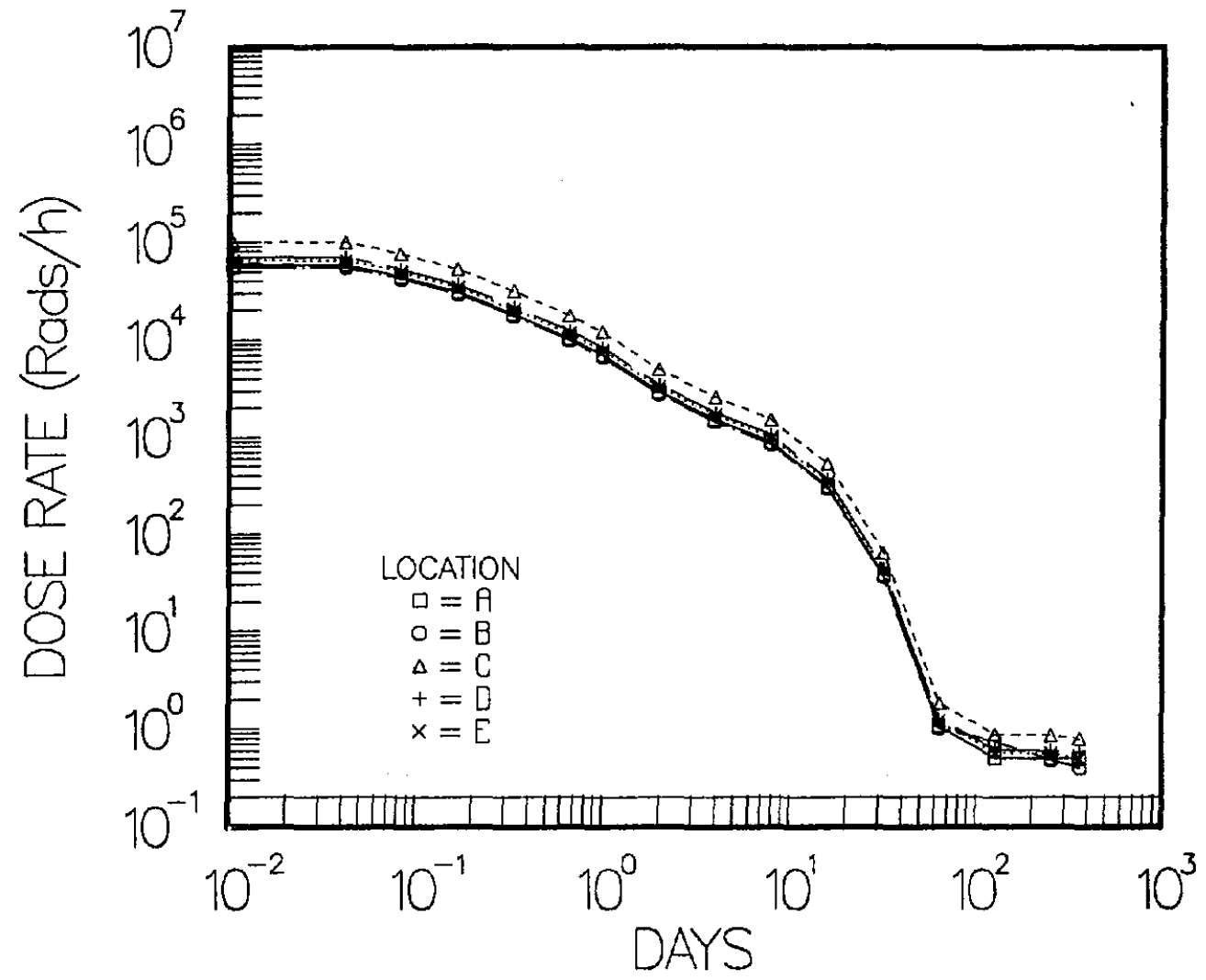

Figure B.59. Surry Case 3 Steam Generator A Gamma Dose Rate

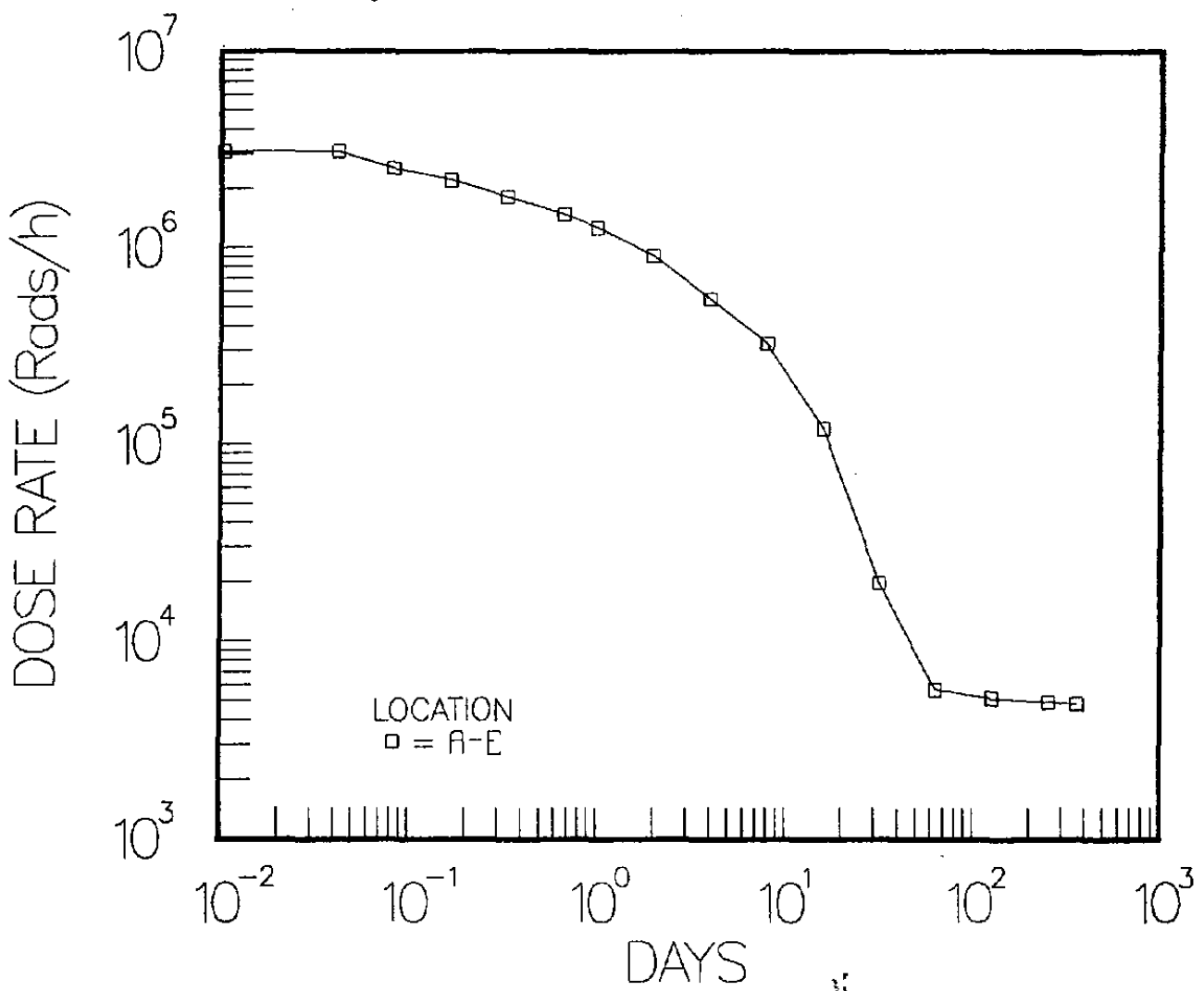

Figure B.60. Surry Case 3 Steam Generator A Beta Dose Rate 


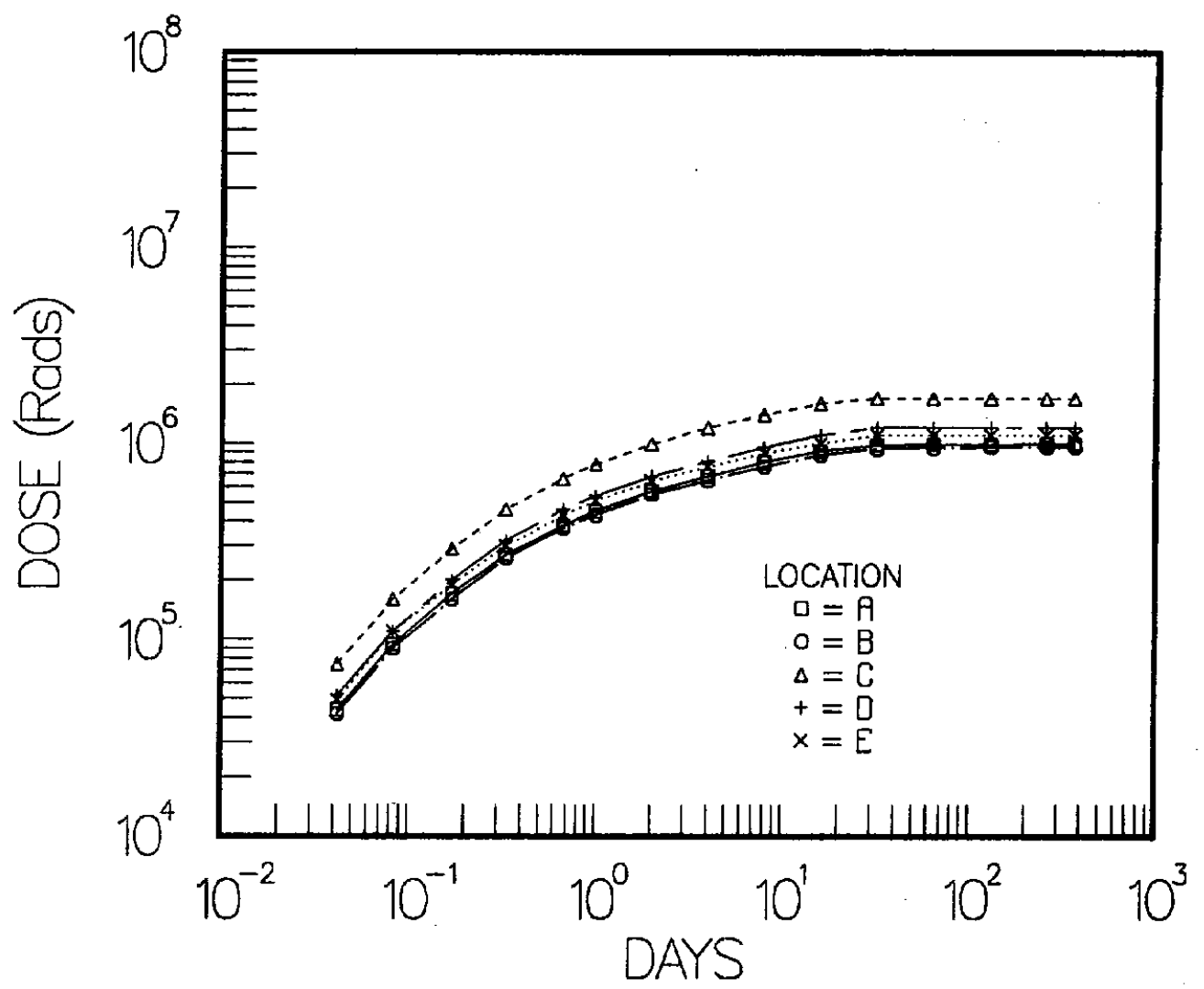

Figure B.61. Surry Case 3 Steam Generator A Total Gamma Dose

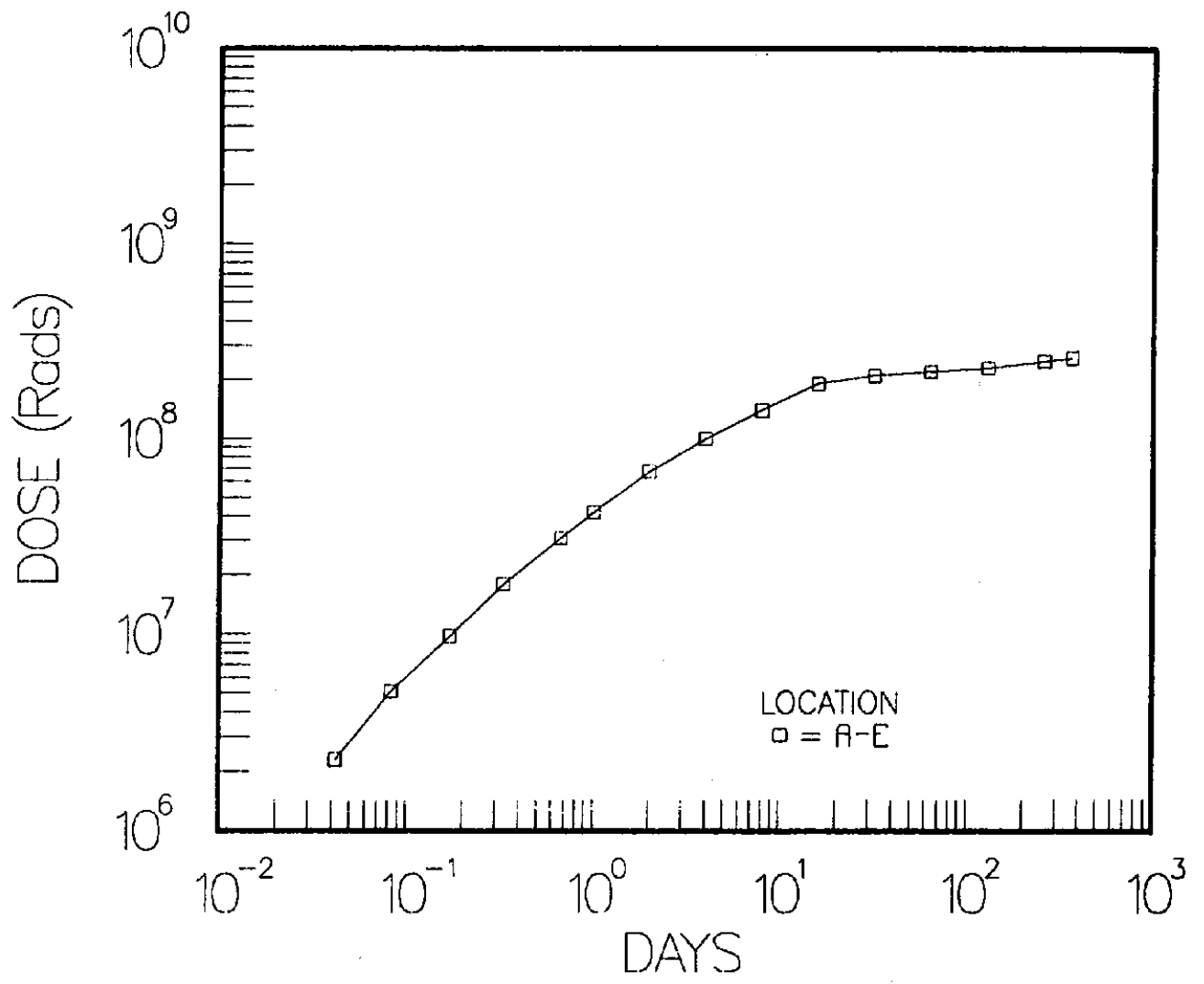

Figure B.62. Surry Case 3 Steam Generator A Total Beta Dose 


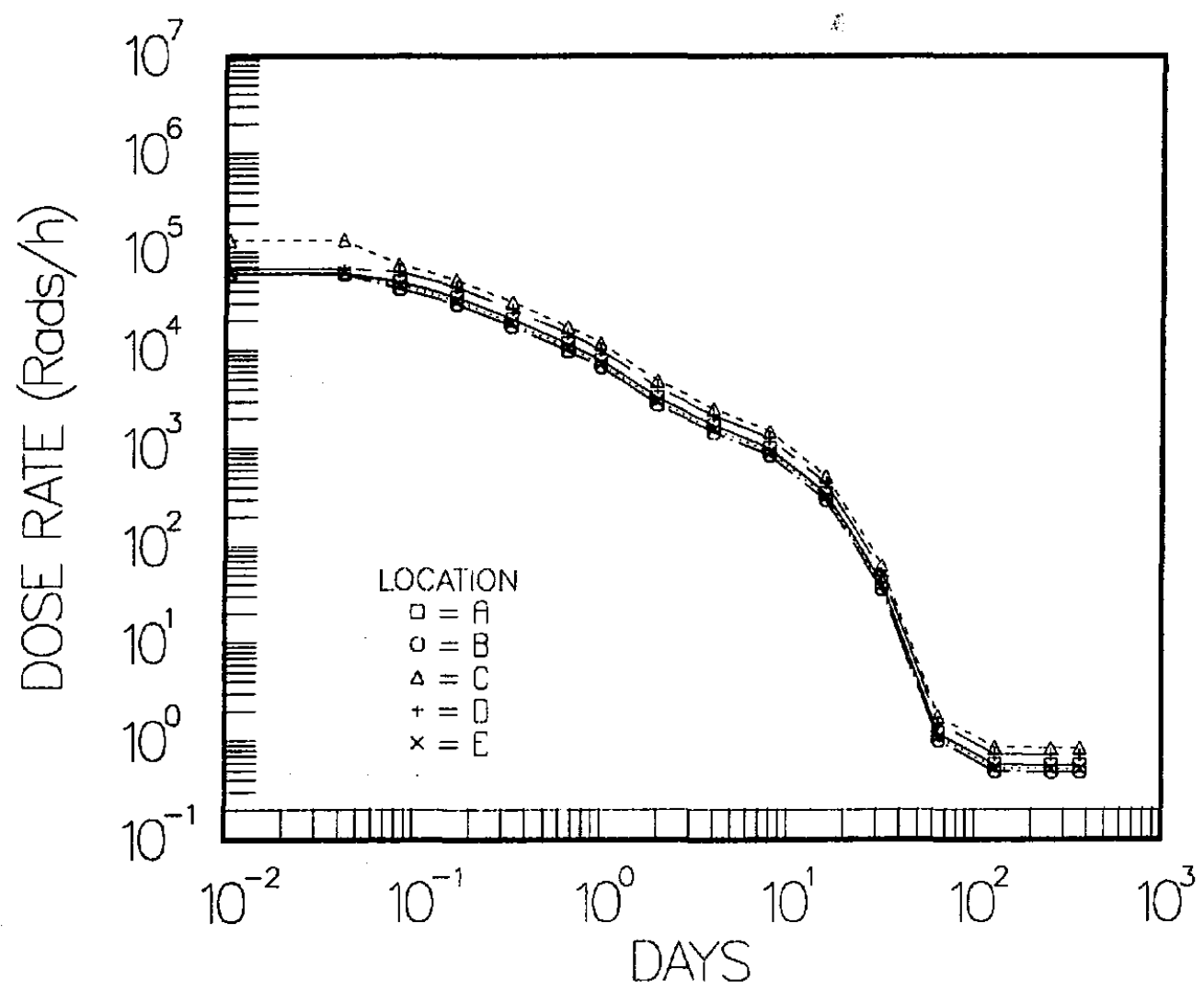

Figure B.63. Surry Case 3 Steam Generator B Gamma Dose Rate

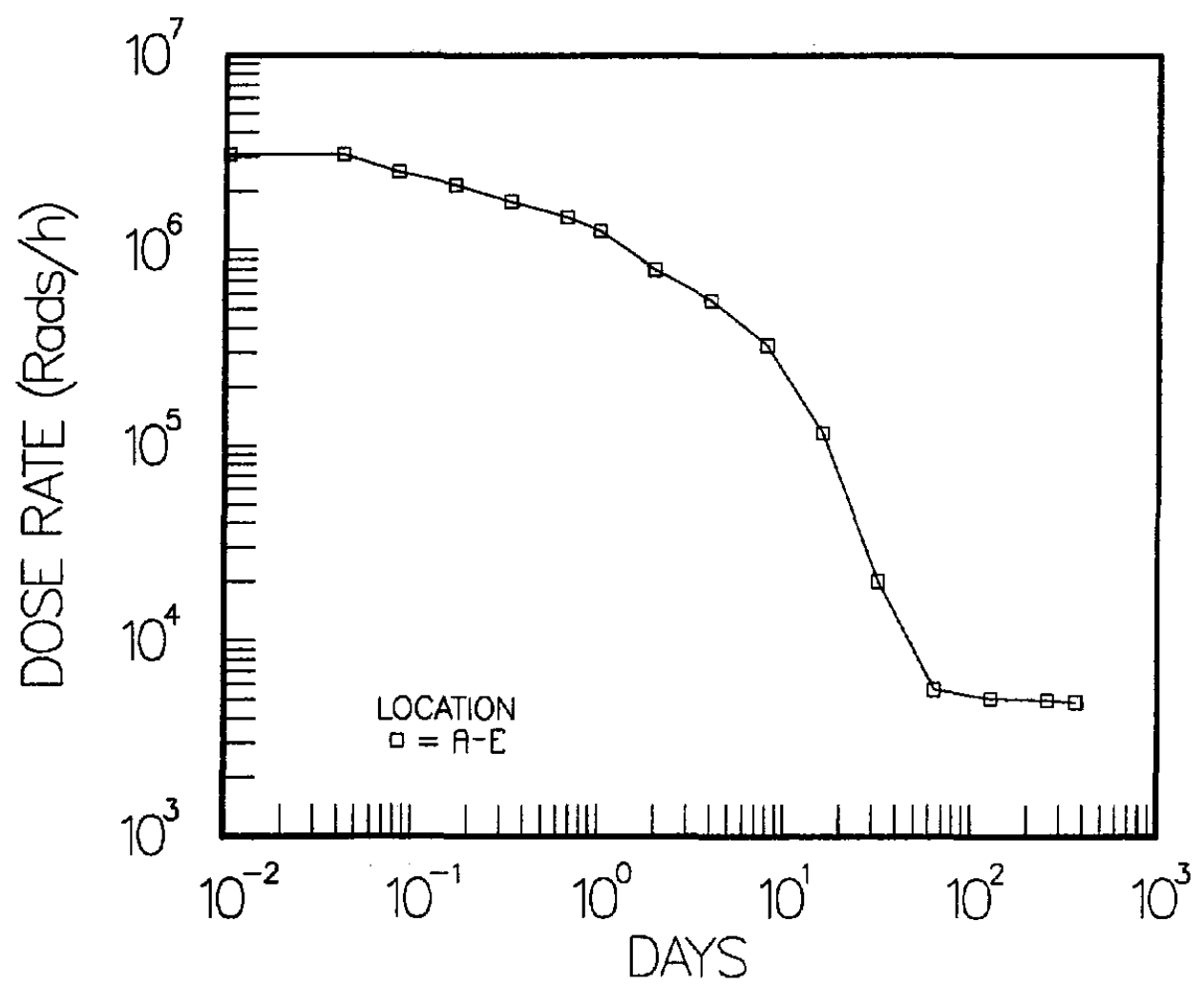

Figure B.64. Surry Case 3 Steam Generator B Beta Dose Rate 


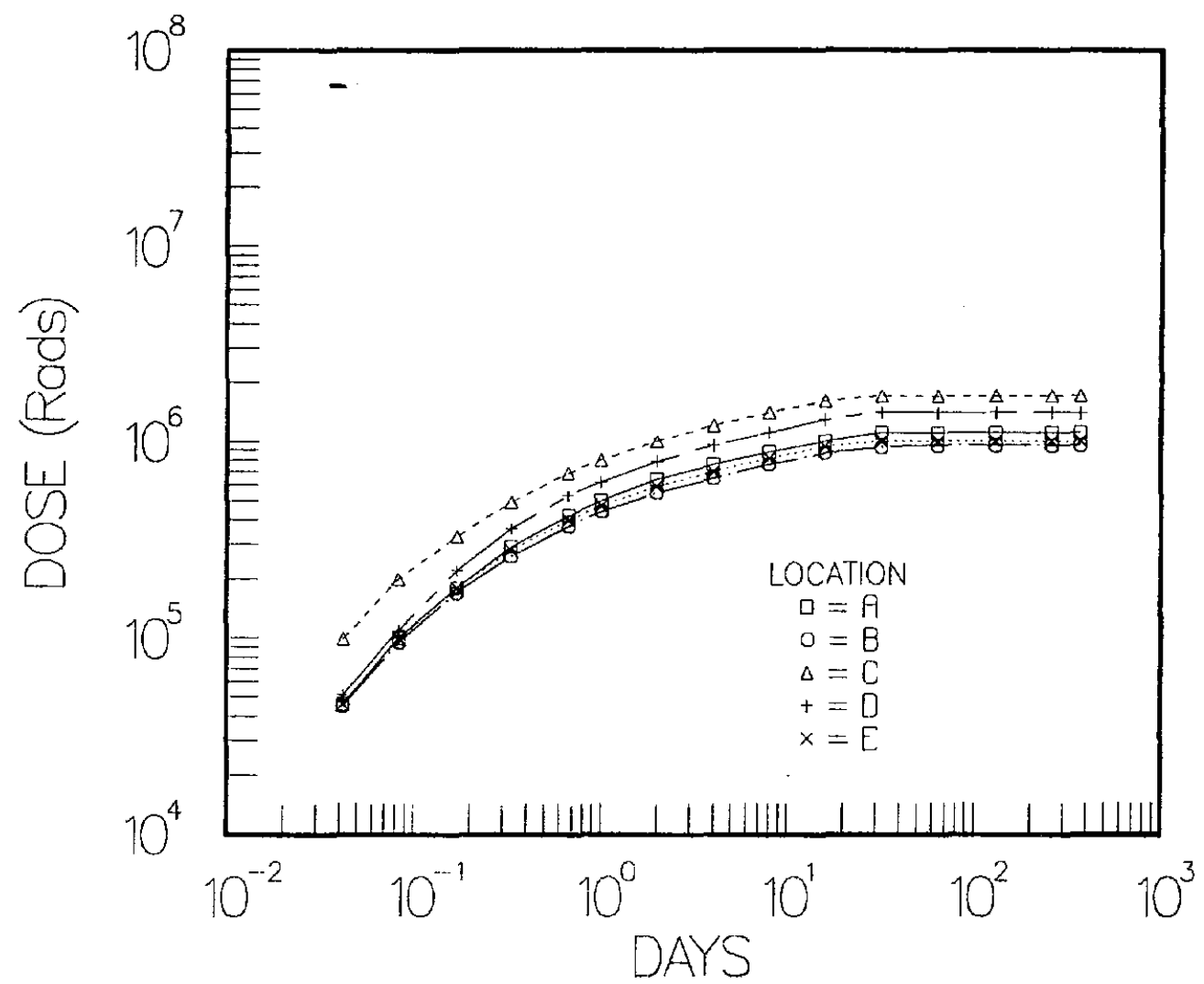

Figure B.65. Surry Case 3 Steam Generator B Total Gamma Dose

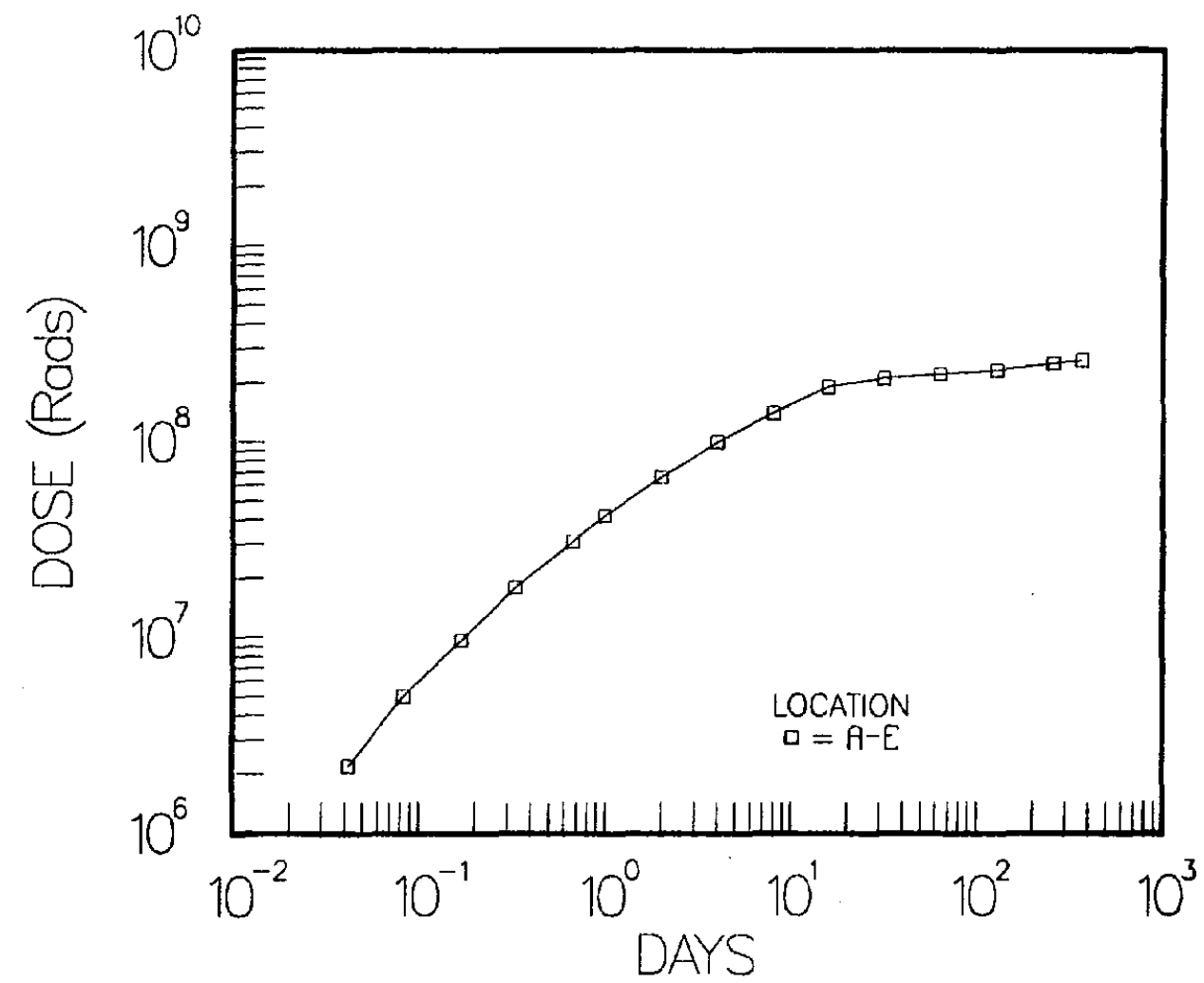

Figure B.66. Surry Case 3 Steam Generator B Total Beta Dose 


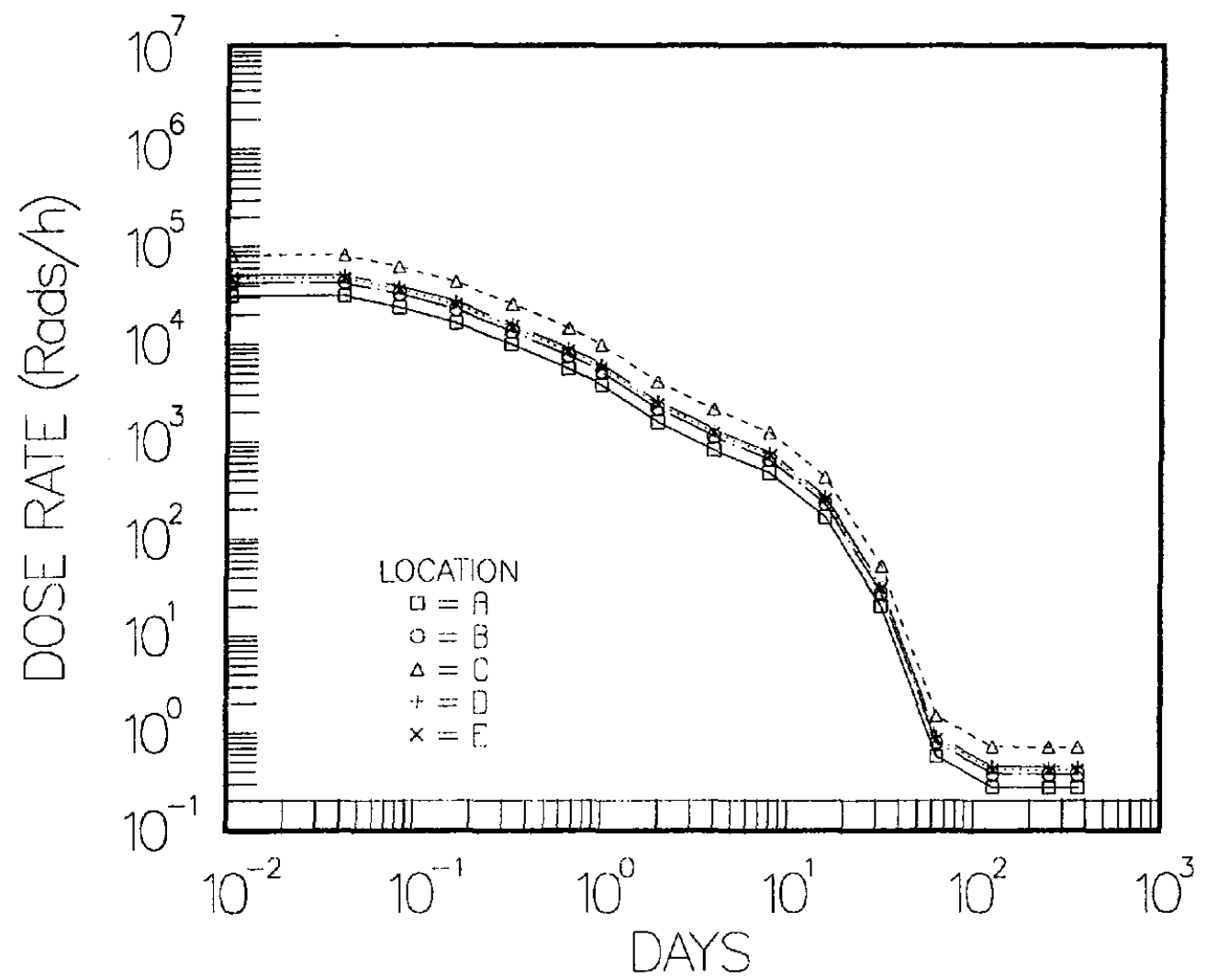

Figure B.67. Surry Case 3 RHR Cubicle Gamma Dose Rate

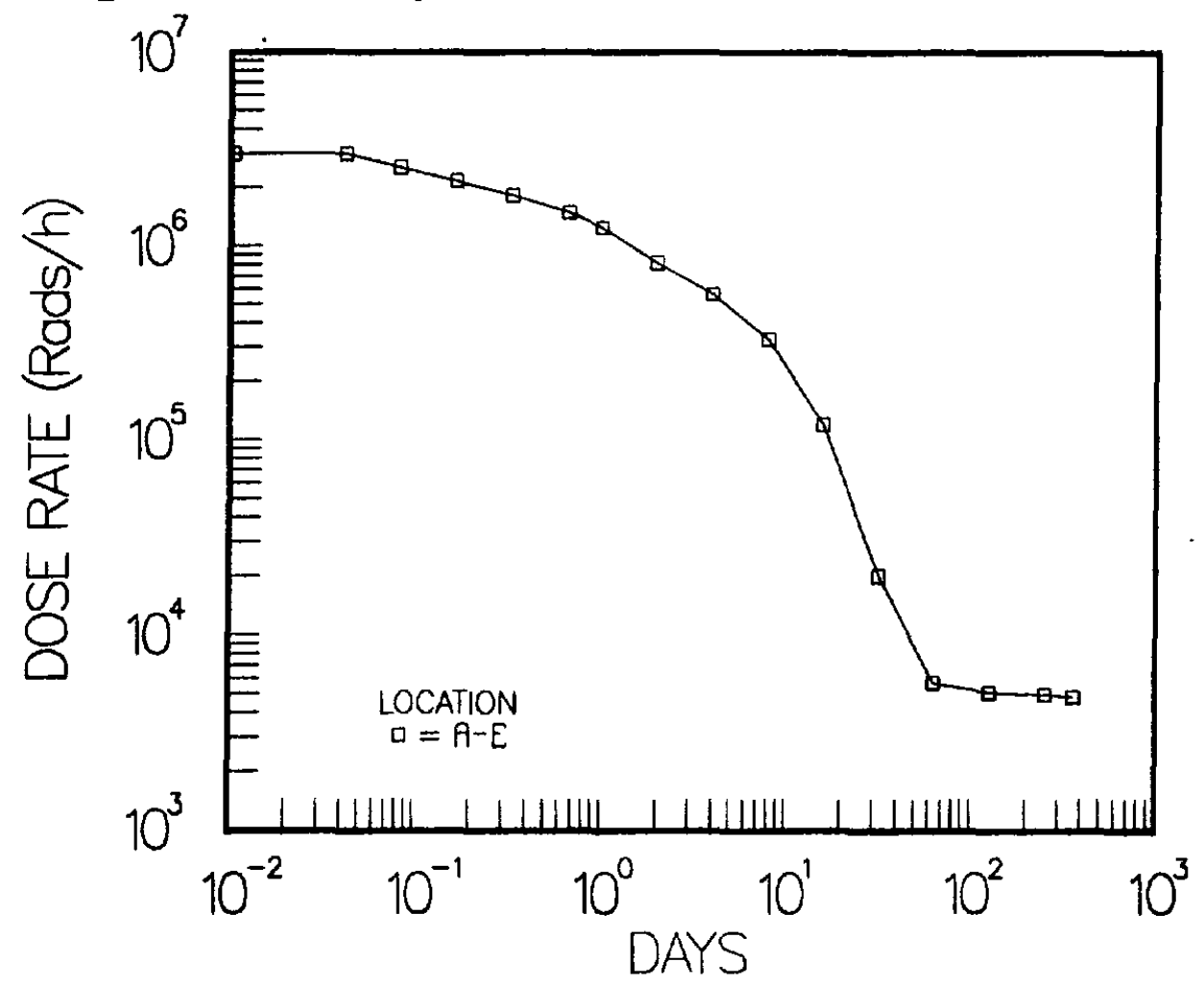

Figure B.68. Surry Case 3 RHR Cubicle Beta Dose Rate 


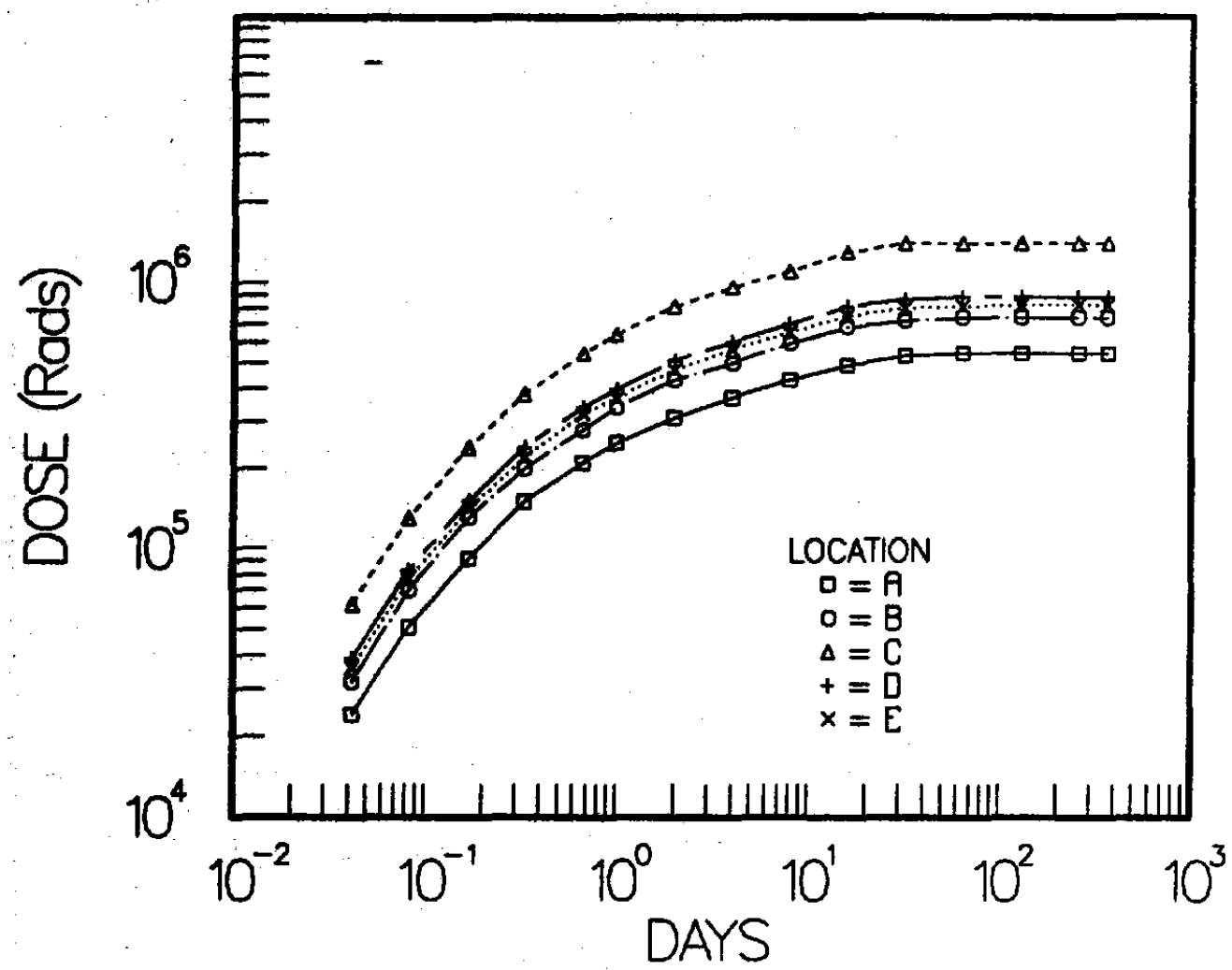

Figure B.69. Surry Case 3 RHR Cubicle Total Gamma Dose

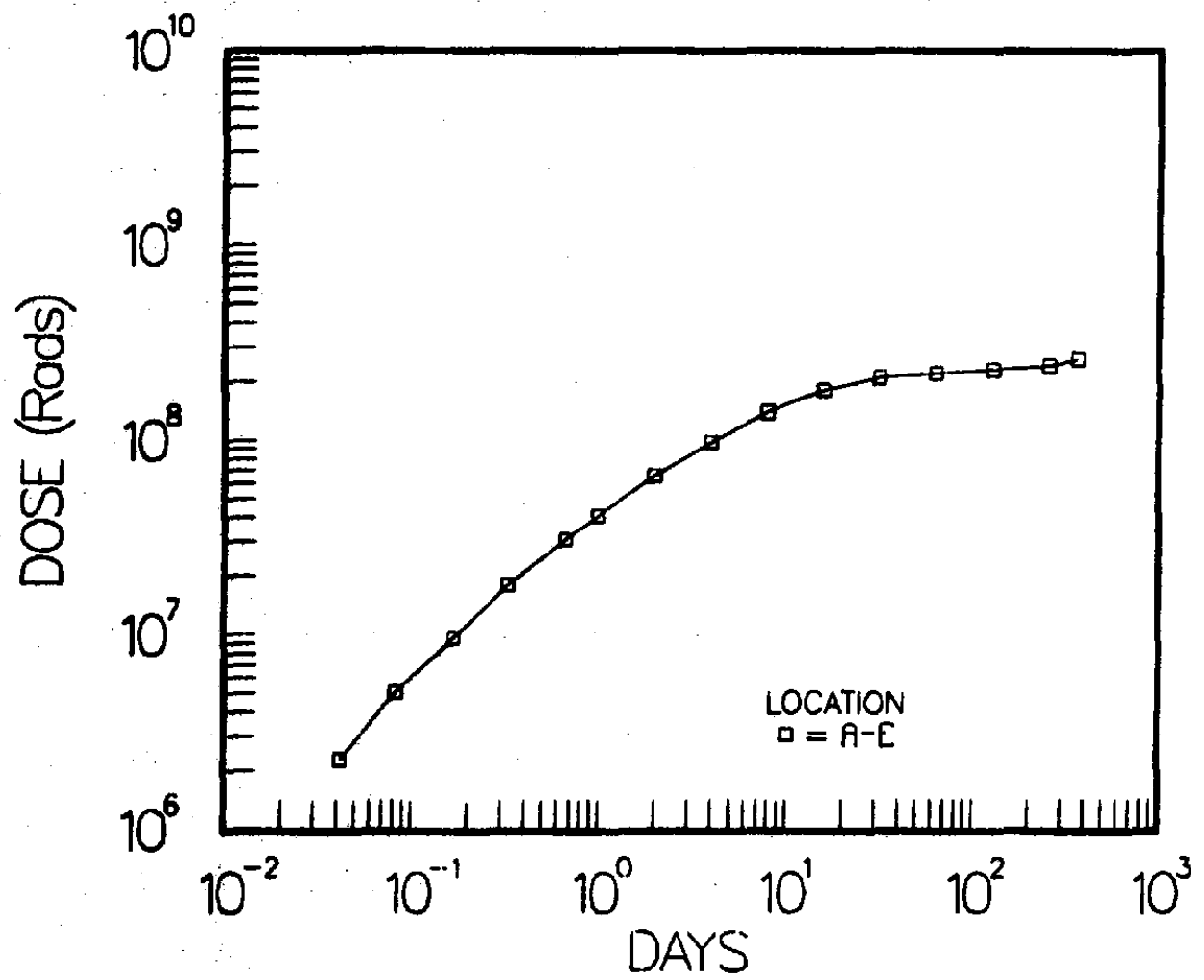

Figure B.70. Surry Case 3 RHR Cubicle Total Beta Dose 


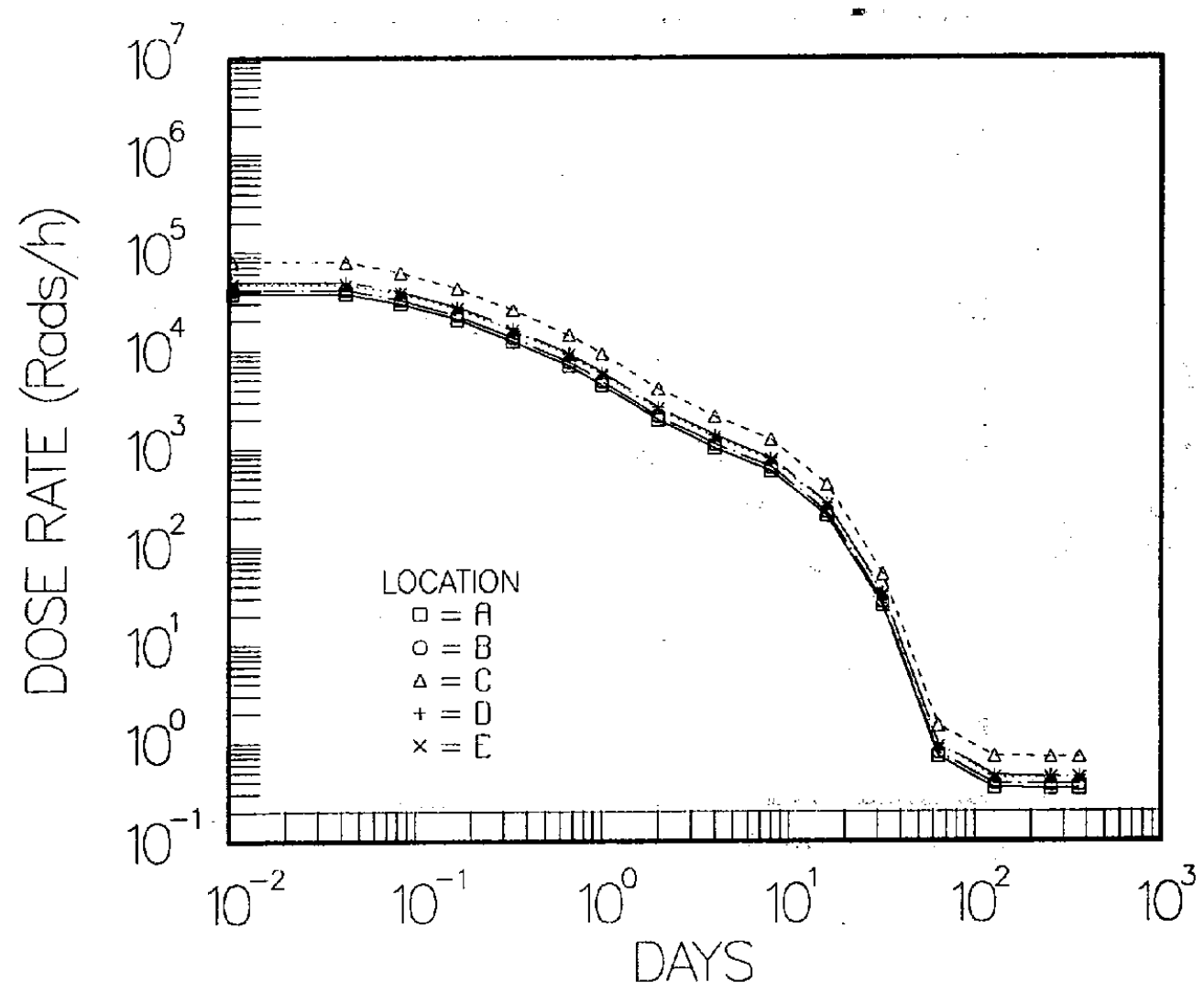

Figure B.71. Surry Case 3 Incore Instrumentation Roon

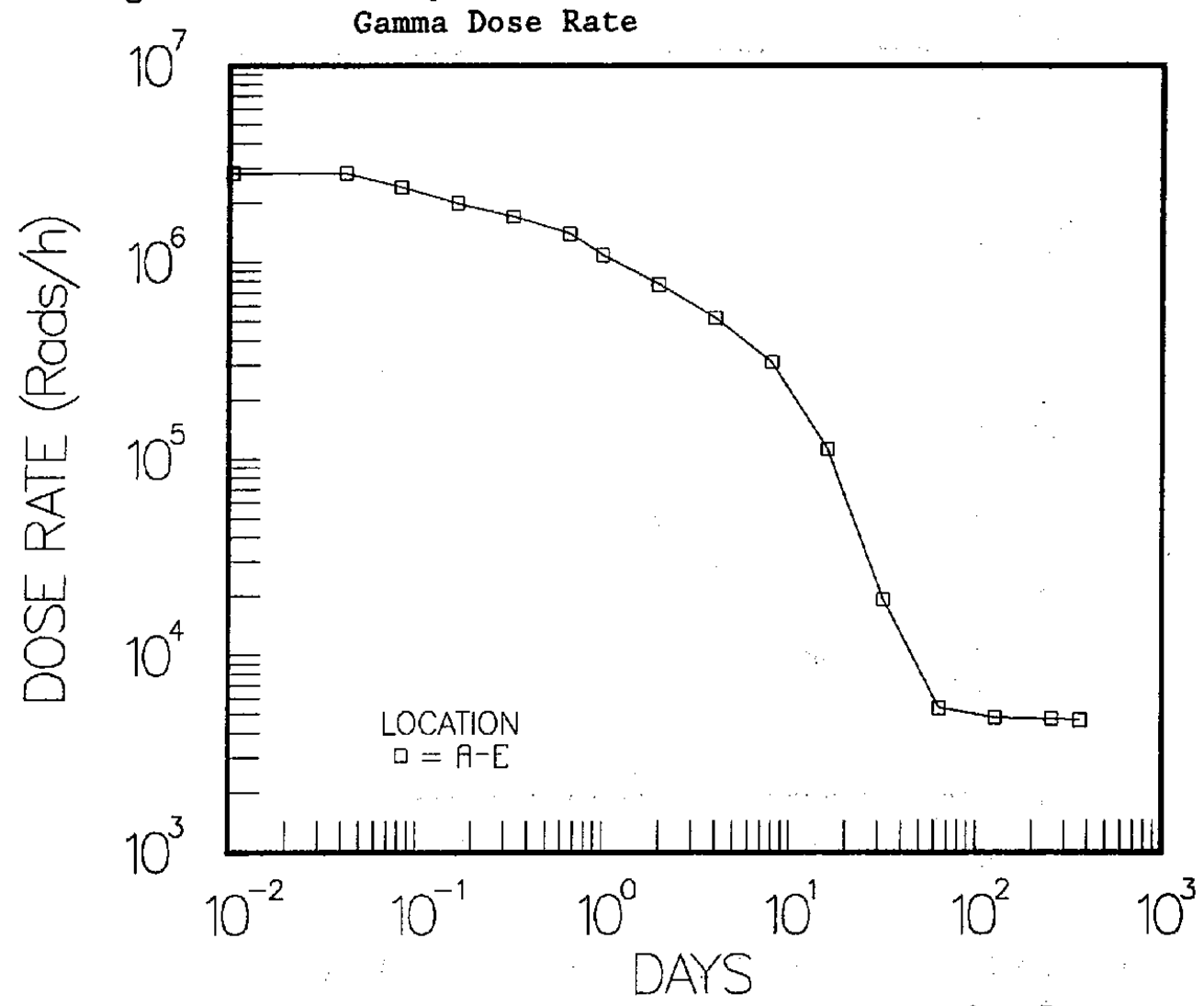

Figure B.72. Surry Case 3 Incore Instrumentation Room Beta Dose Rate 


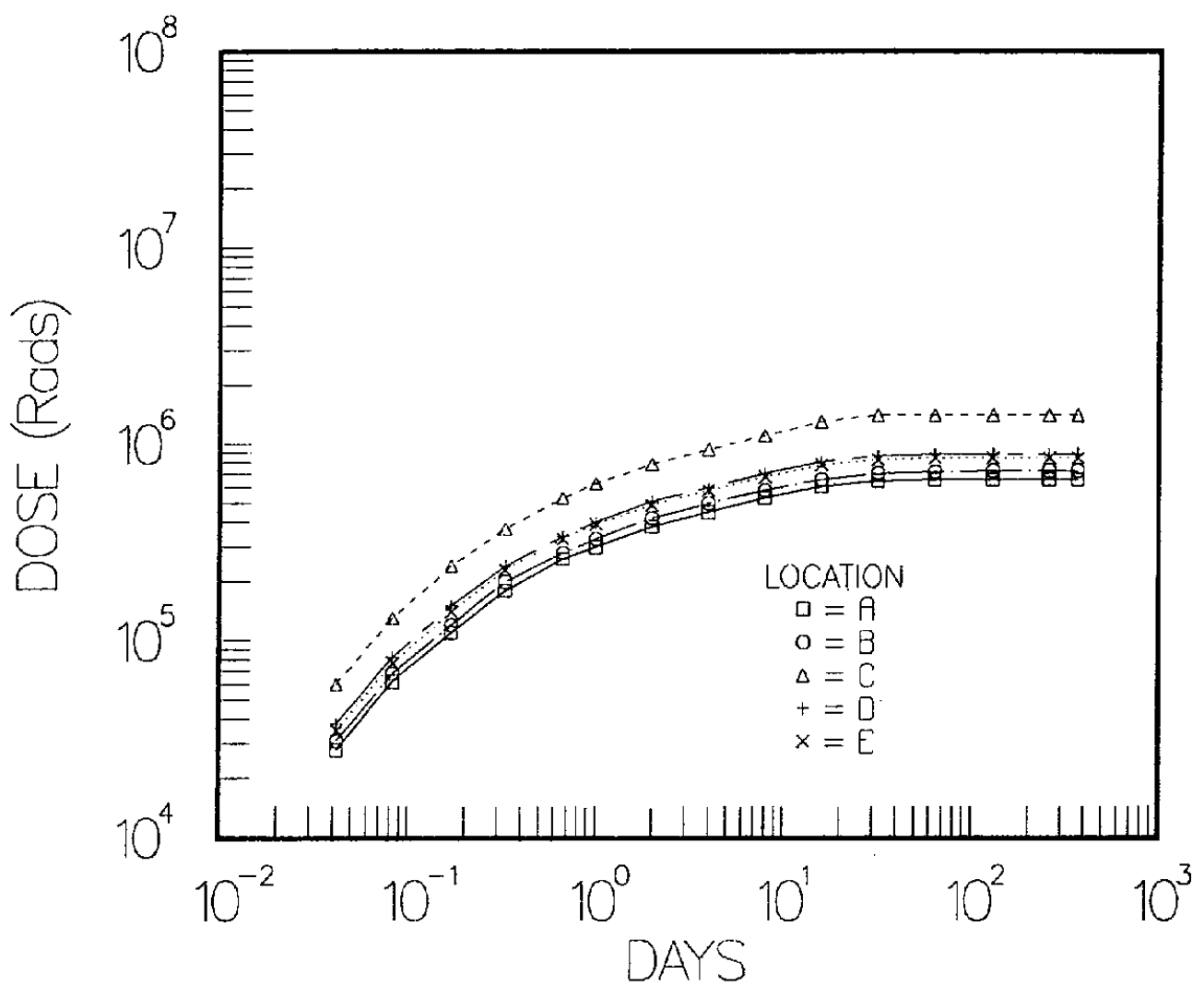

Figure B.73. Surry Case 3 Incore Instrumentation Room

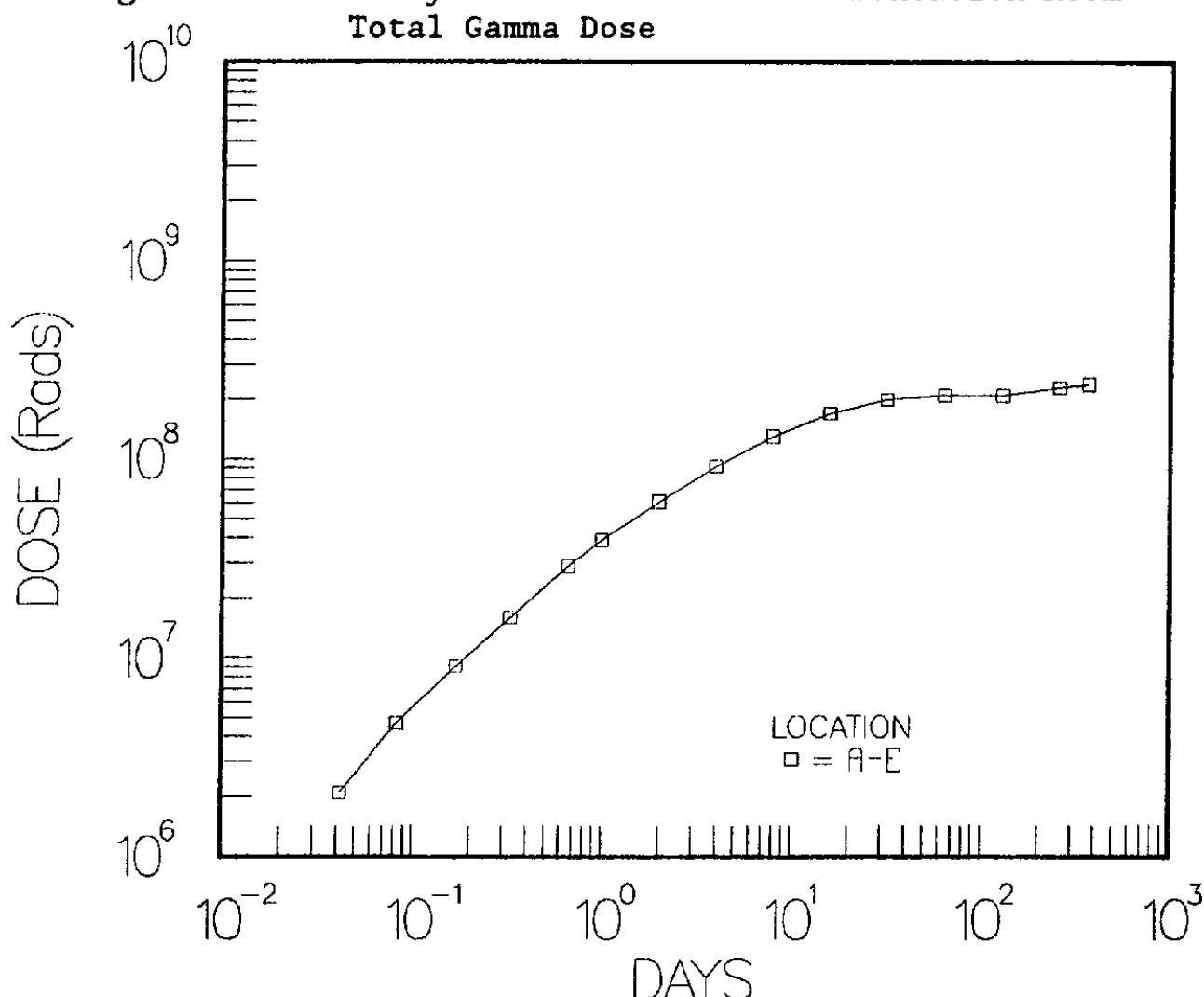

Figure B.74. Surry Case 3 Incore Instrumentation Room Total Beta Dose 

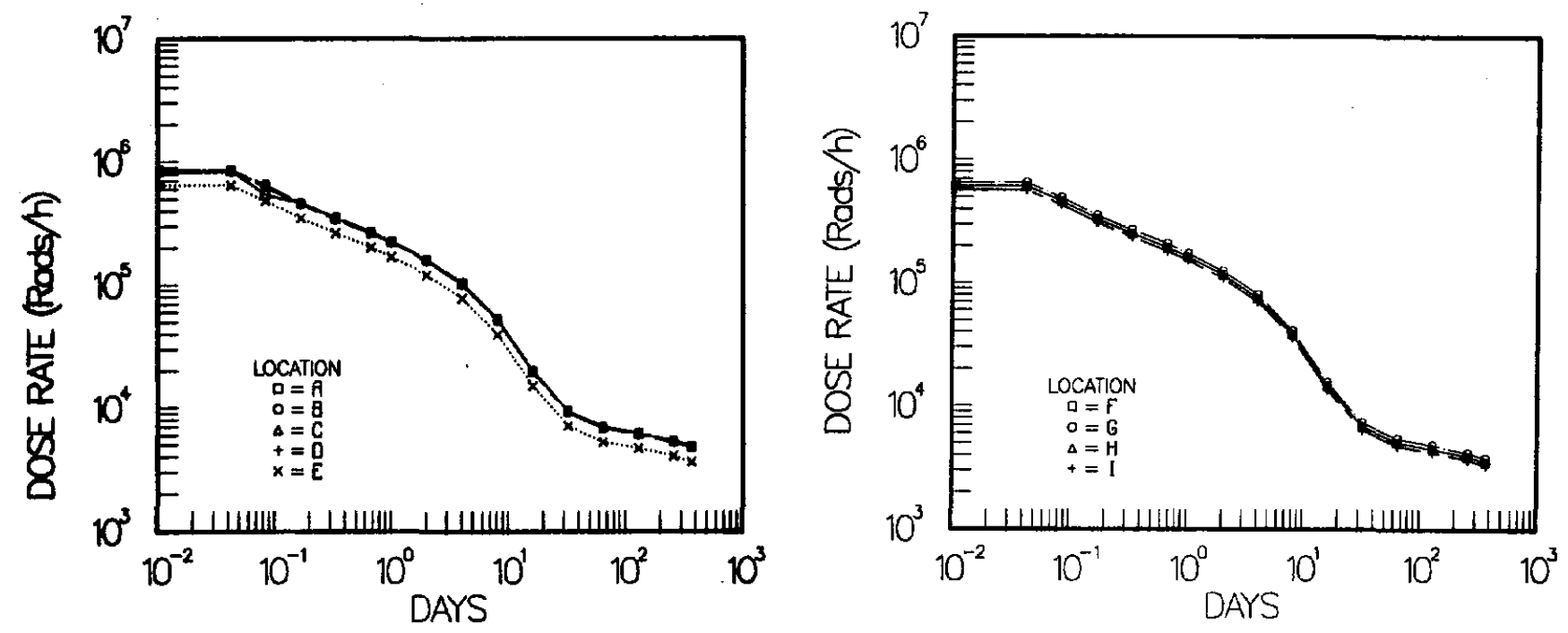

Figure B.75. Surry Case 4 Basement Gamma Dose Rate

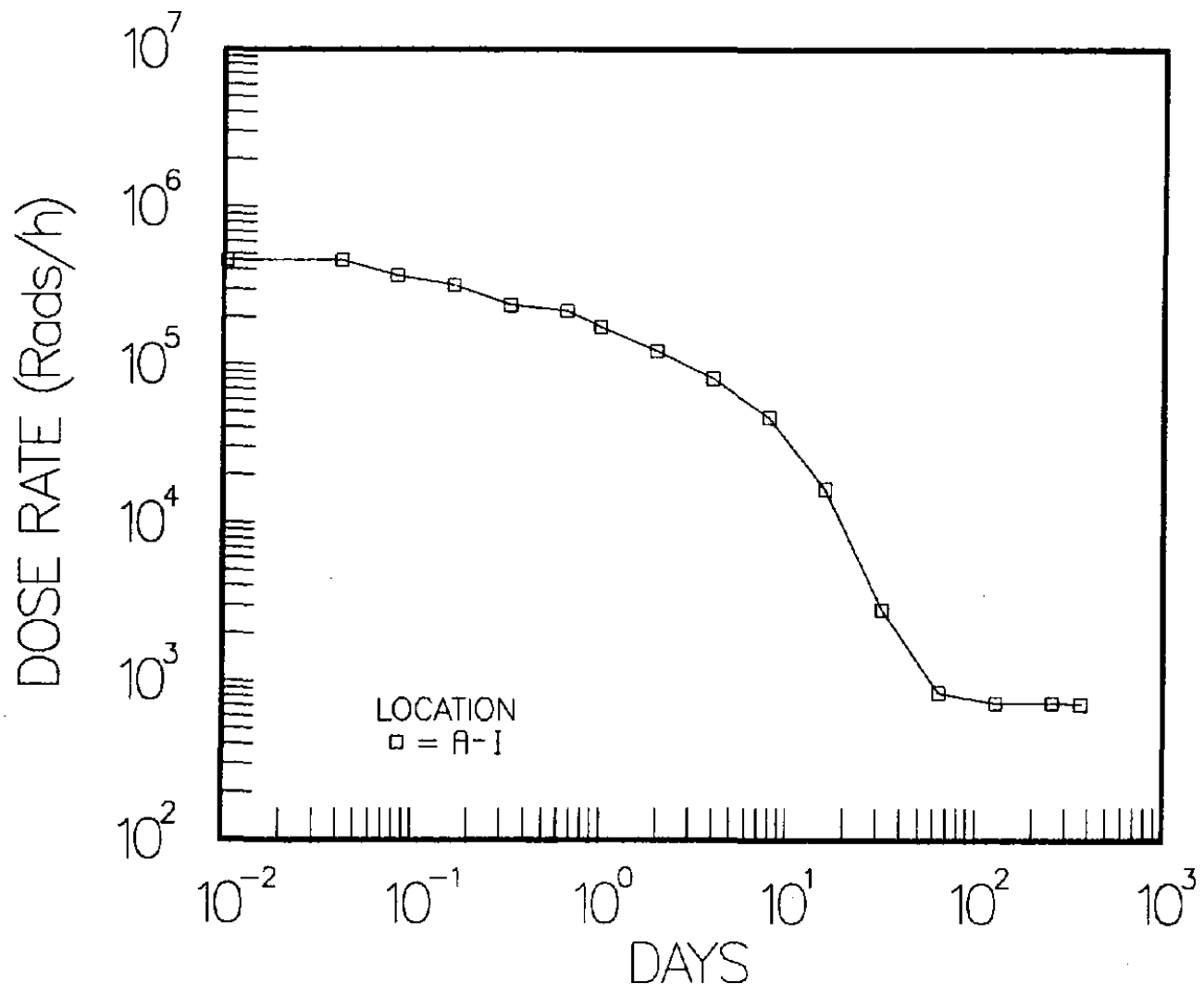

Figure B.76. Surry Case 4 Basement Beta Dose Rate 


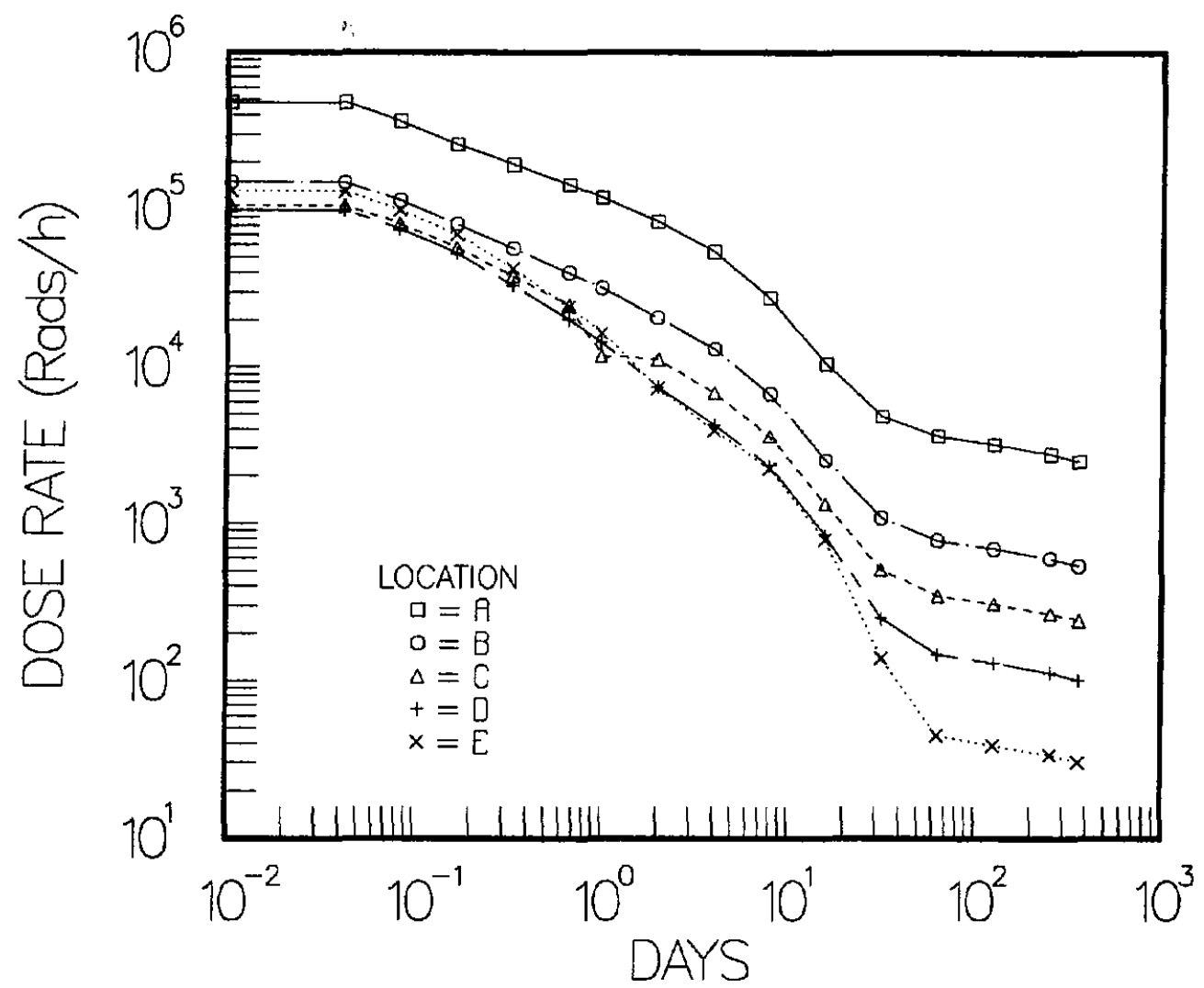

Figure B.77. Surry Case 4 Annulus Gamma Dose Rate

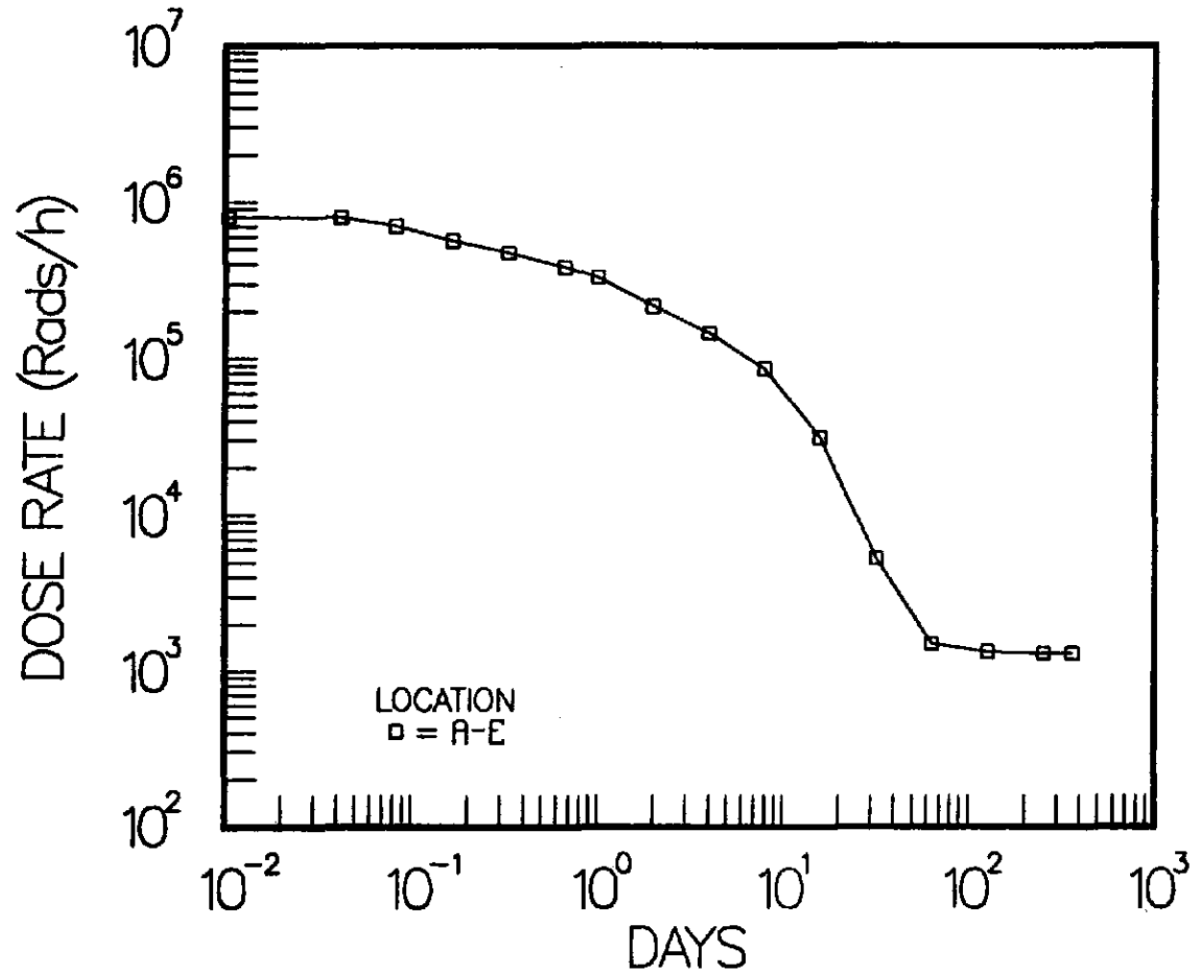

Figure B.78. Surry Case 4 Annulus Beta Dose Rate 

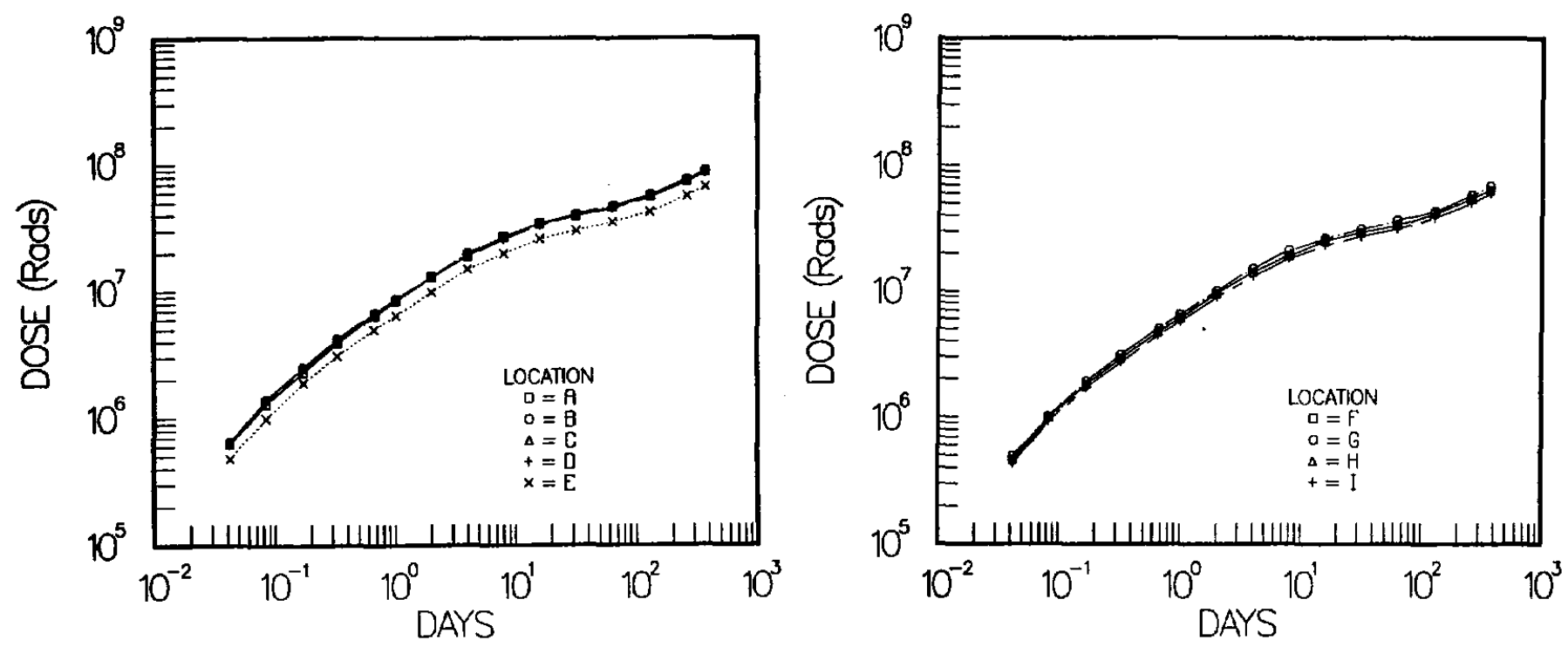

Figure B.79. Surry Case 4 Basement Gamma Total Dose

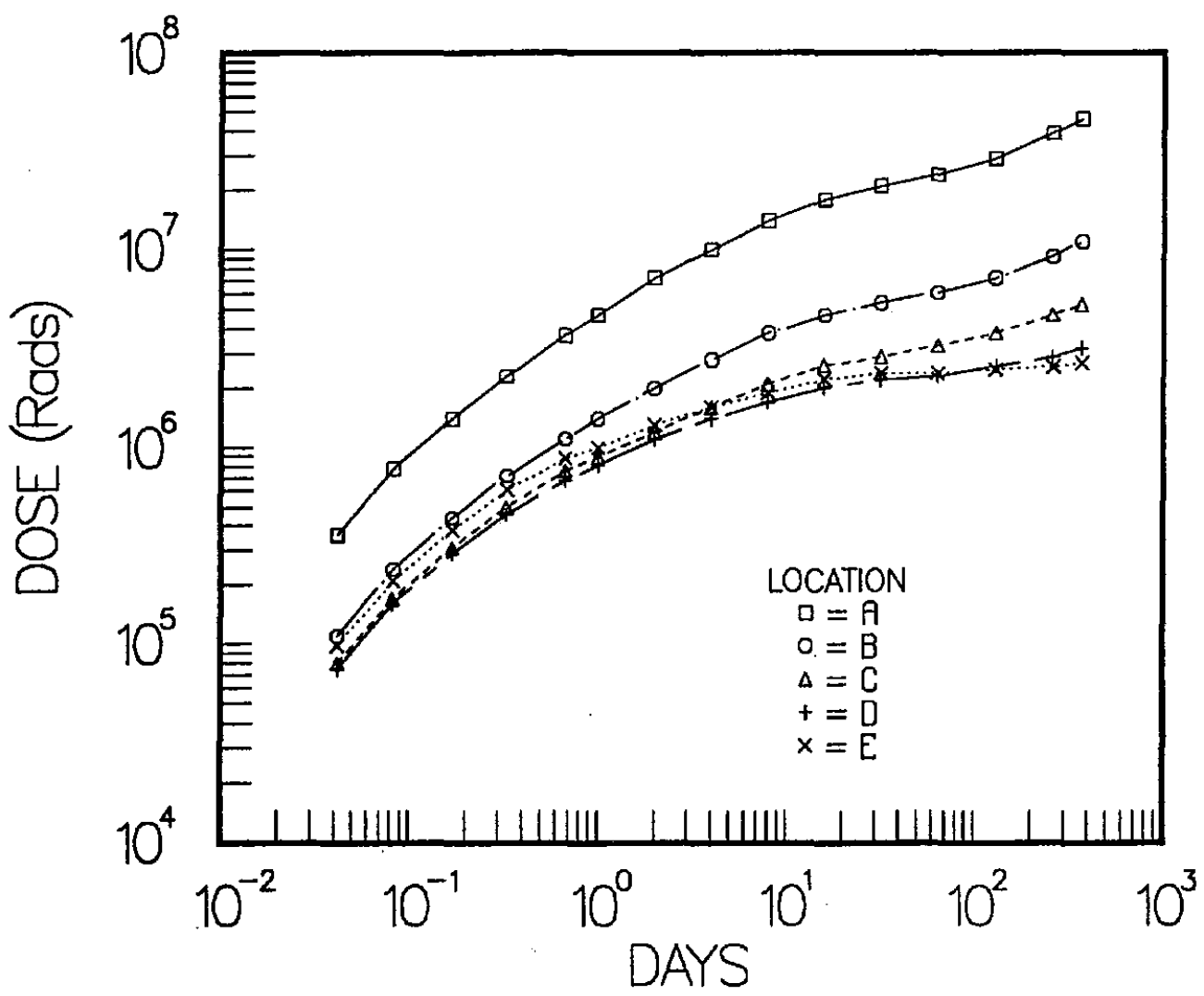

Figure B.80. Surry Case 4 Annulus Total Gamma Dose 


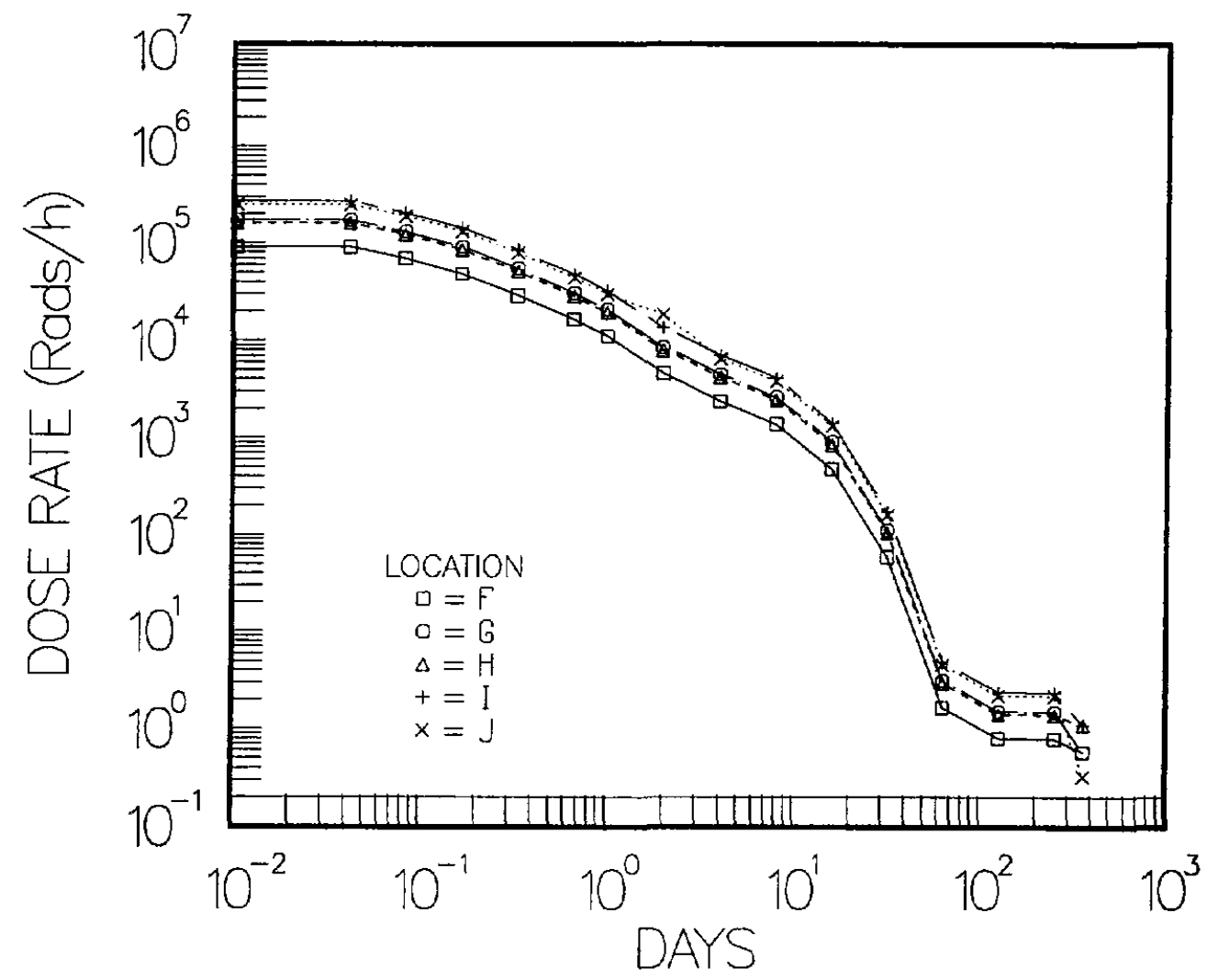

Figure B.81. Surry Case 4 Operating and Dome Gamma Dose Rate

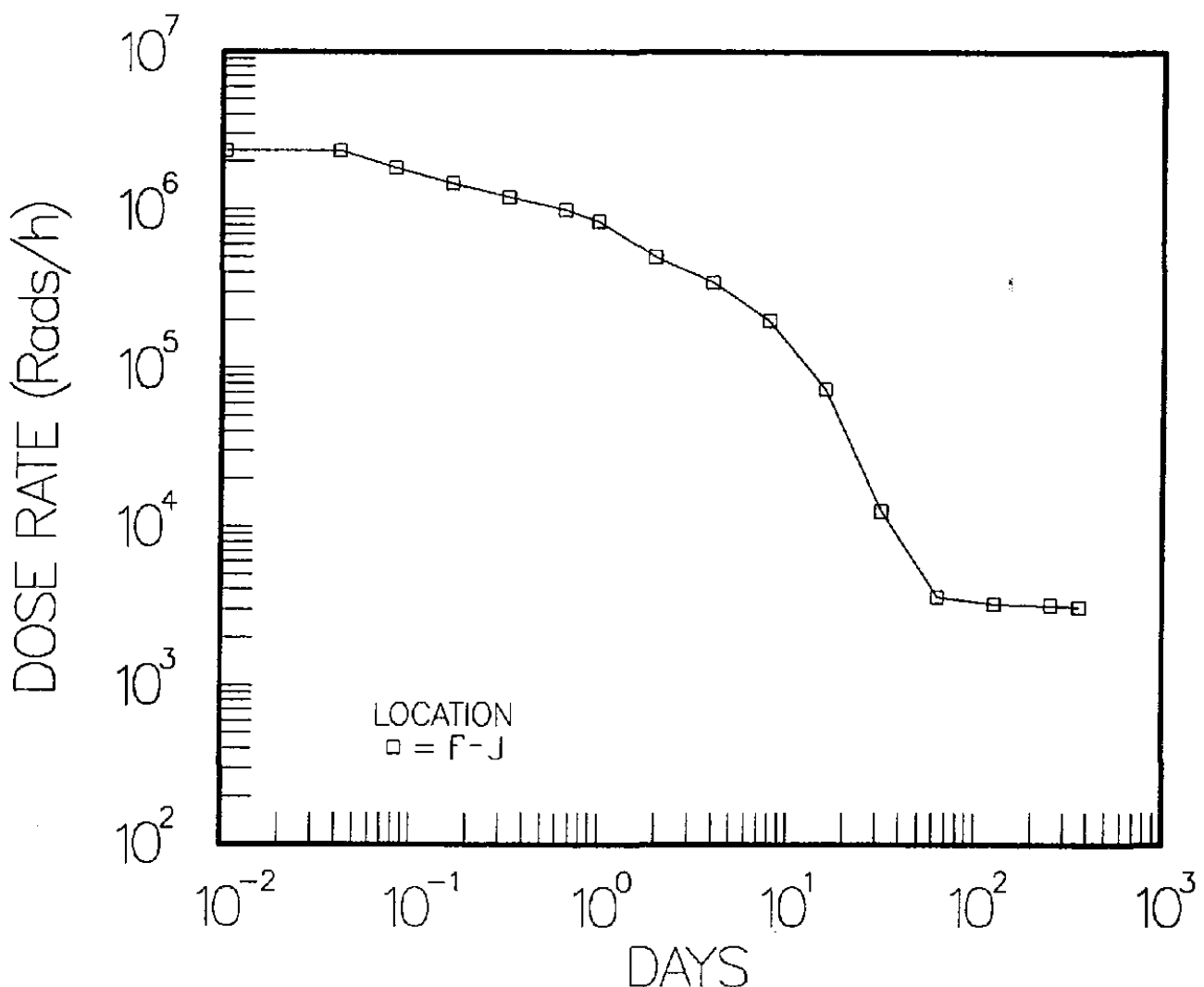

Figure B.82. Surry Case 4 Operating Floor and Dome Beta Dose Rate 


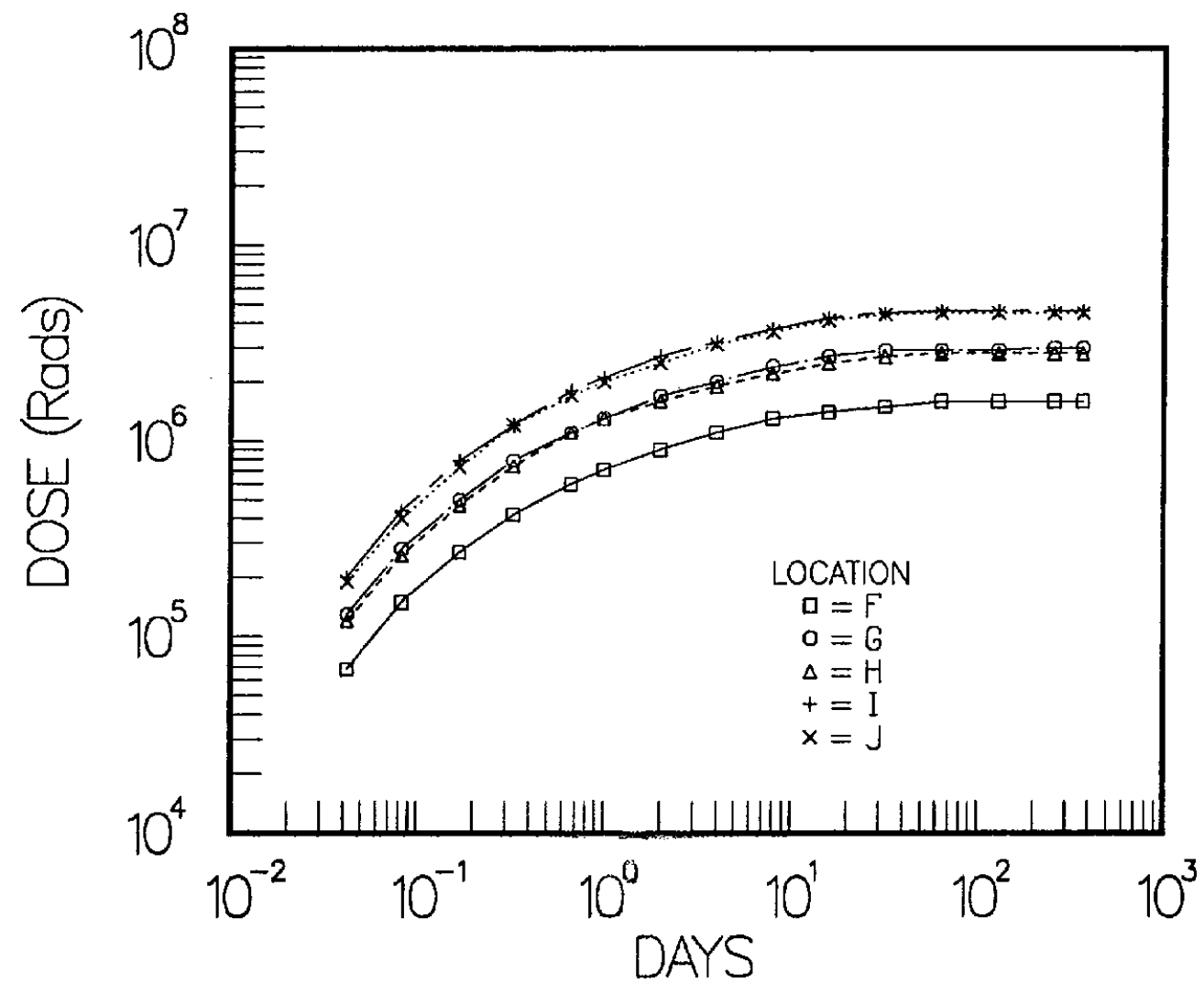

Figure B.83. Surry Case 4 Operating Floor and Dome Gamma Total Dose

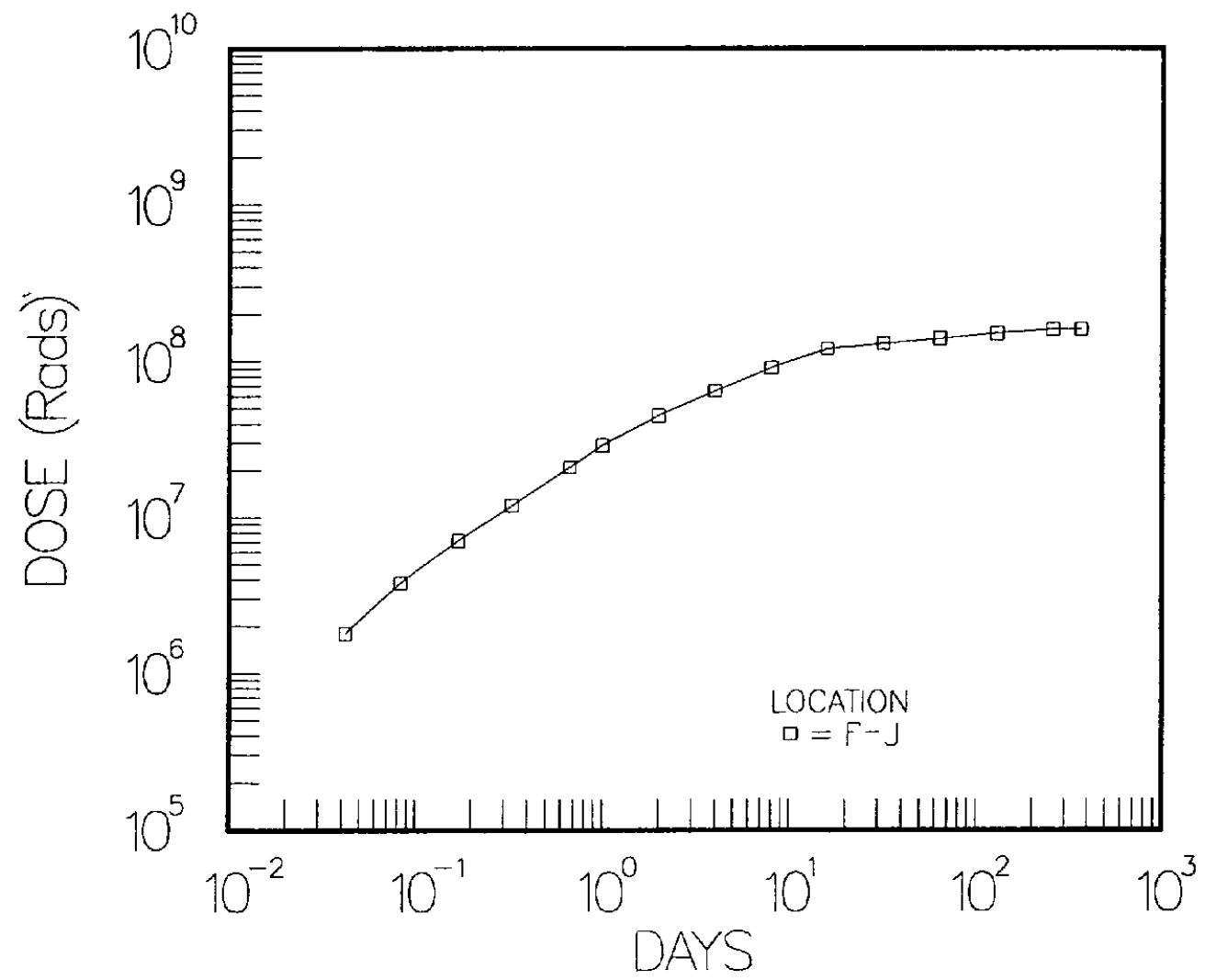

Figure B.84. Surry Case 4 Operating Floor and Dome Beta Total Dose 


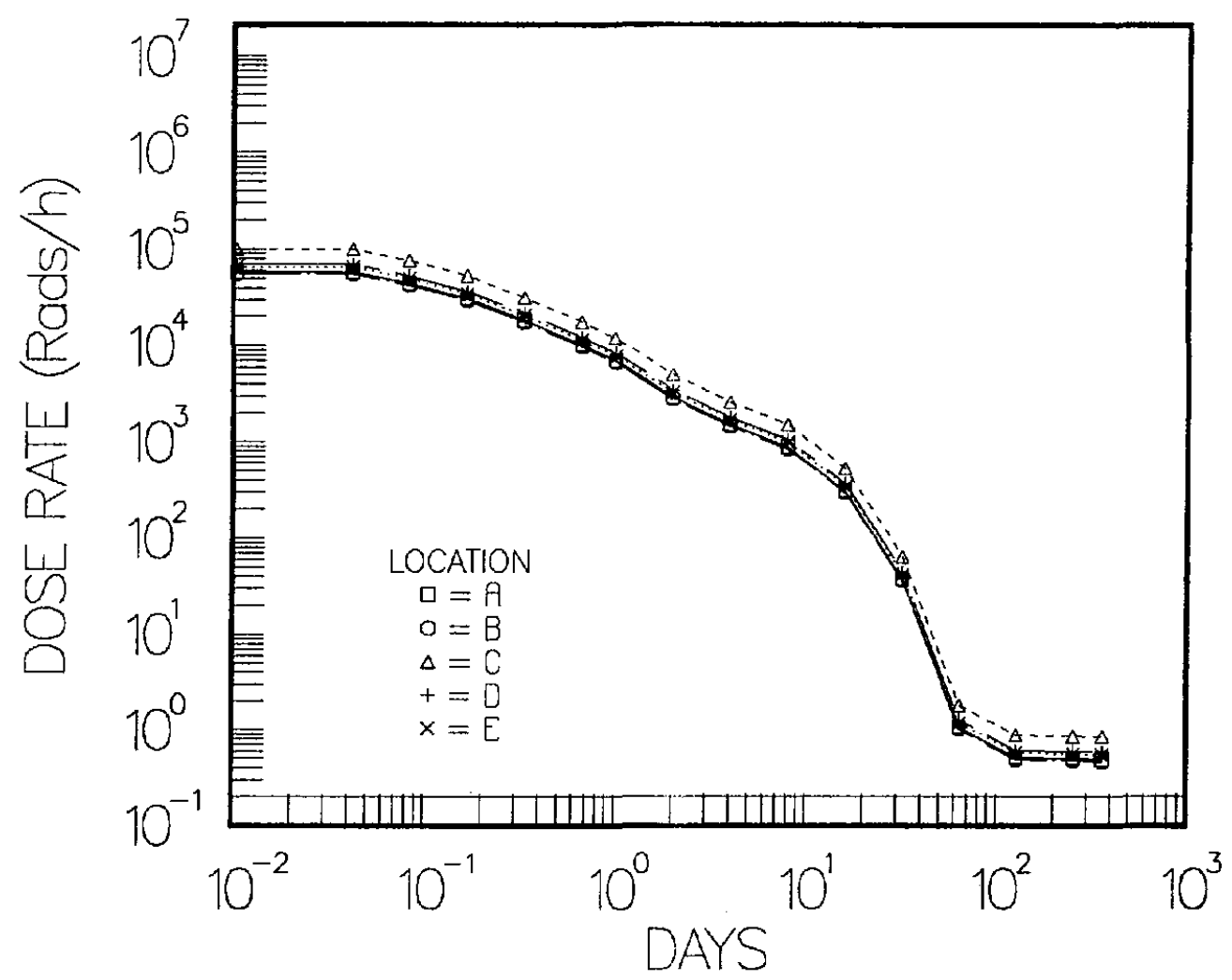

Figure B.85. Surry Case 4 Steam Generator A Gamma Dose Rate

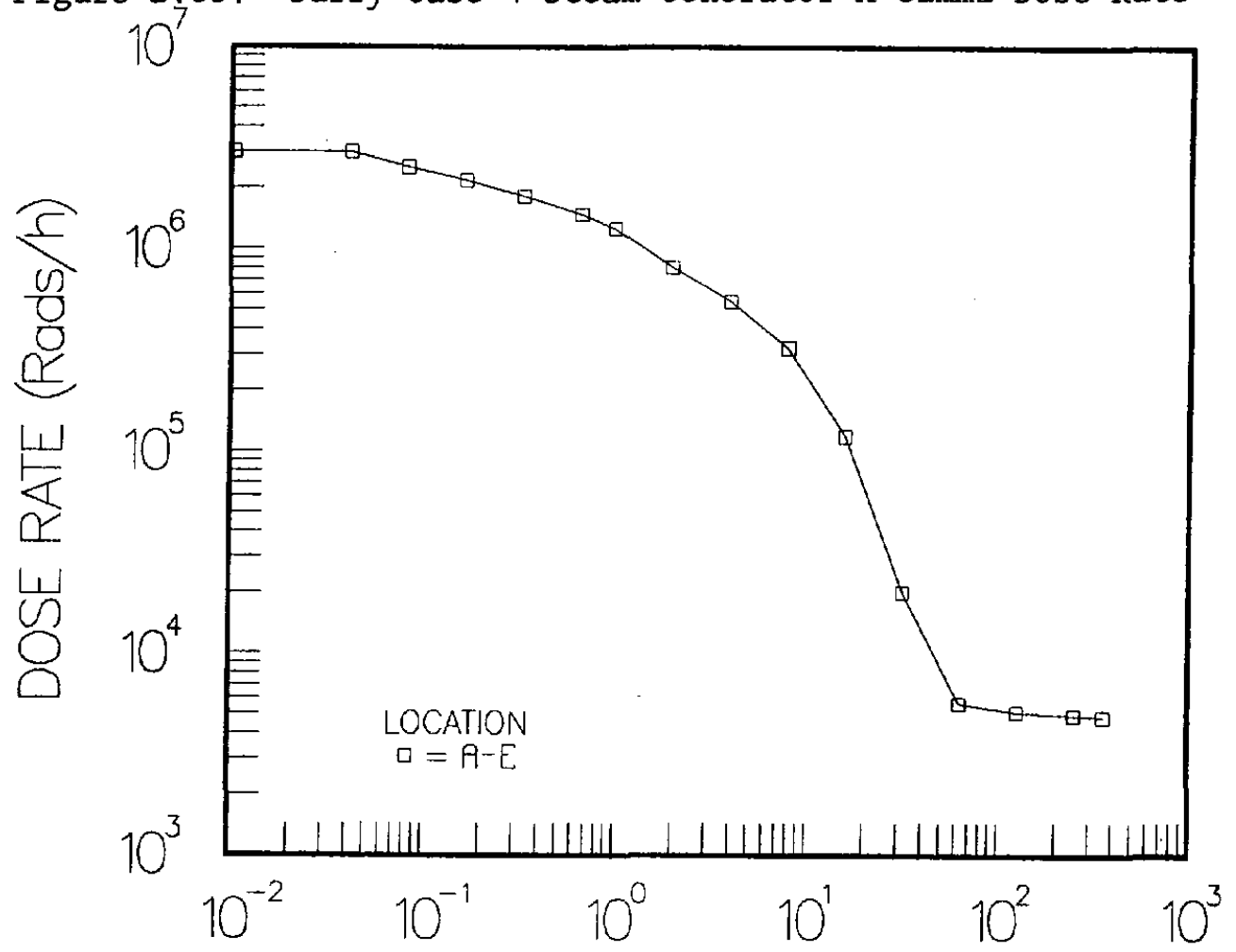

DAYS

Figure B.86. Surry Case 4 Steam Generator A Beta Dose Rate 


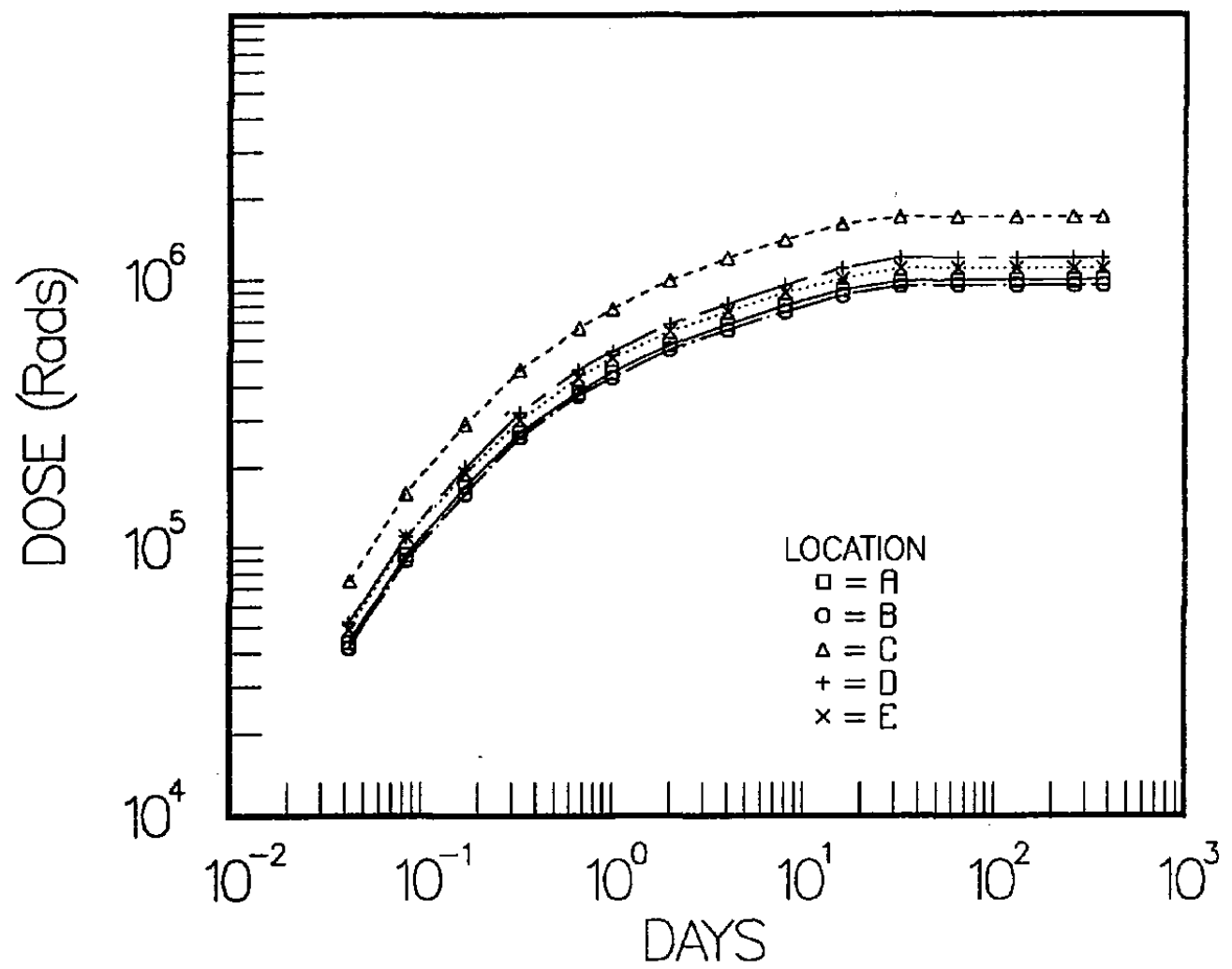

Figure B.87. Surry Case 4 Steam Generator A Gamma Total Dose

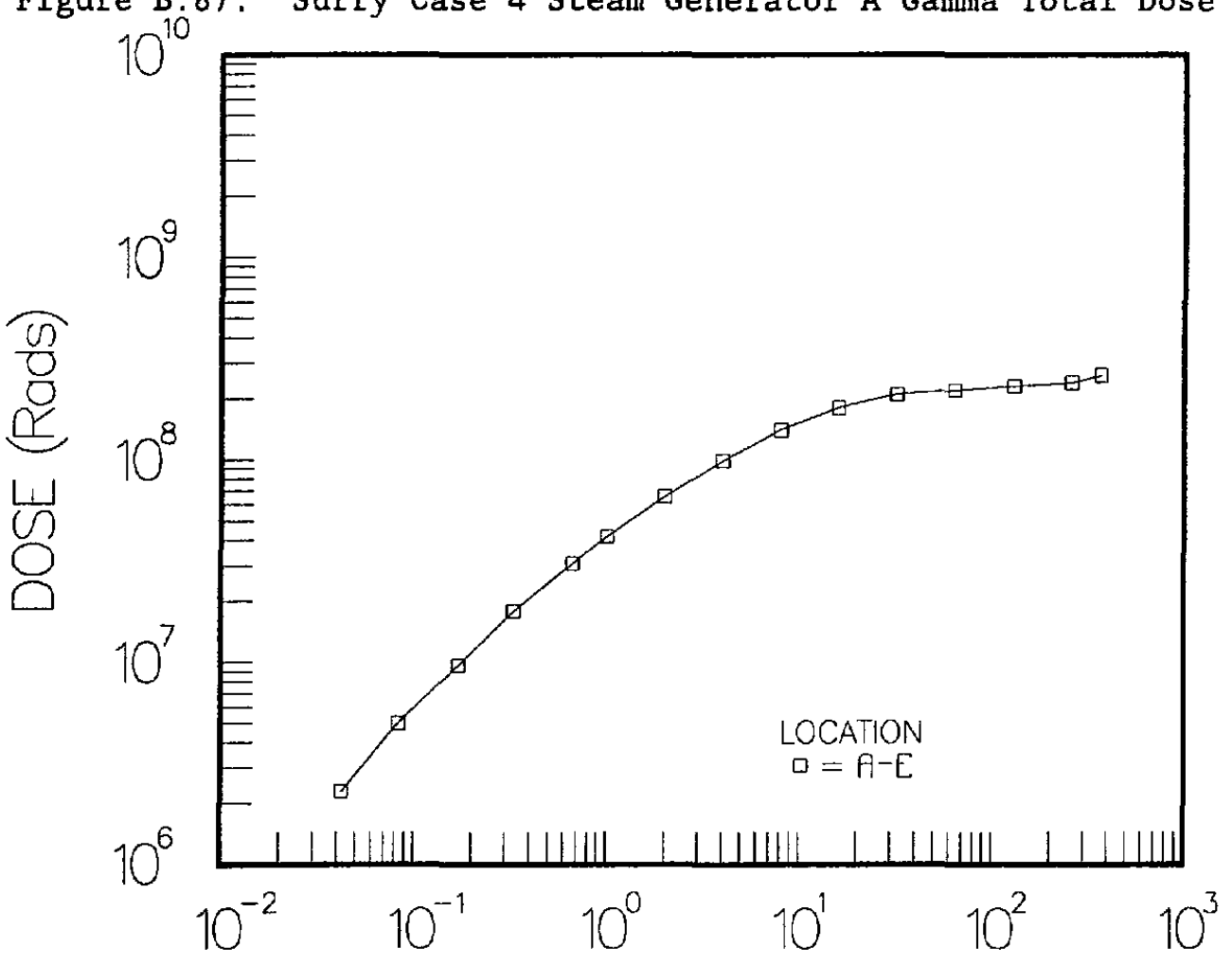

DAYS

Figure B.88. Surry Case 4 Steam Generator A Beta Total Dose 


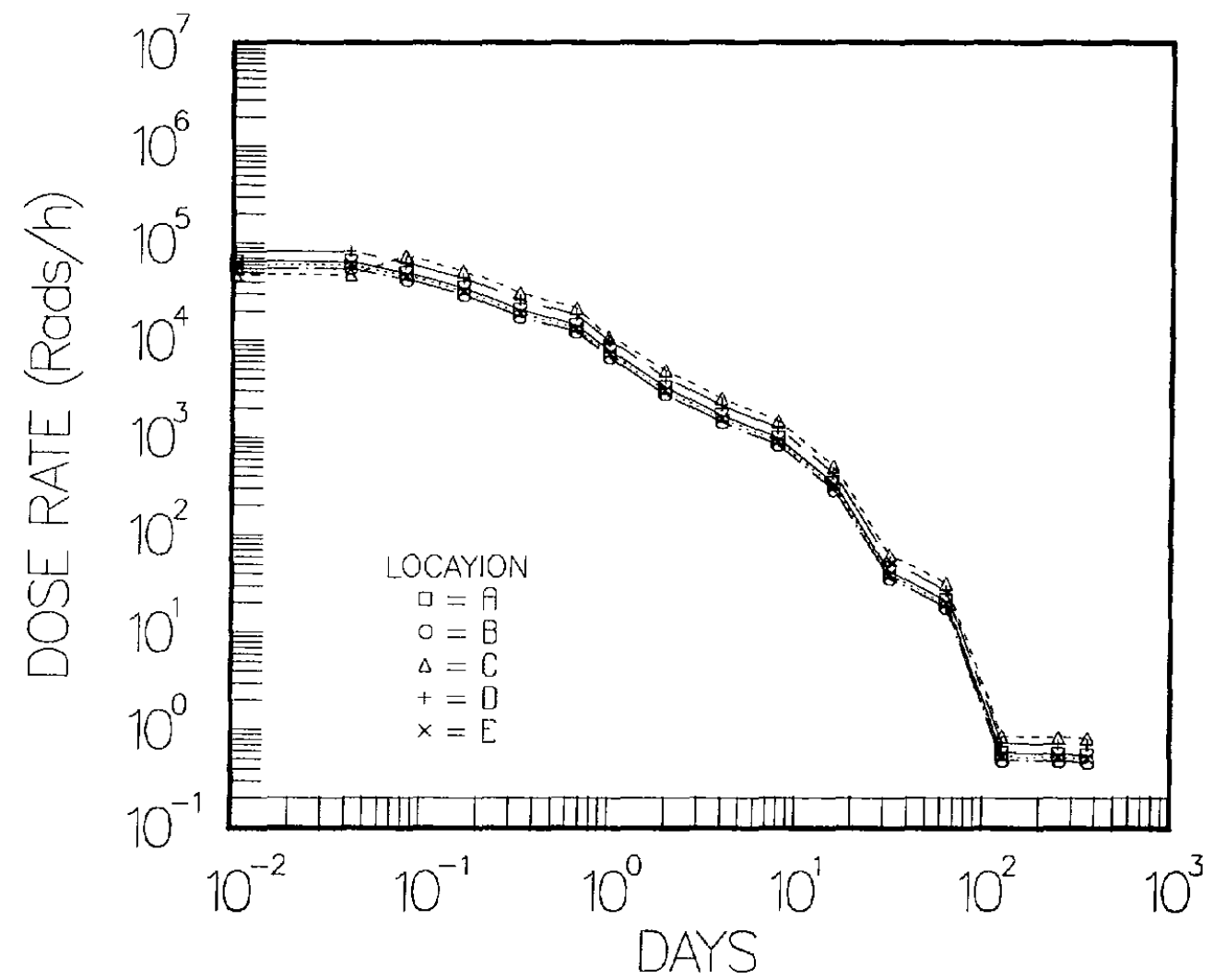

Figure B.89. Surry Case 4 Steam Generator B Gamma Dose Rate

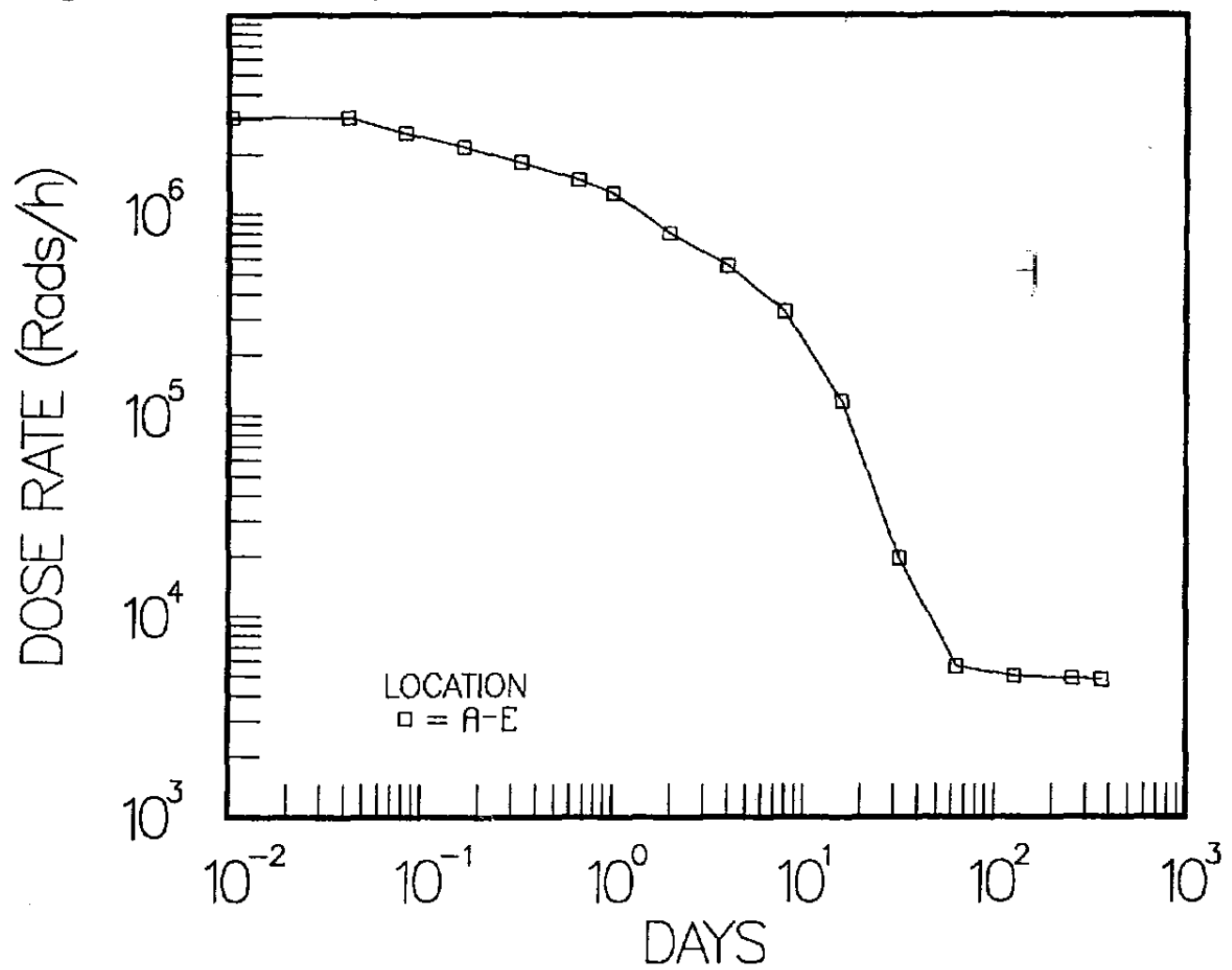

Figure B.90. Surry Case 4 Steam Generator B Beta Dose Rate 


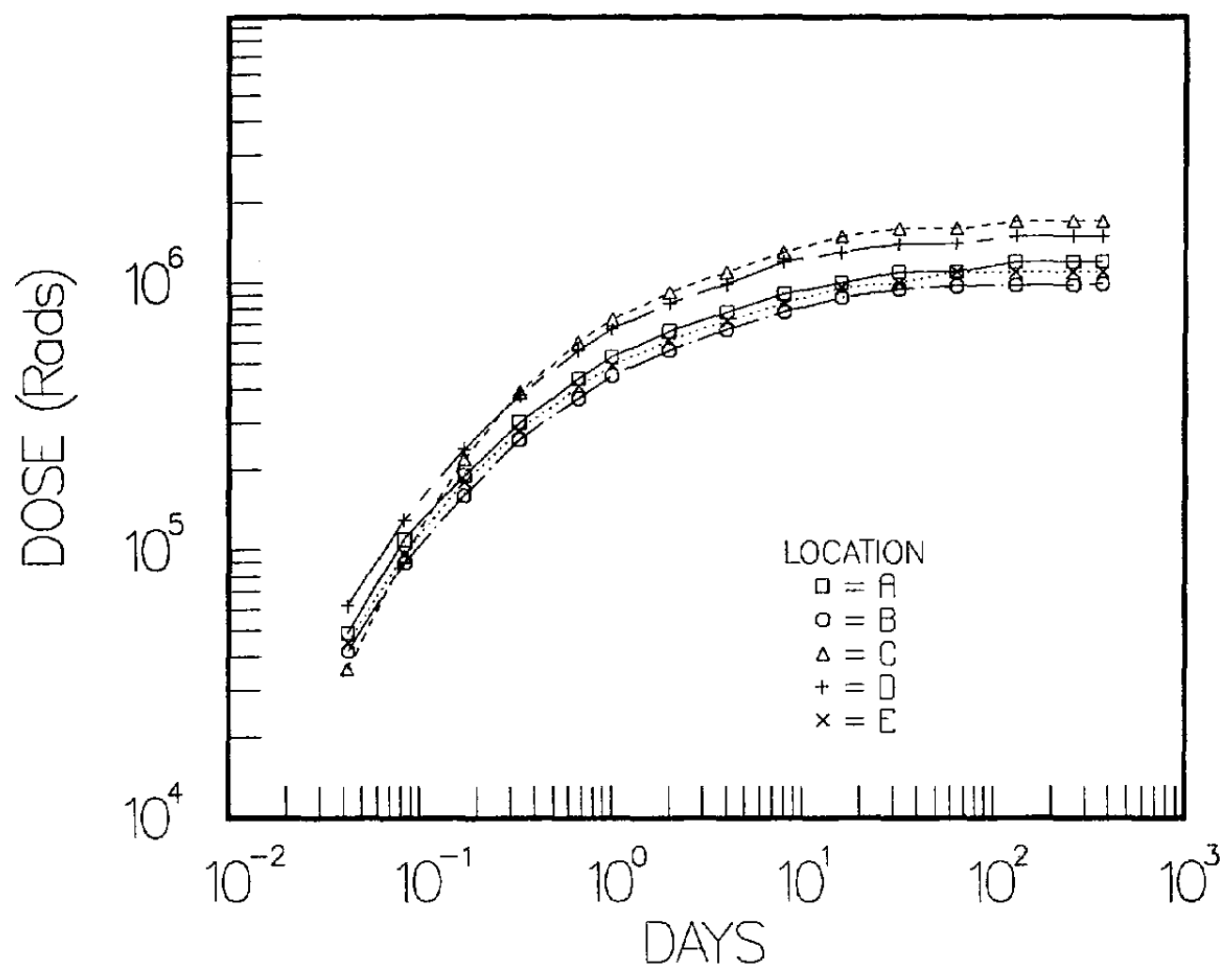

Figure B.91. Surry Case 4 Steam Generator B Total Gamma Dose

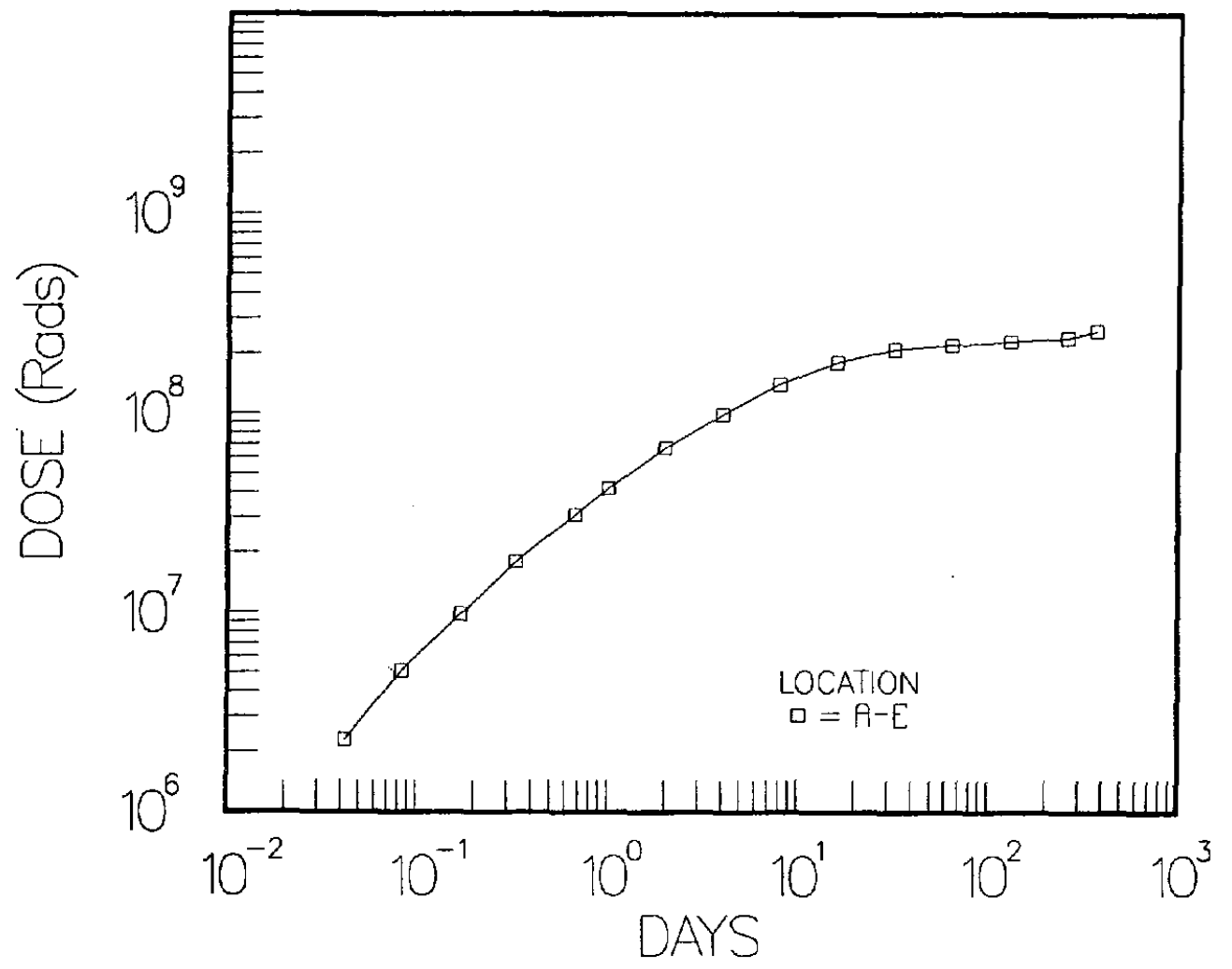

Figure B.92. Surry Case 4 Steam Generator B Total Beta Dose 


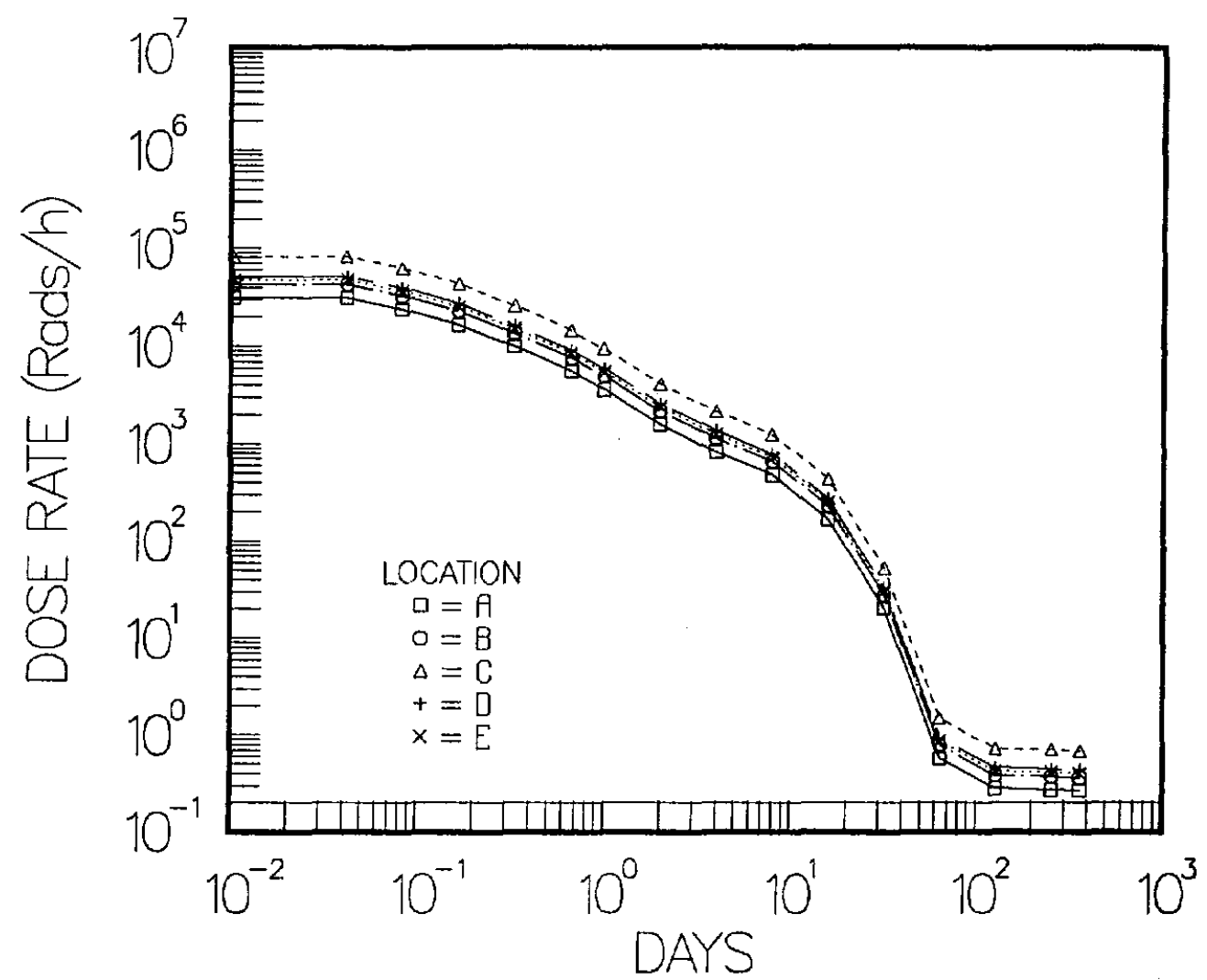

Figure B.93. Surry Case 4 RHR Cubicle Gamma Dose Rate

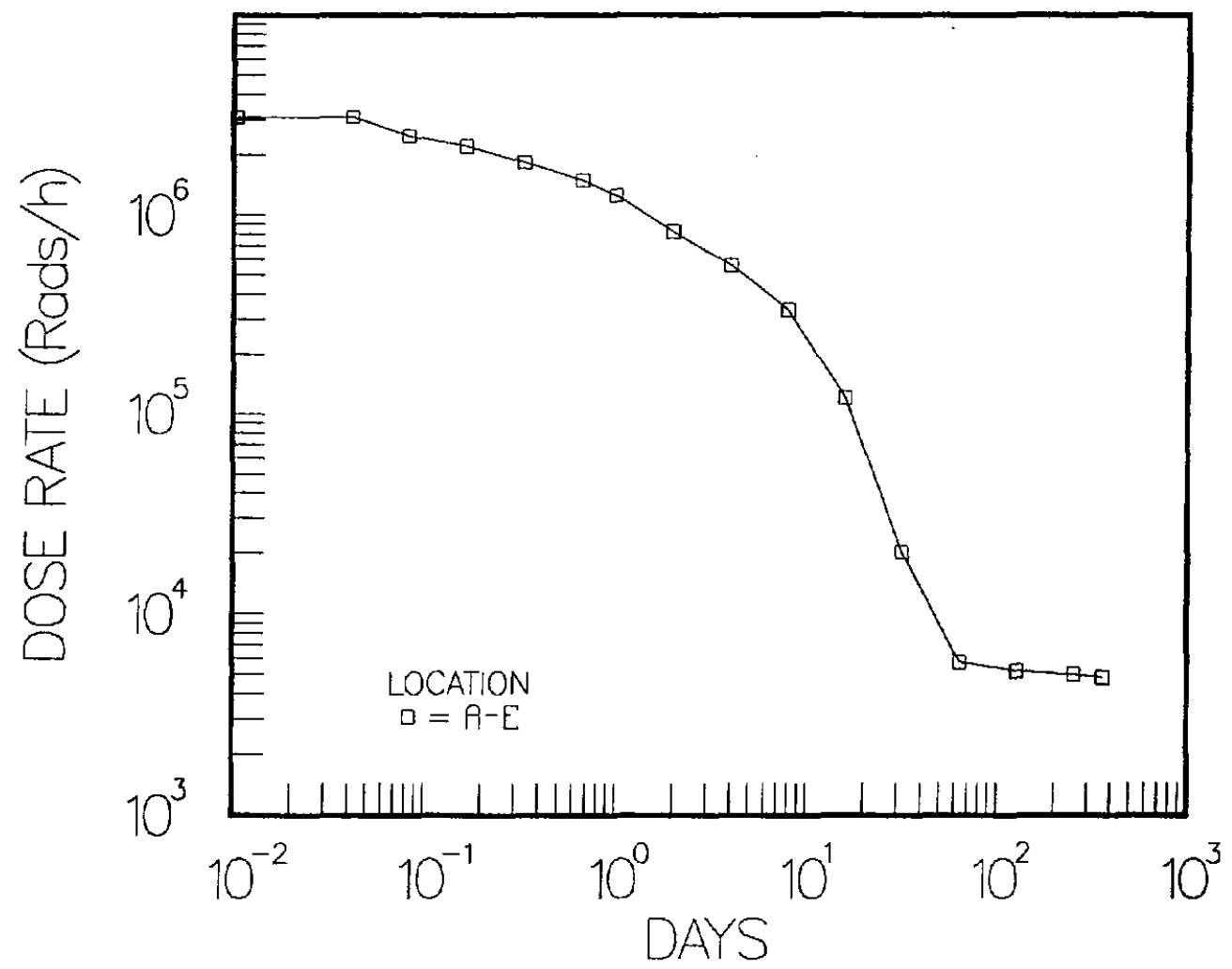

Figure B.94. Surry Case 4 RHR Cubicle Beta Dose Rate 


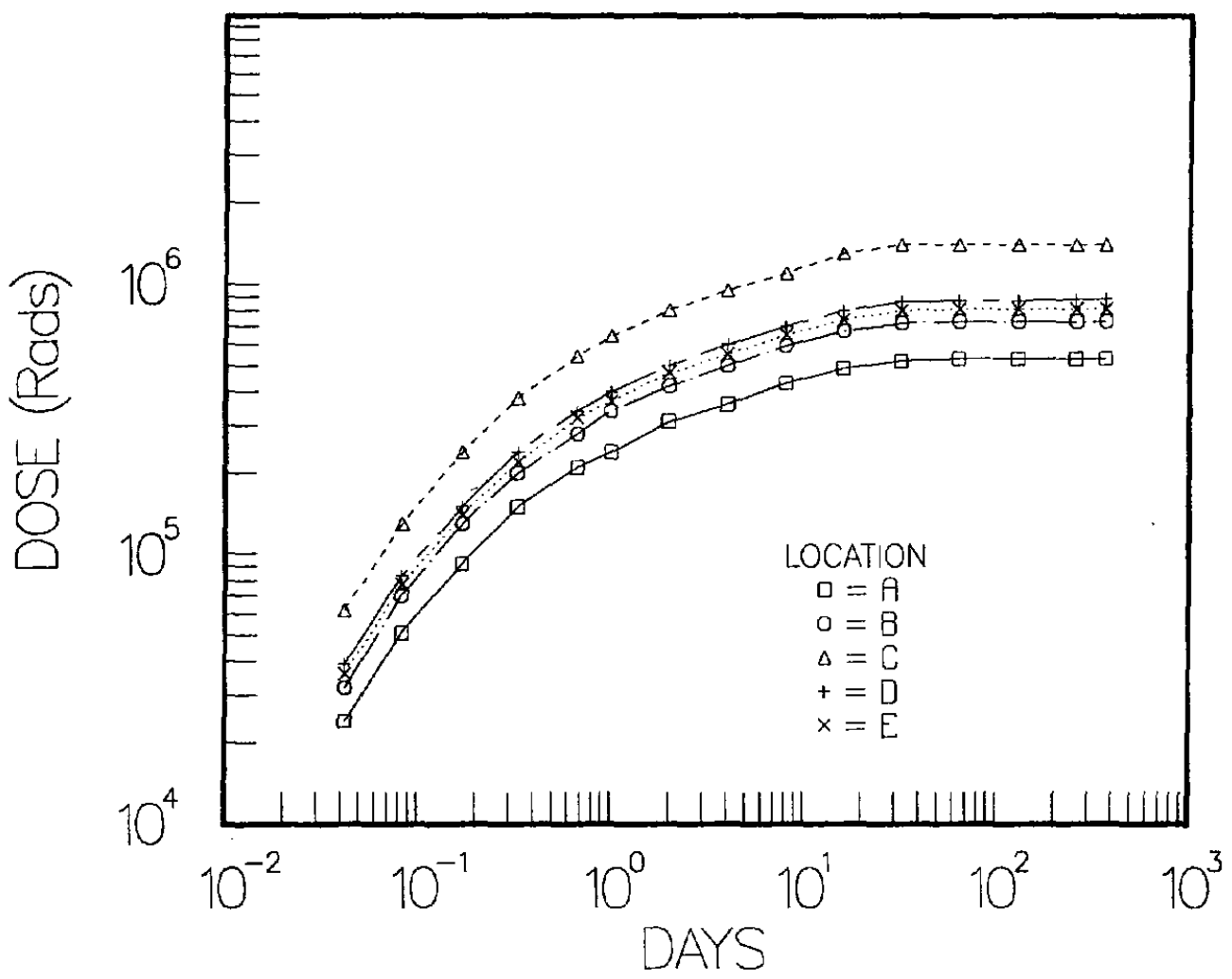

Figure B.95. Surry Case 4 RHR Cubicle Total Gamma Dose

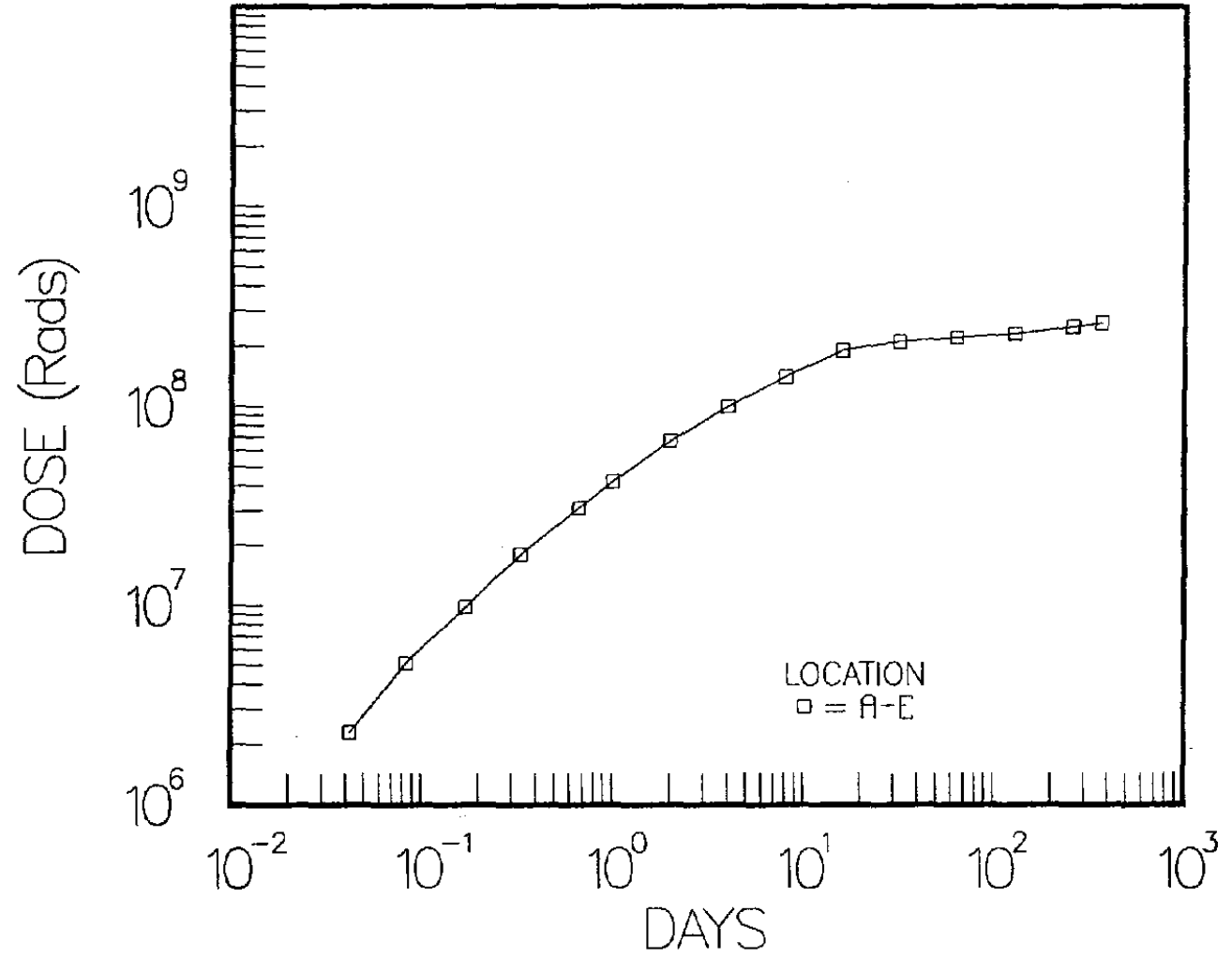

Figure B.96. Surry Case 4 RHR Cubicle Total Beta Dose 


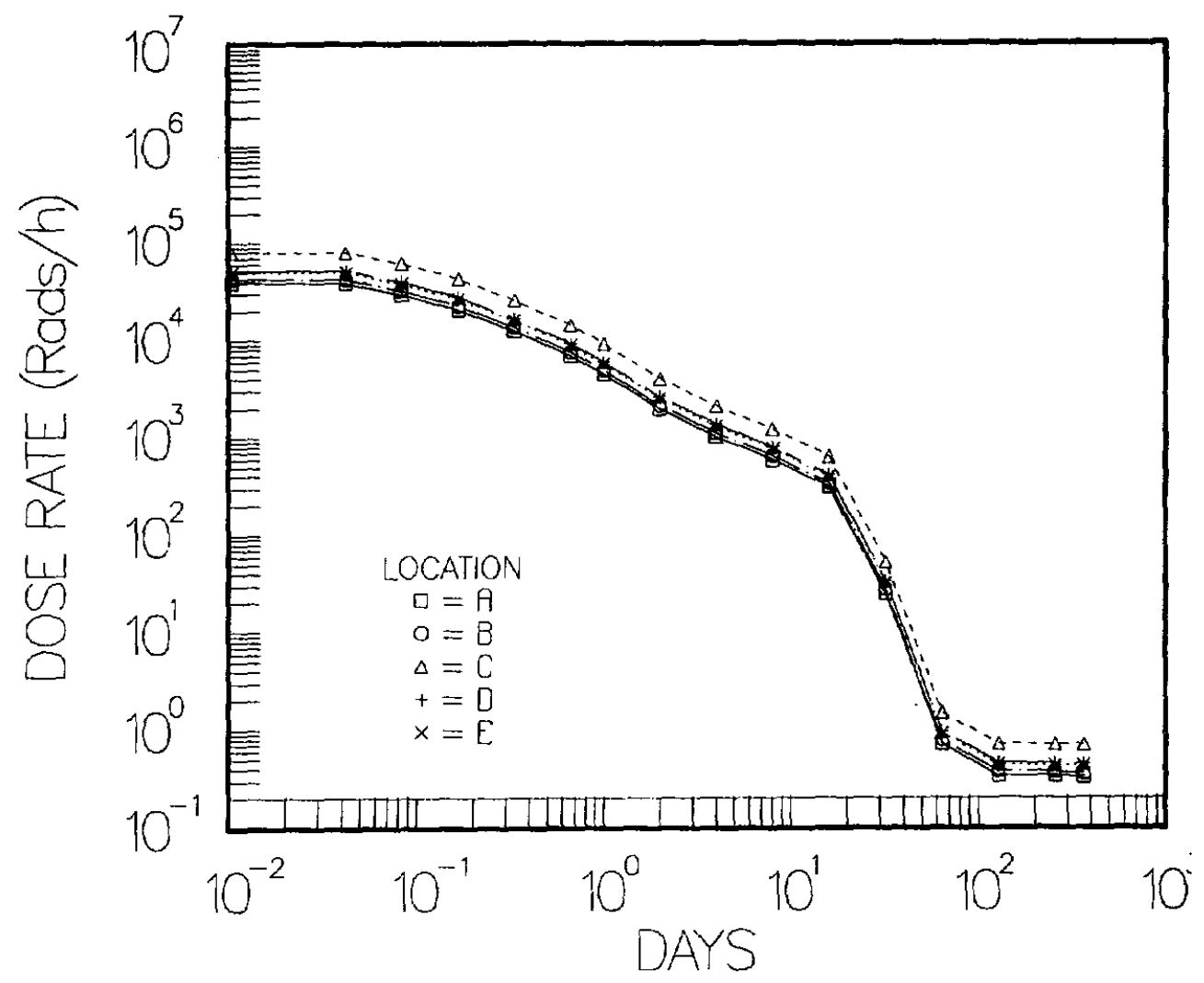

Figure B.97. Surry Case 4 Incore Instrumentation Room Gamma Dose Rate

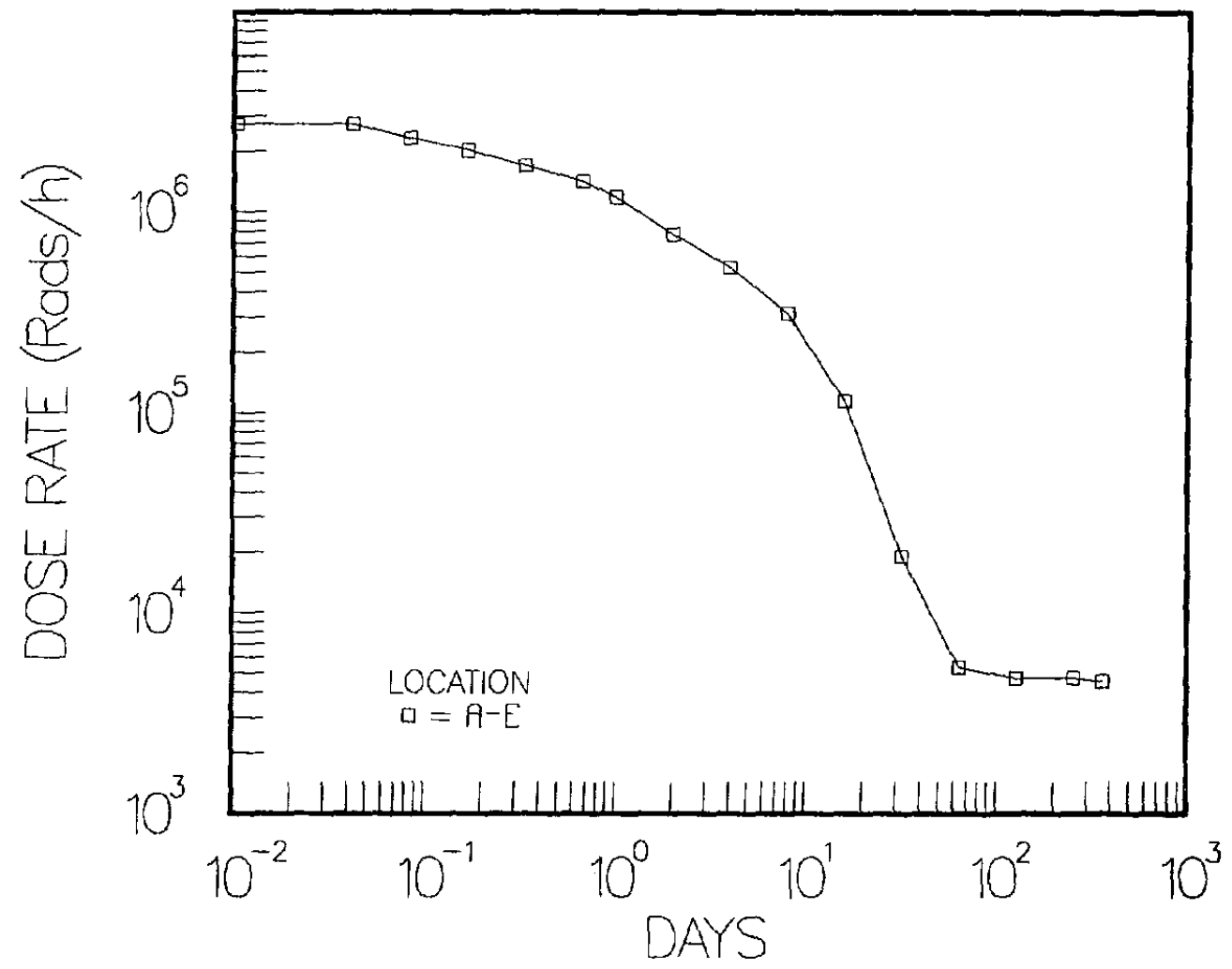

Figure B.98. Surry Case 4 Incore Instrumentation Room Beta Dose Rate 


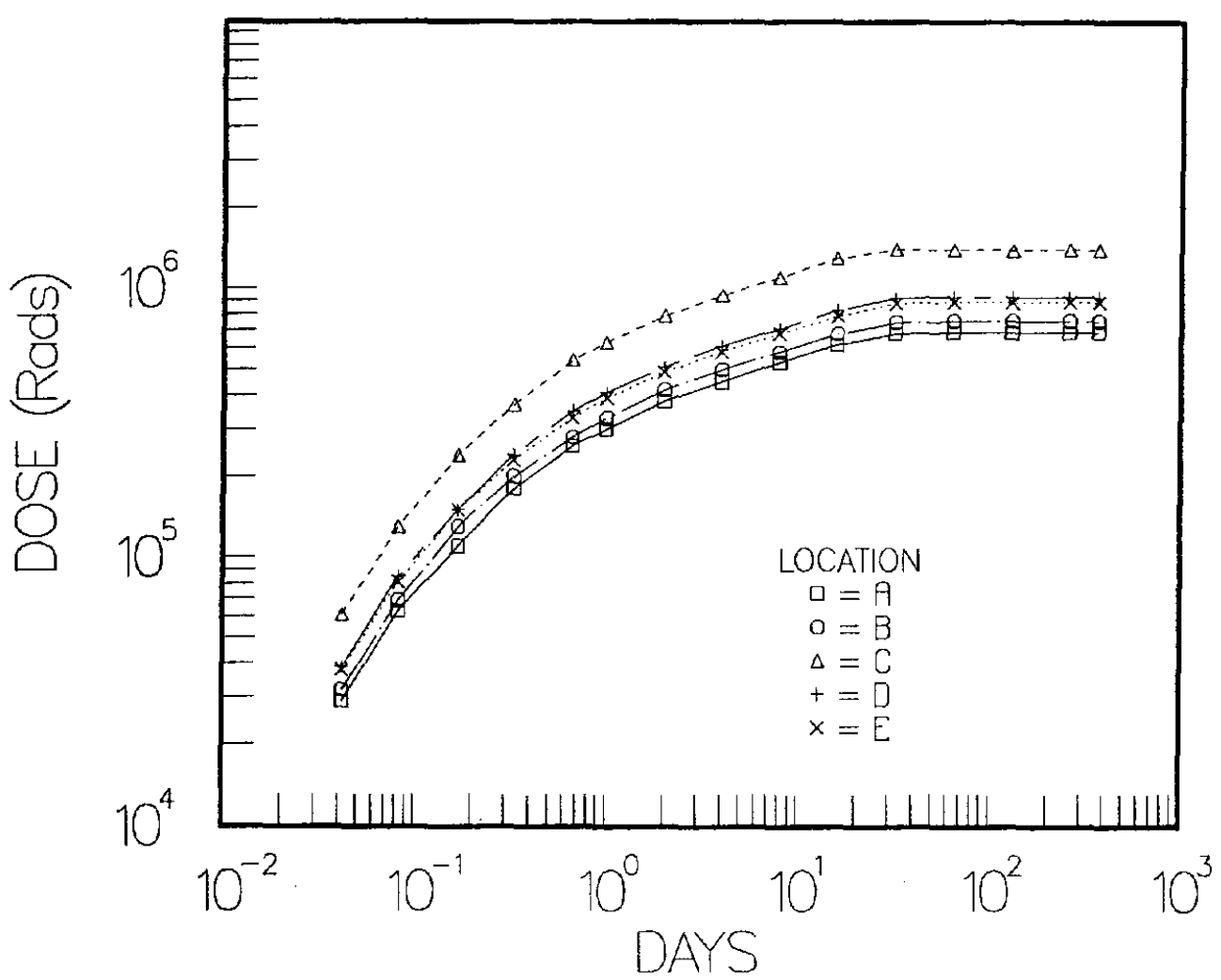

Figure B.99. Surry Case 4 Incore Instrumentation Room Total Gamma Dose

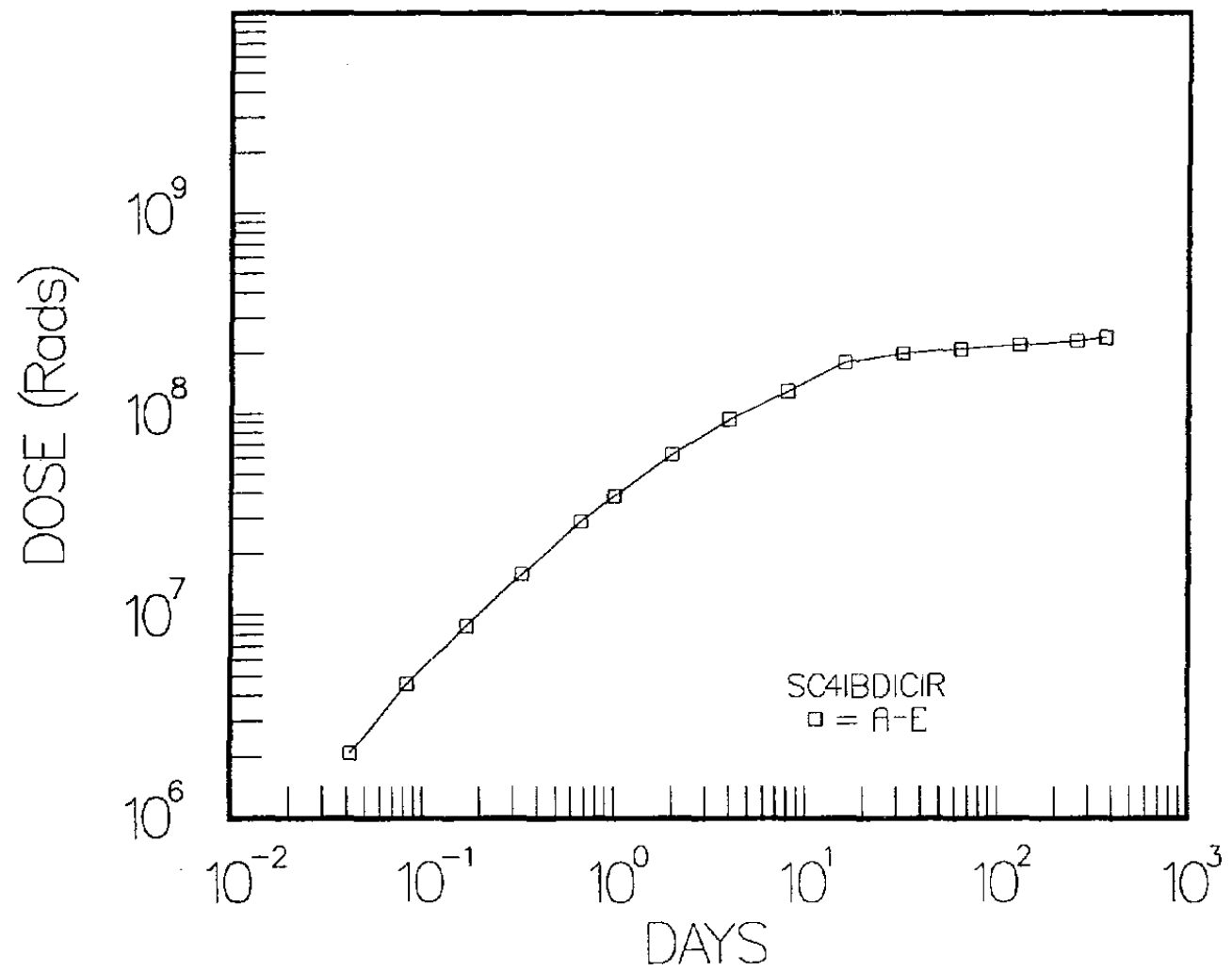

Figure B.100. Surry Case 4 Incore Instrumentation Room Total Beta Dose. 

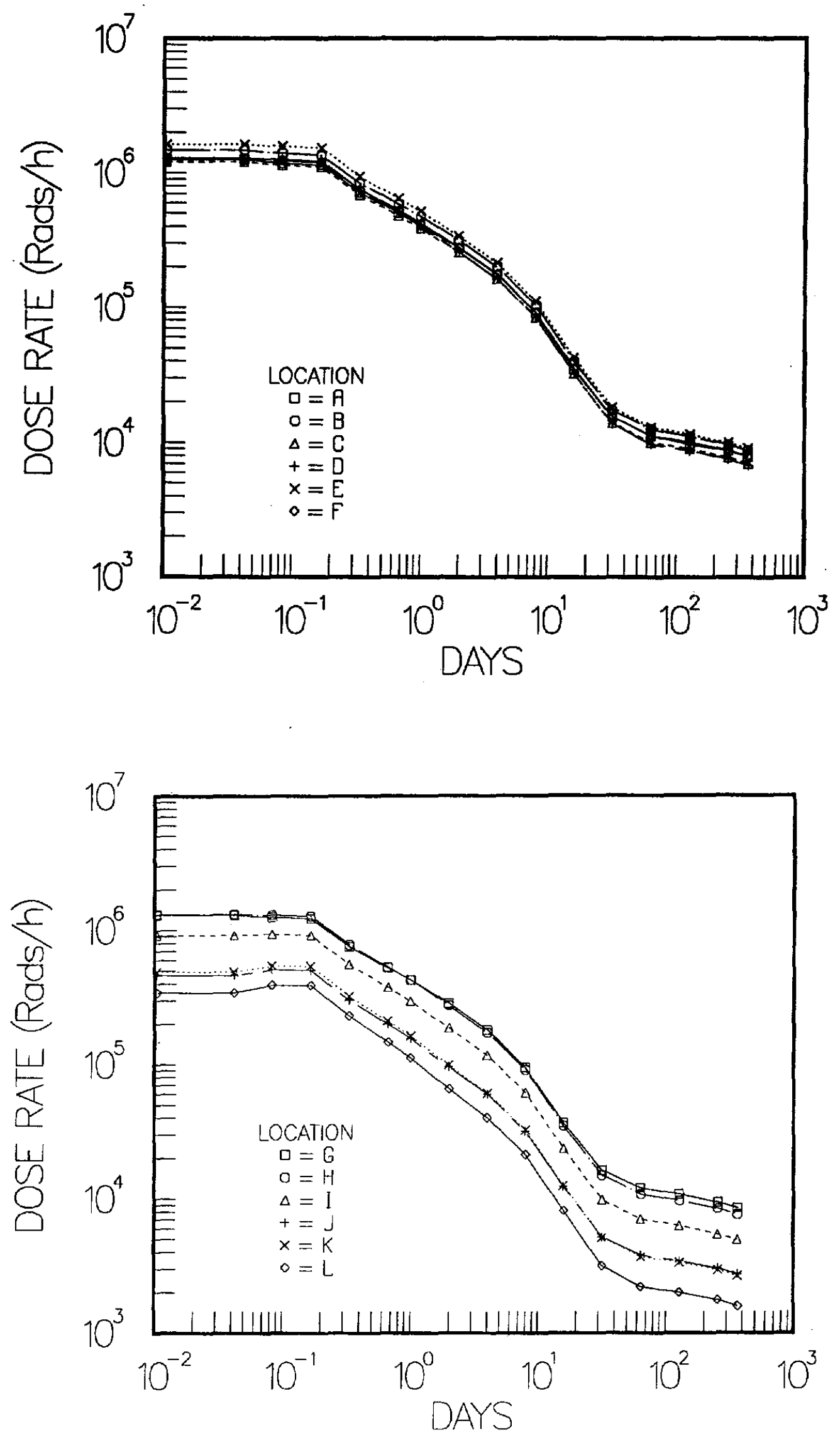

Figure B.101. Peach Bottom Case 1 Drywell Gamma Dose Rates 

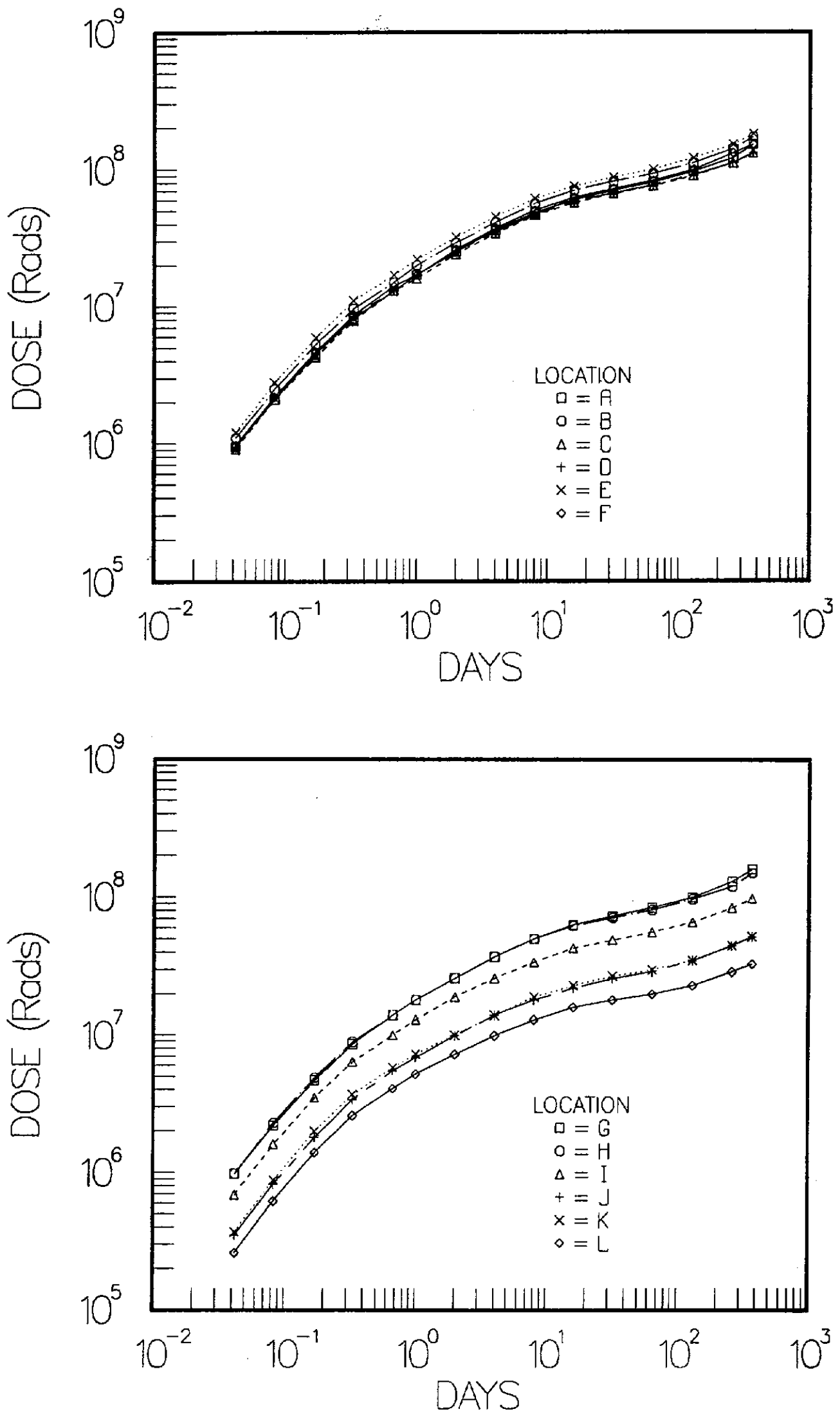

Figure B.102. Peach Bottom Case 1 Drywell Total Gamma Dose 

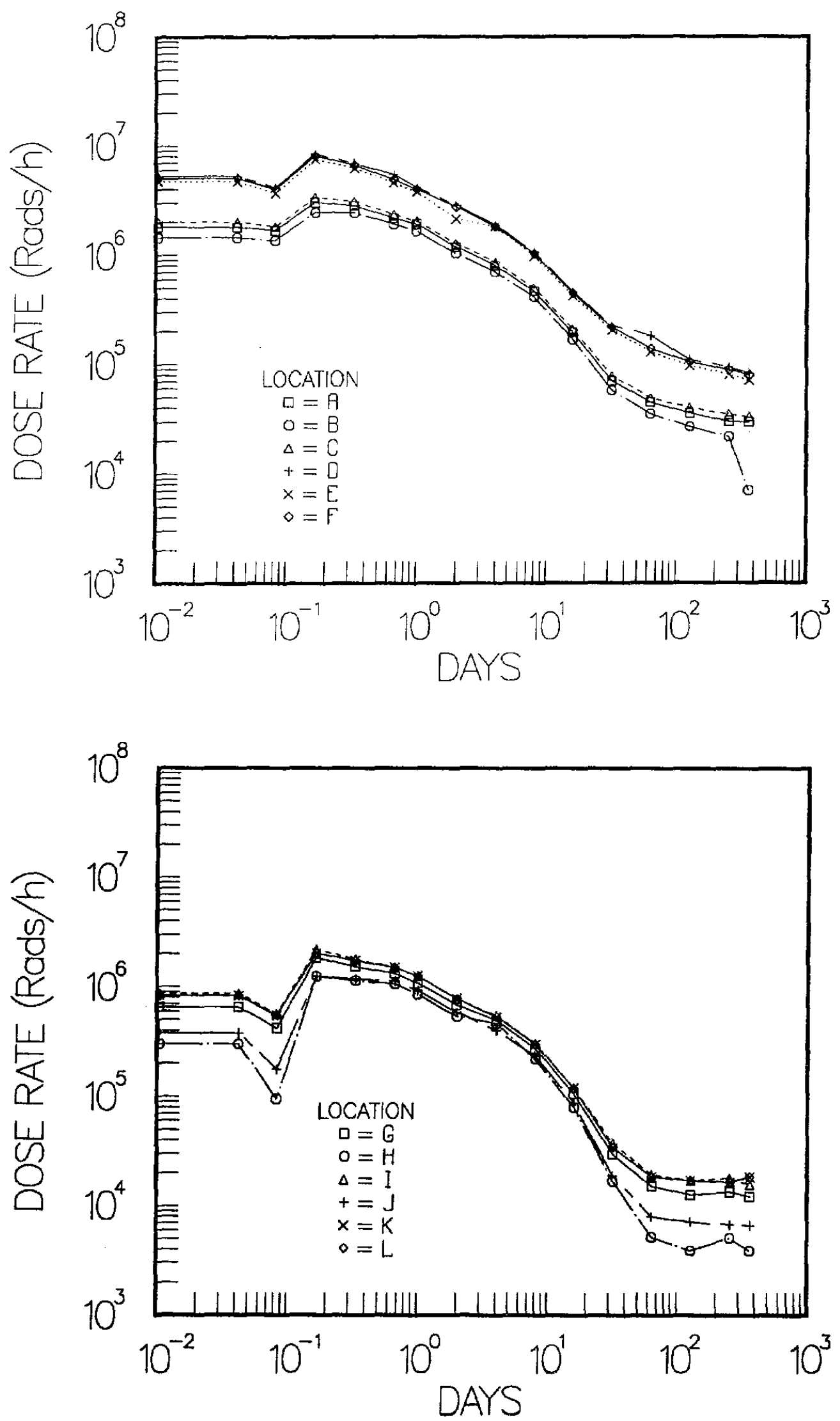

Figure B.103. Peach Bottom Case 1 Drywell Beta Dose Rates 

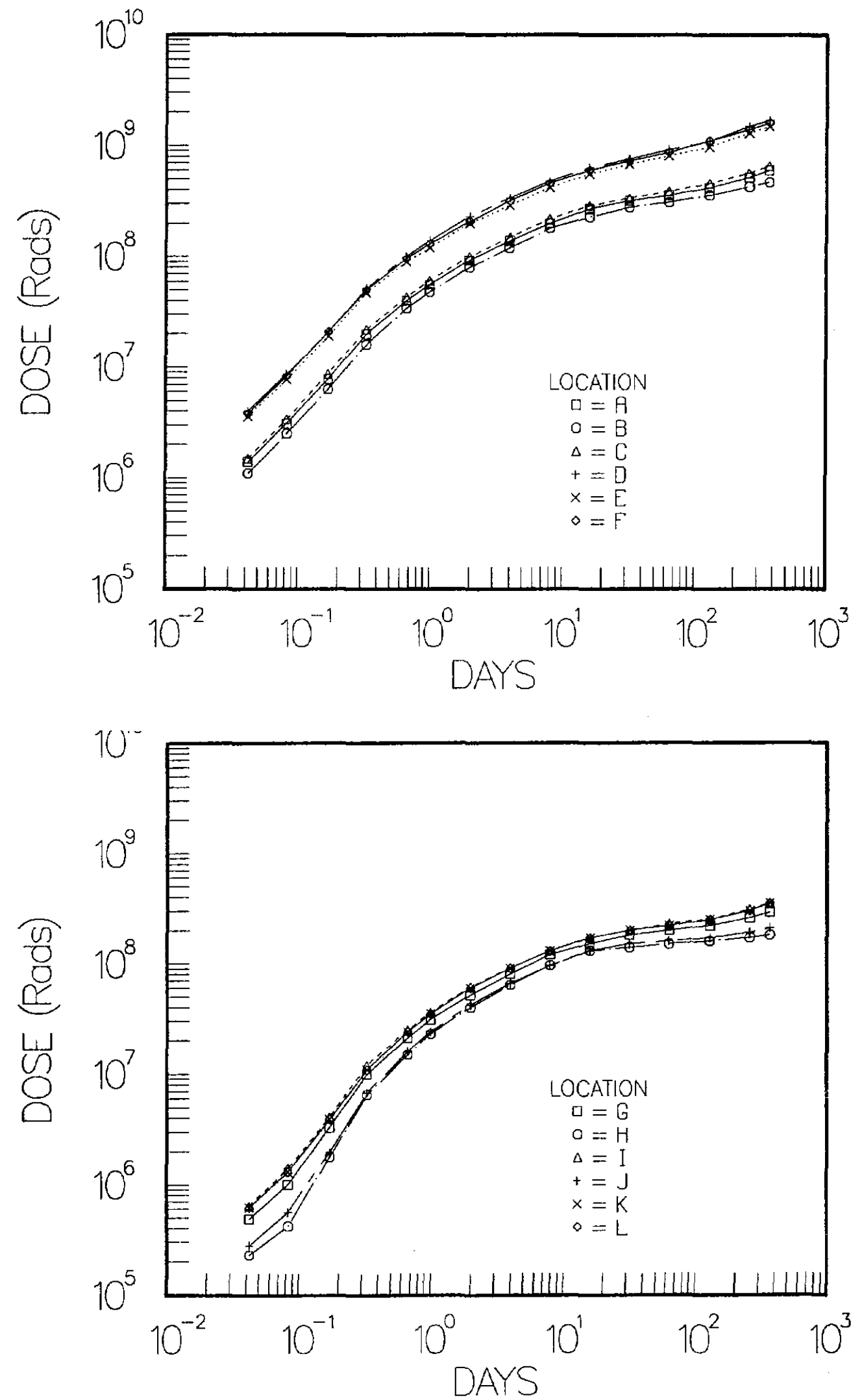

Figure B.104. Peach Bottom Case 1 Drywell Total Beta Dose 


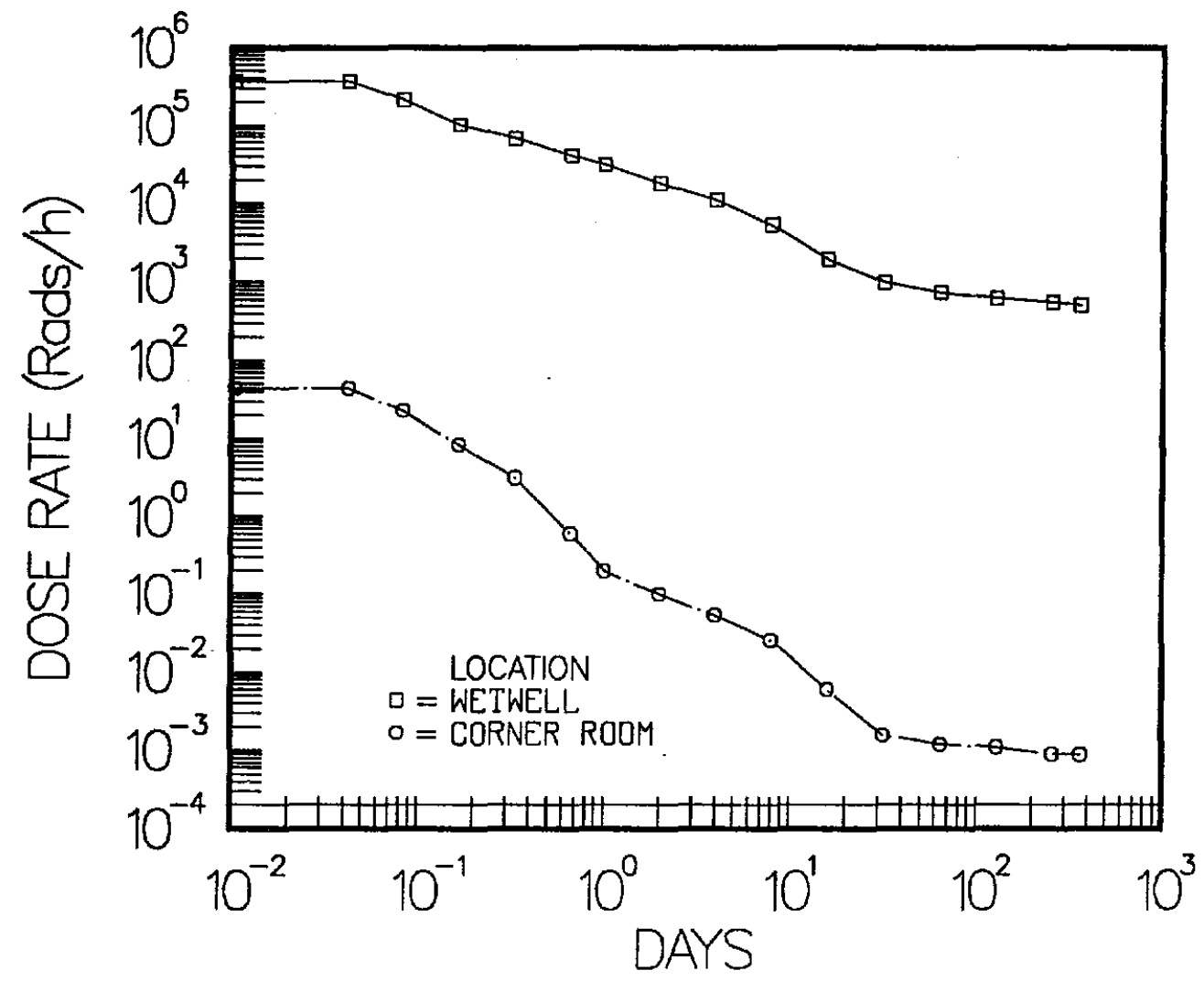

Figure B.105. Peach Bottom Case 1 Wetwell Gamma Dose Rate 


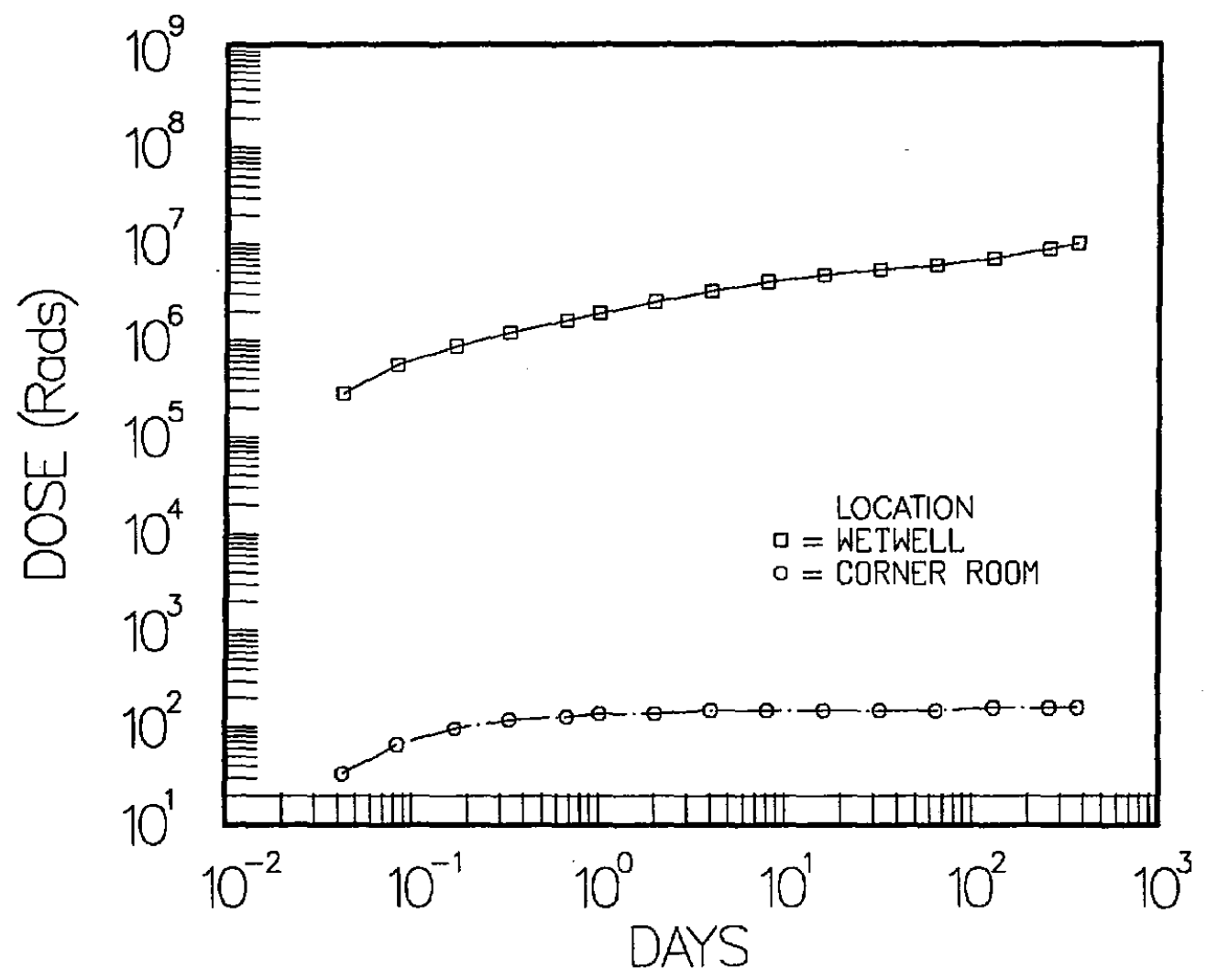

Figure B.106. Peach Bottom Case 1 Wetwell Total Gamma Dose 

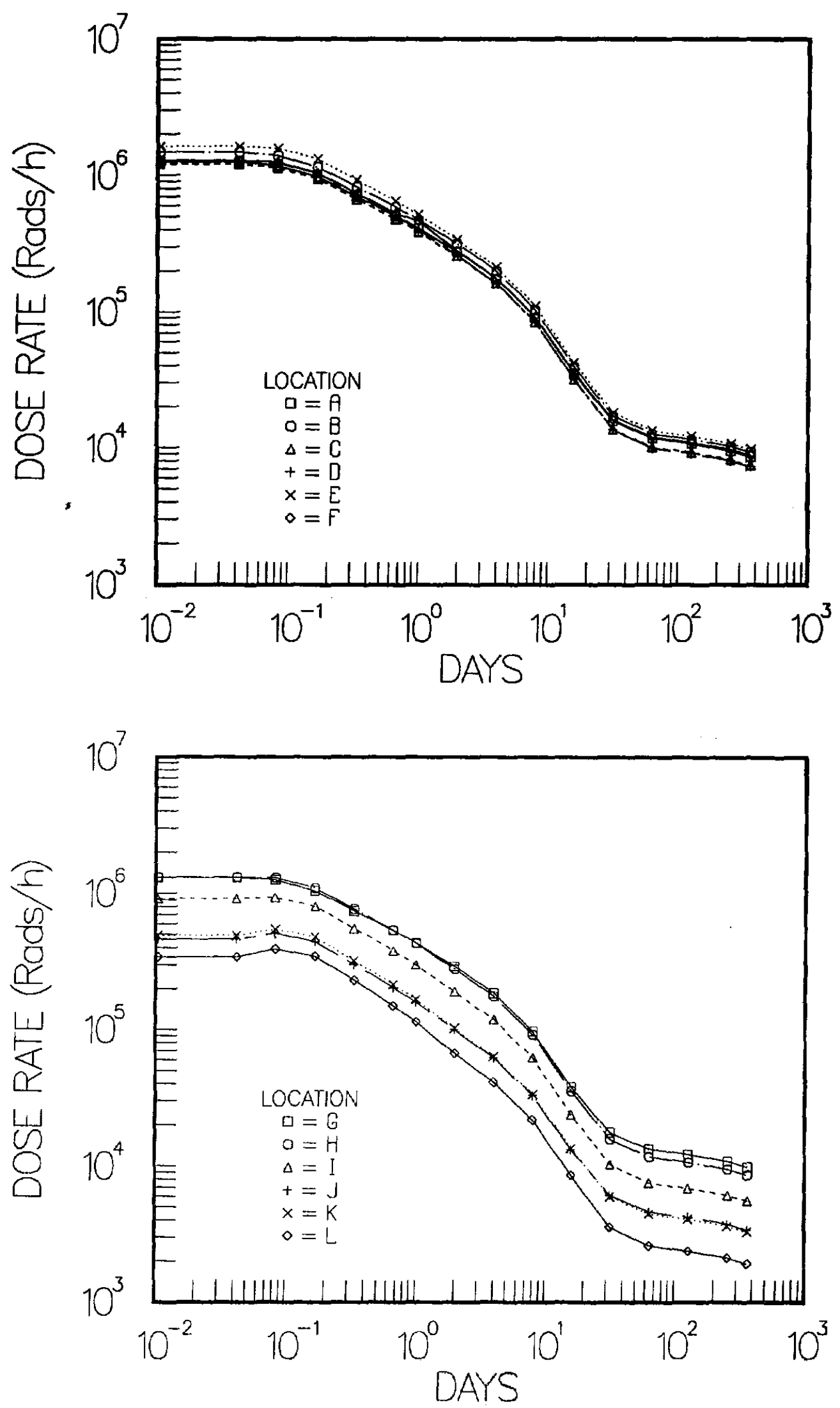

Figure B.107: Peach Bottom Case 2 Drywell Gamma Dose Rate 

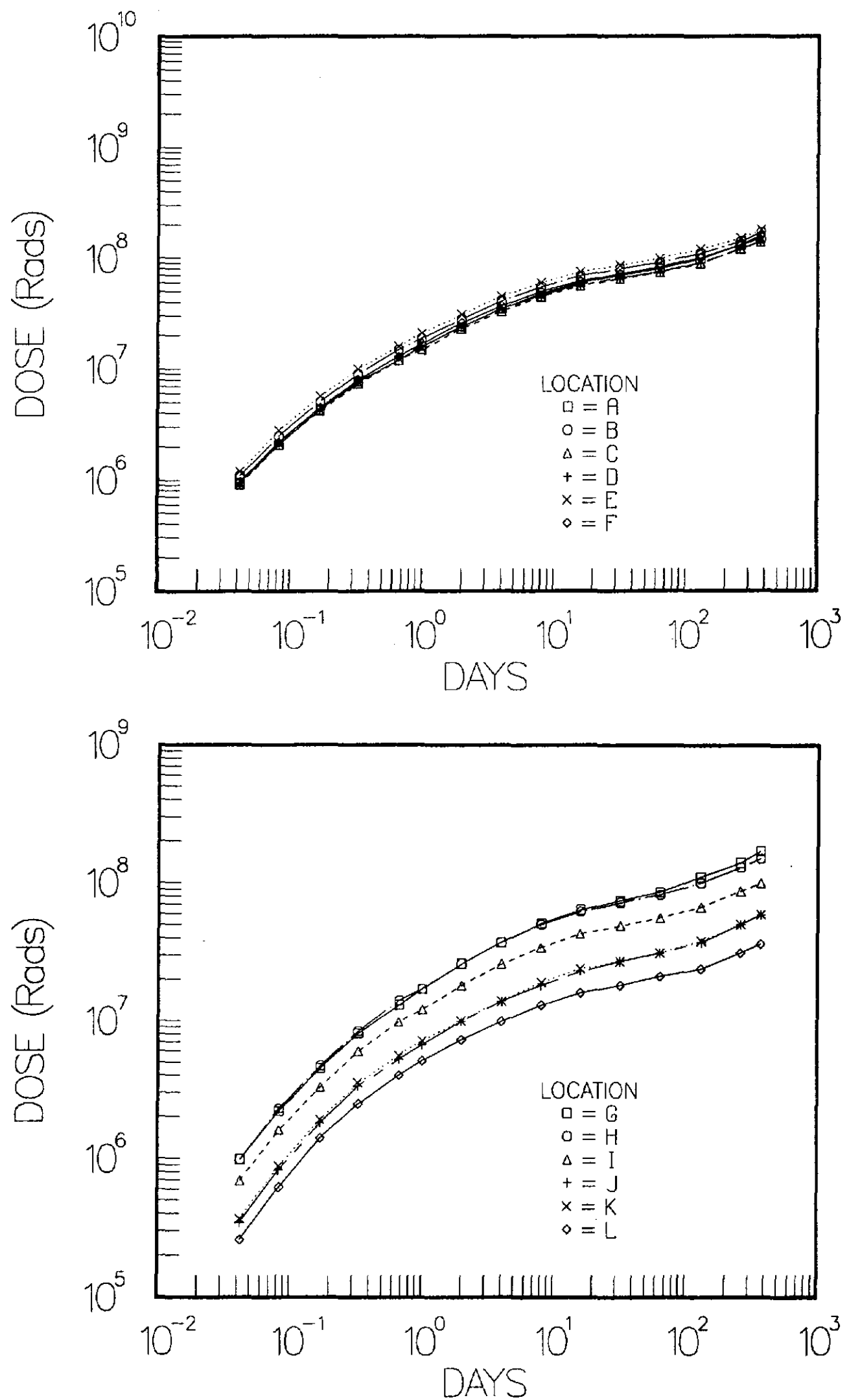

Figure B.108. Peach Bottom Case 2 Drywell Total Gamma Dose 

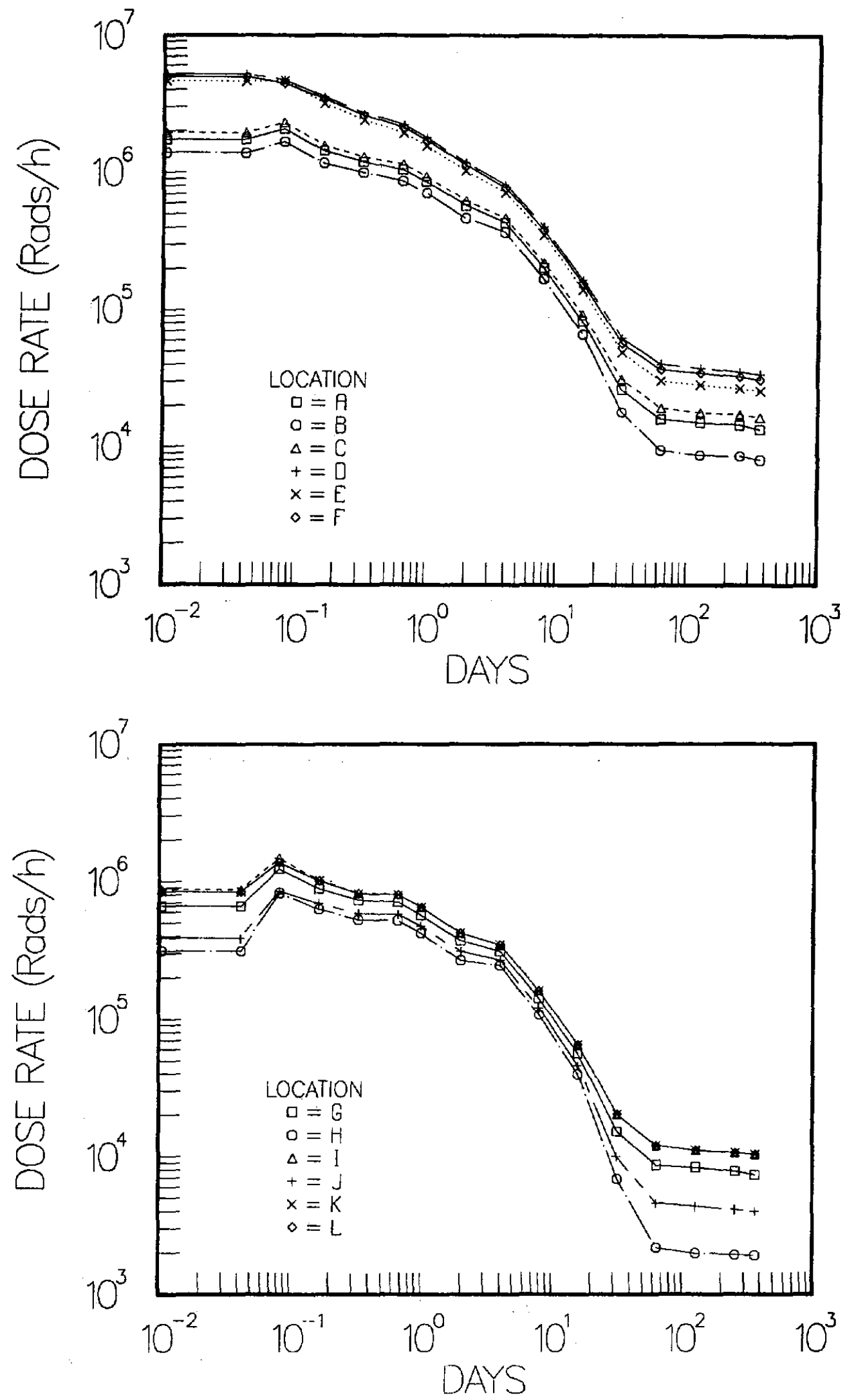

Figure B.109: Peach Bottom Case 2 Drywell Beta Dose Rate 

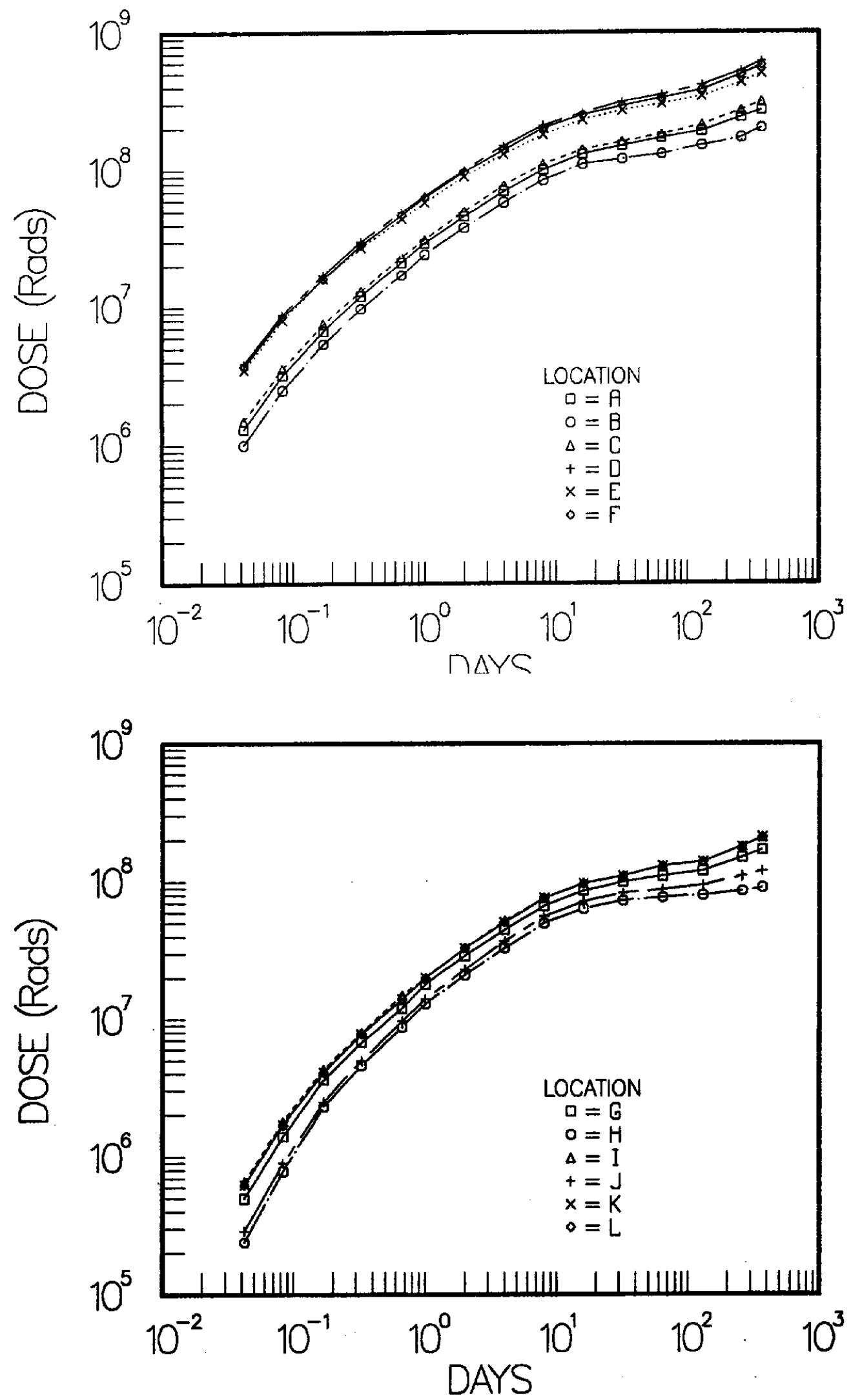

Figure B.110. Peach Bottom Case 2 Drywell Total Beta Dose 


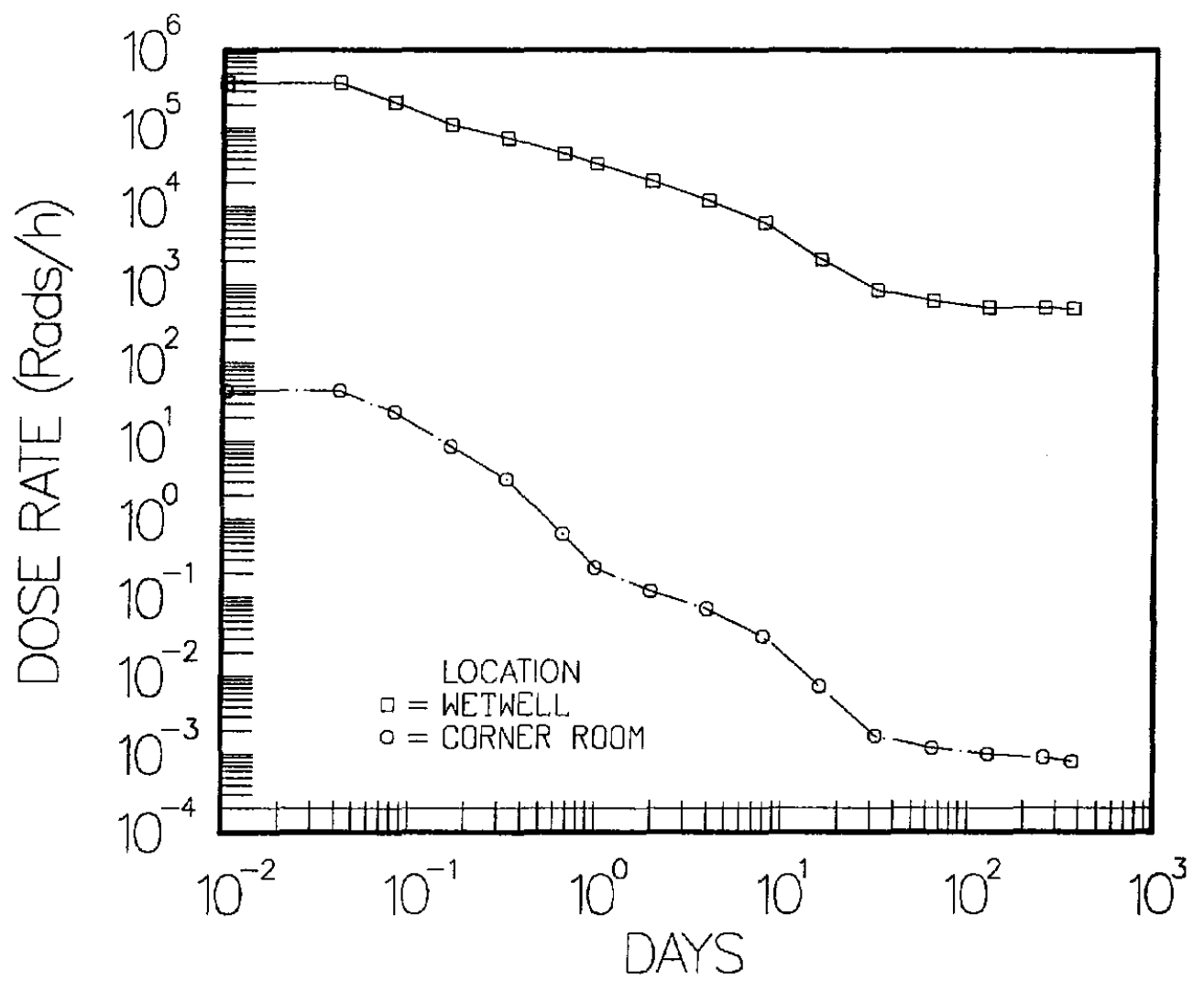

Figure B.111. Peach Bottom Case 2 Wetwell Gamma Dose Rates 


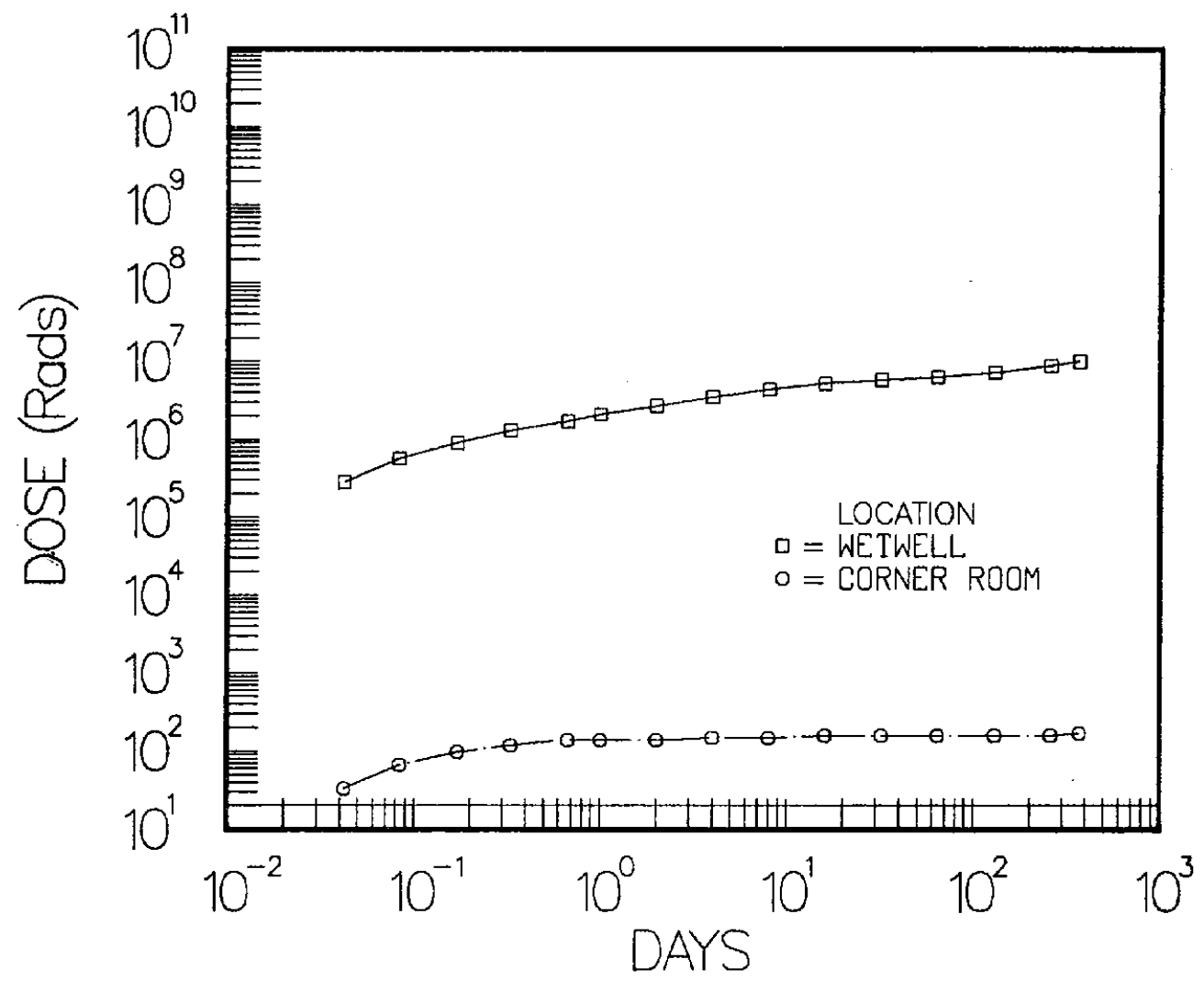

Figure B.112. Peach Bottom Case 2 Wetwell Total Gamma Doses 

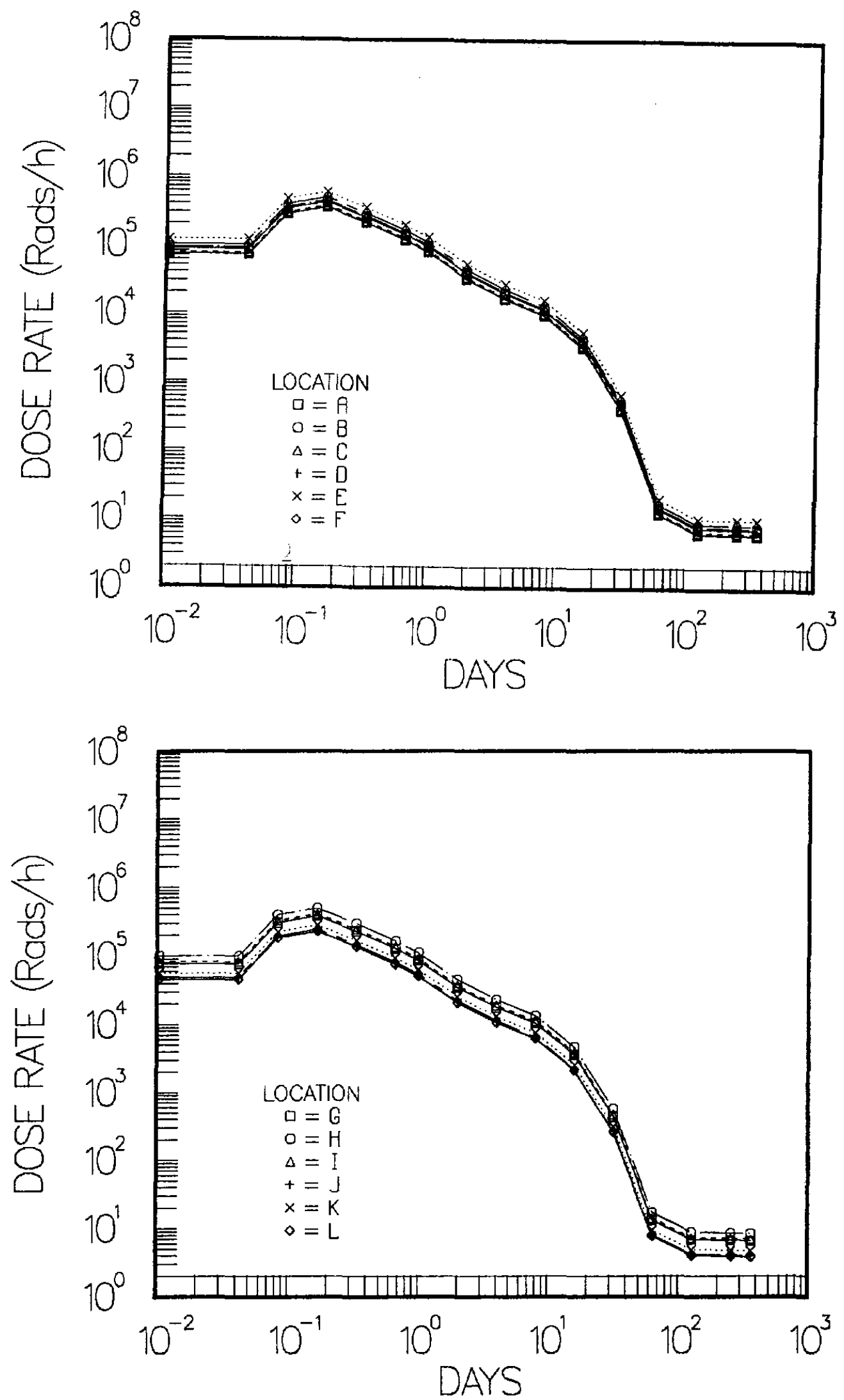

Figure B.113. Peach Bottom Case 3 Drywe11 Gamma Dose Rates 

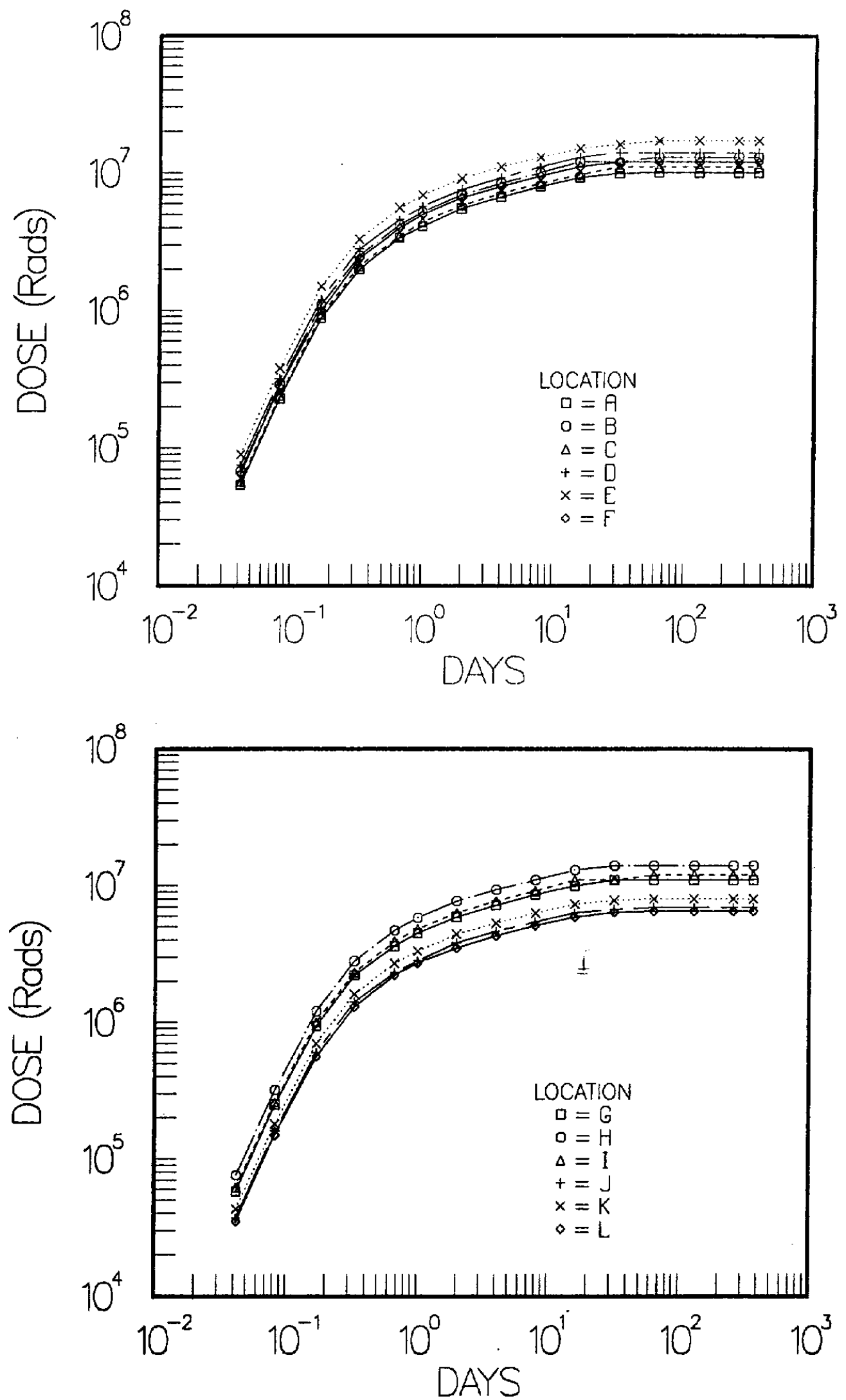

Figure B.114. Peach Bottom Case 3 Drywell Total Gamma Dose 


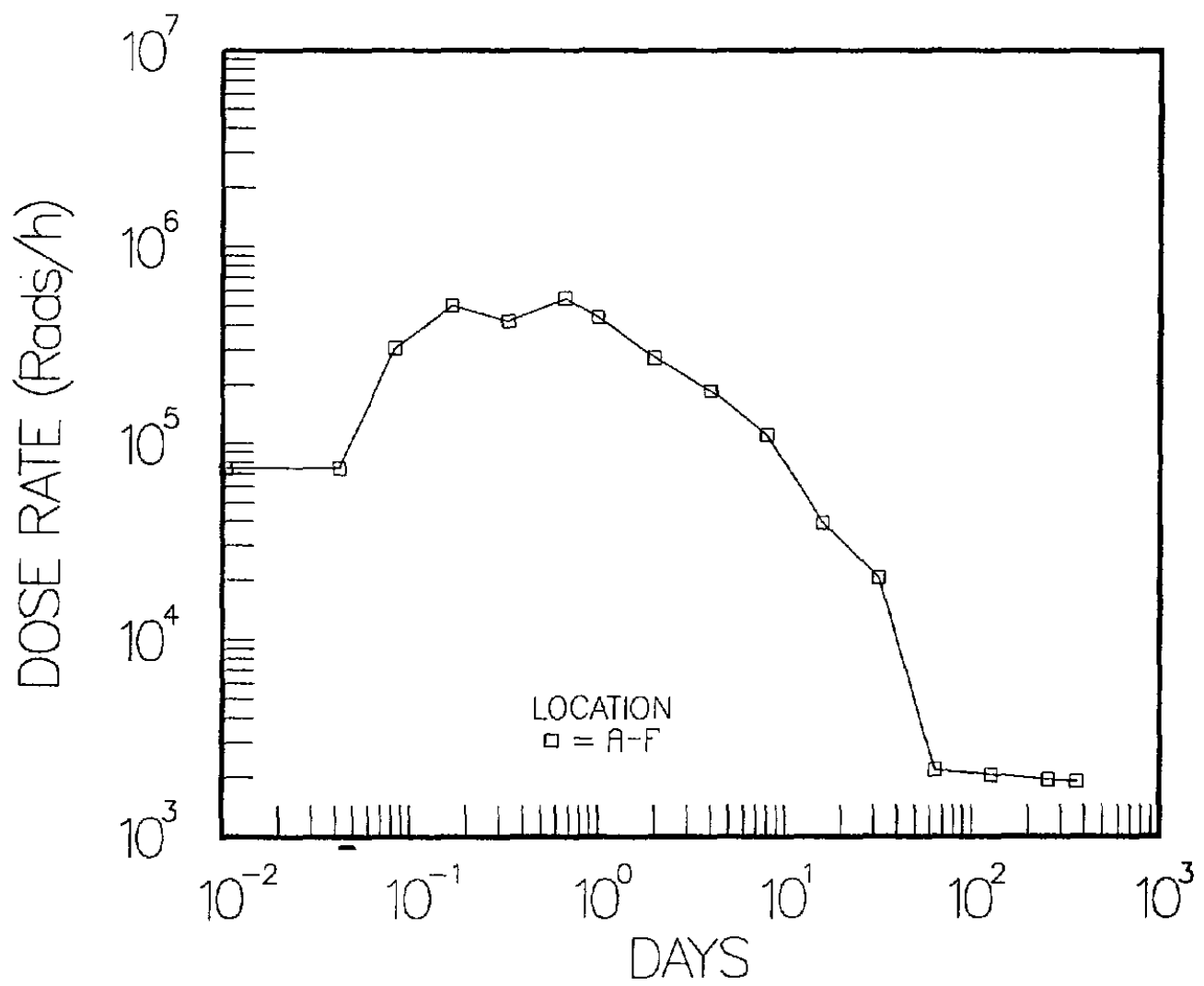

Figure B.115. Peach Bottom Case 3 Drywe11 Beta Dose Rates 


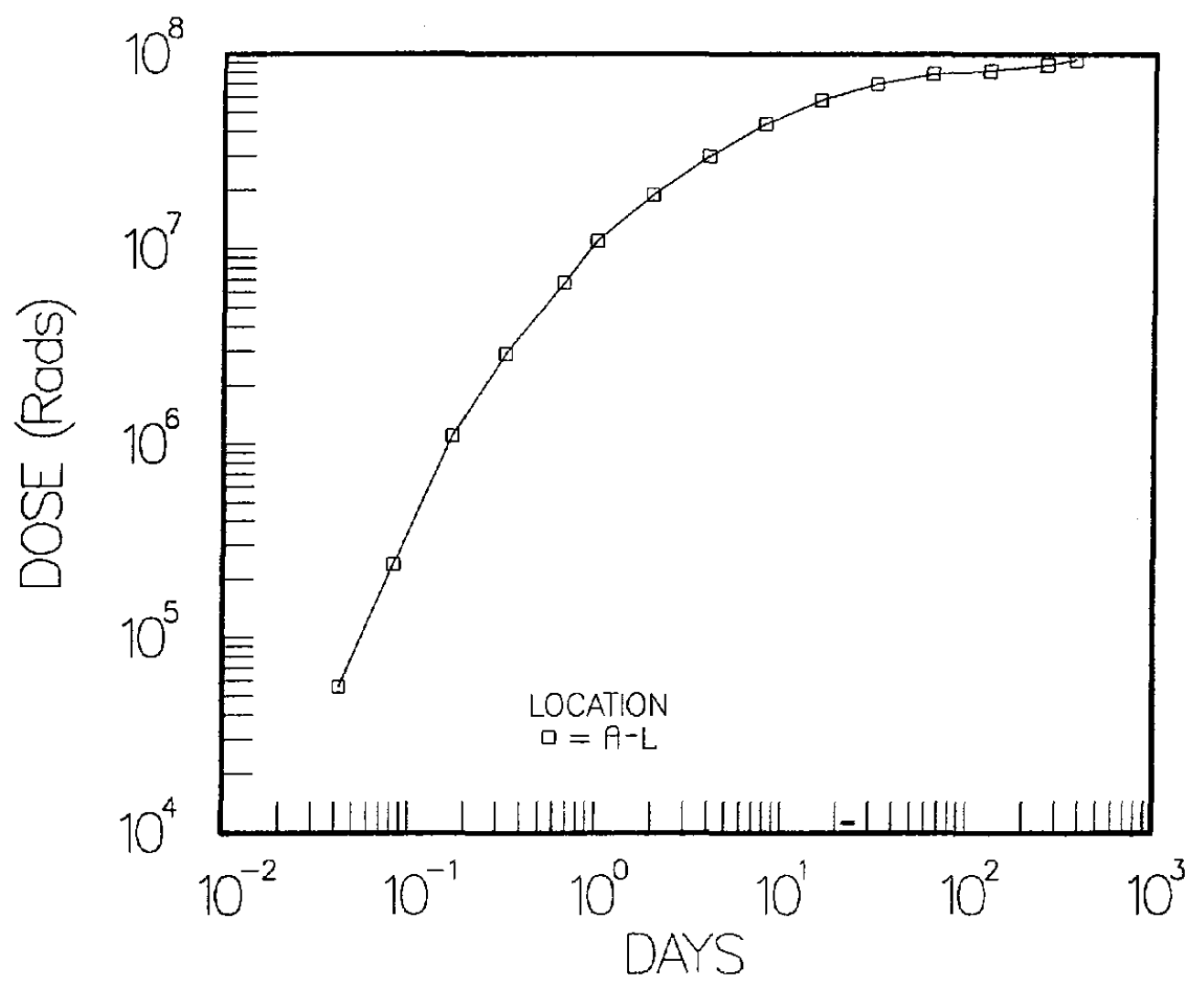

Figure B.116: Peach Bottom Case 3 Drywell Total Beta Dose 


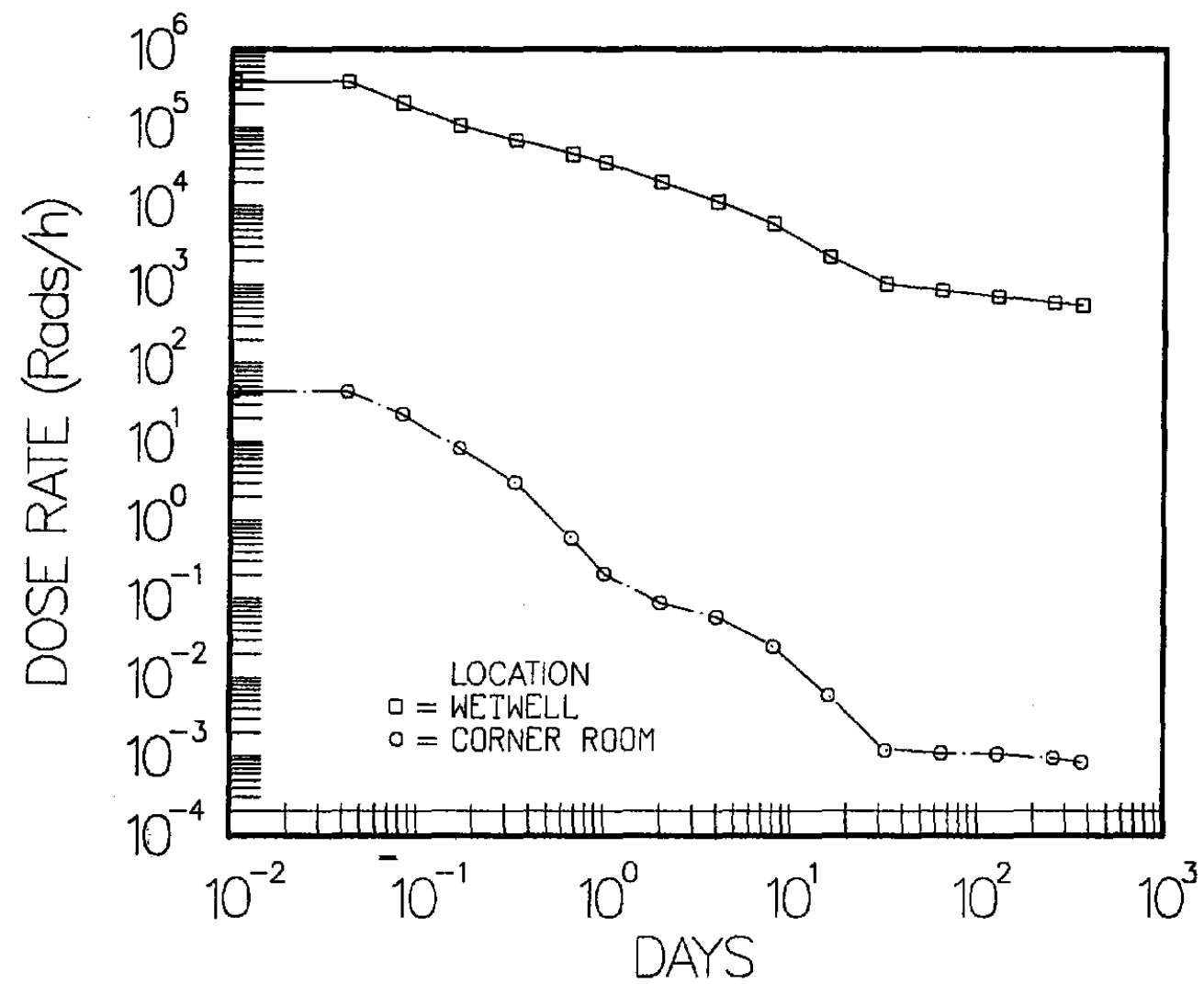

Figure B.117. Peach Bottom Case 3 Wetwell Gamma Dose Rate 


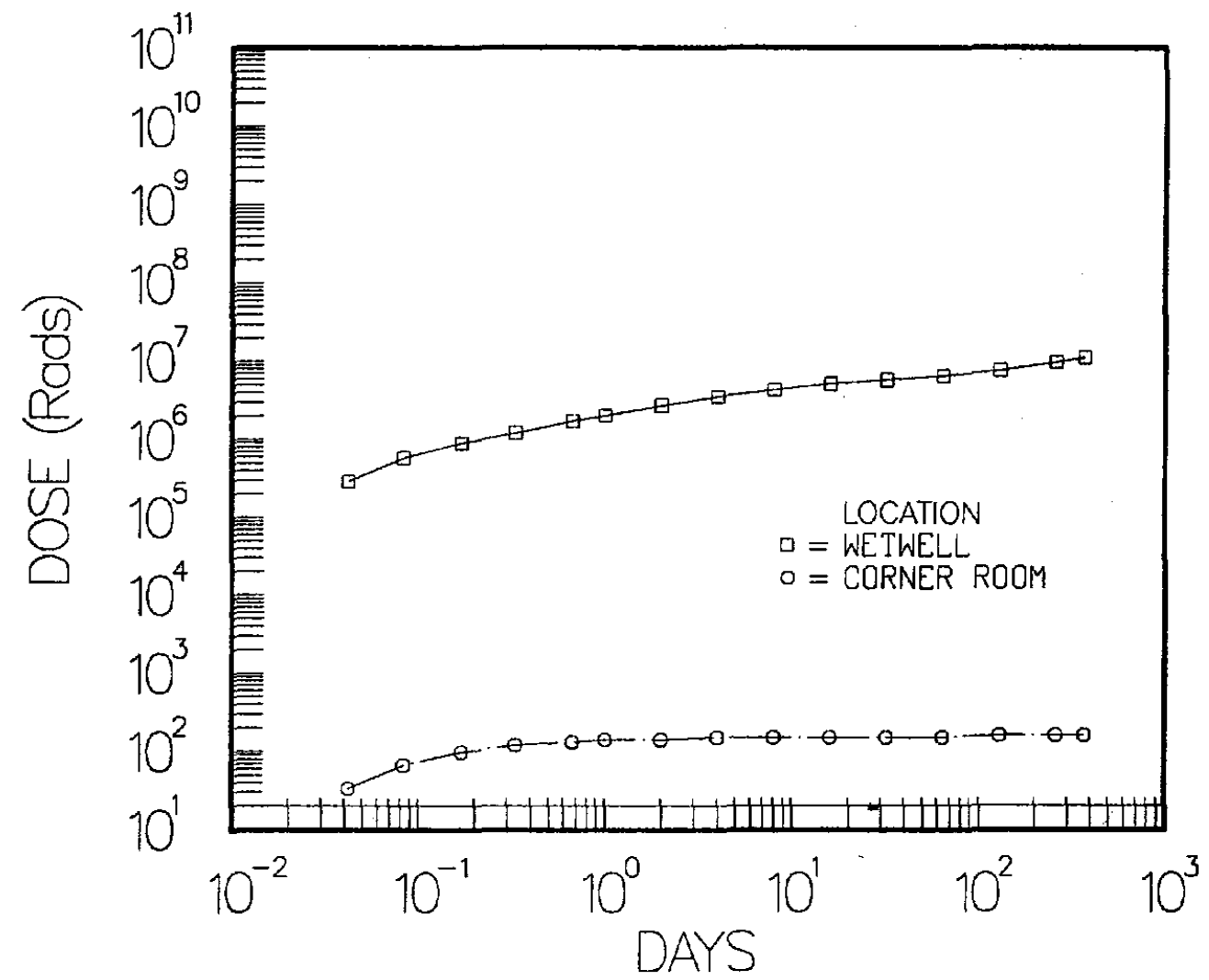

Figure B.118. Peach Bottom Case 3 Wetwell Total Gamma Dose 

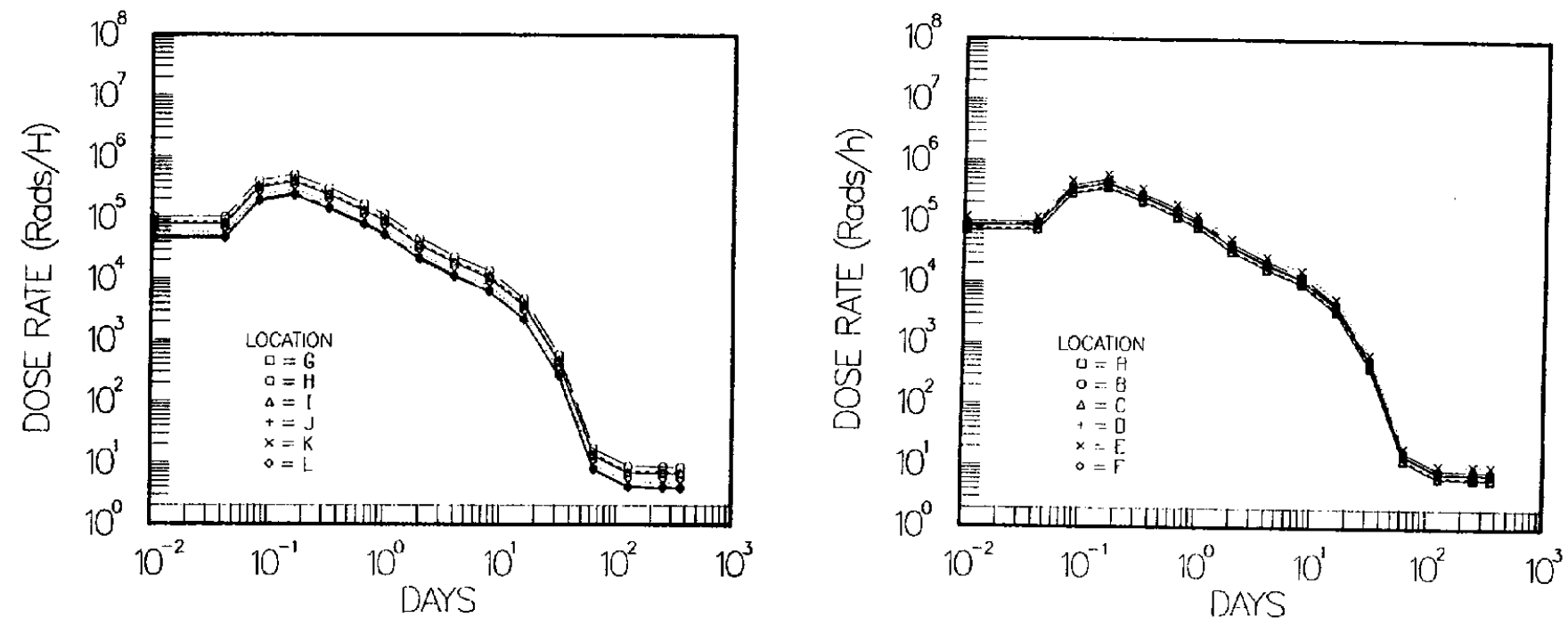

Figure B.119. Peach Bottom Case 4 Drywel1 Gamma Dose Rate

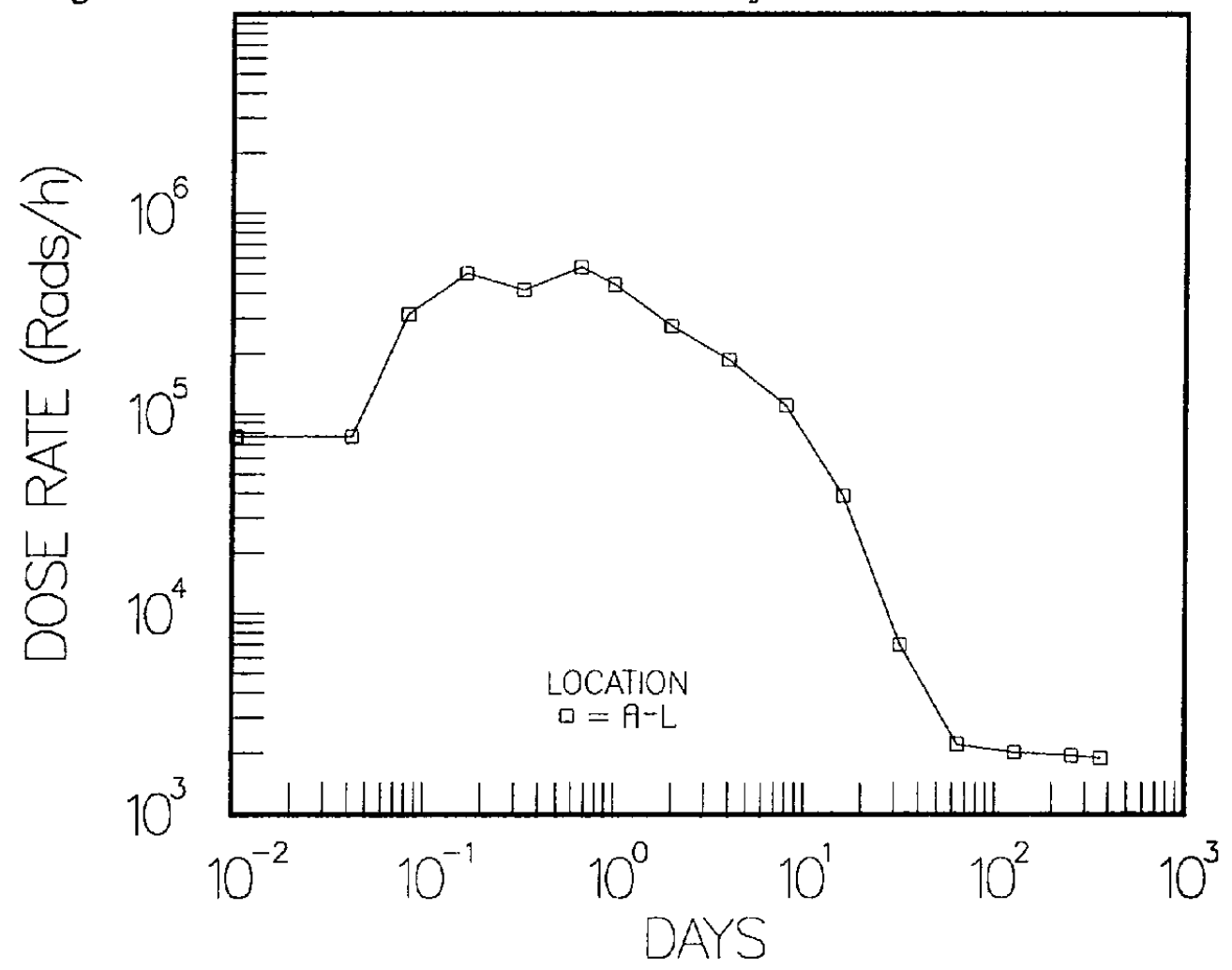

Figure B.120. Peach Bottom Case 4 Drywel1 Beta Dose Rate 

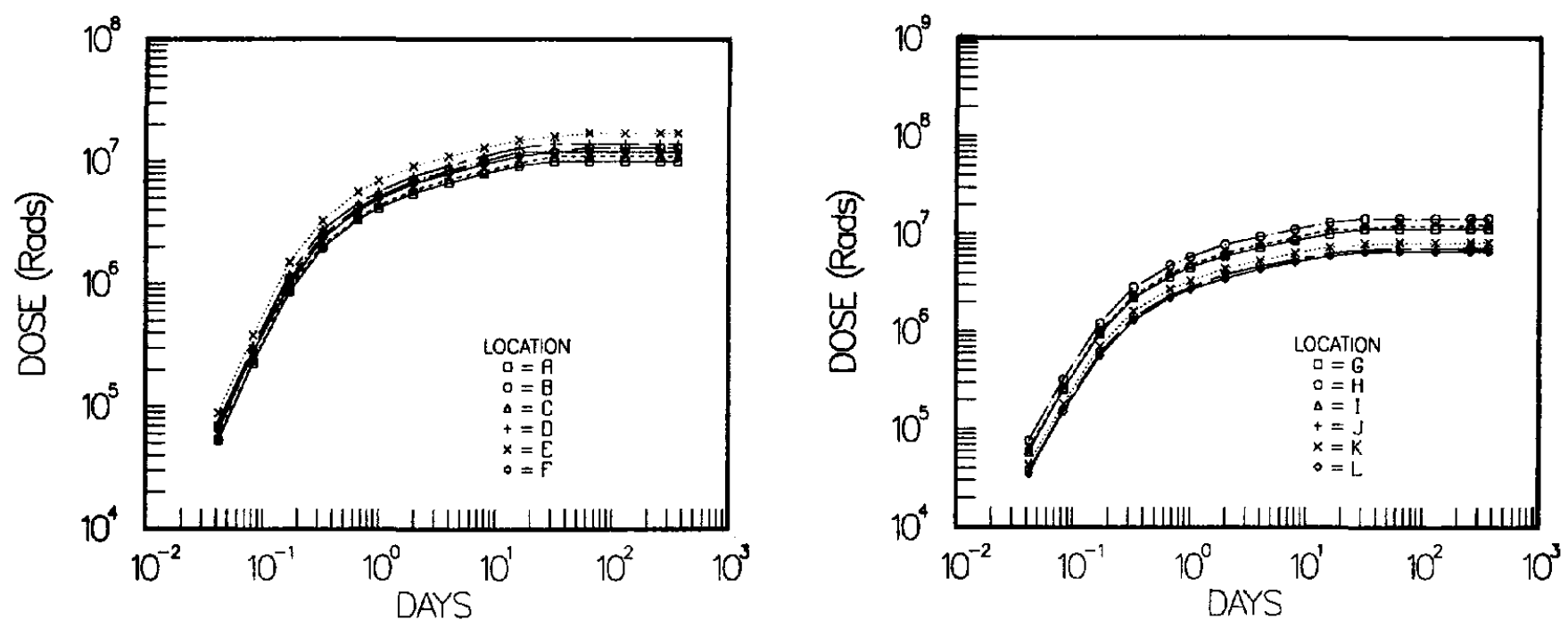

Figure B.121. Peach Bottom Case 4 Drywell Total Gamma Dose

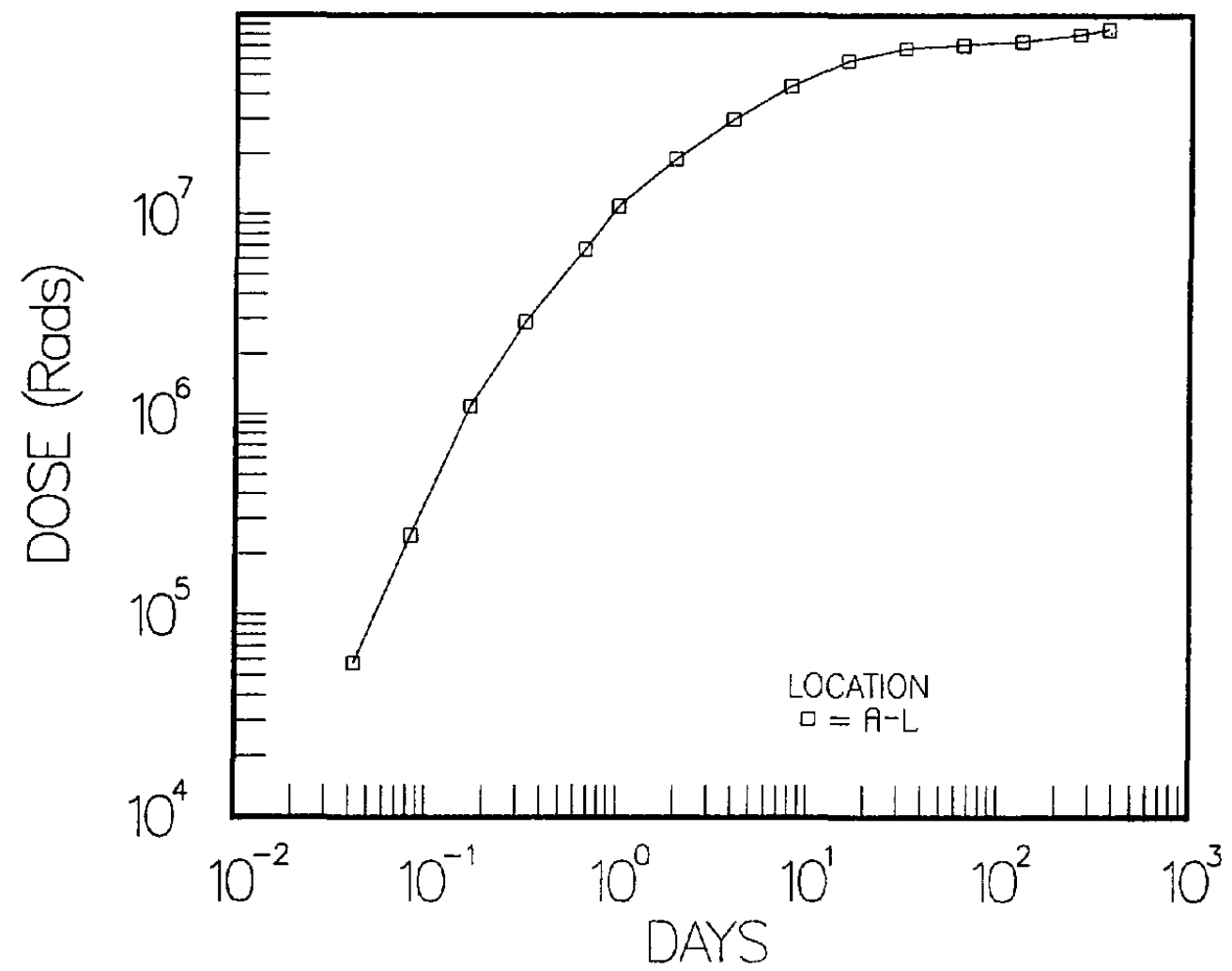

Figure B.122. Peach Bottom Case 4 Drywell Total Beta Dose 


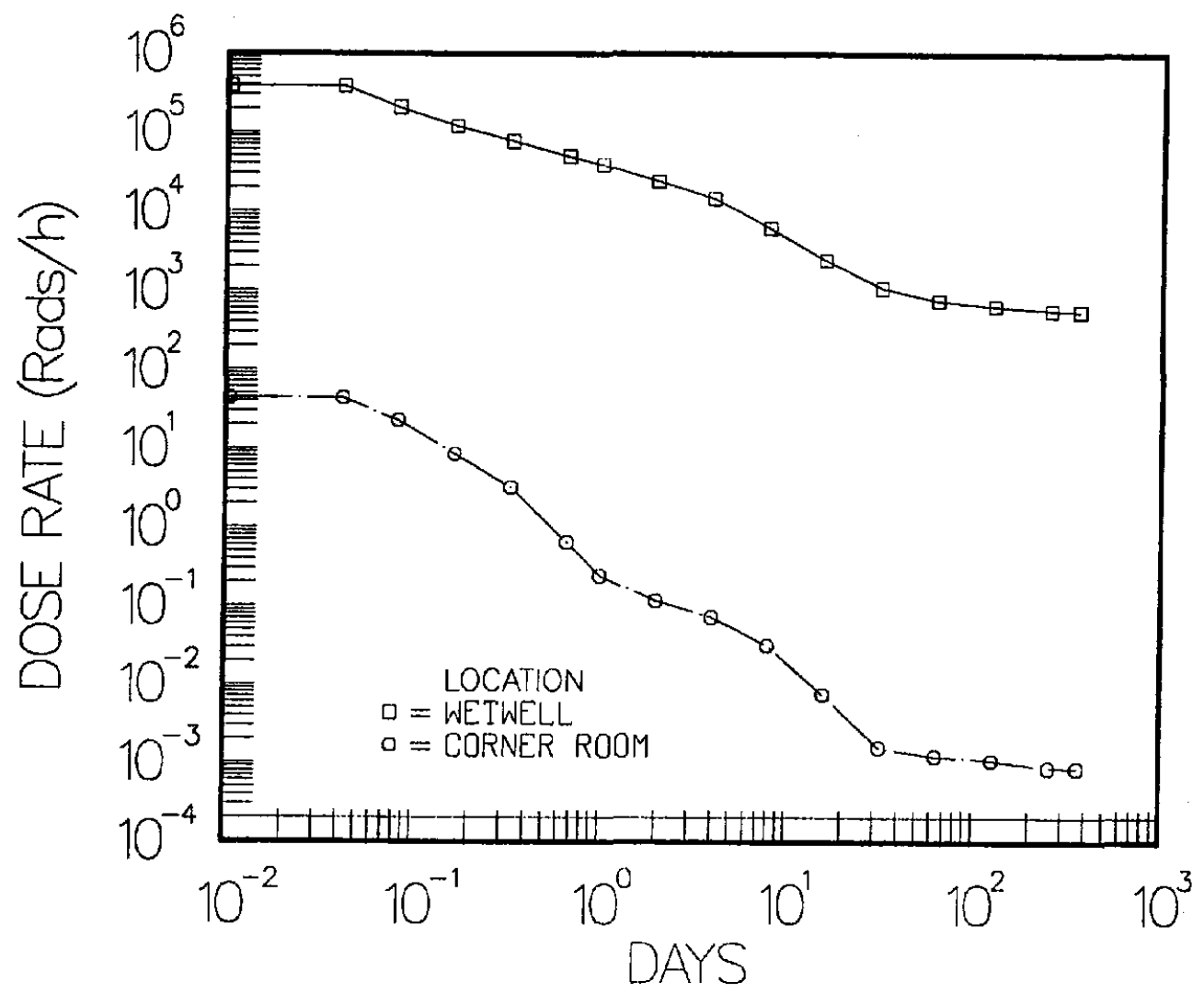

Figure B.123. Peach Bottom Case 4 Wetwell Gamma Dose Rate

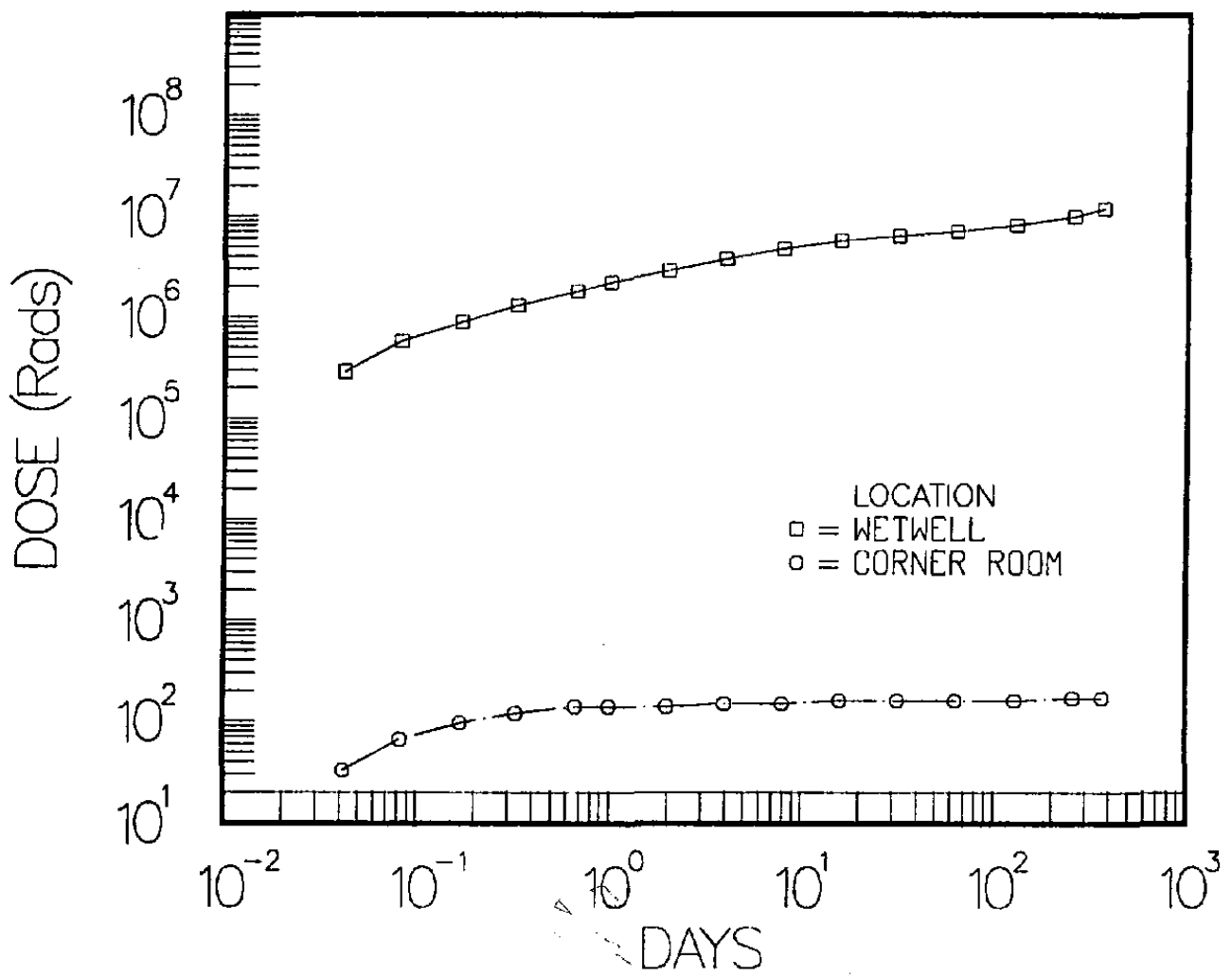

Figure B.124. Peach Bottom Case 4 Wetwell Total Gamma Dose 


\section{APPENDIX C}

AIRBORNE, WALL, FLOOR, AND SUMP CONTRIBUTIONS TO DOSE RATES FOR SELECTED CONTAINMENT LOCATIONS 
Table C.1

Surry Case 1 Basement Gamma Dose Rates

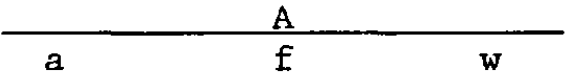

$\begin{array}{rlll}1 \mathrm{~h} & 7.77 \mathrm{e} 5 & 3.09 \mathrm{e} 5 & 2.21 \mathrm{e} 4 \\ 2 \mathrm{~h} & 3.09 \mathrm{e} 5 & 7.17 \mathrm{e} 5 & 2.93 \mathrm{e} 4 \\ 4 \mathrm{~h} & 1.91 \mathrm{e} 5 & 7.11 \mathrm{e} 5 & 2.78 \mathrm{e} 4 \\ 8 \mathrm{~h} & 5.27 \mathrm{e} 4 & 7.07 \mathrm{e} 5 & 2.23 \mathrm{e} 4 \\ 16 \mathrm{~h} & 2.25 \mathrm{e} 4 & 5.74 \mathrm{e} 5 & 1.75 \mathrm{e} 4 \\ 1 \mathrm{~d} & 1.42 \mathrm{e} 4 & 4.94 \mathrm{e} 5 & 1.58 \mathrm{e} 4 \\ 2 \mathrm{~d} & 5.91 \mathrm{e} 3 & 3.71 \mathrm{e} 5 & 1.11 \mathrm{e} 4 \\ 4 \mathrm{~d} & 3.06 \mathrm{e} 3 & 2.58 \mathrm{e} 5 & 6.94 \mathrm{e} 3 \\ 8 \mathrm{~d} & 1.79 \mathrm{e} 3 & 1.53 \mathrm{e} 5 & 5.22 \mathrm{e} 3 \\ 16 \mathrm{~d} & 6.22 \mathrm{e} 2 & 8.01 \mathrm{e} 4 & 1.88 \mathrm{e} 3 \\ 32 \mathrm{~d} & 7.60 \mathrm{e} 1 & 4.51 \mathrm{e} 4 & 9.24 \mathrm{e} 2 \\ 64 \mathrm{~d} & 2.14 \mathrm{e} 0 & 2.92 \mathrm{e} 4 & 7.98 \mathrm{e} 2 \\ 128 \mathrm{~d} & 1.04 \mathrm{e} 0 & 2.06 \mathrm{e} 4 & 5.99 \mathrm{e} 2 \\ 256 \mathrm{~d} & 1.01 \mathrm{e} 0 & 1.39 \mathrm{e} 4 & 4.99 \mathrm{e} 2 \\ 1 \mathrm{y} & 9.95 \mathrm{e}-1 & 1.16 \mathrm{e} 4 & 2.99 \mathrm{e} 2\end{array}$

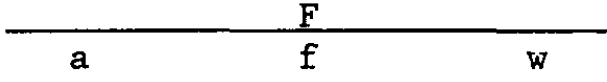

$5.97 \mathrm{e} 5$

$2.12 \mathrm{e} 5$

$5.98 \mathrm{e} 4$

$2.12 \mathrm{e} 5$

$4.87 \mathrm{e} 5$

$1.10 \mathrm{e} 5$

1. $31 \mathrm{e} 5$

$4.82 \mathrm{e} 5$

$2.23 \mathrm{e} 5$

$3.63 \mathrm{e} 4$

$4.8 \mathrm{e} 5$

$7.87 \mathrm{e} 4$

$1.55 \mathrm{e} 4$

$3.89 \mathrm{e} 5$

$6.45 \mathrm{e} 4$

$9.81 \mathrm{e} 3$

3. $35 \mathrm{e} 5$

$5.52 \mathrm{e} 4$

$4.07 \mathrm{e} 3$

2. $52 \mathrm{e} 5$

1. $75 \mathrm{e} 5$

$3.99 \mathrm{e} 4$

$2.10 \mathrm{e} 3$

$1.04 \mathrm{e} 5$

$5.43 e 4$

$2.69 \mathrm{e} 4$

$1.23 \mathrm{e} 3$

$4.28 \mathrm{e} 2$

$5.24 \mathrm{e} 1$

$3.06 \mathrm{e} 4$

1. $58 \mathrm{e} 4$

$1.48 \mathrm{e} 0$

$1.98 \mathrm{e} 4$

$6.77 \mathrm{e} 3$

$3.55 \mathrm{e} 3$

$7.15 e-1$

$1.40 e^{4}$

$2.40 \mathrm{e} 3$

$6.99 e-1$

$6.86 e-1$

$1.90 \mathrm{e} 3$

$1.42 \mathrm{e} 3$

$1.26 \mathrm{e} 3$

Capital letters refer to dose locations.

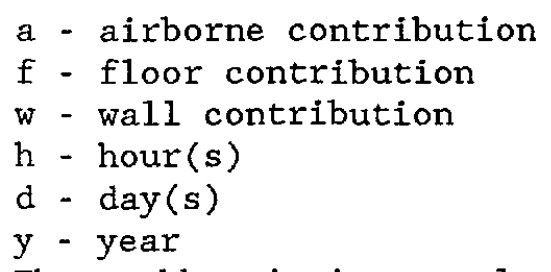

These abbreviations apply to all Appendix $\mathrm{C}$ tables. 
Table C. 2

Surry Case 1 Basement Beta Dose Rates

\begin{tabular}{|c|c|c|c|c|c|c|c|}
\hline & & A & & & F & & $\mathrm{F}$ \\
\hline & $a$ & $\mathrm{f}$ & $w$ & a & $f$ & $w$ & $w^{\prime}$ \\
\hline Ih & $1.25 e 6$ & $5.35 e 5$ & $1.19 \mathrm{e} 5$ & $1.25 e^{6}$ & $5.35 e 5$ & $2.71 \mathrm{e} 6$ & $4.68 \mathrm{e} 5$ \\
\hline $2 \mathrm{~h}$ & $6.74 \mathrm{e} 5$ & $1.03 \mathrm{e} 6$ & $1.51 \mathrm{e} 5$ & $6.74 \mathrm{e} 5$ & $1.03 \mathrm{e} 6$ & $4.20 \mathrm{e} 6$ & $5.36 e 5$ \\
\hline $4 h$ & $5.58 \mathrm{e} 5$ & $1.28 \mathrm{e} 6$ & $8.98 \mathrm{e} 4$ & $5.58 e 5$ & $1.28 \mathrm{e} 6$ & $3.37 e^{6}$ & $2.96 \mathrm{e} 5$ \\
\hline $8 \mathrm{~h}$ & $1.84 \mathrm{e}^{5}$ & $1.36 \mathrm{e} 6$ & $1.0 \mathrm{e} 5$ & $1.84 \mathrm{e} 5$ & $1.36 \mathrm{e} 6$ & $3.78 \mathrm{e} 6$ & $4.28 \mathrm{e} 5$ \\
\hline $16 \mathrm{~h}$ & $1.2 \mathrm{e} 5$ & $1.07 \mathrm{e} 6$ & $8.36 e^{4}$ & $1.20 \mathrm{e} 5$ & $1.07 \mathrm{e} 6$ & $3.15 e^{6}$ & $3.28 \mathrm{e} 5$ \\
\hline $1 d$ & $9.99 \mathrm{e} 4$ & 8.11 es & $6.54 \mathrm{e} 4$ & $9.99 \mathrm{e} 4$ & 8.11 e 5 & $2.72 \mathrm{e} 6$ & 2.81 es \\
\hline $2 d$ & $6.06 e^{4}$ & $5.80 \mathrm{e} 5$ & $4.68 \mathrm{e} 4$ & $6.06 \mathrm{e} 4$ & $5.80 \mathrm{e} 5$ & $1.97 e^{6}$ & $2.23 \mathrm{e} 5$ \\
\hline $4 d$ & $4.24 \mathrm{e} 4$ & $5.07 e 5$ & $3.17 \mathrm{e} 4$ & $4.24 \mathrm{e} 4$ & $5.07 \mathrm{e} 5$ & $1.45 \mathrm{e} 6$ & $1.42 \mathrm{e} 5$ \\
\hline $8 d$ & $2.52 \mathrm{e} 4$ & $3.77 e 5$ & $2.31 \mathrm{e} 4$ & $2.52 \mathrm{e} 4$ & $3.77 e 5$ & $9.94 \mathrm{e} 5$ & $9.22 \mathrm{e} 4$ \\
\hline $16 d$ & $9.54 \mathrm{e} 3$ & $2.66 \mathrm{e} 5$ & $1.39 \mathrm{e} 4$ & $9.54 \mathrm{e} 3$ & $2.66 e 5$ & $6.13 \mathrm{e} 5$ & $6.02 \mathrm{e} 4$ \\
\hline $32 d$ & $1.57 \mathrm{e} 3$ & $2.14 \mathrm{e} 5$ & $1.04 \mathrm{e}^{4}$ & $1.57 \mathrm{e} 3$ & $2.14 \mathrm{e} 5$ & $3.87 \mathrm{e}^{5}$ & $4.38 \mathrm{e} 4$ \\
\hline $64 d$ & & & & & & & \\
\hline $128 d$ & $4.09 \mathrm{e} 2$ & $8.65 \mathrm{e} 4$ & $4.42 \mathrm{e} 3$ & $4.09 \mathrm{e} 2$ & $8.65 \mathrm{e} 4$ & $1.57 \mathrm{e} 5$ & $1.68 \mathrm{e} 4$ \\
\hline $256 d$ & $4.03 e 2$ & $4.76 \mathrm{e} 4$ & $2.71 \mathrm{e}^{3}$ & $4.03 \mathrm{e} 2$ & $4.76 \mathrm{e} 4$ & $1.04 \mathrm{e} 5$ & $8.26 \mathrm{e} 3$ \\
\hline $1 y$ & $3.99 \mathrm{e} 2$ & $3.37 \mathrm{e} 4$ & $2.21 \mathrm{e}^{3}$ & $3.99 \mathrm{e} 2$ & $3.37 \mathrm{e} 4$ & $8.89 \mathrm{e} 4$ & $6.95 \mathrm{e} 3$ \\
\hline
\end{tabular}


Table C. 3

Surry Case 1 Annulus Gamma Dose Rates

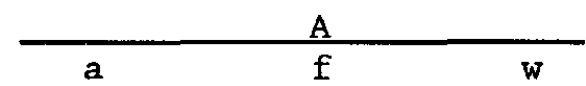

$\begin{array}{lll}5.94 \mathrm{e} 5 & 7.46 \mathrm{e} 4 & 1.31 \mathrm{e} 5 \\ 2.25 \mathrm{e} 5 & 1.74 \mathrm{e} 5 & 1.78 \mathrm{e} 5 \\ 1.42 \mathrm{e} 5 & 1.72 \mathrm{e} 5 & 1.81 \mathrm{e} 5 \\ 3.91 \mathrm{e} 4 & 1.71 \mathrm{e} 5 & 1.27 \mathrm{e} 5 \\ 1.67 \mathrm{e} 4 & 1.39 \mathrm{e} 5 & 1.02 \mathrm{e} 5 \\ 1.06 \mathrm{e} 4 & 1.19 \mathrm{e} 5 & 8.87 \mathrm{e} 4 \\ 4.38 \mathrm{e} 3 & 8.98 \mathrm{e} 4 & 6.53 \mathrm{e} 4 \\ 2.28 \mathrm{e} 3 & 6.24 \mathrm{e} 4 & 4.39 \mathrm{e} 4 \\ 1.56 \mathrm{e} 3 & 3.72 \mathrm{e} 4 & 2.40 \mathrm{e} 4 \\ 4.61 \mathrm{e} 2 & 1.93 \mathrm{e} 4 & 1.09 \mathrm{e} 4 \\ 5.71 \mathrm{e} 1 & 1.09 \mathrm{e} 4 & 5.7 \mathrm{e} 3 \\ 1.6 \mathrm{e} 0 & 7.08 \mathrm{e} 3 & 3.81 \mathrm{e} 3 \\ 7.7 \mathrm{e}-1 & 4.99 \mathrm{e} 3 & 3.03 \mathrm{e} 3 \\ 7.5 \mathrm{e}-1 & 3.38 \mathrm{e} 3 & 2.33 \mathrm{e} 3 \\ 7.4 \mathrm{e}-1 & 2.81 \mathrm{e} 3 & 2.07 \mathrm{e} 3\end{array}$

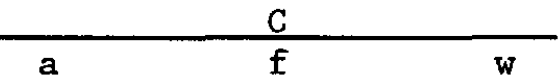

4. $90 \mathrm{e} 5$

$1.87 \mathrm{e} 5$

1. 17 e 5

3. $23 \mathrm{e} 4$

1. $32 \mathrm{e} 4$

$8.72 \mathrm{e} 3$

$3.62 \mathrm{e} 3$

$1.88 \mathrm{e} 3$

$1.09 \mathrm{e} 3$

3. $81 \mathrm{e} 2$

4. $66 \mathrm{el}$

1. $30 \mathrm{e} 0$

6. $4 \mathrm{e}-1$

6. $2 \mathrm{e}-1$

6. $1 \mathrm{e}-1$

$\begin{array}{ll}9.27 \mathrm{e} 3 & 1.64 \mathrm{e} 5 \\ 2.16 \mathrm{e} 4 & 1.80 \mathrm{e} 5 \\ 2.14 \mathrm{e} 4 & 1.97 \mathrm{e} 5 \\ 2.13 \mathrm{e} 4 & 1.64 \mathrm{e} 5 \\ 1.73 \mathrm{e} 4 & 1.32 \mathrm{e} 5 \\ 1.49 \mathrm{e} 4 & 1.13 \mathrm{e} 5 \\ 1.12 \mathrm{e} 4 & 8.37 \mathrm{e} 4 \\ 7.80 \mathrm{e} 3 & 5.64 \mathrm{e} 4 \\ 4.65 \mathrm{e} 3 & 3.11 \mathrm{e} 4 \\ 2.42 \mathrm{e} 3 & 1.32 \mathrm{e} 4 \\ 1.36 \mathrm{e} 3 & 7.27 \mathrm{e} 3 \\ 8.84 \mathrm{e} 2 & 4.99 \mathrm{e} 3 \\ 6.25 \mathrm{e} 2 & 3.90 \mathrm{e} 3 \\ 4.23 \mathrm{e} 2 & 3.02 \mathrm{e} 3 \\ 3.52 \mathrm{e} 2 & 2.63 \mathrm{e} 3\end{array}$

\begin{tabular}{|c|c|c|}
\hline $\mathbf{a}$ & $\mathrm{f}$ & $w$ \\
\hline $8.85 e 5$ & $1.18 \mathrm{e} 3$ & $3.24 \mathrm{e} 5$ \\
\hline $3.39 \mathrm{e} 5$ & $9.11 \mathrm{e} 3$ & $4.38 \mathrm{e} 5$ \\
\hline $2.12 \mathrm{e} 5$ & $2.74 \mathrm{e} 3$ & $3.74 \mathrm{e} 5$ \\
\hline $5.84 \mathrm{e} 4$ & $2.73 \mathrm{e} 3$ & $3.23 e 5$ \\
\hline $2.50 \mathrm{e} 4$ & $2.22 \mathrm{e} 3$ & $2.60 \mathrm{e} 5$ \\
\hline $1.58 \mathrm{e} 4$ & $1.91 \mathrm{e} 3$ & $2.23 e 5$ \\
\hline $6.55 \mathrm{e} 3$ & $1.44 \mathrm{e} 3$ & $1.67 \mathrm{e} 5$ \\
\hline $3.39 \mathrm{e} 3$ & $9.90 \mathrm{e} 2$ & $1.11 \mathrm{e} 5$ \\
\hline $1.98 \mathrm{e} 3$ & $5.96 \mathrm{e} 2$ & $6.10 \mathrm{e} 4$ \\
\hline $6.89 \mathrm{e} 2$ & $3.10 \mathrm{e} 2$ & $2.77 e^{4}$ \\
\hline $8.42 \mathrm{el}$ & $1.74 \mathrm{e} 2$ & $1.43 \mathrm{e}^{4}$ \\
\hline $2.4 \mathrm{eO}$ & $1.13 \mathrm{e} 2$ & $9.81 \mathrm{e} 3$ \\
\hline $1.15 \mathrm{e} 0$ & $8.01 e 1$ & $7.32 \mathrm{e} 3$ \\
\hline $1.12 \mathrm{e} 0$ & $5.42 \mathrm{el}$ & $5.95 \mathrm{e} 3$ \\
\hline $1.1 \mathrm{e} 0$ & $4.52 \mathrm{e} 1$ & $5.25 \mathrm{e} 3$ \\
\hline
\end{tabular}


Table C.4

Surry Case 1 Annulus Beta Dose Rates

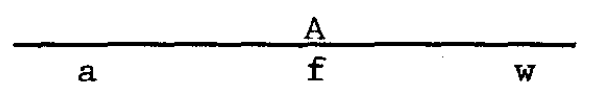

$\begin{array}{rccc}1 \mathrm{~h} & 2.14 \mathrm{e} 6 & 5.36 \mathrm{e} 5 & 5.64 \mathrm{e} 5 \\ 2 \mathrm{~h} & 1.11 \mathrm{e} 6 & 1.03 \mathrm{e} 6 & 7.38 \mathrm{e} 5 \\ 4 \mathrm{~h} & 9.41 \mathrm{e} 5 & 1.29 \mathrm{e} 6 & 3.39 \mathrm{e} 5 \\ 8 \mathrm{~h} & 3.65 \mathrm{e} 5 & 1.36 \mathrm{e} 6 & 5.23 \mathrm{e} 5 \\ 16 \mathrm{~h} & 2.33 \mathrm{e} 5 & 1.07 \mathrm{e} 6 & 3.68 \mathrm{e} 5 \\ 1 \mathrm{~d} & 1.87 \mathrm{e} 5 & 8.13 \mathrm{e} 5 & 2.91 \mathrm{e} 5 \\ 2 \mathrm{~d} & 1.14 \mathrm{e} 5 & 5.80 \mathrm{e} 5 & 2.08 \mathrm{e} 5 \\ 4 \mathrm{~d} & 7.75 \mathrm{e} 4 & 5.07 \mathrm{e} 5 & 1.35 \mathrm{e} 5 \\ 8 \mathrm{~d} & 4.72 \mathrm{e} 4 & 3.75 \mathrm{e} 5 & 1.01 \mathrm{e} 5 \\ 16 \mathrm{~d} & 1.62 \mathrm{e} 4 & 2.66 \mathrm{e} 5 & 6.21 \mathrm{e} 4 \\ 32 \mathrm{~d} & 2.92 \mathrm{e} 3 & 2.14 \mathrm{e} 5 & 4.43 \mathrm{e} 4 \\ 64 \mathrm{~d} & & & \\ 128 \mathrm{~d} & 7.82 \mathrm{e} 2 & 8.65 \mathrm{e} 4 & 1.84 \mathrm{e} 4 \\ 256 \mathrm{~d} & 7.45 \mathrm{e} 2 & 4.76 \mathrm{e} 4 & 1.92 \mathrm{e} 3 \\ 1 \mathrm{y} & 7.22 \mathrm{e} 2 & 3.37 \mathrm{e} 4 & 7.05 \mathrm{e} 2\end{array}$

\begin{tabular}{ccc} 
& $\mathrm{C}$ & \\
\hline $\mathrm{a}$ & $\mathrm{f}$ & $\mathrm{w}$ \\
$2.14 \mathrm{e} 6$ & - & $5.64 \mathrm{e} 5$ \\
$1.11 \mathrm{e} 6$ & - & $7.38 \mathrm{e} 5$ \\
$9.41 \mathrm{e} 5$ & - & $3.39 \mathrm{e} 5$ \\
$3.65 \mathrm{e} 5$ & - & $5.23 \mathrm{e} 5$ \\
$2.33 \mathrm{e} 5$ & - & $3.68 \mathrm{e} 5$ \\
$1.87 \mathrm{e} 5$ & - & $2.91 \mathrm{e} 5$ \\
$1.14 \mathrm{e} 5$ & - & $2.08 \mathrm{e} 5$ \\
$7.75 \mathrm{e} 5$ & - & $1.35 \mathrm{e} 5$ \\
$4.72 \mathrm{e} 4$ & - & $1.01 \mathrm{e} 5$ \\
$1.62 \mathrm{e} 4$ & - & $6.21 \mathrm{e} 4$ \\
$2.92 \mathrm{e} 3$ & - & $4.43 \mathrm{e} 4$ \\
$7.82 \mathrm{e} 2$ & - & $1.84 \mathrm{e} 4$ \\
$7.45 \mathrm{e} 2$ & - & $1.92 \mathrm{e} 3$ \\
$7.22 \mathrm{e} 2$ & - & $7.05 \mathrm{e} 2$
\end{tabular}

\begin{tabular}{ccc} 
& $\mathrm{E}$ & \\
\hline $\mathrm{a}$ & $\mathrm{f}$ & $\mathrm{w}$ \\
$2.14 \mathrm{e} 6$ & - & $5.64 \mathrm{e} 5$ \\
$1.11 \mathrm{e} 6$ & - & $7.38 \mathrm{e} 5$ \\
$9.41 \mathrm{e} 5$ & - & $3.39 \mathrm{e} 5$ \\
$3.65 \mathrm{e} 5$ & - & $5.23 \mathrm{e} 5$ \\
$2.33 \mathrm{e} 5$ & - & $3.68 \mathrm{e} 5$ \\
$1.87 \mathrm{e} 5$ & - & $2.91 \mathrm{e} 5$ \\
$1.14 \mathrm{e} 5$ & - & $2.08 \mathrm{e} 5$ \\
$7.75 \mathrm{e} 4$ & - & $1.35 \mathrm{e} 5$ \\
$4.72 \mathrm{e} 4$ & - & $1.01 \mathrm{e} 5$ \\
$1.62 \mathrm{e} 4$ & - & $6.21 \mathrm{e} 4$ \\
$2.92 \mathrm{e} 3$ & - & $4.43 \mathrm{e} 4$ \\
$7.82 \mathrm{e} 2$ & - & $1.84 \mathrm{e} 4$ \\
$7.45 \mathrm{e} 2$ & - & $1.92 \mathrm{e} 3$ \\
$7.22 \mathrm{e} 2$ & - & $7.05 \mathrm{e} 2$
\end{tabular}


Table C. 5

Surry Case 1 Dome Gamma Dose Rates

\begin{tabular}{|c|c|c|c|c|c|c|c|c|c|}
\hline & & $\mathrm{H}$ & & & $I$ & & & $\mathrm{~J}$ & \\
\hline & $a$ & $f$ & $\mathrm{w}$ & $a$ & $f$ & $\mathrm{w}$ & a & $\mathrm{f}$ & w \\
\hline $1 \mathrm{~h}$ & $1.20 \mathrm{e} 6$ & $6.47 \mathrm{e} 4$ & $4.08 \mathrm{e} 5$ & $1.84 \mathrm{e} 6$ & $9.72 \mathrm{e} 4$ & $2.34 \mathrm{e} 5$ & $1.72 \mathrm{e} 6$ & $4.42 \mathrm{e} 4$ & $3.48 \mathrm{e} 5$ \\
\hline $2 \mathrm{~h}$ & $4.58 \mathrm{e} 5$ & $1.51 \mathrm{e} 5$ & $4.29 \mathrm{e} 5$ & $7.03 \mathrm{e} 5$ & $2.26 \mathrm{e} 5$ & $3.24 \mathrm{e} 5$ & $6.62 \mathrm{e} 5$ & $1.03 \mathrm{e} 5$ & $4.82 \mathrm{e} 5$ \\
\hline $4 \mathrm{~h}$ & $2.86 e 5$ & $1.50 \mathrm{e} 5$ & $4.76 e 5$ & $4.4 e 5$ & $2.25 e 5$ & $2.68 \mathrm{e} 5$ & $4.13 \mathrm{e} 5$ & $1.02 \mathrm{e} 5$ & $4.00 \mathrm{e} 5$ \\
\hline $8 \mathrm{~h}$ & $7.89 \mathrm{e} 4$ & $1.49 \mathrm{e} 5$ & $4.06 e 5$ & $1.21 \mathrm{e} 5$ & $2.23 e 5$ & $2.33 \mathrm{e} 5$ & $1.14 \mathrm{e} 5$ & $1.01 \mathrm{e} 5$ & $3.47 \mathrm{e} 5$ \\
\hline $16 \mathrm{~h}$ & $3.38 \mathrm{e} 4$ & $1.21 e 5$ & $3.27 e 5$ & $5.19 \mathrm{e} 4$ & $1.81 \mathrm{e} 5$ & $1.88 \mathrm{e} 5$ & $4.88 \mathrm{e} 4$ & $8.28 \mathrm{e} 4$ & $2.79 e 5$ \\
\hline $1 \mathrm{~d}$ & $2.13 e^{4}$ & $1.04 \mathrm{e} 5$ & $2.82 \mathrm{e} 5$ & $3.27 \mathrm{e} 4$ & $1.56 \mathrm{e} 5$ & $1.62 \mathrm{e} 5$ & $3.08 \mathrm{e} 4$ & $7.14 \mathrm{e} 4$ & $2.40 \mathrm{e} 5$ \\
\hline $2 d$ & $8.86 \mathrm{e} 3$ & $7.84 \mathrm{e}^{4}$ & $2.09 \mathrm{e} 5$ & $1.36 \mathrm{e} 4$ & $1.17 \mathrm{e} 5$ & $1.20 \mathrm{e} 5$ & $1.28 \mathrm{e} 4$ & $5.35 \mathrm{e} 4$ & $1.78 \mathrm{e} 5$ \\
\hline $4 d$ & $4.58 \mathrm{e} 3$ & $5.45 e 4$ & $1.40 \mathrm{e} 5$ & $7.05 \mathrm{e} 3$ & $8.17 \mathrm{e} 4$ & $8.03 e 4$ & $6.63 \mathrm{e} 3$ & $3.72 \mathrm{e} 4$ & $1.20 \mathrm{e} 5$ \\
\hline $8 d$ & $1.42 \mathrm{e} 3$ & $3.25 \mathrm{e} 4$ & $7.7 \mathrm{e} 4$ & $2.67 \mathrm{e} 3$ & $4.87 e^{4}$ & $4.41 \mathrm{e} 4$ & $3.87 \mathrm{e} 3$ & $2.22 \mathrm{e} 4$ & $6.57 \mathrm{e} 4$ \\
\hline $16 \mathrm{~d}$ & $9.31 \mathrm{e} 2$ & $1.69 \mathrm{e} 4$ & $3.47 \mathrm{e} 4$ & $1.43 \mathrm{e} 3$ & $2.53 \mathrm{e} 4$ & $2.0 \mathrm{e} 4$ & $1.35 \mathrm{e} 3$ & $1.15 \mathrm{e} 4$ & $2.98 \mathrm{e} 4$ \\
\hline $32 d$ & $1.14 \mathrm{e} 2$ & $9.52 \mathrm{e} 3$ & $1.81 \mathrm{e} 4$ & $1.76 \mathrm{e} 2$ & $1.42 \mathrm{e}^{4}$ & $1.05 \mathrm{e} 4$ & $1.65 \mathrm{e} 2$ & $6.50 \mathrm{e} 3$ & $1.54 \mathrm{e} 4$ \\
\hline $64 d$ & $3.2 \mathrm{e} 0$ & $6.17 \mathrm{e}^{3}$ & $1.24 \mathrm{e} 4$ & $4.9 \mathrm{e} 0$ & $9.26 \mathrm{e} 3$ & $7.1 \mathrm{e} 3$ & $4.6 \mathrm{e} 0$ & $4.22 \mathrm{e} 3$ & $1.05 \mathrm{e} 4$ \\
\hline $128 \mathrm{~d}$ & $9.3 e-1$ & $4.36 \mathrm{e} 3$ & $9.73 \mathrm{e} 3$ & $1.26 \mathrm{e} 0$ & $6.54 \mathrm{e} 3$ & $5.6 \mathrm{e} 3$ & $1.9 \mathrm{e} 0$ & $2.98 \mathrm{e} 3$ & $8.28 \mathrm{e} 3$ \\
\hline $256 \mathrm{~d}$ & $1.52 \mathrm{e} 0$ & $2.95 \mathrm{e} 3$ & $7.45 \mathrm{e} 3$ & $2.34 \mathrm{e} 0$ & $4.42 \mathrm{e} 3$ & $4.27 \mathrm{e} 3$ & $2.2 \mathrm{e} 0$ & $2.02 \mathrm{e} 3$ & $6.43 \mathrm{e} 3$ \\
\hline $1 y$ & $1.49 \mathrm{e} 0$ & $2.46 \mathrm{e} 3$ & $6.5 \mathrm{e} 3$ & $2.29 \mathrm{e} 0$ & $3.69 \mathrm{e} 3$ & $3.70 \mathrm{e} 3$ & $2.15 \mathrm{e} 0$ & $1.68 \mathrm{e} 3$ & $5.57 \mathrm{e} 3$ \\
\hline
\end{tabular}


Table C. 6

Surry Case 1 Dome Beta Dose Rates
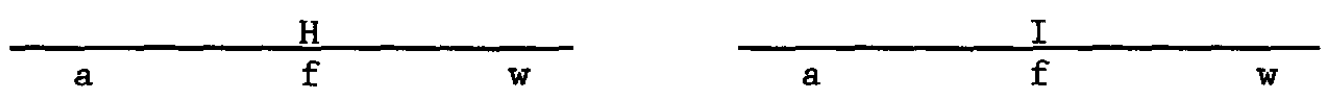

\begin{tabular}{|c|c|c|c|c|c|c|c|c|c|}
\hline & \multicolumn{3}{|c|}{$\mathrm{H}$} & \multicolumn{3}{|c|}{$I$} & \multicolumn{3}{|c|}{$\mathrm{J}$} \\
\hline & a & $f$ & $w$ & $a$ & $f$ & $w$ & a & $f$ & $w$ \\
\hline 1h & $5.56 e^{6}$ & $8.27 e 3$ & $4.04 \mathrm{e} 5$ & $5.56 e 6$ & $8.27 e^{3}$ & $6.3 e 2$ & $5.56 \mathrm{e} 5$ & - & $3.26 \mathrm{e} 5$ \\
\hline $2 \mathrm{~h}$ & 3.01 e 6 & $5.24 \mathrm{e} 4$ & $5.76 \mathrm{e} 5$ & $3.01 \mathrm{e} 6$ & $5.24 \mathrm{e} 4$ & $4.3 \mathrm{e} 0$ & 3.01 e 6 & - & $4.37 e 5$ \\
\hline $4 \mathrm{~h}$ & $2.37 e 6$ & $1.69 \mathrm{e} 4$ & $4.95 e 5$ & $2.37 e^{6}$ & $1.69 \mathrm{e} 4$ & $7.07 \mathrm{e} 2$ & $2.37 e^{6}$ & - & $2.94 \mathrm{E} 5$ \\
\hline $8 \mathrm{~h}$ & $8.77 \mathrm{e} 5$ & $1.99 \mathrm{e} 4$ & $5.50 \mathrm{e} 5$ & $8.77 \mathrm{e} 5$ & $1.99 \mathrm{e} 4$ & $9.52 \mathrm{e} 2$ & $8.77 \mathrm{e} 5$ & - & $3.65 \mathrm{e} 5$ \\
\hline $16 \mathrm{~h}$ & $5.63 e 5$ & $2.31 \mathrm{e} 3$ & $4.51 \mathrm{e} 5$ & $5.63 e 5$ & $2.31 \mathrm{e} 3$ & $9.6 \mathrm{e} 1$ & $5.63 \mathrm{e} 5$ & - & 2.81 e 5 \\
\hline $1 d$ & $4.51 e 5$ & $5.18 \mathrm{e} 2$ & $3.61 \mathrm{e} 5$ & $4.51 e 5$ & $5.18 \mathrm{e} 2$ & $8.4 e-1$ & $4.51 \mathrm{e} 5$ & - & $2.39 \mathrm{e} 5$ \\
\hline $2 d$ & $2.71 \mathrm{e} 5$ & $7.24 \mathrm{el}$ & $2.82 \mathrm{e} 5$ & $2.71 e 5$ & $7.24 \mathrm{e} 1$ & $1.16 \mathrm{e} 1$ & $2.71 e 5$ & - & $1.71 \mathrm{e} 5$ \\
\hline $4 d$ & $1.86 \mathrm{e} 5$ & $7.44 \mathrm{e} 1$ & $2.14 \mathrm{e} 5$ & $1.86 \mathrm{e} 5$ & $7.44 \mathrm{e} 1$ & - & $1.86 \mathrm{e} 5$ & - & $1.22 \mathrm{e} 5$ \\
\hline $8 d$ & $1.12 \mathrm{e} 5$ & $8.97 e 2$ & $1.46 \mathrm{e} 5$ & $1.12 \mathrm{e} 5$ & $8.97 e 2$ & - & $1.12 \mathrm{e} 5$ & - & $8.72 \mathrm{e} 4$ \\
\hline $16 d$ & $4.06 \mathrm{e} 4$ & $3.68 \mathrm{e} 2$ & $8.92 \mathrm{e} 4$ & $4.06 \mathrm{e} 4$ & $3.68 \mathrm{e} 2$ & - & $4.06 e 4$ & - & $5.55 e^{4}$ \\
\hline $32 d$ & $7.09 \mathrm{e} 3$ & $3.41 \mathrm{el}$ & $5.45 e 4$ & $7.09 \mathrm{e} 3$ & $3.41 \mathrm{e} 1$ & - & $7.09 \mathrm{e} 3$ & - & $3.58 \mathrm{e} 4$ \\
\hline $64 d$ & & & & & & & & & \\
\hline $128 d$ & $1.85 \mathrm{e} 3$ & $7.94 \mathrm{e} 1$ & $2.26 e^{4}$ & $1.85 \mathrm{e} 3$ & $7.94 \mathrm{e} 1$ & - & $1.85 \mathrm{e} 3$ & - & $1.39 \mathrm{e} 4$ \\
\hline $256 d$ & $1.79 \mathrm{e} 3$ & $1.52 \mathrm{e} 2$ & $1.49 \mathrm{e} 4$ & $1.79 \mathrm{e} 3$ & $1.52 \mathrm{el}$ & - & $1.79 \mathrm{e}^{3}$ & - & $8.91 \mathrm{e} 3$ \\
\hline $1 y$ & $1.73 \mathrm{e} 3$ & $9.7 \mathrm{e} 0$ & $1.24 \mathrm{e} 4$ & $1.73 \mathrm{e} 3$ & $9.70 \mathrm{e} 0$ & - & $1.73 \mathrm{e} 3$ & - & $7.02 \mathrm{e} 3$ \\
\hline
\end{tabular}


Table C.7

Surry Case 1 Steam Generator A Cubicle Gamma Dose Rates

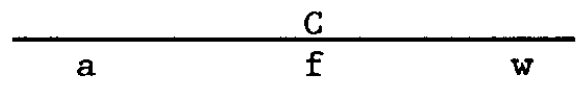

$\begin{array}{lll}8.73 \mathrm{e} 5 & 4.94 \mathrm{e} 4 & 7.26 \mathrm{e} 4 \\ 3.34 \mathrm{e} 5 & 1.15 \mathrm{e} 5 & 1.01 \mathrm{e} 5 \\ 2.08 \mathrm{e} 5 & 1.14 \mathrm{e} 5 & 8.40 \mathrm{e} 4 \\ 5.75 \mathrm{e} 4 & 1.13 \mathrm{e} 5 & 7.25 \mathrm{e} 4 \\ 2.45 \mathrm{e} 4 & 9.22 \mathrm{e} 4 & 5.83 \mathrm{e} 4 \\ 1.55 \mathrm{e} 4 & 7.94 \mathrm{e} 4 & 5.01 \mathrm{e} 4 \\ 6.44 \mathrm{e} 3 & 5.96 \mathrm{e} 4 & 3.7 \mathrm{e} 4 \\ 3.34 \mathrm{e} 3 & 4.14 \mathrm{e} 4 & 2.48 \mathrm{e} 4 \\ 1.94 \mathrm{e} 3 & 2.47 \mathrm{e} 4 & 1.37 \mathrm{e} 4 \\ 6.78 \mathrm{e} 2 & 1.28 \mathrm{e} 4 & 6.22 \mathrm{e} 3 \\ 8.29 \mathrm{e} 1 & 7.24 \mathrm{e} 3 & 3.18 \mathrm{e} 3 \\ 2.33 \mathrm{e} 0 & 4.69 \mathrm{e} 3 & 2.20 \mathrm{e} 3 \\ 1.13 \mathrm{e} 0 & 3.31 \mathrm{e} 3 & 1.72 \mathrm{e} 3 \\ 1.10 \mathrm{e} 0 & 2.24 \mathrm{e} 3 & 1.36 \mathrm{e} 3 \\ 1.08 \mathrm{e} 0 & 1.87 \mathrm{e} 3 & 1.15 \mathrm{e} 3\end{array}$

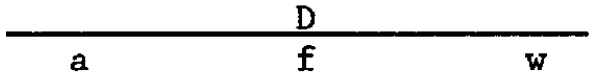

$\begin{array}{lll}4.77 \mathrm{e} 5 & 3.98 \mathrm{e} 4 & 1.57 \mathrm{e} 5 \\ 1.82 \mathrm{e} 5 & 9.28 \mathrm{e} 4 & 2.18 \mathrm{e} 5 \\ 1.14 \mathrm{e} 5 & 9.2 \mathrm{e} 4 & 1.79 \mathrm{e} 5 \\ 3.14 \mathrm{e} 4 & 9.15 \mathrm{e} 4 & 1.56 \mathrm{e} 5 \\ 1.34 \mathrm{e} 4 & 7.43 \mathrm{e} 4 & 1.25 \mathrm{e} 5 \\ 8.49 \mathrm{e} 3 & 6.4 \mathrm{e} 4 & 1.08 \mathrm{e} 5 \\ 3.52 \mathrm{e} 3 & 4.80 \mathrm{e} 4 & 8.05 \mathrm{e} 4 \\ 1.82 \mathrm{e} 3 & 3.34 \mathrm{e} 4 & 5.38 \mathrm{e} 4 \\ 1.06 \mathrm{e} 3 & 1.99 \mathrm{e} 4 & 2.95 \mathrm{e} 4 \\ 3.71 \mathrm{e} 2 & 1.03 \mathrm{e} 4 & 1.34 \mathrm{e} 4 \\ 4.53 \mathrm{e} 1 & 5.84 \mathrm{e} 3 & 7.01 \mathrm{e} 3 \\ 1.27 \mathrm{e} 0 & 3.78 \mathrm{e} 3 & 4.76 \mathrm{e} 3 \\ 6.18 \mathrm{e}-1 & 2.67 \mathrm{e} 3 & 3.73 \mathrm{e} 3 \\ 6.04 \mathrm{e}-1 & 1.80 \mathrm{e} 3 & 2.88 \mathrm{e} 3 \\ 5.93 \mathrm{e}-1 & 1.51 \mathrm{e} 3 & 2.5 \mathrm{e} 3\end{array}$

\begin{tabular}{ccc}
\multicolumn{3}{c}{$\mathrm{E}$} \\
\hline $\mathrm{a}$ & $\mathrm{f}$ & $\mathrm{w}$ \\
$4.59 \mathrm{e} 5$ & $3.99 \mathrm{e} 4$ & $1.57 \mathrm{e} 5$ \\
$1.76 \mathrm{e} 5$ & $9.31 \mathrm{e} 4$ & $2.16 \mathrm{e} 5$ \\
$1.09 \mathrm{e} 5$ & $9.23 \mathrm{e} 4$ & $1.80 \mathrm{e} 5$ \\
$3.02 \mathrm{e} 4$ & $9.18 \mathrm{e} 4$ & $1.56 \mathrm{e} 5$ \\
$1.29 \mathrm{e} 4$ & $7.45 \mathrm{e} 4$ & $1.25 \mathrm{e} 5$ \\
$8.17 \mathrm{e} 3$ & $6.42 \mathrm{e} 4$ & $1.08 \mathrm{e} 5$ \\
$3.39 \mathrm{e} 3$ & $4.82 \mathrm{e} 4$ & $7.94 \mathrm{e} 4$ \\
$1.76 \mathrm{e} 3$ & $3.35 \mathrm{e} 4$ & $5.34 \mathrm{e} 4$ \\
$1.02 \mathrm{e} 3$ & $1.99 \mathrm{e} 4$ & $1.95 \mathrm{e} 4$ \\
$3.57 \mathrm{e} 2$ & $1.04 \mathrm{e} 4$ & $1.33 \mathrm{e} 4$ \\
$4.36 \mathrm{e} 1$ & $5.85 \mathrm{e} 3$ & $6.91 \mathrm{e} 3$ \\
$1.23 \mathrm{e} 0$ & $3.79 \mathrm{e} 3$ & $4.75 \mathrm{e} 3$ \\
$5.95-1$ & $2.68 \mathrm{e} 3$ & $3.71 \mathrm{e} 3$ \\
$5.82 \mathrm{e}-1$ & $1.81 \mathrm{e} 3$ & $2.86 \mathrm{e} 3$ \\
$5.71 \mathrm{e}-1$ & $1.51 \mathrm{e} 3$ & $2.49 \mathrm{e} 3$ \\
& &
\end{tabular}


Table C. 8

Surry Case 1 Steam Generator A Cubicle Beta Dose Rates

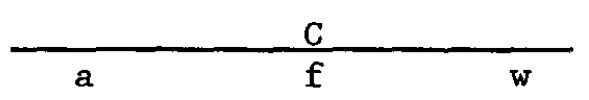

$\begin{array}{lll}8.03 \mathrm{e} 6 & 2.62 \mathrm{e} 2 & 4.34 \mathrm{e} 2 \\ 4.33 \mathrm{e} 6 & 6.04 \mathrm{e} 2 & 5.05 \mathrm{e} 2 \\ 3.58 \mathrm{e} 6 & 7.30 \mathrm{e} 2 & 4.11 \mathrm{e} 2 \\ 1.33 \mathrm{e} 6 & 8.36 \mathrm{e} 2 & 3.28 \mathrm{e} 2 \\ 8.99 \mathrm{e} 5 & 7.87 \mathrm{e} 2 & \\ 7.09 \mathrm{e} 5 & 5.87 \mathrm{e} 2 & 2.24 \mathrm{e} 2 \\ 4.20 \mathrm{e} 5 & 4.60 \mathrm{e} 2 & 1.39 \mathrm{e} 2 \\ 3.01 \mathrm{e} 5 & 3.50 \mathrm{e} 2 & \\ 1.82 \mathrm{e} 5 & 2.60 \mathrm{e} 2 & 7.20 \mathrm{el} \\ 6.61 \mathrm{e} 4 & 1.84 \mathrm{e} 2 & \\ 1.12 \mathrm{e} 4 & 1.30 \mathrm{e} 2 & 3.30 \mathrm{el} \\ 2.90 \mathrm{e} 3 & 4.70 \mathrm{el} & 1.40 \mathrm{el} \\ 2.78 \mathrm{e} 3 & 2.11 \mathrm{e} 1 & 5.40 \mathrm{e} 0\end{array}$

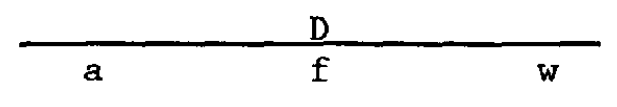

$\begin{array}{lll}8.03 \mathrm{e} 6 & 7.02 \mathrm{e} 5 & 7.71 \mathrm{e} 5 \\ 4.33 \mathrm{e} 6 & 1.71 \mathrm{e} 6 & 1.11 \mathrm{e} 6 \\ 3.58 \mathrm{e} 6 & 2.13 \mathrm{e} 6 & 1.06 \mathrm{e} 6 \\ 1.33 \mathrm{e} 6 & 2.39 \mathrm{e} 6 & 9.80 \mathrm{e} 5 \\ 8.99 \mathrm{e} 5 & 2.43 \mathrm{e} 6 & \\ 7.09 \mathrm{e} 5 & 1.77 \mathrm{e} 6 & 7.14 \mathrm{e} 5 \\ 4.20 \mathrm{e} 5 & 1.28 \mathrm{e} 6 & 5.31 \mathrm{e} 5 \\ 3.01 \mathrm{e} 5 & 1.00 \mathrm{e} 6 & \\ 1.82 \mathrm{e} 5 & 8.28 \mathrm{e} 5 & 2.67 \mathrm{e} 5 \\ 6.61 \mathrm{e} 4 & 4.92 \mathrm{e} 5 & \\ 1.12 \mathrm{e} 4 & 3.60 \mathrm{e} 5 & 1.05 \mathrm{e} 5 \\ 2.90 \mathrm{e} 3 & 1.31 \mathrm{e} 5 & 4.11 \mathrm{e} 4 \\ 2.78 \mathrm{e} 3 & 6.33 \mathrm{e} 4 & 2.06 \mathrm{e} 4\end{array}$

\begin{tabular}{ccc} 
& $\mathrm{E}$ & $\mathrm{w}$ \\
\hline $\mathrm{a}$ & $\mathrm{f}$ & \\
$8.03 \mathrm{e} 6$ & $5.53 \mathrm{e} 5$ & $7.32 \mathrm{e} 5$ \\
$4.33 \mathrm{e} 6$ & $1.18 \mathrm{e} 6$ & $1.09 \mathrm{e} 6$ \\
$3.58 \mathrm{e} 6$ & $1.65 \mathrm{e} 6$ & $1.07 \mathrm{e} 6$ \\
$1.33 \mathrm{e} 6$ & $1.75 \mathrm{e} 6$ & $8.73 \mathrm{e} 5$ \\
$8.99 \mathrm{e} 5$ & $1.69 \mathrm{e} 6$ & \\
$7.09 \mathrm{e} 5$ & $1.24 \mathrm{e} 6$ & $6.33 \mathrm{e} 5$ \\
$4.20 \mathrm{e} 5$ & $1.00 \mathrm{e} 6$ & $4.81 \mathrm{e} 5$ \\
$3.01 \mathrm{e} 5$ & $7.98 \mathrm{e} 5$ & \\
$1.82 \mathrm{e} 5$ & $5.21 \mathrm{e} 5$ & $2.44 \mathrm{e} 5$ \\
$6.61 \mathrm{e} 4$ & $4.07 \mathrm{e} 5$ & \\
$1.12 \mathrm{e} 4$ & $2.70 \mathrm{e} 5$ & $9.39 \mathrm{e} 4$ \\
$2.90 \mathrm{e} 3$ & $1.15 \mathrm{e} 5$ & $3.49 \mathrm{e} 4$ \\
$2.78 \mathrm{e} 3$ & $4.77 \mathrm{e} 4$ & $2.00 \mathrm{e} 4$ \\
\hline
\end{tabular}


Table C. 9

Surry Case 1 RHR Cubicle Gamma Dose Rates

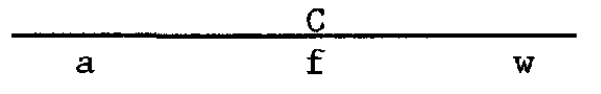

$\begin{array}{lll}5.49 \mathrm{e} 5 & 1.08 \mathrm{e} 5 & 7.30 \mathrm{e} 4 \\ 2.40 \mathrm{e} 5 & 2.53 \mathrm{e} 5 & 8.70 \mathrm{e} 4 \\ 1.50 \mathrm{e} 5 & 2.51 \mathrm{e} 5 & 7.40 \mathrm{e} 4 \\ 4.13 \mathrm{e} 4 & 2.49 \mathrm{e} 5 & 6.97 \mathrm{e} 4 \\ 1.76 \mathrm{e} 4 & 2.02 \mathrm{e} 5 & 5.24 \mathrm{e} 4 \\ 1.11 \mathrm{e} 4 & 1.74 \mathrm{e} 5 & 4.49 \mathrm{e} 4 \\ 4.62 \mathrm{e} 3 & 1.30 \mathrm{e} 5 & 3.44 \mathrm{e} 4 \\ 2.40 \mathrm{e} 3 & 9.10 \mathrm{e} 4 & 2.26 \mathrm{e} 4 \\ 1.39 \mathrm{e} 3 & 5.42 \mathrm{e} 4 & 1.23 \mathrm{e} 4 \\ 4.87 \mathrm{e} 2 & 2.82 \mathrm{e} 4 & 5.51 \mathrm{e} 3 \\ 5.95 \mathrm{e} 1 & 1.59 \mathrm{e} 4 & 3.04 \mathrm{e} 3 \\ 1.67 \mathrm{e} 0 & 1.03 \mathrm{e} 4 & 2.00 \mathrm{e} 3 \\ 8.12 \mathrm{e}-1 & 7.28 \mathrm{e} 3 & 1.54 \mathrm{e} 3 \\ 7.94 \mathrm{e}-1 & 4.92 \mathrm{e} 3 & 1.19 \mathrm{e} 3 \\ 7.78 \mathrm{e}-1 & 4.10 \mathrm{e} 3 & 1.04 \mathrm{e} 3\end{array}$

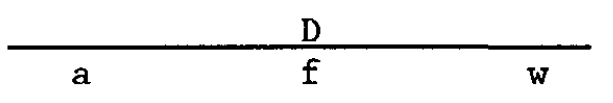

$\begin{array}{lll}3.40 \mathrm{e} 5 & 8.25 \mathrm{e} 4 & 2.08 \mathrm{e} 5 \\ 1.75 \mathrm{e} 5 & 1.93 \mathrm{e} 5 & 2.02 \mathrm{e} 5 \\ 1.09 \mathrm{e} 5 & 1.91 \mathrm{e} 5 & 1.68 \mathrm{e} 5 \\ 3.02 \mathrm{e} 4 & 1.90 \mathrm{e} 5 & 1.45 \mathrm{e} 5 \\ 1.29 \mathrm{e} 4 & 1.54 \mathrm{e} 5 & 1.17 \mathrm{e} 5 \\ 8.16 \mathrm{e} 3 & 1.33 \mathrm{e} 5 & 9.98 \mathrm{e} 4 \\ 3.39 \mathrm{e} 3 & 9.98 \mathrm{e} 4 & 7.38 \mathrm{e} 4 \\ 1.75 \mathrm{e} 3 & 6.93 \mathrm{e} 4 & 5.0 \mathrm{e} 4 \\ 1.02 \mathrm{e} 3 & 4.13 \mathrm{e} 4 & 2.77 \mathrm{e} 4 \\ 3.56 \mathrm{e} 2 & 2.15 \mathrm{e} 4 & 1.24 \mathrm{e} 4 \\ 4.36 \mathrm{e} 1 & 1.21 \mathrm{e} 4 & 6.56 \mathrm{e} 3 \\ 1.22 \mathrm{e} 0 & 7.86 \mathrm{e} 3 & 4.44 \mathrm{e} 3 \\ 5.94 \mathrm{e}-1 & 5.55 \mathrm{e} 3 & 3.45 \mathrm{e} 3 \\ 5.81 \mathrm{e}-1 & 3.75 \mathrm{e} 3 & 2.66 \mathrm{e} 3 \\ 5.70 \mathrm{e}-1 & 3.13 \mathrm{e} 3 & 2.31 \mathrm{e} 3\end{array}$

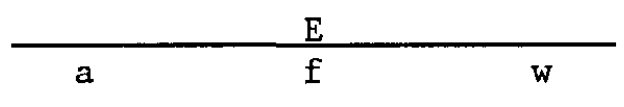

$\begin{array}{lll}3.73 \mathrm{e} 5 & 7.86 \mathrm{e} 4 & 1.51 \mathrm{e} 5 \\ 1.92 \mathrm{e} 5 & 1.83 \mathrm{e} 5 & 2.15 \mathrm{e} 5 \\ 1.20 \mathrm{e} 5 & 1.82 \mathrm{e} 5 & 1.74 \mathrm{e} 5 \\ 3.31 \mathrm{e} 4 & 1.81 \mathrm{e} 5 & 1.51 \mathrm{e} 5 \\ 1.41 \mathrm{e} 4 & 1.47 \mathrm{e} 5 & 1.21 \mathrm{e} 5 \\ 3.93 \mathrm{e} 3 & 1.26 \mathrm{e} 5 & 1.05 \mathrm{e} 5 \\ 3.71 \mathrm{e} 3 & 9.50 \mathrm{e} 4 & 7.83 \mathrm{e} 4 \\ 1.92 \mathrm{e} 3 & 6.6 \mathrm{e} 4 & 5.21 \mathrm{e} 4 \\ 1.12 \mathrm{e} 3 & 3.93 \mathrm{e} 4 & 2.86 \mathrm{e} 4 \\ 3.90 \mathrm{e} 2 & 2.05 \mathrm{e} 4 & 1.29 \mathrm{e} 4 \\ 4.77 \mathrm{e} 1 & 1.15 \mathrm{e} 4 & 6.75 \mathrm{e} 3 \\ 1.34 \mathrm{e} 0 & 7.49 \mathrm{e} 3 & 4.61 \mathrm{e} 3 \\ 6.51 \mathrm{e}-1 & 5.27 \mathrm{e} 3 & 3.60 \mathrm{e} 3 \\ 6.36 \mathrm{e}-1 & 3.57 \mathrm{e} 3 & 2.77 \mathrm{e} 3 \\ 6.24 \mathrm{e}-1 & 2.98 \mathrm{e} 3 & 2.42 \mathrm{e} 3\end{array}$


Table C.10

Surry Case 1 RHR Cubicle Beta Dose Rates

\begin{tabular}{|c|c|c|c|c|c|c|c|c|c|}
\hline & \multicolumn{3}{|c|}{ C } & \multicolumn{3}{|c|}{ D } & \multicolumn{3}{|c|}{$E$} \\
\hline & $a$ & $f$ & $w$ & $a$ & $f$ & $w$ & $\mathrm{a}$ & $f$ & $w$ \\
\hline $1 \mathrm{~h}$ & $7.92 \mathrm{e} 6$ & $1.29 \mathrm{e} 3$ & $2.29 \mathrm{e} 2$ & $7.92 \mathrm{e} 6$ & $5.24 \mathrm{e} 5$ & $7.54 \mathrm{e} 5$ & $7.92 \mathrm{e} 6$ & $5.91 \mathrm{e} 5$ & $4.30 \mathrm{e} 5$ \\
\hline $2 \mathrm{~h}$ & $4.21 \mathrm{e} 6$ & $2.86 \mathrm{e} 3$ & $2.95 \mathrm{e} 2$ & $4.21 \mathrm{e} 6$ & $1.06 \mathrm{e} 6$ & $9.77 \mathrm{e} 5$ & 4.21 e 6 & $6.03 e 5$ & $1.03 \mathrm{e} 6$ \\
\hline $4 \mathrm{~h}$. & $3.56 \mathrm{e} 6$ & $3.29 \mathrm{e} 3$ & $2.43 \mathrm{e} 2$ & $3.56 \mathrm{e} 6$ & $1.30 \mathrm{e} 6$ & $9.52 \mathrm{e} 5$ & $3.56 \mathrm{e} 6$ & $1.23 \mathrm{e} 6$ & $5.98 \mathrm{e} 5$ \\
\hline $8 \mathrm{~h}$ & $1.34 \mathrm{e} 6$ & $3.48 \mathrm{e} 3$ & $2.07 \mathrm{e} 2$ & $1.34 \mathrm{e} 6$ & $1.62 \mathrm{e} 6$ & $9.55 \mathrm{e} 5$ & $1.34 \mathrm{e} 6$ & $1.32 \mathrm{e} 6$ & $5.42 \mathrm{e} 5$ \\
\hline $16 \mathrm{~h}$ & $8.85 e 5$ & $2.61 \mathrm{e} 3$ & $1.39 \mathrm{e} 2$ & $8.85 e 5$ & $9.66 \mathrm{e} 5$ & $7.85 e 5$ & $8.85 e 5$ & $8.95 \mathrm{e} 5$ & $4.34 \mathrm{e} 5$ \\
\hline $1 d$ & $7.28 \mathrm{e} 5$ & $2.24 \mathrm{e} 3$ & $1.27 \mathrm{e} 2$ & $7.28 \mathrm{e} 5$ & $7.9 \mathrm{e} 5$ & $6.87 e 5$ & $7.28 \mathrm{e} 5$ & $7.32 \mathrm{e} 5$ & $3.73 \mathrm{e} 5$ \\
\hline $2 d$ & $4.34 e 5$ & $1.55 \mathrm{e} 3$ & $8.39 \mathrm{el}$ & $4.34 \mathrm{e} 5$ & $6.04 \mathrm{e} 5$ & $4.75 \mathrm{e} 5$ & $4.34 \mathrm{e} 5$ & $5.64 \mathrm{e} 5$ & $2.62 \mathrm{e} 5$ \\
\hline $4 d$ & $3.06 \mathrm{e} 5$ & $1.13 \mathrm{e} 3$ & $5.64 \mathrm{e} 1$ & $3.06 e 5$ & $4.59 \mathrm{e} 5$ & $3.50 \mathrm{e} 5$ & $3.06 \mathrm{e} 5$ & $4.62 e 5$ & $1.83 \mathrm{e} 5$ \\
\hline $8 d$ & $1.84 \mathrm{e} 5$ & $9.39 \mathrm{e} 2$ & $4.19 \mathrm{e} 1$ & $1.84 \mathrm{e} 5$ & $4.74 e 5$ & $2.49 \mathrm{e} 5$ & $1.84 \mathrm{e} 5$ & $3.70 \mathrm{e} 5$ & $1.30 \mathrm{e} 5$ \\
\hline $16 d$ & $6.88 \mathrm{e} 4$ & $6.68 \mathrm{e} 2$ & & $6.88 \mathrm{e} 4$ & $2.24 \mathrm{e} 5$ & & $6.88 \mathrm{e} 4$ & $2.20 \mathrm{e} 5$ & \\
\hline $32 d$ & $1.14 \mathrm{e} 4$ & $5.22 \mathrm{e} 2$ & $2.11 \mathrm{e} 1$ & $1.14 \mathrm{e} 4$ & $1.92 \mathrm{e} 5$ & $9.02 \mathrm{e} 4$ & $1.14 \mathrm{e} 4$ & $2.22 \mathrm{e} 5$ & $5.23 e 4$ \\
\hline $64 d$ & $3.24 e 3$ & $3.29 \mathrm{e} 2$ & $1.34 \mathrm{e} 1$ & $3.24 \mathrm{e} 3$ & $1.21 \mathrm{e} 5$ & $5.74 e^{4}$ & $3.24 \mathrm{e} 3$ & $1.40 \mathrm{e} 5$ & $3.33 e 4$ \\
\hline $128 d$ & $2.91 \mathrm{e} 3$ & & & $2.91 \mathrm{e} 3$ & $3.78 \mathrm{e} 4$ & & $2.91 \mathrm{e} 3$ & $1.98 \mathrm{e} 4$ & \\
\hline $256 d$ & $2.86 \mathrm{e} 3$ & $1.14 \mathrm{e} 2$ & $4.08 \mathrm{e} 0$ & $2.86 \mathrm{e} 3$ & $3.77 \mathrm{e} 4$ & $2.41 \mathrm{e} 4$ & $2.86 \mathrm{e} 3$ & $4.35 e 4$ & $1.32 \mathrm{e} 4$ \\
\hline $1 y$ & $2.82 \mathrm{e} 3$ & $8.46 \mathrm{e} 1$ & $2.87 \mathrm{e} 0$ & $2.82 \mathrm{e} 3$ & $3.51 \mathrm{e} 4$ & $2.00 \mathrm{e} 4$ & $2.82 \mathrm{e} 3$ & $2.08 \mathrm{e} 4$ & $1.04 \mathrm{e} 4$ \\
\hline
\end{tabular}


Table C.11

Surry Case 2 Basement Gamma Dose Rates

\begin{tabular}{|c|c|c|c|c|c|c|}
\hline & & A & & & $\mathbf{F}$ & \\
\hline & a & $f$ & $w$ & a & f & w \\
\hline 1h & $7.99 \mathrm{e} 5$ & $3.07 \mathrm{e} 5$ & $1.40 \mathrm{e} 4$ & $5.51 e 5$ & $2.08 \mathrm{e} 5$ & $8.00 \mathrm{e} 4$ \\
\hline $2 h$ & $2.71 \mathrm{e} 5$ & $7.07 \mathrm{e} 5$ & $3.20 \mathrm{e} 4$ & $1.86 \mathrm{e} 5$ & $4.80 \mathrm{e} 5$ & $1.10 \mathrm{e} 5$ \\
\hline $4 \mathrm{~h}$ & $1.24 \mathrm{e} 5$ & $6.01 e 5$ & $2.60 \mathrm{e} 4$ & $8.52 e^{4}$ & $4.08 e 5$ & $9.28 \mathrm{e} 4$ \\
\hline $8 \mathrm{~h}$ & $3.73 e 4$ & $5.31 \mathrm{e} 5$ & $2.17 \mathrm{e} 4$ & $2.57 e 4$ & $3.60 \mathrm{e} 5$ & 8. $23 e^{4}$ \\
\hline $16 \mathrm{~h}$ & $2.09 \mathrm{e} 4$ & $4.21 e 5$ & $1.81 \mathrm{e} 4$ & $1.44 \mathrm{e} 4$ & $2.86 e 5$ & $6.56 e^{4}$ \\
\hline $1 d$ & $1.42 \mathrm{e} 4$ & $3.61 \mathrm{e} 5$ & $1.48 \mathrm{e} 4$ & $9.81 \mathrm{e} 3$ & $2.44 \mathrm{e} 5$ & $5.62 \mathrm{e} 4$ \\
\hline $2 d$ & $5.91 \mathrm{e} 3$ & $2.65 \mathrm{e} 5$ & $1.11 \mathrm{e} 4$ & $4.07 \mathrm{e} 3$ & $1.80 \mathrm{e} 5$ & $4.09 \mathrm{e} 4$ \\
\hline $4 d$ & $3.06 \mathrm{e} 3$ & $1.73 \mathrm{e} 5$ & $7.94 \mathrm{e} 3$ & $2.10 \mathrm{e} 3$ & $1.17 \mathrm{e} 5$ & $2.69 e^{4}$ \\
\hline $8 d$ & $1.79 \mathrm{e} 3$ & $8.91 \mathrm{e} 4$ & $3.71 e 3$ & $1.23 \mathrm{e} 3$ & $6.05 \mathrm{e} 4$ & $1.37 \mathrm{e} 4$ \\
\hline $16 d$ & $6.22 \mathrm{e} 2$ & $3.47 \mathrm{e} 4$ & $1.48 \mathrm{e} 3$ & $4.29 \mathrm{e} 2$ & $2.35 \mathrm{e} 4$ & $5.37 \mathrm{e} 3$ \\
\hline $32 d$ & $7.60 \mathrm{e} 1$ & $1.62 \mathrm{e} 4$ & $7.24 \mathrm{e} 2$ & $5.24 \mathrm{e} 1$ & $1.10 \mathrm{e} 4$ & $2.45 \mathrm{e} 3$ \\
\hline $64 d$ & $2.14 \mathrm{e} 0$ & $1.18 \mathrm{e} 4$ & $5.98 \mathrm{e} 2$ & $1.47 \mathrm{e} 0$ & $8.05 \mathrm{e} 3$ & $1.81 \mathrm{e} 3$ \\
\hline $128 d$ & $1.04 \mathrm{e} 0$ & $1.04 \mathrm{e} 4$ & $4.99 \mathrm{e} 2$ & $7.15 \mathrm{e}-1$ & $7.09 \mathrm{e} 3$ & $1.61 \mathrm{e} 3$ \\
\hline $256 d$ & $1.01 \mathrm{e} 0$ & $9.06 \mathrm{e} 3$ & $3.79 \mathrm{e} 2$ & $6.99 e-1$ & $6.15 \mathrm{e} 3$ & $1.40 \mathrm{e} 3$ \\
\hline $1 y$ & $9.95 e-1$ & $8.14 \mathrm{e} 3$ & $3.49 \mathrm{e} 2$ & $6.85 e-1$ & $5.53 e 3$ & $1.26 \mathrm{e} 3$ \\
\hline
\end{tabular}


Table C.12

Surry Case 2 Basement Beta Dose Rates
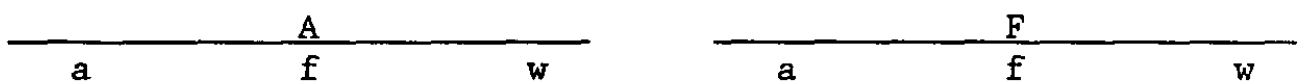

\begin{tabular}{rllllll}
$1 \mathrm{~h}$ & $1.22 \mathrm{e} 6$ & $5.17 \mathrm{e} 5$ & $1.06 \mathrm{e} 5$ & $1.22 \mathrm{e} 6$ & $5.17 \mathrm{e} 5$ & $2.66 \mathrm{e} 6$ \\
$2 \mathrm{~h}$ & $4.78 \mathrm{e} 5$ & $1.24 \mathrm{e} 6$ & $1.48 \mathrm{e} 5$ & $4.78 \mathrm{e} 5$ & $1.24 \mathrm{e} 6$ & $4.04 \mathrm{e} 6$ \\
$4 \mathrm{~h}$ & $2.60 \mathrm{e} 5$ & $9.50 \mathrm{e} 5$ & $1.42 \mathrm{e} 5$ & $2.60 \mathrm{e} 5$ & $9.50 \mathrm{e} 5$ & $3.71 \mathrm{e} 6$ \\
$8 \mathrm{~h}$ & $1.45 \mathrm{e} 5$ & $7.42 \mathrm{e} 5$ & $9.18 \mathrm{e} 4$ & $1.45 \mathrm{e} 5$ & $7.42 \mathrm{e} 5$ & $3.38 \mathrm{e} 6$ \\
$16 \mathrm{~h}$ & $1.27 \mathrm{e} 5$ & $6.08 \mathrm{e} 5$ & $7.95 \mathrm{e} 4$ & $1.27 \mathrm{e} 5$ & $6.08 \mathrm{e} 5$ & $2.65 \mathrm{e} 6$ \\
$1 \mathrm{~d}$ & $9.96 \mathrm{e} 4$ & $4.10 \mathrm{e} 5$ & $5.22 \mathrm{e} 4$ & $9.96 \mathrm{e} 4$ & $4.10 \mathrm{e} 5$ & $2.21 \mathrm{e} 6$ \\
$2 \mathrm{~d}$ & $6.56 \mathrm{e} 4$ & $2.37 \mathrm{e} 5$ & $4.00 \mathrm{e} 4$ & $6.56 \mathrm{e} 4$ & $2.37 \mathrm{e} 5$ & $1.62 \mathrm{e} 6$ \\
$4 \mathrm{~d}$ & $4.18 \mathrm{e} 4$ & $1.58 \mathrm{e} 5$ & $2.43 \mathrm{e} 4$ & $4.18 \mathrm{e} 4$ & $1.58 \mathrm{e} 5$ & $1.09 \mathrm{e} 6$ \\
$8 \mathrm{~d}$ & $2.54 \mathrm{e} 4$ & $8.63 \mathrm{e} 4$ & $1.22 \mathrm{e} 4$ & $2.54 \mathrm{e} 4$ & $8.63 \mathrm{e} 4$ & $6.38 \mathrm{e} 5$ \\
$16 \mathrm{~d}$ & $8.91 \mathrm{e} 3$ & $4.00 \mathrm{e} 4$ & $6.94 \mathrm{e} 3$ & $8.91 \mathrm{e} 3$ & $4.00 \mathrm{e} 4$ & $3.31 \mathrm{e} 5$ \\
$32 \mathrm{~d}$ & $1.59 \mathrm{e} 3$ & $2.00 \mathrm{e} 4$ & $3.42 \mathrm{e} 3$ & $1.59 \mathrm{e} 3$ & $2.00 \mathrm{e} 4$ & $1.69 \mathrm{e} 5$ \\
$64 \mathrm{~d}$ & $4.58 \mathrm{e} 2$ & $1.32 \mathrm{e} 4$ & $2.07 \mathrm{e} 3$ & $4.58 \mathrm{e} 2$ & $1.32 \mathrm{e} 4$ & $1.06 \mathrm{e} 5$ \\
$128 \mathrm{~d}$ & $4.19 \mathrm{e} 2$ & $9.25 \mathrm{e} 3$ & $1.83 \mathrm{e} 3$ & $4.19 \mathrm{e} 2$ & $9.25 \mathrm{e} 3$ & $8.49 \mathrm{e} 4$ \\
$256 \mathrm{~d}$ & $4.06 \mathrm{e} 2$ & $5.10 \mathrm{e} 3$ & $1.41 \mathrm{e} 3$ & $4.06 \mathrm{e} 2$ & $5.10 \mathrm{e} 3$ & $7.30 \mathrm{e} 4$ \\
$1 \mathrm{y}$ & $4.00 \mathrm{e} 2$ & $3.52 \mathrm{e} 3$ & $1.21 \mathrm{e} 3$ & $4.00 \mathrm{e} 2$ & $3.52 \mathrm{e} 3$ & $6.75 \mathrm{e} 4$ \\
\hline
\end{tabular}


Table C. 13

Surxy Case 2 Annulus Gamma Dose Rates
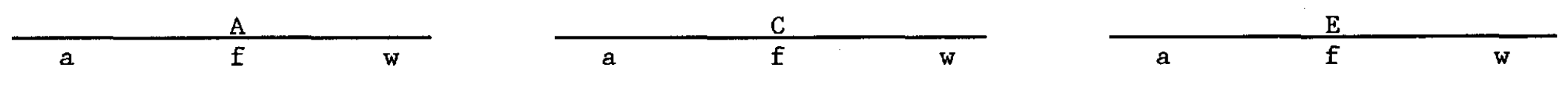

\begin{tabular}{|c|c|c|c|}
\hline 1h & $5.93 e 5$ & $7.46 e^{4}$ & $1.28 \mathrm{e} 5$ \\
\hline $2 \mathrm{~h}$ & $2.01 \mathrm{e} 5$ & $1.71 \mathrm{e} 5$ & $1.84 \mathrm{e}$ \\
\hline $4 h$ & $9.16 \mathrm{e} 4$ & $1.45 \mathrm{e} 5$ & 1.52 \\
\hline $8 h$ & $2.77 \mathrm{e} 4$ & 1. $28 \mathrm{e} 5$ & 1.34 \\
\hline $16 \mathrm{~h}$ & $1.56 \mathrm{e} 4$ & $1.02 \mathrm{e} 5$ & $1.06 \epsilon$ \\
\hline $1 d$ & $8.89 \mathrm{e} 3$ & $8.73 \mathrm{e} 4$ & 8.98 \\
\hline $2 d$ & $4.38 \mathrm{e} 3$ & $6.42 \mathrm{e} 4$ & 6.74 \\
\hline $4 d$ & $2.27 \mathrm{e} 3$ & $4.19 \mathrm{e} 4$ & 4.24 \\
\hline $8 d$ & $1.32 \mathrm{e} 3$ & $2.15 \mathrm{e} 4$ & 2.25 \\
\hline $16 \mathrm{~d}$ & $4.61 \mathrm{e} 2$ & $8.40 \mathrm{e} 3$ & 8.74 \\
\hline $32 d$ & $5.63 \mathrm{e} 1$ & $3.93 \mathrm{e} 3$ & 4.05 \\
\hline $64 d$ & $1.59 \mathrm{e} 0$ & $2.86 \mathrm{e} 3$ & 2.94 \\
\hline $128 \mathrm{~d}$ & $7.70 e-1$ & $2.53 \mathrm{e} 3$ & 2.60 \\
\hline $256 d$ & $5.22 e-1$ & $2.19 \mathrm{e} 3$ & 2.27 \\
\hline $1 y$ & $7.38 e-1$ & $1.97 \mathrm{e} 3$ & 2.04 \\
\hline
\end{tabular}

$\begin{array}{lll}4.90 \mathrm{e} 5 & 9.27 \mathrm{e} 3 & 1.65 \mathrm{e} 3 \\ 1.66 \mathrm{e} 5 & 2.13 \mathrm{e} 4 & 2.28 \mathrm{e} 5 \\ 7.57 \mathrm{e} 4 & 1.81 \mathrm{e} 4 & 1.94 \mathrm{e} 5 \\ 2.29 \mathrm{e} 4 & 1.60 \mathrm{e} 4 & 1.71 \mathrm{e} 5 \\ 1.28 \mathrm{e} 4 & 1.27 \mathrm{e} 4 & 1.37 \mathrm{e} 5 \\ 8.72 \mathrm{e} 3 & 1.09 \mathrm{e} 4 & 1.16 \mathrm{e} 5 \\ 3.62 \mathrm{e} 3 & 8.03 \mathrm{e} 3 & 8.61 \mathrm{e} 4 \\ 1.87 \mathrm{e} 3 & 5.24 \mathrm{e} 3 & 5.58 \mathrm{e} 4 \\ 1.09 \mathrm{e} 3 & 2.69 \mathrm{e} 3 & 2.86 \mathrm{e} 4 \\ 3.81 \mathrm{e} 2 & 1.05 \mathrm{e} 3 & 1.12 \mathrm{e} 4 \\ 4.65 \mathrm{e} 1 & 4.91 \mathrm{e} 2 & 5.11 \mathrm{e} 3 \\ 1.31 \mathrm{e} 0 & 3.58 \mathrm{e} 2 & 3.80 \mathrm{e} 3 \\ 6.35 \mathrm{e}-1 & 3.16 \mathrm{e} 2 & 3.36 \mathrm{e} 3 \\ 6.21 \mathrm{e}-1 & 2.74 \mathrm{e} 2 & 2.94 \mathrm{e} 3 \\ 6.09 \mathrm{e}-1 & 2.46 \mathrm{e} 2 & 2.64 \mathrm{e} 3\end{array}$

$8.85 \mathrm{e} 5$
$3.00 \mathrm{e} 5$
$1.37 \mathrm{e} 5$
$4.14 \mathrm{e} 4$
$2.32 \mathrm{e} 4$
$1.58 \mathrm{e} 4$
$6.55 \mathrm{e} 3$
$3.39 \mathrm{e} 3$
$1.97 \mathrm{e} 3$
$6.88 \mathrm{e} 2$
$8.41 \mathrm{e} 1$
$2.37 \mathrm{e} 0$
$1.15 \mathrm{e} 0$
$1.12 \mathrm{e} 0$
$1.10 \mathrm{e} 0$

$\begin{array}{ll}1.18 \mathrm{e} 3 & 3.24 \mathrm{e} 5 \\ 2.46 \mathrm{e} 3 & 4.46 \mathrm{e} 5 \\ 2.32 \mathrm{e} 3 & 3.88 \mathrm{e} 5 \\ 2.05 \mathrm{e} 3 & 3.37 \mathrm{e} 5 \\ 1.63 \mathrm{e} 3 & 2.67 \mathrm{e} 5 \\ 1.40 \mathrm{e} 3 & 2.30 \mathrm{e} 5 \\ 1.03 \mathrm{e} 3 & 1.68 \mathrm{e} 5 \\ 6.72 \mathrm{e} 2 & 1.10 \mathrm{e} 5 \\ 3.45 \mathrm{e} 2 & 5.69 \mathrm{e} 4 \\ 1.34 \mathrm{e} 2 & 2.35 \mathrm{e} 4 \\ 6.30 \mathrm{e} 1 & 1.01 \mathrm{e} 4 \\ 4.60 \mathrm{e} 1 & 7.44 \mathrm{e} 3 \\ 4.05 \mathrm{e} 1 & 6.69 \mathrm{e} 3 \\ 3.15 \mathrm{e} 1 & 5.71 \mathrm{e} 3 \\ 3.16 \mathrm{e} 1 & 5.30 \mathrm{e} 3\end{array}$


Table C.14

Surry Case 2 Annulus Beta Dose Rates
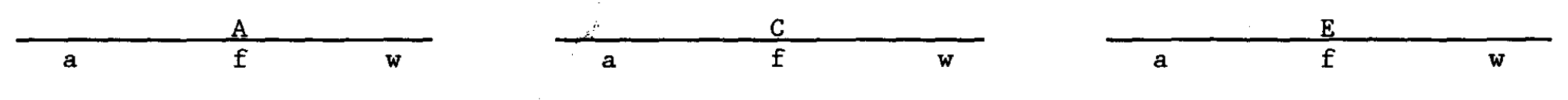

\begin{tabular}{|c|c|c|c|}
\hline 1h & $2.11 \mathrm{e} 6$ & $5.17 e 5$ & $5.92 \mathrm{e} 5$ \\
\hline $2 \mathrm{~h}$ & $8.83 e 5$ & $1.24 \mathrm{e} 6$ & $7.34 \mathrm{e} 5$ \\
\hline $4 h$ & $4.94 \mathrm{e} 5$ & $9.5 \mathrm{e} 5$ & $5.60 \mathrm{e} 5$ \\
\hline $8 \mathrm{~h}$ & $2.80 e^{5}$ & $7.42 e 5$ & $4.17 e 5$ \\
\hline $16 \mathrm{~h}$ & 2.11 es & $3.58 \mathrm{e} 5$ & $3.48 \mathrm{e} 5$ \\
\hline $1 d$ & $1.78 \mathrm{e} 5$ & $4.10 \mathrm{e} 5$ & $2.35 \mathrm{e} 5$ \\
\hline $2 d$ & $1.13 \mathrm{e} 5$ & $2.37 \mathrm{e} 5$ & $1.51 \mathrm{e} 5$ \\
\hline $4 d$ & $8.03 \mathrm{e} 4$ & $1.58 \mathrm{e} 5$ & $1.09 \mathrm{e} 5$ \\
\hline $8 d$ & $4.61 \mathrm{e} 4$ & $8.63 \mathrm{e} 4$ & $7.93 \mathrm{e} 4$ \\
\hline $16 \mathrm{~d}$ & $1.71 \mathrm{e} 4$ & $3.99 \mathrm{e} 4$ & $2.23 \mathrm{e} 4$ \\
\hline $32 d$ & $2.90 \mathrm{e} 3$ & $2.01 \mathrm{e}^{4}$ & $1.17 \mathrm{e} 4$ \\
\hline $64 d$ & $8.36 \mathrm{e} 2$ & $1.32 \mathrm{e} 4$ & $8.34 \mathrm{e} 3$ \\
\hline $128 d$ & $7.64 \mathrm{e} 2$ & $9.25 \mathrm{e} 3$ & $4.78 \mathrm{e} 3$ \\
\hline $256 d$ & $7.50 \mathrm{e} 2$ & $5.10 \mathrm{e} 3$ & $6.87 \mathrm{e} 2$ \\
\hline $1 y$ & $7.45 \mathrm{e} 2$ & $3.52 \mathrm{e} 3$ & $2.15 \mathrm{e} 3$ \\
\hline
\end{tabular}

$\begin{array}{lll}2.11 \mathrm{e} 6 & - & 5.92 \mathrm{e} 5 \\ 8.83 \mathrm{e} 5 & - & 7.34 \mathrm{e} 5 \\ 4.94 \mathrm{e} 5 & - & 5.60 \mathrm{e} 5 \\ 2.80 \mathrm{e} 5 & - & 4.17 \mathrm{e} 5 \\ 2.11 \mathrm{e} 5 & - & 3.48 \mathrm{e} 5 \\ 1.78 \mathrm{e} 5 & - & 2.35 \mathrm{e} 5 \\ 1.13 \mathrm{e} 5 & - & 1.51 \mathrm{e} 5 \\ 8.03 \mathrm{e} 4 & - & 1.09 \mathrm{e} 5 \\ 4.61 \mathrm{e} 4 & - & 7.93 \mathrm{e} 4 \\ 1.71 \mathrm{e} 4 & - & 2.23 \mathrm{e} 4 \\ 2.90 \mathrm{e} 3 & - & 1.17 \mathrm{e} 4 \\ 8.36 \mathrm{e} 2 & - & 8.34 \mathrm{e} 3 \\ 7.64 \mathrm{e} 2 & - & 4.78 \mathrm{e} 3 \\ 7.50 \mathrm{e} 2 & - & 6.87 \mathrm{e} 2 \\ 7.45 \mathrm{e} 2 & - & 2.15 \mathrm{e} 3\end{array}$

$\begin{array}{lll}2.11 \mathrm{e} 6 & - & 5.92 \mathrm{e} 5 \\ 8.83 \mathrm{e} 5 & - & 7.34 \mathrm{e} 5 \\ 4.94 \mathrm{e} 5 & - & 5.60 \mathrm{e} 5 \\ 2.80 \mathrm{e} 5 & - & 4.17 \mathrm{e} 5 \\ 2.11 \mathrm{e} 5 & - & 3.48 \mathrm{e} 5 \\ 1.78 \mathrm{e} 5 & - & 2.35 \mathrm{e} 5 \\ 1.13 \mathrm{e} 5 & - & 1.51 \mathrm{e} 5 \\ 8.03 \mathrm{e} 4 & - & 1.09 \mathrm{e} 5 \\ 4.61 \mathrm{e} 4 & - & 7.93 \mathrm{e} 4 \\ 1.71 \mathrm{e} 4 & - & 2.23 \mathrm{e} 4 \\ 2.90 \mathrm{e} 3 & - & 1.17 \mathrm{e} 4 \\ 8.36 \mathrm{e} 2 & - & 8.34 \mathrm{e} 3 \\ 7.64 \mathrm{e} 2 & - & 4.78 \mathrm{e} 3 \\ 7.50 \mathrm{e} 2 & - & 6.87 \mathrm{e} 2 \\ 7.45 \mathrm{e} 2 & - & 2.15 \mathrm{e} 3\end{array}$


Table C.15

Surry Case 2 Dome Gamma Dose Rates

\begin{tabular}{|c|c|c|c|c|c|c|c|c|}
\hline \multicolumn{3}{|c|}{$\mathrm{H}$} & \multicolumn{3}{|c|}{$I$} & \multicolumn{3}{|c|}{$\mathrm{J}$} \\
\hline $\mathbf{a}$ & $\mathrm{f}$ & $w$ & $\mathbf{a}$ & $\mathrm{f}$ & $w$ & $a$ & $\mathbf{f}$ & $w$ \\
\hline $1.08 \mathrm{e} 6$ & $1.62 \mathrm{e} 5$ & $4.28 \mathrm{e} 5$ & $1.83 \mathrm{e} 6$ & $9.71 \mathrm{e} 4$ & $2.43 e 5$ & 1.71 e 6 & $4.42 \mathrm{e} 4$ & $3.56 \mathrm{e} 5$ \\
\hline $1.84 \mathrm{e} 5$ & $3.05 e 5$ & $3.08 \mathrm{e} 5$ & $2.84 \mathrm{e} 5$ & $1.90 \mathrm{e} 5$ & $2.76 \mathrm{e} 5$ & $2.67 e 5$ & $8.66 \mathrm{e} 4$ & 4. 10 e 5 \\
\hline $5.07 \mathrm{e}^{4}$ & $2.63 \mathrm{e} 5$ & $2.63 \mathrm{e} 5$ & $8.59 \mathrm{e} 4$ & $1.68 \mathrm{e} 5$ & $2.38 e 5$ & $8.07 \mathrm{e} 4$ & $7.65 \mathrm{e} 4$ & $3.61 \mathrm{e} 5$ \\
\hline $2.83 \mathrm{e} 4$ & $2.04 \mathrm{e} 5$ & $2.27 e 5$ & $4.81 \mathrm{e} 4$ & $1.33 \mathrm{e} 5$ & $1.94 \mathrm{e} 5$ & $4.53 \mathrm{e} 4$ & $6.08 \mathrm{e} 4$ & $2.91 \mathrm{e} 5$ \\
\hline $8.02 \mathrm{e} 3$ & 1.25 e 5 & $1.44 \mathrm{e} 5$ & $1.36 \mathrm{e} 4$ & $8.40 \mathrm{e} 4$ & $1.21 e 5$ & $1.28 \mathrm{e} 4$ & $3.83 \mathrm{e} 4$ & 1.81 e 5 \\
\hline $2.73 \mathrm{e} 3$ & $3.66 \mathrm{e} 4$ & $1.41 \mathrm{e} 5$ & $3.73 \mathrm{e} 3$ & $5.49 \mathrm{e} 4$ & $8.14 \mathrm{e} 4$ & $5.62 \mathrm{e} 3$ & $2.50 \mathrm{e} 4$ & $1.19 \mathrm{e} 5$ \\
\hline $1.59 \mathrm{e} 3$ & $1.88 \mathrm{e} 4$ & $7.23 \mathrm{e} 4$ & $2.17 \mathrm{e} 3$ & $2.82 \mathrm{e} 4$ & $4.25 e^{4}$ & $3.27 \mathrm{e} 3$ & $1.28 \mathrm{e} 4$ & $6.12 \mathrm{e}^{4}$ \\
\hline $5.54 \mathrm{e} 2$ & $7.34 \mathrm{e} 3$ & $2.79 \mathrm{e} 4$ & $7.57 \mathrm{e} 2$ & $1.10 \mathrm{e} 4$ & $1.64 \mathrm{e} 4$ & $1.14 \mathrm{e} 3$ & $5.02 \mathrm{e} 3$ & $2.37 \mathrm{e} 4$ \\
\hline $6.78 \mathrm{el}$ & $3.43 e 3$ & $1.28 \mathrm{e} 4$ & $9.25 \mathrm{el}$ & $5.14 \mathrm{e} 3$ & $7.27 \mathrm{e} 3$ & $1.39 \mathrm{e} 2$ & $2.34 \mathrm{e} 3$ & $1.08 \mathrm{e} 4$ \\
\hline $1.91 \mathrm{e} 0$ & $2.51 \mathrm{e} 3$ & $9.39 \mathrm{e} 3$ & $2.61 \mathrm{e} 0$ & $3.75 \mathrm{e} 3$ & $5.45 \mathrm{e} 3$ & $3.92 \mathrm{e} 0$ & $1.71 \mathrm{e} 3$ & $8.02 \mathrm{e} 3$ \\
\hline $9.26 e-1$ & $2.21 \mathrm{e} 3$ & $8.39 \mathrm{e} 3$ & $1.26 \mathrm{e} 0$ & $3.31 \mathrm{e} 3$ & $4.84 \mathrm{e} 3$ & $1.90 \mathrm{e} 0$ & $1.51 \mathrm{e} 3$ & $7.15 \mathrm{e} 3$ \\
\hline $9.05 e-1$ & $1.91 \mathrm{e} 3$ & $7.29 \mathrm{e} 3$ & $1.23 \mathrm{e} 0$ & $2.87 \mathrm{e} 3$ & $4.21 \mathrm{e} 3$ & $1.85 \mathrm{eO}$ & $1.30 \mathrm{e} 3$ & $6.28 \mathrm{e} 3$ \\
\hline
\end{tabular}


Table C.16

Surry Case 2 Dome Beta Dose Rates

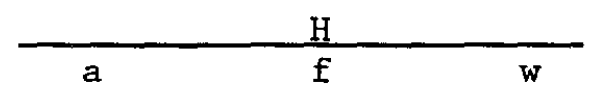

$\begin{array}{rccc}\text { 1h } & 5.65 \mathrm{e} 6 & 9.90 \mathrm{e} 3 & 4.04 \mathrm{e} 5 \\ 2 \mathrm{~h} & 2.22 \mathrm{e} 6 & 5.87 \mathrm{e} 4 & 5.99 \mathrm{e} 5 \\ 4 \mathrm{~h} & 1.31 \mathrm{e} 6 & 8.89 \mathrm{e} 3 & 5.37 \mathrm{e} 5 \\ 8 \mathrm{~h} & 6.76 \mathrm{e} 5 & 5.18 \mathrm{e} 3 & 4.68 \mathrm{e} 5 \\ 16 \mathrm{~h} & 5.52 \mathrm{e} 5 & 2.62 \mathrm{e} 4 & 3.72 \mathrm{e} 5 \\ 1 \mathrm{~d} & 4.49 \mathrm{e} 5 & 7.53 \mathrm{e} 3 & 3.20 \mathrm{e} 5 \\ 2 \mathrm{~d} & 2.76 \mathrm{e} 5 & 1.79 \mathrm{e} 2 & 2.35 \mathrm{e} 5 \\ 4 \mathrm{~d} & 1.83 \mathrm{e} 5 & 1.67 \mathrm{e} 1 & 1.56 \mathrm{e} 5 \\ 8 \mathrm{~d} & 1.12 \mathrm{e} 5 & 1.88 \mathrm{e} 1 & 9.25 \mathrm{e} 4 \\ 16 \mathrm{~d} & 3.98 \mathrm{e} 4 & 5.84 \mathrm{e} 1 & 4.56 \mathrm{e} 4 \\ 32 \mathrm{~d} & 7.04 \mathrm{e} 3 & 1.78 \mathrm{e} 1 & 2.40 \mathrm{e} 4 \\ 64 \mathrm{~d} & 2.01 \mathrm{e} 3 & - & 1.53 \mathrm{e} 4 \\ 128 \mathrm{~d} & 1.79 \mathrm{e} 3 & - & 1.23 \mathrm{e} 4 \\ 256 \mathrm{~d} & 1.76 \mathrm{e} 3 & - & 1.00 \mathrm{e} 4 \\ 1 \mathrm{y} & 1.74 \mathrm{e} 3 & - & 9.11 \mathrm{e} 3\end{array}$

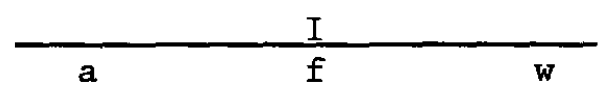

$\begin{array}{ccc}5.65 \mathrm{e} 6 & 9.90 \mathrm{e} 3 & 8.77 \mathrm{e} 2 \\ 2.22 \mathrm{e} 6 & 5.87 \mathrm{e} 4 & 2.41 \mathrm{e} 2 \\ 1.31 \mathrm{e} 6 & 8.89 \mathrm{e} 3 & 1.82 \mathrm{e} 2 \\ 6.76 \mathrm{e} 5 & 5.18 \mathrm{e} 3 & - \\ 5.52 \mathrm{e} 5 & 2.62 \mathrm{e} 4 & 2.44 \mathrm{e} 1 \\ 4.49 \mathrm{e} 5 & 7.53 \mathrm{e} 3 & - \\ 2.76 \mathrm{e} 5 & 1.79 \mathrm{e} 2 & - \\ 1.83 \mathrm{e} 5 & 1.67 \mathrm{e} 1 & - \\ 1.12 \mathrm{e} 5 & 1.88 \mathrm{e} 1 & - \\ 3.98 \mathrm{e} 4 & - & - \\ 7.04 \mathrm{e} 3 & 1.78 \mathrm{e} 1 & - \\ 2.01 \mathrm{e} 3 & - & - \\ 1.79 \mathrm{e} 3 & - & - \\ 1.76 \mathrm{e} 3 & - & - \\ 1.74 \mathrm{e} 3 & - & -\end{array}$

\begin{tabular}{ccc} 
& J & w \\
\hline $\mathrm{a}$ & $\mathrm{f}$ & \\
$5.65 \mathrm{e} 6$ & - & $3.30 \mathrm{e} 5$ \\
$2.22 \mathrm{e} 6$ & - & $4.45 \mathrm{e} 5$ \\
$1.31 \mathrm{e} 6$ & - & $3.70 \mathrm{e} 5$ \\
$6.76 \mathrm{e} 5$ & - & $3.25 \mathrm{e} 5$ \\
$5.52 \mathrm{e} 5$ & - & $2.49 \mathrm{e} 5$ \\
$4.49 \mathrm{e} 5$ & - & $1.90 \mathrm{e} 5$ \\
$2.76 \mathrm{e} 5$ & - & $1.37 \mathrm{e} 5$ \\
$1.83 \mathrm{e} 5$ & - & $8.63 \mathrm{e} 4$ \\
$1.12 \mathrm{e} 5$ & - & $4.98 \mathrm{e} 4$ \\
$3.98 \mathrm{e} 4$ & - & $2.50 \mathrm{e} 4$ \\
$7.04 \mathrm{e} 3$ & - & $1.28 \mathrm{e} 4$ \\
$2.01 \mathrm{e} 3$ & - & $8.38 \mathrm{e} 3$ \\
$1.79 \mathrm{e} 3$ & - & $6.31 \mathrm{e} 3$ \\
$1.76 \mathrm{e} 3$ & - & $4.91 \mathrm{e} 3$ \\
$1.74 \mathrm{e} 3$ & - & $4.35 \mathrm{e} 3$
\end{tabular}


Table C.17

Surry Case 2 Steam Generator A Cubicle Gamma Dose Rates

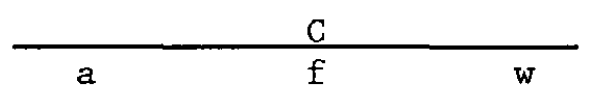

\begin{tabular}{|c|c|c|c|}
\hline $1 \mathrm{~h}$ & $8.73 e 5$ & $4.94 \mathrm{e}^{4}$ & $7.26 \mathrm{e} 4$ \\
\hline $2 \mathrm{~h}$ & $2.96 \mathrm{e} 5$ & $1.13 \mathrm{e} 5$ & $1.00 \mathrm{e} 5$ \\
\hline $4 h$ & $1.34 \mathrm{e} 5$ & $9.66 \mathrm{e} 4$ & $8.54 \mathrm{e} 4$ \\
\hline $8 \mathrm{~h}$ & $4.07 \mathrm{e} 4$ & $8.52 \mathrm{e} 4$ & $7.41 \mathrm{e} 4$ \\
\hline $16 \mathrm{~h}$ & $2.27 e^{4}$ & $6.77 \mathrm{e} 4$ & $5.96 e^{4}$ \\
\hline $1 d$ & $1.55 \mathrm{e} 4$ & $5.79 \mathrm{e} 4$ & $5.06 \mathrm{e}^{4}$ \\
\hline $2 d$ & $6.44 \mathrm{e} 3$ & $4.26 e^{4}$ & $3.75 \mathrm{e} 4$ \\
\hline $4 d$ & $3.34 \mathrm{e} 3$ & $2.78 \mathrm{e} 4$ & $2.45 \mathrm{e} 4$ \\
\hline $8 d$ & $1.94 \mathrm{e} 3$ & $1.43 \mathrm{e} 4$ & $1.26 \mathrm{e} 4$ \\
\hline $16 \mathrm{~d}$ & $6.78 \mathrm{e} 2$ & $5.57 \mathrm{e} 3$ & $4.85 \mathrm{e}^{3}$ \\
\hline $32 d$ & $8.29 \mathrm{el}$ & $2.60 \mathrm{e} 3$ & $2.27 \mathrm{e}^{3}$ \\
\hline $64 d$ & $2.33 \mathrm{eo}$ & $1.90 \mathrm{e} 3$ & $1.67 \mathrm{e}^{3}$ \\
\hline $128 d$ & $1.13 \mathrm{eO}$ & $1.67 \mathrm{e} 3$ & $1.48 \mathrm{e} 3$ \\
\hline $256 d$ & $1.10 \mathrm{e} 0$ & $1.45 \mathrm{e} 3$ & $1.29 \mathrm{e} 3$ \\
\hline $1 y$ & $1.08 \mathrm{e} 0$ & $1.30 \mathrm{e} 3$ & $1.16 \mathrm{e} 3$ \\
\hline
\end{tabular}

\begin{tabular}{ccc}
\multicolumn{3}{c}{$\mathrm{D}$} \\
\hline $\mathrm{a}$ & $\mathrm{f}$ & $\mathrm{w}$ \\
$4.77 \mathrm{e} 5$ & $3.98 \mathrm{e} 4$ & $1.57 \mathrm{e} 5$ \\
$1.61 \mathrm{e} 5$ & $9.15 \mathrm{e} 4$ & $2.18 \mathrm{e} 5$ \\
$7.37 \mathrm{e} 4$ & $7.78 \mathrm{e} 4$ & $1.85 \mathrm{e} 5$ \\
$2.22 \mathrm{e} 4$ & $6.87 \mathrm{e} 4$ & $1.62 \mathrm{e} 5$ \\
$1.24 \mathrm{e} 4$ & $5.46 \mathrm{e} 4$ & $1.29 \mathrm{e} 5$ \\
$8.49 \mathrm{e} 3$ & $4.66 \mathrm{e} 4$ & $1.10 \mathrm{e} 5$ \\
$3.52 \mathrm{e} 3$ & $3.43 \mathrm{e} 4$ & $8.12 \mathrm{e} 4$ \\
$1.82 \mathrm{e} 3$ & $2.24 \mathrm{e} 4$ & $5.31 \mathrm{e} 4$ \\
$1.06 \mathrm{e} 3$ & $1.15 \mathrm{e} 4$ & $2.72 \mathrm{e} 4$ \\
$3.71 \mathrm{e} 2$ & $4.49 \mathrm{e} 3$ & $1.05 \mathrm{e} 4$ \\
$4.53 \mathrm{e} 1$ & $2.10 \mathrm{e} 3$ & $4.91 \mathrm{e} 3$ \\
$1.27 \mathrm{e} 0$ & $1.53 \mathrm{e} 3$ & $3.61 \mathrm{e} 3$ \\
$6.18 \mathrm{e}-1$ & $1.35 \mathrm{e} 3$ & $3.20 \mathrm{e} 3$ \\
$6.04 \mathrm{e}-1$ & $1.17 \mathrm{e} 3$ & $2.79 \mathrm{e} 3$ \\
$5.93 \mathrm{e}-1$ & $1.05 \mathrm{e} 3$ & $2.51 \mathrm{e} 3$
\end{tabular}

\begin{tabular}{ccc}
\multicolumn{3}{c}{$E$} \\
\hline $\mathrm{a}$ & $\mathrm{f}$ & $\mathrm{w}$ \\
$4.59 \mathrm{e} 5$ & $3.99 \mathrm{e} 4$ & $1.57 \mathrm{e} 5$ \\
$1.55 \mathrm{e} 5$ & $9.18 \mathrm{e} 4$ & $2.16 \mathrm{e} 5$ \\
$7.10 \mathrm{e} 4$ & $7.81 \mathrm{e} 4$ & $1.83 \mathrm{e} 5$ \\
$2.14 \mathrm{e} 4$ & $6.89 \mathrm{e} 4$ & $1.62 \mathrm{e} 5$ \\
$1.20 \mathrm{e} 4$ & $5.47 \mathrm{e} 4$ & $1.28 \mathrm{e} 5$ \\
$8.17 \mathrm{e} 3$ & $4.68 \mathrm{e} 4$ & $1.09 \mathrm{e} 5$ \\
$3.39 \mathrm{e} 3$ & $3.44 \mathrm{e} 4$ & $8.02 \mathrm{e} 4$ \\
$1.76 \mathrm{e} 3$ & $2.25 \mathrm{e} 4$ & $5.27 \mathrm{e} 4$ \\
$1.02 \mathrm{e} 3$ & $1.15 \mathrm{e} 4$ & $2.71 \mathrm{e} 4$ \\
$3.57 \mathrm{e} 2$ & $4.51 \mathrm{e} 3$ & $1.04 \mathrm{e} 4$ \\
$4.36 \mathrm{e} 1$ & $2.10 \mathrm{e} 3$ & $4.90 \mathrm{e} 3$ \\
$1.23 \mathrm{e} 0$ & $1.53 \mathrm{e} 3$ & $3.60 \mathrm{e} 3$ \\
$5.95 \mathrm{e}-1$ & $1.35 \mathrm{e} 3$ & $3.20 \mathrm{e} 3$ \\
$5.82 \mathrm{e}-1$ & $1.17 \mathrm{e} 3$ & $2.78 \mathrm{e} 3$ \\
$5.71 \mathrm{e}-1$ & $1.05 \mathrm{e} 3$ & $2.50 \mathrm{e} 3$ \\
& & \\
\hline
\end{tabular}


Table C.18

Surry Case 2 Steam Generator Cubicle A Beta Dose Rates

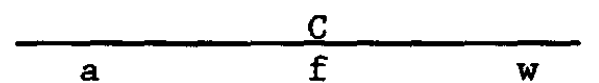

\begin{tabular}{|c|c|c|c|}
\hline 1h & $7.78 \mathrm{e} 6$ & $2.37 \mathrm{e} 2$ & $6.28 \mathrm{e} 2$ \\
\hline $2 h$ & $3.35 \mathrm{e} 6$ & $5.83 \mathrm{e} 2$ & $8.96 \mathrm{e} 2$ \\
\hline 4h & $1.86 \mathrm{e} 6$ & $4.80 \mathrm{e} 6$ & $6.92 \mathrm{e} 2$ \\
\hline $8 h$ & $1.02 \mathrm{e} 6$ & $4.10 \mathrm{e} 2$ & $4.92 \mathrm{e} 2$ \\
\hline $16 \mathrm{~h}$ & $8.42 \mathrm{e} 5$ & $3.31 \mathrm{e} 2$ & $4.24 \mathrm{e} 2$ \\
\hline $1 d$ & $6.89 \mathrm{e} 5$ & $2.63 \mathrm{e} 2$ & $2.72 \mathrm{e} 2$ \\
\hline $2 d$ & $4.38 \mathrm{e} 5$ & $1.85 \mathrm{e} 2$ & $1.77 \mathrm{e} 2$ \\
\hline $4 d$ & $3.04 \mathrm{e} 5$ & $1.16 \mathrm{e} 2$ & $1.05 \mathrm{e} 2$ \\
\hline $8 d$ & $1.79 \mathrm{e} 5$ & $6.99 \mathrm{el}$ & $5.19 \mathrm{el}$ \\
\hline $16 d$ & $6.52 \mathrm{e} 4$ & $3.54 \mathrm{e} 1$ & $2.64 \mathrm{el}$ \\
\hline $32 d$ & $3.42 \mathrm{e} 4$ & $1.86 \mathrm{e} 1$ & $1.47 \mathrm{el}$ \\
\hline $64 d$ & $3.20 \mathrm{e} 3$ & 1.20e1 & $9.52 e-1$ \\
\hline $128 d$ & $2.88 \mathrm{e} 3$ & $8.83 \mathrm{e} 0$ & $6.31 e-1$ \\
\hline $256 d$ & $2.81 \mathrm{e} 3$ & $6.50 \mathrm{e}-1$ & $3.49 e-1$ \\
\hline $1 y$ & $2.79 \mathrm{e} 3$ & $6.29 e-1$ & $2.58 e-1$ \\
\hline
\end{tabular}

\begin{tabular}{ccc}
\multicolumn{3}{c}{$\mathrm{D}$} \\
\hline $\mathrm{a}$ & $\mathrm{f}$ & $\mathrm{w}$ \\
$7.78 \mathrm{e} 6$ & $5.48 \mathrm{e} 5$ & $7.83 \mathrm{e} 5$ \\
$3.35 \mathrm{e} 6$ & $1.38 \mathrm{e} 6$ & $1.10 \mathrm{e} 6$ \\
$1.86 \mathrm{e} 6$ & $1.34 \mathrm{e} 6$ & $1.06 \mathrm{e} 6$ \\
$1.02 \mathrm{e} 6$ & $9.55 \mathrm{e} 5$ & $.8 .89 \mathrm{e} 5$ \\
$8.42 \mathrm{e} 5$ & $8.45 \mathrm{e} 5$ & $7.02 \mathrm{e} 5$ \\
$6.89 \mathrm{e} 5$ & $6.87 \mathrm{e} 5$ & $5.75 \mathrm{e} 5$ \\
$4.38 \mathrm{e} 5$ & $4.79 \mathrm{e} 5$ & $4.02 \mathrm{e} 5$ \\
$3.04 \mathrm{e} 5$ & $3.23 \mathrm{e} 5$ & $2.68 \mathrm{e} 5$ \\
$1.79 \mathrm{e} 5$ & $1.75 \mathrm{e} 5$ & $1.69 \mathrm{e} 5$ \\
$6.52 \mathrm{e} 4$ & $9.27 \mathrm{e} 4$ & $8.52 \mathrm{e} 4$ \\
$3.42 \mathrm{e} 4$ & $4.87 \mathrm{e} 4$ & $4.11 \mathrm{e} 4$ \\
$3.20 \mathrm{e} 3$ & $3.31 \mathrm{e} 4$ & $2.73 \mathrm{e} 4$ \\
$2.88 \mathrm{e} 3$ & $2.24 \mathrm{e} 4$ & $2.20 \mathrm{e} 4$ \\
$2.81 \mathrm{e} 3$ & $1.87 \mathrm{e} 4$ & $1.69 \mathrm{e} 4$ \\
$2.79 \mathrm{e} 3$ & $1.80 \mathrm{e} 4$ & $1.64 \mathrm{e} 4$
\end{tabular}

\begin{tabular}{ccc}
\multicolumn{3}{c}{$\mathrm{E}$} \\
\hline $\mathrm{a}$ & $\mathrm{f}$ & $\mathrm{w}$ \\
$7.78 \mathrm{e} 6$ & $5.28 \mathrm{e} 5$ & $6.90 \mathrm{e} 5$ \\
$3.35 \mathrm{e} 6$ & $1.20 \mathrm{e} 6$ & $1.07 \mathrm{e} 6$ \\
$1.86 \mathrm{e} 6$ & $1.11 \mathrm{e} 6$ & $9.15 \mathrm{e} 5$ \\
$1.02 \mathrm{e} 6$ & $9.04 \mathrm{e} 5$ & $8.73 \mathrm{e} 5$ \\
$8.42 \mathrm{e} 5$ & $7.66 \mathrm{e} 5$ & $6.55 \mathrm{e} 5$ \\
$6.89 \mathrm{e} 5$ & $6.04 \mathrm{e} 5$ & $5.56 \mathrm{e} 5$ \\
$4.38 \mathrm{e} 5$ & $4.25 \mathrm{e} 5$ & $4.06 \mathrm{e} 5$ \\
$3.04 \mathrm{e} 5$ & $2.89 \mathrm{e} 5$ & $2.55 \mathrm{e} 5$ \\
$1.79 \mathrm{e} 5$ & $1.85 \mathrm{e} 5$ & $1.43 \mathrm{e} 5$ \\
$6.52 \mathrm{e} 4$ & $9.02 \mathrm{e} 4$ & $7.26 \mathrm{e} 4$ \\
$3.42 \mathrm{e} 4$ & $4.54 \mathrm{e} 4$ & $3.62 \mathrm{e} 4$ \\
$3.20 \mathrm{e} 3$ & $2.98 \mathrm{e} 4$ & $2.37 \mathrm{e} 4$ \\
$2.88 \mathrm{e} 3$ & $2.09 \mathrm{e} 4$ & $1.98 \mathrm{e} 4$ \\
$2.81 \mathrm{e} 3$ & $1.70 \mathrm{e} 4$ & $1.61 \mathrm{e} 4$ \\
$2.79 \mathrm{e} 3$ & $1.64 \mathrm{e} 4$ & $1.37 \mathrm{e} 4$
\end{tabular}


Table C.19

Surry Case 3 Basement Gamma Dose Rate
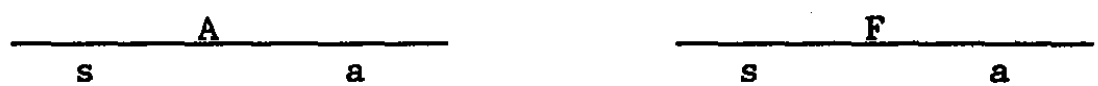

\begin{tabular}{rrrrr}
$1 \mathrm{~h}$ & $7.56 \mathrm{e} 5$ & $9.40 \mathrm{e} 4$ & $5.49 \mathrm{e} 5$ & $6.10 \mathrm{e} 4$ \\
$2 \mathrm{~h}$ & $6.01 \mathrm{e} 5$ & $7.27 \mathrm{e} 4$ & $4.36 \mathrm{e} 5$ & $4.80 \mathrm{e} 4$ \\
$4 \mathrm{~h}$ & $4.99 \mathrm{e} 5$ & $5.05 \mathrm{e} 4$ & $3.62 \mathrm{e} 5$ & $3.33 \mathrm{ee}$ \\
$8 \mathrm{~h}$ & $3.91 \mathrm{e} 5$ & $3.00 \mathrm{e} 4$ & $2.83 \mathrm{e} 5$ & $2.07 \mathrm{e} 4$ \\
$16 \mathrm{~h}$ & $3.05 \mathrm{e} 5$ & $1.75 \mathrm{e} 4$ & $2.22 \mathrm{e} 5$ & $1.14 \mathrm{e} 4$ \\
$1 \mathrm{~d}$ & $2.60 \mathrm{e} 5$ & $1.25 \mathrm{e} 4$ & $1.88 \mathrm{e} 5$ & $7.81 \mathrm{e} 3$ \\
$2 \mathrm{~d}$ & $1.93 \mathrm{e} 5$ & $5.40 \mathrm{e} 3$ & $1.40 \mathrm{e} 5$ & $3.92 \mathrm{e} 3$ \\
$4 \mathrm{~d}$ & $1.33 \mathrm{e} 5$ & $2.40 \mathrm{e} 3$ & $9.64 \mathrm{e} 4$ & $1.63 \mathrm{e} 3$ \\
$8 \mathrm{~d}$ & $7.17 \mathrm{e} 4$ & $1.50 \mathrm{e} 3$ & $5.60 \mathrm{e} 4$ & $9.80 \mathrm{e} 2$ \\
$16 \mathrm{~d}$ & $3.88 \mathrm{e} 4$ & $5.50 \mathrm{e} 2$ & $2.81 \mathrm{e} 4$ & $3.80 \mathrm{e} 2$ \\
$32 \mathrm{~d}$ & $2.17 \mathrm{e} 4$ & $1.10 \mathrm{e} 2$ & $1.58 \mathrm{e} 4$ & $3.96 \mathrm{e} 1$ \\
$64 \mathrm{~d}$ & $1.43 \mathrm{e} 4$ & $9.00 \mathrm{e} 1$ & $1.05 \mathrm{e} 4$ & $1.11 \mathrm{e} 0$ \\
$128 \mathrm{~d}$ & $1.04 \mathrm{e} 4$ & $8.23 \mathrm{e}-1$ & $7.56 \mathrm{e} 3$ & $5.41 \mathrm{e}-1$ \\
$256 \mathrm{~d}$ & $7.27 \mathrm{e} 3$ & $8.05 \mathrm{e}-1$ & $5.28 \mathrm{e} 3$ & $5.30 \mathrm{e}-1$ \\
$1 \mathrm{y}$ & $6.12 \mathrm{e} 3$ & $7.90 \mathrm{e}-1$ & $4.44 \mathrm{e} 3$ & $5.20 \mathrm{e}-1$ \\
\hline
\end{tabular}

s - sump contribution

a - airborne contribution 
Table C. 20

Surry Case 3 Annulus Gamma Dose Rate
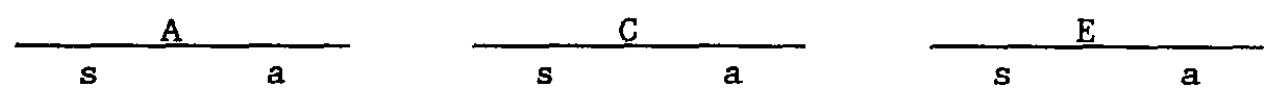

\begin{tabular}{rllllll}
$1 \mathrm{~h}$ & \multicolumn{7}{c}{} & & & \\
$2 \mathrm{~h}$ & $3.08 \mathrm{e} 5$ & $7.10 \mathrm{e} 4$ & $2.97 \mathrm{e} 4$ & $5.36 \mathrm{e} 4$ & $3.65 \mathrm{e} 3$ & $9.64 \mathrm{e} 4$ \\
$4 \mathrm{~h}$ & $2.55 \mathrm{e} 5$ & $4.97 \mathrm{e} 4$ & $2.46 \mathrm{e} 4$ & $3.73 \mathrm{e} 4$ & $3.02 \mathrm{e} 3$ & $6.75 \mathrm{e} 4$ \\
$8 \mathrm{~h}$ & $2.00 \mathrm{e} 5$ & $2.96 \mathrm{e} 4$ & $1.93 \mathrm{e} 4$ & $2.24 \mathrm{e} 4$ & $2.37 \mathrm{e} 3$ & $4.05 \mathrm{e} 4$ \\
$16 \mathrm{~h}$ & $1.57 \mathrm{e} 5$ & $1.64 \mathrm{e} 4$ & $1.51 \mathrm{e} 4$ & $1.25 \mathrm{e} 4$ & $1.84 \mathrm{e} 3$ & $2.27 \mathrm{e} 4$ \\
$1 \mathrm{~d}$ & $1.33 \mathrm{e} 5$ & $1.06 \mathrm{e} 4$ & $1.28 \mathrm{e} 4$ & $8.60 \mathrm{e} 3$ & $1.57 \mathrm{e} 3$ & $1.54 \mathrm{e} 4$ \\
$2 \mathrm{~d}$ & $9.91 \mathrm{e} 4$ & $4.90 \mathrm{e} 3$ & $9.57 \mathrm{e} 3$ & $3.53 \mathrm{e} 3$ & $1.17 \mathrm{e} 3$ & $6.41 \mathrm{e} 3$ \\
$4 \mathrm{~d}$ & $6.80 \mathrm{e} 4$ & $2.40 \mathrm{e} 3$ & $6.57 \mathrm{e} 3$ & $1.83 \mathrm{e} 3$ & $8.03 \mathrm{e} 2$ & $3.32 \mathrm{e} 3$ \\
$8 \mathrm{~d}$ & $3.95 \mathrm{e} 4$ & $1.40 \mathrm{e} 3$ & $3.82 \mathrm{e} 3$ & $1.07 \mathrm{e} 3$ & $4.66 \mathrm{e} 2$ & $1.93 \mathrm{e} 3$ \\
$16 \mathrm{~d}$ & $1.99 \mathrm{e} 4$ & $5.50 \mathrm{e} 2$ & $1.92 \mathrm{e} 3$ & $3.70 \mathrm{e} 2$ & $2.34 \mathrm{e} 2$ & $6.75 \mathrm{e} 2$ \\
$32 \mathrm{~d}$ & $1.12 \mathrm{e} 4$ & $4.60 \mathrm{e} 1$ & $1.07 \mathrm{e} 3$ & $4.54 \mathrm{e} 1$ & $1.31 \mathrm{e} 2$ & $8.23 \mathrm{e} 1$ \\
$64 \mathrm{~d}$ & $7.38 \mathrm{e} 3$ & $1.29 \mathrm{e} 0$ & $7.13 \mathrm{e} 2$ & $1.28 \mathrm{e} 0$ & $8.73 \mathrm{e} 1$ & $2.32 \mathrm{e} 0$ \\
$128 \mathrm{~d}$ & $5.34 \mathrm{e} 3$ & $6.22 \mathrm{e}-1$ & $5.16 \mathrm{e} 2$ & $6.20 \mathrm{e}-1$ & $6.31 \mathrm{e} 1$ & $1.13 \mathrm{e} 0$ \\
$256 \mathrm{~d}$ & $3.72 \mathrm{e} 3$ & $6.08 \mathrm{e}-1$ & $3.60 \mathrm{e} 2$ & $5.89 \mathrm{e}-1$ & $4.41 \mathrm{e} 1$ & $1.10 \mathrm{e} 0$ \\
$1 \mathrm{y}$ & $3.13 \mathrm{e} 3$ & $5.96 \mathrm{e}-1$ & $3.03 \mathrm{e} 2$ & $5.94 \mathrm{e}-1$ & $3.71 \mathrm{e} 1$ & $1.08 \mathrm{e} 0$
\end{tabular}


Table C. 21

Surry Case 4 Basement Gamma Dose Rate
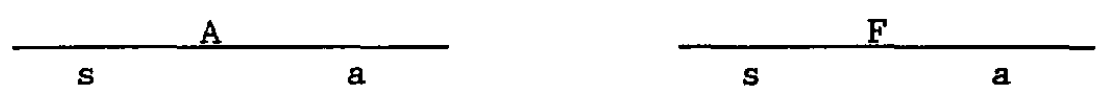

\begin{tabular}{rcccc}
$1 \mathrm{~h}$ & $7.56 \mathrm{e} 5$ & $9.40 \mathrm{e} 4$ & $5.49 \mathrm{e} 5$ & $6.10 \mathrm{e} 4$ \\
$2 \mathrm{~h}$ & $5.71 \mathrm{e} 5$ & $7.17 \mathrm{e} 4$ & $4.14 \mathrm{e} 5$ & $4.79 \mathrm{e} 4$ \\
$4 \mathrm{~h}$ & $4.12 \mathrm{e} 5$ & $4.92 \mathrm{e} 4$ & $2.98 \mathrm{e} 5$ & $3.30 \mathrm{e} 4$ \\
$8 \mathrm{~h}$ & $3.20 \mathrm{e} 5$ & $2.95 \mathrm{e} 4$ & $2.31 \mathrm{e} 5$ & $2.00 \mathrm{e} 4$ \\
$16 \mathrm{~h}$ & $2.50 \mathrm{e} 5$ & $1.67 \mathrm{e} 4$ & $1.82 \mathrm{e} 5$ & $1.11 \mathrm{e} 4$ \\
$1 \mathrm{~d}$ & $2.12 \mathrm{e} 5$ & $1.18 \mathrm{e} 4$ & $1.55 \mathrm{e} 5$ & $7.30 \mathrm{e} 3$ \\
$2 \mathrm{~d}$ & $1.55 \mathrm{e} 5$ & $5.40 \mathrm{e} 3$ & $1.13 \mathrm{e} 5$ & $3.11 \mathrm{e} 3$ \\
$4 \mathrm{~d}$ & $1.01 \mathrm{e} 5$ & $2.20 \mathrm{e} 3$ & $7.33 \mathrm{e} 4$ & $1.73 \mathrm{e} 3$ \\
$8 \mathrm{~d}$ & $5.12 \mathrm{e} 4$ & $1.51 \mathrm{e} 3$ & $3.72 \mathrm{e} 4$ & $1.00 \mathrm{e} 3$ \\
$16 \mathrm{~d}$ & $1.96 \mathrm{e} 4$ & $5.10 \mathrm{e} 2$ & $1.42 \mathrm{e} 4$ & $3.86 \mathrm{e} 2$ \\
$32 \mathrm{~d}$ & $9.35 \mathrm{e} 3$ & $7.00 \mathrm{e} 1$ & $6.79 \mathrm{e} 3$ & $4.60 \mathrm{e} 1$ \\
$64 \mathrm{~d}$ & $7.01 \mathrm{e} 3$ & $9.00 \mathrm{e} 0$ & $5.09 \mathrm{e} 3$ & $9.00 \mathrm{e} 0$ \\
$128 \mathrm{~d}$ & $6.22 \mathrm{e} 3$ & - & $4.52 \mathrm{e} 3$ & - \\
$256 \mathrm{~d}$ & $5.40 \mathrm{e} 3$ & - & $3.92 \mathrm{e} 3$ & - \\
$1 \mathrm{y}$ & $4.85 \mathrm{e} 3$ & - & $3.52 \mathrm{e} 3$ & - \\
\hline
\end{tabular}


Table C.22

Surry Case 4 Annulus Gamma Dose Rate
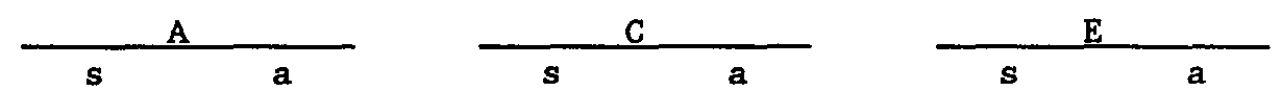

$\begin{array}{rcccccc}1 \mathrm{~h} & 3.88 \mathrm{e} 5 & 9.24 \mathrm{e} 4 & 3.74 \mathrm{e} 4 & 6.96 \mathrm{e} 4 & 4.59 \mathrm{e} 3 & 1.27 \mathrm{e} 5 \\ 2 \mathrm{~h} & 2.93 \mathrm{e} 5 & 7.10 \mathrm{e} 4 & 2.82 \mathrm{e} 4 & 5.36 \mathrm{e} 4 & 3.47 \mathrm{e} 3 & 9.65 \mathrm{e} 4 \\ 4 \mathrm{~h} & 2.11 \mathrm{e} 5 & 4.87 \mathrm{e} 4 & 2.03 \mathrm{e} 4 & 3.73 \mathrm{e} 4 & 2.49 \mathrm{e} 3 & 6.75 \mathrm{e} 4 \\ 8 \mathrm{~h} & 1.63 \mathrm{e} 5 & 2.97 \mathrm{e} 4 & 1.58 \mathrm{e} 4 & 2.23 \mathrm{e} 4 & 1.93 \mathrm{e} 3 & 4.05 \mathrm{e} 4 \\ 16 \mathrm{~h} & 1.29 \mathrm{e} 5 & 1.64 \mathrm{e} 4 & 1.24 \mathrm{e} 4 & 1.25 \mathrm{e} 4 & 1.51 \mathrm{e} 3 & 2.27 \mathrm{e} 4 \\ 1 \mathrm{~d} & 1.09 \mathrm{e} 5 & 1.09 \mathrm{e} 4 & 1.05 \mathrm{e} 4 & 8.60 \mathrm{e} 3 & 1.28 \mathrm{e} 3 & 1.54 \mathrm{e} 4 \\ 2 \mathrm{~d} & 7.96 \mathrm{e} 4 & 4.60 \mathrm{e} 3 & 7.69 \mathrm{e} 3 & 3.51 \mathrm{e} 3 & 9.41 \mathrm{e} 2 & 6.42 \mathrm{e} 3 \\ 4 \mathrm{~d} & 5.17 \mathrm{e} 4 & 2.40 \mathrm{e} 3 & 4.99 \mathrm{e} 3 & 1.84 \mathrm{e} 3 & 6.10 \mathrm{e} 2 & 3.32 \mathrm{e} 3 \\ 8 \mathrm{~d} & 2.62 \mathrm{e} 4 & 1.52 \mathrm{e} 3 & 2.53 \mathrm{e} 3 & 1.07 \mathrm{e} 3 & 3.09 \mathrm{e} 2 & 1.94 \mathrm{e} 3 \\ 16 \mathrm{~d} & 1.00 \mathrm{e} 4 & 4.60 \mathrm{e} 2 & 9.71 \mathrm{e} 2 & 3.69 \mathrm{e} 2 & 1.18 \mathrm{e} 2 & 6.75 \mathrm{e} 2 \\ 32 \mathrm{~d} & 4.79 \mathrm{e} 3 & 6.00 \mathrm{e} 1 & 4.63 \mathrm{e} 2 & 4.60 \mathrm{e} 1 & 5.66 \mathrm{e} 1 & 8.24 \mathrm{e} 1 \\ 64 \mathrm{~d} & 3.60 \mathrm{e} 3 & - & 3.49 \mathrm{e} 2 & - & 4.25 \mathrm{e} 1 & 2.40 \mathrm{e} 0 \\ 128 \mathrm{~d} & 3.18 \mathrm{e} 3 & 1.00 \mathrm{e} 1 & 3.08 \mathrm{e} 2 & 1.00 \mathrm{e} 0 & 3.77 \mathrm{e} 1 & 1.20 \mathrm{e} 0 \\ 256 \mathrm{~d} & 2.76 \mathrm{e} 3 & 8.00 \mathrm{e} 0 & 2.67 \mathrm{e} 2 & - & 3.27 \mathrm{e} 1 & 1.10 \mathrm{e} 0 \\ 1 \mathrm{y} & 2.48 \mathrm{e} 3 & 6.00 \mathrm{e} 0 & 2.40 \mathrm{e} 2 & - & 2.94 \mathrm{e} 1 & -\end{array}$


Table C.23

Peach Bottom Case 1 Drywell Gamma Dose Rates

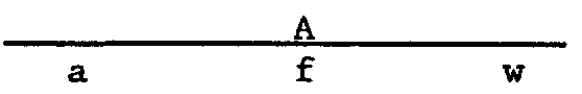

$a$

$\begin{array}{lll}2.57 \mathrm{e} 5 & 7.20 \mathrm{e} 5 & 2.80 \mathrm{e} 5 \\ 3.69 \mathrm{e} 5 & 5.51 \mathrm{e} 5 & 2.63 \mathrm{e} 5 \\ 3.72 \mathrm{e} 5 & 5.21 \mathrm{e} 5 & 2.59 \mathrm{e} 5 \\ 2.15 \mathrm{e} 5 & 3.39 \mathrm{e} 5 & 1.58 \mathrm{e} 5 \\ 1.19 \mathrm{e} 5 & 2.61 \mathrm{e} 5 & 1.20 \mathrm{e} 5 \\ 8.05 \mathrm{e} 4 & 2.23 \mathrm{e} 5 & 1.03 \mathrm{e} 5 \\ 3.27 \mathrm{e} 4 & 1.64 \mathrm{e} 5 & 7.60 \mathrm{e} 4 \\ 1.67 \mathrm{e} 4 & 1.07 \mathrm{e} 5 & 5.00 \mathrm{e} 4 \\ 9.74 \mathrm{e} 3 & 5.47 \mathrm{e} 4 & 2.59 \mathrm{e} 4 \\ 3.39 \mathrm{e} 3 & 2.10 \mathrm{e} 4 & 1.04 \mathrm{e} 4 \\ 4.15 \mathrm{e} 2 & 9.74 \mathrm{e} 3 & 5.16 \mathrm{e} 3 \\ 1.27 \mathrm{e} 1 & 7.09 \mathrm{e} 3 & 4.07 \mathrm{e} 3 \\ 6.61 \mathrm{e} 0 & 6.25 \mathrm{e} 3 & 3.72 \mathrm{e} 3 \\ 6.43 \mathrm{e} 0 & 5.40 \mathrm{e} 3 & 3.29 \mathrm{e} 3 \\ 6.30 \mathrm{e} 0 & 4.85 \mathrm{e} 3 & 2.98 \mathrm{e} 3\end{array}$

$2.98 \mathrm{e} 3$
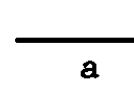

$$
\begin{gathered}
3.22 \mathrm{e} 5 \\
4.62 \mathrm{e} 5 \\
4.66 \mathrm{e} 5 \\
2.68 \mathrm{e} 5 \\
1.49 \mathrm{e} 5 \\
1.01 \mathrm{e} 5 \\
4.09 \mathrm{e} 4 \\
2.09 \mathrm{e} 4 \\
1.22 \mathrm{e} 4 \\
4.24 \mathrm{e} 3 \\
5.19 \mathrm{e} 2 \\
1.59 \mathrm{e} 1 \\
8.26 \mathrm{e} 0 \\
8.04 \mathrm{e} 0 \\
7.87 \mathrm{e} 0
\end{gathered}
$$

\begin{tabular}{ccc}
\multicolumn{3}{c}{$\mathrm{C}$} \\
\hline $\mathrm{a}$ & $\mathrm{f}$ & $\mathrm{w}$ \\
$2.72 \mathrm{e} 5$ & $7.61 \mathrm{e} 5$ & $1.76 \mathrm{e} 5$ \\
$3.90 \mathrm{e} 5$ & $5.83 \mathrm{e} 5$ & $1.64 \mathrm{e} 5$ \\
$3.93 \mathrm{e} 5$ & $5.50 \mathrm{e} 5$ & $1.61 \mathrm{e} 5$ \\
$2.27 \mathrm{e} 5$ & $3.58 \mathrm{e} 5$ & $9.90 \mathrm{e} 4$ \\
$1.26 \mathrm{e} 5$ & $2.76 \mathrm{e} 5$ & $7.50 \mathrm{e} 4$ \\
$8.50 \mathrm{e} 4$ & $2.36 \mathrm{e} 5$ & $6.40 \mathrm{e} 4$ \\
$3.46 \mathrm{e} 4$ & $1.73 \mathrm{e} 5$ & $4.70 \mathrm{e} 4$ \\
$1.77 \mathrm{e} 4$ & $1.13 \mathrm{e} 5$ & $3.11 \mathrm{e} 4$ \\
$1.03 \mathrm{e} 4$ & $5.78 \mathrm{e} 4$ & $1.60 \mathrm{e} 4$ \\
$3.58 \mathrm{e} 3$ & $2.23 \mathrm{e} 4$ & $6.40 \mathrm{e} 3$ \\
$4.38 \mathrm{e} 2$ & $8.96 \mathrm{e} 3$ & $4.57 \mathrm{e} 3$ \\
$1.34 \mathrm{e} 1$ & $7.50 \mathrm{e} 3$ & $2.53 \mathrm{e} 3$ \\
$6.98 \mathrm{e} 0$ & $6.61 \mathrm{e} 3$ & $2.31 \mathrm{e} 3$ \\
$6.79 \mathrm{e} 0$ & $5.71 \mathrm{e} 3$ & $2.04 \mathrm{e} 3$ \\
$6.65 \mathrm{e} 0$ & $5.12 \mathrm{e} 3$ & $1.86 \mathrm{e} 3$
\end{tabular}


Table C.23

Peach Bottom Case 1 Drywe11 Gamma Dose Rates (Continued)

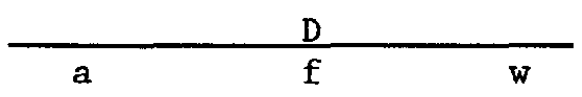

\begin{tabular}{|c|c|c|c|}
\hline Ih & $3.54 \mathrm{e} 5$ & $6.96 \mathrm{e} 5$ & $1.97 \mathrm{e} 5$ \\
\hline $2 \mathrm{~h}$ & $5.09 \mathrm{e} 5$ & $5.32 \mathrm{e} 5$ & $1.85 \mathrm{e} 5$ \\
\hline $4 h$ & $5.13 \mathrm{e} 5$ & $5.02 \mathrm{e} 5$ & $1.87 \mathrm{e} 5$ \\
\hline $8 \mathrm{~h}$ & $2.95 e 5$ & $3.28 \mathrm{e} 5$ & $1.10 \mathrm{e} 5$ \\
\hline $16 \mathrm{~h}$ & $1.64 \mathrm{e} 5$ & $2.51 \mathrm{e} 5$ & $8.50 \mathrm{e} 4$ \\
\hline $1 d$ & $1.11 \mathrm{e} 5$ & $2.15 \mathrm{e} 5$ & $7.30 \mathrm{e} 4$ \\
\hline $2 d$ & $4.50 \mathrm{e} 4$ & $1.58 \mathrm{e} 5$ & $5.30 e^{4}$ \\
\hline $4 d$ & $2.30 e^{4}$ & $1.03 \mathrm{e} 5$ & $3.50 \mathrm{e} 4$ \\
\hline $8 d$ & $1.34 \mathrm{e} 4$ & $5.28 \mathrm{e} 4$ & $1.82 \mathrm{e} 4$ \\
\hline $16 d$ & $4.67 \mathrm{e} 3$ & $2.03 \mathrm{e} 4$ & $7.30 \mathrm{e}^{3}$ \\
\hline $32 d$ & $5.72 \mathrm{e} 2$ & $9.40 \mathrm{e} 3$ & $3.67 \mathrm{e} 3$ \\
\hline $64 d$ & $1.75 \mathrm{e} 1$ & $6.86 \mathrm{e} 3$ & $2.85 \mathrm{e} 3$ \\
\hline $128 d$ & $9.10 \mathrm{e} 0$ & $6.04 \mathrm{e} 3$ & $2.61 \mathrm{e} 3$ \\
\hline $256 d$ & $8.85 \mathrm{e} 0$ & $5.22 \mathrm{e} 3$ & $2.30 \mathrm{e} 3$ \\
\hline $1 y$ & $8.66 \mathrm{e} 0$ & $4.68 \mathrm{e} 3$ & 2.09 \\
\hline
\end{tabular}

\begin{tabular}{ccc}
\multicolumn{3}{c}{$E$} \\
\hline a & f & w \\
$4.26 \mathrm{e} 5$ & $9.10 \mathrm{e} 5$ & $2.70 \mathrm{e} 5$ \\
$6.11 \mathrm{e} 5$ & $6.98 \mathrm{e} 5$ & $2.56 \mathrm{e} 5$ \\
$6.16 \mathrm{e} 5$ & $6.58 \mathrm{e} 5$ & $2.53 \mathrm{e} 5$ \\
$3.55 \mathrm{e} 5$ & $4.29 \mathrm{e} 5$ & $1.55 \mathrm{e} 5$ \\
$1.97 \mathrm{e} 5$ & $3.30 \mathrm{e} 5$ & $1.18 \mathrm{e} 5$ \\
$1.33 \mathrm{e} 5$ & $2.82 \mathrm{e} 5$ & $1.01 \mathrm{e} 5$ \\
$5.41 \mathrm{e} 4$ & $2.08 \mathrm{e} 5$ & $7.40 \mathrm{e} 4$ \\
$2.76 \mathrm{e} 4$ & $1.35 \mathrm{e} 5$ & $4.90 \mathrm{e} 4$ \\
$1.61 \mathrm{e} 4$ & $6.92 \mathrm{e} 4$ & $2.53 \mathrm{e} 4$ \\
$5.61 \mathrm{e} 3$ & $2.67 \mathrm{e} 4$ & $1.01 \mathrm{e} 4$ \\
$6.87 \mathrm{e} 2$ & $1.23 \mathrm{e} 4$ & $5.13 \mathrm{e} 3$ \\
$2.10 \mathrm{e} 1$ & $8.98 \mathrm{e} 3$ & $3.96 \mathrm{e} 3$ \\
$1.09 \mathrm{e} 1$ & $7.91 \mathrm{e} 3$ & $3.63 \mathrm{e} 3$ \\
$1.06 \mathrm{e} 1$ & $6.83 \mathrm{e} 3$ & $3.22 \mathrm{e} 3$ \\
$1.04 \mathrm{e} 1$ & $6.13 \mathrm{e} 3$ & $2.91 \mathrm{e} 3$
\end{tabular}

\begin{tabular}{ccc}
\multicolumn{3}{c}{$\mathrm{F}$} \\
\hline $\mathrm{a}$ & $\mathrm{f}$ & $\mathrm{w}$ \\
$3.07 \mathrm{e} 5$ & $6.66 \mathrm{e} 5$ & $3.20 \mathrm{e} 5$ \\
$4.41 \mathrm{e} 5$ & $5.10 \mathrm{e} 5$ & $2.99 \mathrm{e} 5$ \\
$4.45 \mathrm{e} 5$ & $4.81 \mathrm{e} 5$ & $2.95 \mathrm{e} 5$ \\
$2.56 \mathrm{e} 5$ & $3.13 \mathrm{e} 5$ & $1.81 \mathrm{e} 5$ \\
$1.43 \mathrm{e} 5$ & $2.42 \mathrm{e} 5$ & $1.36 \mathrm{e} 5$ \\
$9.61 \mathrm{e} 4$ & $2.07 \mathrm{e} 5$ & $1.16 \mathrm{e} 5$ \\
$3.91 \mathrm{e} 4$ & $1.52 \mathrm{e} 5$ & $8.60 \mathrm{e} 4$ \\
$2.00 \mathrm{e} 4$ & $9.90 \mathrm{e} 4$ & $5.68 \mathrm{e} 4$ \\
$1.16 \mathrm{e} 4$ & $5.06 \mathrm{e} 4$ & $2.94 \mathrm{e} 4$ \\
$4.05 \mathrm{e} 3$ & $1.95 \mathrm{e} 4$ & $1.18 \mathrm{e} 4$ \\
$4.96 \mathrm{e} 2$ & $9.01 \mathrm{e} 3$ & $5.94 \mathrm{e} 3$ \\
$1.52 \mathrm{e} 1$ & $6.57 \mathrm{e} 3$ & $5.23 \mathrm{e} 3$ \\
$7.89 \mathrm{e} 0$ & $5.78 \mathrm{e} 3$ & $4.52 \mathrm{e} 3$ \\
$7.68 \mathrm{e} 0$ & $5.00 \mathrm{e} 3$ & $3.74 \mathrm{e} 3$ \\
$7.52 \mathrm{e} 0$ & $4.48 \mathrm{e} 3$ & $3.39 \mathrm{e} 3$
\end{tabular}


Table C.23

Peach Bottom Case 1 Drywe11 Gamma Dose Rates (Continued)

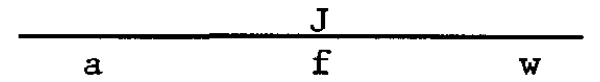

$\begin{array}{rrrrr} & 1 \mathrm{~h} & 1.76 \mathrm{e} 5 & 7.59 \mathrm{e} 4 & 2.10 \mathrm{e} 5 \\ & 2 \mathrm{~h} & 2.53 \mathrm{e} 5 & 5.82 \mathrm{e} 4 & 1.96 \mathrm{e} 5 \\ 4 \mathrm{~h} & 2.55 \mathrm{e} 5 & 5.48 \mathrm{e} 4 & 1.93 \mathrm{e} 5 \\ & 8 \mathrm{~h} & 1.47 \mathrm{e} 5 & 3.58 \mathrm{e} 4 & 1.18 \mathrm{e} 5 \\ 0 \quad 16 \mathrm{~h} & 8.16 \mathrm{e} 4 & 2.75 \mathrm{e} 4 & 8.95 \mathrm{e} 4 \\ \mathcal{N} & 1 \mathrm{~d} & 5.50 \mathrm{e} 4 & 2.36 \mathrm{e} 4 & 7.64 \mathrm{e} 4 \\ \mathrm{~N} & 2 \mathrm{~d} & 2.23 \mathrm{e} 4 & 1.73 \mathrm{e} 4 & 5.69 \mathrm{e} 4 \\ & 4 \mathrm{~d} & 1.14 \mathrm{e} 4 & 1.13 \mathrm{e} 4 & 3.73 \mathrm{e} 4 \\ 8 \mathrm{~d} & 6.64 \mathrm{e} 3 & 5.79 \mathrm{e} 3 & 1.93 \mathrm{e} 4 \\ 16 \mathrm{~d} & 2.31 \mathrm{e} 3 & 2.22 \mathrm{e} 3 & 7.77 \mathrm{e} 3 \\ 32 \mathrm{~d} & 2.83 \mathrm{e} 2 & 1.03 \mathrm{e} 3 & 3.90 \mathrm{e} 3 \\ 64 \mathrm{~d} & 8.68 \mathrm{e} 0 & 7.50 \mathrm{e} 2 & 3.03 \mathrm{e} 3 \\ 128 \mathrm{~d} & 4.52 \mathrm{e} 0 & 6.61 \mathrm{e} 2 & 2.77 \mathrm{e} 3 \\ 256 \mathrm{~d} & 4.40 \mathrm{e} 0 & 5.70 \mathrm{e} 2 & 2.46 \mathrm{e} 3 \\ 1 \mathrm{y} & 4.30 \mathrm{e} 0 & 5.12 \mathrm{e} 2 & 2.22 \mathrm{e} 3\end{array}$

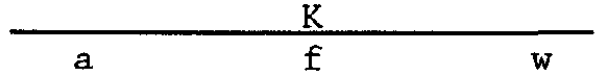

$2.04 e 5$

$2.93 e 5$

$2.95 e 5$

$1.70 \mathrm{e} 5$

$9.45 \mathrm{e} 4$

$6.37 \mathrm{e} 4$

$2.59 \mathrm{e} 4$

$1.32 \mathrm{e} 4$

$7.70 \mathrm{e} 3$

$2.68 \mathrm{e} 3$

$3.28 \mathrm{e} 2$

1.01e1

5. $24 \mathrm{e} 0$

5. $10 \mathrm{e} 0$

$4.99 \mathrm{eO}$

$\begin{array}{ll}8.97 \mathrm{e} 4 & 1.95 \mathrm{e} 5 \\ 6.88 \mathrm{e} 4 & 1.81 \mathrm{e} 5 \\ 6.48 \mathrm{e} 4 & 1.79 \mathrm{e} 5 \\ 4.23 \mathrm{e} 4 & 1.10 \mathrm{e} 5 \\ 3.25 \mathrm{e} 4 & 8.35 \mathrm{e} 4 \\ 2.78 \mathrm{e} 4 & 7.15 \mathrm{e} 4 \\ 2.04 \mathrm{e} 4 & 5.28 \mathrm{e} 4 \\ 1.34 \mathrm{e} 4 & 3.46 \mathrm{e} 4 \\ 6.82 \mathrm{e} 3 & 1.79 \mathrm{e} 4 \\ 2.63 \mathrm{e} 3 & 2.20 \mathrm{e} 3 \\ 1.22 \mathrm{e} 3 & 3.61 \mathrm{e} 3 \\ 8.86 \mathrm{e} 2 & 2.81 \mathrm{e} 3 \\ 7.81 \mathrm{e} 2 & 2.57 \mathrm{e} 3 \\ 6.74 \mathrm{e} 2 & 2.28 \mathrm{e} 3 \\ 6.05 \mathrm{e} 2 & 2.06 \mathrm{e} 3\end{array}$

\begin{tabular}{ccc}
\multicolumn{3}{c}{$\mathrm{L}$} \\
\hline $\mathrm{a}$ & $\mathrm{f}$ & $\mathrm{w}$ \\
$1.65 \mathrm{e} 5$ & $7.44 \mathrm{e} 4$ & $1.02 \mathrm{e} 5$ \\
$2.37 \mathrm{e} 5$ & $5.71 \mathrm{e} 4$ & $9.49 \mathrm{e} 4$ \\
$2.39 \mathrm{e} 5$ & $5.38 \mathrm{e} 4$ & $9.42 \mathrm{e} 4$ \\
$1.38 \mathrm{e} 5$ & $3.50 \mathrm{e} 4$ & $5.77 \mathrm{e} 4$ \\
$7.65 \mathrm{e} 4$ & $2.70 \mathrm{e} 4$ & $4.39 \mathrm{e} 4$ \\
$5.16 \mathrm{e} 4$ & $2.31 \mathrm{e} 4$ & $3.75 \mathrm{e} 4$ \\
$2.10 \mathrm{e} 4$ & $1.70 \mathrm{e} 4$ & $2.77 \mathrm{e} 4$ \\
$1.07 \mathrm{e} 4$ & $1.11 \mathrm{e} 4$ & $1.81 \mathrm{e} 4$ \\
$6.24 \mathrm{e} 3$ & $5.66 \mathrm{e} 3$ & $9.34 \mathrm{e} 3$ \\
$2.17 \mathrm{e} 3$ & $2.18 \mathrm{e} 3$ & $3.79 \mathrm{e} 3$ \\
$2.66 \mathrm{e} 2$ & $1.01 \mathrm{e} 3$ & $1.90 \mathrm{e} 3$ \\
$8.14 \mathrm{e} 0$ & $7.35 \mathrm{e} 2$ & $1.48 \mathrm{e} 3$ \\
$4.24 \mathrm{e} 0$ & $6.48 \mathrm{e} 2$ & $1.34 \mathrm{e} 3$ \\
$4.12 \mathrm{e} 0$ & $5.59 \mathrm{e} 2$ & $1.20 \mathrm{e} 3$ \\
$4.04 \mathrm{e} 0$ & $5.02 \mathrm{e} 2$ & $1.08 \mathrm{e} 3$
\end{tabular}


Table C. 24

Peach Bottom Case 1 Drywe11 Beta Dose Rates

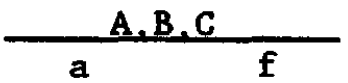

$\begin{array}{ll}2.35 \mathrm{e} 5 & 1.18 \mathrm{e} 6 \\ 4.70 \mathrm{e} 5 & 8.56 \mathrm{e} 5 \\ 9.95 \mathrm{e} 5 & 1.37 \mathrm{e} 6 \\ & 1.37 \mathrm{e} 6 \\ 1.02 \mathrm{e} 6 & 8.59 \mathrm{e} 5 \\ 8.25 \mathrm{e} 5 & 8.07 \mathrm{e} 5 \\ 5.15 \mathrm{e} 5 & 5.04 \mathrm{e} 5 \\ 3.58 \mathrm{e} 5 & 3.31 \mathrm{e} 5 \\ 2.11 \mathrm{e} 5 & 1.99 \mathrm{e} 5 \\ 7.72 \mathrm{e} 4 & 9.09 \mathrm{e} 4 \\ 1.36 \mathrm{e} 4 & 4.39 \mathrm{e} 4 \\ 4.23 \mathrm{e} 3 & 3.07 \mathrm{e} 4 \\ 3.81 \mathrm{e} 3 & 2.29 \mathrm{e} 4 \\ 3.69 \mathrm{e} 3 & 1.80 \mathrm{e} 4 \\ 3.62 \mathrm{e} 3 & 1.78 \mathrm{e} 4\end{array}$

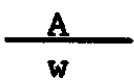

$3.86 \mathrm{e} 5$

$3.55 \mathrm{e} 5$

$6.81 \mathrm{e} 5$

$4.59 \mathrm{e} 5$

$3.02 \mathrm{e} 5$

$2.56 \mathrm{e} 5$

$1.72 \mathrm{e} 5$

$1.15 \mathrm{e} 5$

$5.94 \mathrm{e} 4$

$2.75 \mathrm{e} 4$

$1.32 \mathrm{e} 4$

$1.00 \mathrm{e} 4$

$8.83 \mathrm{e} 3$

$8.39 \mathrm{e} 3$

8. $27 \mathrm{e} 3$

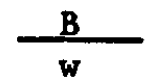

$3.44 \mathrm{e} 4$

$2.93 \mathrm{e} 4$

$9.10 \mathrm{e} 4$

$7.44 e^{4}$

$4.13 \mathrm{e} 4$

$2.75 \mathrm{e} 4$

$1.96 \mathrm{e} 4$

$1.04 \mathrm{e} 4$

$4.64 \mathrm{e}^{4}$

$1.09 \mathrm{e} 3$

$2.86 \mathrm{e} 2$

$1.48 \mathrm{e} 2$

8. $52 \mathrm{e} 1$

3. $59 \mathrm{e} 1$

2. $90 \mathrm{e} 1$

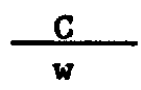

$5.97 \mathrm{e} 5$

$5.01 \mathrm{e} 5$

$1.02 \mathrm{e} 6$

$7.23 \mathrm{e} 5$

$4.83 \mathrm{e} 5$

4. $20 \mathrm{e} 5$

$2.63 \mathrm{e} 5$

$1.71 \mathrm{e} 5$

$9.00 \mathrm{e} 4$

$4.20 \mathrm{e} 4$

$2.08 \mathrm{e} 4$

$1.42 \mathrm{e} 4$

$1.33 \mathrm{e} 4$

$1.28 \mathrm{e} 4$

$1.17 \mathrm{e} 4$

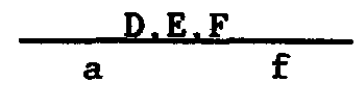

$2.35 \mathrm{e} 5 \quad 4.46 \mathrm{e} 6$

4.70e5

9.95e5

$1.02 \mathrm{e} 6$

8.25e5

$5.15 e 5$

$3.58 \mathrm{e} 5$

2.11e5

7.72e4

$1.36 \mathrm{e} 4$

$4.23 \mathrm{e} 3$

3.81 e 3

$3.69 \mathrm{e} 3$

$3.62 \mathrm{e} 3$

\section{$3.19 \mathrm{e} 6$}

$6.47 \mathrm{e} 6$

$5.19 \mathrm{e} 6$

3. $55 \mathrm{e} 6$

$2.94 \mathrm{e} 6$

$2.08 \mathrm{e} 6$

$1.36 \mathrm{e} 6$

7.61e5

$3.43 \mathrm{e} 5$

1.91e5

$1.25 \mathrm{e} 5$

$9.27 \mathrm{e} 4$

$7.67 \mathrm{e} 4$

$6.76 \mathrm{e} 4$
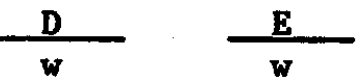

5.97es

$5.01 e 5$

$1.02 \mathrm{e} 6$

7. $23 \mathrm{es}$

$4.83 \mathrm{es}$

4. $20 \mathrm{e} 5$

$2.63 \mathrm{e} 5$

$1.71 \mathrm{e} 5$

$9.00 \mathrm{e} 4$

$4.20 \mathrm{e} 4$

$2.08 \mathrm{e} 4$

$1.42 \mathrm{e} 4$

$1.33 \mathrm{e} 4$

$1.28 \mathrm{e} 4$

$1.17 \mathrm{e} 4$
$3.44 \mathrm{e} 4$

$2.93 \mathrm{e} 4$

$9.10 \mathrm{e} 4$

$7.44 \mathrm{e} 4$

$4.13 \mathrm{e} 4$

$2.75 \mathrm{e} 4$

$1.96 \mathrm{e} 4$

$1.04 \mathrm{e} 4$

4. $64 \mathrm{e} 3$

$1.09 \mathrm{e} 3$

$2.86 \mathrm{e} 2$

$1.48 \mathrm{e} 2$

8.52e1

3. $59 \mathrm{el}$

2. $90 \mathrm{e} 1$

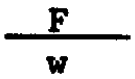

$3.86 \mathrm{e} 5$

$3.55 \mathrm{e} 5$

$6.81 \mathrm{e} 5$

$4.59 \mathrm{e} 5$

$3.02 \mathrm{e} 5$

$2.56 \mathrm{e} 5$

$1.72 \mathrm{e} 5$

$1.15 \mathrm{e} 5$

$5.94 \mathrm{e} 4$

$2.75 e 4$

$1.32 \mathrm{e} 4$

$1.00 \mathrm{e} 4$

8.83 e 3

8. $39 \mathrm{e} 3$

8.27e 3 
Table C.24

Peach Bottom Case 1 Drywell Beta Dose Rates (Continued)
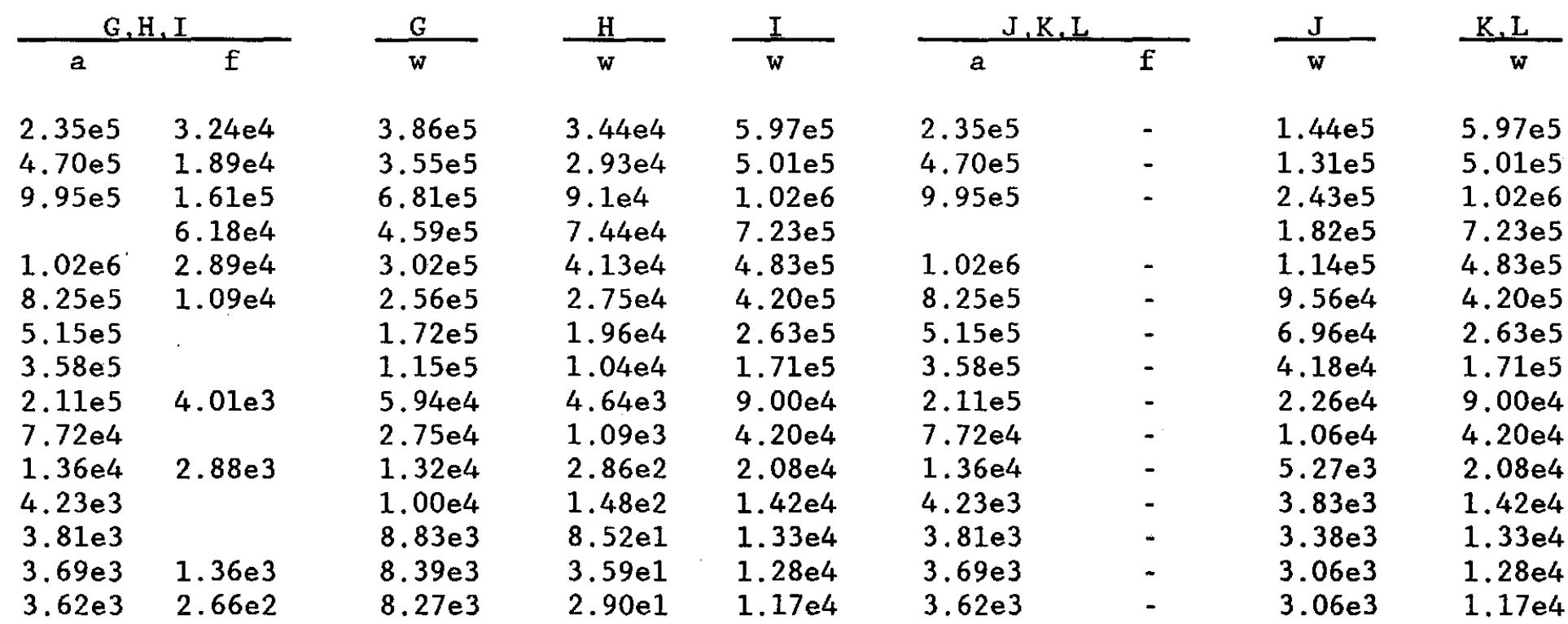

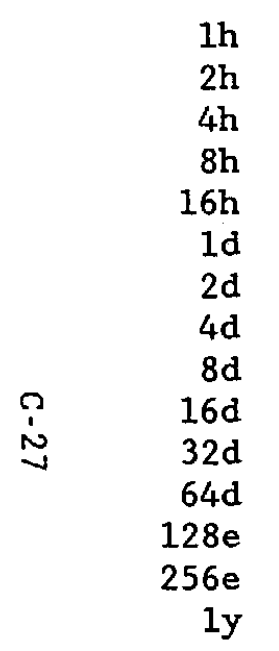

$\begin{array}{lll}2.35 \mathrm{e} 5 & 3.24 \mathrm{e} 4 & 3.86 \mathrm{e} 5 \\ 4.70 \mathrm{e} 5 & 1.89 \mathrm{e} 4 & 3.55 \mathrm{e} 5 \\ 9.95 \mathrm{e} 5 & 1.61 \mathrm{e} 5 & 6.81 \mathrm{e} 5 \\ & 6.18 \mathrm{e} 4 & 4.59 \mathrm{e} 5 \\ 1.02 \mathrm{e} 6 & 2.89 \mathrm{e} 4 & 3.02 \mathrm{e} 5 \\ 8.25 \mathrm{e} 5 & 1.09 \mathrm{e} 4 & 2.56 \mathrm{e} 5 \\ 5.15 \mathrm{e} 5 & & 1.72 \mathrm{e} 5 \\ 3.58 \mathrm{e} 5 & & 1.15 \mathrm{e} 5 \\ 2.11 \mathrm{e} 5 & 4.01 \mathrm{e} 3 & 5.94 \mathrm{e} 4 \\ 7.72 \mathrm{e} 4 & & 2.75 \mathrm{e} 4 \\ 1.36 \mathrm{e} 4 & 2.88 \mathrm{e} 3 & 1.32 \mathrm{e} 4 \\ 4.23 \mathrm{e} 3 & & 1.00 \mathrm{e} 4 \\ 3.81 \mathrm{e} 3 & & 8.83 \mathrm{e} 3 \\ 3.69 \mathrm{e} 3 & 1.36 \mathrm{e} 3 & 8.39 \mathrm{e} 3 \\ 3.62 \mathrm{e} 3 & 2.66 \mathrm{e} 2 & 8.27 \mathrm{e} 3\end{array}$

$\begin{array}{ll}3.44 \mathrm{e} 4 & 5.97 \mathrm{e} 5 \\ 2.93 \mathrm{e} 4 & 5.01 \mathrm{e} 5 \\ 9.1 \mathrm{e} 4 & 1.02 \mathrm{e} 6 \\ 7.44 \mathrm{e} 4 & 7.23 \mathrm{e} 5 \\ 4.13 \mathrm{e} 4 & 4.83 \mathrm{e} 5 \\ 2.75 \mathrm{e} 4 & 4.20 \mathrm{e} 5 \\ 1.96 \mathrm{e} 4 & 2.63 \mathrm{e} 5 \\ 1.04 \mathrm{e} 4 & 1.71 \mathrm{e} 5 \\ 4.64 \mathrm{e} 3 & 9.00 \mathrm{e} 4 \\ 1.09 \mathrm{e} 3 & 4.20 \mathrm{e} 4 \\ 2.86 \mathrm{e} 2 & 2.08 \mathrm{e} 4 \\ 1.48 \mathrm{e} 2 & 1.42 \mathrm{e} 4 \\ 8.52 \mathrm{e} 1 & 1.33 \mathrm{e} 4 \\ 3.59 \mathrm{e} 1 & 1.28 \mathrm{e} 4 \\ 2.90 \mathrm{e} 1 & 1.17 \mathrm{e} 4\end{array}$

$2.35 e 5$

$1.44 \mathrm{e} 5$

$4.70 \mathrm{e} 5 \quad-\quad 1.31 \mathrm{e} 5$

$9.95 \mathrm{e} 5 \quad-\quad 2.43 \mathrm{e} 5$

$1.82 \mathrm{e} 5$

$1.02 \mathrm{e} 6$

$1.14 \mathrm{e} 5$

$9.56 \mathrm{e} 4$

$6.96 \mathrm{e} 4$

$4.18 \mathrm{e}^{4}$

$2.26 \mathrm{e} 4$

$1.06 \mathrm{e} 4$

$5.27 \mathrm{e} 3$

$3.83 \mathrm{e} 3$

$3.38 \mathrm{e} 3$

5. $97 e 5$

$5.01 e 5$

1. $02 \mathrm{e} 6$

$7.23 e 5$

4. 83 e 5

4. 20 e 5

$2.63 \mathrm{e} 5$

$1.71 \mathrm{e} 5$

$9.00 \mathrm{e} 4$

4. $20 \mathrm{e} 4$

$2.08 \mathrm{e} 4$

$1.42 \mathrm{e} 4$

4. $23 \mathrm{e} 3$

$3.69 \mathrm{e} 3 \quad-\quad 3.06 \mathrm{e} 3 \quad 1.28 \mathrm{e} 4$

$1.33 \mathrm{e} 4$

rav

$1.17 \mathrm{e} 4$ 
Table C. 25

Surry Case 1 Wetwell Gamma Dose Rates

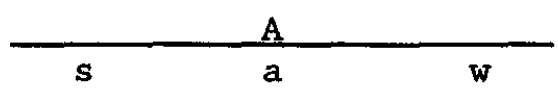

$\begin{array}{rccr}1 \mathrm{~h} & 1.68 \mathrm{e} 4 & 2.99 \mathrm{e} 5 & 5.58 \mathrm{e} 4 \\ 2 \mathrm{~h} & 1.22 \mathrm{e} 4 & 1.58 \mathrm{e} 5 & 4.26 \mathrm{e} 4 \\ 4 \mathrm{~h} & 9.43 \mathrm{e} 3 & 6.01 \mathrm{e} 4 & 3.14 \mathrm{e} 4 \\ 8 \mathrm{~h} & 6.88 \mathrm{e} 3 & 3.39 \mathrm{e} 4 & 2.47 \mathrm{e} 4 \\ 16 \mathrm{~h} & 5.16 \mathrm{e} 3 & 1.68 \mathrm{e} 4 & 1.95 \mathrm{e} 4 \\ 1 \mathrm{~d} & 4.29 \mathrm{e} 3 & 1.02 \mathrm{e} 4 & 1.67 \mathrm{e} 4 \\ 2 \mathrm{~d} & 3.06 \mathrm{e} 3 & 2.49 \mathrm{e} 3 & 1.23 \mathrm{e} 4 \\ 4 \mathrm{~d} & 1.95 \mathrm{e} 3 & 4.26 \mathrm{e} 2 & 7.93 \mathrm{e} 3 \\ 8 \mathrm{~d} & 9.63 \mathrm{e} 2 & 2.07 \mathrm{e} 2 & 3.99 \mathrm{e} 3 \\ 16 \mathrm{~d} & 3.53 \mathrm{e} 2 & 7.05 \mathrm{e} 1 & 1.49 \mathrm{e} 3 \\ 32 \mathrm{~d} & 1.74 \mathrm{e} 2 & 9.56 \mathrm{e} 0 & 7.01 \mathrm{e} 2 \\ 64 \mathrm{~d} & 1.35 \mathrm{e} 2 & 1.42 \mathrm{e} 0 & 5.40 \mathrm{e} 2 \\ 128 \mathrm{~d} & 1.20 \mathrm{e} 2 & 1.27 \mathrm{e} 0 & 4.95 \mathrm{e} 2 \\ 256 \mathrm{~d} & 1.04 \mathrm{e} 2 & 1.24 \mathrm{e} 0 & 4.38 \mathrm{e} 2 \\ 1 \mathrm{y} & 9.43 \mathrm{e} 1 & 1.21 \mathrm{e} 0 & 3.96 \mathrm{e} 2\end{array}$

\begin{tabular}{ccc}
\multicolumn{4}{c}{$\mathrm{B}$} \\
\hline $\mathrm{s}$ & $\mathrm{a}$ & $\mathrm{w}$ \\
- & $4.16 \mathrm{e} 1$ & $2.40 \mathrm{e} 0$ \\
- & $2.14 \mathrm{e} 1$ & $1.42 \mathrm{e} 0$ \\
- & $7.61 \mathrm{e} 0$ & $6.90 \mathrm{e}-1$ \\
- & $2.73 \mathrm{e} 0$ & $3.86 \mathrm{e}-1$ \\
- & $3.83 \mathrm{e}-1$ & $2.17 \mathrm{e}-1$ \\
- & $5.49 \mathrm{e}-2$ & $1.45 \mathrm{e}-1$ \\
- & - & - \\
- & - & - \\
- & - & - \\
- & - & - \\
- & - & - \\
- & - & - \\
- & - & - \\
- & - & -
\end{tabular}


Table C.26

Peach Bottom Case 2 Drywel1 Gamma Dose Rates

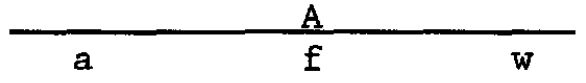

\begin{tabular}{|c|c|c|c|}
\hline Ih & $2.57 \mathrm{e} 5$ & $7.20 \mathrm{e} 5$ & $2.80 \mathrm{e}^{5}$ \\
\hline $2 \mathrm{~h}$ & $3.69 \mathrm{e} 5$ & $5.52 \mathrm{e} 5$ & $2.62 \mathrm{e} 5$ \\
\hline $4 \mathrm{~h}$ & $3.57 \mathrm{e} 5$ & $4.15 \mathrm{e} 5$ & $2.04 \mathrm{e} 5$ \\
\hline $8 \mathrm{~h}$ & $2.14 \mathrm{e} 5$ & $3.25 e 5$ & $1.60 \mathrm{e} 5$ \\
\hline $16 \mathrm{~h}$ & $1.19 \mathrm{e} 5$ & $2.59 \mathrm{e} 5$ & $1.26 \mathrm{e}$ \\
\hline Id & $8.05 \mathrm{e} 4$ & $1.78 \mathrm{e} 5$ & $1.52 €$ \\
\hline $2 d$ & $3.27 \mathrm{e} 4$ & $1.62 \mathrm{e} 5$ & 8.10 \\
\hline $4 d$ & $1.67 \mathrm{e} 4$ & $1.05 \mathrm{e} 5$ & $5.30 €$ \\
\hline $8 \mathrm{~d}$ & $9.73 \mathrm{e} 3$ & $5.28 \mathrm{e} 4$ & 2.85 \\
\hline $16 d$ & $3.39 \mathrm{e} 3$ & $1.95 \mathrm{e} 4$ & 1.22 \\
\hline $32 d$ & $4.14 \mathrm{e} 2$ & $8.71 \mathrm{e} 3$ & 6.59 \\
\hline $64 d$ & $1.24 \mathrm{e} 1$ & $6.48 \mathrm{e} 3$ & 5.22 \\
\hline $128 \mathrm{~d}$ & $6.40 \mathrm{e} 0$ & $5.90 \mathrm{e} 3$ & 4.80 \\
\hline $256 d$ & - & $5.25 e^{3}$ & 4.29 \\
\hline $1 y$ & - & $4.74 \mathrm{e} 3$ & 3.89 \\
\hline
\end{tabular}

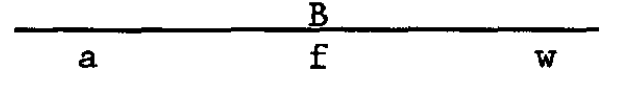

$\begin{array}{ccc}3.22 \mathrm{e} 5 & 9.16 \mathrm{e} 5 & 2.39 \mathrm{e} 5 \\ 4.62 \mathrm{e} 5 & 7.02 \mathrm{e} 5 & 2.23 \mathrm{e} 5 \\ 4.47 \mathrm{e} 5 & 5.27 \mathrm{e} 5 & 1.74 \mathrm{e} 5 \\ 2.68 \mathrm{e} 5 & 4.13 \mathrm{e} 5 & 1.36 \mathrm{e} 5 \\ 1.49 \mathrm{e} 5 & 3.29 \mathrm{e} 5 & 1.07 \mathrm{e} 5 \\ 1.01 \mathrm{e} 5 & 2.81 \mathrm{e} 5 & 9.20 \mathrm{e} 4 \\ 4.09 \mathrm{e} 4 & 2.06 \mathrm{e} 5 & 6.80 \mathrm{e} 4 \\ 2.09 \mathrm{e} 4 & 1.34 \mathrm{e} 5 & 4.50 \mathrm{e} 4 \\ 1.22 \mathrm{e} 4 & 6.73 \mathrm{e} 4 & 2.40 \mathrm{e} 4 \\ 4.23 \mathrm{e} 3 & 2.48 \mathrm{e} 4 & 1.03 \mathrm{e} 4 \\ 5.18 \mathrm{e} 2 & 1.11 \mathrm{e} 4 & 5.50 \mathrm{e} 3 \\ 1.55 \mathrm{e} 1 & 8.24 \mathrm{e} 3 & 4.46 \mathrm{e} 3 \\ 8.0 \mathrm{e} 0 & 7.51 \mathrm{e} 3 & 4.09 \mathrm{e} 3 \\ - & 6.67 \mathrm{e} 3 & 3.63 \mathrm{e} 3 \\ - & 6.03 \mathrm{e} 3 & 3.30 \mathrm{e} 3\end{array}$

\begin{tabular}{ccc}
\multicolumn{3}{c}{$\mathrm{c}$} \\
\hline $\mathrm{a}$ & $\mathrm{f}$ & $\mathrm{w}$ \\
$2.72 \mathrm{e} 5$ & $7.61 \mathrm{e} 5$ & $1.76 \mathrm{e} 5$ \\
$3.90 \mathrm{e} 5$ & $5.83 \mathrm{e} 5$ & $1.64 \mathrm{e} 5$ \\
$3.77 \mathrm{e} 5$ & $4.38 \mathrm{e} 5$ & $1.27 \mathrm{e} 5$ \\
$2.27 \mathrm{e} 5$ & $3.43 \mathrm{e} 5$ & $1.00 \mathrm{e} 5$ \\
$1.26 \mathrm{e} 5$ & $2.73 \mathrm{e} 5$ & $7.90 \mathrm{e} 4$ \\
$8.5 \mathrm{e} 4$ & $2.33 \mathrm{e} 5$ & $6.80 \mathrm{e} 4$ \\
$3.45 \mathrm{e} 4$ & $1.72 \mathrm{e} 5$ & $4.90 \mathrm{e} 4$ \\
$1.76 \mathrm{e} 4$ & $1.11 \mathrm{e} 5$ & $3.34 \mathrm{e} 4$ \\
$1.03 \mathrm{e} 4$ & $5.59 \mathrm{e} 4$ & $1.77 \mathrm{e} 4$ \\
$3.58 \mathrm{e} 3$ & $2.06 \mathrm{e} 4$ & $7.60 \mathrm{e} 3$ \\
$4.38 \mathrm{e} 2$ & $9.20 \mathrm{e} 3$ & $4.11 \mathrm{e} 3$ \\
$1.31 \mathrm{e} 1$ & $6.85 \mathrm{e} 3$ & $3.25 \mathrm{e} 3$ \\
$6.76 \mathrm{e} 0$ & $6.24 \mathrm{e} 3$ & $3.01 \mathrm{e} 3$ \\
- & $5.54 \mathrm{e} 3$ & $2.68 \mathrm{e} 3$ \\
- & $4.94 \mathrm{e} 3$ & $2.50 \mathrm{e} 3$
\end{tabular}


Table C.26

Peach Bottom Case 2 Drywell Gamma Dose Rates (Continued)

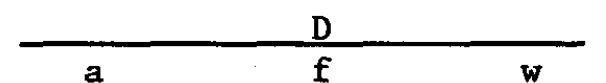

a

$\begin{array}{rrccc}1 \mathrm{~h} & 3.54 \mathrm{e} 5 & 6.96 \mathrm{e} 5 & 2.00 \mathrm{e} 5 \\ 2 \mathrm{~h} & 5.09 \mathrm{e} 5 & 5.32 \mathrm{e} 5 & 1.85 \mathrm{e} 5 \\ 4 \mathrm{~h} & 4.92 \mathrm{e} 5 & 4.00 \mathrm{e} 5 & 1.44 \mathrm{e} 5 \\ 8 \mathrm{~h} & 2.95 \mathrm{e} 5 & 3.14 \mathrm{e} 5 & 1.12 \mathrm{e} 5 \\ 16 \mathrm{~h} & 1.64 \mathrm{e} 5 & 2.49 \mathrm{e} 5 & 9.00 \mathrm{e} 4 \\ \mathrm{c} & 1 \mathrm{~d} & 1.11 \mathrm{e} 5 & 2.13 \mathrm{e} 5 & 7.70 \mathrm{e} 4 \\ \mathrm{w} & 2 \mathrm{~d} & 4.50 \mathrm{e} 4 & 1.57 \mathrm{e} 5 & 5.60 \mathrm{e} 4 \\ 4 \mathrm{~d} & 2.30 \mathrm{e} 4 & 1.02 \mathrm{e} 5 & 3.70 \mathrm{e} 4 \\ 8 \mathrm{~d} & 1.34 \mathrm{e} 4 & 5.11 \mathrm{e} 4 & 2.00 \mathrm{e} 4 \\ 16 \mathrm{~d} & 4.66 \mathrm{e} 3 & 1.89 \mathrm{e} 4 & 8.50 \mathrm{e} 3 \\ 32 \mathrm{~d} & 5.71 \mathrm{e} 2 & 8.42 \mathrm{e} 3 & 4.63 \mathrm{e} 3 \\ 64 \mathrm{~d} & 1.71 \mathrm{el} & 6.27 \mathrm{e} 3 & 3.70 \mathrm{e} 3 \\ 128 \mathrm{~d} & 8.81 \mathrm{e} 0 & 5.71 \mathrm{e} 3 & 3.39 \mathrm{e} 3 \\ 256 \mathrm{~d} & - & 5.06 \mathrm{e} 3 & 3.02 \mathrm{e} 3 \\ 1 \mathrm{y} & - & 4.57 \mathrm{e} 3 & 2.74 \mathrm{e} 3\end{array}$

\begin{tabular}{ccc}
\multicolumn{3}{c}{$E$} \\
\hline $\mathrm{a}$ & $\mathrm{f}$ & $\mathrm{w}$ \\
$4.26 \mathrm{e} 5$ & $9.10 \mathrm{e} 5$ & $2.70 \mathrm{e} 5$ \\
$6.11 \mathrm{e} 5$ & $6.98 \mathrm{e} 5$ & $2.56 \mathrm{e} 5$ \\
$5.91 \mathrm{e} 5$ & $5.23 \mathrm{e} 5$ & $2.01 \mathrm{e} 5$ \\
$3.55 \mathrm{e} 5$ & $4.11 \mathrm{e} 5$ & $1.57 \mathrm{e} 5$ \\
$1.97 \mathrm{e} 5$ & $3.27 \mathrm{e} 5$ & $1.24 \mathrm{e} 5$ \\
$1.33 \mathrm{e} 5$ & $2.79 \mathrm{e} 5$ & $1.07 \mathrm{e} 5$ \\
$5.41 \mathrm{e} 4$ & $2.05 \mathrm{e} 4$ & $7.90 \mathrm{e} 4$ \\
$2.76 \mathrm{e} 4$ & $1.33 \mathrm{e} 5$ & $5.24 \mathrm{e} 4$ \\
$1.61 \mathrm{e} 4$ & $6.69 \mathrm{e} 4$ & $2.79 \mathrm{e} 4$ \\
$5.60 \mathrm{e} 3$ & $2.48 \mathrm{e} 4$ & $1.18 \mathrm{e} 4$ \\
$6.85 \mathrm{e} 2$ & $1.10 \mathrm{e} 4$ & $6.48 \mathrm{e} 3$ \\
$2.05 \mathrm{e} 1$ & $8.19 \mathrm{e} 3$ & $5.17 \mathrm{e} 3$ \\
$1.06 \mathrm{e} 1$ & $7.47 \mathrm{e} 3$ & $4.74 \mathrm{e} 3$ \\
- & $6.63 \mathrm{e} 3$ & $4.21 \mathrm{e} 3$ \\
- & $6.00 \mathrm{e} 3$ & $3.80 \mathrm{e} 3$
\end{tabular}

\begin{tabular}{ccc}
\multicolumn{3}{c}{$\mathbf{f}$} \\
\hline $\mathrm{a}$ & $\mathrm{f}$ & $\mathrm{w}$ \\
$3.07 \mathrm{e} 5$ & $6.66 \mathrm{e} 5$ & $3.20 \mathrm{e} 5$ \\
$4.41 \mathrm{e} 5$ & $5.32 \mathrm{e} 5$ & $2.77 \mathrm{e} 5$ \\
$4.27 \mathrm{e} 5$ & $3.82 \mathrm{e} 5$ & $2.34 \mathrm{e} 5$ \\
$2.56 \mathrm{e} 5$ & $3.01 \mathrm{e} 5$ & $1.82 \mathrm{e} 5$ \\
$1.42 \mathrm{e} 5$ & $2.40 \mathrm{e} 5$ & $1.43 \mathrm{e} 5$ \\
$1.33 \mathrm{e} 5$ & $2.05 \mathrm{e} 5$ & $1.23 \mathrm{e} 5$ \\
$3.91 \mathrm{e} 4$ & $1.50 \mathrm{e} 5$ & $9.20 \mathrm{e} 4$ \\
$2.00 \mathrm{e} 4$ & $9.74 \mathrm{e} 4$ & $6.08 \mathrm{e} 4$ \\
$1.16 \mathrm{e} 4$ & $4.90 \mathrm{e} 4$ & $3.23 \mathrm{e} 4$ \\
$4.05 \mathrm{e} 3$ & $1.81 \mathrm{e} 4$ & $1.38 \mathrm{e} 4$ \\
$4.95 \mathrm{e} 2$ & $8.06 \mathrm{e} 3$ & $7.44 \mathrm{e} 3$ \\
$1.48 \mathrm{e} 1$ & $6.00 \mathrm{e} 3$ & $6.01 \mathrm{e} 3$ \\
$7.65 \mathrm{e} 0$ & $5.47 \mathrm{e} 3$ & $5.50 \mathrm{e} 3$ \\
- & $4.86 \mathrm{e} 3$ & $4.88 \mathrm{e} 3$ \\
- & $4.39 \mathrm{e} 3$ & $4.42 \mathrm{e} 3$
\end{tabular}


Table C.26

Peach Bottom Case 2 Drywell Gamma Dose Rates (Continued)

\begin{tabular}{ccc}
\multicolumn{3}{c}{$\mathrm{G}$} \\
\hline $\mathrm{a}$ & $\mathrm{f}$ & $\mathrm{w}$ \\
$2.76 \mathrm{e} 5$ & $5.83 \mathrm{e} 5$ & $4.27 \mathrm{e} 5$ \\
$3.96 \mathrm{e} 5$ & $4.46 \mathrm{e} 5$ & $4.04 \mathrm{e} 5$ \\
$3.84 \mathrm{e} 5$ & $3.35 \mathrm{e} 5$ & $3.15 \mathrm{e} 5$ \\
$2.30 \mathrm{e} 5$ & $2.63 \mathrm{e} 5$ & $2.46 \mathrm{e} 5$ \\
$1.28 \mathrm{e} 5$ & $2.09 \mathrm{e} 5$ & $1.95 \mathrm{e} 5$ \\
$8.64 \mathrm{e} 4$ & $1.78 \mathrm{e} 5$ & $1.68 \mathrm{e} 5$ \\
$3.51 \mathrm{e} 4$ & $1.31 \mathrm{e} 5$ & $1.24 \mathrm{e} 5$ \\
$1.79 \mathrm{e} 4$ & $8.52 \mathrm{e} 4$ & $8.18 \mathrm{e} 4$ \\
$1.05 \mathrm{e} 4$ & $4.28 \mathrm{e} 4$ & $4.37 \mathrm{e} 4$ \\
$3.64 \mathrm{e} 3$ & $1.58 \mathrm{e} 4$ & $1.87 \mathrm{e} 4$ \\
$4.46 \mathrm{e} 2$ & $2.05 \mathrm{e} 3$ & $1.02 \mathrm{e} 4$ \\
$1.33 \mathrm{e} 1$ & $5.25 \mathrm{e} 3$ & $8.05 \mathrm{e} 3$ \\
$6.88 \mathrm{e} 0$ & $4.78 \mathrm{e} 3$ & $7.42 \mathrm{e} 3$ \\
- & $4.24 \mathrm{e} 3$ & $6.56 \mathrm{e} 3$ \\
- & $3.84 \mathrm{e} 3$ & $3.47 \mathrm{e} 3$
\end{tabular}

\begin{tabular}{ccc}
\multicolumn{3}{c}{$\mathrm{H}$} \\
\hline $\mathrm{a}$ & $\mathrm{f}$ & $\mathrm{w}$ \\
$3.59 \mathrm{e} 5$ & $6.21 \mathrm{e} 5$ & $3.25 \mathrm{e} 5$ \\
$5.15 \mathrm{e} 5$ & $4.76 \mathrm{e} 5$ & $3.03 \mathrm{e} 5$ \\
$4.98 \mathrm{e} 5$ & $3.57 \mathrm{e} 5$ & $2.37 \mathrm{e} 5$ \\
$3.00 \mathrm{e} 5$ & $2.81 \mathrm{e} 5$ & $1.84 \mathrm{e} 5$ \\
$1.66 \mathrm{e} 5$ & $2.23 \mathrm{e} 5$ & $1.47 \mathrm{e} 5$ \\
$1.12 \mathrm{e} 5$ & $1.90 \mathrm{e} 5$ & $1.26 \mathrm{e} 5$ \\
$4.56 \mathrm{e} 4$ & $1.39 \mathrm{e} 5$ & $9.40 \mathrm{e} 4$ \\
$2.33 \mathrm{e} 4$ & $9.09 \mathrm{e} 4$ & $6.11 \mathrm{e} 4$ \\
$1.35 \mathrm{e} 4$ & $4.57 \mathrm{e} 4$ & $3.28 \mathrm{e} 4$ \\
$4.71 \mathrm{e} 3$ & $1.69 \mathrm{e} 4$ & $1.40 \mathrm{e} 4$ \\
$5.76 \mathrm{e} 2$ & $7.52 \mathrm{e} 3$ & $7.63 \mathrm{e} 3$ \\
$1.73 \mathrm{e} 1$ & $5.59 \mathrm{e} 3$ & $6.01 \mathrm{e} 3$ \\
$8.91 \mathrm{e} 0$ & $5.10 \mathrm{e} 3$ & $5.50 \mathrm{e} 3$ \\
- & $4.52 \mathrm{e} 3$ & $4.97 \mathrm{e} 3$ \\
- & $4.10 \mathrm{e} 3$ & $4.49 \mathrm{e} 3$
\end{tabular}

\begin{tabular}{ccc}
\multicolumn{3}{c}{$I$} \\
\hline $\mathrm{a}$ & $\mathrm{f}$ & $\mathrm{w}$ \\
$2.95 \mathrm{e} 5$ & $4.19 \mathrm{e} 5$ & $2.01 \mathrm{e} 5$ \\
$4.24 \mathrm{e} 5$ & $3.22 \mathrm{e} 5$ & $1.86 \mathrm{e} 5$ \\
$4.10 \mathrm{e} 5$ & $2.41 \mathrm{e} 5$ & $1.46 \mathrm{e} 5$ \\
$2.46 \mathrm{e} 5$ & $1.89 \mathrm{e} 5$ & $1.14 \mathrm{e} 5$ \\
$1.37 \mathrm{e} 5$ & $1.50 \mathrm{e} 5$ & $9.10 \mathrm{e} 4$ \\
$9.23 \mathrm{e} 4$ & $1.28 \mathrm{e} 5$ & $7.80 \mathrm{e} 4$ \\
$3.75 \mathrm{e} 4$ & $9.46 \mathrm{e} 4$ & $5.74 \mathrm{e} 4$ \\
$1.91 \mathrm{e} 4$ & $6.13 \mathrm{e} 4$ & $3.82 \mathrm{e} 4$ \\
$1.12 \mathrm{e} 4$ & $3.08 \mathrm{e} 4$ & $2.03 \mathrm{e} 4$ \\
$3.88 \mathrm{e} 3$ & $1.14 \mathrm{e} 4$ & $8.68 \mathrm{e} 3$ \\
$4.75 \mathrm{e} 2$ & $5.08 \mathrm{e} 3$ & $4.72 \mathrm{e} 3$ \\
$1.42 \mathrm{e} 1$ & $3.78 \mathrm{e} 3$ & $3.77 \mathrm{e} 3$ \\
$7.34 \mathrm{e} 0$ & $3.44 \mathrm{e} 3$ & $3.46 \mathrm{e} 3$ \\
- & $3.06 \mathrm{e} 3$ & $3.06 \mathrm{e} 3$ \\
- & $2.76 \mathrm{e} 3$ & $2.78 \mathrm{e} 3$
\end{tabular}


Table C.26

Peach Bottom Case 2 Drywell Gamma Dose Rates (Continue:1)

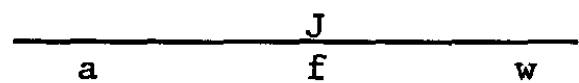

a

$\begin{array}{ccc}1.76 \mathrm{e} 5 & 7.59 \mathrm{e} 4 & 2.10 \mathrm{e} 5 \\ 2.53 \mathrm{e} 5 & 5.82 \mathrm{e} 4 & 1.96 \mathrm{e} 5 \\ 2.44 \mathrm{e} 5 & 4.36 \mathrm{e} 4 & 1.52 \mathrm{e} 5 \\ 1.47 \mathrm{e} 5 & 3.43 \mathrm{e} 4 & 1.19 \mathrm{e} 5 \\ 8.15 \mathrm{e} 4 & 2.73 \mathrm{e} 4 & 9.47 \mathrm{e} 4 \\ 5.50 \mathrm{e} 4 & 2.33 \mathrm{e} 4 & 8.07 \mathrm{e} 4 \\ 2.23 \mathrm{e} 4 & 1.72 \mathrm{e} 4 & 6.03 \mathrm{e} 4 \\ 1.14 \mathrm{e} 4 & 1.11 \mathrm{e} 4 & 4.00 \mathrm{e} 4 \\ 6.33 \mathrm{e} 3 & 5.60 \mathrm{e} 3 & 2.12 \mathrm{e} 4 \\ 2.20 \mathrm{e} 3 & 2.07 \mathrm{e} 3 & 9.07 \mathrm{e} 3 \\ 2.70 \mathrm{e} 2 & 9.21 \mathrm{e} 2 & 4.93 \mathrm{e} 3 \\ 8.10 \mathrm{e} 1 & 6.85 \mathrm{e} 2 & 3.95 \mathrm{e} 3 \\ 7.34 \mathrm{e} 0 & 6.24 \mathrm{e} 2 & 3.62 \mathrm{e} 3 \\ - & 5.54 \mathrm{e} 2 & 3.21 \mathrm{e} 3 \\ - & 5.01 \mathrm{e} 2 & 2.90 \mathrm{e} 3\end{array}$

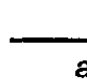

$2.04 e 5$

$2.93 \mathrm{e} 5$

$2.83 \mathrm{e} 5$

$1.70 \mathrm{e} 5$

$9.45 \mathrm{e} 4$

$6.37 e 4$

2. $59 \mathrm{e} 4$

$1.32 \mathrm{e} 4$

$7.44 \mathrm{e} 3$

$2.59 \mathrm{e} 3$

$3.17 \mathrm{e} 2$

9. $50 \mathrm{el}$

$4.17 \mathrm{e} 0$

-

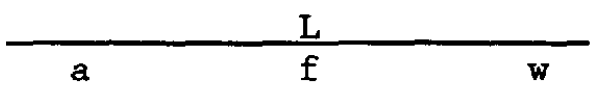

$1.65 \mathrm{e} 5$

$7.44 e^{4}$

$1.02 \mathrm{e} 5$

$8.97 e 4 \quad 1.94 e 5$

$6.88 \mathrm{e} 4 \quad 1.81 \mathrm{e} 5$

$5.16 \mathrm{e} 4 \quad 1.41 \mathrm{e} 5$

$4.05 \mathrm{e} 4 \quad 1.11 \mathrm{e} 5$

$3.22 \mathrm{e} 4 \quad 8.78 \mathrm{e} 4$

$2.76 \mathrm{e} 4 \quad 7.54 \mathrm{e} 4$

$2.02 \mathrm{e} 4 \quad 5.60 \mathrm{e} 4$

$1.31 \mathrm{e} 4 \quad 3.71 \mathrm{e} 4$

$6.61 \mathrm{e} 3 \quad 1.97 \mathrm{e} 4$

$2.44 \mathrm{e} 3 \quad 8.41 \mathrm{e} 3$

$1.09 \mathrm{e} 3 \quad 4.57 \mathrm{e} 3$

8.10e2 $3.65 \mathrm{e} 3$

$7.38 \mathrm{e} 2 \quad 3.35 \mathrm{e} 3$

$6.56 \mathrm{e} 2 \quad 2.97 \mathrm{e} 3$

$5.93 \mathrm{e} 2 \quad 2.69 \mathrm{e} 3$
2. 37 e 5

$2.29 \mathrm{e} 5$

1. $38 \mathrm{e} 5$

$7.65 \mathrm{e} 4$

5. $16 \mathrm{e} 4$

$2.10 \mathrm{e} 4$

$1.07 \mathrm{e} 4$

$6.14 \mathrm{e} 3$

$2.14 \mathrm{e} 3$

2. $62 \mathrm{e} 2$

$7.84 \mathrm{e} 1$

4. $05 \mathrm{e} 0$

-
$5.71 e^{4}$

4. $28 \mathrm{e} 4$

3. $36 \mathrm{e} 4$

$2.68 \mathrm{e} 4$

2. $29 \mathrm{e} 4$

$1.68 \mathrm{e} 4$

$1.09 \mathrm{e} 4$

$5.48 \mathrm{e} 3$

$2.02 \mathrm{e} 3$

$9.03 \mathrm{e} 2$

$6.72 \mathrm{e} 2$

$6.12 \mathrm{e} 2$

$5.43 e 2$
$9.49 \mathrm{e} 4$

$7.42 \mathrm{e} 4$

$5.83 \mathrm{e} 4$

$4.62 \mathrm{e} 4$

$3.96 \mathrm{e} 4$

$2.94 \mathrm{e} 4$

$1.95 \mathrm{e} 4$

$1.03 \mathrm{e} 4$

$4.43 \mathrm{e} 3$

$2.40 \mathrm{e} 3$

$1.92 \mathrm{e} 3$

$1.76 \mathrm{e} 3$ 
Table C.27

Peach Bottom Case 2 Drywell Beta Dose Rates
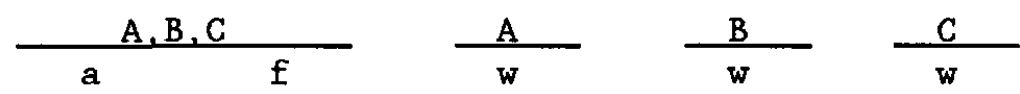

$2.44 \mathrm{e} 5 \quad 1.11 \mathrm{e} 6$

$6.63 e 5 \quad 9.43 e 5$

5.88 e 5 5.61e 5

$4.72 \mathrm{e} 5$

$2.77 \mathrm{e} 5$

$2.09 \mathrm{e} 5$

$1.89 \mathrm{e} 5$

$1.53 e 5$

$1.06 \mathrm{e} 5$

$6.68 \mathrm{e} 4$

$3.54 \mathrm{e} 4$

$1.66 \mathrm{e} 4$

$8.49 \mathrm{e} 3$

$6.55 \mathrm{e} 3$

$6.42 \mathrm{e} 3$

$5.93 e 3$

$5.48 e^{3}$

$\begin{array}{ll}3.58 \mathrm{e} 4 & 5.97 \mathrm{e} 5 \\ 6.54 \mathrm{e} 4 & 7.06 \mathrm{e} 5 \\ 2.17 \mathrm{e} 4 & 4.18 \mathrm{e} 5 \\ 7.92 \mathrm{e} 3 & 3.06 \mathrm{e} 5 \\ 7.01 \mathrm{e} 3 & 2.90 \mathrm{e} 5 \\ 6.66 \mathrm{e} 3 & 2.35 \mathrm{e} 5 \\ 1.96 \mathrm{e} 3 & 1.57 \mathrm{e} 5 \\ 1.70 \mathrm{e} 3 & 1.04 \mathrm{e} 5 \\ 7.25 \mathrm{e} 2 & 5.37 \mathrm{e} 4 \\ 2.28 \mathrm{e} 2 & 2.62 \mathrm{e} 4 \\ 8.27 \mathrm{e} 1 & 1.30 \mathrm{e} 4 \\ 2.48 \mathrm{e} 1 & 9.91 \mathrm{e} 3 \\ 2.31 \mathrm{e} 1 & 9.25 \mathrm{e} 3 \\ & 8.81 \mathrm{e} 3 \\ 2.29 \mathrm{el} 1 & 8.49 \mathrm{e} 3\end{array}$

(

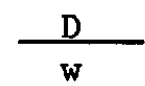

$6.63 e 5$

$5.88 \mathrm{e} 5$

$5.09 \mathrm{e} 5$

$5.06 \mathrm{e} 5$

$4.14 \mathrm{e} 5$

$2.65 e 5$

$2.43 \mathrm{e} 5$

$1.07 \mathrm{e} 5$

$3.98 \mathrm{e} 4$

$6.82 \mathrm{e}^{3}$

$2.17 \mathrm{e} 3$

$1.99 \mathrm{e} 3$

$1.93 \mathrm{e} 3$

1. 91 e 3

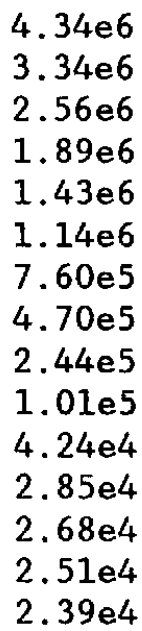

$5.97 \mathrm{e} 5$

$7.06 \mathrm{e} 5$

$4.18 \mathrm{e} 5$

$3.06 \mathrm{e} 5$

2. $90 \mathrm{e} 5$

2. $35 \mathrm{e} 5$

$1.57 \mathrm{e} 5$

$1.04 \mathrm{e} 5$

5. $37 \mathrm{e} 4$

$2.62 \mathrm{e} 4$

$1.36 \mathrm{e} 4$

$9.91 e 3$

$9.25 \mathrm{e} 3$

$8.81 \mathrm{e} 3$

$8.49 \mathrm{e} 3$
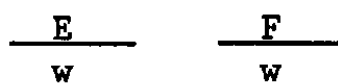

$3.58 \mathrm{e} 4 \quad 3.84 \mathrm{e} 5$

$6.45 \mathrm{e} 4 \quad 4.72 \mathrm{e} 5$

$2.17 \mathrm{e} 4 \quad 2.77 \mathrm{e} 5$

$7.92 \mathrm{e} 3 \quad 2.09 \mathrm{e} 5$

$7.01 \mathrm{e} 3 \quad 1.89 \mathrm{e} 5$

$6.66 \mathrm{e} 3 \quad 1.53 \mathrm{e} 5$

$1.96 \mathrm{e} 3 \quad 1.06 \mathrm{e} 5$

$1.70 \mathrm{e} 3 \quad 6.68 \mathrm{e} 4$

$7.25 \mathrm{e} 2 \quad 3.54 \mathrm{e} 4$

$2.28 \mathrm{e} 2 \quad 1.66 \mathrm{e} 4$

$8.27 \mathrm{el} \quad 8.49 \mathrm{e} 3$

$2.48 \mathrm{e} 16.55 \mathrm{e} 3$

2.3lel $6.42 \mathrm{e} 3$

$5.93 e 3$

$2.29 \mathrm{el} \quad 5.48 \mathrm{e} 3$ 
Table C.27

Peach Bottom Case 2 Drywell Beta Dose Rates (Continued)
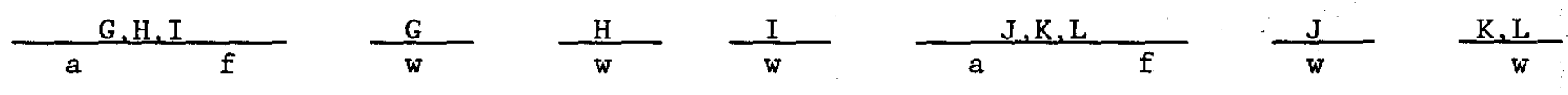

\begin{tabular}{|c|c|c|c|}
\hline & $1 \mathrm{~h}$ & $2.44 \mathrm{e} 5$ & $3.27 \mathrm{e} 4$ \\
\hline & $2 h$ & $6.63 \mathrm{e} 5$ & $9.65 \mathrm{e}$ \\
\hline & $4 h$ & $5.88 e 5$ & $1.70 \mathrm{e}$ \\
\hline & $8 \mathrm{~h}$ & $5.09 \mathrm{e} 5$ & 9.65 \\
\hline & $16 \mathrm{~h}$ & $5.06 \mathrm{e} 5$ & 7.82 \\
\hline & $1 d$ & $4.14 \mathrm{e} 5$ & \\
\hline & $2 d$ & $2.65 \mathrm{e} 5$ & 1.58 \\
\hline & $4 d$ & $2.43 \mathrm{e} 5$ & \\
\hline & $8 d$ & $1.07 \mathrm{e} 5$ & \\
\hline & $16 \mathrm{~d}$ & $3.98 e^{4}$ & \\
\hline & $32 d$ & $6.82 \mathrm{e}^{3}$ & \\
\hline & $64 d$ & $2.17 \mathrm{e}^{3}$ & \\
\hline & $128 d$ & $1.99 \mathrm{e} 3$ & \\
\hline & $256 d$ & $1.93 \mathrm{e} 3$ & \\
\hline & $1 y$ & $1.91 \mathrm{e} 3$ & \\
\hline
\end{tabular}

$3.84 \mathrm{e} 5$
$4.72 \mathrm{e} 5$
$2.77 \mathrm{e} 5$
$2.09 \mathrm{e} 5$
$1.89 \mathrm{e} 5$
$1.53 \mathrm{e} 5$
$1.06 \mathrm{e} 5$
$6.68 \mathrm{e} 4$
$3.59 \mathrm{e} 4$
$1.66 \mathrm{e} 4$
$8.49 \mathrm{e} 3$
$6.55 \mathrm{e} 3$
$6.42 \mathrm{e} 3$
$5.93 \mathrm{e} 3$
$5.48 \mathrm{e} 3$

$\begin{array}{ll}3.58 \mathrm{e} 4 & 5.97 \mathrm{e} 5 \\ 6.45 \mathrm{e} 4 & 7.06 \mathrm{e} 5 \\ 2.17 \mathrm{e} 4 & 4.18 \mathrm{e} 5 \\ 7.92 \mathrm{e} 3 & 3.06 \mathrm{e} 5 \\ 7.01 \mathrm{e} 3 & 2.90 \mathrm{e} 5 \\ 6.66 \mathrm{e} 3 & 2.35 \mathrm{e} 5 \\ 1.96 \mathrm{e} 3 & 1.57 \mathrm{e} 5 \\ 1.70 \mathrm{e} 3 & 1.04 \mathrm{e} 5 \\ 7.25 \mathrm{e} 2 & 5.37 \mathrm{e} 4 \\ 2.28 \mathrm{e} 2 & 2.62 \mathrm{e} 4 \\ 8.27 \mathrm{e} 1 & 1.36 \mathrm{e} 4 \\ 2.48 \mathrm{e} 1 & 9.91 \mathrm{e} 3 \\ 2.31 \mathrm{e} 1 & 9.25 \mathrm{e} 3 \\ & 8.81 \mathrm{e} 3 \\ 2.29 \mathrm{e} 1 & 8.49 \mathrm{e} 3\end{array}$

$\begin{array}{ll}2.44 \mathrm{e} 5 & - \\ 6.63 \mathrm{e} 5 & - \\ 5.88 \mathrm{e} 5 & - \\ 5.09 \mathrm{e} 5 & - \\ 5.06 \mathrm{e} 5 & - \\ 4.14 \mathrm{e} 5 & - \\ 2.65 \mathrm{e} 5 & - \\ 2.43 \mathrm{e} 5 & - \\ 1.07 \mathrm{e} 5 & - \\ 3.98 \mathrm{e} 4 & - \\ 6.82 \mathrm{e} 3 & - \\ 2.17 \mathrm{e} 3 & - \\ 1.99 \mathrm{e} 3 & - \\ 1.93 \mathrm{e} 3 & - \\ 1.91 \mathrm{e} 3 & -\end{array}$

$1.43 \mathrm{e} 5$

$5.97 \mathrm{e} 5$

$1.87 \mathrm{e} 5$

$7.06 \mathrm{e} 5$

$1.06 \mathrm{e} 5$

$4.18 \mathrm{e} 5$

$7.56 \mathrm{e} 4$

$3.06 \mathrm{e} 5$

$7.20 \mathrm{e} 4$

$2.90 \mathrm{e} 5$

$5.86 \mathrm{e} 4$

$2.35 \mathrm{e} 5$

4. $38 \mathrm{e} 4$

$1.57 \mathrm{e} 5$

$2.46 \mathrm{e} 4$

1.04e5

1. $36 \mathrm{e} 4$

$5.37 \mathrm{e} 4$

$6.53 \mathrm{e} 3$

$2.62 \mathrm{e} 4$

$3.21 \mathrm{e} 3$

1. $36 \mathrm{e} 4$

$2.45 \mathrm{e} 3$

$9.91 \mathrm{e} 3$

$2.38 \mathrm{e} 3$

$9.25 \mathrm{e} 3$

2. $21 \mathrm{e} 3$

8.81 e3

$2.10 \mathrm{e} 3$

$8.49 \mathrm{e} 3$ 
Table C. 28

Peach Bottom Case 2 Wetwell Gamma Dose Rates

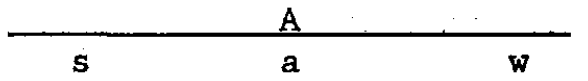

\begin{tabular}{|c|c|c|c|c|c|c|}
\hline & \multicolumn{3}{|c|}{ A } & \multicolumn{3}{|c|}{ B } \\
\hline & s & a & $w$ & $\mathbf{s}$ & a & $w$ \\
\hline Ih & $1.68 \mathrm{e} 4$ & $2.99 e 5$ & $5.59 \mathrm{e} 4$ & - & $4.16 \mathrm{e} 1$ & $2.44 \mathrm{e} 0$ \\
\hline $2 \mathrm{~h}$ & $1.23 \mathrm{e} 4$ & $1.55 \mathrm{e} 5$ & $4.26 \mathrm{e} 4$ & - & $2.13 \mathrm{e} 1$ & $1.40 \mathrm{e} 0$ \\
\hline $4 \mathrm{~h}$ & $8.66 \mathrm{e} 3$ & $6.86 \mathrm{e} 4$ & $3.09 \mathrm{e} 4$ & - & $7.79 \mathrm{eo}$ & $6.11 \mathrm{e}-1$ \\
\hline $8 \mathrm{~h}$ & $6.49 \mathrm{e} 3$ & $4.08 \mathrm{e} 4$ & $2.43 \mathrm{e} 4$ & - & $2.84 \mathrm{e} 0$ & $3.96 e-1$ \\
\hline $16 \mathrm{~h}$ & $4.91 \mathrm{e} 3$ & $2.22 e^{4}$ & $1.93 \mathrm{e} 4$ & - & $4.49 e-1$ & $2.01 e-1$ \\
\hline $1 d$ & $4.08 \mathrm{e} 3$ & $1.49 \mathrm{e} 4$ & $1.65 \mathrm{e} 4$ & - & $1.02 \mathrm{e}-1$ & 1. $38 \mathrm{e}-1$ \\
\hline $2 d$ & $2.91 e 3$ & $5.84 e^{3}$ & $1.21 e^{4}$ & - & $2.91 e-2$ & $9.09 e-2$ \\
\hline $4 d$ & $1.85 e 3$ & $2.53 \mathrm{e} 3$ & $7.81 \mathrm{e} 3$ & - & - & - \\
\hline $8 d$ & $8.99 \mathrm{e} 2$ & $1.17 \mathrm{e} 3$ & $3.92 \mathrm{e} 3$ & - & - & - \\
\hline $16 \mathrm{~d}$ & $3.17 \mathrm{e} 2$ & $3.23 e 2$ & $1.47 \mathrm{e} 3$ & - & - & - \\
\hline $32 d$ & $1.54 \mathrm{e} 2$ & $5.35 \mathrm{e} 1$ & $6.90 \mathrm{e} 2$ & - & - & - \\
\hline $64 d$ & $1.26 \mathrm{e} 2$ & $1.49 \mathrm{e} 1$ & $5.32 \mathrm{e} 2$ & - & - & - \\
\hline $128 d$ & $1.16 \mathrm{e} 2$ & $1.20 \mathrm{e} 1$ & $4.87 e 2$ & - & - & - \\
\hline $256 d$ & & $1.07 \mathrm{e} 1$ & $4.33 \mathrm{e} 2$ & - & - & - \\
\hline $1 y$ & $9.32 \mathrm{e} 1$ & $9.83 \mathrm{e} 0$ & $3.91 \mathrm{e} 2$ & & & \\
\hline
\end{tabular}


Table C. 29

Peach Bottom Case 3 Wetwell Gamma Dose Rates

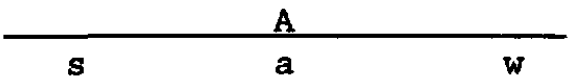

\begin{tabular}{|c|c|c|c|c|c|c|}
\hline & \multicolumn{3}{|c|}{ A } & \multicolumn{3}{|c|}{ B } \\
\hline & $\mathbf{s}$ & a & w & $\mathbf{s}$ & a & w \\
\hline Ih & $2.17 \mathrm{e} 4$ & $2.99 e 5$ & $5.58 \mathrm{e} 4$ & - & $4.16 \mathrm{e} 1$ & $2.25 \mathrm{e} 0$ \\
\hline $2 \mathrm{~h}$ & $1.57 \mathrm{e} 4$ & $1.58 \mathrm{e} 5$ & $4.26 e^{4}$ & - & $2.14 \mathrm{el}$ & $1.28 \mathrm{e} 0$ \\
\hline $4 \mathrm{~h}$ & $1.55 \mathrm{e} 4$ & $6.01 \mathrm{e} 4$ & $3.14 \mathrm{e} 4$ & - & $7.62 \mathrm{eo}$ & $6.74 \mathrm{e}-1$ \\
\hline $8 \mathrm{~h}$ & $1.15 \mathrm{e} 4$ & $3.39 \mathrm{e} 4$ & $2.47 \mathrm{e} 4$ & - & $2.73 \mathrm{e} 0$ & $3.75 \mathrm{e}-1$ \\
\hline $16 \mathrm{~h}$ & $8.69 \times 3$ & $1.68 \mathrm{e} 4$ & $1.95 \mathrm{e} 4$ & - & & \\
\hline $1 d$ & $7.21 \mathrm{e} 3$ & $1.02 \mathrm{e} 4$ & $1.67 \mathrm{e} 4$ & - & $5.49 e-2$ & $1.42 \mathrm{e}-1$ \\
\hline $2 d$ & $5.15 \mathrm{e} 3$ & $2.49 \mathrm{e} 3$ & $1.23 \mathrm{e} 4$ & - & $3.11 e-4$ & $8.71 \mathrm{e}-2$ \\
\hline $4 d$ & $3.32 \mathrm{e} 3$ & $4.26 \mathrm{e} 2$ & $7.93 \mathrm{e} 3$ & - & - & $5.46 e-2$ \\
\hline $8 d$ & $1.99 \mathrm{e} 3$ & $2.07 \mathrm{e} 2$ & $3.99 \mathrm{e} 3$ & - & - & $2.41 e-2$ \\
\hline $16 d$ & $6.62 \mathrm{e} 2$ & $7.04 \mathrm{e} 1$ & $1.49 \mathrm{e} 3$ & - & - & $5.92 e-3$ \\
\hline $32 d$ & $3.38 \mathrm{e} 2$ & $9.56 \mathrm{e} 0$ & $7.01 \mathrm{e} 2$ & - & - & \\
\hline $64 d$ & $2.52 \mathrm{e} 2$ & $1.42 \mathrm{e} 0$ & $5.40 \mathrm{e} 2$ & - & - & \\
\hline $28 d$ & $2.13 \mathrm{e} 2$ & $1.27 \mathrm{e} 0$ & $4.94 \mathrm{e} 2$ & - & - & $1.01 \mathrm{e}-3$ \\
\hline $56 d$ & $1.78 \mathrm{e} 2$ & $1.24 \mathrm{e} 0$ & $4.38 \mathrm{e} 2$ & - & - & $8.99 e-4$ \\
\hline $1 y$ & $1.59 \mathrm{e} 2$ & $1.21 \mathrm{e} 0$ & $3.96 \mathrm{e} 2$ & - & - & - \\
\hline
\end{tabular}


Table C. 30

Peach Bottom Case 4 Wetwell Gamma Dose Rates

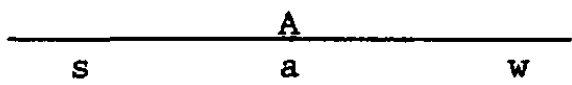

\begin{tabular}{|c|c|c|c|c|c|c|}
\hline & & $A$ & & & B & \\
\hline & $\mathrm{s}$ & a & $w$ & $\mathbf{s}$ & $a$ & w \\
\hline $1 \mathrm{~h}$ & $2.17 \mathrm{e} 4$ & $2.99 \mathrm{e} 5$ & $5.58 \mathrm{e} 4$ & - & $4.16 \mathrm{el}$ & $2.25 \mathrm{e} 0$ \\
\hline $2 \mathrm{~h}$ & $1.57 \mathrm{e} 4$ & $1.55 \mathrm{e} 5$ & $4.26 \mathrm{e} 4$ & - & $2.13 \mathrm{el}$ & $1.29 \mathrm{e} 0$ \\
\hline $4 h$ & $1.43 \mathrm{e} 4$ & $6.86 \mathrm{e} 4$ & $3.09 \mathrm{e} 4$ & - & $7.57 \mathrm{e} 0$ & $6.66 \mathrm{e}-1$ \\
\hline $8 \mathrm{~h}$ & $1.07 \mathrm{e} 4$ & $4.08 \mathrm{e} 4$ & $2.42 \mathrm{e} 4$ & - & $2.84 \mathrm{e} 0$ & $3.70 e-1$ \\
\hline $16 \mathrm{~h}$ & $8.11 \mathrm{e} 3$ & $2.22 \mathrm{e} 4$ & $1.83 \mathrm{e} 4$ & - & $4.49 e-1$ & $2.01 e-1$ \\
\hline $1 d$ & $6.74 \mathrm{e}^{3}$ & $1.49 \mathrm{e} 4$ & $1.65 \mathrm{e} 4$ & - & $1.02 \mathrm{e}-1$ & $1.40 e-1$ \\
\hline $2 d$ & $4.80 \mathrm{e} 3$ & $5.84 \mathrm{e}^{3}$ & $1.21 \mathrm{e}^{4}$ & - & $2.91 e-2$ & $8.58 e-2$ \\
\hline $4 d$ & $3.04 \mathrm{e} 3$ & $2.52 \mathrm{e} 3$ & $7.80 \mathrm{e} 3$ & - & $1.77 e-2$ & $5.37 e-2$ \\
\hline $8 d$ & $1.46 \mathrm{e}^{3}$ & $1.17 \mathrm{e} 3$ & $3.92 \mathrm{e} 3$ & - & $7.51 e-3$ & $2.39 e-2$ \\
\hline $16 d$ & $5.07 e 2$ & $3.23 e 2$ & $1.47 \mathrm{e} 3$ & - & $1.41 \mathrm{e}-3$ & $5.80 e-3$ \\
\hline $32 d$ & $2.42 \mathrm{e} 2$ & $5.35 \mathrm{e} 1$ & $8.19 \mathrm{e} 2$ & - & - & - \\
\hline $64 d$ & $1.96 \mathrm{e} 2$ & $1.49 \mathrm{el}$ & $5.32 e 2$ & - & - & - \\
\hline $128 d$ & $1.80 \mathrm{e} 2$ & $1.20 \mathrm{el}$ & $4.87 e 2$ & - & - & - \\
\hline $256 d$ & $1.59 \mathrm{e} 2$ & $1.07 \mathrm{e} 1$ & $4.33 \mathrm{e} 2$ & - & - & - \\
\hline $1 y$ & $1.44 \mathrm{e} 2$ & $9.83 \mathrm{el}$ & $3.91 \mathrm{e} 2$ & - & - & - \\
\hline
\end{tabular}


APPENDIX D

MAJOR ISOTOPE CONTRIBUTORS TO TOTAL DOSE 
Table D.1

Surry Major Radionuclide Contributors to Gamma Dose

Case 1

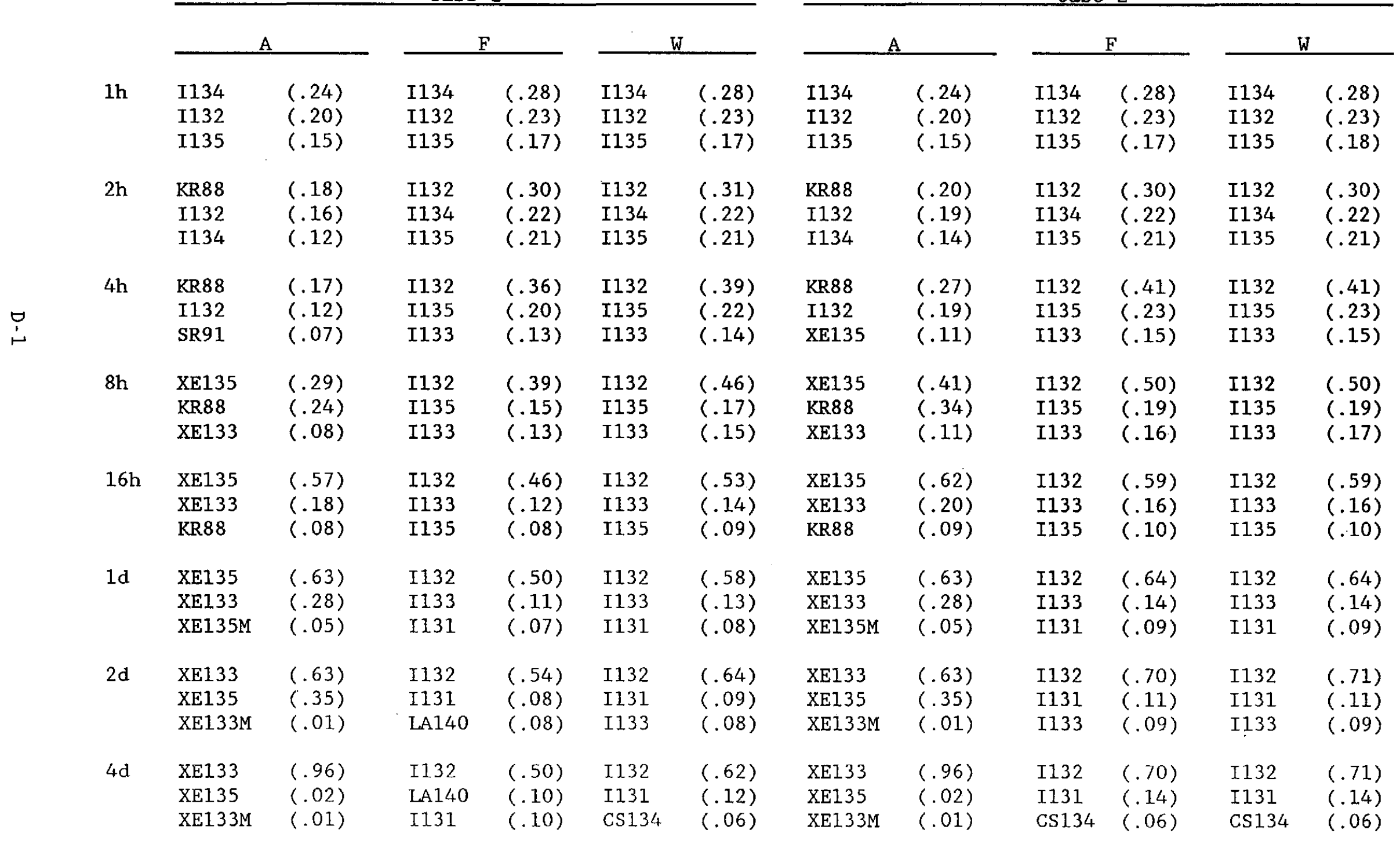


Table D.1

Surry Major Radionuclide Contributors to Gamma Dose

(Continued)

Case

\begin{tabular}{|c|c|c|c|c|c|c|}
\hline \multirow[b]{2}{*}{$8 d$} & \multicolumn{2}{|c|}{ A } & \multicolumn{2}{|l|}{$F$} & \multicolumn{2}{|c|}{ W. } \\
\hline & $\begin{array}{l}\text { XE133 } \\
\text { XE133M } \\
\text { KR85 }\end{array}$ & $\begin{array}{l}(.99) \\
(.007) \\
(.0006)\end{array}$ & $\begin{array}{l}\text { I132 } \\
\text { LA140 } \\
\text { I131 }\end{array}$ & $\begin{array}{l}(.36) \\
(.14) \\
(.12)\end{array}$ & $\begin{array}{l}\text { I132 } \\
\text { I131 } \\
\text { CS134 }\end{array}$ & $\begin{array}{l}(.48) \\
(.15) \\
(.10)\end{array}$ \\
\hline $16 \mathrm{~d}$ & $\begin{array}{l}\text { XE133 } \\
\text { KR85 } \\
\text { XE133M }\end{array}$ & $\begin{array}{l}(.99) \\
(.0017) \\
(.0016)\end{array}$ & $\begin{array}{l}\text { LA140 } \\
\text { CS134 } \\
\text { I132 }\end{array}$ & $\begin{array}{l}(.18) \\
(.14) \\
(.13)\end{array}$ & $\begin{array}{l}\text { CS134 } \\
\text { I132 } \\
\text { I131 }\end{array}$ & $\begin{array}{l}(.22) \\
(.19) \\
(.18)\end{array}$ \\
\hline $32 d$ & $\begin{array}{l}\text { XE133 } \\
\text { KR85 } \\
\text { XE133M }\end{array}$ & $\begin{array}{l}(.99) \\
(.014) \\
(.0001)\end{array}$ & $\begin{array}{l}\text { CS134 } \\
\text { NB95 } \\
\text { ZR95 }\end{array}$ & $\begin{array}{l}(.25) \\
(.21) \\
(.16)\end{array}$ & $\begin{array}{l}\text { CS134 } \\
\text { NB95 } \\
\text { ZR95 }\end{array}$ & $\begin{array}{l}(.42) \\
(.14) \\
(.10)\end{array}$ \\
\hline $64 d$ & $\begin{array}{l}\text { XE133 } \\
\text { KR85 }\end{array}$ & $\begin{array}{l}(.51) \\
(.49)\end{array}$ & $\begin{array}{l}\text { CS134 } \\
\text { NB95 } \\
\text { ZR95 }\end{array}$ & $\begin{array}{l}(.38) \\
(.27) \\
(.17)\end{array}$ & $\begin{array}{l}\text { CS134 } \\
\text { NB95 } \\
\text { ZR95 }\end{array}$ & $\begin{array}{l}(.60) \\
(.17) \\
(.11)\end{array}$ \\
\hline $128 \mathrm{~d}$ & $\begin{array}{l}\text { KR85 } \\
\text { XE133 }\end{array}$ & $\begin{array}{l}(.9998) \\
(.0002)\end{array}$ & $\begin{array}{l}\text { CS134 } \\
\text { NB95 } \\
\text { ZR95 }\end{array}$ & $\begin{array}{l}(.50) \\
(.23) \\
(.12)\end{array}$ & $\begin{array}{l}\text { CS134 } \\
\text { NB95 } \\
\text { BA137M }\end{array}$ & $\begin{array}{l}(.72) \\
(.13) \\
(.07)\end{array}$ \\
\hline $256 d$ & KR85 & $(1.0)$ & $\begin{array}{l}\text { CS134 } \\
\text { BA137M } \\
\text { NB95 }\end{array}$ & $\begin{array}{l}(.66) \\
(.17) \\
(.10)\end{array}$ & $\begin{array}{l}\text { CS134 } \\
\text { BA137M } \\
\text { NB95 }\end{array}$ & $\begin{array}{l}(.83) \\
(.09) \\
(.05)\end{array}$ \\
\hline $1 y$ & KR85 & $(1.0)$ & $\begin{array}{l}\text { CS134 } \\
\text { BA137M } \\
\text { NB95 }\end{array}$ & $\begin{array}{l}(.72) \\
(.2) \\
(.04)\end{array}$ & $\begin{array}{l}\text { CS134 } \\
\text { BA137M } \\
\text { NB95 }\end{array}$ & $\begin{array}{l}(.86) \\
(.10) \\
(.02)\end{array}$ \\
\hline
\end{tabular}

Case 2

\begin{tabular}{lllllll}
\multicolumn{1}{c}{$\mathrm{A}$} & & \multicolumn{2}{c}{$\mathrm{F}$} & \multicolumn{2}{c}{$\mathrm{W}$} \\
\cline { 6 - 7 } \cline { 5 - 6 } XE133 & $(.99)$ & I132 & $(.58)$ & I132 & $(.59)$ \\
XE133M & $(.007)$ & I131 & $(.19)$ & I131 & $(.19)$ \\
KR85 & $(.0006)$ & CS134 & $(.12)$ & CS134 & $(.12)$ \\
& & & & & \\
XE133 & $(.99)$ & CS134 & $(.31)$ & CS134 & $(.32)$ \\
KR85 & $(.002)$ & I132 & $(.27)$ & I132 & $(.28)$ \\
XE133M & $(.002)$ & I131 & $(.25)$ & I131 & $(.25)$ \\
& & & & & \\
XE133 & $(.99)$ & CS134 & $(.66)$ & CS134 & $(.67)$ \\
KR85 & $(.01)$ & I131 & $(.13)$ & I131 & $(.14)$ \\
XE133M & $(.0001)$ & CS136 & $(.07)$ & CS136 & $(.07)$ \\
& & & & & \\
XE133 & $(.51)$ & CS134 & $(.87)$ & CS134 & $(.89)$ \\
KR85 & $(.49)$ & NB95 & $(.03)$ & NB95 & $(.03)$ \\
& & ZR95 & $(.02)$ & CS136 & $(.02)$ \\
KR85 & $(.99)$ & CS134 & $(.93)$ & CS134 & $(.944)$ \\
XE133 & $(.0002)$ & NB95 & $(.02)$ & BA137M & $(.02)$ \\
& & BA137M & $(.02)$ & NB95 & $(.02)$ \\
KR85 & $(1.0)$ & CS134 & $(.96)$ & CS134 & $(.96)$ \\
& & BA137M & $(.03)$ & BA137M & $(.02)$ \\
& & NB95 & $(.008)$ & NB95 & $(.006)$ \\
KR85 & $(1.0)$ & CS134 & $(.96)$ & CS134 & $(.97)$ \\
& & BA137M & $(.03)$ & BA137M & $(.02)$ \\
& & SB125 & $(.004)$ & SB125 & $(.003)$ \\
& & & & &
\end{tabular}


Table D.I

Surry Major Radionuclide Contributors to Gamma Dose (Continued)

Case 3

\begin{tabular}{|c|c|c|c|c|c|c|c|c|}
\hline \multirow[b]{2}{*}{ 1h } & \multicolumn{2}{|c|}{ A } & \multicolumn{2}{|c|}{$S$} & \multicolumn{2}{|c|}{ A } & \multicolumn{2}{|c|}{$\mathrm{S}$} \\
\hline & $\mathrm{KR} 88$ & $(.60)$ & I134 & $(.28)$ & KR88 & $(.60)$ & I134 & $(.28)$ \\
\hline & KR87 & $(.13)$ & I132 & $(.22)$ & KR87 & $(.13)$ & I132 & $(.22)$ \\
\hline & XE135 & $(.09)$ & I135 & $(.18)$ & XE135 & $(.09)$ & I135 & $(.18)$ \\
\hline \multirow[t]{3}{*}{$2 \mathrm{~h}$} & KR88 & $(.62)$ & I132 & $(.28)$ & KR88 & $(.62)$ & I132 & $(.29)$ \\
\hline & XE135 & $(.13)$ & I134 & $(.20)$ & XE135 & $(.13)$ & I134 & $(.22)$ \\
\hline & KR87 & $(.10)$ & I135 & $(.20)$ & $\mathrm{KR} 87$ & $(.10)$ & I135 & $(.22)$ \\
\hline \multirow[t]{3}{*}{$4 h$} & KR88 & $(.54)$ & I132 & $(.33)$ & KR8 8 & $(.54)$ & I132 & $(.40)$ \\
\hline & XE135 & $(.22)$ & I135 & $(.20)$ & XE135 & $(.22)$ & I135 & $(.24)$ \\
\hline & $\mathrm{XE} 135 \mathrm{M}$ & $(.10)$ & $\mathrm{I} 133$ & $(.12)$ & $\mathrm{XE135M}$ & $(.10)$ & I133 & $(.14)$ \\
\hline \multirow[t]{3}{*}{$8 \mathrm{~h}$} & XE135 & $(.41)$ & I132 & $(.41)$ & XE135 & $(.41)$ & I132 & $(.50)$ \\
\hline & KR88 & $(.34)$ & I135 & $(.17)$ & KR88 & $(.34)$ & I135 & $(.20)$ \\
\hline & XE135M & $(.11)$ & I133 & $(.13)$ & XE133 & (.11) & I133 & $(.16)$ \\
\hline \multirow[t]{3}{*}{$16 \mathrm{~h}$} & XE135 & $(.62)$ & I132 & $(.49)$ & XE135 & $(.62)$ & I132 & $(.60)$ \\
\hline & XE133 & $(.20)$ & I133 & $(.13)$ & XE133 & $(.20)$ & I133 & $(.16)$ \\
\hline & KR88 & $(.09)$ & I135 & $(.09)$ & KR88 & $(.09)$ & I135 & $(.11)$ \\
\hline \multirow[t]{3}{*}{ Id } & XE135 & $(.63)$ & I132 & $(.54)$ & XE135 & $(.63)$ & I132 & $(.65)$ \\
\hline & XE133 & $(.28)$ & I133 & $(.12)$ & XE133 & $(.28)$ & I133 & $(.14)$ \\
\hline & XE135M & $(.05)$ & I131 & $(.06)$ & XE133M & $(.05)$ & $\mathrm{I} 131$ & $(.07)$ \\
\hline \multirow[t]{3}{*}{$2 d$} & XE133 & $(.63)$ & I132 & $(.58)$ & XE133 & $(.63)$ & I132 & $(.72)$ \\
\hline & XE135 & $(.35)$ & LA140 & $(.07)$ & XE135 & $(.35)$ & I131 & $(.09)$ \\
\hline & XE133M & $(.01)$ & I131 & $(.07)$ & XE133M & $(.01)$ & I133 & $(.09)$ \\
\hline \multirow[t]{3}{*}{$4 d$} & XE133 & $(.96)$ & I132 & $(.55)$ & XE133 & $(.96)$ & I132 & $(.73)$ \\
\hline & XE135 & $(.02)$ & LA140 & $(.10)$ & XE135 & $(.02)$ & I131 & $(.12)$ \\
\hline & $\mathrm{XE} 133 \mathrm{M}$ & $(.01)$ & I131 & $(.09)$ & XE133M & $(.01)$ & CS134 & $(.06)$ \\
\hline
\end{tabular}


Table D.1

Surry Major Radionuclide Contributors to Gamma Dose (Concluded)

\begin{tabular}{|c|c|c|c|c|c|c|c|c|}
\hline \multirow[b]{3}{*}{$8 d$} & \multicolumn{4}{|c|}{ Case 3} & \multicolumn{4}{|c|}{ Case 4} \\
\hline & \multicolumn{2}{|c|}{ A } & \multicolumn{2}{|c|}{$S$} & \multicolumn{2}{|c|}{ A } & \multicolumn{2}{|c|}{$\mathrm{S}$} \\
\hline & $\begin{array}{l}\text { XE133 } \\
\text { XE133M } \\
\text { KR85 }\end{array}$ & $\begin{array}{l}(.99) \\
(.007) \\
(.0006)\end{array}$ & $\begin{array}{l}\text { I132 } \\
\text { LA140 } \\
\text { I131 }\end{array}$ & $\begin{array}{l}(.41) \\
(.14) \\
(.11)\end{array}$ & $\begin{array}{l}\text { XE133 } \\
\text { XE133M } \\
\text { KR85 }\end{array}$ & $\begin{array}{l}(.99) \\
(.007) \\
(.0006)\end{array}$ & $\begin{array}{l}\text { I132 } \\
\text { I131 } \\
\text { CS134 }\end{array}$ & $\begin{array}{l}(.61) \\
(.16) \\
(.13)\end{array}$ \\
\hline $16 \mathrm{~d}$ & $\begin{array}{l}\text { XE133 } \\
\text { KR85 } \\
\text { XE133M }\end{array}$ & $\begin{array}{l}(.997) \\
(.002) \\
(.001)\end{array}$ & $\begin{array}{l}\text { LA140 } \\
\text { CS134 } \\
\text { I132 }\end{array}$ & $\begin{array}{l}(.18) \\
(.17) \\
(.15)\end{array}$ & $\begin{array}{l}\text { XE133 } \\
\text { KR85 } \\
\text { XE133M }\end{array}$ & $\begin{array}{l}(.997) \\
(.002) \\
(.001)\end{array}$ & $\begin{array}{l}\text { CS134 } \\
\text { I132 } \\
\text { I131 }\end{array}$ & $\begin{array}{l}(.33) \\
(.29) \\
(.21)\end{array}$ \\
\hline $32 d$ & $\begin{array}{l}\text { XE133 } \\
\text { KR85 } \\
\text { XE133M }\end{array}$ & $\begin{array}{l}(.99) \\
(.009) \\
(.0001)\end{array}$ & $\begin{array}{l}\text { CS134 } \\
\text { NB95 } \\
\text { ZR95 }\end{array}$ & $\begin{array}{l}(.29) \\
(.20) \\
(.15)\end{array}$ & $\begin{array}{l}\text { XE133 } \\
\text { KR85 } \\
\text { XE133M }\end{array}$ & $\begin{array}{l}(.99) \\
(.009) \\
(.0001)\end{array}$ & $\begin{array}{l}\text { CS134 } \\
\text { I131 } \\
\text { CS136 }\end{array}$ & $\begin{array}{l}(.68) \\
(.11) \\
(.07)\end{array}$ \\
\hline $64 d$ & $\begin{array}{l}\text { XE133 } \\
\text { KR85 }\end{array}$ & $\begin{array}{l}(.51) \\
(.49)\end{array}$ & $\begin{array}{l}\text { CS134 } \\
\text { NB95 } \\
\text { ZR95 }\end{array}$ & $\begin{array}{l}(.43) \\
(.25) \\
(.16)\end{array}$ & $\begin{array}{l}\text { XE133 } \\
\text { KR85 }\end{array}$ & $\begin{array}{l}(.51) \\
(.49)\end{array}$ & $\begin{array}{l}\text { CS134 } \\
\text { NB95 } \\
\text { ZR95 }\end{array}$ & $\begin{array}{l}(.88) \\
(.03) \\
(.02)\end{array}$ \\
\hline $128 d$ & $\begin{array}{l}\text { KR85 } \\
\text { XE133 }\end{array}$ & $\begin{array}{l}(.9998) \\
(.0002)\end{array}$ & $\begin{array}{l}\text { CS134 } \\
\text { NB95 } \\
\text { ZR95 }\end{array}$ & $\begin{array}{l}(.56) \\
(.21) \\
(.11)\end{array}$ & $\begin{array}{l}\text { KR85 } \\
\text { XE133 }\end{array}$ & $\begin{array}{l}(.9998) \\
(.0002)\end{array}$ & $\begin{array}{l}\text { CS134 } \\
\text { NB95 } \\
\text { BA137M }\end{array}$ & $\begin{array}{l}(.94) \\
(.02) \\
(.02)\end{array}$ \\
\hline $256 d$ & KR85 & $(1.0)$ & $\begin{array}{l}\text { CS134 } \\
\text { BA137M } \\
\text { NB95 }\end{array}$ & $\begin{array}{l}(.71) \\
(.14) \\
(.08)\end{array}$ & KR85 & $(1.0)$ & $\begin{array}{l}\text { CS134 } \\
\text { BA137M } \\
\text { NB95 }\end{array}$ & $\begin{array}{l}(.96) \\
(.02) \\
(.001)\end{array}$ \\
\hline $1 y$ & KR85 & $(1.0)$ & $\begin{array}{l}\text { CS134 } \\
\text { BA137M } \\
\text { NB95 }\end{array}$ & $\begin{array}{l}(.76) \\
(.17) \\
(.03)\end{array}$ & KR85 & $(1.0)$ & $\begin{array}{l}\text { CS134 } \\
\text { BA137M } \\
\text { SB125 }\end{array}$ & $\begin{array}{l}(.96) \\
(.03) \\
(.004)\end{array}$ \\
\hline$E$ & $\begin{array}{l}\text { irborne } \\
\text { loor }\end{array}$ & $\begin{array}{ll}\text { W: } & \text { Wal } \\
\text { S: } & \text { Sum }\end{array}$ & & & & & & \\
\hline
\end{tabular}


Table D.2

Surry Major Radionuclide Contributors to Beta Dose

Case 1

\begin{tabular}{|c|c|c|c|c|c|c|c|c|c|c|c|c|}
\hline \multirow{4}{*}{$1 \mathrm{~h}$} & \multicolumn{2}{|c|}{ A } & \multicolumn{2}{|c|}{$F$} & \multicolumn{2}{|c|}{$W$} & \multicolumn{2}{|c|}{ A } & \multicolumn{2}{|c|}{$F$} & \multicolumn{2}{|c|}{$\mathrm{W}$} \\
\hline & RB88 & $(.16)$ & RB88 & $(.22)$ & $\mathrm{RB} 88$ & $(.22)$ & RB88 & $(.16)$ & RB88 & $(.22)$ & RB88 & $(.22)$ \\
\hline & I134 & $(.12)$ & I134 & $(.16)$ & $\operatorname{cs} 138$ & $(.16)$ & I134 & $(.12)$ & I134 & $(.16)$ & $\operatorname{CS} 138$ & $(.16)$ \\
\hline & CS138 & $(.12)$ & CS138 & $(.16)$ & I134 & $(.16)$ & $\operatorname{CS} 138$ & $(.12)$ & CS138 & $(.16)$ & I134 & $(.16)$ \\
\hline $2 \mathrm{~h}$ & XE133 & $(.10)$ & RB88 & $(.23)$ & RB88 & $(.24)$ & XE133 & $(.13)$ & RB88 & $(.24)$ & $\mathrm{RB} 88$ & $(.24)$ \\
\hline & KR87 & $(.09)$ & I133 & $(.18)$ & I133 & $(.18)$ & KR87 & (.11) & I133 & $(.18)$ & $\mathrm{I} 133$ & $(.18)$ \\
\hline & RB88 & $(.08)$ & $\mathrm{I} 132$ & $(.16)$ & I132 & $(.16)$ & RB88 & $(.11)$ & I132 & $(.16)$ & I132 & $(.16)$ \\
\hline $4 h$ & XE133 & $(.13)$ & I133 & $(.17)$ & I133 & $(.21)$ & XE133 & $(.24)$ & I133 & $(.24)$ & I133 & $(.24)$ \\
\hline & XE135 & $(.10)$ & I132 & $(.16)$ & I132 & $(.20)$ & XE135 & $(.20)$ & I132 & $(.22)$ & I132 & $(.22)$ \\
\hline & SR91 & $(.08)$ & RB88 & $(.15)$ & RB88 & $(.18)$ & KR88 & $(.09)$ & $\mathrm{RB} 88$ & $(.20)$ & RB88 & $(.20)$ \\
\hline $8 h$ & XE133 & $(.35)$ & I132 & $(.16)$ & I132 & $(.23)$ & XE133 & $(.44)$ & I132 & $(.29)$ & I132 & $(.30)$ \\
\hline & XE135 & $(.32)$ & I133 & $(.16)$ & I133 & $(.22)$ & XE135 & $(.41)$ & I133 & $(.28)$ & I133 & $(.29)$ \\
\hline & KR88 & $(.05)$ & SR89 & $(.09)$ & I135 & $(.10)$ & KR88 & $(.06)$ & I135 & $(.13)$ & I135 & $(.13)$ \\
\hline $16 \mathrm{~h}$ & XE133 & $(.51)$ & I132 & $(.19)$ & I132 & $(.28)$ & $\mathrm{XE} 133$ & $(.53)$ & I132 & $(.37)$ & I132 & $(.38)$ \\
\hline & XE135 & $(.40)$ & I133 & $(.15)$ & I133 & $(.22)$ & XE135 & $(.42)$ & I133 & $(.30)$ & I133 & $(.30)$ \\
\hline & XE133M & $(.02)$ & SR89 & $(.12)$ & I131 & $(.08)$ & XE133M & $(.02)$ & I131 & $(.11)$ & I131 & $(.11)$ \\
\hline Id & XE133 & $(.61)$ & I132 & $(.21)$ & I132 & $(.31)$ & XE133 & $(.61)$ & I132 & $(.42)$ & I132 & $(.43)$ \\
\hline & XE135 & $(.34)$ & SR89 & $(.14)$ & I133 & $(.20)$ & XE135 & $(.34)$ & I133 & $(.27)$ & I133 & $(.28)$ \\
\hline & XE133M & $(.02)$ & I123 & $(.14)$ & I131 & $(.09)$ & XE133M & $(.02)$ & I131 & $(.13)$ & I131 & $(.13)$ \\
\hline $2 d$ & XE133 & $(.84)$ & I132 & $(.22)$ & I132 & $(.34)$ & XE133 & $(.84)$ & I132 & $(.49)$ & I132 & $(.50)$ \\
\hline & XE135 & $(.12)$ & SR89 & $(.19)$ & $\mathrm{I} 133$ & $(.12)$ & XE135 & $(.12)$ & I133 & $(.18)$ & I133 & $(.18)$ \\
\hline & XE133M & $(.03)$ & BA140 & $(.16)$ & SR89 & $(.12)$ & $\mathrm{XE} 133 \mathrm{M}$ & $(.03)$ & I131 & $(.17)$ & I131 & $(.17)$ \\
\hline $4 d$ & XE133 & $(.95)$ & SR89 & $(.23)$ & I132 & $(.31)$ & XE133 & $(.95)$ & I132 & $(.50)$ & I132 & $(.51)$ \\
\hline & XE133M & $(.03)$ & I132 & $(.19)$ & SR89 & $(.17)$ & XE133M & $(.03)$ & I131 & $(.22)$ & I131 & $(.23)$ \\
\hline & KR85 & $(.008$ & BA140 & $(.18)$ & I131 & $(.14)$ & KR85 & $(.008)$ & SR89 & $(.07)$ & SR89 & $(.06)$ \\
\hline
\end{tabular}

Case 2 
Table D.2

Surry Major Radionuclide Contributors to Beta Dose (Continued)

Case I

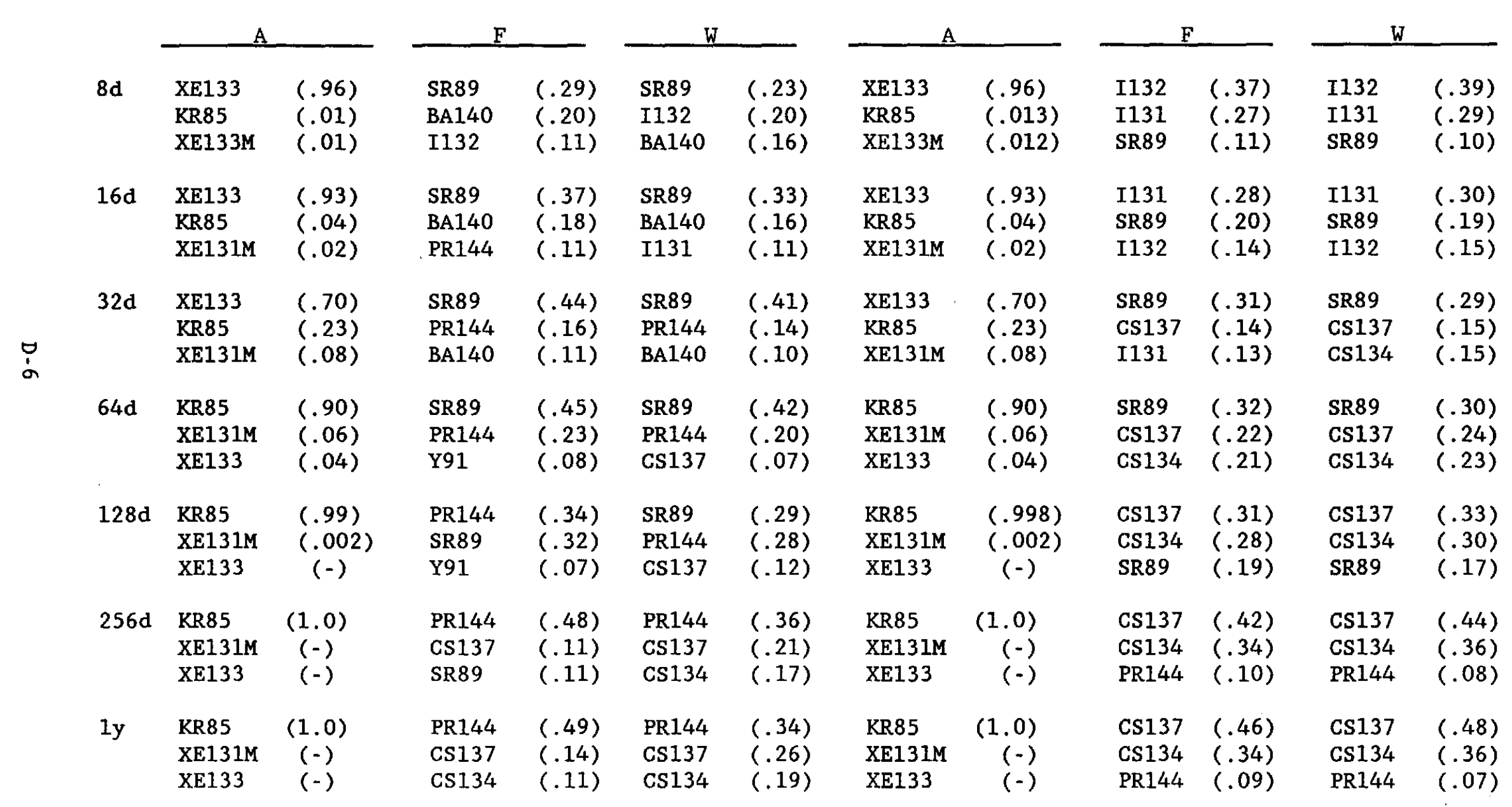


Table D.2

Surry Major Radionuclide Contributors to Beta Dose (Continued)

\begin{tabular}{|c|c|c|c|c|c|c|c|c|}
\hline & & Cas & & & & & 4 & \\
\hline & & & & & A & & & \\
\hline $1 \mathrm{~h}$ & KR87 & $(.34)$ & $\mathrm{RB} 88$ & $(.21)$ & KR87 & $(.34)$ & RB88 & $(.21)$ \\
\hline & XE133 & $(.23)$ & I134 & $(.16)$ & XE133 & $(.23)$ & I134 & $(.16)$ \\
\hline & KR88 & $(.17)$ & $\operatorname{Cs} 138$ & $(.16)$ & KR88 & $(.17)$ & $\operatorname{cs} 138$ & $(.16)$ \\
\hline $2 \mathrm{~h}$ & XE133 & $(.29)$ & RB88 & $(.20)$ & XE133 & $(.29)$ & RB88 & $(.23)$ \\
\hline & KR87 & $(.25)$ & I133 & $(.15)$ & KR87 & $(.25)$ & I133 & $(.17)$ \\
\hline & XE135 & $(.20)$ & I132 & $(.14)$ & XE135 & $(.20)$ & I132 & $(.15)$ \\
\hline $4 \mathrm{~h}$ & XE133 & $(.37)$ & I133 & $(.15)$ & XE133 & $(.37)$ & I133 & $(.23)$ \\
\hline & XE135 & $(.30)$ & I132 & $(.14)$ & XE135 & $(.30)$ & II32 & $(.22)$ \\
\hline & KR88 & $(.13)$ & RB88 & $(.13)$ & KR88 & $(.13)$ & RB88 & $(.20)$ \\
\hline $8 \mathrm{~h}$ & XE133 & $(.44)$ & I132 & $(.17)$ & XE133 & $(.44)$ & I132 & $(.29)$ \\
\hline & XE135 & $(.41)$ & I133 & $(.17)$ & XE135 & $(.41)$ & I133 & $(.28)$ \\
\hline & KR88 & $(.06)$ & SR89 & $(.09)$ & KR88 & $(.06)$ & I135 & $(.13)$ \\
\hline $16 \mathrm{~h}$ & XE133 & $(.52)$ & I132 & $(.22)$ & XE133 & $(.53)$ & I132 & $(.38)$ \\
\hline & XE135 & $(.42)$ & I133 & $(.17)$ & XE135 & $(.42)$ & I133 & $(.30)$ \\
\hline & XE133M & $(.02)$ & SR89 & $(.11)$ & XE133M & $(.22)$ & I131 & $(.11)$ \\
\hline $1 d$ & XE133 & $(.61)$ & I132 & $(.24)$ & XE133 & $(.62)$ & $\mathrm{I} 132$ & $(.42)$ \\
\hline & XE135 & $(.34)$ & $\mathrm{I} 133$ & $(.15)$ & XE135 & $(.34)$ & I133 & $(.28)$ \\
\hline & XE133M & $(.02)$ & SR89 & $(.13)$ & XE133M & $(.02)$ & I131 & $(.13)$ \\
\hline $2 d$ & XE133 & $(.84)$ & $\mathrm{I} 132$ & $(.25)$ & XE133 & $(.84)$ & I132 & $(.49)$ \\
\hline & XE135 & $(.12)$ & SR89 & $(.17)$ & XE135 & $(.12)$ & I133 & $(.18)$ \\
\hline & XE133M & $(.03)$ & BA140 & $(.14)$ & XE133M & $(.03)$ & I131 & $(.17)$ \\
\hline $4 d$ & XE133 & $(.95)$ & SR89 & $(.22)$ & XE133 & $(.95)$ & I132 & $(.50)$ \\
\hline & XE133M & $(.03)$ & I132 & $(.22)$ & $\mathrm{XE} 133 \mathrm{M}$ & $(.03)$ & 1131 & $(.22)$ \\
\hline & KR85 & $(.008)$ & BA140 & $(.17)$ & KR85 & $(.008)$ & SR89 & $(.06)$ \\
\hline
\end{tabular}


Table D.2

Surry Major Radionuclide Contributors to Beta Dose (Concluded)

Case 3

\begin{tabular}{|c|c|c|c|c|c|c|c|c|}
\hline \multirow{4}{*}{$8 \mathrm{~d}$} & \multicolumn{2}{|c|}{ A } & \multicolumn{2}{|c|}{$\underline{S}$} & \multicolumn{2}{|c|}{ A } & \multicolumn{2}{|c|}{$\mathrm{S}$} \\
\hline & XE133 & $(.96)$ & SR89 & $(.28)$ & XE133 & $(.96)$ & I132 & $(.38)$ \\
\hline & KR85 & $(.013)$ & BA140 & $(.19)$ & KR8 5 & $(.013)$ & I131 & $(.28)$ \\
\hline & XE133M & $(.012)$ & I132 & $(.12)$ & XE133M & $(.012)$ & SR89 & $(.11)$ \\
\hline \multirow[t]{3}{*}{$16 \mathrm{~d}$} & XE133 & $(.93)$ & SR89 & $(.36)$ & XE133 & $(.94)$ & I131 & $(.29)$ \\
\hline & KR85 & $(.04)$ & BA140 & $(.17)$ & KR85 & $(.04)$ & SR89 & $(.20)$ \\
\hline & XE131M & $(.02)$ & PR144 & $(.11)$ & XE131M & $(.02)$ & I132 & $(.14)$ \\
\hline \multirow[t]{3}{*}{$32 d$} & XE133 & $(.70)$ & SR89 & $(.43)$ & XE133 & $(.70)$ & SR89 & $(.31)$ \\
\hline & KR85 & $(.23)$ & PR144 & $(.15)$ & KR85 & $(.23)$ & CS137 & $(.14)$ \\
\hline & XE131M & $(.08)$ & BA140 & $(.11)$ & XE131M & $(.08)$ & $\operatorname{cs} 134$ & $(.14)$ \\
\hline \multirow[t]{3}{*}{$64 d$} & KR85 & $(.90)$ & SR89 & $(.44)$ & KR85 & $(.90)$ & SR89 & $(.31)$ \\
\hline & XE131M & $(.06)$ & PR144 & $(.22)$ & $\mathrm{XE131M}$ & $(.06)$ & $\operatorname{CS} 137$ & $(.23)$ \\
\hline & XE133 & $(.04)$ & Y91 & $(.08)$ & XE133 & $(.04)$ & CS134 & $(.22)$ \\
\hline \multirow[t]{3}{*}{$128 d$} & KR85 & $(.998)$ & PR144 & $(.33)$ & KR85 & $(.998)$ & CS137 & $(.32)$ \\
\hline & $\mathrm{XE131M}$ & $(.002)$ & SR89 & $(.32)$ & XE131M & $(.0017)$ & CS134 & $(.29)$ \\
\hline & XE133 & $(-)$ & CS137 & $(.07)$ & XE133 & $(-)$ & SR89 & $(.18)$ \\
\hline \multirow[t]{3}{*}{$256 \mathrm{~d}$} & KR85 & $(1.0)$ & PR144 & $(.45)$ & KR85 & $(1.0)$ & CS137 & $(.42)$ \\
\hline & XE131M & $(-)$ & CS137 & $(.13)$ & XE131M & $(-)$ & CS134. & $(.34)$ \\
\hline & XE133 & $(-)$ & $\operatorname{CS} 134$ & $(.10)$ & $\mathrm{XE133}$ & $(-)$ & PR144 & $(.10)$ \\
\hline \multirow[t]{3}{*}{$1 \mathrm{y}$} & KR85 & $(1.0)$ & PR144 & $(.46)$ & KR85 & $(1.0)$ & $\operatorname{Cs} 137$ & $(.47)$ \\
\hline & XE131M & $(-)$ & CS137 & $(.17)$ & XE131M & $(-)$ & CS134 & $(.35)$ \\
\hline & XE133 & $(-)$ & $\operatorname{CS134}$ & $(.12)$ & XE133 & $(-)$ & PR144 & $(.08)$ \\
\hline
\end{tabular}


Table D. 3

Peach Bottom Drywe1l Major Radionuclide Contributors to Gamma Dose

\begin{tabular}{|c|c|c|c|c|c|c|c|c|c|c|c|c|}
\hline \multirow{4}{*}{$1 \mathrm{~h}$} & \multicolumn{6}{|c|}{ Case 1} & \multicolumn{6}{|c|}{ Case 2} \\
\hline & \multicolumn{2}{|c|}{ A } & \multicolumn{2}{|c|}{$\mathrm{F}$} & \multicolumn{2}{|c|}{$\mathrm{W}$} & \multicolumn{2}{|c|}{ A } & \multicolumn{2}{|c|}{ F } & \multicolumn{2}{|c|}{$\mathrm{W}$} \\
\hline & I134 & $(.20)$ & I134 & $(.28)$ & 1134 & $(.26)$ & I134 & $(.20)$ & I134 & $(.28)$ & I134 & $(.26)$ \\
\hline & KR88 & $(.17)$ & I132 & $(.23)$ & $\mathrm{I} 132$ & $(.22)$ & KR8 8 & $(.17)$ & I132 & $(.23)$ & I132 & $(.22)$ \\
\hline & I132 & $(.16)$ & I135 & $(.17)$ & I135 & $(.16)$ & I132 & $(.16)$ & I135 & $(.17)$ & I135 & $(.16)$ \\
\hline \multirow[t]{3}{*}{$2 \mathrm{~h}$} & KR88 & $(.47)$ & $\mathrm{I} 132$ & $(.30)$ & I132 & $(.30)$ & KR88 & $(.47)$ & I132 & $(.30)$ & I132 & $(.30)$ \\
\hline & XE135 & $(.11)$ & I134 & $(.22)$ & I134 & $(.21)$ & XE135 & $(.11)$ & I134 & $(.22)$ & I134 & $(.21)$ \\
\hline & KR87 & $(.07)$ & I135 & $(.21)$ & I135 & $(.20)$ & KR87 & $(.07)$ & I 135 & $(.21)$ & I135 & $(.20)$ \\
\hline \multirow[t]{3}{*}{$4 h$} & KR88 & $(.51)$ & I132 & $(.34)$ & I132 & $(.32)$ & KR8 8 & $(.53)$ & $\mathrm{I} 132$ & $(.41)$ & I132 & $(.40)$ \\
\hline & XE135 & $(.23)$ & I135 & $(.19)$ & I135 & $(.18)$ & XE135 & $(.24)$ & I135 & $(.23)$ & I135 & $(.22)$ \\
\hline & XE135M & $(.09)$ & I133 & $(.12)$ & $\mathrm{I} 133$ & $(.12)$ & XE135M & $(.10)$ & I133 & $(.15)$ & I133 & $(.15)$ \\
\hline \multirow[t]{3}{*}{$8 \mathrm{~h}$} & XE135 & $(.43)$ & I132 & $(.48)$ & I132 & $(.48)$ & XE135 & $(.43)$ & I132 & $(.51)$ & I132 & $(.49)$ \\
\hline & KR88 & $(.33)$ & I135 & $(.18)$ & I135 & $(.18)$ & KR88 & $(.33)$ & I135 & $(.20)$ & I135 & $(.19)$ \\
\hline & $\mathrm{XE} 133$ & $(.11)$ & I133 & $(.16)$ & I133 & $(.16)$ & XE135M & $(.11)$ & I133 & $(.17)$ & I133 & $(.17)$ \\
\hline \multirow[t]{3}{*}{$16 \mathrm{~h}$} & XE135 & $(.63)$ & I132 & $(.58)$ & I132 & $(.59)$ & XE135 & $(.63)$ & I132 & $(.60)$ & I132 & $(.59)$ \\
\hline & XE133 & $(.19)$ & I133 & $(.16)$ & I133 & $(.16)$ & XE133 & $(.19)$ & I133 & $(.16)$ & I133 & $(.16)$ \\
\hline & $\mathrm{KR} 88$ & $(.09)$ & I135 & $(.10)$ & I135 & $(.10)$ & $\mathrm{KR} 88$ & $(.08)$ & I135 & $(.10)$ & I135 & $(.10)$ \\
\hline \multirow[t]{3}{*}{$1 \mathrm{~d}$} & XE135 & $(.65)$ & I132 & $(.64)$ & I1 32 & $(.64)$ & XE135 & $(.65)$ & I132 & $(.65)$ & I132 & $(.64)$ \\
\hline & XE133 & $(.27)$ & I133 & $(.14)$ & I133 & $(.14)$ & XE133 & $(.27)$ & I133 & $(.15)$ & I133 & $(.14)$ \\
\hline & XE135M & $(.05)$ & I131 & $(.08)$ & I131 & $(.08)$ & XE135M & $(.05)$ & $\mathrm{I} 131$ & $(.09)$ & I131 & $(.08)$ \\
\hline \multirow[t]{3}{*}{$2 d$} & $\mathrm{XE} 133$ & $(.61)$ & I132 & $(.70)$ & $\mathrm{I} 132$ & $(.71)$ & XE133 & $(.61)$ & I132 & $(.72)$ & I132 & $(.69)$ \\
\hline & XE135 & $(.36)$ & I131 & $(.10)$ & I131 & $(.11)$ & XE135 & $(.36)$ & I131 & $(.11)$ & 1131 & $(.11)$ \\
\hline & $\mathrm{XE135M}$ & $(.01)$ & I133 & $(.09)$ & $\mathrm{I} 133$ & $(.09)$ & XE133M & $(.01)$ & I133 & $(.09)$ & I133 & $(.09)$ \\
\hline \multirow[t]{3}{*}{$4 d$} & XE133 & $(.96)$ & I132 & $(.70)$ & I132 & $(.70)$ & XE133 & $(.96)$ & $\mathrm{I} 132$ & $(.73)$ & I132 & $(.68)$ \\
\hline & XE135 & $(.02)$ & I131 & $(.14)$ & I131 & $(.14)$ & XE135 & $(.02)$ & I131 & $(.14)$ & I131 & $(.13)$ \\
\hline & XE133M & $(.01)$ & $\operatorname{CS} 134$ & $(.06)$ & CS134 & $(.08)$ & XE133M & $(.01)$ & CS134 & $(.06)$ & $\operatorname{CS} 134$ & $(.10)$ \\
\hline
\end{tabular}


Table D. 3

Peach Bottom Drywel1 Major Radionuclide Contributors to Gamma Dose (Continued)

Case 1

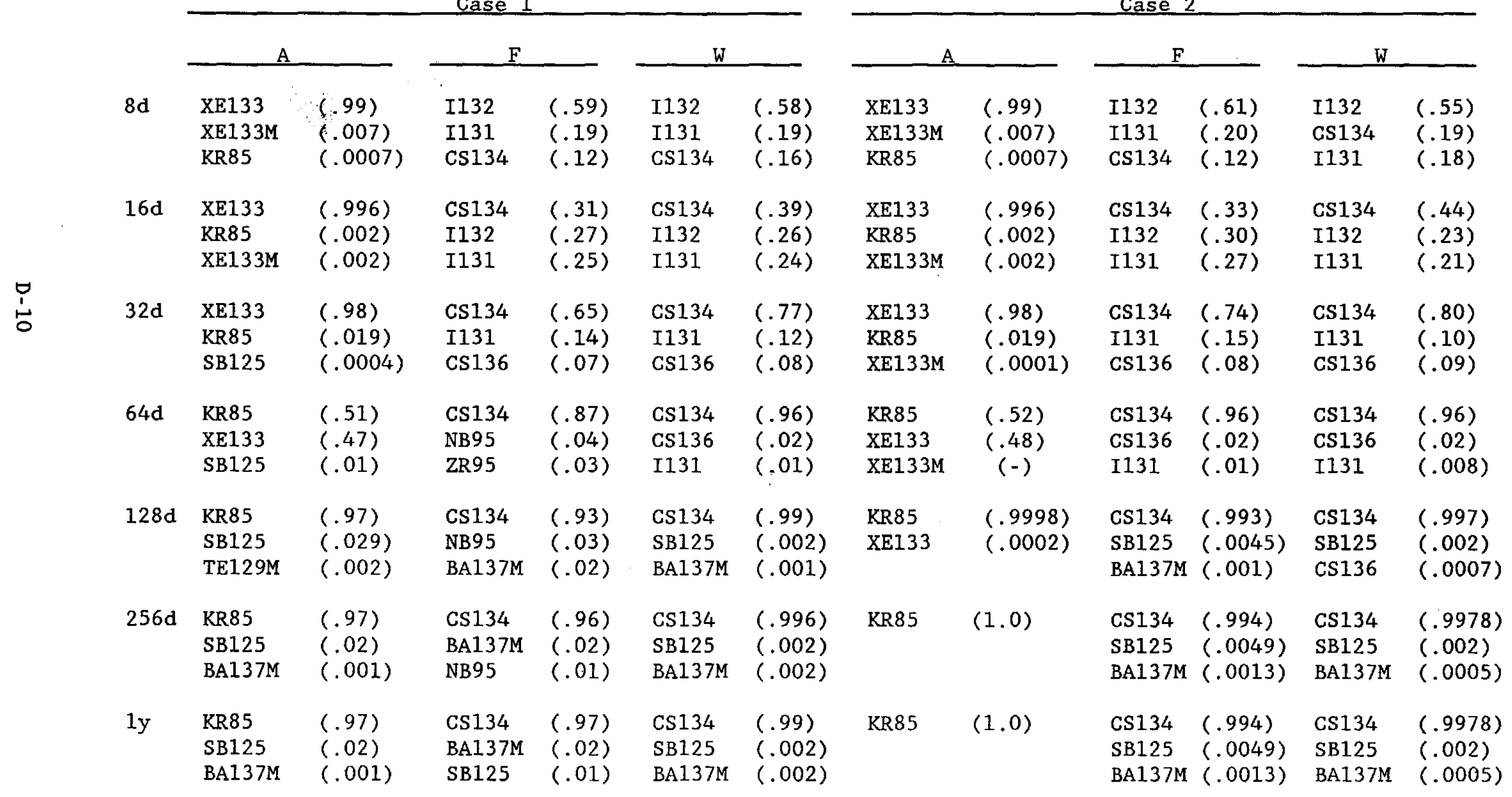


Table D. 3

Peach Bottom Drywell Radionuclide Contributors to Gamma Dose (Continued)

\begin{tabular}{|c|c|c|c|c|}
\hline & $\mathrm{Ca}$ & 3 & & 4 \\
\hline & & & & \\
\hline $1 \mathrm{~h}$ & $\mathrm{KR} 88$ & $(.59)$ & KR88 & $(.59)$ \\
\hline & KR87 & $(.13)$ & KR87 & $(.13)$ \\
\hline & XE135 & $(.10)$ & XE135 & $(.10)$ \\
\hline $2 \mathrm{~h}$ & KR88 & $(.61)$ & KR88 & $(.61)$ \\
\hline & XE135 & $(.15)$ & XE135 & $(.15)$ \\
\hline & KR87 & $(.09)$ & KR87 & $(.09)$ \\
\hline $4 \mathrm{~h}$ & KR8 8 & $(.53)$ & KR88 & $(.53)$ \\
\hline & XE135 & $(.24)$ & XE135 & $(.24)$ \\
\hline & XE135M & $(.10)$ & $\mathrm{XE} 135 \mathrm{M}$ & $(.10)$ \\
\hline $8 \mathrm{~h}$ & XE135 & $(.43)$ & XE135 & $(.43)$ \\
\hline & KR88 & $(.33)$ & KR88 & $(.33)$ \\
\hline & XE135M & $(.11)$ & XE133 & $(.11)$ \\
\hline $16 \mathrm{~h}$ & XE135 & $(.63)$ & XE135 & $(.63)$ \\
\hline & XE133 & $(.33)$ & XE133 & $(.19)$ \\
\hline & KR88 & $(.11)$ & KR88 & $(.09)$ \\
\hline $1 d$ & XE135 & $(.65)$ & XE135 & $(.65)$ \\
\hline & XE133 & $(.27)$ & XE133 & $(.27)$ \\
\hline & XE135M & $(.05)$ & XE135M & $(.05)$ \\
\hline $2 d$ & XE133 & $(.62)$ & XE133 & $(.62)$ \\
\hline & XE135 & $(.36)$ & XE135 & $(.36)$ \\
\hline & XE133M & $(.012)$ & XE133M & $(.01)$ \\
\hline $4 d$ & XE133 & $(.96)$ & $\mathrm{XE} 133$ & $(.96)$ \\
\hline & XE135 & $(.02)$ & XE135 & $(.02)$ \\
\hline & XE133M & $(.014)$ & XE133M & $(.01)$ \\
\hline
\end{tabular}


Table D.3

Peach Bottom Drywe11 Radionuclide Contributors to Gamma Dose (Concluded)

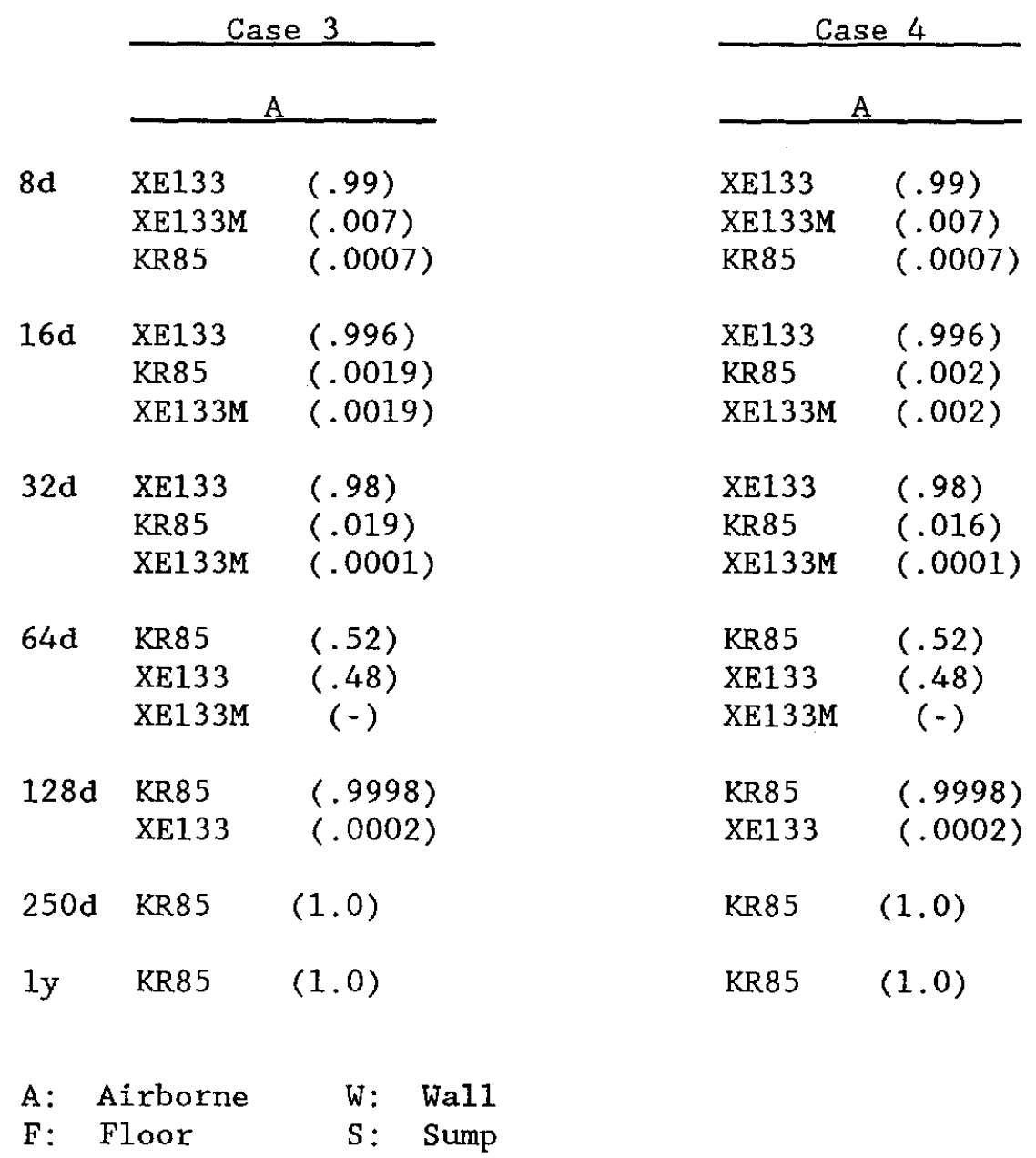


Table D.4

Peach Bottom Drywel1 Radionuclide Contributors to Beta Dose

Case 1

\begin{tabular}{|c|c|c|c|c|c|c|c|c|c|c|c|c|}
\hline \multirow{4}{*}{ Ih } & \multicolumn{2}{|c|}{ A } & \multicolumn{2}{|c|}{$F$} & \multicolumn{2}{|c|}{ W } & \multicolumn{2}{|c|}{ A } & \multicolumn{2}{|c|}{$F$} & \multicolumn{2}{|c|}{ W } \\
\hline & KR87 & $(.13)$ & RB88 & $(.22)$ & RB88 & $(.28)$ & $\mathrm{KR} 87$ & $(.13)$ & RB88 & $(.22)$ & RB88 & $(.28)$ \\
\hline & $\mathrm{RB} 88$ & $(.13)$ & $\operatorname{CS} 138$ & $(.16)$ & $\operatorname{CS} 138$ & $(.20)$ & RB88 & $(.13)$ & $\operatorname{CS} 138$ & $(.16)$ & $\operatorname{CS} 138$ & $(.20)$ \\
\hline & $\operatorname{cs} 138$ & $(.09)$ & $\mathrm{I} 134$ & $(.16)$ & $\mathrm{I} 134$ & $(.14)$ & $\operatorname{cs} 138$ & $(.09)$ & 1134 & $(.16)$ & I134 & $(.14)$ \\
\hline \multirow[t]{3}{*}{$2 \mathrm{~h}$} & XE133 & $(.24)$ & RB88 & $(.24)$ & $\mathrm{RB} 88$ & $(.30)$ & XE133 & $(.24)$ & RB88 & $(.25)$ & RB88 & $(.30)$ \\
\hline & KR87 & $(.21)$ & I133 & $(.21)$ & I133 & $(.18)$ & KR87 & $(.21)$ & I133 & $(.18)$ & I133 & $(.16)$ \\
\hline & XE135 & $(.20)$ & I132 & $(.16)$ & I132 & $(.16)$ & XE135 & $(.20)$ & I132 & $(.16)$ & I132 & $(.14)$ \\
\hline \multirow[t]{3}{*}{$4 \mathrm{~h}$} & XE133 & $(.33)$ & I133 & $(.15)$ & RB88 & $(.16)$ & XE133 & $(.35)$ & $\mathrm{I} 133$ & $(.24)$ & RB88 & $(.32)$ \\
\hline & XE135 & $(.32)$ & I132 & $(.14)$ & I133 & $(.14)$ & XE135 & $(.33)$ & I132 & $(.23)$ & I133 & $(.21)$ \\
\hline & KR88 & $(.12)$ & $\mathrm{RB} 88$ & $(.14)$ & I132 & $(.13)$ & KR88 & $(.13)$ & $\mathrm{RB} 88$ & $(.22)$ & I132 & $(.20)$ \\
\hline \multirow[t]{3}{*}{$8 \mathrm{~h}$} & XE135 & $(.27)$ & I132 & $(.43)$ & I132 & $(.31)$ & XE135 & $(.43)$ & I132 & $(.31)$ & I132 & $(.29)$ \\
\hline & XE133 & $(.26)$ & I133 & $(.42)$ & I133 & $(.30)$ & XE133 & $(.42)$ & I133 & $(.30)$ & I133 & $(.28)$ \\
\hline & KR88 & $(.13)$ & I135 & $(.06)$ & RB88 & $(.14)$ & KR88 & $(.06)$ & I135 & $(.14)$ & RB88 & $(.18)$ \\
\hline \multirow[t]{3}{*}{$16 \mathrm{~h}$} & XE133 & $(.51)$ & I132 & $(.38)$ & I132 & $(.40)$ & XE133 & $(.51)$ & I132 & $(.41)$ & I132 & $(.40)$ \\
\hline & $\mathrm{XE} 135$ & $(.43)$ & I133 & $(.30)$ & I133 & $(.32)$ & XE135 & $(.43)$ & $\mathrm{I} 133$ & $(.32)$ & I133 & $(.32)$ \\
\hline & XE133M & $(.02)$ & I131 & $(.11)$ & I131 & $(.11)$ & XE133M & $(.21)$ & $\mathrm{I} 131$ & $(.12)$ & I131 & $(.11)$ \\
\hline \multirow[t]{3}{*}{$1 d$} & XE133 & $(.60)$ & I132 & $(.43)$ & I132 & $(.46)$ & XE133 & $(.60)$ & $\mathrm{I} 132$ & $(.46)$ & I132 & $(.46)$ \\
\hline & XE135 & $(.36)$ & I133 & $(.28)$ & I133 & $(.30)$ & XE135 & $(.36)$ & I133 & $(.30)$ & I133 & $(.30)$ \\
\hline & XE133M & $(.02)$ & I131 & $(.13)$ & I131 & $(.14)$ & XE133M & $(.24)$ & I131 & $(.14)$ & I131 & $(.14)$ \\
\hline \multirow[t]{3}{*}{$2 d$} & XE133 & $(.83)$ & I132 & $(.50)$ & I132 & $(.54)$ & XE133 & $(.83)$ & I132 & $(.54)$ & I132 & $(.54)$ \\
\hline & XE135 & $(.12)$ & I133 & $(.18)$ & I133 & $(.20)$ & $\mathrm{XE} 135$ & $(.12)$ & I133 & $(.20)$ & I133 & $(.20)$ \\
\hline & XE133M & $(.03)$ & I131 & $(.17)$ & $\mathrm{I} 131$ & $(.18)$ & XE133M & $(.03)$ & I131 & $(.19)$ & I131 & $(.18)$ \\
\hline \multirow[t]{3}{*}{$4 d$} & XE133 & $(.95)$ & I132 & $(.51)$ & I132 & $(.58)$ & $\mathrm{XE} 133$ & $(.95)$ & $I 132$ & $(.58)$ & I132 & $(.57)$ \\
\hline & XE133M & $(.02)$ & I131 & $(.23)$ & I131 & $(.26)$ & XE133M & $(.03)$ & I131 & $(.26)$ & I131 & $(.25)$ \\
\hline & KR85 & $(.009)$ & I133 & $(.06)$ & I133 & $(.07)$ & KR85 & $(.009)$ & I133 & $(.07)$ & I133 & $(.06)$ \\
\hline
\end{tabular}


Table 0.4

Peach Bottom Drywell Radionuclide Contributors to Beta Dose (Continued)

Case 1

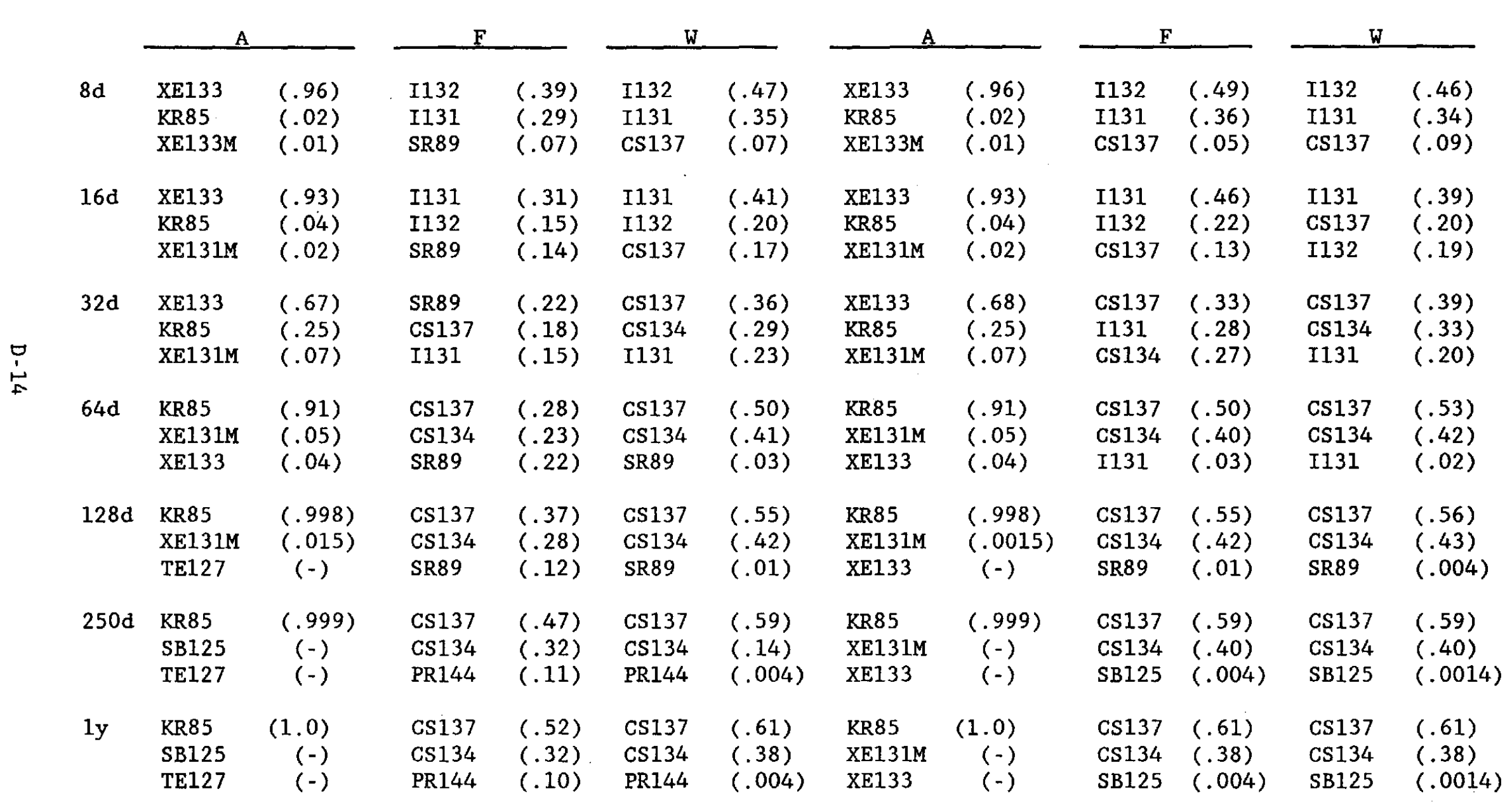


Table D.4

Peach Bottom Drywell Radionuclide Contributors to Beta Dose (Continued)

\begin{tabular}{|c|c|c|}
\hline \multirow[b]{2}{*}{ lh } & \multicolumn{2}{|c|}{ A } \\
\hline & $\begin{array}{l}\text { KR87 } \\
\text { XE133 } \\
\text { KR88 }\end{array}$ & $\begin{array}{l}(.33) \\
(.22) \\
(.16)\end{array}$ \\
\hline $2 \mathrm{~h}$ & $\begin{array}{l}\text { XE133 } \\
\text { KR87 } \\
\text { XE135 }\end{array}$ & $\begin{array}{l}(.27) \\
(.24) \\
(.23)\end{array}$ \\
\hline $4 \mathrm{~h}$ & $\begin{array}{l}\text { XE133 } \\
\text { XE135 } \\
\text { KR88 }\end{array}$ & $\begin{array}{l}(.35) \\
(.33) \\
(.13)\end{array}$ \\
\hline $8 \mathrm{~h}$ & $\begin{array}{l}\text { XE135 } \\
\text { XE133 } \\
\text { KR88 }\end{array}$ & $\begin{array}{l}(.43) \\
(.42) \\
(.06)\end{array}$ \\
\hline $16 \mathrm{~h}$ & $\begin{array}{l}\text { XE133 } \\
\text { XE135 } \\
\text { XE133M }\end{array}$ & $\begin{array}{l}(.51) \\
(.43) \\
(.02)\end{array}$ \\
\hline $1 d$ & $\begin{array}{l}\text { XE133 } \\
\text { XE135 } \\
\text { XE133M }\end{array}$ & $\begin{array}{l}(.60) \\
(.36) \\
(.02)\end{array}$ \\
\hline $2 d$ & $\begin{array}{l}\text { XE133 } \\
\text { XE135 } \\
\text { XE133M }\end{array}$ & $\begin{array}{l}(.83) \\
(.12) \\
(.03)\end{array}$ \\
\hline $4 d$ & $\begin{array}{l}\text { XE133 } \\
\text { XE133M } \\
\text { KR85 }\end{array}$ & $\begin{array}{l}(.95) \\
(.03) \\
(.009)\end{array}$ \\
\hline
\end{tabular}

\begin{tabular}{ll}
\multicolumn{2}{c}{ Case 4} \\
\hline \multicolumn{1}{c}{ A } \\
\hline KR87 & $(.33)$ \\
XE133 & $(.22)$ \\
KR88 & $(.16)$ \\
& \\
XE133 & $(.27)$ \\
KR87 & $(.24)$ \\
XE135 & $(.23)$ \\
& \\
XE133 & $(.35)$ \\
XE135 & $(.33)$ \\
KR88 & $(.13)$ \\
& \\
XE135 & $(.43)$ \\
XE133 & $(.42)$ \\
KR88 & $(.06)$ \\
& \\
XE133 & $(.51)$ \\
XE135 & $(.43)$ \\
XE133M & $(.02)$ \\
XE133 & $(.60)$ \\
XE135 & $(.36)$ \\
XE133M & $(.02)$ \\
XE133 & $(.83)$ \\
XE135 & $(.12)$ \\
XE133M & $(.03)$ \\
& \\
XE133 & $(.95)$ \\
XE133M & $(.03)$ \\
KR85 & $(.009)$ \\
&
\end{tabular}


Table D.4

Peach Bottom Drywe11 Radionuclide Contributors to Beta Dose (Concluded)

\begin{tabular}{lll}
\multicolumn{1}{c}{ Case 3} \\
\cline { 2 - 3 } 8d & & \multicolumn{2}{c}{ A } \\
\cline { 2 - 3 } 16d & XE133 & $(.96)$ \\
& KR85 & $(.02)$ \\
& XE133M & $(.01)$ \\
& XE133 & $(.93)$ \\
& KR85 & $(.04)$ \\
& XE131M & $(.02)$ \\
32d & XE133 & $(.68)$ \\
& KR85 & $(.25)$ \\
& XE131M & $(.07)$ \\
64d & KR85 & $(.91)$ \\
& XE131M & $(.05)$ \\
& XE133 & $(.04)$ \\
128d & KR85 & $(.998)$ \\
& XE131M & $(.0015)$ \\
& XE133 & $(-)$ \\
256d & KR85 & $(1.0)$ \\
& XE131M & $(-)$ \\
& XE133 & $(-)$ \\
& & \\
1y & KR85 & $(1.0)$ \\
& XE131M & $(-)$ \\
& XE133 & $(-)$ \\
& &
\end{tabular}

\begin{tabular}{lc}
\multicolumn{2}{c}{ Case 4} \\
\hline & A \\
\hline XE133 & $(.96)$ \\
KR85 & $(.02)$ \\
XE133M & $(.01)$ \\
& \\
XE133 & $(.93)$ \\
KR85 & $(.04)$ \\
XE131M & $(.02)$ \\
& \\
XE133 & $(.68)$ \\
KR85 & $(.25)$ \\
XE131M & $(.07)$ \\
& \\
KR85 & $(.91)$ \\
XE131M & $(.05)$ \\
XE133 & $(.04)$ \\
& \\
KR85 & $(.998)$ \\
XE131M & $(.0015)$ \\
XE133 & $(-)$ \\
KR85 & $(1.0)$ \\
XE131M & $(-)$ \\
XE133 & $(-)$ \\
KR85 & $(1.0)$ \\
XE131M & $(-)$ \\
XE133 & $(-)$ \\
&
\end{tabular}

A: Airborne W: Wall

F: Floor S: Sump 
Table D. 5

Peach Bottom Wetwell Major Radionuclide Contributors to Gamma Dose

Case 1

\begin{tabular}{|c|c|c|c|c|c|c|c|c|c|c|c|c|}
\hline & \multicolumn{2}{|c|}{ A } & \multicolumn{2}{|c|}{ W } & \multicolumn{2}{|c|}{$\mathrm{S}$} & \multicolumn{2}{|c|}{ A } & \multicolumn{2}{|c|}{$\mathrm{W}$} & \multicolumn{2}{|c|}{$\mathbf{S}$} \\
\hline Ih & $\begin{array}{l}\text { KR88 } \\
\text { KR87 } \\
\text { XE135 }\end{array}$ & $\begin{array}{l}(.53) \\
(.11) \\
(.08)\end{array}$ & $\begin{array}{l}\text { I134 } \\
\text { I132 } \\
\text { I135 }\end{array}$ & $\begin{array}{l}(.28) \\
(.23) \\
(.17)\end{array}$ & $\begin{array}{l}\text { I134 } \\
\text { I135 } \\
\text { I132 }\end{array}$ & $\begin{array}{l}(.27) \\
(.20) \\
(.20)\end{array}$ & $\begin{array}{l}\text { KR88 } \\
\text { KR87 } \\
\text { XE135 }\end{array}$ & $\begin{array}{l}(.53) \\
(.11) \\
(.08)\end{array}$ & $\begin{array}{l}\text { I134 } \\
\text { I132 } \\
\text { I135 }\end{array}$ & $\begin{array}{l}(.28) \\
(.23) \\
(.17)\end{array}$ & $\begin{array}{l}\text { I134 } \\
\text { I135 } \\
\text { I132 }\end{array}$ & $\begin{array}{l}(.27) \\
(.20) \\
(.20)\end{array}$ \\
\hline & $\begin{array}{l}\text { KR88 } \\
\text { KR87 } \\
\text { XE138 }\end{array}$ & $\begin{array}{l}(.78) \\
(.13) \\
(.04)\end{array}$ & $\begin{array}{l}\text { CS138 } \\
\text { I134 } \\
\text { I135 }\end{array}$ & $\begin{array}{l}(.33) \\
(.23) \\
(.17)\end{array}$ & & & $\begin{array}{l}\text { KR88 } \\
\text { KR87 } \\
\text { XE138 }\end{array}$ & $\begin{array}{l}(.78) \\
(.13) \\
(.04)\end{array}$ & $\begin{array}{l}\text { CS138 } \\
\text { I134 } \\
\text { I135 }\end{array}$ & $\begin{array}{l}(.33) \\
(.23) \\
(.17)\end{array}$ & & \\
\hline $2 \mathrm{~h}$ & $\begin{array}{l}\text { KR88 } \\
\text { XE135 } \\
\text { KR87 }\end{array}$ & $\begin{array}{l}(.57) \\
(.13) \\
(.09)\end{array}$ & $\begin{array}{l}\text { I132 } \\
\text { I134 } \\
\text { I135 }\end{array}$ & $\begin{array}{l}(.31) \\
(.22) \\
(.21)\end{array}$ & $\begin{array}{l}\text { I132 } \\
\text { I135 } \\
\text { I134 }\end{array}$ & $\begin{array}{l}(.27) \\
(.26) \\
(.22)\end{array}$ & $\begin{array}{l}\text { KR88 } \\
\text { XE135 } \\
\text { KR87 }\end{array}$ & $\begin{array}{l}(.58) \\
(.13) \\
(.09)\end{array}$ & $\begin{array}{l}\text { I132 } \\
\text { I134 } \\
\text { I135 }\end{array}$ & $\begin{array}{l}(.31) \\
(.22) \\
(.21)\end{array}$ & $\begin{array}{l}\text { I132 } \\
\text { I135 } \\
\text { I134 }\end{array}$ & $\begin{array}{l}(.27) \\
(.26) \\
(.22)\end{array}$ \\
\hline & $\begin{array}{l}\text { KR88 } \\
\text { KR87 } \\
\text { I135 }\end{array}$ & $\begin{array}{l}(.86) \\
(.11) \\
(.007)\end{array}$ & $\begin{array}{l}\text { I135 } \\
\text { I134 } \\
\text { RB88 }\end{array}$ & $\begin{array}{l}(.27) \\
(.24) \\
(.19)\end{array}$ & & & $\begin{array}{l}\text { KR88 } \\
\text { KR87 } \\
\text { I135 }\end{array}$ & $\begin{array}{l}(.86) \\
(.11) \\
(.007)\end{array}$ & $\begin{array}{l}I 135 \\
I 134 \\
\text { RB88 }\end{array}$ & $\begin{array}{l}(.27) \\
(.24) \\
(.19)\end{array}$ & & \\
\hline $4 \mathrm{~h}$ & $\begin{array}{l}\text { KR88 } \\
\text { XE135 } \\
\text { XE135M }\end{array}$ & $\begin{array}{l}(.58) \\
(.24) \\
(.11)\end{array}$ & $\begin{array}{l}\text { I132 } \\
\text { I135 } \\
\text { I133 }\end{array}$ & $\begin{array}{l}(.42) \\
(.23) \\
(.15)\end{array}$ & $\begin{array}{l}\text { I132 } \\
\text { I135 } \\
\text { I133 }\end{array}$ & $\begin{array}{l}(.37) \\
(.28) \\
(.12)\end{array}$ & $\begin{array}{l}\text { KR88 } \\
\text { XE135 } \\
\text { XE135M }\end{array}$ & $\begin{array}{l}(.51) \\
(.21) \\
(.10)\end{array}$ & $\begin{array}{l}I 132 \\
\text { I135 } \\
\text { I133 }\end{array}$ & $\begin{array}{l}(.42) \\
(.23) \\
(.15)\end{array}$ & $\begin{array}{l}I 132 \\
I 135 \\
I 133\end{array}$ & $\begin{array}{l}(.39) \\
(.30) \\
(.13)\end{array}$ \\
\hline & $\begin{array}{l}\text { KR88 } \\
\text { KR87 } \\
\text { XE135M }\end{array}$ & $\begin{array}{l}(.94) \\
(.059) \\
(.0005)\end{array}$ & $\begin{array}{l}\text { I135 } \\
\text { RB88 } \\
\text { I132 }\end{array}$ & $\begin{array}{l}(.42) \\
(.22) \\
(.17)\end{array}$ & & & $\begin{array}{l}\text { KR88 } \\
\text { KR87 } \\
\text { I135 }\end{array}$ & $\begin{array}{l}(.91) \\
(.06) \\
(.01)\end{array}$ & $\begin{array}{l}\text { I135 } \\
\text { RB88 } \\
\text { I132 }\end{array}$ & $\begin{array}{l}(.42) \\
(.22) \\
(.17)\end{array}$ & & \\
\hline $8 \mathrm{~h}$ & $\begin{array}{l}\text { XE135 } \\
\text { KR88 } \\
\text { XE135M }\end{array}$ & $\begin{array}{l}(.45) \\
(.38) \\
(.13)\end{array}$ & $\begin{array}{l}I 132 \\
I 135 \\
\text { RB88 }\end{array}$ & $\begin{array}{l}(.49) \\
(.30) \\
(.15)\end{array}$ & $\begin{array}{l}\text { I132 } \\
\text { I135 } \\
\text { I133 }\end{array}$ & $\begin{array}{l}(.60) \\
(.14) \\
(.14)\end{array}$ & $\begin{array}{l}\text { XE135 } \\
\text { KR88 } \\
\text { XE135M }\end{array}$ & $\begin{array}{l}(.38) \\
(.32) \\
(.11)\end{array}$ & $\begin{array}{l}\text { I132 } \\
\text { I135 } \\
\text { I133 }\end{array}$ & $\begin{array}{l}(.52) \\
(.20) \\
(.17)\end{array}$ & $\begin{array}{l}\text { I132 } \\
\text { I135 } \\
\text { I133 }\end{array}$ & $\begin{array}{l}(.50) \\
(.26) \\
(.15)\end{array}$ \\
\hline & $\begin{array}{l}\text { KR88 } \\
\text { KR87 } \\
\text { XE135M }\end{array}$ & $\begin{array}{l}(.97) \\
(.02) \\
(.001)\end{array}$ & $\begin{array}{l}\text { I132 } \\
\text { I1 } 33 \\
\text { I1 } 35\end{array}$ & $\begin{array}{l}(.61) \\
(.17) \\
(.11)\end{array}$ & & & $\begin{array}{l}\text { KR88 } \\
\text { I135 } \\
\text { KR87 }\end{array}$ & $\begin{array}{l}(.94) \\
(.02) \\
(.02)\end{array}$ & $\begin{array}{l}\text { I135 } \\
\text { I132 } \\
\text { RB88 }\end{array}$ & $\begin{array}{l}(.50) \\
(.30) \\
(.15)\end{array}$ & & \\
\hline
\end{tabular}


Table D. 5

Peach Bottom Wetwel1 Major Radionuclide Contributors to Gamma Dose (Continued)

Case 1

\begin{tabular}{|c|c|c|c|}
\hline \multicolumn{2}{|c|}{ A } & \multicolumn{2}{|c|}{ W } \\
\hline XE135 & $(.74)$ & I132 & $(.61)$ \\
\hline XE135M & $(.11)$ & I133 & $(.17)$ \\
\hline KR88 & $(.11)$ & I135 & $(.11)$ \\
\hline $\mathrm{KR} 88$ & $(.99)$ & I132 & $(.51)$ \\
\hline XE135M & $(.003)$ & II35 & $(.39)$ \\
\hline XE135 & $(.002)$ & I133 & $(.04)$ \\
\hline XE135 & $(.84)$ & I132 & $(.66)$ \\
\hline XE135M & $(.08)$ & I133 & $(.15)$ \\
\hline XE133 & $(.05)$ & II31 & $(.08)$ \\
\hline KR88 & $(.98)$ & I132 & $(.68)$ \\
\hline XE135 & $(.01)$ & I135 & $(.24)$ \\
\hline XE135M & $(.01)$ & I133 & $(.04)$ \\
\hline XE135 & $(.76)$ & II32 & $(.73)$ \\
\hline XE133 & $(.19)$ & I131 & $(.10)$ \\
\hline $\mathrm{XE} 135 \mathrm{M}$ & $(.03)$ & I133 & $(.09)$ \\
\hline KR88 & $(.48)$ & I132 & $(.90)$ \\
\hline XE135 & $(.37)$ & I135 & $(.03)$ \\
\hline XE135M & $(.12)$ & I133 & $(.03)$ \\
\hline XE133 & $(.79)$ & I132 & $(.74)$ \\
\hline XE135 & $(.13)$ & $\operatorname{CS} 136$ & $(.13)$ \\
\hline XE133M & $(.08)$ & CS134 & $(.07)$ \\
\hline XE135 & $(.45)$ & I132 & $(.94)$ \\
\hline TE131M & $(.34)$ & CS136 & $(.03)$ \\
\hline KR85 & $(.09)$ & CS134 & $(.02)$ \\
\hline
\end{tabular}

Case 2

\begin{tabular}{|c|c|c|c|c|c|}
\hline \multicolumn{2}{|c|}{ A } & \multicolumn{2}{|c|}{ W } & \multicolumn{2}{|c|}{$\mathrm{S}$} \\
\hline XE135 & $(.56)$ & I132 & $(.61)$ & I132 & $(.62)$ \\
\hline I132 & $(.15)$ & I133 & $(.17)$ & 1135 & $(.15)$ \\
\hline XE135M & $(.08)$ & I135 & $(.11)$ & I133 & $(.15)$ \\
\hline KR88 & $(.84)$ & I132 & $(.51)$ & & \\
\hline I132 & $(.08)$ & I135 & $(.39)$ & & \\
\hline I135 & $(.06)$ & I133 & $(.04)$ & & \\
\hline XE135 & $(.58)$ & I132 & $(.66)$ & I132 & $(.69)$ \\
\hline I132 & $(.21)$ & I133 & $(.15)$ & I133 & $(.14)$ \\
\hline XE135M & $(.05)$ & I131 & $(.08)$ & I135 & $(.08)$ \\
\hline KR88 & $(.52)$ & I132 & $(.68)$ & & \\
\hline I132 & $(.33)$ & I135 & $(.24)$ & & \\
\hline I135 & $(.12)$ & I133 & $(.04)$ & & \\
\hline II32 & $(.44)$ & I132 & $(.73)$ & $\mathrm{I} 132$ & $(.79)$ \\
\hline XE135 & $(.33)$ & I131 & $(.10)$ & $\mathrm{I} 133$ & $(.09$ \\
\hline XE133 & $(.08)$ & I133 & $(.09)$ & CS134 & $(.04)$ \\
\hline I132 & $(.91)$ & I132 & $(.90)$ & & \\
\hline I133 & $(.03)$ & I135 & $(.03)$ & & \\
\hline I135 & $(.03)$ & I133 & $(.03)$ & & \\
\hline I132 & $(.65)$ & I132 & $(.74)$ & I132 & $(.81)$ \\
\hline XE133 & $(.15)$ & I131 & $(.13)$ & $\operatorname{cs} 134$ & $(.07)$ \\
\hline I131 & $(.11)$ & CS134 & $(.07)$ & I131 & $(.05)$ \\
\hline $\mathrm{I} 132$ & $(.98)$ & I132 & $(.94)$ & & \\
\hline I133 & $(.01)$ & $\operatorname{CS} 136$ & $(.02)$ & & \\
\hline TE131M & $(.004)$ & $\operatorname{Cs} 134$ & $(.02)$ & & \\
\hline
\end{tabular}


Table D. 5

Peach Bottom Wetwell Major Radionuclide Contributors to Gamma Dose (Continued)

Case 1

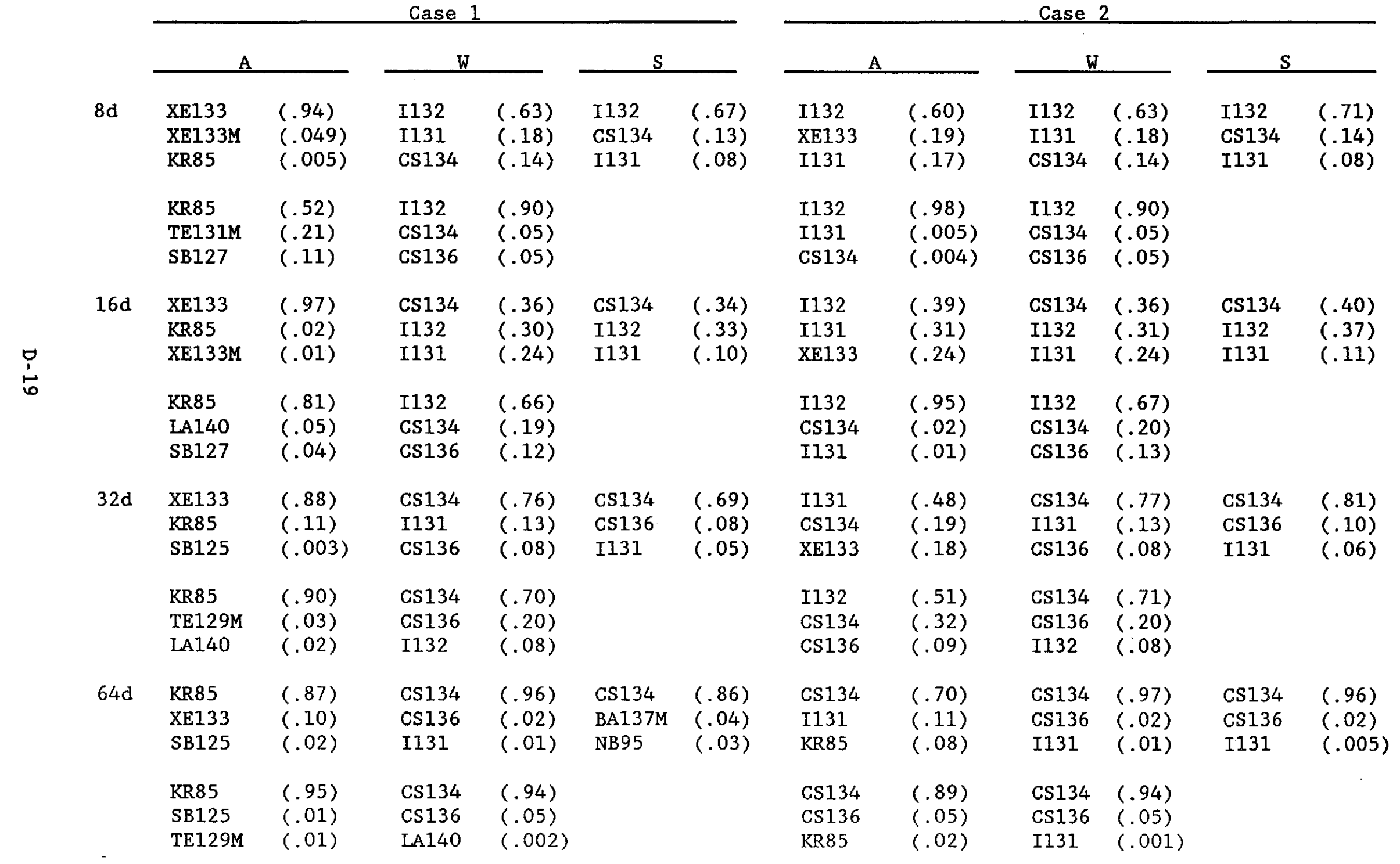

Case 2 
Table D. 5

Peach Bottom Wetwell Major Radionuclide Contributors to Gamma Dose (Concluded)

Case 1

\begin{tabular}{|c|c|c|c|c|c|c|}
\hline \multirow[b]{2}{*}{$128 d$} & \multicolumn{2}{|c|}{ A } & \multicolumn{2}{|l|}{$\mathrm{W}$} & \multicolumn{2}{|l|}{$\underline{S}$} \\
\hline & KR85 & $(.97)$ & $\operatorname{cs} 134$ & $(.99)$ & CS134 & $(.91)$ \\
\hline & SB125 & $(.02)$ & SB125 & $(.002)$ & BA137M & $(.04)$ \\
\hline & BA137M & $(.002)$ & BA137M & $(.002)$ & NB95 & $(.02)$ \\
\hline & KB85 & $(.97)$ & CS134 & $(.996)$ & & \\
\hline & SB125 & $(.014)$ & CS136 & $(.002)$ & & \\
\hline & TE129M & $(.004)$ & PR144 & $(.0004)$ & & \\
\hline $256 d$ & KR85 & $(.97)$ & CS134 & $(.996)$ & CS134 & $(.94)$ \\
\hline & SB125 & $(.02)$ & SB125 & $(.0025)$ & BA137M & $(.05)$ \\
\hline & BA137M & $(.002)$ & BA137M & $(.002)$ & NB95 & $(.007)$ \\
\hline & KR85 & $(.98)$ & CS134 & $(.999)$ & & \\
\hline & SB125 & $(.01)$ & SB125 & $(.0004)$ & & \\
\hline & BA137M & $(.002)$ & BA137M & $(.0004)$ & & \\
\hline $1 y$ & KR85 & $(.98)$ & CS134 & $(.996)$ & CS134 & $(.94)$ \\
\hline & SB125 & $(.018)$ & SB125 & $(.0026)$ & BA137M & $(.05)$ \\
\hline & BA137M & $(.002)$ & BA137M & $(.0018)$ & SB125 & $(.007)$ \\
\hline & KR85 & $(.984)$ & CS134 & $(.9988)$ & & \\
\hline & SB125 & $(.013)$ & SB125 & $(.0004)$ & & \\
\hline & BA137M & $(.002)$ & BA137M & $(.0004)$ & & \\
\hline
\end{tabular}

Case 2

\begin{tabular}{|c|c|c|c|c|c|}
\hline \multicolumn{2}{|c|}{ A } & \multicolumn{2}{|l|}{$\mathrm{W}$} & \multicolumn{2}{|l|}{$S$} \\
\hline $\operatorname{cs} 134$ & $(.82)$ & CS134 & $(.99)$ & CS134 & $(.994)$ \\
\hline KR85 & $(.10)$ & SB125 & $(.002)$ & SB125 & $(.003)$ \\
\hline SB125 & $(.05)$ & $\operatorname{cs} 136$ & $(.0007)$ & BA137M & $(.001)$ \\
\hline CS134 & $(.95)$ & CS134 & $(.997)$ & & \\
\hline KR85 & $(.03)$ & CS136 & $(.002)$ & & \\
\hline SB125 & $(.01)$ & SB125 & $(.003)$ & & \\
\hline $\operatorname{cs} 134$ & $(.82)$ & $\operatorname{CS134}$ & $(.997)$ & $\operatorname{CS} 134$ & $(.995)$ \\
\hline KR85 & $(.11)$ & SB125 & $(.002)$ & SB125 & $(.003)$ \\
\hline SBI25 & $(.05)$ & BA137M & $(.0004)$ & BA137M & $(.001)$ \\
\hline $\operatorname{CS134}$ & $(.95)$ & CS134 & $(.9996)$ & & \\
\hline KR85 & $(.03)$ & SB125 & $(.0003)$ & & \\
\hline SB125 & $(.01)$ & BA137M & $(.0001)$ & & \\
\hline $\operatorname{cs} 134$ & $(.81)$ & CS134 & $(.9977)$ & $\operatorname{cs} 134$ & $(.995)$ \\
\hline KR85 & $(.12)$ & SB125 & $(.0018)$ & SB125 & $(.003)$ \\
\hline SB125 & $(.05)$ & BA137M & $(.0004)$ & BA137M & $(.001)$ \\
\hline $\operatorname{CS} 134$ & $(.95)$ & $\operatorname{CS} 134$ & $(.999)$ & & \\
\hline KR85 & $(.03)$ & SB125 & $(.0003)$ & & \\
\hline SB125 & $(.01)$ & BA137M & $(.0001)$ & & \\
\hline
\end{tabular}


Peach Bottom Wetwell Major Radionuclide Contributors to Beta Dose

\begin{tabular}{|c|c|c|c|c|c|c|c|c|c|c|c|c|}
\hline \multirow{5}{*}{$1 \mathrm{~h}$} & \multicolumn{6}{|c|}{ Case 3} & \multirow{2}{*}{\multicolumn{2}{|c|}{ A }} & \multirow{2}{*}{\multicolumn{2}{|c|}{ W }} & \multirow{2}{*}{\multicolumn{2}{|c|}{$\mathrm{S}$}} \\
\hline & \multicolumn{2}{|c|}{ A } & \multicolumn{2}{|c|}{$\mathrm{W}$} & \multicolumn{2}{|c|}{$S$} & & & & & & \\
\hline & KR88 & $(.53)$ & I134 & $(.28)$ & I134 & $(.27)$ & KR88 & $(.53)$ & I134 & $(.28)$ & I134 & $(.27)$ \\
\hline & KR87 & $(.11)$ & I132 & $(.23)$ & I135 & $(.20)$ & KR87 & $(.11)$ & I132 & $(.23)$ & I135 & $(.20)$ \\
\hline & XE135 & $(.08)$ & I135 & $(.17)$ & I132 & $(.20)$ & XE135 & $(.08)$ & I135 & $(.17)$ & I132 & $(.20)$ \\
\hline & KR88 & $(.78)$ & $\operatorname{CS} 138$ & $(.33)$ & & & KR88 & $(.78)$ & $\operatorname{CS} 138$ & $(.33)$ & & \\
\hline & KR87 & $(.13)$ & I134 & $(.23)$ & & & KR87 & $(.13)$ & I134 & $(.23)$ & & \\
\hline & $\mathrm{XE} 138$ & $(.04)$ & I135 & $(.17)$ & & & XE138 & $(.04)$ & I135 & $(.17)$ & & \\
\hline $2 \mathrm{~h}$ & KR88 & $(.57)$ & I132 & $(.31)$ & $\mathrm{I} 132$ & $(.27)$ & KR88 & $(.58)$ & I132 & $(.31)$ & I132 & $(.27)$ \\
\hline $\begin{array}{l}0 \\
1 \\
N\end{array}$ & XE135 & $(.13)$ & I134 & $(.22)$ & $\mathrm{I} 135$ & $(.26)$ & XE135 & $(.13)$ & $\mathrm{I} 134$ & $(.22)$ & I135 & $(.26)$ \\
\hline & KR87 & $(.09)$ & I135 & $(.21)$ & I134 & $(.22)$ & $\mathrm{KR} 87$ & $(.09)$ & I135 & $(.21)$ & I134 & $(.22)$ \\
\hline & KR88 & $(.86)$ & I135 & $(.27)$ & & & KR88 & $(.86)$ & I135 & $(.27)$ & & \\
\hline & KR87 & $(.11)$ & I134 & $(.24)$ & & & KR87 & $(.11)$ & I134 & $(.24)$ & & \\
\hline & I135 & $(.007)$ & $\mathrm{RB} 88$ & $(.19)$ & & & I135 & $(.007)$ & $\mathrm{RB} 88$ & $(.19)$ & & \\
\hline $4 \mathrm{~h}$ & $\mathrm{KR} 88$ & $(.58)$ & $\mathrm{I} 132$ & $(.42)$ & $\mathrm{I} 132$ & $(.36)$ & KR88 & $(.51)$ & I132 & $(.42)$ & $\mathrm{I} 132$ & $(.38)$ \\
\hline & XE135 & $(.24)$ & I135 & $(.23)$ & I135 & $(.27)$ & XE135 & $(.21)$ & I135 & $(.23)$ & I135 & $(.29)$ \\
\hline & XE135M & $(.11)$ & $\mathrm{I} 133$ & $(.15)$ & I133 & $(.12)$ & XE135M & $(.10)$ & I133 & $(.15)$ & I133 & $(.12)$ \\
\hline & KR88 & $(.94)$ & I135 & $(.42)$ & & & KR88 & $(.91)$ & I135 & $(.42)$ & & \\
\hline & KR87 & $(.059)$ & RB88 & $(.22)$ & & & KR87 & $(.06)$ & RB88 & $(.22)$ & & \\
\hline & XE135M & $(.0005)$ & I132 & $(.17)$ & & & I135 & $(.01)$ & I.132 & $(.17)$ & & \\
\hline $8 \mathrm{~h}$ & $\mathrm{XE} 135$ & $(.45)$ & $\mathrm{I} 132$ & $(.52)$ & II32 & $(.46)$ & XE135 & $(.38)$ & I132 & $(.52)$ & $\mathrm{I} 132$ & $(.49)$ \\
\hline & KR88 & $(.38)$ & I135 & $(.20)$ & I135 & $(.24)$ & KR8 8 & $(.32)$ & $\mathrm{I} 135$ & $(.20)$ & 1135 & $(.26)$ \\
\hline & XE135M & $(.13)$ & I133 & $(.17)$ & I133 & $(.14)$ & $\mathrm{XE} 135 \mathrm{M}$ & $(.11)$ & $\mathrm{I} 133$ & $(.17)$ & I133 & $(.14)$ \\
\hline & KR88 & $(.97)$ & I135 & $(.50)$ & & & $\mathrm{KR} 88$ & $(.94)$ & I135 & $(.50)$ & & \\
\hline & KR87 & $(.02)$ & I132 & $(.30)$ & & & I135 & $(.02)$ & I132 & $(.30)$ & & \\
\hline 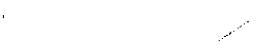 & XE135M & $(.001)$ & $\mathrm{RB} 88$ & $(.15)$ & & & KR87 & $(.02)$ & $\mathrm{RB} 88$ & $(.15)$ & & \\
\hline
\end{tabular}


Table D. 6

Peach Bottom Wetwell Major Radionuclide Contributors to Beta Dose (Continued)

Case 1

\begin{tabular}{|c|c|c|c|c|c|}
\hline \multicolumn{2}{|c|}{ A } & \multicolumn{2}{|c|}{$\mathrm{W}$} & \multicolumn{2}{|c|}{$\mathbf{S}$} \\
\hline XE135 & $(.74)$ & I132 & $(.61)$ & I132 & $(.58)$ \\
\hline XE135M & $(.11)$ & I133 & $(.17)$ & I135 & $(.14)$ \\
\hline KR88 & $(.11)$ & I135 & $(.11)$ & I133 & $(.14)$ \\
\hline
\end{tabular}

Case

\begin{tabular}{|c|c|c|c|c|c|}
\hline \multicolumn{2}{|c|}{ A } & \multicolumn{2}{|c|}{$\mathrm{W}$} & \multicolumn{2}{|c|}{$S$} \\
\hline XE135 & $(.56)$ & I132 & $(.61)$ & I132 & $(.61)$ \\
\hline I133 & $(.15)$ & I135 & $(.17)$ & I135 & $(.15)$ \\
\hline XE135M & $(.08)$ & I135 & $(.11)$ & I133 & $(.15)$ \\
\hline KR88 & $(.84)$ & I132 & $(.51)$ & & \\
\hline $\mathrm{I} 132$ & $(.08)$ & I135 & $(.39)$ & & \\
\hline I135 & $(.06)$ & $\mathrm{I} 133$ & $(.04)$ & & \\
\hline XE135 & $(.78)$ & I132 & $(.66)$ & I132 & $(.69)$ \\
\hline I132 & $(.21)$ & I133 & $(.15)$ & I133 & $(.14)$ \\
\hline XE135M & $(.05)$ & I131 & $(.08)$ & I135 & $(.08)$ \\
\hline KR88 & $(.52)$ & I132 & $(.68)$ & & \\
\hline I132 & $(.33)$ & $I 135$ & $(.24)$ & & \\
\hline I135 & $(.12)$ & I133 & $(.04)$ & & \\
\hline I132 & $(.44)$ & I132 & $(.73)$ & I132 & $(.78)$ \\
\hline XE135 & $(.33)$ & I131 & $(.10)$ & $\mathrm{I} 133$ & $(.09)$ \\
\hline XE133 & $(.08)$ & I133 & $(.09)$ & $\operatorname{cs} 134$ & $(.04)$ \\
\hline I132 & $(.91)$ & I132 & $(.89)$ & & \\
\hline 1133 & $(.03)$ & I135 & $(.03)$ & & \\
\hline I135 & $(.03)$ & I133 & $(.03)$ & & \\
\hline I132 & $(.65)$ & I132 & $(.74)$ & I132 & $(.80)$ \\
\hline XE133 & $(.15)$ & I131 & $(.13)$ & $\operatorname{cs} 134$ & $(.07)$ \\
\hline I131 & $(.11)$ & $\operatorname{cs} 134$ & $(.07)$ & I131 & $(.05)$ \\
\hline I132 & $(.98)$ & I132 & $(.93)$ & & \\
\hline I133 & $(.01)$ & $\operatorname{cs} 136$ & $(.03)$ & & \\
\hline TE131M & $(.004)$ & $\operatorname{cs} 134$ & $(.02)$ & & \\
\hline
\end{tabular}


Table D. 6

Peach Bottom Wetwell Major Radionuclide Contributors to Betaa Dose (Continued)

Case 1

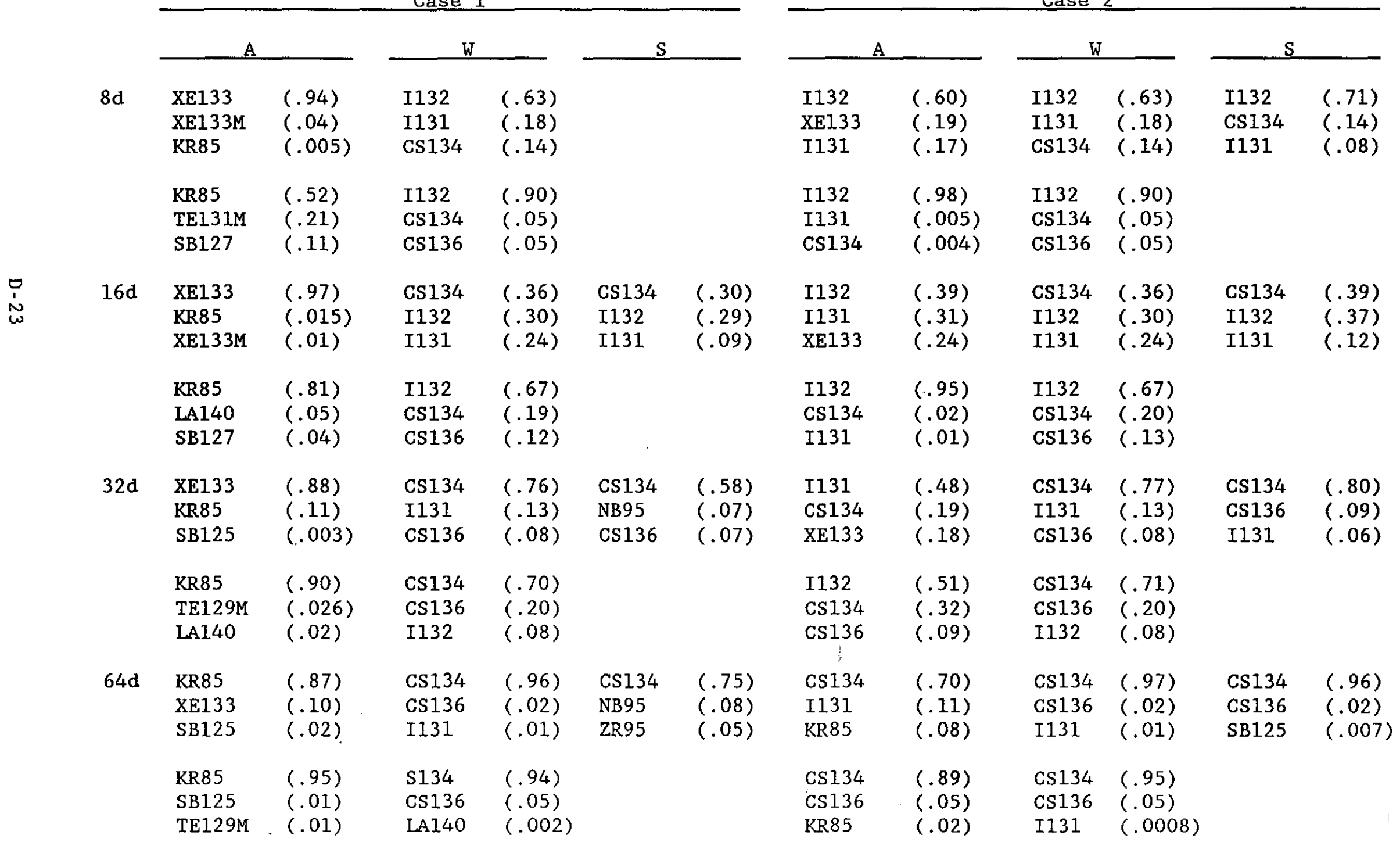


Table D.6

Peach Bottom Wetwell Major Radionuclide Contributors to Betaa Dose (Concluded)

Case 1

\begin{tabular}{|c|c|c|c|c|c|c|c|c|c|c|c|c|}
\hline \multirow[b]{2}{*}{$128 d$} & \multicolumn{2}{|c|}{ A } & \multicolumn{2}{|l|}{ W } & \multicolumn{2}{|l|}{$\mathrm{s}$} & \multicolumn{2}{|c|}{ A } & \multicolumn{2}{|l|}{ W } & \multicolumn{2}{|l|}{$S$} \\
\hline & KR85 & $(.97)$ & $\operatorname{Cs} 134$ & $(.994)$ & CS134 & $(.83)$ & CS134 & $(.82)$ & $\operatorname{CS} 134$ & $(.996)$ & $\operatorname{cs} 134$ & $(.99)$ \\
\hline & SB125 & $(.02)$ & SB125 & $(.002)$ & NB95 & $(.06)$ & KR85 & $(.10)$ & SB125 & $(.002)$ & SB125 & $(.008)$ \\
\hline & BA137M & $(.002)$ & BA137M & $(.0015)$ & BA137M & $(.06)$ & SB125 & $(.05)$ & CS136 & $(.001)$ & BA137M & $(.002)$ \\
\hline & KR85 & $(.97)$ & $\operatorname{Cs} 134$ & $(.996)$ & & & CS134 & $(.95)$ & CS134 & $(.997)$ & & \\
\hline & SB125 & $(.01)$ & $\operatorname{CS} 136$ & $(.002)$ & & & KR85 & $(.03)$ & CS136 & $(.002)$ & & \\
\hline & TE129M & $(.004)$ & PR144 & $(.0004)$ & & & SB125 & $(.01)$ & SB125 & $(.0003)$ & & \\
\hline $256 d$ & KR85 & $(.97)$ & CS134 & $(.996)$ & CS134 & $(.89)$ & CS134 & $(.82)$ & CS134 & $(.997)$ & CS134 & $(.98)$ \\
\hline & SB125 & $(.02)$ & SB125 & $(.0025)$ & BA137M & $(.07)$ & KR85 & $(.11)$ & SB125 & $(.002)$ & SB125 & $(.0076)$ \\
\hline & BA137M & $(.002)$ & BA137M & $(.002)$ & NB95 & $(.02)$ & SB125 & $(.05)$ & BA137M & $(.0004)$ & BA137M & $(.002)$ \\
\hline & KR85 & $(.98)$ & CS134 & $(.998)$ & & & CS134 & $(.956)$ & CS134 & $(.9996)$ & & \\
\hline & SB125 & $(.014)$ & SB125 & $(.0004)$ & & & KR85 & $(.03)$ & SB125 & $(.0003)$ & & \\
\hline & BA137M & $(.002)$ & BA137M & $(.0004)$ & & & SB125 & $(.01$ & BA137M & $(.0001)$ & & \\
\hline $1 y$ & KR85 & $(.98)$ & CS134 & $(.995)$ & CS134 & $(.90)$ & CS134 & $(.81)$ & CS134 & $(.9977)$ & CS134 & $(.99)$ \\
\hline & SB125 & $(.018)$ & SB125 & $(.0026)$ & BA137M & $(.08)$ & KR85 & $(.12)$ & SB125 & $(.0018)$ & SB125 & $(.008)$ \\
\hline & BA137M & $(.0019)$ & BA137M & $(.0018)$ & SB125 & $(.01)$ & SB125 & $(.05)$ & BA137M & $(.0004)$ & BA137M & $(.002)$ \\
\hline & KR85 & $(.98)$ & $\operatorname{CS} 134$ & $(.998)$ & & & CS134 & $(.95)$ & $\operatorname{cs} 134$ & $(.9996)$ & & \\
\hline & SB125 & $(.013)$ & SB125 & $(.0004)$ & & & KR85 & $(.03)$ & SB125 & $(.0003)$ & & \\
\hline & BA137M & $(.0019)$ & BA137M & $(.0004)$ & & & SB125 & $(.01)$ & BA137M & $(.0001)$ & & \\
\hline
\end{tabular}


DISTRIBUTION

W. S. Farmer (5)

U.S. Nuclear Regulatory Commission

office of Nuclear Regulatory Research

Division of Engineering

Washington DC 20555

Z . Rosztoczy

U.S. Nuclear Regulatory Commission

Office of Nuclear Regulatory Research

Division of Regulatory Applications

Washington, DC 20555

G. Arlotto

U.S. Nuclear Regulatory Commission

Office of Nuclear Regulatory Research

Division of Engineering

Washington, DC 20555

M. Vagins

U.S. Nuclear Regulatory Commission

office of Nuclear Regulatory Commission

Division of Engineering

Washington, DC 20555

S. Carfagno

Franklin Research Center

Valley Forge Corporate Center

2600 Monroe Blvd.

Norristown, PA 19403

R. Denning

Battelle Columbus Laboratory

505 King Avenue

Columbus, OH 43201

G. Sliter

EPRI

3412 Hillview Ave.

Palo Alto, CA 94304 
Sandia Distribution:
6400 D. J. McCloskey
6500 A. W. Snyder
6410 D. A. Dahlgren
6413 E. Gorham-Bergeron
6413 S. J. Higgins
6419 M. P. Bohn
6419 L. D. Bustard
6419 M. J. Jacobus
6420 W. B. Gauster
6521 D. D. Carlson
6524 W. R. Dawes
6524 S. M. Luker
6524 F. V. Thome
6524 D. B. King (15)
3141 S. A. Landenberger (5)
3151 W. I. Klein
8524 J. A. Wackerly 


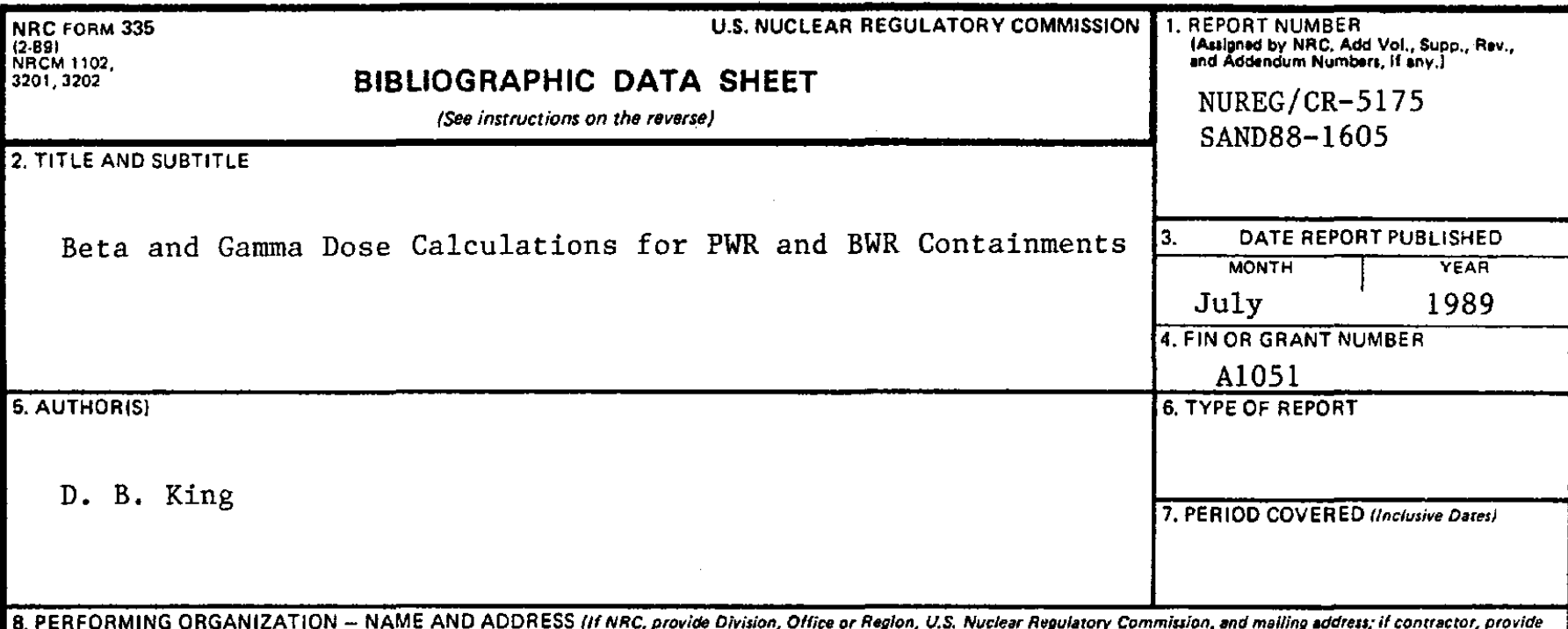

8. PERFORMING ORGANIZ
neme and meiling odoress)

Sandia National Laboratories

Albuquerque, NM 87185

9. SPONSORING ORGANIZATION - NAME AND ADDRESS (I" NRC, type "Seme as sbove"; if contractor, provide NRC Divlsion, Office or Region, U.S. Nuclear Regulatory Commission, end malling eddross.)

Division of Engineering

Office of Nuclear Regulatory Research

U.S. Nuclear Regulatory Commission

Washington. DC 20555

10. SUPPLEMENTARY NOTES

11. ABSTRACT (200 woros or less) Analyses of gamma and beta dose in selected regions in PWR and BWR containment buildings have been performed for a range of fission product releases from selected severe accidents. The objective of this study was to determine the radiation dose that safety-related equipment could experience during the selected severe accident sequences. The resulting dose calculations demonstrate the extent to which design basis accident qualified equipment would also be qualified for the severe accident environments. Surry was chosen as the representative PWR plant while Peach Bottom was selected to represent BWRs. Battelle Columbus Laboratory performed the source term release analyses. The $A B$ epsilon scenario (an intermediate to large LOCA with fallure to recover onsite or offsite electrical power) was selected as the base case surry accident, and the AE scenario (a large break LOCA with one Initiating event and a combination of fallures in two emergency cooling systems) was selected as the base case Peach Bottom accident. Radlonuclide release was bounded for both scenarios by including spray operation and arrested sequences as variations of the base scenarios. Sandia National Laboratories used the source terms to calculate dose to selected containment regions. Scenarios with sprays operational resulted in a total dose comparable to that $\left(2.20 \times 10^{\circ}\right.$ rads) used in current equipment qualification testing (for design basis accidents or Regulatory Guide 1.89). The base case scenarios resulted in some calculated doses roughly an order of magnitude above the current $2.20 \times 10^{8}$ rad equipment qualification test region.

Beta Dose Calculations

Gamma Dose Calculations PWR containment buildings BWR containment buildings Radiation dose

\begin{tabular}{|c|}
\hline $\begin{array}{l}\text { 13. AVAILABILITY STATEMENT } \\
\text { Unlimited }\end{array}$ \\
\hline 14. SECUAITY CLASSIFICATION \\
\hline $\begin{array}{l}\text { Trh/s Pegel } \\
\text { Unclassified }\end{array}$ \\
\hline $\begin{array}{l}\text { This Report } \\
\text { Unclassified }\end{array}$ \\
\hline 15. NUMBER OF PAGES \\
\hline 16. PRICE \\
\hline
\end{tabular}

